HENRIQUE PAULO DE BRIDA

\title{
O SISTEMA DE PAGAMENTOS BRASILEIRO À LUZ DO CÓDIGO CIVIL
}

\author{
Tese de Doutorado
}

Orientador: Prof. Dr. Eduardo Tomasevicius Filho

Faculdade de Direito da Universidade de São Paulo São Paulo

2014 


\section{O SISTEMA DE PAGAMENTOS BRASILEIRO À LUZ DO CÓDIGO CIVIL}

Tese de Doutorado apresentada ao Departamento de Direito Civil da Faculdade de Direito da Universidade de São Paulo como requisito parcial para a obtenção do título de Doutor em Direito, sob a orientação do Professor Doutor Eduardo Tomasevicius Filho

Candidato: Henrique Paulo De Brida

Faculdade de Direito da Universidade de São Paulo São Paulo 
Banca Examinadora 


\section{AGRADECIMENTOS}

Primeiramente, meu especial agradecimento à Faculdade de Direito da Universidade de São Paulo, por todas as oportunidades acadêmicas que me têm sido facultadas, desde a colação do grau de Bacharel em Direito até o reconhecimento do grau de Mestre em Direito, originalmente obtido na Universidade de Würzburg.

Agradeço igualmente ao meu orientador, Professor Doutor Eduardo Tomasevicius Filho, pela rara oportunidade acadêmica, bem como pela liberdade franqueada durante todo o curso de Doutorado.

Finalmente, agradeço à minha família, particularmente às minhas mãe e irmã, pelo apoio incondicional, e também à minha prima, as quais muito me incentivaram ao longo da vida acadêmica, e ainda a todas as pessoas que me apoiaram, ou de alguma forma proporcionaram o necessário conforto à realização desta empreitada.

À memória de meu pai, que sempre me incentivou e proporcionou os meios materiais e morais imprescindíveis à minha formação.

Por fim, agradeço muito a Deus, pois sem a Sua Presença nada teria sido possível em minha vida. 
RESUMO

DE BRIDA, Henrique Paulo. O Sistema de Pagamentos Brasileiro à luz do Código Civil. 2014. 392 p. Tese de Doutorado. Departamento de Direito Civil. Faculdade de Direito da Universidade de São Paulo. São Paulo, 2014.

O estudo jurídico do sistema de pagamentos sob o enfoque do direito obrigacional requer exame prévio do fenômeno socioeconômico representado pela moeda, enquanto elemento fundamental da relação obrigacional de compra e venda, determinante do preço e objeto do pagamento. Antes, porém, da análise do pagamento e de seus instrumentos jurídicos, ou seja, da moeda (em sentido largo) como efeito jurídico, tem-se de perquirir sobre sua natureza com o auxílio dos conceitos elaborados sobretudo pela ciência econômica, mas também pela sociologia e pela história social. O exame da realidade socioeconômica sob o prisma da essência dos fatos, não apenas de sua aparência, busca na materialidade do fenômeno monetário o suporte teórico para o encaminhamento da análise jurídica desse mesmo fenômeno e seus correlatos, tanto sob o enfoque positivista (dogmático) quanto sob o interativo, ou seja, enquanto relação entre o mundo jurídico positivo e a globalidade social por meio da interpretação ou aplicação das normas. A partir desse quadro analítico, procura o presente trabalho apresentar, primeiramente, um panorama do sistema monetário, situando o problema da moeda no contexto econômico e jurídico. Na segunda parte são expostos os fundamentos analíticos da economia em sua forma monetária (análise econômica da moeda). A terceira seção abrange o efetivo funcionamento do sistema monetário, particularmente examinando as funções do dinheiro numa economia monetária. A quarta e última parte apresenta o Sistema de Pagamentos Brasileiro (SPB) em seus moldes institucionais, situando-o no arcabouço do ordenamento jurídico nacional. A partir de seus fundamentos jurídicos, procede-se ao exame das matérias específicas do Direito obrigacional, em particular do pagamento e de suas garantias institucionais.

Palavras-chave: Sistema de Pagamentos Brasileiro. Moeda. Economia monetária. Política monetária. Código Civil. Obrigações. Pagamento. Compensação. Garantias. Patrimônio especial. 
ABSTRACT

DE BRIDA, Henrique Paulo. The Brazilian payment system in the light of Civil Code. 2014. 392 p. Doctoral thesis. Civil law department. College of Law from the University of São Paulo. São Paulo, 2014.

The legal study of the system of payments under the focus given by law requires prior examination of the economic phenomenon represented by currency as a key element of the obligational relationship given by purchase agreement, as by establishing the price and also as an object of payment. However, previously to the analysis of the payment and its legal instruments, i.e. the currency (in broad sense) as a legal effect, one should assess his nature with the aid of concepts specially developed by economic science, but also by sociology and social history. The examination of the socio-economic reality lit by the essence of the facts, not just by their appearance, search through the materiality of monetary phenomenon for the theoretical support for legally dealing with such a phenomenon and the correlated ones, both under the positivist approach (dogmatic) as under the interactive one, that is, as a relationship between the effective legal world and the social universe as a result of the interpretation or application of law. From this analytical framework, the ongoing writing seeks firstly to show a panorama of the monetary system by focusing the currency problem in the economic and legal context. The second part deals with the analytical foundations of the economy in its monetary form (economic analysis of currency). The third section covers the effective functioning of the monetary system, particularly by assessing the functions of money in the context of a monetary economy. The fourth and last part deals with the Brazilian Payment System (SPB) in its institutional patterns, by placing it in the framework of the national legal system. From their legal grounds, one assesses the specific matters concerning the Law of obligations, in particular the payment and its institutional collaterals.

Key words: Brazilian payment system. Money. Monetary Economics. Monetary policy. Civil Code. Law of obligations. Payment. Compensation. Collaterals. Special property. 


\section{KURZFASSUNG}

DE BRIDA, Henrique Paulo. Das brasilianische Zahlungssystem unter der Licht des Zivilgesetzbuchs. 2014. 392 S. Doktorarbeit. Lehrstuhl für Bürgerliches Recht. Rechtsfakultät der Universität São Paulo. São Paulo, 2014.

Die juristische Studie des Zahlungssystems im Rahmen des gesetzlichen Schwerpunkts erfordert die vorherige Prüfung des durch Währung representiert, wirtschaftlichen Phänomens - als ein Schlüsselelement des durch Kaufvertrag gegeben Rechtsverhältnisses, als Preisfestsetzendes und auch als Zahlungsziel. Vor der Analyse der Zahlung und der Rechtsinstrumente, d.h. die Währung (im weitesten Sinne) als rechtliche Wirkung, ist es jedoch seine Natur mit Hilfe von speziell entwickelten Begriffen nicht nur der Wirtschaftswissenschaft, sondern auch der Soziologie und der Sozialgeschichte zu prüfen. Die Prüfung der sozialökonomischen Realität unter der Licht des Wesens der Tatsachen, nicht nur ihrer Erscheinung, sucht die Materialität des monetären Phänomens durch, um die theoretische Unterstützung zum Rechtsumgang mit solchem Phänomen und dessen korrelierten zu finden, beide unter dem positivistischen Ansatz (dogmatisch) wie unter dem interaktiven, d. h. als eine Beziehung zwischen wirksamen rechtlichen und sozialen Universum aufgrund der Rechtsauslegung bzw. -anwendung. In diesem analytischen Rahmen ist die laufende Schrift zunächst ein Panorama des Währungssystems, durch die Betrachtung der Währungsfrage im Zusammenhang mit wirtschaftlichen und rechtlichen Umständen zu fassen. Der zweite Teil befasst sich mit den analytischen Grundlagen der Wirtschaft auf monetärer Weise (wirtschaftliche Analyse der Währung). Der dritte Abschnitt behandelt das effektive Funktionieren des Währungssystems, insbesondere durch die Bewertung der Funktionen des Geldes im Zusammenhang mit einer Geldwirtschaft. Der vierte und letzte Teil befasst sich mit dem brasilianischen Zahlungssystem (SPB) auf seinen institutionellen Mustern, um es im Rahmen des nationalen Rechtssystems festzustellen. Über dessen Rechtsgrundlagen hinaus ist die spezifische Rechtsfragen bzgl. dem Schuldrecht, insbesondere der Zahlung und deren institutionellen Gewährleistungen zu beurteilen.

Kernwörter: Brasilianische Zahlungssystem. Geld. Monetäre Wirtschaftswissenschaft. Geldpolitik. Bürgerliches Gesetzbuch. Schuldrecht. Zahlung. Aufrechnung. Gewährleistungen. Spezielle Vermögenschaft. 


\section{SUMÁRIO}

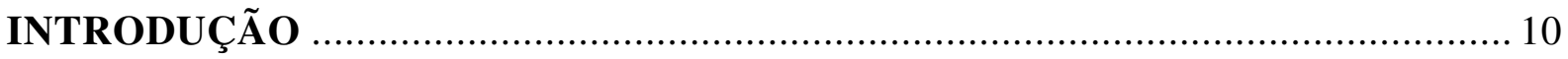

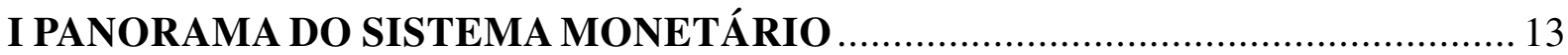

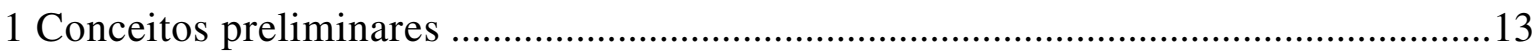

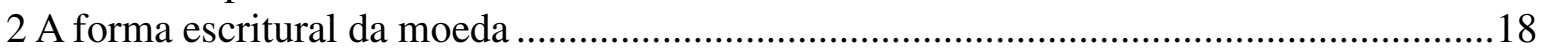

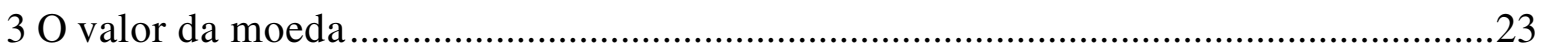

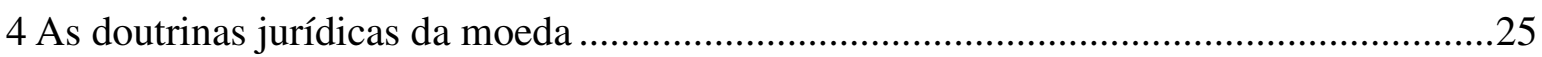

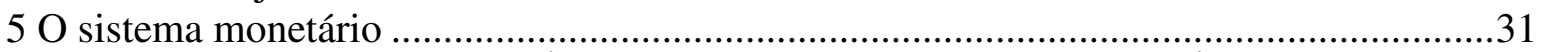

II OS FUNDAMENTOS ANALÍTICOS DA ECONOMIA MONETÁRIA ................ 42

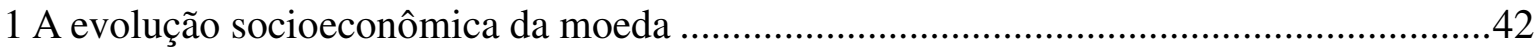

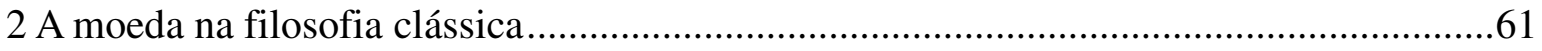

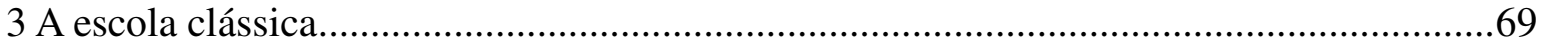

4 Keynes e o advento da ciência econômica monetária.......................................................103

III O FUNCIONAMENTO DO SISTEMA MONETÁRIO ................................... 117

1 As funções do dinheiro numa economia monetária ...................................................117

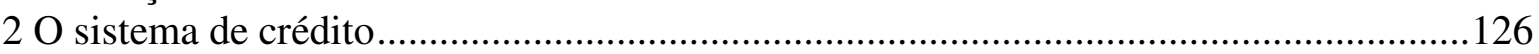

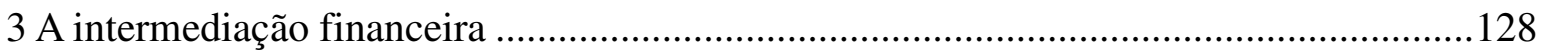

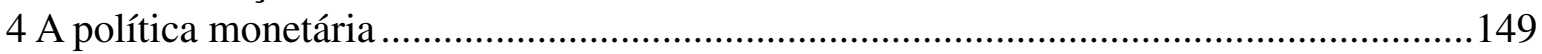

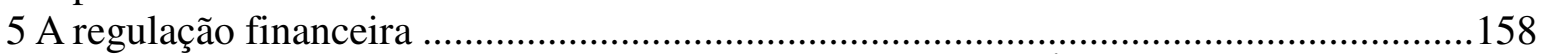

IV O SISTEMA DE PAGAMENTOS BRASILEIRO E O CÓDIGO CIVIL .............. 175

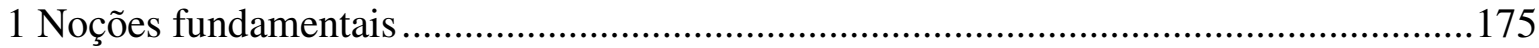

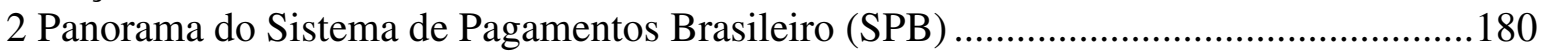

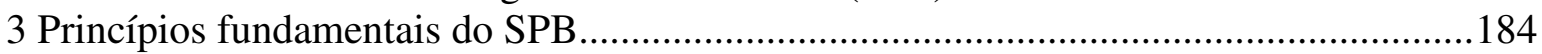

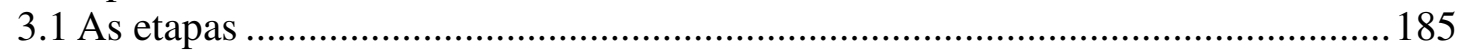

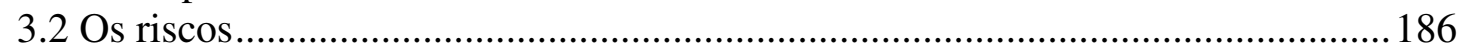

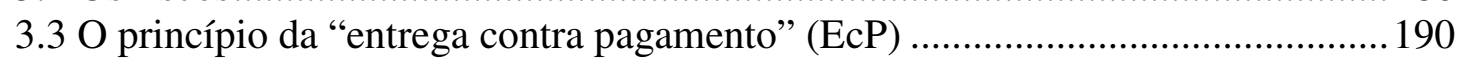

3.4 Os modelos de liquidação ................................................................................. 190

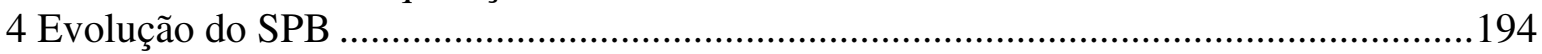

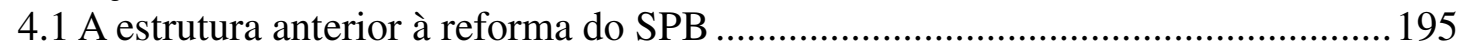

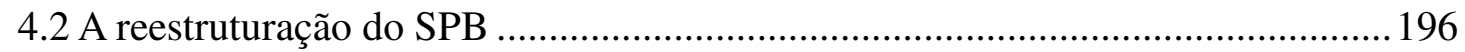

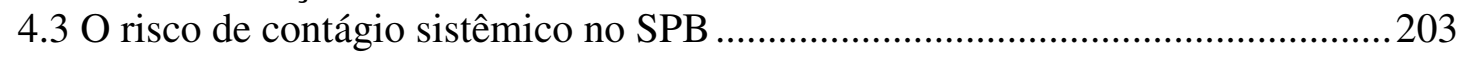

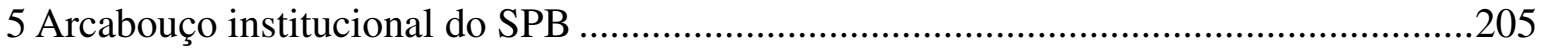

5.1 A Constituição brasileira face ao nomos financeiro.........................................209

5.2 O Código Civil face à ordem constitucional.....................................................219

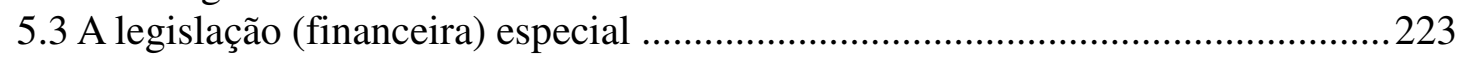

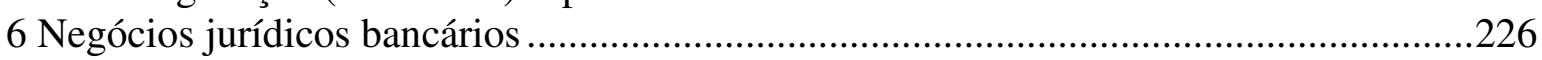

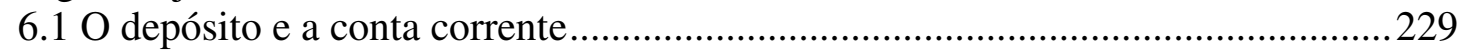

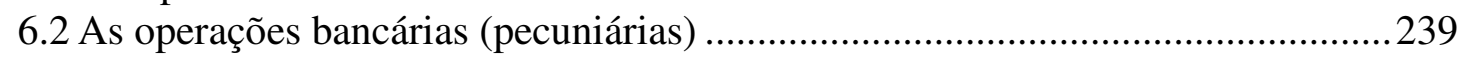

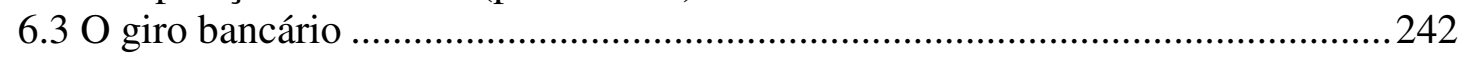

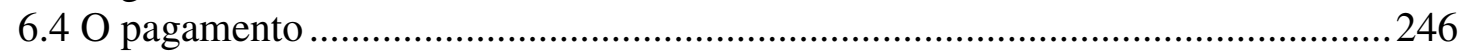

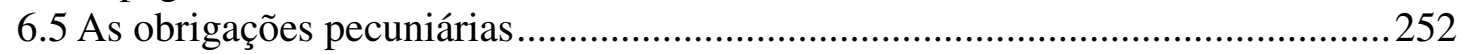

7 Fundamentos do SPB sob o prisma do Código Civil.........................................................258

7.1 A natureza jurídica da "entrega contra pagamento"..........................................261

7.1.1 Os valores mobiliários e sua tradição ..........................................................262

7.1.2 A transferência eletrônica de fundos ...........................................................295 
7.1.3 Excurso: A moeda nacional como bem púbico.

7.2 A compensação

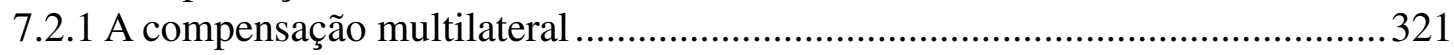

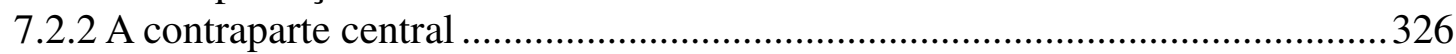

7.3 A não sujeição das obrigações aos efeitos da execução....................................... 333

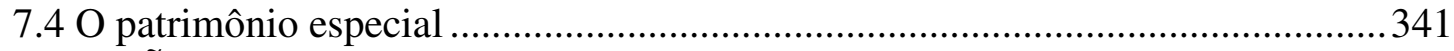

CONCLUSẪ

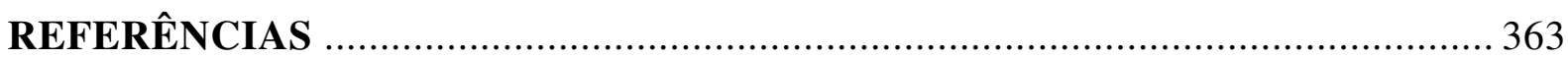

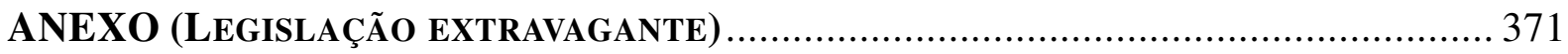




\section{INTRODUÇÃO}

$\mathrm{O}$ ordenamento jurídico, enquanto sistema, regra situações da vida por meio de suas proposições, regulando os bens da vida e sua distribuição social, segundo interesses e valores prevalentes, de modo a reduzir a complexidade inerente à vida de relação. Como tal tem ele também um caráter lógico, donde ser necessário um discrimine daquilo que, conceitualmente, nele penetra ou não. Não obstante, não se há de exigir que a lógica do sistema jurídico resulte em formulação meramente dedutiva das regras jurídicas, vez que essas também podem ser reveladas pelo jurista, desde que não firam ao sistema jurídico, pois que a subordinação hermenêutica é ao Direito, não à lei.

A lógica, aliás, somente assume o sentido de moldura, sendo que a hermenêutica como doutrina do entendimento correto e os critérios para a objetivação de valores cumprem papel decisivo no pensamento jurídico.

Diante da complexidade própria da realidade social, depara-se o jurista, não raro, com fatos e aspectos da realidade muito mais abrangentes do que aqueles presentes na rotina forense ou na pesquisa e elaboração jurídicas cotidianas. Tomando-se como premissa da juridicidade a incidência da regra jurídica sobre os fatos sociais, muitas vezes a questão a ser solvida é anterior ao regramento de ordem, abrangendo os elementos do suporte fático daquela regra, requerendo, portanto, a investigação da natureza desses elementos.

Dessa forma, é mister se iniciar um estudo jurídico, enquanto empreendido sob a égide da ciência e não só da técnica jurídica, se examinado como os elementos da realidade social penetram no mundo jurídico, antes, portanto, de se descreverem os efeitos decorrentes de sua ordenação pelo direito (eficácia jurídica).

Para tanto, faz-se necessária a pesquisa científica do fenômeno social, objeto de regramento jurídico, socorrendo-se o jurista dos estudos produzidos pelos particulares ramos da ciência que têm naquele fenômeno a sua razão.

Nesse sentido, a teoria jurídica, enquanto teoria social, requer influxos, informações e comparação com outras teorias que pretendem organizar o funcionamento social. Não se dissocia e não pode ser compreendida ou interpretada sem a contribuição e o diálogo com outras teorias sociais. Assim, a interdisciplinaridade é essencial à análise integral da realidade, e pois à sua aplicação a essa mesma realidade.

Dessarte, somente através da identificação das estruturas jurídicas e econômicas, bem como de sua formação histórica, é que se franqueia a possibilidade de construção e 
reconstrução da totalidade do sistema jurídico em sede interpretativa, afastando-se da circularidade viciosa do positivismo dogmático, que basicamente beneficia as estruturas de poder dominante - ora se aplicando literalmente as regras em favor dessas estruturas, ora os princípios superiores, gerais, quando as regras não beneficiam as mesmas estruturas.

Na hipótese presente, o estudo jurídico do sistema de pagamentos sob o enfoque do direito obrigacional requer exame prévio do fenômeno socioeconômico representado pela moeda, enquanto elemento fundamental da relação obrigacional de compra e venda, determinante do preço e objeto do pagamento. Antes, porém, da análise do pagamento e de seus instrumentos jurídicos, ou seja, da moeda (em sentido largo) como efeito jurídico, tem-se de perquirir sobre sua natureza com o auxílio dos conceitos elaborados sobretudo pela ciência econômica, mas também pela sociologia e pela história social.

O exame da realidade socioeconômica sob o prisma da essência dos fatos, não apenas de sua aparência, busca na materialidade do fenômeno monetário o suporte teórico para o encaminhamento da análise jurídica desse mesmo fenômeno e seus correlatos, tanto sob o enfoque positivista (dogmático) quanto sob o interativo, ou seja, enquanto relação entre o mundo jurídico positivo e a globalidade social por meio da interpretação ou aplicação das normas.

A despeito da influência exercida pelas relações da vida, e de sua ordem imanente, sobre o ordenamento jurídico, advirta-se que com esse último não se identifica plenamente, sob pena de se recair em sociologismo alheio ao valor próprio do Direito.

Não obstante, é mister que o jurisconsulto evite a natural recaída na armadilha do autorreferenciamento e intimismo, próprios da dogmática legalista, vale dizer, na tendência histórica ao positivismo.

A partir dos moldes analíticos acima delineados, procura o presente trabalho apresentar, primeiramente, um panorama do sistema monetário, situando o problema da moeda, de modo sintético, no contexto econômico e jurídico, e pois já introduzindo alguns aspectos relevantes do sistema de pagamentos, enquanto parte integrante do sistema monetário.

Na segunda parte são expostos os fundamentos analíticos da economia em sua forma monetária (análise econômica da moeda). Desse modo, a partir do exame sociológico dos fatos monetários, apresenta-se sua influência nas teorias e doutrinas monetárias mais relevantes para a História da análise econômica.

A terceira seção, por sua vez, abrange o efetivo funcionamento do sistema 
monetário, particularmente examinando as funções do dinheiro numa economia monetária. Assim, mostra-se o sistema de crédito e a intermediação financeira, fenômenos econômicos que se encontram à base da política econômica e monetária, e pois do próprio sistema de pagamentos enquanto matéria essencialmente atinente à política monetária. Esse exame acaba por fluir necessariamente para os canais institucionais, cujo exame se completa com uma exposição sintética da regulação financeira.

A quarta e última parte apresenta o Sistema de Pagamentos Brasileiro (SPB) em seus moldes institucionais, situando-o no arcabouço do ordenamento jurídico nacional, particularmente no âmbito do Direito Econômico constitucional. A partir de seus fundamentos jurídicos, procede-se ao exame das matérias específicas do Direito obrigacional do adimplemento (pagamento), e pois de suas garantias institucionais, na medida em que o funcionamento do SPB se desenvolve no sentido de dar cumprimento efetivo às obrigações oriundas dos negócios jurídicos cursados em seu âmbito. 


\section{PANORAMA DO SISTEMA MONETÁRIO}

\section{Conceitos preliminares}

Aos bens econômicos podem se associar basicamente dois tipos de valor: o de uso e o de troca. Tal distinção não implica polaridade, senão indica apenas duas dimensões do fenômeno valorativo. O valor de uso tem caráter individual, ou familiar; o de troca decorre da divisão do trabalho, pois possibilita a reiteração das trocas, surgindo, assim, um consenso social quanto à utilidade e grau de escassez do bem. $\mathrm{O}$ valor de uso pode ser considerado, portanto, pressuposto do valor de troca, sendo esse último o valor econômico de um bem (NUSDEO, 2001).

O aumento da importância da moeda está ligado ao desenvolvimento do processo de divisão do trabalho e consequente perda da autossuficiência econômica dos indivíduos. Salvo em comunidades extremamente isoladas, um homem dos nossos tempos produz parcela minúscula daquilo que consome. Portanto, a perda de autossuficiência é uma contingência do progresso e da produção em massa, alcançáveis apenas com intensa divisão do trabalho. Nesse sentido, quanto mais uma sociedade se desenvolve mais se especializam seus indivíduos, aumentando sua interdependência. O corolário imediato da divisão do trabalho é o estabelecimento das trocas (NUSDEO, 2001).

A troca direta emperrava, no entanto, o progresso trazido pela divisão do trabalho. No mundo primitivo, aos poucos, o ato uno e compacto da troca se bipartiu em entidades funcionalmente separadas, em que uma das mercadorias objeto da troca não tinha valor de uso imediato para seu proprietário, senão era havida como instrumento facilitador de trocas futuras (p. ex., o sal). A partir desse momento, a troca sofre uma alteração substancial de sentido, pela alteração funcional da segunda mercadoria nela envolvida. Estava criada, portanto, a moeda, pois o sal não fora aceito como mercadoria em si, mas como meio de troca, portanto, instrumento monetário (NUSDEO, 2001).

Originariamente, portanto, era a moeda uma mercadoria como outra qualquer, institucionalizando-se e padronizando-se gradativamente. Para tanto, alguns requisitos físicos se tornam indispensáveis à mercadoria-moeda, tais como a possibilidade de manuseio, a divisibilidade, a fungibilidade, além do requisito econômico, qual seja, a capacidade de reserva de valor. Esse último confere à moeda-mercadoria a possibilidade de conversão futura em um bem idêntico àquele que seria obtido com a troca direta, caso não 
houvesse sido utilizado como intermediário (NUSDEO, 2001).

Ainda nesse sentido, há aqueles que entendem dever a moeda não apenas conservar a si própria fisicamente, mas incorporar permanentemente o valor original pelo qual foi aceita (NUSDEO, 2001, p. 49). Quando tal não ocorre, ela sofre uma disfunção, como no caso da inflação, tendo seu poder aquisitivo desgastado, mantendo-se somente como instrumento de troca. O tema do valor da moeda será retomado, contudo, mais adiante.

Os metais logo se impuseram como bens perfeitamente adaptáveis aos requisitos mencionados, permitindo uma crescente padronização (peça metálica arredondada com características padronizadas), a tal ponto de a moeda se reduzir, hoje, a um simples lançamento contábil. Com o tempo, a moeda se oficializa, e cunhá-la passa a ser uma prerrogativa da soberania estatal - assim, por exemplo, a efígie do soberano aparece como traço de legitimidade (NUSDEO, 2001).

Em razão da mobilidade e celeridade do comércio (p. ex., as grandes feiras medievais), passou-se a oferecer o serviço de depósito de moedas metálicas, ofício assumido por grandes comerciantes, permitindo-se, assim, aumento da circulação monetária através do uso do recibo de depósito como meio de pagamento. Dessa forma, surgia a moeda-papel, com lastro metálico, bem como o banqueiro, profissional das operações financeiras (moedas e seus títulos representativos) (NUSDEO, 2001).

A emissão da moeda em papel, antes responsabilidade dos bancos privados, passa gradualmente a ser monopólio estatal, sobretudo a partir da formação dos estados nacionais europeus. O lastro metálico ou lastro ouro, havido como elemento legitimador da circulação, foi adotado pelos grandes países, principalmente entre 1870 e 1914. No entanto, as dificuldades para a manutenção da relação entre o valor da moeda e aquele dos metais que lhe serviam de lastro ou padrão (padrão-ouro), agravadas pelo início da Grande Guerra e o surgimento de novas necessidades, fazem com que caia em desuso, passando os estados nacionais a emitir moeda livremente, i.e., papel-moeda, de acordo com suas necessidades. Ressalve-se, aliás, que a associação da estabilidade da moeda com as reservas metálicas de um país não se sustentou ao longo da história econômica. Consolidase, portanto, a tendência mundial de recurso à chamada "moeda fiduciária", cujo valor é fundado apenas na confiança que os agentes econômicos depositam em seu emissor, trilhando-se, igualmente, o caminho irreversível da desmaterialização monetária (NUSDEO, 2001; YAZBEK, 2009). 
A introdução da moeda no comércio jurídico aperfeiçoou o sistema de trocas, uma vez que, através dela, identificam-se as formas inferior e superior de troca, ou seja, aquela permite uma satisfação imediata das necessidades recíprocas das partes (escambo), enquanto essa traduz funções diversas, pois que apenas uma das partes obtém satisfação imediata, postergando-se a satisfação alheia por meio do dinheiro (JHERING, 1956, p. 122).

A moeda foi criada, portanto, para facilitar as trocas, viabilizando a especialização do trabalho. Seria impossível imaginar a atual organização socioeconômica sem a moeda, o crédito e as instituições que a emitem e intermedeiam, sob o regime de mercado.

Sua utilização conduziu, em rigor, à dissociação de cada troca em duas operações: uma de compra e outra de venda (ALMEIDA, 2009; DE CHIARA, 1986). A moeda, por sua vez, passou a desempenhar as seguintes funções fundamentais: a) intermediária de trocas; b) unidade de conta (padrão geral de valor de troca); reserva de valor; e instrumento (meio) de pagamento.

Do ponto de vista espacial, a função da moeda como intermediário de trocas é inerente à sua própria definição. O segundo papel, o de unidade (padrão) de valor ou de conta, resume-se na praxe de se exprimir o valor de troca das mercadorias em termos de uma unidade comum - a unidade monetária (padrão monetário). A existência desse padrão deu origem aos sistemas atuais de preços, tornando possível a contabilização da atividade econômica e permitindo a construção de sistemas aglutinantes de contabilidade social.

Dentre as funções no tempo, a principal é a de reserva de valor, que decorre do desdobramento das trocas em compras e vendas. No momento em que um indivíduo vende serviços ou mercadorias e recebe moeda em troca, pode guardá-la para utilizá-la no futuro. A preferência pela utilização da moeda como reserva de valor ocorre em razão de sua pronta e imediata aceitação, pois tem como característica a liquidez por excelência, podendo ser convertida em outros ativos, financeiros ou reais (NUSDEO, 2001; ALMEIDA, 2009).

A outra função no tempo, que corresponde ao papel da moeda como instrumento ou padrão de pagamentos, diferidos ou não, decorre das facilidades relacionadas ao crédito e da distribuição temporal de formas de adiantamentos. Dessa forma, são viabilizados os processos de investimento, de produção e de consumo, pois a moeda permite interpor parcelas de pagamentos ao longo das etapas de geração dos bens econômicos (ALMEIDA, 2009). 
A moeda tem também como característica a função liberatória, pois detém o poder de saldar dívidas, de liquidar débitos e de livrar o detentor de uma situação passiva. O poder liberatório é garantido pelo Estado, que pode forçar o curso da moeda, impondo sua aceitação como forma de pagamento (JANSEN, 2009; PEREIRA, 2011). A rigor, o curso forçado vedaria a conversão da moeda em outros ativos, prevalecendo seu valor nominal; já a obrigatoriedade de aceitação da moeda como meio de pagamento, impondo-se legalmente sua circulação compulsória, denotaria seu curso legal (NUSSBAUM, 1925).

Ressalte-se ainda que a moeda é instrumento que traduz poder econômico, político e social. Ao passo que se admite a moeda como um título de crédito, segundo doutrina mais antiga (p. ex., nota promissória), aqueles que a detêm passam a possuir direitos de haver sobre bens e serviços disponíveis no mercado, tanto maiores e mais amplos quanto maior for o montante disponível de moeda (MANN, 1992), aumentando, na mesma medida, sua parcela do produto social.

Em regime de mercado, a moeda assume, essencialmente, a função de poder de compra, ou seja, de aquisição de bens e serviços, cujo nível há de definir o próprio valor real da moeda em razão das oscilações de preços, em contraposição a seu valor nominal, que lhe transmite apenas a aparência de padrão estável.

Tendo em vista a qualidade de valor líquido própria da moeda, ao se examinar o poder de compra sob o prisma do comportamento do titular da disponibilidade monetária no mercado, qualifica-se a moeda, então, como instrumento de liquidez, conferindo a seu titular o poder de escolha entre os bens e serviços dispostos no mercado (VIDIGAL, 1977). A esse atributo monetário, quando analisado do ponto de vista subjetivo, ou seja, do titular da moeda enquanto agente econômico, pode-se denominar situação de liquidez (DE CHIARA, 1986), ou seja, a disponibilidade, mediata ou imediata, de moeda ou dinheiro. Nesse sentido, uma boa situação econômica em termos patrimoniais (bens e direitos), pode concomitantemente denotar uma precária situação financeira em razão da falta de recursos monetários disponíveis ou mobilizáveis para o pagamento de obrigações. A esse tema se retornará oportunamente.

Sob o prisma do comportamento global de mercado, ao se analisar o referido poder de compra da moeda, revela-se sua função como instrumento de procura efetiva, ou seja, tornando eficaz a procura de bens e serviços no mercado em razão da capacidade de pagamento de seus preços, influindo, portanto, na determinação dos preços de mercado (VIDIGAL, 1977). 
A importância da moeda decorre não só de suas tradicionais funções de instrumento de troca, unidade de conta (ou padrão de valor), reserva de valor e padrão de pagamentos, mas também de seu preço (juros) e de sua estabilidade interna (inflação ou deflação) e externa (câmbio). Finalmente, a moeda também influencia e serve de referência para a avaliação das condições e perspectivas econômicas do ente soberano que a emite.

Em períodos caracterizados por altas taxas de inflação, muitas vezes causadas por emissões desenfreadas, as funções da moeda passam a ser negadas econômica e socialmente. As primeiras a sofrerem esse processo são as funções no tempo, pois, com a perda de valor, a moeda deixa de ser usada como reserva; em seguida, como padrão de pagamentos. O processo inflacionário implica, portanto, uma disfunção da moeda (NUSDEO, 2001; ALMEIDA, 2009).

A persistência de taxas de inflação elevadas interfere também nas funções da moeda no espaço, que é substituída por outros ativos que passam a desempenhar o papel de unidade de conta ou padrão geral de valor de troca. Num regime hiperinflacionário, a moeda pode perder até mesmo sua função de intermediária de troca (NUSDEO, 2001).

A perda do poder de compra da moeda eleva os custos de sua retenção e de contabilidade das operações negociais. O uso de ativos alternativos como padrão de valor provoca dissociação entre o meio de conta e o meio de troca. No Brasil, por exemplo, entre 1981 e 1986, muitos contratos eram celebrados em Obrigações Reajustáveis do Tesouro Nacional (ORTN), enquanto o acerto final se dava em cruzeiros. Essa separação trouxe ineficiência para o sistema econômico, pois os cálculos para converter os preços dos bens em ORTN (ou em dólar) e reconvertê-los para moeda corrente por ocasião de sua venda envolviam um custo fixo por transação, independentemente do valor total da operação. Do ponto de vista do vendedor, entretanto, a dissociação era vantajosa, pois dispensava a necessidade de repetida remarcação dos preços denominados em valores monetários.

A separação entre meio de conta e meio de troca se acentua nas fases de inflação elevada, que se caracterizam por remarcações frequentes, atingindo preponderantemente os bens e serviços transacionados em maiores intervalos de tempo. A denominação de preços em ORTN foi adotada principalmente em transações de longo prazo, como nos financiamentos para aquisição de moradias. A inflação elevada também reduz sensivelmente a eficiência da moeda como reserva de valor, principalmente na ausência de mecanismos de correção. É importante destacar, contudo, que nos anos que antecederam a implantação do Plano Real (1994), o uso intenso de indexadores, que corrigiam os valores 
de praticamente todas os negócios, foi o que impediu a dolarização da economia brasileira (NUSDEO, 2001; ALMEIDA, 2009).

Hipoteticamente, quaisquer mercadorias podem, potencialmente, ser consideradas formas de moeda. Três fatores, no entanto, delimitam essa possibilidade: custos de transação, custos de estocagem e custos relacionados à sua função como unidade de conta (padrão de valor).

A moeda, enquanto ativo padronizado utilizado como meio de pagamento universal, permite, portanto, a redução dos custos de transação nas relações econômicas em geral, bem como uma melhor administração do risco e da incerteza futuros (YAZBEK, 2009).

Em relação especificamente ao papel-moeda, para cumprir bem suas funções, deve possuir características essenciais, impostas por sua evolução e pelo aumento da complexidade das economias monetárias, sendo as mais relevantes: indestrutibilidade e inalterabilidade; homogeneidade; divisibilidade; alienabilidade; facilidade de manuseio e transporte (NUSDEO, 2001; ALMEIDA, 2009).

Esses mesmos fatores têm condicionado, ao longo do tempo, a evolução da moeda, em particular o aparecimento da moeda eletrônica e de plástico, como os cheques ou cartões magnetizados, os cartões de crédito, de compras, informatizados ou as transferências eletrônicas de fundos, cujo uso tem se intensificado largamente, em processo de desmaterialização irreversível (NUSDEO, 2001; VIDIGAL, 1977).

Mencione-se ainda que a adoção da moeda como medida e reserva de valor resultou também na distinção entre dois campos distintos, não obstante conexos, de estudo da atividade econômica, a saber, a Economia e as Finanças. Com efeito, muitas operações ou situações da vida econômica têm por objeto apenas a moeda ou títulos que a representam. É o caso da atividade bancária, englobando depósitos, empréstimos, aplicações diversas, operações cambiais e tantas outras, dando origem ao que se denomina mercado financeiro, no qual o bem negociado é, sempre, em última análise, o dinheiro, sem referência ao assim chamado setor real da economia, aquele no qual se operam bens e serviços, tal como o mercado de café, o de eletrodomésticos ou o de serviços de segurança.

\section{A forma escritural da moeda}

O entendimento claro do funcionamento do sistema bancário se torna imprescindível para a compreensão dos modernos sistemas de pagamento, tal é a 
relevância dos bancos na economia contemporânea como provedores de liquidez aos agentes econômicos e facilitadores das relações de pagamento (CORTEZ, 2004).

Com efeito, a moeda fiduciária estatal não é a única adotada nas sociedades contemporâneas. Em razão de questões de segurança ou ainda do atendimento de necessidades específicas, criaram-se, paralelamente à moeda de emissão pública, mecanismos não convencionais de multiplicação do estoque monetário: as "moedas" ou “quase-moedas" de origem privada (VIDIGAL, 1977; YAZBEK, 2009).

Mencionem-se, como tal, os produtos e serviços financeiros básicos ofertados pelo sistema bancário a seus clientes, relacionados à necessidade de administração dos fluxos financeiros e à procura de instrumentos que lhes ofereçam maior segurança. Frise-se a importância das relações creditícias no suprimento de moeda, promovendo uma troca, diferida no tempo, entre moeda atual, disponibilizada ao mutuário, e moeda futura, acrescida de juros (CORTEZ, 2004; NUSDEO, 2001; VIDIGAL, 1977; YAZBEK, 2009).

Originado ainda no século XIV, o processo de equiparação dos depósitos bancários à moeda se dá em razão das facilidades de retirada e movimentação do dinheiro depositado. A possibilidade de emissão da chamada moeda escritural, ou seja, existente e movimentável nos registros contábeis das instituições bancárias, sob a forma de depósitos, imprimiu aos bancos uma importante característica: o multiplicador bancário, mecanismo que permite ao sistema bancário multiplicar o estoque de moeda (CORTEZ, 2004; YAZBEK, 2009).

O conceito de multiplicador dos meios de pagamento, extremamente importante em economia monetária, delineia-se como efeito do processo de intermediação financeira realizado pelos bancos, custodiantes do dinheiro depositado pelo público. Na medida em que recebem depósitos e, na sequencia, emprestam essas quantias a terceiros, lucrando com o diferencial de juros, produzem os bancos tal efeito multiplicador, pois o crédito do depositante contra o banco se transforma em disponibilidade para um terceiro, mutuário, e assim sucessivamente ao longo da cadeia bancária (NUSDEO, 2001; YAZBEK, 2009) ${ }^{1}$

Ressalte-se ainda que nas economias modernas os depósitos à vista não são remunerados, apenas os a prazo o são. Por razões de custos operacionais, além do atendimento a eventuais saques, os bancos mantêm provisões em caixa, o chamado encaixe, restringindo, portanto, a parcela destinada aos empréstimos. A esse encaixe

1 Esse esquema traduz basicamente o entendimento tradicional da atividade bancária, o qual na realidade não se sustenta face à moderna análise econômica, cujo entendimento será esposado na sequência deste trabalho. 
particular, acresça-se a obrigação de depósito compulsório de uma parcela dos depósitos à vista em contas junto ao banco central, de forma a também limitar o montante passível de empréstimo, mitigando-se os riscos envolvidos no processo multiplicador. Outrossim, configura o depósito compulsório instrumento de política monetária (NUSDEO, 2001; YAZBEK, 2009).

Distinguem-se, portanto, a moeda oficialmente emitida pela autoridade monetária (em regra, o banco central), denominada meio circulante, e o conjunto da moeda multiplicada escrituralmente pelo sistema bancário, a moeda escritural, basicamente os depósitos à vista. Há ainda outras aplicações de recursos financeiros, tais como depósitos a curto prazo, depósitos de poupança, alguns títulos, de curto prazo, da dívida pública, que são considerados "quase-moeda", em razão de se transformarem em recursos líquidos (moeda corrente) a intervalos muito curtos de tempo, sendo, portanto, facilmente mobilizáveis para efeito de pagamentos. Ainda que não tenham, por si sós, poder liberatório, permitem a liquidação (quase) imediata de transações, gozando de relevância e mesmo centralidade na atual organização das relações econômicas e na elaboração da política monetária (ALMEIDA, 2009; NUSDEO, 2001; YAZBEK, 2009).

A complexidade do fenômeno monetário implicou, portanto, uma maior diferenciação da moeda em circulação, ampliando-se substancialmente o conjunto dos meios de pagamento. Em face desse fenômeno, a definição clássica de meios de pagamento, ou seja, a soma de depósitos à vista e papel-moeda (M), não se mostra adequada do ponto de vista operacional, uma vez que a liquidez dos ativos financeiros de renda fixa (títulos) permite sua transformação em meios de pagamento a um custo razoável, particularmente em face de um cenário estável ou de reduzida flutuação na taxa de juros, com grande probabilidade de adimplemento pelo devedor (ALMEIDA, 2009).

Dessarte, a forma de quantificação da moeda circulante também sofreu alterações, de modo a se permitir um aperfeiçoamento da política monetária, enfatizando-se a liquidez da economia, é dizer, "a combinação entre o nível das taxas de juros do mercado e a capacidade de o total dos ativos financeiros se transformarem em moeda" (ALMEIDA, 2009, p. 88). Surge, assim, a figura dos agregados monetários, ou seja, “distintos grupos de meios de troca, conforme a sua liquidez" (YAZBEK, 2009, p. 69).

No caso brasileiro, no entanto, considera-se a maior parte dos ativos de renda fixa como tendo elevada liquidez, definindo-se os agregados monetários por instituições depositárias ou emitentes semelhantes, desprezando-se as diferenças nas velocidades de 
conversão dos haveres em disponibilidades imediatas, ou seja, em $M$ (posteriormente denominado $\mathrm{Ml}$ ). Essa é a posição oficial da autoridade monetária brasileira - Banco Central do Brasil (BCB) -, desde agosto de 2001 (ALMEIDA, 2009).

Identificam-se, no Brasil, os seguintes agregados monetários: a) meio circulante: a moeda emitida pelo $\mathrm{BCB}$, também chamada de base monetária; b) papel-moeda em poder do público: o meio circulante diminuído do encaixe dos bancos (em moeda corrente e aquele junto ao BCB); c) $M 1$ : o papel-moeda em poder do público acrescido dos depósitos à vista em bancos comerciais, públicos e privados; d) $M 2: M 1$ juntamente com os depósitos especiais remunerados, depósitos em poupança e títulos emitidos em mercado primário por instituições do mercado financeiro; e) $M 3: M 2$ acrescido das quotas de fundos de renda fixa e operações compromissadas registradas no Selic (Sistema Especial de Liquidação e Custódia); e f) M4: M3 e ainda os títulos públicos de alta liquidez.

Ressalte-se que os depósitos voluntários e compulsórios junto ao BCB compõem a conta de "reservas bancárias", também chamadas de "moeda de banco central", ou seja, relações obrigacionais, denominadas na unidade monetária oficial, entre o Estado (banco central) e os bancos titulares dessas contas (bancos criadores de moeda - no caso brasileiro: os comerciais, os múltiplos e as caixas econômicas) (ALMEIDA, 2009; CORTEZ, 2004).

As reservas bancárias, juntamente com o papel-moeda em circulação fora do banco central (dinheiro em espécie, ou simplesmente, espécie), compõem o passivo monetário do banco central, moeda de "alto poder de expansão". Desse modo, esse passivo configura a base da expansão monetária, ou simplesmente "base monetária", pois sobre ela haverá a expansão de moeda. O resultado dessa expansão fornecerá o total dos meios de pagamento da economia, portanto, o passivo monetário do sistema monetário (ALMEIDA, 2009; COSTA 1999).

A oferta monetária corresponde assim ao total dos meios de pagamento: os ativos financeiros ${ }^{2}$ habitualmente utilizados e, em regra, legalmente aceitos na liquidação de operações negociais. A principal fonte de expansão da base é a variação da reserva bancária, constituída normalmente pelos saldos de depósitos voluntários e de compulsórios em espécie (ALMEIDA, 2009; COSTA, 1999). Tal expansão afeta o multiplicador de meios de pagamento, e pois o comportamento do setor bancário, ao servir de dínamo ao processo de multiplicação bancária, na medida em que o nível de empréstimos bancários é

2 A moeda e seus substitutos (líquidos) conversíveis em dinheiro de curso legal. 
inversamente proporcional ao nível de encaixe (inclusas as reservas bancárias).

O comportamento bancário também pode ser afetado pela persuasão moral (poder de convencimento da autoridade monetária através de sua política monetária) e por mudanças na taxa de reservas (bancárias) totais, normalmente determinadas pela variação dos depósitos compulsórios dos bancos comerciais, alterando, portanto, o multiplicador bancário (ALMEIDA, 2009).

Por outro, as operações de mercado aberto e os empréstimos do banco central aos bancos comerciais, ou seja, as operações de redesconto, alteram apenas o total da base monetária, mas não o comportamento bancário nem, portanto, o multiplicador de meios de pagamento (ALMEIDA, 2009).

No Brasil, a circulação da moeda emitida pelo banco central se dá apenas para fins de compensação financeira definitiva das operações realizadas no âmbito do sistema de pagamentos brasileiro (SPB), processadas pelo próprio BCB através do Sistema de Transferência de Reservas (STR). No STR há três tipos de contas mantidas pelo BCB: a) Conta de Reservas Bancárias, já mencionada (Circular BCB no 3.439, de 2009, art. 4º); b) Conta Única do Tesouro Nacional, onde se depositam as disponibilidades de caixa da União (art. 164, § $3^{\circ}$, da Constituição Federal); e c) Contas de Liquidação, cujos titulares são câmaras de compensação ou prestadores de serviços de compensação e liquidação participantes do SPB (Circular BCB n 3.439, de 2009, art. $2^{\circ}$ ).

As Contas de Liquidação desempenham papel relevante no funcionamento do SPB, pois através delas se liquidam definitivamente as operações realizadas pelo titulares das Contas Reservas Bancárias nas câmaras de liquidação pertencentes ao SPB. Possuem, no entanto, apenas caráter instrumental, uma vez que se estabelece o encerramento diário de suas operações com saldo zero, transferindo o BCB eventuais saldos positivos para contas bancárias previamente indicadas, inclusive as de reserva bancária (Circular BCB n 3.439, de 2009, art. $6^{\circ}$ ). Dessa forma, esses recursos perdem o caráter de moeda de banco central, saindo da base monetária $(M)$ e passando a ser moeda escritural bancária $(M 1)$, ao menos em caráter temporário, uma vez que os saldos diários dessas contas poderão retornar à base monetária, alterando-a por meio de seu lançamento nas contas de reserva.

Nota-se, portanto, que a evolução da moeda e sua utilização originaram outros instrumentos de modo a aperfeiçoar o funcionamento das economias monetárias, atendendo a outras necessidades dos agentes econômicos que não só aquelas inerentes às funções básicas da moeda (YAZBEK, 2009). Outrossim, evidencia-se como a moeda e os 
padrões típicos das relações monetárias conformam todo o sistema financeiro, influindo, assim, na formatação institucional do mercado financeiro.

\section{0 valor da moeda}

Cabem algumas reflexões básicas sobre o conceito de valor aplicado ao fenômeno monetário, em particular por seus reflexos na conceituação jurídica da moeda e, em particular, no estudo das obrigações pecuniárias.

Segundo JANSEN (2009, p. 64), deve-se sobretudo a SMITH (1984) a noção de poder aquisitivo como inerente ao conceito de valor de troca, admitindo-se, dessa forma, a existência de um valor intrínseco à moeda, de caráter econômico, consistente naquilo que ela pode comprar. Aproximar-se-ia, com isso, da doutrina do valor intrínseco, ou metalista, pois referente ao valor lastreado da moeda.

A moeda, porém, não teria valor, mas seria um valor per se, pois o valor não está na natureza, sendo apenas modo de interpretar a realidade. Nesse sentido, a moeda também não poderia ser padrão ou medida de valor, de que decorre o preço (expressão monetária do valor econômico), pois ainda se estaria situando o valor na natureza, como algo intrínseco aos bens ou serviços. Valor e realidade estariam, portanto, em planos distintos, não se incorporando o valor à moeda nem aos bens (JANSEN, 2009).

Ressalte-se, porém, que o valor econômico não deve ser de todo confundido com o valor no sentido ético e filosófico, ainda que ambos os conceitos se imbriquem na medida em que aquele requer uma série de pressupostos institucionais para sua manifestação, aos quais subjazem, por sua vez, os valores éticos. Em certa medida, a ética social determina o consenso sobre a utilidade e escassez dos bens, portanto, seu valor econômico e, em última instância, o próprio mercado, que se define institucionalmente nos moldes da ordem jurídica e política de determinado país em cada época (NUSDEO, 2001; YAZBEK, 2009).

De modo geral, assevera-se que o valor da moeda, necessário para sua aceitação em pagamento e, ainda, para o cumprimento adequado de suas outras funções, não reside em nenhuma característica intrínseca, mas, sim, na garantia de valor outorgada pelo poder emissor, ou seja, de seu poder de compra, não apenas de seu valor nominal. Nesse mesmo sentido, a moeda se apoia, sobretudo, na confiança que os agentes nela depositam (YAZBEK, 2009). A essa linha teórica também se denomina "teoria valorista" (CORTEZ, 2004). 
Em contraponto, o chamado nominalismo vincula o cumprimento das obrigações ao valor nominal da moeda, valor de face, não importando seu valor intrínseco ou os processos de desvalorização que a tenham afligido (MANN, 1992). Em razão dos processos inflacionários e dos diversos períodos de instabilidade, criaram-se, no entanto, exceções a tal princípio, como assevera DE CHIARA (1986, p. 43),

o valor da moeda se expressa em termos do seu poder de compra, do 'quantum' de bens e serviços cuja aquisição assegura nos mercados. $\mathrm{O}$ valor nominal imposto pelo emissor da moeda tem apenas a finalidade de oferecer um suporte referencial para a consecução das trocas.

No entanto, como observado por DE CHIARA (1986) e CORTEZ (2004), na esteira dos ensinamentos de VIDIGAL (1977), a moeda não tem um poder aquisitivo abstrato, pois confere a seu detentor um poder aquisitivo inserto no mercado, ou seja, um instrumento de procura efetiva que lhe permite atuar no mercado, influenciando, inclusive, na formação dos preços, observadas as situações de liquidez particulares dos agentes econômicos ${ }^{3}$.

Firmou-se, ao longo do tempo, a convicção de que as peças monetárias, em razão de serem compostas por metais preciosos, ou de tê-los como lastro (padrão-ouro), tinham um valor medido pela própria moeda, justificando-se, assim, um suposto direito de propriedade sobre as peças monetárias enquanto bens móveis fungíveis ${ }^{4}$.

No entanto, ao contrário dos bens em geral, passíveis de apropriação privada, as peças monetárias são resultado de emissão oficial, sob regime de monopólio estatal. Dessa forma, podem ser objeto apenas de detenção, cuja transmissão ocorre para fins de adimplemento das obrigações em razão do poder liberatório conferido a seus detentores pelo Estado. Aliás, o Estado sempre conserva para si o poder de desmonetizar o meio circulante nacional (JANSEN, 2009).

Sob o aspecto econômico, em sentido estrito, as moedas nacionais sempre apresentaram variações no seu valor, ou seja, no chamado poder aquisitivo: a quantidade de bens ou serviços passíveis de aquisição por um número fixo de unidades monetárias. Tal fato se revela diante dos diferenciais de preços entre as economias nacionais, considerando-se que o nível de preços exprime o poder de compra da moeda, portanto, a

3 Essa questão será explorada mais adiante, ao ser esboçada a análise monetária, em particular a teoria keynesiana.

4 Assunto a ser retomado na sequência da exposição, delineando-se então os aspectos fundamentais da história econômica e social da moeda (dinheiro). 
relação de troca entre as moedas nacionais, ou seja, a taxa de câmbio indica a evolução da relação de poder de compra.

Há observar ainda que a moeda, de acordo com sua disponibilidade na economia, ou seja, seu grau de liquidez, influi nos níveis de poupança e consumo, configurando um fator importante nas decisões dos agentes econômicos, em particular através uma variável monetária específica: a taxa de juros (DE CHIARA, 1986; NUSDEO, 2001).

Nota-se, portanto, a importância do emprego preciso da noção de poder aquisitivo no campo econômico, subjacente à técnica estatística de números-índice, destinada a medir a variação dos níveis de preços, referindo a moeda, portanto, como balizamento para a valoração dos bens (YAZBEK, 2009). Ademais, contribuiu tal noção para a superação das restrições físicas à emissão monetária, ao contrário do que ocorria com o conceito anterior de valor intrínseco (JANSEN, 2009). Quanto à abrangência dos tipos de moeda, tal noção abarca não apenas as peças monetárias, mas também o papel-moeda, os créditos e os preços de bens e serviços.

Não obstante, muitos entendem como equivocado o emprego jurídico da noção de poder aquisitivo no sentido de implicar conteúdo monetário, portanto, fundamento último da moeda nacional, em substituição à noção anterior de valor intrínseco, mas com a mesma finalidade, qual seja, dar aos credores, em regra, os detentores da riqueza - patrimônio financeiro, na acepção de HUBER (2011) -, a segurança jurídica necessária à manutenção do valor (poderio) econômico da moeda e dos ativos financeiros componentes de seu patrimônio (JANSEN, 2009).

No Brasil, contudo, não se deve olvidar de que o nominalismo foi minado por altos índices históricos de inflação e, ainda, pelo advento da correção monetária. Assim, por exemplo, o art. 315 do vigente Código Civil estabelece uma regra geral de nominalismo, porém pleno de ressalvas, contidas nas normas dos artigos que lhe seguem, bem como na legislação especial (YAZBEK, 2009).

\section{As doutrinas jurídicas da moeda}

Diversos doutores entendem, não sem razão, que a questão em torno do valor da moeda não lhe é inerente, mas diz respeito sobretudo ao objeto e conteúdo das obrigações monetárias (MANN, 1992, p. 23 e s.). Aliás, o alemão George Knapp, maior referência para a chamada "teoria estatal da moeda", adotou a doutrina da obrigação monetária como ponto de partida para sua conceituação (NUSSBAUM, 1925, p. 64). 
A questão se torna relevante, portanto, visto que a relação jurídica de direito das obrigações se caracteriza por ser determinada a prestação e, nesse sentido, a moeda é “objeto" da prestação, seja nas dívidas de prestação abstrata, ou de valor, seja naquelas de prestação concreta, ou pecuniárias (NUSSBAUM, 1925; PONTES DE MIRANDA, 1959, p. 289 e s.).

Segundo a teoria estatal da moeda, uma mercadoria somente assume o caráter de moeda quando tal atributo lhe é conferido por força de lei, ou seja, pelo Estado (MANN, 1992). Nesse sentido, a capacidade de circulação dos instrumentos de pagamento, sua principal característica, é um atributo jurídico conferido pelo Estado por meio de um ato normativo (CORTEZ, 2004).

O nominalismo caracterizaria, portanto, as dívidas em dinheiro, além da própria unidade de moeda, sendo corolário da prerrogativa estatal de estabelecer tanto a unidade monetária quanto o instrumento de pagamento (JANSEN, 2009).

Outra consequência da teoria estatal da moeda é que essa só se descaracteriza enquanto tal em razão de desmonetização formal, não importando a incidência de leis de caráter empírico, como a "lei (princípio) de Gresham", segundo a qual "a moeda ruim afasta da circulação a boa moeda" (MANN, 1992, p. 21).

Com efeito, esclarece-se tal fato diante da alteração do padrão monetário: instituídos uma nova unidade monetária e um novo meio de pagamento, todas as dívidas em dinheiro terão de ser saldadas com o novo instrumento.

Diante disso, entende-se que a unidade monetária não seria definida tecnicamente, mas apenas historicamente. A definição técnica estaria ligada a uma contingência política do Estado, enquanto a definição histórica seria uma necessidade lógica, além de uma prerrogativa estatal apta a aclarar a instauração de um novo padrão monetário (CORTEZ, 2004).

Em oposição à teoria estatal, há outra, que funda a moeda em relações sociais (comerciais) e, portanto, na concordância e confiança de todos os agentes. Trata-se da chamada teoria social da moeda, cujo principal fautor foi o austríaco Carl Menger 5 . Ressalte-se todavia que poucos juristas, ainda que de escol, aderiram a essa teoria, concentrando-se particularmente na Alemanha, como sejam Savigny, Nussbaum ou Reinhardt (MANN, 1992).

5 As concepções monetárias da chamada "escola austríaca" serão tratadas na sequência, esboçando-se os fundamentos da Economia monetária. 
Corolário natural da teoria social da moeda é o entendimento de que a unidade monetária seria uma unidade ideal, ou mesmo real, de valor, correspondente ao poder aquisitivo outorgado ao detentor, ou credor. Em razão dos processos inflacionários e suas repercussões sobre as dívidas de dinheiro, tal concepção teve ampla aceitação entre os juristas (p. ex.: ASCARELLI, 1969; MANN, 1992), inaugurando o que se sói denominar "valorismo" ou "metalismo", como acima referenciado. Seu precursor foi Savigny, cuja concepção da moeda residia em seu poder aquisitivo abstrato, ou poder patrimonial (Vermögensmacht) (ASCARELLI, 1969; CORTEZ, 2004; MANN, 1992, p. 28).

A concepção patrimonial da moeda, ainda com apelo à doutrina clássica do valor intrínseco, encontra seu balizamento econômico na função de reserva de valor, correntemente atribuída à moeda. Nesse sentido, a moeda seria objeto do direito de propriedade, permitindo a conservação dos valores (GOMES, 1980) ${ }^{6}$.

Impulsionada pelas análises estatísticas que desenvolveram os índices de preços, balizadores da perda de poder aquisitivo da própria moeda, a concepção valorista contribuiu para o desenvolvimento de novos institutos jurídicos aptos a fazer frente aos efeitos da inflação sobre as relações obrigacionais, como a teoria da imprevisão, as cláusulas escalares, a teoria das dívidas de valor ou a doutrina da correção monetária.

Como se frisou em tópico anterior, a teoria valorista é passível de crítica no seguinte aspecto: a moeda não teria nenhum poder de compra em abstrato, pois que confere a seus detentores um poder de adquirir bens e serviços nos mercados (DE CHIARA, 1986).

Dessa forma, fragiliza-se tal concepção diante da realidade das estatísticas econômicas, uma vez que pressupõe condições hipotéticas de produção e preços, próprios da ciência macroeconômica. Assim, por exemplo, o teorema de Fischer $(M V=P Q)$ indica que a taxa de crescimento da moeda reflete, de modo (quase) uniforme, a evolução dos preços, pressupondo, no entanto, um quadro de relativa estabilidade econômica (ALMEIDA, 2009).

O poder aquisitivo da moeda, portanto, serve de instrumento de análise econômica, não se prestando, em princípio, a conceituar operacionalmente a moeda, como requer, em regra, a técnica jurídica. Isso se reflete no exame das circunstâncias e efeitos do processo inflacionário, que não permitem se aferir, precisa e aprioristicamente, o modo

6 Essa função monetária do dinheiro é ressaltada sobretudo no âmbito da teoria monetária keynesiana, como será visto adiante. 
como se afeta o valor (econômico) das disponibilidades patrimoniais, financeiras, de cada indivíduo, ou grupo social específico. Assim, por exemplo, os reajustes de preços não se aplicam de maneira uniforme a todos os bens no decorrer do processo inflacionário, de modo que a depreciação dos ativos líquidos (monetários) variará de acordo com os hábitos econômicos (investimento e consumo) individuais. Evidencia-se também esse aspecto pela variação dos diferentes índices de preços existentes no Brasil (CORTEZ, 2004).

Mencione-se ainda uma importante corrente da teoria metalista ("valorista") que entende ser a moeda (unidade monetária) um padrão (medida) de valor, não representando necessariamente um poder aquisitivo (NUSDEO, 2001; NUSSBAUM, 1925). Ao contrário da linha metalista tradicional, esse argumento não reivindica para a moeda um valor real, garantindo seu poder de compra, mas somente uma unidade ideal de valor que corresponda a um múltiplo ou submúltiplo da unidade ideal de uma ordem monetária específica (ASCARELLI, 1969; NUSSBAUM, 1925, p. 6).

A concepção da unidade monetária como unidade ideal de valor remete a uma importante função da moeda, já apresentada anteriormente: a unidade de conta ou padrão geral de valor (de troca). Nesse sentido, pode se citar o exemplo da "Unidade Real de Valor" (URV), instrumento introduzido no Brasil, a partir de 1994, durante a segunda fase do "Plano Real" (plano governamental de estabilização econômica), cuja função principal foi a de auxiliar na reorganização das demandas sociais pelo produto, expressando-as assim em uma única unidade de conta, de modo a fixá-las em bases consistentes com a magnitude do produto. Dessa forma, adotou-se tal ferramenta para combater a inércia inflacionária, permitindo a elevação diária dos preços das mercadorias para obter a sincronização dos reajustes de preços. Uma vez obtida essa sincronização da variação dos preços, estabilizando-se o sistema de remunerações e preços relativos, bastaria executar a reforma monetária estabilizadora, ou seja, materializar o índice-moeda "URV" como meio de pagamento, em última instância, a nova moeda: o "Real" (CORTEZ, 2004; SICSÚ, 1996).

Ressalte-se, no entanto, que a moeda pode apenas fornecer informações sobre o valor de troca das mercadorias, não expressando nenhum valor em si, mas apenas estabelecendo relações, pois é justamente por meio dela que os preços das mercadorias são expressos (CORTEZ, 2004; analogamente, JANSEN, 2009).

Nesse sentido, a função de padrão geral de valor se define sobretudo em função de ser a moeda instrumento geral de troca (MISES, 2005), não por ser fração ideal da unidade 
legal.

CORTEZ (2004, p. 95), com apelo à semiótica, assim assevera:

A unidade monetária pode ser utilizada para denominar quantitativamente dívidas e preços porque existem normas sociais que a definem como tal e conformam sua utilização. Sem essas normas, as palavras real, peso, dólar ou libra seriam carentes de qualquer significação monetária.

Ainda nessa linha, DE CHIARA (1986, p. 57) entende ser a moeda um produto da linguagem jurídica, na esteira de OLIVECRONA (2012) e FERRAZ JR. (1978).

Em sentido contrário, MANN (1992, p. 25 e ss.) critica a redução do conceito de moeda à sua função de denominação, considerando-a apenas uma de suas características, aliás, coerentemente à sua concepção savigniana da natureza (intrínseca) da moeda, que a vê como poder patrimonial.

Afeto, em princípio, à linha normativa inaugurada por Knapp, interessante notar que JANSEN (2009) define a moeda a partir de sua emissão, ato jurídico administrativo complexo, entendendo ser ela o instrumento público desse ato. Com esteio na teoria kelseniana, o mesmo autor entende ser a moeda nacional norma monetária geral, que fundamentaria a moeda (meio circulante) e as obrigações monetárias como normas monetárias individuais.

As normas monetárias se manifestariam, assim, por meio de proposições numéricas, não verbais, embora vinculadas à palavra que lhes denomina. Descrevem deontologicamente as condutas humanas, seu conteúdo de validade, mas de modo quantitativo, ou seja, não determinam qual deverá ser a conduta, senão quanto deverá ser (JANSEN, 2009).

$\mathrm{O}$ aspecto sancionador da norma monetária residiria no seu poder liberatório, sanção positiva e descentralizada, aplicada pelos detentores de moeda ao utilizarem-na na circulação econômica, dando-lhe assim o devido curso legal a partir da competência delegada pela ordem monetária (parte do ordenamento jurídico econômico), reservando-se ao Estado somente o monopólio de emissão (JANSEN, 2009).

Em princípio, convergem as teorias anteriores fundamentalmente no sentido da definição daquilo que deva ser considerado como moeda, e pois instrumento válido de pagamento, seja em razão de seu curso legal, seja em razão de sua aceitação social.

Parece-nos que a melhor definição se encaminharia, ao menos à título de consenso doutrinário, no sentido da validade institucional desses meios de pagamento, aptos ao 
adimplemento das obrigações face à ordem jurídica que conforma o sistema (geral) de pagamentos. No entanto, tal caráter institucional permanece vago, pois que pode fundamentar a validade tendo por base tanto o poder estatal (validade formal, contrafática) quanto as instituições sociais, dentre elas os mercados (eficácia social).

Do ponto de vista institucional (política monetária), poder-se-ia argumentar, ainda que preliminarmente, no sentido de que a própria estrutura conceitual dos chamados "agregados monetários" projetaria a liquidez como aspecto preponderante na definição dos ativos capazes de servir de moeda, enquanto pretensão ao dinheiro de curso legal (SCHUMPETER, 1964a).

Entendendo-se a liquidez como característica funcional a fundamentar a capacidade de circulação de determinado ativo financeiro - "moedicidade", na acepção de MAYER (1993) -, e pois sua "negociabilidade", encontraria assim na função liberatória seu corolário natural. A função liberatória, por sua vez, seria então como que projeção ou efeito (socioeconômico) do poder liberatório juridicamente conferido, ou ainda sancionado pelo Estado ao titular daquele ativo, observada todavia a situação (real) de liquidez desse mesmo titular.

Particularmente em relação à moeda em espécie (meio circulante), esse efeito jurídico (sancionador) se traduz simplesmente no curso legal, ou seja, a prescrição legal quanto ao efeito liberatório de determinada moeda nacional (Währungsgeld, ou somente Währung, currency) (ASCARELLI, 1969; FARIA, 1990; GOODE, 2004; PEREIRA, $2011)^{7}$.

Nesse sentido, o poder liberatório (funcional) teria, em princípio, natureza de direito potestativo público, correspondente ao uso do instrumento de pagamento legalmente reconhecido como $\mathrm{tal}^{8}$.

Especificamente, a validade institucional dos meios de pagamento remete fundamentalmente a outra questão, qual seja a do ordenamento jurídico da moeda, é dizer,

7 Na precisa lição de GOODE (2004, p. 450): “Thus in England money in its technical legal sense means physical money, that is, notes issued by the Bank of England and coin distributed by the Mint, when transferred as currency, not as a curio or other commodity. It does not include bank money or electronic money".

8 Observe-se, somente à guisa de exemplo, o reconhecimento institucional, ainda que apenas em nível regulamentar (administrativo), de muitas das chamadas "moedas sociais", que são alternativas ao meio circulante legal, aceitas como meio de pagamento restrito ao ambiente socioeconômico e territorial em que se lhes permite a circulação. Conclui-se, empiricamente, que a única característica institucional possível àquela moeda é a função liberatória (meio de pagamento) que exerce no âmbito restrito de sua circulação. Não obstante, do ponto de vista econômico, abstraído o aspecto institucional, tal moeda seria apenas instrumento de troca (Verkehrsgeld), de curso comercial. 
o sistema monetário que os conforma.

\section{O sistema monetário}

Do articulado, nota-se um complexo encadeamento de fatores, conceituados a partir dos diversos estudos do fenômeno monetário, que se apresenta ao intérprete da realidade social de modo um tanto ambíguo. Com efeito, são os diversos aspectos do mesmo fenômeno, visualizados a partir de critérios analíticos das diferentes ciências que sobre o tema se debruçam, de modo a revelar a inteira materialidade do universo monetário, que contribuem para o complexo monetário.

A apreensão dessa materialidade fenomênica, sob o prisma do mundo jurídico, determinando-lhe a forma, prévia ou supervenientemente, só pode ocorrer através da norma que, enquanto discurso regrador, do ponto de vista da pragmática jurídica, também registra ambiguidade na sua formulação, pois ora revela seu suporte fático de modo hipotético, ora de forma imperativa, requerendo ela própria interpretação, vez que alberga múltiplos sentidos (interpretabilidade), mas também obediência, enquanto premissa de discussões (dogmaticidade) (FERRAZ JR., 1978).

Do ponto de vista epistemológico, a materialidade do fenômeno monetário, enquanto complexo, pode ser apreendida, em seu conjunto, de forma reduzida, por meio daquilo que se denomina sistema, ou seja, um conjunto de elementos e seus atributos, formando seu repertório, somado a suas relações recíprocas, que lhe dão sentido (unidade de conteúdo), conforme certas regras estruturantes (FERRAZ JR., 1978, p. 140). Na lição de CANARIS (1989), destacam-se duas características essenciais ao sistema: a ordenação e a unidade.

A ordenação sistemática permite que se apreenda racionalmente um estado de coisas intrínseco, fundado na realidade, enquanto a unidade permite a recondução de particularidades desconexas a poucos princípios fundamentais (CANARIS, 1989, p. 13).

O apelo epistemológico ao conceito de sistema, no âmbito jurídico, fundamentase, segundo CANARIS (1989), no princípio da justiça e de sua concretização tanto no princípio da igualdade como da tendência para a generalização. Com efeito, a exigência de ordem resulta diretamente do postulado da justiça (equidade), já a unidade não diz respeito somente a postulado da lógica, mas reflete antes o princípio da igualdade e a tendência generalizadora do Direito, que exigem a superação da diversidade de aspectos inerentes ao concreto em prol de poucos princípios, abstratos e gerais. 
Dessa forma, a busca de ordenação e unidade interior (de sentido) nas relações entre os elementos sistêmicos implica necessária adequação valorativa, pois que se trata de emanações e postulados inerentes à ideia de Direito, devendo um sistema, no âmbito jurídico, refletir e realizar tal desiderato, sempre em busca de solução aos problemas. Ressalte-se que a unidade valorativa é sempre de tipo material e historicamente determinada, portanto permeável à realidade circundante (CANARIS, 1989; FREITAS, 2002).

A polissemia do termo moeda reflete a complexidade do fenômeno monetário, na medida em que pode referir, como já examinado, a peça monetária concreta, a moeda nacional, nominando-lhe (p. ex., o real, o dólar, a libra), a unidade monetária abstrata, em distinção à unidade contábil como medida de valor de troca, a moeda em espécie e a moeda de banco central (moeda estatal, na lição de KEYNES, 2012), moeda bancária (escritural), bem como os preços relativos dos bens, o poder de compra em termos de taxa de câmbio, o valor de um crédito, do depósito à vista, ou mesmo de um título à curto prazo, enfim, qualquer instrumento de pagamento aceito no tráfico jurídico.

Como já afirmava GUDIN (1976), há coincidência generalizada entre unidade monetária e unidade de conta, cuja distinção apenas prevalece por tradição histórica, pois que a moeda é, a um tempo, unidade monetária e unidade de conta, mas também instrumento de pagamento.

Pode-se englobar todas essas ideias e fatores no conceito de "sistema monetário", de modo a reduzir a complexidade do fenômeno socioeconômico em torno da moeda, permitindo maior coesão e unidade de sentido no exame dos diversos aspectos que a compõem, de modo a imprimir-lhe, a partir de seus elementos, eficácia jurídica.

O próprio legislador nacional, ao estabelecer um diálogo (normativo) com o fenômeno monetário, não prescindiu de tal uniformidade conceitual ao prescrever no art. $1^{\circ}$ da Lei no 9.069, de 1995 (Plano Real), que "a unidade do Sistema Monetário Nacional passa ser o Real, que terá curso legal em todo o território nacional”. Da mesma forma, ao prescrever que as estipulações de pagamento deverão ser feitas em REAL (Lei nº 10.192, de 2001, art. $1^{\circ}$ ).

Tem-se aqui o elemento fundamental do sistema monetário, ou seja, a unidade monetária, a conferir, desde seus diversos aspectos, sentido aos elementos e relações que formam o conjunto do sistema monetário (nesse sentido, ASCARELLI, 1969; MANN, 1992; NUSSBAUM, 1925). Do ponto de vista sociológico, esse elemento é inaugural para 
qualquer novo sistema que se conforme em torno de um novo padrão monetário, sem que com isso se afirme o caráter meramente histórico da unidade monetária, no sentido da teoria estatal da moeda.

Em torno da unidade monetária se estruturam os demais elementos que operacionalizam o fenômeno monetário, colocando em funcionamento o sistema monetário ao permitir a circulação da moeda e do crédito nos diversos mercados de trocas (indiretas), instrumentados por moeda. Nesse sentido, na venda como na compra, surge a necessidade e a função do pagamento, sendo essa a principal função da moeda, corolário natural de sua função como meio de troca, pois que a venda e compra origina uma obrigação, que só se extingue pelo pagamento em moeda, ou pela compensação de créditos e débitos no livros contábeis dos bancos, cujo saldo final há de ser pago, sempre, em moeda, manual ou escritural (GUDIN, 1976).

Dessa forma, o sistema monetário se estrutura na concatenação dos diversos instrumentos com os quais se efetuam os pagamentos, cuja unidade de sentido (conteúdo) corresponde à unidade monetária de valor. Em torno desse padrão monetário, muitas vezes objeto de uma norma fundamental daquele sistema, erige-se, modernamente, um subsistema de pagamentos, formado por diversos instrumentos de pagamentos, da mesma forma que um subsistema creditício, todos presididos pela atividade bancária estruturada no âmbito maior do sistema financeiro (SCHUMPETER, 1982), do qual o sistema monetário é parte fundamental.

Importante digressão a ser feita sobre o conceito de moeda enquanto meio de pagamento. Muitas vezes objeto de crítica dos economistas, que veem nele um atributo jurídico, não econômico, pois que ao se descerrar o véu monetário, ou seja, a troca de valores, restaria apenas a questão econômica da troca (MISES, 2005; ROBERTSON, 1969).

Não obstante, ao se dissociar a troca de bens em duas operações envolvendo moeda, passa a ser justamente esse o objeto de investigação da economia monetária, qual seja, o de determinar os efeitos da introdução da moeda nessas operações (GUDIN, 1976). Com efeito, ainda que a questão em torno da extinção de obrigações seja eminentemente jurídica, sob o aspecto econômico relatado, a principal função da moeda continua a ser a de meio de pagamento.

A questão de quais são os meios de pagamento de que a sociedade pode lançar mão em determinado momento, ou seja, os elementos que compõem a denominada oferta 
monetária, é respondida pela economia monetária a partir da noção quantitativa daqueles meios, essencial ao estudo da teoria econômica do valor da moeda. A isso se responde do seguinte modo: o total dos meios de pagamento à disposição do público se representa pelo total de moeda em espécie (papel-moeda), menos os encaixes bancários de toda natureza, acrescidos dos depósitos à vista nos bancos, à disposição do público, inclusas, na lição de KEYNES (2012), as reservas bancárias enquanto moeda de banco central, à disposição dos próprios bancos.

Não obstante, como inicialmente exposto, a questão convergente das diversas doutrinas monetárias apresentadas, eminentemente jurídicas, é a de como se definir quando determinado ativo deva ser considerado instrumento válido de pagamento, seja em razão de seu curso legal, seja em razão de sua aceitação social. Assim, a questão gira em torno da validade institucional dos elementos que compõem o conceito econômico de oferta monetária.

Sob o prisma do conceito adotado de sistema monetário, a questão institucional dos meios de pagamento, ou seja, sua validade, pode ser colocada da seguinte forma: quais os meio de pagamento que os agentes econômicos da sociedade contemporânea podem ou devem lançar mão em razão de sua aptidão para representar, de modo direto ou indireto, a unidade monetária, fundante do sistema monetário?

Como também colocado anteriormente, o consenso doutrinário se encaminharia no sentido da validade institucional dos meios de pagamento, aptos ao adimplemento das obrigações face à ordem jurídico-monetária que conforma o sistema (geral) de pagamentos. Não obstante, esse caráter institucional permaneceria vago diante da própria ambiguidade de sua fundamentação, pois que poderia ter por base tanto o poder estatal quanto as instituições sociais, dentre elas os mercados.

Parece ser consensual a ideia de que o sistema monetário deva ter um caráter eminentemente estatal. Com efeito. Retornando à teoria estatal da moeda, frise-se que a moeda seria essencialmente um negócio de Estado, o qual a regularia de acordo com seus interesses. Enquanto criação do Direito, surgiu historicamente sob diversas formas, de modo que sua conceituação seria presidida necessariamente por uma teoria da História do Direito. Como corolário, sobreleva a questão em torno do fundamento de validade da moeda, restando a questão em torno de seu valor em segundo plano. O que importa, portanto, é sua validade jurídica (Geltung), traduzida pela força liberatória que lhe confere o Estado ou aquilo a que ela dá direito em virtude de lei. Essa força liberatória não se 
confere à moeda em espécie, mas à unidade monetária, cujo símbolo linguístico varia de acordo com o Estado emissor. A razão de ser do poder liberatório reside no fato de liberar definitivamente as dívidas obrigacionais. A forma de representação material da unidade monetária pouco importa, podendo ser papel ou ouro, a critério estatal, pois é essa unidade que é provida do direito de liberar obrigações (Knapp, 1924, pp. 20-1 apud CORTEZ ${ }^{9}$, 2004, p. 82 e s.).

A essência da tese "cartalista", eminentemente estatal, se resume ao entendimento de ser a moeda essencialmente um padrão de referência, em dado momento histórico, sem valor intrínseco, cabendo ao Estado legislar sobre o que é e o que não é moeda legal, admissível em contratos. Quanto a isso, os fatos socioeconômicos e a experiência monetária aí estão para confirmá-la.

Não obstante, como nos alerta GUDIN (1976), a alma da moeda, ou seja, sua capacidade de funcionar como meio de troca e de pagamento, em regime de mercado, reside em sua aceitação geral. Cite-se, por exemplo, a libra esterlina, aceita universalmente no passado, mas sem que gozasse de curso legal até 1833.

O Estado, portanto, emite ou controla a emissão da moeda corrente, mas não pode controlar o valor dessa moeda, pois que esse se determina no mercado. O Estado pode forçar o curso de determinada moeda, mas não lhe pode fixar o valor. A emissão desordenada implica um decréscimo do valor total da emissão monetária tão ou mais rapidamente do que o aumento da quantidade de moeda emitida. O Estado pode dar curso legal a uma moeda sem aceitação nem valor e declarar a possibilidade de solução das obrigações nessa moeda, mas não pode forçar o curso comercial dessa moeda, na medida em que bens e serviços não sejam ofertados contra pagamento nessa mesma moeda. Assim, os assignats da Revolução francesa, apesar da pena de morte àqueles que os recusassem em pagamento; do mesmo modo na grande depressão alemã, em 1923, em que os negócios passaram a ser realizados em dólares, como em passado recente na Argentina, ou mesmo, em certa medida, entre nós. O Estado pode, enfim, alterar a unidade monetária, afetando seu poder de compra, mas lhe mantendo a mesma denominação e estipulando o poder liberatório da nova unidade para as obrigações contraídas na antiga, o que abala, sobretudo, a confiança na instituição do contrato, sobre a qual se baseia a ordem econômica.

Na clássica lição de GUDIN (1976), o Estado muito pode, como acima mostrado, mas não pode forçar a aceitação de uma moeda que não mereça confiança, nem lhe

9 KNAPP, Georg F. The state theory of money. Trad. Londres: McMillan, 1924. 
conferir valor diverso daquele arbitrado pelo mercado (nesse sentido, no que toca ao pilar da confiança, CORTEZ, 2004). "A moeda deve a vida à sua aceitação geral e, subsidiariamente, à lei”, sendo que a aceitação deriva da confiança e do hábito, no entanto, tem antes por base um comportamento racional, em razão do mercado, não simplesmente psicológico (GUDIN, 1976, p. 26).

Do exposto, não se há de descurar o jurista, ao se debruçar sobre o fenômeno monetário, das lições da economia monetária, lastreada em estudos empíricos, pois que o substrato material desse fenômeno deve não só orientar a atividade do intérprete do sistema monetário, como conferir ao próprio sistema uma unidade de sentido, material e historicamente determinada pelo ambiente socioeconômico que o permeia, e com o qual normativamente interage.

Somente assim se pode revelar as regras jurídicas consentâneas com as hipóteses fáticas impressas de juridicidade, em conformidade com a tarefa hermenêutica, essencialmente orientada ao correto entendimento das normas e suas premissas.

Em particular no que tange ao fundamento de validade da moeda, ressalte-se que mesmo a teoria estatal da moeda, de larga aceitação entre os juristas, somente atribui ao padrão monetário (unidade monetária) a validade formal, objeto de curso legal. Nada mais. Quanto aos outros meios de pagamento, assim entendidos sob o prisma do sistema monetário, nada diz a respeito de onde devem retirar sua validade em sentido formal (jurídico, e pois estatal).

Em 1900, Georg Simmel (1990, p. 172 apud CORTEZ ${ }^{10}$, 2004, p. 125) já antevia, em sua Philosophie des Geldes, a essência da moeda (dinheiro) como pura abstração, de modo que o desenvolvimento socioeconômico e cultural tornaria prescindíveis quaisquer atributos físicos ao dinheiro, na mesma proporção em que aumentassem a segurança e a coesão das relações de troca por ele instrumentadas.

No sentido de abstração, de padrão ideal de valor, resta claro que a moeda somente enquanto unidade monetária gozaria de privilégio estatal, forçando-lhe legalmente o curso. Em verdade, a única conversão possível, no arcabouço do sistema jurídico monetário, seria aquela dos instrumentos de pagamento em unidade monetária estatal (dinheiro de curso legal).

Importante referir a questão da conversibilidade enquanto corolário do exercício do poder monetário soberano, qual seja, aquele de emitir moeda de curso forçado como 
padrão geral e único de conversão. A ordem jurídica deve oferecer os elementos basilares para a conformação do ambiente social, solucionando o exercício do poder a partir de determinada conjuntura histórica.

Nesse sentido, observa-se que as distorções verificadas no funcionamento dos mercados no século XIX, sob a égide do modelo liberal, encontraram campo fértil na falta de regramento jurídico da criação e administração monetárias, dadas sua emissão e utilização desordenadas, tal como ocorria em razão do free banking que então predominava (DE CHIARA, 1986).

A partir de então, a configuração jurídica do poder emissor como monopólio estatal, entendido como parcela do poder político, permitiu a utilização válida do instrumento monetário no jogo dos mercados.

Retomando-se, mais uma vez, o ensinamento de DE CHIARA (1986, p. 20), a moeda é denominador comum e fundamento para as considerações de riqueza individual e social, atuando como catalisador das possíveis combinações nos processos de solução racional entre diferentes alternativas. Serve de parâmetro de valor para a comparação, de modo simples, entre as possíveis soluções de escolha entre os bens de natureza e utilidade diversas. Sobreleva, portanto, sua natureza de padrão monetário enquanto caráter imanente, conferindo o sentido de unidade ao sistema monetário.

Dessa forma, somente o padrão monetário (unidade monetária) requer, como fundamento de sua validade, uma norma jurídica estatal, que lhe confira um caráter contrafático, no sentido proposto por FERRAZ JR. (1978). Isso em razão de se preservar a última fronteira do poder soberano, conferindo certa uniformidade aos mercados, de modo a se evitar, do ponto de vista de uma política monetária racional, empiricamente fundada, eventual fracionamento da ordem monetária enquanto sistema que se alicerça univocamente.

Do contrário, o poder emissor, enquanto uno, correria o risco de ver a si próprio desafiado pela livre conversibilidade dos ativos (passivos) que instrumentam os pagamentos, como sejam os depósitos bancários escriturados (valores), em outros ativos que sirvam como meio geral de troca, ou referenciados em outros padrões que não o uniformemente admitido pela ordem jurídica estatal, tal como tragicamente revelado em períodos convulsionados da história social.

Observe-se, por exemplo, o disposto no art. $1^{\circ}, \S$ único, incisos I e II, da Lei $\mathrm{n}^{\circ}$ 10.192, de 2001, que veda, sob pena de nulidade, quaisquer estipulações de pagamento 
expressas em, ou vinculadas a ouro ou moeda estrangeira, bem como o reajuste ou correção monetária vinculados a unidade monetária de conta de qualquer natureza.

Os instrumentos de pagamento, por sua vez, dado seu caráter essencialmente funcional, encontram seu fundamento de validade na efetividade socioeconômica de que gozam, em razão da confiança e aceitação geral entre os agentes econômicos atuantes no mercados (GUDIN, 1976).

Mesmo na visão de alguns juristas de escol (ASCARELLI, 1969; NUSSBAUM, 1925), o principal fator para a determinação jurídica daquilo que seja um instrumento de pagamento reside no comportamento social. Não se há olvidar de que, historicamente, somente o instrumento cunhado que se revista de características e condições reconhecidas socialmente tem poder liberatório dos vínculos obrigacionais (DE CHIARA, 1986, p. 18).

Segundo MISES (2005), a ordem jurídica recepciona alguns instrumentos de troca já acolhidos pelo mundo dos negócios, conferindo-lhes o caráter de exigibilidade do pagamento.

Não obstante sua razão empírica, econômica, esse argumento de MISES não difere essencialmente daquele adotado pelos juristas citados (em particular, ASCARELLI, 1969), pois que se fundamentam numa visão estática do sistema jurídico. Dessa forma, haveria uma dicotomia conceitual entre o sentido econômico da moeda, enquanto referencial de troca (padrão de valor e meio de troca), e seu sentido jurídico, enquanto padrão de conduta jurídica (instrumento de pagamento).

Do ponto de vista de um sistema jurídico interativo, aberto e dinâmico, a assertiva anterior não permite uma fundamentação racional da eficácia social (efetividade) como critério de validade jurídica dos instrumentos de pagamentos presentes em determinado sistema monetário, que os ordena e regula juridicamente.

Ressalte-se, novamente, que a noção comum de moeda refere o instrumento físico utilizado na intermediação de trocas e na liberação de vínculos obrigacionais, ou seja, o meio de pagamento. No entanto, cada vez mais se prescinde de instrumentos divisionários para a efetivação de pagamentos, recorrendo-se largamente a cheques, cartões de débito ou crédito e mesmo transferências eletrônicas de fundos para a liquidação dos mais variados negócios do cotidiano.

Igualmente, recorde-se que a liquidação de pagamentos se efetiva mediante transferências de fundos entre os parceiros nas trocas (fluxos monetários), convergindo para os depósitos bancários, pela liquidação das obrigações interbancárias nas câmaras de 
compensação e, não raro, dos créditos dos próprios bancos junto ao banco central (reservas bancárias). Dessa forma, os mecanismos de troca instrumentada por moeda requerem apenas a existência da unidade de valor, padrão de referência que quantifica os pagamentos, em última instância, a unidade do sistema monetário. Portanto, a unidade ideal estabelecida pela ordem jurídica, identificada apenas por um nome (OLIVECRONA, 2012).

Para o cumprimento adequado de suas funções, cabe à ordem jurídica definir a competência para estabelecer o padrão monetário. A conotação de moeda atribuída a determinados vocábulos se subordina ao contexto social em que se insere o ordenamento jurídico, estabelecendo-se o caráter de validade de sua utilização (efetividade jurídica). A mudança de um padrão monetário acarretaria, portanto, a perda da conotação de moeda nacional, conservando, no entanto, outras denotações que o contexto histórico lhe atribua.

Entende-se a moeda, portanto, como instrumento de comunicação, de especial dimensão, seja em razão de encaminhar o relacionamento entre o Estado e os administrados, tal como na imposição tributária, nos orçamentos e nos limites da função de governar, seja por sua inerente e necessária correlação com os mecanismos de mercado (DE CHIARA, 1986, p. 52).

Do articulado, restringir-se-ia a validade jurídica, formal, porquanto contrafática, à moeda enquanto unidade essencial do sistema monetário, validade essa conferida por uma norma fundamental desse sistema (norma-origem, no sentido da pragmática jurídica FERRAZ JR., 1978), tendo como fundamento a ordenação jurídica de poder, no caso em tela, do poder emissor, tendo em vista a materialidade histórica do fenômeno monetário a encaminhar a solução racional de uma política monetária adequada a esse contexto e aos valores que orientam o ordenamento. A legitimidade jurídica do padrão monetário enquanto reflexo direto do poder estatal exigiria, portanto, uma fundamentação formalística de caráter concentrado e geral.

No que tange à moeda enquanto instrumento de pagamento presidindo a vida de relação econômica, tendo em mira sua natureza funcional e seu forte caráter socializante, impõe-se uma abordagem não positivista para sua fundamentação jurídica como elemento do sistema monetário (FARIA, 2004).

Nesse sentido, caberia lembrar a lição de Aarnio (1991, pp. 123, 295 apud 
FREITAS $^{11}$, 2002, p. 48, n. 44), que vê no mundo da vida a fonte última de legitimidade, balizada por uma aceitabilidade racional elevada a princípio regulador da comunidade jurídica. Assim, toda razão passível de uso como base justificativa da interpretação deveria ser tida como fonte jurídica, sendo razoável que se intente interpretações aptas a contar com o apoio consensual de uma comunidade jurídica que opera racionalmente.

De modo confluente, FREITAS (2002) destaca dois pontos centrais a serem realçados na hermenêutica jurídica: a exigência de racionalidade e a de aceitabilidade dos conteúdos.

Em consequência, extrapolando-se a lição anterior para o contexto diversificado dos ramos científicos que abordam o fenômeno monetário, cabe racionalmente o argumento que vê na moeda enquanto meio de pagamento um símbolo social que dá sentido (conteúdo) às diversas relações de troca que se estabelecem na vida de relação, sob o regime de mercado, devendo seu fundamento de validade à aceitabilidade pelos agentes de mercado, do ponto de vista tanto da ciência econômica (monetária) como da jurídica.

Dessa forma, diante da estrutura funcional e institucional dos modernos sistemas financeiros, a função liberatória da moeda de emissão estatal como de outros ativos financeiros nela conversíveis (substitutos do dinheiro), ofertados pelo sistema bancário enquanto meios de pagamento em sentido largo (SCHUMPETER, 1964a, 1982), confere a eles o caráter de moeda enquanto elemento do sistema jurídico monetário.

O poder liberatório, frise-se, nada mais é que o corolário jurídico da liquidez enquanto característica funcional que fundamenta a capacidade de circulação de um ativo financeiro, em última instância, sua negociabilidade nos mercados financeiros, tornando-o apto, portanto, a servir como moeda, seja instrumentando pagamentos (fluxos monetários), seja como reserva para investimentos (poupança).

Tem-se, assim, racionalmente fundamentada a juridicidade dos meios de pagamento presentes nos mercados e nos sistemas financeiros (incluso o sistema de pagamentos), que lhes dão funcionalidade. Sua validade jurídica se deve antes à sua presença efetiva na instrumentação das operações em curso, possibilitando sua normatização em caráter difuso, derivado. As normas que os dimensionam nas relações do sistema monetário se legitimam em razão da materialidade fenomênica tornada substrato normativo, interagindo com esse sistema e seus elementos, fornecendo ao dinheiro (riqueza

11 AARNIO, Aulis. Lo racional como razonable: um tratado sobre la justificación juridica. Madrid: Centro de Estudios Constitucionales, 1991. 
financeira) circulante, em última instância, o caráter jurídico de moeda.

Não por outra razão, o entendimento do sistema de pagamentos requer previamente a caracterização do fenômeno monetário tanto no âmbito da evolução socioeconômica como da própria ciência econômica (análise monetária), dado o papel central desse sistema na economia monetária contemporânea, cujo funcionamento permeia a própria ordem econômica e, portanto, os arranjos institucionais que dão efetividade ao sistema monetário, sobretudo através das políticas econômica e monetária. 


\section{OS FUNDAMENTOS ANALÍTICOS DA ECONOMIA MONETÁRIA}

\section{A evolução socioeconômica da moeda}

A atividade econômica se orienta pela busca de utilidades (bens e serviços) necessárias (desejadas) ou das possibilidades de sua apropriação (poder de disposição). Em sentido estrito, no entanto, somente o exercício pacífico desse poder de disposição, orientado economicamente de forma prioritária, caracteriza a economia (WEBER, 2011, p. 23 e ss.).

O poder de disposição, em sentido econômico, se caracteriza pela autonomia, não sendo apenas instrumental em relação ao próprio titular. Característica relevante é a própria capacidade laboral: o escravo, por exemplo, é instrumento econômico de seu senhor, da mesma forma que o operário de fábrica tem no seu trabalho um meio de produção a serviço do capitalista.

O elemento pacífico é também indispensável, vez que qualquer forma de violência, tal como a pilhagem de guerra, ainda que orientada economicamente, se submete a outras regras que não as de transferência (apropriação) por meios pacíficos. Não obstante, há sempre um elemento coercitivo por detrás da economia, seja o Estado moderno ou os antigos estamentos, mas somente como meio assecuratório da atividade econômica (WEBER, 2011).

Nesse sentido, o aspecto jurídico da economia, operando na exclusão do acaso, torna-se imprescindível para a garantia da satisfação das necessidades humanas como forma fundamental da existência social, e a organização regulada dessa satisfação, desenvolvendo-se à medida que as necessidades socioeconômicas acompanham o evolver das relações da vida (JHERING, 1953, p. 100 e s.).

Por último, a atividade econômica em sentido estrito deve ser constante e precípua, não apenas esporádica ou acidental.

A ação econômica ocorre primordialmente através da unidade (associação) econômica, sendo autocéfala enquanto condicionante de seu grupo dirigente na consecução da atividade economicamente orientada e de forma prevalente. Há hipóteses outras cujo escopo da associação não se direciona à intervenção direta na vida econômica, distinguindo-se, então, associações com gestão econômica acidental, ou ainda associações voltadas à ordenação da atividade econômica de outras associações, fixando-lhes normas 
gerais, ou mesmo as regulamentando materialmente de modo integral.

A atividade econômica em si mesma pode ter como escopo: a) a distribuição planejada das utilidades disponíveis; b) a produção e distribuição planejadas dessas utilidades; ou c) a aquisição do poder de disposição sobre as utilidades, quando essas se encontram em poder de uma economia alheia. Na última hipótese, os meios (pacíficos) de apropriação consistem na formação de uma associação econômico-reguladora (entre os titulares do poder de disposição), ou no intercâmbio (troca).

A associação econômico-reguladora compreende dois tipos básicos: a) associação administrativa (economia planificada ou autárquica); e b) associação reguladora. A primeira se expressa por uma direção econômica unitária das diversas unidades de produção, utilização ou distribuição das utilidades, segundo um planejamento centralizado. A segunda, por sua vez, se presta a regulamentar as atividades econômicas de seus integrantes, eliminando a concorrência interna através do racionamento da produção e do consumo.

O intercâmbio ou troca pode ser: a) ocasional, característico de épocas primitivas, abrangendo apenas o excedente produzido, pois o abastecimento se faz prioritariamente com a produção da unidade econômica fundamental; ou b) mercantil, caracterizado pela oferta e demanda de bens em caráter geral (mercadorias), portanto, pela existência de probabilidades de mercado.

Quando a troca no mercado consiste na forma prevalecente da economia, tem-se uma economia de trocas em sentido estrito. A troca se baseia na luta pacífica por meio dos preços, no regateio, e eventualmente na competição. Do ponto de vista jurídico, a troca pode estar regulada de modo formal, como na economia capitalista livre, ou de modo material, mediante guildas, grêmios, monopólios etc.

Há que se observar, no entanto, que a troca pode ser natural (em espécie) ou por dinheiro. Somente na troca instrumentada pelo dinheiro se constitui plenamente a orientação da atividade econômica segundo as possibilidades mercadológicas, no sentido de uma economia de trocas, caracterizando, portanto, uma vida econômica em sentido próprio (HUGON, 1973, p. 31; WEBER, 2011).

$\mathrm{O}$ instrumento ou meio de troca se constitui geralmente em um objeto que, reiteradamente e em larga escala, é aceito por um círculo de pessoas somente em razão de que se espera poder utilizá-lo em trocas futuras.

Observe-se, no entanto, que nem sempre os meios de troca e os de pagamento são 
idênticos. O meio de pagamento é somente um elemento genérico que permite a realização de determinadas prestações, tal como o pagamento de dívidas; não obstante, nem todas as dívidas correspondem a operações de troca, tal como os tributos. A história econômica traz evidências a esse respeito: na África, as vacas eram meio de pagamento, mas não de troca; entre os mongóis, as autoridades fizeram circular moeda de papel para as trocas, mas que não era aceita como meio de pagamento de impostos. De modo similar na Áustria, onde, em determinado período, moedas de ouro só se utilizavam para pagamento de taxas aduaneiras. Aliás, nem todo meio geral de troca gozou, sempre, de universalidade: na África, novamente, não se adquiriam as mulheres com moedas de concha, mas somente em troca de rezes (WEBER, 2011).

Frise-se que dessas duas funções, meio (legal) de pagamento e meio (geral) de troca, a de meio de pagamento é a mais antiga - nessa fase, aliás, o dinheiro nada tem a ver com a troca (WEBER, 2011, p. 255) ${ }^{12}$. A aquisição dessa peculiaridade ocorre a partir do momento em que uma economia sem trocas conheça determinadas prestações econômicas que também requeiram meios de pagamento, sem lastro em troca econômica, tal como tributos, presentes aos chefes tribais, dote, multas, soldos etc.

Já a função do dinheiro como meio geral de troca tem sua fonte mais remota no comércio exterior (WEBER, 2011, p. 256 e s.). O estado de paz entre os impérios antigos pressupunha uma troca de presentes entre os seus soberanos, originando o comércio entre soberanias: assim, por exemplo, no Egito e no Oriente antigos. A quebra de tal intercâmbio entre soberanos denotava um estado de beligerância. Outra fonte reside no comércio tribal em que mercadorias exóticas, muito difundidas, não se encontravam nos mercados locais. Desde que pagamentos de caráter mercantil houvessem de ser feitos, tal como em troca da segurança prestada aos mercadores estrangeiros por chefes locais, os meios disponíveis para tanto eram os trazidos por aqueles mercadores, penetrando, assim, a moeda estrangeira no tráfico interior.

Como relata WEBER (2011, p. 255 e ss.), nessa fase evolutiva apresenta o dinheiro a seguinte tipologia: a) dinheiro ornamental, composto de uma série de objetos empregados, em proporções distintas, como meio de pagamento ou de troca, tal como as conchas cauri, na África e territórios do Oceano Índico, servindo em princípio ao comércio

12 Em sentido contrário, FRIEDMAN (1994, p. 27), ao afirmar que antes do abandono definitivo do padrãoouro pelo mundo, na esteira do governo norte-americano (1971), "toda moeda importante desde tempos imemoriais, estivera vinculada direta ou indiretamente a uma mercadoria”. Infere-se, portanto, ser antes a moeda um meio de troca que de pagamento; no entanto, o citado autor não apresenta razões históricas suficientes que justifiquem tal assertiva. 
interior e, mais a frente, também de meio de troca ao comércio exterior devido à utilização uniforme de determinado objeto como meio de pagamento por diferentes tribos; b) dinheiro utilitário, composto por objetos de uso geral, geralmente artigos de consumo em larga escala, tais como trigo, gado, tabaco, sal, armas ou escravos, e que se utilizavam, em princípio, como moeda para o comércio exterior, expressando tanto as obrigações de pagamento como as valorações de outros bens; c) dinheiro indumentário, tal como peles, couros ou tecidos, geralmente servindo à circulação interior; e d) dinheiro-signo, ou seja, meros signos sem representação de valor algum, introduzidos pelo costume social de se considerar determinadas coisas como objeto de propriedade ou de utilizá-las como meios de pagamento, tais como as fichas de jogo chinesas, na Indochina inglesa, ou o dinheiropele, na Rússia, os quais não tinham sequer valor de uso.

Haja vista não haver nessa fase um meio de pagamento único, senão que circulem como tal diversos, simultaneamente, resulta indispensável o estabelecimento de uma equivalência, de modo a se fixar uma escala de valores. Para tanto se utilizava, em regra, mais de uma classe de objetos a fim de se constituir uma unidade de pagamento, tal como na ilha de Java, onde tal unidade se fixava em uma pedra de determinado valor e de vinte conchas de nácar, ou nas tribos indígenas norte-americanas, em que se fixava o preço de compra de uma mulher como equivalente ao equipamento integral para um guerreiro índio. A base de tais valorações não repousa apenas na utilidade econômica, senão antes no valor de uso de certos bens, seu valor social segundo as tradições, ou ainda na necessidade contábil de manuseio com algarismos inteiros, em particular as dezenas. Também os acordos ou compromissos, as multas e tarifas expressas em dinheiro se fixam mais em razão de seu valor social que de sua utilidade econômica. Assim, por exemplo, um franco livre valia duzentos soldos, em comparação com o compromisso a ser pago por um semilivre ou por um servo. São, em suma, valorações de cunho social assim estabelecidas pela tradição, expressas por meio de tarifas. Frise-se, contudo, que a avaliação ou valoração em determinada tipo de dinheiro não implica necessariamente que o pagamento seja efetuado sempre na mesma classe de moeda, servindo apenas como valoração global para a estimativa da prestação obrigacional ${ }^{13}$.

13 Note-se que o desenvolvimento das relações econômicas de troca já traziam consigo fenômenos inflacionários incipientes, tais como se verificam entre tribos nigerianas, em razão do fabrico artificial, em excesso, de objetos aceitos como forma geral de pagamento no intercâmbio tribal, ou ainda na alta Idade Média, com a exigência de importes superiores às tarifas tradicionalmente cobradas para o desenlace de compromissos, cujos valores anteriores correspondiam apenas às indenização por dano (WEBER, 2011, p. 258 e s., n. 33). 
Em razão das circunstâncias anteriormente indicadas, compreende-se mais facilmente a evolução paulatina que culmina na aceitação geral dos metais nobres como base da organização monetária. Tal imposição se dá sobretudo por razões de ordem técnica: os metais preciosos dificilmente se oxidam, não se alterando sua substância; são relativamente escassos, gozando, portanto, de valor econômico elevado quando comparados com outros objetos ornamentais; e, por último, são mais facilmente trabalháveis e divisíveis. Como fator decisivo, tem-se ainda a utilização da balança para pesá-los. Desde cedo foram os metais preciosos empregados como bens de consumo, mas sobretudo como meios de pagamento, antes mesmo de serem utilizados como meios de troca: na qualidade de meios de pagamento já apareciam preferencialmente no intercâmbio comercial da Ásia Menor, cujos soberanos esperavam do faraó o ouro em ornamentos; mas também como forma predileta de presente do príncipe a seu séquito. Nessa última hipótese, aliás tão antiga quanto a anterior, reside outra função típica do dinheiro, qual seja, a de meio de entesouramento ou, em linguagem atual, reserva de valor - daí o imenso valor atribuído ao tesouro tanto pelo rajá hindu como pelo rei merovíngio. Nesse caso não é ainda o dinheiro sequer meio de troca, mas simplesmente objeto de propriedade permanente, sendo acumulado sobretudo por razões de prestígio social. Em consequência, sua qualidade mais importante deve ser a durabilidade, característica dos metais nobres, muito mais que sua facilidade de transporte. Nessa condição de criador de propriedade individual radica, em princípio, a própria origem do dinheiro ${ }^{14}$, pois não há objeto que tenha revestido seu caráter que não tenha sido objeto de propriedade, aí incluso o direito sucessório (WEBER, 2011, p. 254).

$\mathrm{Na}$ forma de moeda surge o dinheiro, pela primeira vez, no século VII antes de nossa era, supostamente na costa da Lídia, em virtude da cooperação entre o rei e as colônias gregas. Precursor da moeda foi o lingote de metal nobre, selado ou autenticado por comerciantes e utilizado inicialmente no comércio indiano e, mais tarde, na Babilônia e na China. Somente muito mais tarde surgiu o interesse dos poderes públicos pela cunhagem, até se chegar a seu monopólio. Assim, por exemplo, o rei persa ordenava a cunhagem de suas moedas para pagamento dos mercenários gregos a seu serviço, bem como em Cartago, somente para o pagamento de mercenários. Como meio de troca, no

14 Nesse sentido, assevera ARISTÓTELES (1985, p. 26) que “a arte de enriquecer está especialmente vinculada ao dinheiro, e que sua função é descobrir as fontes capazes de proporcionar um suprimento maior de produtos, no pressuposto de que esta arte cria riquezas e posses; efetivamente, presume-se que a riqueza consiste em grande quantidade de dinheiro, pois é com o dinheiro que se fazem os negócios e o comércio". 
entanto, deve-se aos gregos sua introdução no comércio de mercadorias: a vantagem técnica do uso da moeda constitui o principal fator de superioridade do comércio helênico em relação aos seus contemporâneos, tal como o comércio fenício, que se realizava sem o dinheiro. Também Roma, apesar do acentuado comércio passivo desde os primórdios, tardou muito na cunhagem de moeda, sendo iniciada pelas de cobre, mas ainda em circulação simultânea com diversas classes de moeda, até que se decidiu pela cunhagem da prata, em 269 a.C.

A técnica da cunhagem era praticamente artesanal até o século XVI, sendo que na Antiguidade a moeda era fundida e, no Medievo, cunhada, cujo custo era extremamente elevado, podendo alcançar até um quarto de seu valor de face, decrescendo continuamente, mas ainda em torno de $10 \%$ entre os séculos XIV e XV. Essas circunstâncias não raro importavam em oscilações no peso das moedas cunhadas (p. ex., a coroa de ouro inglesa, apesar de sua relativa perfeição, apresentava uma oscilação em torno de 10\%). Em geral, o comércio reagia a isso aceitando apenas moedas a peso, quando possível. A autenticação (selagem) constituía uma garantia relativamente segura da lei do metal. A primeira moeda com certo grau de exatidão foi o florim de ouro de Florença (1252). Sem embargo, até fins do século XVII não gozava a cunhagem de verdadeiras garantias técnicas ${ }^{15}$.

O padrão metálico, ou seja, a aceitação de determinadas moedas como meios de pagamento, seja ilimitadamente (padrão monetário), seja limitado a um montante máximo (moeda divisionária), foi de uso generalizado ao longo da história econômica. O padrão monetário pode ser monometalista ou bimetalista. O bimetalismo, por sua vez, pode se caracterizar pelo padrão duplo, ou seja, os vários metais, presentes na mesma moeda, guardam entre si uma proporção fixa estabelecida por lei, tal como na época contemporânea se estabelecia uma relação fixa do ouro com a prata, ou pelo padrão paralelo, mais frequente no passado. Nessa última hipótese havia liberdade plena de cunhagem, sem relação fixa entre os diferentes metais, sendo determinantes as necessidades do tráfico para a escolha do metal a ser cunhado. Assim, por exemplo, o comércio interior e local se realizavam, em regra, com base em metais não tão nobres como padrão monetário, tais como o cobre e a prata. Já o comércio exterior, conforme crescia em importância, substituía o uso da prata pelo do ouro. No mundo ocidental, a evolução das relações de valor entre os distintos metais usados na cunhagem monetária

15 A técnica de serrilhamento das moedas (recortes serreados em torno da circunferência) foi empregada a partir de 1663, sendo utilizada na Inglaterra pelo Grande Recunhamento, de 1696 a 1698, tornado a cunhagem muito mais homogênea. 
ocorreu praticamente sem solução de continuidade. Estabeleceu-se na Babilônia uma contabilidade em prata, os chekel, autenticados por particulares, cuja relação da prata com o ouro era de treze e um quarto por um, sendo que tal relação subsistiu praticamente ao longo de toda a Antiguidade.

Em Atenas, apesar da política de enfraquecimento do título das moedas praticada por Sólon (594 a.C.), durante os quatro séculos seguintes, até o domínio romano, a dracma manteve constante seu conteúdo em prata (65 grãos de prata), tornando-se a moeda padrão no comércio grego, bem como em boa parte da Ásia e Europa, continuando a ser cunhada e amplamente usada mesmo após a conquista romana (FRIEDMAN, 1994, p. 50 e ss.).

No que tange ao padrão monetário, a política de Roma influiu decisivamente entre o final da Antiguidade e o início da Idade Média, até a dinastia merovíngia. No princípio predomina de modo efetivo o padrão paralelo entre cobre e prata, na proporção de 112:1. A criação do sestércio de prata (269 a.C.), equivalente a uma libra de cobre, se revestiu de importância decisiva no estabelecimento de um padrão metálico, pois que o ouro cunhado servia apenas ao tráfico comercial, enquanto o cobre se reduziu progressivamente à condição de moeda de crédito para o comércio de menor importância, funcionando como moeda-signo. Note-se que a cunhagem era realizada sobretudo pelos chefes militares, cujos nomes se encontram geralmente nas moedas de prata e ouro do período republicano. Essa cunhagem tem por base o botim e se realiza antes com a finalidade de pagamento das tropas do que para atender a necessidades econômicas. A partir da criação do Império por César é que tem início a regulação monetária definitiva: o aureus cesarino (87 a.C.) refletia a adoção do ouro como padrão, devendo valer cem sestércios de prata, tendo por base a proporção de 11,9:1. Verifica-se, com isso, que a prata teve acréscimo em seu valor como sintoma de sua maior demanda. O aureus subsistiu até o tempo de Constantino, já a prata sofreu diversas alterações, entre elas a adulteração de sua cunhagem ocasionada pela introdução do denário de Nero (54 d.C.), fazendo com que aumentasse o prestígio do aureus. Deve-se a Caracala e seus sucessores da casta militar a política sistemática de exploração do negócio de adulteração (depreciação) de moedas, reduzindo-se o conteúdo do metal precioso das moedas de ouro e prata enquanto se aumentava a proporção da liga para três quartos ou mais do peso da moeda, provocando assim a degeneração do denário de prata em uma moeda de cobre banhada a prata ou a estanho. Essa adulteração durou 
mais de três séculos, o que levou a organização monetária romana à ruína ${ }^{16}$. A restauração monetária se deve ao imperador Constantino, substituindo o aureus pelo soldo de ouro, tendo por base 72 peças por libra $(327,45 \mathrm{~g})$ de ouro - supõe-se que esse soldo era contado a peso no uso comercial. Essa moeda gozou de grande prestígio ainda na época merovíngia, sobretudo nas áreas onde a economia romana havia imperado.

Não obstante a relevante importação de ouro do Oriente, o império carolíngio, por sua vez, conheceu a passagem do padrão ouro para o padrão prata, na base de uma libra monetária de $409 \mathrm{~g}$, dividida em vinte soldos de prata de doze denários (dinheiros) cada um. Oficialmente, o sistema monetário carolíngio, cuja última sobrevivência foi o sistema monetário britânico (libra, xelim e pence), permaneceu em vigor até fins da Idade Média ${ }^{17}$, tendo a prata como padrão predominante em quase todo o continente europeu ${ }^{18}$.

Observe-se, no entanto, que o problema fundamental do sistema monetário medieval nada teve com o padrão monetário adotado, senão que residiu em questões de caráter socioeconômico em torno da produção de moedas. A Antiguidade conheceu de modo decisivo o monopólio monetário estatal, ao passo que a Idade Média vivenciou um fracionamento considerável da fabricação de moedas entre diversos territórios (PIRENNE, 1963, p. 116 e ss.; WEBER, 2011, p. 264). Assim que, desde o século XI, o sistema monetário carolíngio vigorava como mero direito comum nos diversos territórios do império, de modo que o privilégio da cunhagem permanecia em poder da Coroa, mas se efetivava por meio de um sistema cooperativo artesanal, pertencendo aos senhores feudais os rendimentos gerados pelo negócio de cunhagem. A concessão indiscriminada daquele privilégio resultou no incentivo à prática da adulteração de moeda, alcançando proporções extraordinárias no decorrer de todo o Medievo ${ }^{19}$. Na Alemanha, por exemplo, entre os

16 Segundo FRIEDMAN (1994, p. 51), a adulteração monetária em Roma apenas refletiu a ausência de uma política fiscal explícita para o financiamento governamental, mas piorando, sem dúvida, a situação econômica do Império, sendo um dos fatores que levaram Roma ao colapso.

17 É paradoxal o fato de que o sistema monetário carolíngio tenha servido de base a todo o sistema europeu do antigo regime, vez que se estabeleceu justamente quando a circulação monetária havia atingido seu nível mais baixo, desde o merovíngio, em face de uma economia agrícola e sem comércio. Com efeito, o soldo de ouro de Constantino, cunhado no ocidente em nome dos reinos bárbaros após a queda de Roma, conquanto moeda internacionalmente aceita - da Síria à Espanha e desde a África até as fronteiras setentrionais da Gália -, não teria como subsistir diante do desmoronamento comercial resultante da ruptura, no século VIII, da economia antiga (comércio mediterrâneo) devido às invasões muçulmanas. Nesse sentido, é indubitável o papel relevante de Carlos Magno ao dotar a sociedade da época de uma moeda adequada à economia rural e sem mercados exteriores, implantando o monometalismo da prata (PIRENNE, 1963, p. 113 e s.).

18 A libra portuguesa correspondia a doze marcos de prata, conforme regimento régio de 1253 (JANSEN, 2009, p. 109).

19 Tal prática consistia no cerceamento (raspagem das bordas das moedas) ou desgaste (colhimento do pó resultante do atrito entre as moedas), permitindo que moedas mais leves fossem postas em circulação pelo 
séculos XIII e XVI passou o soldo a um sexto de seu conteúdo original, tendo o mesmo ocorrido na Inglaterra, entre os séculos XII e XIV; em França, o solidus grossus se reduziu a um sétimo de seu valor original entre os séculos XIV e $\mathrm{XVI}^{20}$. Justamente essa adulteração da moeda de prata resultou no aumento do prestígio do ouro como moeda comercial, dado interesse dos comerciante em reger seus negócios por unidades constantes $^{21}$. Fato marcante desse período foi a cunhagem, em 1252, de um soldo de ouro de 3,5g de peso, o florim de Florença (florenus), que se generalizou como moeda básica corrente para os cálculos do comércio, sobretudo em razão de sua duradoura cunhagem sempre com o mesmo conteúdo. Até 1500 , a proporção da prata em relação ao ouro cresceu de 12,5:1 para 10,5:1, entretanto, oscilações nas cotações relativas ocorriam simultaneamente, estabelecendo-se ainda diferenças entre o metal em lingote e o amoedado. Enquanto no comércio atacadista o cálculo se fazia à base de lingotes ou florins florentinos, no comércio a retalho o "valor" das moedas era atribuído ad hoc. A depreciação da moeda não resultou apenas da cobiça dos detentores do privilégio de cunhagem, mas também em virtude das diferenças existentes entre moedas da mesma classe, em torno de $10 \%$, permanecendo assim somente as moedas leves, de pior qualidade, em circulação, enquanto que as pesadas, de melhor qualidade, eram selecionadas e refundidas, ou ainda estocadas pelo valor metálico ${ }^{22}$. A cobiça dos detentores da regalia da cunhagem agravava tal situação na medida em que se aproveitavam desse monopólio para emitir novas moedas, retirando de circulação as antigas ${ }^{23}$. Não obstante, essas últimas ainda circulavam além dos limites das jurisdições daqueles senhores feudais, o que impedia, de fato, a imposição de qualquer monopólio monetário, situação essa que se modifica somente a partir da realização de convênios monetários entre diversos príncipes. Abstraindo-se, portanto, da cunhagem e vigor do florim florentino, deve-se concordar com

seu valor (original) de face.

20 Em 1378, a libra portuguesa foi fortemente desvalorizada, passando a corresponder a 1/25 do marco de prata de onze dinheiros, prosseguindo a depreciação até sua substituição pelo real, em 1427 (JANSEN, 2009, p. 112 e ss.).

21 Nesse sentido, é digna de nota a suspensão da vedação de circulação de moedas de ouro, em 1391, por d. João I de Portugal, atendendo aos reclamos das Cortes de Évora (JANSEN, 2009, p. 114).

22 Daí a conhecida "lei" de Gresham (Sir Thomas Gresham, conselheiro financista da rainha Elizabeth da Inglaterra), segundo a qual "quando duas moedas, ligadas por uma relação legal de valor, circulam ao mesmo tempo dentro de um país, aquela que é considerada como a melhor das duas tende a desaparecer" (GUDIN, 1976, p. 43), o que também se exprime, de modo menos rigoroso, pela proposição de que o dinheiro ruim expulsa o bom, desde que haja uma taxa de câmbio fixa entre eles (FRIEDMAN, 1994).

23 Periodicamente, editos públicos proibiam a circulação das moedas em curso e impunham aos súditos sua entrega às fábricas de moeda, retornando à circulação sob a forma de moedas de menor peso e maior amálgama, resultando a diferença em prol dos príncipes. A esse processo de apropriação, espécie de tributo, se denomina senhoriagem (LOPES, 1980, p. 25). 
WEBER (2011, p. 265) no sentido de que a Idade Média representou uma época de irracionalidade no campo monetário. Precisamente em razão dessa irracionalidade que permeava a fabricação de moedas, a livre cunhagem resultara num fato natural, pois que o senhor que detinha seu privilégio arbitrava livremente o volume de moeda cunhada a fim de obter seu benefício, buscando atrair para si a maior quantidade possível de metal nobre. Proibições de exportação de tais metais nos territórios onde havia minas não logrou efeito devido ao contrabando em larga escala. Ademais, mesmo quando se produzia moeda para outros territórios, mediante contrato, aquelas moedas acabavam por retornar ao território de origem na qualidade de moeda estrangeira. Tal comércio de moedas assim perdurou durante toda a Idade Média, pois resultava impossível se aferir a aceitação de que gozava cada classe de moeda, sobretudo em razão das fortes oscilações no volume de cunhagem, tendo somente a competição entre os próprios detentores dessa regalia ocasionado um decréscimo na produção de moeda.

Sob o prisma econômico, somente a partir do século XVI, com o crescente influxo de metais nobres, evidencia-se no ocidente europeu o estabelecimento de relações fixas no regime monetário do padrão metálico. Do ponto de vista político, o estado absolutista põe fim à pluralidade de titulares de privilégios monetários e à sua competição ${ }^{24}$. Diversos fatores econômicos contribuíram para tal resultado: o descobrimento da rota marítima das Índias orientais, encerrando o monopólio árabe no intercâmbio comercial; a exploração das minas mexicanas e sul-americanas, resultando num grande aporte de metais nobres para a Europa; e, ainda, a descoberta do procedimento técnico de beneficiamento da prata à base de seu amálgama com o mercúrio. Em termos de afluxo de metais para a Europa, entre 1493 e 1800, estima-se em 2,5 mil toneladas de ouro e 100 mil toneladas de prata. De início, tal incremento resultou em forte acréscimo da prata amoedada, alargando-se as fronteiras do padrão prata por todo o tráfico comercial, inclusive como unidade de conta. Na Alemanha, por exemplo, o florim florentino, de ouro, foi largamente substituído pelo Joachimstaler, de prata. Essa situação só se modifica com o afluxo do ouro vindo das minas do Brasil, a partir do século XVIII, em que pese sua produção ter sido breve, por pouco mais de meio século. Não obstante, o ouro se impôs no mercado europeu, sobretudo na Inglaterra, onde se adotou somente esse padrão. A partir de meados do século XVIII, no

24 O papel estatal desempenhado no monopólio da cunhagem visa não só à garantia do peso e toque da moeda, facilitando as operações por conta, ou número, não pelo peso, o que de fato reduz os custos dos negócios, mas sobretudo à política fiscal de arrecadação, pois que gera a senhoriagem, i.e., o tributo cobrado pela conversão do metal em barra em moeda, realizada pela casa da moeda. 
entanto, a produção de prata retorna ao primeiro escalão, resultando assim na adoção do padrão bimetálico na França e no restante do continente.

No que tange especificamente ao comércio, a partir dos séculos XIII e XIV se acentua progressivamente a emancipação da cunhagem monetária, sobretudo em razão da instabilidade e depreciação das moedas metálicas. $\mathrm{O}$ cálculo era feito em barras de metal nobre, aceitando-se as moedas circulantes somente à base de pesagem e fixando-se os pagamentos em determinada classe de moeda, predominando nessa quadra o florim florentino. Essa situação gozava de reconhecimento por parte do Império, em caráter de costume. Tal processo monetário no âmbito comercial culminou na utilização da liquidação dos pagamentos por meio de bancos de giro ou desconto, à semelhança do modelo adotado na China, onde a adulteração da moeda acarretara a introdução de bancos de desconto metálico em atendimento às necessidades mercantis. Fixou-se, dessa forma, uma unidade de peso em prata, realizando-se os pagamentos ao banco de giro, por meio de cheque ou assinação análoga, devendo para isso ter o comerciante efetuado o depósito bancário em barras de metal contra o qual se sacaria a ordem de pagamento, ou alternativamente se efetuando o pagamento em barras de prata em espécie, de determinado tamanho e aferidas (tael), predominando, entretanto, os pagamentos por meio de cheque. Criou-se, assim, uma moeda bancária baseada apenas na posse de metal nobre pelo comerciante interessado, e considerada como meio de pagamento exclusivo entre as pessoas envolvidas nas distintas operações de desconto. Esse modelo teve lugar na Europa a partir do século XVI, em Veneza (Banco Rialto), depois em Amsterdã (Banco Wissel), em 1609, e mais tarde em Hamburgo (1629). Os cálculos bancários eram feitos por um sistema exclusivamente ponderal, aceitando-se somente moedas cunhadas em pagamento, de modo que a cada conta, ou pagamento, correspondia ordinariamente uma quantidade mínima de moeda. Em Amsterdã, por exemplo, o saque ou ordem de pagamento de valor mínimo importava em trezentos florins, sendo que todo pagamento superior a seiscentos florins devia ser efetuado obrigatoriamente por meio de um banco. Em Hamburgo, esse regime de dinheiro bancário sobreviveu até 1873 .

Não obstante as observações anteriores, a racionalização do sistema monetário europeu resultou num processo moroso, sujeito a percalços de todo o gênero ${ }^{25}$. A adulteração das moedas implicava repetidas recunhagens, sempre limitadas pelo custo real

25 No entendimento de FRIEDMAN (1994, p. 51), a adulteração, em si mesma, da moeda tinha de ser um processo lento. 
dos metais usados como base monetária. Ademais, numerosas classes de moedas permaneciam em vigor nos distintos países, não havendo um dinheiro no sentido atual. Assim, por exemplo, o edito de Fernando I, de 1559, versando sobre a moeda, permitia a circulação de nada menos que trinta classes de moedas estrangeiras. Ainda no século XVI, na Alemanha, apesar da imperfeição reinante entre as moedas de menor quantia, limitou-se o poder liberatório das pequenas moedas de prata, mas sem que se as transformassem somente em moeda divisionária (subsidiária), cuja criação resultou posteriormente da política monetária inglesa, já no século XVIII.

A disseminação do papel-moeda a partir do século XVIII possibilitou a aceleração desse processo. A maior parte do dinheiro em circulação passou a consistir não mais em metal nobre, mas em moeda fiduciária, ou seja, promessas de pagar quantidades específicas de ouro ou prata. Emitidas inicialmente por particulares, sob a forma de notas bancárias ou lançamentos contábeis (depósitos). Posteriormente, assume o Estado papel de relevo nessa emissão, sobretudo em razão da emissão de papel-moeda de curso forçado, ou seja, notas representando a moeda nominal (francos ou escudos), de curso legal, mas sem qualquer promessa de resgate de qualquer metal. Registra-se como primeira emissão moderna de moeda de curso forçado, em larga escala, aquela feita em França, no início do século XVIII. Também ali, posteriormente, emitiu o governo revolucionário papel-moeda sob a forma de assignats, entre 1789 e 1796. Tais experiências, no entanto, não foram bem sucedidas em razão do excesso de emissões e da consequente carestia, culminando na desvalorização drástica do dinheiro em papel, passando a ser novamente resgatado em moeda metálica, ou promessa de pagar moeda metálica, mas por frações inferiores ao valor nominal. Em verdade, todas as emissões subsequentes de moeda de curso forçado nos principais países ocidentais, incluso no século XIX, representaram afastamentos temporários do padrão metálico (FRIEDMAN, 1994). Na Inglaterra, por exemplo, houve suspensão do pagamento em ouro de notas bancárias em circulação durante as guerras napoleônicas, entre 1797 e 1816. Da mesma forma nos Estados Unidos, onde a conversibilidade em espécie da moeda da União quedou suspensa durante a Guerra Civil, restabelecendo-se somente em $1879^{26}$.

26 Observe-se que o Brasil sempre foi exceção no que diz respeito ao padrão metálico, tendo sido ínfima a circulação metálica desde o início (JANSEN, 2009, p. 124 e ss.). Quando d. João VI aqui chegou, em 1808, a situação era de penúria em termos de numerário, havendo em circulação não mais que dez mil contos de réis em moedas metálicas. A criação do Banco do Brasil, naquele mesmo ano, promoveu a colocação de bilhetes bancários em circulação, de mil réis e pagáveis ao portador, em substituição à circulação metálica. Ainda no período da Regência, em 1831, havia em circulação cerca de cinco mil 
No entendimento de WEBER (2011), a política monetária moderna se distingue daquela praticada anteriormente, sobretudo em razão de não contemplar interesses fiscais $^{27}$, de arrecadação, guiando-se antes por critérios de ordem puramente econômica, tal como o interesse do comércio em dispor de uma base fixa para os cálculos de capital. Nesse sentido, a política monetária inaugurada em Inglaterra. Ali se adotava o padrão bimetálico até 1797 , em que se pagava em prata no tráfico nacional, utilizando-se o ouro amoedado como unidade de conta no comércio exterior. Não obstante, a partir do grande influxo de ouro brasileiro durante o século XVIII, o padrão duplo impôs uma séria de complicações. Com efeito, a cunhagem de moedas de ouro crescia na mesma proporção do barateamento desse metal, ao passo que se recolhia a prata para fundição, o que ameaçava sua circulação. Em consequência, afetou-se substancialmente a capacidade de pagamento de todos os setores econômicos, tal como o pagamento de salários. Diante de tal quadro, intentou-se, em 1717, com a colaboração de Isaac Newton, então chefe da casa da moeda, a regulação definitiva do padrão bimetálico a partir da fixação do valor do guineu, típica moeda de ouro inglesa, em 21 xelins $^{28}$. Não obstante, o preço do ouro prosseguiu sua rota de baixa ao longo do século XVIII, resultando na constante sobrevalorização e sequente evasão da prata, o que levou o governo a adotar efetivamente o padrão ouro em 1774, abolindo o curso forçado da prata em operações negociais superiores a 25 libras. Sem êxito efetivo, o governo britânico se viu forçado a tomar medidas drásticas posteriormente: primeiramente a adoção do papel-moeda inconversível como padrão, entre 1797 e 1816, seguida da demonetização da prata, em 1816, e a reassunção do padrão metálico somente à base do ouro, em 1821, mantendo-se a prata enquanto moeda fracionária (subsidiária) para negócios de pouca monta, não sendo mais cunhada em seu valor pleno, portanto sem força liberatória ilimitada, o que evitava sua evasão (EICHENGREEN, 2000, p. 35) ${ }^{29}$. Na

contos de réis, compostos de notas do primeiro Banco do Brasil, então extinto, cédulas da província da Bahia, peças monetárias de cobre, legalmente emitidas, além de cobre falso. A cunhagem de cobre como recurso financeiro, adotada a partir de 1821, pretendia fortalecer o valor desse metal por meio de sua circulação como moeda, o que se mostrou inócuo desde cedo, pois sua cunhagem desordenada, pelas diversas casas da moeda provinciais, resultou em crise monetária, determinando seu resgate pelo governo através de recolhimentos compulsórios aos tesouros provinciais em troca de cédulas. Desde então se prende ao papel inconversível toda a vida econômica e financeira de nosso país.

27 Em sentido contrário, FRIEDMAN (1994), que realça a ação governamental como importante fonte de alterações na quantidade de moeda ao longo da história, destacando os ganhos fiscais com a senhoriagem.

28 Segundo SMITH (1984, p. 155), ainda em 1695, “o valor da moeda de prata não era mantido pela de ouro; um guinéu era nessa época frequentemente trocado por trinta xelins dessa moeda de prata desgastada”.

29 Como relata FRIEDMAN (1994, p. 64), seis décadas mais tarde experimentaram os Estados Unidos uma sequência correspondente àquela da Inglaterra, entre o término da conversibilidade com a adoção do padrão-papel (1873) e a reassunção do padrão-espécie baseado no ouro (1879). No mesmo sentido, 
França, em contrapartida, se adotou o padrão bimetálico baseado na prata (1803), cunhando-se mil francos com nove libras de prata (aproximadamente $222 \mathrm{~kg}$ ), enquanto que a equivalência entre prata e ouro se estabeleceu na razão de 15,5:1, vigente até a derrota na Guerra Franco-Prussiana, em 1871. Acredita-se que a extraordinária demanda de moeda pelo interior francês foi a responsável pela relativa estabilidade da relação de valor entre ambos os metais naquele país (WEBER, 2011) ${ }^{30}$. Na Alemanha, por sua vez, o padrão prata não se alterou sobretudo em razão de não haver uma instância centralizadora que impusesse o padrão ouro. Somente na Prússia se cunhou o ouro para o comércio, mas na qualidade de moeda tributada. A vultosa indenização de guerra de 1871, imposta à França, em fundos conversíveis em ouro, aliada ao aumento das reservas mundiais de ouro graças ao descobrimento das minas desse metal na Califórnia, permitiram a passagem daquele país também ao padrão ouro. Sob tais circunstâncias se criou o marco alemão, equivalendo 1.395 marcos a uma libra de ouro, na tentativa de se igualar à Inglaterra em poder econômico e liderança mundial. Resultado dessa adoção foi a grande oferta de prata ao mercado, devido a sua retirada de circulação pela Alemanha. Em consequência, a França se viu drenada do ouro e inundada pela prata, o que resultaria em grande inflação, em termos de prata, não fosse o fechamento de suas casas da moeda para a livre cunhagem de prata e a adoção subsequente do padrão ouro (FRIEDMAN, 1994, p. 131; GUDIN, 1976, p. 41 e s.).

A análise socioeconômica, pautada em evidências históricas, fornece assim fortes indícios de traduzir o dinheiro, desde o início, a fonte de propriedade individual (direitos subjetivos $)^{31} \mathrm{e}$, do ponto de vista técnico, funcionar como meio de pagamento que, simultaneamente, pode ser utilizado como meio de troca no âmbito de determinado círculo social. Não só. Dotado de "valor nominal", resultado da cunhagem de moedas metálicas, ou ainda da moderna emissão bancária, serve também de unidade contábil (WEBER, 2011).

Ressalte-se, no entanto, que tais peculiaridades técnicas do dinheiro não se

EICHENGREEN (2000, p. 35 e s.).

30 Além da extraordinária propensão do povo francês ao uso de metal como dinheiro, tanto na forma de moeda como na de depósito ou reserva, destaca-se a importância econômica no mundo de então (FRIEDMAN, 1994, p. 129). Ilustra-se esse aspecto pelo fato de que a prata monetária presente naquele país, entre 1850 e 1870, representava nada menos que $10 \%$ de toda a prata produzida no mundo desde 1493; já o ouro monetário alcançou a metade do estoque mundial em 1870. Ambos os fatores, portanto, permitiram à França vincular de modo estável a relação de preços entre prata e ouro, apesar das grandes flutuações na produção desses metais.

31 Como esclarece FISHER (1984, p. 28), o capital não é dinheiro efetivo real, mas antes o direito, medido em termos de dinheiro, a serviços e benefícios que fluem dos ativos em geral. 
vinculam necessariamente à circunstância de ter o dinheiro determinada forma exterior. Com efeito. O papel emitido pelo Banco de Hamburgo, por exemplo, similarmente a algumas instituições chinesas, trazia como garantia os depósitos de prata, cuja forma era indiferente; já as letras de câmbio sacadas contra aqueles depósitos, ao contrário, eram dinheiro (WEBER, 2011, p. 27) - ou seja, a prata era tecnicamente dinheiro, independentemente de sua cunhagem e do tipo ou forma de título que lastreasse. Outro exemplo fornece o financiamento das relações comerciais entre a metrópole britânica e as colônias americanas, que se realizava sobretudo por meio de títulos de crédito em razão da escassez de dinheiro em espécie na própria metrópole, ao longo do século XVII, e da consequente proibição de sua exportação. Dessa forma, tanto os exportadores britânicos sacavam letras de câmbio contra seus correspondentes londrinos, vendendo-as aos importadores coloniais, como o próprio governo britânico pagava por mercadorias e serviços de origem colonial por meio de letras de câmbio ou notas promissórias pagáveis pelo Tesouro ou por outras repartições governamentais. Aliás, desde 1692, antes mesmo da primeira impressão de cédula bancária na Inglaterra, em 1729, as letras emitidas pela Colônia de Massachusetts gozavam de curso legal, em substituição ao dinheiro (NUSSBAUM, 1967, p. 21, 36 e s.).

Em função da prevalência do dinheiro, sobretudo sua centralidade na instrumentação do sistema de trocas econômicas, pode-se distinguir a economia natural da economia monetária.

A economia natural se caracteriza, em princípio, por prescindir das trocas para a satisfação das necessidades das unidades econômicas que nela atuam ou, quando as contempla, geralmente as faz em espécie. Nessa última hipótese, tem-se uma economia natural de troca ${ }^{32}$.

Como exemplo de economia natural, tomem-se as civilizações ocidentais antigas, aglutinadas em castas, cujas cidades importantes estavam sempre próximas ao litoral, onde o crescente comércio exterior impulsionava o florescimento de uma economia de mercado. Apesar de o interior desses países estar desde cedo incorporado a essa incipiente economia

32 Von Martius, quando aqui esteve, entre 1817 e 1829, fez o seguinte registro sobre a economia das tribos indígenas ( $O$ estado do direito entre os autóctones do Brasil. Trad. São Paulo: Edusp, 1982, p. 42. Apud JANSEN, 2009, p. 120): "Nas tribos brasileiras só se conhece o valor relativo, mas o dinheiro lhes é desconhecido e onde eles possuem metal, serve este somente para enfeites. Por causa dessa falta total de idéias determinantes de um valor definitivo dos objetos, a aquisição de bens ou de propriedades é possível somente por permuta, visto que compra ou outros modos de adquirir são desconhecidos, e por isso as dádivas ou presentes são muito raros, e a natureza dos índios nada tem de generosa." 
de mercado, os proprietários de terras mais ao continente não dispunham de poder aquisitivo suficiente para superar um regime de economia natural, fundada na unidade econômica doméstica (oikos, casa) ${ }^{33}$, praticamente fechada.

Com efeito. A cidade antiga, por excelência, tinha na escravidão um pilar socioeconômico. Na medida em que se avança para o interior, tal regime tende contudo a desaparecer. Impulsionados à autossuficiência, os senhores de terra buscam independência em relação ao mercado, de modo a suprirem suas necessidades com mão de obra própria. Em verdade, verificou-se nas regiões mais continentais da civilização antiga um crescente retorno à economia natural, caracterizada por uma progressiva redução do mercado, predominando, assim, o regime econômico autárquico, cujo ápice ocorre na época carolíngia $^{34}$ (PIRENNE, 1963, p. 109 e ss.; WEBER, 2011, p. 160). Também no Egito antigo predominou, durante algum tempo, uma economia de trocas em espécie, mas cuja contabilidade era levada a efeito por meio de estimativas prévias em dinheiro. Dessarte, ainda que houvesse trocas econômicas, não havia dinheiro ${ }^{35}$.

33 A questão da organização econômica doméstica, da regulamentação da casa (oikonomia), ou seja, daqueles que cooperam sob um mesmo teto, na verdade, perpassa toda a estrutura política e socioeconômica antiga e medieval. A casa ou comunidade familiar, enquanto célula da vida social, sob a figura do pai de família (ARISTÓTELES, 1985, p. 17 e ss.), se sedimenta institucionalmente com o direito romano. Toda a organização da vida política e social, tanto antiga como medieval, foi concebida a partir dessa ideia: a cidade-estado, o senhor feudal, ou o monarca eram responsáveis pelo bem-estar dos membros da comunidade que, em troca, prestavam sua lealdade a essas instituições. Sob o prisma estritamente econômico, as comunidades antigas e medievais eram economias planificadas, do tipo econômico-regulador (HEIMANN, 1965; WEBER, 2011). Nesse mesmo sentido, a administração da economia doméstica é tarefa tanto do chefe de família como do estadista (ARISTÓTELES, 1985, p. 27 e s.).

34 Há um aspecto a ser ressaltado ao se conceituar como natural a economia europeia entre os séculos IX e XII, a saber, empregou-se numerário em todo pagamento em solução de uma venda e compra, tanto que a economia natural determinou a forma dos pagamentos que exonerassem totalmente, ou seja, sem qualquer outra contraprestação. Em que pese toda a organização dominial da época prescindir da moeda, é certo que havia uma circulação mínima de numerário a ponto de representar um dos fatores essenciais na dissolução daquele regime sob a influência do tráfico mercantil (PIRENNE, 1963, p. 112).

35 Outro exemplo instigante de economia natural de trocas fornece o período colonial norte-americano (NUSSBAUM, 1967, p. 9 e ss.). Conquanto o dinheiro em si mesmo simbolize a história americana, no início da era colonial havia acentuada escassez de dinheiro, sobretudo em razão do forte desequilíbrio entre o reduzido montante de dinheiro trazido da Inglaterra pelos colonos e os altos dispêndios realizados com as importações da metrópole. Não obstante, as mercadorias e os serviços eram avaliados em termos de libras, xelins e dinheiros (pences). Como costuma ocorrer em sistemas de trocas em espécie, tanto as mercadorias que proporcionam grandes excedentes como aquelas que gozam de certa durabilidade fazem as vezes de meios monetários - no caso estadunidense, o trigo e as peles de castor e, no Sul, o fumo e o arroz. Tais mercadorias foram declaradas pelos governos coloniais como aceites enquanto meios de pagamento da dívida pública, inclusive, de acordo com os preços fixados pelas autoridades locais, em termos de libras, xelins e dinheiros: tais pagamentos, ditos "rurais", se tornaram sucedâneos do dinheiro conquanto realizados pelos entes públicos. No entanto, a Colônia de Massachusetts, em 1631, prescreveu curso legal ao milho como meio de pagamento de obrigações entre particulares, sem que se afetasse contudo a utilização de outras espécies costumeiras de pagamento. Outras colônias também seguiram o exemplo, determinando a obrigatoriedade do recebimento de certos artigos pelo governo ou por credores particulares como pagamento. A escassez monetária, portanto, resultado tanto da balança comercial 
A economia monetária, por sua vez, permite uma separação pessoal e temporal dos momentos consistentes da troca, prescindindo da necessidade de correspondência entre os bens trocados, criando, assim, a possibilidade de expansão do mercado e, portanto, de suas probabilidades. Dessa forma, há uma emancipação da ação econômica em relação à conjuntura do momento da troca, permitindo a especulação sobre as futuras circunstâncias do mercado sob a estimativa monetária das possibilidades de venda e compra (WEBER, 2011). Com efeito, a onipotência do dinheiro proporciona uma expansão ilimitada da latitude econômica, quanto a tempo, lugar, pessoas e extensão (JHERING, 1953).

No entendimento de WEBER (2011, p. 28), a função monetária de denominador comum de todos os bens numa economia de troca, em senso estrito, se apresenta como premissa para a racionalidade calculadora da atividade econômica, permitindo assim uma contabilidade racional. Dessa forma, tal circunstância orienta uma economia lucrativa no sentido exclusivo das probabilidades de mercado, enquanto permite a uma economia de consumo o estabelecimento prévio de um plano econômico para a utilização do montante de dinheiro disponível segundo sua utilidade marginal.

Nessa ordem de ideias, é mister se anotar os dois tipos fundamentais de toda economia, quais sejam: a consuntiva e a lucrativa (WEBER, 2011, p. 28 e ss.). Ainda que entrelaçadas por algumas formas históricas de transição, ambas são conceitualmente antagônicas. A economia consuntiva se orienta ao suprimento das próprias necessidades da unidade (associação) econômica, seja o Estado, a família ou uma cooperativa de consumo, seja apenas o indivíduo. A economia lucrativa, ao contrário, se orienta no sentido das probabilidades de lucro, concretizando-se por meio do sistema (monetizado) de trocas.

Desde que presente a figura do dinheiro, ainda que de modo incipiente, as categorias fundamentais da economia consuntiva são o patrimônio e a renda. Ainda que possa haver, em princípio, renda e propriedade em espécie, ambas só encontram seu denominador comum mediante a estimativa em dinheiro. Com efeito, o tráfico jurídico somente pode reconhecer a figura unitária do patrimônio (universalidade de bens) no âmbito de uma economia de trocas baseadas em dinheiro. A renda implica a disposição, durante certo tempo, de certos bens estimados em dinheiro; o patrimônio, ao contrário, equivale à posse de bens que podem ser valorados em dinheiro, servindo ao uso da unidade consuntiva ou como sua fonte de renda.

altamente desfavorável às colônias como da proibição legal, em 1695, de exportação de moedas metálicas inglesas a partir da metrópole, originou uma economia natural de trocas, desmonetizada, ainda que aperfeiçoada e de longa duração, praticamente até a eclosão da guerra de independência. 
De outra sorte, a empresa denota uma unidade econômica lucrativa, que se orienta pelas possibilidades mercadológicas, a fim de obter lucros por meio das trocas, podendo ser esporádica, tal como uma expedição marítima - por exemplo, a commenda medieval enquanto forma capitalista de associação -, ou permanente. O objetivo de toda empresa é o lucro, ou seja, um excedente em relação aos bens econômicos nela empregados, cuja estimativa se faz em dinheiro. Para tanto, o cálculo ou conta de capital se apoia num balanço contábil que reflete o valor inicial e final do capital empregado na realização da empresa, ou ao final do período econômico, estabelecendo os lucros e os prejuízos. A universalização de tal procedimento conforma a produção e a troca de mercadorias, que passam a se orientar no sentido das possibilidades de mercado, consoante a probabilidade econômica e mercantil dos bens (PRADO JR., 1966; WEBER, 2011).

A modernidade tratou de separar a economia lucrativa e a consuntiva, aperfeiçoando-as. Contudo, nem sempre foi assim. Na Europa, até o século XVI, em princípio, não se verificava uma separação nítida entre a economia doméstica e os negócios, ainda que levados a efeito com terceiros, estranhos à família. Citem-se os Fugger e os Welser, na Alemanha, e as famílias de comerciantes florentinos, na Itália: na casa dos Médici, por exemplo, havia uma mesma conta para os gastos domésticos e para as operações monetárias com o papado. Com a difusão da comenda, empresa inicialmente ocasional, resultando na aceitação cada vez maior de comanditários estranhos à família, formas permanentes de exploração empresarial foram então criadas. A liquidação, em separado, do negócio em comandita, ensejou a separação entre a administração doméstica comum e a dos negócios externos. Com a introdução paulatina da técnica contábil medieval e, sobretudo, a necessidade de crédito e de suas garantias para empreendimentos de longo prazo, operou-se de modo decisivo a separação entre a contabilidade doméstica e a comercial (WEBER, 2011, p. 245 e s.).

A contemporaneidade econômica trouxe não apenas a separação exterior entre os negócios empresariais e a atividade de consumo privada dos seus titulares, senão a sua diferenciação contábil. Dessa forma, somente a partir do lucro contábil da empresa fluirão rendimentos destinados às economias consuntivas particulares, seja na empresa individual, seja na sociedade empresarial.

Desde que presente a moeda, ao menos como denominador comum, tanto na economia consuntiva quanto na lucrativa depende o cálculo monetário, sempre, das probabilidades de mercado, em última instância, da luta pacífica entre os membros da 
coletividade. Dessa forma, a presença do dinheiro não é inócua nem neutro o seu papel, como se fosse apenas um instrumento ou padrão de medição, senão que a avaliação, ou o preço, em dinheiro, conquanto sirva de estimativa, reflete antes uma negociação entre as probabilidades de luta no mercado mediante a atuação das unidades econômicas. Disso resulta a racionalidade formal da economia monetária, em particular quando comparada com a economia natural, pois que a monetização (o dinheiro, ou preço em dinheiro) permite a contabilidade completa de todas as possibilidades de lucro, ou prejuízo, já concretizadas ou a se concretizarem, implicando a máxima previsibilidade possível, de longe prevalecendo, ao menos do ponto de vista técnico, sobre qualquer outro tipo de contabilidade em espécie (WEBER, 2011, p. 30).

Ressalte-se ainda que a lucratividade em si mesma somente encontra seu auge na racionalidade da economia monetária.

A monetização desempenha um papel ativo no fomento da atividade econômica, sobretudo quando da introdução efetiva do dinheiro na circulação de uma economia natural de trocas, de caráter eminentemente consuntivo e pré-monetário. Contundente a esse respeito é o testemunho histórico dado, em 1764, por Benjamin Franklin à Comissão Inglesa de Comércio (apud NUSSBAUM, 1967, p. 33, n. 60636):

A Pensilvânia, antes de fabricar o papel-moeda, foi totalmente despojada de seu ouro e de sua prata... as dificuldades da obtenção de dinheiro eram, consequentemente, muito grandes, e a maior parte das operações comerciais era realizada pelo extremamente incômodo processo das trocas em espécie; quando, em 1723, aí se fabricou papel-moeda, pela primeira vez, este insuflou nova vida aos negócios e promoveu grandemente a colonização de novas terras (mediante o empréstimo de pequenas somas a pequenos juros aos iniciantes, que os pagavam em prestações), com o que aumentou de tal forma o número de seus habitantes que as exportações daqui para aí são, agora, mais de dez vezes o que eram; e, através do comércio com colônias estrangeiras, pôde-se obter grandes quantidades de ouro e prata, para remeter para aí em pagamento das manufaturas desse país. Nova York e Nova Jersey também cresceram consideravelmente durante o mesmo período, com o uso do papel-moeda, de modo que não se afigura que ele tenha o caráter funesto que lhe é atribuído.

36 Works of Benjamin Franklin, organizadas por Sparks, II, p. 343. 
Observa-se, portanto, ser a monetização um marco na passagem de uma economia natural de troca, orientada ao consumo, para uma economia monetária, de caráter lucrativo. Daí se concluir, preliminarmente, que a lucratividade em si mesma, enquanto excedente econômico, somente encontra seu auge na racionalidade da economia monetária, impulsionando a plena realização de uma economia lucrativa.

Tal ordem de ideias indicia os antagonismos inerentes à evolução socioeconômica, que se refletem nos fatos monetários e, consequentemente, na sua interpretação, influenciando definitivamente as teorias e doutrinas monetárias, como se examinará adiante.

\section{A moeda na filosofia clássica}

A cidade antiga grega, até o século VIII antes de nossa era, tinha seu modo de vida econômico restrito à unidade doméstica. Conheceu o desenvolvimento de uma vida econômica mais abrangente, pautada no processo de trocas, somente a partir do período clássico (século V) e, sobretudo, na era helênica dos séculos IV e III a.C.

A economia grega desse período é marcadamente agrícola, de produção artesanal e caráter consuntivo. Dadas as características geográficas das cidades gregas - localização litorânea, população crescente, território exíguo e pobreza do solo -, a navegação e o comércio exterior se impuseram naturalmente como meio de subsistência à polis grega, sendo que os libertos e estrangeiros foram os agentes mais ativos dessa economia (HUGON, 1973, p. 31 e ss.).

O processo de colonização grega representa para a Antiguidade uma revolução econômica, no dizer de HUGON (1973, p. 38), tendo por objetivo a expansão mercantil e agrícola. Nesse mister representa a moeda um instrumento necessário àquela expansão. A época homérica conheceu, entre outras, o gado como moeda corrente, cuja evolução até o advento da dracma se impõe a partir da intensificação do processo de trocas. Nesse contexto se desenvolvem as ideias econômicas do pensamento grego, sobretudo o pensamento aristotélico, que se debruça sobre a questão da economia de trocas e a evolução monetária ${ }^{37}$.

37 Na concepção de SCHUMPETER (1964a, p. 80), a "História da Análise Econômica" tem início somente com o pensamento grego. Não obstante, não se há de olvidar que o pensamento grego e cristão medieval, de matriz aristotélico-tomista, se funda na questão da administração doméstica, a partir da concepção da oikos, tendo na economia autárquica sua organização natural. Nesse sentido, a concepção antiga e medieval do comportamento econômico era basicamente filosófica, orientada à organização da totalidade da vida com vistas ao bem comum, inserindo-se nesse contexto os fatos e as questões de ordem 
Os elementos essenciais da teoria econômica de ARISTÓTELES se encontram sobretudo em sua Ética, livro V (1991), e sua Política, livro I (1985), tendo por base a escassez e a busca de sua satisfação. Em encadeamento genético, peculiar a toda sua análise, parte o estagirita da autossuficiência da unidade econômica doméstica (oikos), progredindo em direção à economia de trocas, até a introdução da moeda enquanto facilitadora da troca. Critica, outrossim, a confusão entre riqueza e dinheiro. Esse legado teórico se refletirá no pensamento econômico clássico ${ }^{38}$, sedimentado na obra de Adam SMITH, e, posteriormente, na obra de Karl MARX (HUGON, 1973; SCHUMPETER, 1964a).

Tendo em mira uma ética da avaliação, ARISTÓTELES (1991) busca a justiça na estimativa das coisas, ou seja, a justiça comutativa. Essa deve ser revelada na troca de coisas úteis para a satisfação das necessidades da vida, podendo a necessidade ser premente ou não conforme as circunstâncias. A troca precisa ser justa, mas as circunstâncias em que ela se dá nem sempre o são: a necessidade premente de uma casa conduzirá o sapateiro a dar em troca um número exagerado de calçados. Daí a questão de se estimar a justiça da troca, ou seja, a reciprocidade dos bens trocados, o que exige que se estabeleça um critério de comparação: tal reciprocidade precisa ser proporcional. Nesse sentido, leciona ARISTÓTELES em sua Ética (1991, pp. 102-9):

Ora, a retribuição proporcional é garantida pela conjunção cruzada. Seja A um arquiteto, B um sapateiro, $\mathrm{C}$ uma casa e D um par de sapatos. O arquiteto, pois, deve receber do sapateiro o produto do trabalho deste último, e dar-lhe o seu em troca. Se, pois, há uma igualdade proporcional de bens e ocorre a ação recíproca, o resultado que mencionamos será efetuado. Senão, a permuta não é igual, nem válida, pois nada impede que o trabalho de um seja superior ao do outro. Devem,portanto, ser igualados.

E isto é verdadeiro também das outras artes, porquanto elas não subsistiriam se o que o paciente sofre não fosse exatamente o mesmo que

econômica, como parte intrínseca à organização social e suas instituições (ARISTÓTELES, 1985, p. 13 e ss.). Em contraste com a concepção contemporânea de ciência econômica, que isola os fatos econômicos enquanto objeto de análise, a ciência social daquele tempo, e nela o estudo da economia, se situava no campo da Ética aplicada, tal como ainda o é do ponto de vista da doutrina social católica (HEIMANN, 1965).

38 O termo clássico não só refere a literatura econômica produzida no século XVIII, de Adam Smith, Ricardo e Stuart Mill, entre outros, mas também a consolidação científica, sedimentada após longo período de controvérsias (SCHUMPETER, 1964a, p. 100 e s., n. 1). Nesse sentido, o termo serve, em princípio, aos diversos ramos do conhecimento científico. 
o agente faz, e da mesma quantidade e espécie. Com efeito, não são dois médicos que se associam para troca, mas um médico e um agricultor, e, de modo geral, pessoas diferentes e desiguais; mas essas pessoas devem ser igualadas. Eis aí por que todas as coisas que são objetos de troca devem ser comparáveis de um modo ou de outro. Foi para esse fim que se introduziu o dinheiro, o qual se torna, em certo sentido, um meio-termo, visto que mede todas as coisas e, por conseguinte, também o excesso e a falta - quantos pares de sapatos são iguais a uma casa ou a uma determinada quantidade de alimento.

O número de sapatos trocados por uma casa (ou por uma determinada quantidade de alimento) deve, portanto, corresponder à razão entre o arquiteto e o sapateiro. Porque, se assim não for, não haverá troca nem intercâmbio. E essa proporção não se verificará, a menos que os bens sejam iguais de um modo. Todos os bens devem, portanto, ser medidos por uma só e a mesma coisa, como dissemos acima. Ora, essa unidade é na realidade a procura [necessidade] ${ }^{39}$, que mantém unidas todas as coisas (porque, se os homens não necessitassem em absoluto dos bens uns dos outros, ou não necessitassem deles igualmente, ou não haveria troca, ou não a mesma troca); mas o dinheiro tornou-se, por convenção, uma espécie de representante da procura [necessidade]; e por isso se chama dinheiro $(v o ́ \mu l \sigma \mu \alpha)$ [nómisma: moeda $]^{40}$, já que existe não por natureza, mas por lei (vónoç), e está em nosso poder mudá-lo e torná-lo sem valor. Haverá, pois, reciprocidade quando os termos forem igualados de modo que, assim como o agricultor está para o sapateiro, a quantidade de produtos do sapateiro esteja para a de produtos de agricultor pela qual é trocada. Mas não devemos, colocá-los em proporção depois de haverem realizado a troca (do contrário ambos os excessos se juntarão num dos extremos), e sim quando cada um possui ainda os seus bens. Desse modo são iguais e associados justamente porque essa igualdade se pode efetivar no seu caso.

Seja A um agricultor, C uma determinada quantidade de alimento, B um sapateiro e D o seu produto, que equiparamos a C. Se não fosse possível efetuar dessa forma a reciprocidade, não haveria associação das partes.

39 Na Política de ARISTÓTELES (1985, trad. direta do grego por Mário da Gama Kury), se emprega o termo "necessidade" (p. 25 e s.).

40 Na Política de ARISTÓTELES (1985, p. 26), se emprega o termo "moeda" em referência ao dinheiro no seu estágio final, ou seja, amoedado e cunhado (nómisma), cujo próprio símbolo indica seu valor. 
Que a procura engloba as coisas numa unidade só é evidenciado pelo fato de que, quando os homens não necessitam um do outro - isto é, quando não há necessidade recíproca ou quando um deles não necessita do segundo - , não realizam a troca, como acontece quando alguém deseja o que temos: por exemplo, quando se permite a exportação de trigo em troca de vinho. E preciso, pois, estabelecer essa equação.

E quanto às trocas futuras - a fim de que, se não necessitamos de uma coisa agora, possamos tê-la quando ela venha a fazer-se necessária -, o dinheiro é, de certo modo, a nossa garantia, pois devemos ter a possibilidade de obter o que queremos em troca do dinheiro. Ora, com o dinheiro [moeda] sucede a mesma coisa que com os bens: nem sempre tem ele o mesmo valor; apesar disso, tende a ser mais estável. Daí a necessidade de que todos os bens tenham um preço marcado; pois assim haverá sempre troca e, por conseguinte, associação de homem com homem.

Deste modo, agindo o dinheiro como uma medida, torna os bens comensuráveis e os equipara entre si; pois nem haveria associação se não houvesse troca, nem troca se não houvesse igualdade, nem igualdade se não houvesse comensurabilidade. Ora, na realidade é impossível que coisas tão diferentes entre si se tornem comensuráveis, mas com referência à procura [necessidade] podem tornar-se tais em grau suficiente. Deve haver, pois, uma unidade, I [uma] unidade estabelecida por comum acordo (por isso se chama ela dinheiro [nómisma: moeda]); pois é ela que torna todas as coisas comensuráveis, já que todas são medidas pelo dinheiro [moeda].

Seja A uma casa, B dez minas, C uma cama. A é a metade de B, se a casa vale cinco minas ou é igual a elas; a cama, $\mathrm{C}$, é um décimo de B; torna-se assim evidente quantas camas igualam uma casa, a saber: cinco. Não há dúvida que a troca se realizava desse modo antes de existir dinheiro [moeda], pois nenhuma diferença faz que cinco camas sejam trocadas por uma casa ou pelo valor monetário de cinco camas.

Do exposto, observa-se que o critério de comparação não pode residir nas propriedades intrínsecas das coisas a serem trocadas, pois, como no exemplo dado, não há como comparar coisas tão diferentes quanto uma casa e um sapato. A igualdade dos bens a serem trocados não é algo inerente, passível de simples constatação, mas resultado de uma comparação, porquanto artificial. Essa comparação deve refletir a equivalência entre os 
trabalhos incorporados em cada produto trocado, pois, em última instância, é o trabalho de cada um que se irá permutar. Ressalta daí, de início, que se está no campo da arte, ou técnica $^{41}$. É mister, portanto, que se estabeleça a igualdade dos bens permutáveis através da troca com um terceiro bem, tomado como referência universal (denominador comum). Essa igualdade se estabelece, assim, por meio da troca (antecedente lógico) com aquele bem de referência, qual seja, o "dinheiro". Com efeito, o que se denomina atualmente valor de troca, ou valor econômico, não é propriedade intrínseca das coisas, mas resulta da própria troca. Nasce aqui a clássica distinção entre valor de uso e valor de troca, repetida desde então por todos os economistas (SCHUMPETER, 1964a), não obstante o próprio ARISTÓTELES (1991) não tenha sido capaz de caracterizá-la com clareza.

Com efeito, o estagirita apela para a "procura" ao conceituar o valor de troca a partir da necessidade (utilidade) do objeto trocado, reduzindo o dinheiro a "representante" dessa necessidade conquanto unidade de conta (ARISTÓTELES, 1991, p. 105):

(...) na realidade é impossível que coisas tão diferentes entre si se tornem comensuráveis, mas com referência à procura [necessidade] podem tornar-se tais em grau suficiente. Deve haver, pois, uma unidade (...) pois é ela que torna todas as coisas comensuráveis, já que todas são medidas pelo dinheiro [moeda].

Dessa forma, acaba por reduzir o valor de troca ao de uso. Talvez se apercebendo disso, recorre à noção genérica de "preço" (ARISTÓTELES, 1991, p. 104), como condição prática à realização das trocas, sem contudo o conceituar. Em última instância, a utilidade constituiria a medida do valor, dificultando assim que se possa aferir "o justo valor de troca $^{42}$ dos objetos que se conservam confundidos com o valor de uso" (PRADO JR., 1966, p. 40 e s.) $)^{43}$.

Essa caracterização incompleta do valor de troca nada mais é do que o reflexo teórico das circunstâncias que revestem o mercado primitivo (pré-moderno), dominado por

41 Nesse sentido, ARISTÓTELES (1985, p. 25 e ss.) refere a "arte de enriquecer" enquanto resultado de experiência e habilidade. Trata-se, assim, de uma arte de aquisição não natural, de natureza comercial, ilimitada conquanto fundada na noção do dinheiro, e assim censurável por visar apenas ao lucro. Ao contrário, haveria uma arte de aquisição natural, em que a permuta se baseia no excedente produzido, e que está intimamente ligada à boa e necessária economia doméstica.

42 A lide doutrinária medieval travada em torno do preço justo também representa um esforço teórico de conceituação do valor de troca (PRADO JR., 1966; SCHUMPETER, 1964a).

43 Em que pese a fundamentada crítica de PRADO JR. (1966) ao exposto na Ética de ARISTÓTELES (1991), é mister que se esclareça a visão do estagirita também a partir de sua Política (1985), onde afirma ser a permuta, em sua origem, natural a todos os bens, no sentido de que "certas coisas os homens têm de mais, outras de menos". Dessa forma, a troca abrangeria, em princípio, o excedente de produção, ou seja, tudo aquilo que não fosse mais necessário (útil) ao produtor, podendo assim ser trocado (valor de troca) de modo a satisfazer a necessidade de outrem (valor de uso). 
uma economia de caráter consuntivo (WEBER, 2011). Com efeito, a probabilidade econômica e mercantil dos bens, ao contrário de sua simples necessidade e utilidade, é ínsita ao fato das trocas mercantis presididas pela figura moderna do mercado, esteando-se esse fato naquela probabilidade. Nesse sentido, a distinção dos esforços produtivos no que tange aos bens (custos), mediante sua comparação, condiciona e norteia a especialização produtiva, a divisão do trabalho e, portanto, o tráfico mercantil. Dada a ausência dos elementos (racionais) que configuram o mercado hodierno ${ }^{44}$, e precisamente em razão do empirismo ou casuísmo estabelecido no processo de comparação entre bens no mercado primitivo, em que as estimativas e avaliações em relação à aquisição de um bem e alienação de outro revestem antes um caráter subjetivo, é que não se caracteriza de forma plena a distinção entre valor de troca e de uso (PRADO JR., 1966, p. 38 e s.).

O dinheiro, conquanto estalão de preços (referência universal) e, portanto, medida de comparação entre os bens permutados, é uma mercadoria, ainda que sua qualidade de medida comum resulte da troca. Outrossim, quando ARISTÓTELES (1991) declara ter havido trocas antes do emprego da moeda, não atesta com isso a possibilidade de permutas antes do estabelecimento de um produto como estalão, mas apenas que a moeda sucede ao estalão. Ainda nesse sentido se manifesta ARISTÓTELES (1985, p. 26):

(...) os homens, para efeito de permutas, pactuaram dar e receber certas substâncias que fossem por si mesmas produtos úteis e fáceis de conduzir nas circunstâncias normais da vida (o ferro, por exemplo, a prata e outros da mesma natureza), definidas em seu início apenas por seu tamanho e peso, mas finalmente marcadas com um símbolo, de modo a dispensar o usuário da obrigação de pesá-las, pois o símbolo indicava o seu valor. Assim, com a invenção da moeda, em decorrência do indispensável intercâmbio de produtos, passou a existir outra forma de arte de enriquecer: o comércio, que a princípio apareceu como uma instituição simples, mas posteriormente se tornou muito mais complexa, à proporção que a experiência revelava fontes e métodos de permuta capazes de proporcionar maiores lucros.

44 Do ponto de vista teórico, o mercado (perfeito) compreende a facilidade de intercâmbio, a fluidez entre oferta e demanda e concorrência efetiva (perfeita). As deficiências do comércio (mercado) pré-moderno, resultam fundamentalmente do fato de ainda não se terem formado as condições necessárias para a aferição do custo de produção no âmbito do processo de trocas, sobretudo à falta de um critério ou padrão para essa medição (PRADO JR., 1966). Aliás, precisamente o fundamento desse padrão marcará a profunda divisão teórica entre as escolas marginalista e marxista no que tange à teoria do valor econômico, residindo, grosso modo, na utilidade dos bens ou fatores produtivos (custo marginal), para a primeira escola, e no tempo de trabalho produtivo, para a segunda (SINGER, 2010). 
Em consequência, a verdadeira natureza do dinheiro é a de ser mercadoria, promovida ao nível de unidade de medida e portadora de uma representação, qual seja, a moeda (indicativa de valor).

No mesmo sentido se orienta a interpretação dada por SCHUMPETER (1964a, p. 91), para quem a teoria monetária aristotélica compreende fundamentalmente duas proposições. Primeiramente, embora sirva a moeda a outras finalidades, sua função fundamental e que define sua natureza é ser instrumento de troca. A segunda proposição é corolário da primeira: o desempenho da função de instrumento de troca no mercado implica ser a moeda em si mesma uma mercadoria, ou seja, também uma utilidade, independentemente de sua função monetária. Para ARISTÓTELES, portanto, o fato da cunhagem não seria a causa do valor da moeda, pois que a moeda (símbolo) apenas o indicaria (1985, p. 26), sendo ela criação legal, não da natureza, assim podendo ser alterada ou demonetizada (1991, p. 104). A causa do valor monetário residiria antes na utilidade (necessidade) como medida desse valor (1991, p. 103), utilidade essa (só) representada por uma mercadoria que se convencionou (pactuou) como dinheiro (1985, p. 26; 1991, p. 103 e s.) $)^{45}$.

Platão (1997, p. 56 e s.), por sua vez, entendia ser a moeda um símbolo utilizado no mercado, assim dialogando em sua República:

Sócrates - Mas, no interior da própria cidade, como os homens irão permutar os produtos do seu trabalho? Já que foi com esse propósito que os associamos ao fundarmos uma cidade.

Adimanto - Evidentemente que será através da venda e da compra.

Sócrates - Neste caso, necessitaríamos de um mercado e de moeda, símbolo do valor das mercadorias permutadas.

Adimanto - Sem dúvida.

Sócrates - Mas, se o lavrador ou qualquer outro operário que leva ao mercado um de seus produtos não conseguir se encontrar com aqueles que querem fazer permutas com ele, interromperá o seu trabalho

45 Propugna-se ser essa teoria a precursora da teoria monetária metalista (valorista), segundo a qual o valor da moeda depende do valor do metal que a constitui, em oposição à teoria nominalista (cartalista) que atribui o valor da moeda à imposição legal, e da qual Platão seria um exemplo (SCHUMPETER, 1964a, pp. 84, 91). Em sentido contrário, entende HUGON (1973, p. 41) ser a teoria aristotélica oscilante entre uma e outra dessas teorias, admitindo-a antes como uma síntese do pensamento anterior, inclusive o de Platão, o que nos parece a posição mais consentânea com os textos clássicos citados, como se verá na sequência. 
para ficar sentado no mercado esperando-os?

Adimanto - De jeito nenhum. Existem pessoas que se encarregam desse serviço; nas cidades bem organizadas, são geralmente as pessoas mais fracas de saúde, incapazes de qualquer outro trabalho. $\mathrm{O}$ seu papel é ficar no mercado, comprar a dinheiro aos que vendem, e depois vender, também a dinheiro, aos que desejam comprar.

Sócrates - Logo, esta necessidade dá origem à classe dos mercadores na nossa cidade; damos este nome - não é mesmo? àqueles que se dedicam à compra e à venda, com estabelecimento aberto no mercado, e o de negociantes aos que viajam de cidade em cidade.

Note-se que Platão se refere à moeda como símbolo do valor das mercadorias permutadas no mercado, mas ao discorrer sobre a compra e venda se refere ao dinheiro. Em suma, o dinheiro seria um facilitador das trocas realizadas no mercado, cumprindo as funções de intermediário e denominador comum (medida de valor) das relações de troca (instrumento de pagamento na compra e venda), simbolizado pela moeda. Nesse sentido convergiu posteriormente a teoria aristotélica ${ }^{46}$.

Observe-se ainda outra passagem de República (PLATÃO, 1997, p. 13):

Sócrates - Sendo assim, em qual circunstância, em que for necessário usar dinheiro ou ouro em sociedade, o homem justo é mais útil que qualquer outro?

Polemarco - Na circunstância de desejarmos fazer um depósito em segurança, Sócrates.

Sócrates - Mas isso significa: quando não utilizamos o dinheiro e preferimos deixá-lo imobilizado. Certo?

Polemarco - Sem dúvida.

PLATÃO, em princípio, parece associar o dinheiro ao bem cujo valor social expressa a riqueza conquanto depósito de valor econômico, a saber, o ouro. Aliás, a associação do dinheiro à riqueza, à acumulação de bens, é recorrente em sua obra (1991, p. 6 e s.). A associação do dinheiro ao metal nobre e, concomitantemente, à riqueza, lhe reconhece, implicitamente, a função de reserva de valor (poder aquisitivo entesourado), o que, por si só, não invalida o entendimento de representar o dinheiro o valor das mercadorias permutadas no mercado, enquanto seu denominador comum (ouro), senão que

46 Em sentido similar, HUGON (1973, p. 41). Apesar de entender que PLATÃO não transmitiu nenhuma visão definitiva da natureza da moeda, SCHUMPETER (1964a, p. 84) assevera a semelhança da posição platônica com aquela adotada pela teoria nominalista (cartalista), considerando-o precursor dessa teoria, enquanto atribui a ARISTÓTELES a paternidade da teoria metalista. 
o complementa na sua função de meio de troca, sedimentado na moeda corrente do mercado $\left(\right.$ doméstico $^{47}$ ). Dessarte, cumpriria o dinheiro suas três funções básicas ${ }^{48}{ }^{49}$

\section{A escola clássica}

Não obstante o aperfeiçoamento do padrões monetários em consequência do desenvolvimento econômico sob as transformações do sistema feudal e o crescimento dos Estados nacionais europeus, o período entre a Antiguidade e o Renascimento pouco registrou em termos de teoria econômica, é dizer, de investigação sistemática dos fundamentos da ação econômica, reduzindo-se ao tratamento da ética aplicada a essa ação, tal como nos tratados escolásticos ${ }^{50}$. Os estudos de caráter sistemático a respeito da moeda

47 O rápido crescimento econômico vivenciado pela Grécia no século V, acompanhado de forte desequilíbrio social, parece ter aterrorizado os filósofos, entre eles Platão, atribuindo-se ao metal precioso, em princípio, o papel de grande vilão. Daí a forte oposição platônica ao uso do ouro ou da prata no comércio. Não obstante, dada a impossibilidade do banimento do metal nobre no comércio exterior, propõe Platão a adoção de um sistema alternativo em que a moeda fiduciária teria apenas vigência doméstica (HUGON, 1973; SCHUMPETER,1964a).

48 A síntese monetária da filosofia clássica parece indiciar alguns aspectos da atual distinção teórica entre moeda e dinheiro, a saber, a moeda enquanto ativo que, em regra, instrumentaliza a compra e venda (além de meio de pagamento de obrigações tributárias), e o dinheiro enquanto ativo (monetário) de aceitação geral (jurídica e social) para o desempenho de todas as suas funções clássicas, ou seja, intermediário de trocas, medida e reserva de valor (COSTA, 1999, p. 36 e s.).

49 É conveniente que se esclareça desde logo a terminologia fundamental da teoria monetária, de que se fez uso anteriormente e que será útil no decorrer deste trabalho, a saber, o metalismo e o nominalismo. Na lição de SCHUMPETER (1964a, p. 361 e ss.), o metalismo teórico designa a teoria segundo a qual o fundamento da moeda reside logicamente em uma mercadoria que lhe é fonte do valor de troca ou poder de compra, independentemente de sua expressão monetária. Essa teoria monetária é corolário da (logicamente anterior) teoria do escambo. Mas, considerando que modernamente apenas o ouro e a prata foram utilizados como base monetária, cunhou-se o termo metalismo, ainda que muitos autores denominem essa teoria "valorista" (JANSEN, 2009) em razão da ênfase no valor intrínseco da moeda, ligado a seu lastro (metálico). Paralelamente à teoria metalista há uma política monetária metalista, orientada pelo princípio de que a unidade monetária deverá se lastrear em uma determinada quantidade de alguma mercadoria (metal), e ser por essa livremente permutável. Não há confundir ainda o metalismo teórico ou a política monetária metalista com o metalismo (vulgar) da era mercantilista enquanto ideia econômica que atribuía ao acúmulo de metais nobres a riqueza de uma nação. De outra sorte, o nominalismo, ou cartalismo na expressão de George Knapp, enquanto teoria nega a necessidade lógica de que seja essencial à moeda consistir de um metal, tal como o ouro, ou ser conversível nesse metal; já a política monetária nominalista adota o princípio de que valor da unidade monetária não deverá se ligar ao valor de qualquer mercadoria (metal). Em regra, teoria e política monetárias caminham juntas na evolução das ideias monetárias, mas não raro se dissociam, em particular se não há a necessária confiabilidade nas autoridades monetárias, quando então um nominalista convicto, do ponto de vista teórico, se decide pela política de caráter metalista. Outrossim, quando um teórico lança mão da comparação entre moeda e bilhete bancário, tende-se a lhe alcunhar de metalista (cartalista), quando na verdade seus fundamentos teóricos não permitem tal ilação. Nesse sentido, a classificação difícil dos pensadores anteriormente citados - ARISTÓTELES e PLATÃO. Registre-se, finalmente, que a teoria metalista, embora nem sempre associada à política monetária de mesmo caráter, dominou as mentes dos séculos XVII e XVIII, prevalecendo na situação clássica conquanto ratificada por Adam SMITH, assim permanecendo por mais de um século, inclusive na teoria monetária de MARX.

50 Observe-se, todavia, que a economia do bem-estar desenvolvida pelos doutores escolásticos penetrava na análise econômica a partir do conceito fundamental de valor, baseado nas necessidades e sua satisfação. Nesse sentido, aprofunda-se a distinção aristotélica entre valor de uso e valor de troca, desenvolvendo-se 
e sua função econômica surgem a partir do Renascimento, sob a égide do Estado moderno ${ }^{51}$.

O Estado nacional europeu é o berço da burguesia e do capitalismo, entendido aquele como requisito para a eclosão desse último. A (re)construção econômica desse Estado, em novas bases do que aquelas do feudalismo, exigia recursos financeiros para sua administração centralizada, burocrática, além da manutenção de suas forças militares. Daí a intervenção direta no domínio econômico através de associações econômico-reguladoras, resultado de políticas monopolistas, além de outros incentivos à atividade industrial e comercial que assegurassem receitas tributárias ao soberano (HEIMANN, 1965; SCHUMPETER, 1964a) ${ }^{52}$.

uma particular teoria utilitária do valor de troca, ou de preço, de um modo não encontrado em ARISTÓTELES ou em São Tomás de Aquino. Entre os autores da última fase do pensamento escolástico, destaca-se o jesuíta Luís Molina, cujo tratado De justitia et iure, publicado entre 1593 e 1600, prenuncia com clareza a teoria da utilidade enquanto fonte ou causa do valor, repudiando a tese de que o custo fosse a fonte lógica ou causa do valor de troca, ou preço, embora o admitisse como um fator na determinação desse valor. A doutrina escolástica ainda evidenciou, tão detidamente quanto o fez posteriormente Carl Menger, que a utilidade não era algo inerente aos bens, mas antes se ligava ao uso que as pessoas pretendiam fazer dos bens e da importância que lhes atribuíam, é dizer, na desejabilidade (complacibilitas) que provocavam na coletividade, termo esse posteriormente empregado pelo grande economista Irving Fisher. De modo implícito, ao menos, logrou-se afastar o paradoxo do valor - i.e., que os bens de uso comum, naturais, tal como a água ou o ar, embora úteis, não possuem valor de troca -, ao relacionar o conceito de utilidade ao de escassez, ou seja, a utilidade não residia numa abstração, resultado da natureza (útil) de um bem, mas de sua quantidade disponível. Arrolaram-se também todos os fatores determinantes dos preços, assim, p. ex., em Molina, ainda que não se lhes integrassem numa teoria definitiva da oferta e demanda, não obstante se quedaram plenamente instituídos, faltando-lhes somente a sistematização conceitual tal qual lhes proporcionou a teoria marginalista do século XIX (SCHUMPETER, 1964a, p. 128 e s.).

51 Exceção feita à obra de Nicolau Orèsme, ilustre pensador do século XIV e considerado o autor da primeira obra escrita sobre questões genuinamente monetárias, ainda que do ponto de vista estritamente jurídico e político, a saber, De origine, natura, jure et mutationibus monetarum, de 1336 . Nessa obra se critica severamente a legitimidade jurídica do soberano para promover alterações monetárias, estudando as formas e inconvenientes dessa adulteração. Discorre sobre a importância da cunhagem, e da aceitação da moeda no processo de trocas em razão da confiança gerada pela aposição do cunho real à moeda. Não obstante, desde que utilizada no tráfico mercantil, passa a moeda a também pertencer à coletividade. Em consequência, caberia à comunidade e não somente ao monarca o direito de decisão sobre a alteração de valor da moeda. Em suma, a mutação monetária não pode se legitimar unicamente em razão de um pretenso direito de propriedade do soberano sobre a moeda. Orèsme já indicava as desastrosas consequências socioeconômicas ocasionadas pelas mutações monetárias, ou seja, a elevação dos preços e o aviltamento dos rendimentos ou vencimentos outrora fixos de determinadas classes sociais. Com isso, antecipa sua obra a polêmica do século XVI a respeito da relação existente entre moeda e preços. Assim restam condenadas as mutações monetárias em virtude de seus efeitos contrários ao interesse geral (HUGON, 1973, p. 57 e ss.; SCHUMPETER, 1964a, p. 126).

52 Na precisa lição de HEIMANN (1965, p. 34), os Estados Unidos representam destacada exceção, "onde, na ausência de tradição feudal, nenhum Estado dotado de poder absoluto, e administrado por uma burocracia permanente, jamais deitou raízes. Ali, o liberalismo tornou-se a forma original da sociedade, surgindo o capitalismo naturalmente como sua organização econômica. Em comparação com as condições nos Estados Unidos, o papel decisivo desempenhado pelo Estado, em tôda a Europa, na fixação de uma economia capitalista, torna-se mais destacado. A tradição européia de fidelidade, primeiro ao senhor como símbolo da comunidade, e em seguida à constituição como a base da comunidade, era desconhecida do nôvo país, porque a idéia de fidelidade a um senhor é totalmente estranha ao mundo 
Dessa forma, o Estado nacional e a economia capitalista confluem de modo orgânico e funcional no devir histórico. Com efeito. Os Estados nacionais, em sua origem, se encontravam em permanente estado de beligerância, em luta por hegemonia geopolítica, tendo de competir pelo capital que, em princípio, era livre em sua circulação. Dessa aliança forçada surge o estamento burguês nacional. Assim que o Estado europeu moderno,

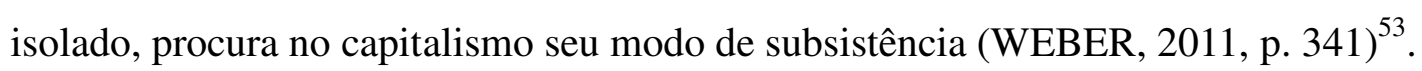

O mundo do renascimento é um mundo em mutação, pouco industrializado, e fortemente marcado por estruturas religiosas e sociais medievais, não obstante seja um mundo em mutação, no sentido de uma libertação da austeridade medieval, a partir da uma construção centralizadora do Estado. Essa centralização estatal é marcada, como anteriormente frisado, pelo dirigismo no campo econômico, em que a formação do capital se orienta no sentido da indústria e do comércio nacionais, promovendo a transição definitiva da economia regional para a economia nacional, no sentido de coordenação estatal dos diferentes recursos, materiais e humanos, da nação (CENECO, s.d., p. 275 e s.; HUGON, 1973, p. 64). Nesse quadro surge a primeira política econômica estatal, de caráter racional, denominada mercantilismo (WEBER, 2011, p. 349) ${ }^{54}$.

Na acepção de WEBER (2011, p. 350), o mercantilismo nada mais é do que o

burguês do contrato, lucro e independência pessoal. O serviço público, nos Estados Unidos, não era uma carreira, pelo menos até bem recentemente; também a tradição de família e de grupo não constituía carreira. Ou, em palavras diferentes, os Estados Unidos não possuíam burocracia. Na Europa, o Estado moderno que brotou do feudalismo usava as relações humanas hierárquicas dêsse feudalismo para finalidades antifeudais, que incluíam o desenvolvimento do capitalismo".

53 No entendimento de WEBER (2011, p. 341 e ss.), o Estado nacional europeu é antes um Estado racional, único terreno onde o capitalismo moderno pode prosperar. O Estado moderno tem como características fundamentais a burocracia especializada e o direito racional. Esse direito racional, cuja origem remonta ao direito romano, requer, sob o aspecto formal, uma burocracia profissional que o conheça e aplique; essa burocracia se forma, aliás, por juristas, dado o papel destacado do notariado na recepção daquele direito e, subsidiariamente, das universidades na sistematização da teoria jurídica. Decisiva foi a racionalização processual, resultado da recepção do direito romano em confluência com o formalismo germânico, sobretudo no atendimento da magna organização administrativa eclesiástica. Ressalte-se, todavia, que o capitalismo não encontra suas origens no direito romano, bastando-se citar o exemplo da Inglaterra, onde tal direito não se recepcionou. Ademais, do ponto de vista material, os institutos jurídicos que marcam a ascensão capitalista não encontram sua origem direta no direito romano, a saber, a letra de câmbio e a sociedade mercantil, entre outros, são produto do direito medieval. A recepção do direito romano foi decisiva somente no sentido da criação de um pensamento jurídico formal. Esse direito formalista orienta a atuação da burocracia, que desconhece princípios de justiça material, tal como a utilidade ou a discricionariedade judicial, típicos das teocracias e dos absolutismos em geral. Além disso, esse direito formal é calculável, no sentido de permitir a probabilidade (racionalidade) das decisões nele baseadas, afastando aspectos rituais ou mágicos (tradicionais) de sua aplicação. O capitalismo requer tal formalização jurídica enquanto processo de decisões econômicas racionais em face das possibilidades do mercado. A criação de semelhante direito resultou, em última instância, da associação do Estado moderno aos juristas de modo a impor o domínio estatal, pois a jurisprudência formal favoreceu, ainda que de modo indireto, o desenvolvimento do capitalismo ocidental.

$54 \mathrm{Na}$ verdade, o termo "mercantilismo" marca não só a política estatal, mas também o conjunto de ideias e práticas econômicas que surgiram na Europa entre 1450 e 1750 (HUGON, 1973, p. 59). 
traslado para a esfera política do objetivo de lucro capitalista. A atuação do Estado passa a ser primordialmente empresarial, cuja política se orienta à maximização das fontes lucrativas do próprio país, de forma a estabelecer com o exterior uma contabilidade sempre favorável, ou seja, em que o valor das exportações supera o das importações. Trata-se, assim, da conhecida teoria mercantilista da balança comercial, que se desenvolveu na Inglaterra sobretudo a partir do século XVI.

Não há que se olvidar do fato de ser a Inglaterra o berço do mercantilismo, cujos primeiros indícios remontam à política inglesa do século XIV, marcada pelo fomento às exportações face à proibição de bens importados, já se valendo do conceito (empírico) de balança comercial. Uma direção claramente mercantilista é tomada apenas a partir de 1440 com a imposição legal de aquisição de produtos ingleses pelos comerciantes estrangeiros em contrapartida aos produtos por eles vendidos e, ainda, a interiorização obrigatória de parte dos lucros auferidos pela venda de artigos ingleses ao exterior. Esse sistema se consolida com o Ato de Navegação, de 1651, eliminado a navegação estrangeira (WEBER, 2011$, p. 351$)^{55}$.

$55 \mathrm{O}$ mercantilismo, enquanto aliança do Estado com os interesses do capital, apresenta duas faces distintas, ainda que complementares WEBER (2011, p. 351 e ss.). Primeiramente se manifesta como um mercantilismo monopolista estamental, tal como revelado pela política dos Stuart e da Igreja anglicana, que aspirava à criação de uma estrutura social estamental de caráter estável, de senso social-cristão. Nessa estrutura se reserva logicamente um lugar à pobreza, em clara oposição ao repúdio que essa causava ao puritanismo. Do ponto de vista da prática econômica, sua política se pautava pelo fiscalismo estatal, sob o rígido controle reinol das autorizações para o funcionamento das companhias comerciais (chartered), cujas importações se realizavam somente sob o regime de monopólios concedidos pelo monarca. Semelhante política, ainda que não tão consequente, foi a aplicada por Colbert na França - a quem se deve a reforma do sistema fiscal francês e uma eficiente política fiscal enquanto instrumento de política econômica (SCHUMPETER, 1964a, p. 213). Outro exemplo de mercantilismo monopolista, colonial, pautado no fomento de grandes companhias privilegiadas, não obstante de grande dinamismo, foi a Holanda e sua talassocracia (MENDES, 1997, p. 88). Em segundo lugar, o mercantilismo se manifesta enquanto mercantilismo nacional, limitando-se a fomentar e proteger a indústria nacional, não apenas aquelas criadas com caráter de monopólio, tal como na Prússia sob Frederico o Grande. Durante décadas, na Inglaterra, a política de monopólios régios, outorgados tanto a estrangeiros como à nobreza local, em particular para a exploração do comércio colonial, foi fortemente combatida pelos puritanos no seio do Parlamento, que acabou por instituir a incapacidade eletiva dos monopolistas. Esse combate à política fiscal e monopolista da monarquia inglesa, derrubada pelo Parlamento no século XVIII, se origina entre uma classe empresarial que prosperara independentemente do poder público. A partir dessa constatação, aliada ao fato de que as indústrias mercantilistas não sobreviveram em nenhuma parte da Europa, o ponto de partida do moderno capitalismo residiria sobretudo naquela atuação empresarial que se desenvolve à margem da política monopolista do mercantilismo, levada a cabo pelos puritanos ingleses, não no mercantilismo nacional, por muitos concebido como a primeira fase do capitalismo (no último sentido, HEIMANN, 1965). O último choque entre o capitalismo monopolista estatal (irracional), orientado pelas possibilidades fiscais e coloniais, e o capitalismo guiado pelas possibilidades automáticas de mercado (racional) ocorre no âmbito do Banco da Inglaterra. Fundado pelo escocês Patterson, monopolista, pertencia também ao banco negociantes do grupo puritano. Excetuada a participação (aventureira) nos negócios da Companhia do Oceano Índico, nota-se a influência (racional) crescente desse grupo até a suplantação do grupo de Patterson. Do ponto de vista teórico, a política de monopólios sofreu acerba crítica de Adam SMITH, no século XVIII, embora houvesse mais de um século suas consequências 
A política da balança comercial externa favorável, aliada à forte expansão marítima colonial, resulta numa concentração comercial e de capital circulante sem precedentes na Europa ocidental, traduzida por um considerável afluxo de metais preciosos no século $\mathrm{XVI}^{56}$. Com efeito, sobretudo na segunda metade desse século, experimenta a Europa uma elevação generalizada de preços, transformando e desequilibrando as relações da vida socioeconômica. Na lição de HUGON (1973, p. 67), as ideias medievais do justo preço e do justo salário, ainda prevalecentes, cristalizavam a taxa dos salários no mesmo nível de outrora, enquanto o custo de vida se apresentava particularmente ascendente ${ }^{57}$.

Diante do fenômeno inflacionário observado, ainda que incidental, porque nem todos os preços se elevaram simultaneamente ou na mesma proporção, diversas tentativas

(HEIMANN, 1965; SCHUMPETER, 1964a), tendo assim impulsionado a teoria do livre-cambismo, obra do dissenso puritano, e o consequente liberalismo, residindo precisamente aí sua contribuição para o desenvolvimento da teoria econômica clássica.

56 A opinião comum entende se assentar a concepção básica da política mercantilista no acúmulo de metais nobres como forma preferencial de riqueza, o chamado metalismo, de modo que a obtenção do saldo positivo na balança comercial seria apenas o caminho para se alcançar a meta desejada, a saber, o acréscimo do tesouro nacional de metal precioso, resultado do ganho na disputa comercial internacional em torno da escassez desse metal (LOPES, 1980, p. 127; SINGER, 2010, p. 146). Em sentido contrário, WEBER (2011, p. 350) qualifica como errônea a crença de que os teóricos e estadistas do mercantilismo tenham confundido a posse de metais preciosos com a riqueza de um país; ao contrário, eram cientes de que a riqueza tinha como fonte a capacidade tributária dos nacionais, somente por essa razão procuraram preservar em seus territórios o dinheiro (metal monetário), evitando assim a ameaça de evasão por meio do tráfico mercantil. Da mesma opinião, mas com outros argumentos, entende HUGON (1973, p. 68 e s.), que o verdadeiro sentido da ideia metalista não reside no entendimento de que os metais preciosos sejam a única fonte de riqueza, mas na consideração de serem o mais perfeito instrumento de aquisição da riqueza. Ainda nesse sentido, tendo em vista a prática integrada das políticas monetária e comercial, também seria adequado o uso da expressão "capitalismo comercial" para a era mercantilista (MENDES, 1997, p. 86).

57 Crítica é a posição de WEBER (2011, p. 318 e ss.) a respeito da verdadeira extensão da chamada revolução dos preços dos séculos XVI e XVII. Com razão, diz ele, se atribui essa revolução ao afluxo constante de metais nobres em razão dos grandes descobrimentos transoceânicos. Não obstante, sua influência foi distinta conforme o ramo da vida econômica que se observa (similarmente, HEIMANN, 1965, p. 38 e s.). Em relação aos produtos agrícolas houve de fato uma elevação generalizada dos preços, permitindo assim a transição para a produção agrícola voltada ao grande mercado. Ao contrário, o setor manufatureiro experimentou uma estabilidade dos preços, ou mesmo sua diminuição quando comparados com o setor agrário, sobretudo em razão do barateamento da produção, resultado sobretudo do progresso técnico. Dessa forma, a evolução se deu em sentido contrário ao que comumente se entende: primeiramente decresceram os preços (custos) relativos, sobrevindo a isso o capitalismo. Nesse sentido, a progressiva racionalização da técnica e da economia visando ao barateamento dos custos de produção gerou, no decorrer do século XVII, uma febril arte inventiva, tal como a ideia do movimento contínuo como fonte energética, além de progressos verificados na metalurgia, química, tinturaria e construção naval. Dado esse avanço da tecnologia, aliada a outros fatores econômicos tal como o aumento da produção destinada ao mercado ou a articulação entre a atividade manufatureira e a rural, alcunhou-se recentemente esse período como protoindustrial, chegando-se a referenciar, não sem exageros, uma primeira revolução industrial, entre os séculos XVI e XVII, destacando-se, todavia, a importância da continuidade no processo de desenvolvimento industrial (MENDES, 1997, p. 95 e s.). Registre-se ainda a importante inovação trazida pela vanguardista lei de patentes inglesa, de 1623, extinguindo o privilégio e limitando temporalmente o aproveitamento do invento (14 anos), tendo atuado como dínamo institucional da revolução industrial que se avizinhava, sobretudo aquela experimentada pela indústria têxtil do século XVIII, decisiva para o desenvolvimento do capitalismo. 
teóricas foram levadas a cabo no intuito de explicar o papel da moeda no funcionamento da economia nacional.

Ainda sob influência da prática medieval de adulteração monetária, e das teorias a seu respeito, julgou De Malestroit (apud HUGON ${ }^{58}$, 1973, p. 67), então chefe da Casa da Moeda da França, que o aumento dos preços era apenas aparente, resultado da queda do valor intrínseco das moedas, tal como ocorria na hipótese da elevação do número de moedas devido ao aumento de sua cunhagem tendo por base a mesma quantidade de metal monetário. Dessa forma, não houvera uma valorização real dos bens, senão uma elevação nominal dos preços.

Observe-se que o problema monetário em torno da carestia que assolava mentes e corações da época mercantilista não era algo novo. Não obstante, esse aumento não se devia ao fato de que os preços se elevavam em razão de uma moeda aviltada em seu peso metálico, mas devido ao metal monetário em si mesmo, que se tornara demasiado abundante. A intensificação da atividade mercantil produziu assim efeitos exatamente semelhantes aos de um influxo monetário. Esse fato (monetário) não escapou à arguta inteligência de Jean Bodin (apud HEIMANN ${ }^{59}$, 1965, p. 38, n. 12), que demonstra, com base em dados estatísticos, ser a desvalorização monetária inferior à elevação dos preços, residindo a verdadeira causa do fenômeno, portanto, no significativo aumento do estoque de metal monetário. Daí a conclusão de não ter o dinheiro um valor intrínseco, mas, como todos os outros bens, um valor determinado pela sua quantidade, cujo aumento se reflete unicamente no nível dos preços. Tal é a teoria quantitativa da moeda, ao menos em sua essência, assim denominada porque explica o nível dos preços a partir da quantidade de numerário em circulação, resultado de elaboração generalizante, portanto, de obra científica (HUGON, 1973; SCHUMPETER, 1964a) ${ }^{60}$.

58 Em relatório apresentado ao monarca, em 1566, sob o título Paradoxes sur le fait des monnaies.

59 Réponse aux paradoxes de Monsieur De Malestroit touchant l'enchérissement de toutes les choses, 1568.

60 Digna de nota é a crítica de SCHUMPETER (1964a, p. 384 e ss.) à "descoberta" dessa teoria universalmente atribuída a Bodin. Com efeito. Tomando por hipótese o metalismo inflexível, em particular o monometalismo perfeito do ouro, ou seja, que esse metal circule livremente tanto dentro como fora do sistema monetário, o valor da unidade monetária de ouro, em termos da mercadoria ouro, decrescerá, ceteris paribus, conquanto haja um incremento na produção aurífera, da mesma maneira como ocorreria para qualquer outro produto face ao aumento de sua produção. Assim que qualquer aumento nos preços, em termos de ouro, é explicado em razão do acréscimo de oferta. Note-se que a amplitude do erro em torno do valor do ouro depende simplesmente da estimativa de previsão da demanda de ouro como mercadoria, em termos de algum outro padrão monetário, sendo a quantidade produtiva em questão (destinada ao uso enquanto mercadoria) a parcela total do acréscimo de ouro. Dessa forma, não há razão em supor que a desvalorização do ouro monetário seja proporcional ao aumento da quantidade de ouro produzido (mercadoria). Não se introduziu até aqui nenhuma hipótese especial nessa argumentação, que fluiria naturalmente da teoria metalista básica e teria sido aceita pela doutrina 
Em razão da forte concentração capitalista gerada pela intensificação do comércio, como verificado na época sob análise, a transferência financeira tende a se acelerar, resultando num fluxo maior de dinheiro no intercâmbio de bens, o que por si só fortalece sua procura. A esse fator chamou atenção a sagaz intuição do filósofo e teórico político John Locke (apud HEIMANN ${ }^{61}$, 1965, p. 41, n. 15), contribuindo assim para o desenvolvimento da teoria quantitativa da moeda (LOPES, 1980, p. 127).

Contemporâneo de Locke, ainda no início do século XVIII, se destaca em termos de política mercantilista, em particular no campo monetário, a atuação extremada do financista escocês John Law ${ }^{62}$ (apud LOPES, 1980, p. 128), conselheiro do governo francês. Law parte do mesmo princípio metalista enquanto fundante da ideia de riqueza, entretanto, substitui o estoque de metais preciosos pelo de moeda fiduciária. Essa forma permitiria uma expansão mais rápida da riqueza do que os velhos mecanismos da política mercantilista, tal como a proibição de exportação de moeda ou o seu repatriamento obrigatório, incluindo-se aí o recurso ao crédito bancário, também moroso em seu entendimento. Percebe a moeda como um simples bônus para aquisição de mercadorias. $\mathrm{O}$ metalismo enquanto lastro monetário trazia seus inconvenientes sobretudo em razão das

escolástica da moeda. De fato, Molina, citado em nota anterior, já havia ressaltado o aspecto quantitativo das utilidades, o que se aplicaria logicamente à moeda enquanto tal (mercadoria). Dessarte, o reconhecimento da relevância do aspecto quantitativo para a determinação do valor da moeda, e somente por essa razão, é que se pode considerar Bodin não mais que um adepto dessa teoria, mas não seu precursor. Não obstante, de modo a ser esclarecer exatamente a questão anterior do ponto de vista do "teorema" da quantidade, partindo das mesmas premissas, tem-se que a razão para a desvalorização da unidade de ouro, e o consequente aumento dos preços, é a mesma de antes na medida em que refere o aumento de sua quantidade produtiva (destinada ao consumo como mercadoria). No entanto, parte desse aumento do estoque aurífero que se espalha pela circulação causará uma queda no valor de troca do ouro monetário justamente em razão do incremento no estoque de ouro "monetário", ou seja, do aumento da quantidade de moeda em si mesma, não da desvalorização do ouro mercadoria, a qual por si só apenas determina a amplitude do acréscimo na quantidade de ouro monetário. Dessa forma, o aumento nessa quantidade, desde que permaneça constante o poder de compra do estoque monetário total, será a causa imediata do decréscimo no valor de troca da unidade monetária. Observe-se, todavia, que essa desvalorização monetária seria a mesma caso esse estoque, permanecendo constante, fosse dividido em unidades monetárias de menor conteúdo em ouro, porque, em qualquer caso, haveria menor quantidade de mercadorias disponíveis (adquiríveis) por unidade de moeda (menor poder aquisitivo da moeda). Nessa última hipótese, as teorias medievais, que influenciaram a opinião externada por De Malestroit, estavam muito próximas da verdade. De fato, o que encambulha os conceitos é que no monometalismo perfeito do ouro o aumento de sua produção influencia tanto seu valor enquanto mercadoria como seu valor monetário, confundindo-se em razão da aparência. Nesse ponto reside precisamente a força dessa teoria que se aplica com perfeição ao caso do papel-moeda sem qualquer ambiguidade resultante do valor da mercadoria moeda. Nota-se, portanto, uma afinidade teórica entre o a teorema quantitativo e o nominalismo teórico no que tange ao tratamento da moeda não como mercadoria mas como um bilhete de compras (vale-compras). Em Bodin não há vestígios acerca de tais considerações, encontradas, todavia, na obra de Davanzati (Lezione delle moneta, 1588), que confrontara o estoque de mercadorias com o estoque monetário.

61 Some Considerations on the Consequences of the Lowering of Interest and Raising the Value of Money, 1691.

62 Money and Trade considered, 1705. 
variações de valor a que estavam sujeitos os metais monetários, conhecidas ao longo da experiência histórica, além dos altos custos envolvidos no cunhagem de moedas metálicas. O papel-moeda, por sua vez, muito mais barato que o metal, não trazia inconvenientes maiores quanto ao custo de sua produção nem à extensão dessa produção ${ }^{63}$.

O mérito de Law reside inicialmente na observação de que o valor da moeda decorre antes de sua função monetária do que de seu valor intrínseco. Na compreensão perfeita do funcionamento do sistema bancário baseado no papel-moeda, sem a necessidade do dispendioso meio de troca metálico, não raro sujeito a oscilações de valor, percebendo particularmente que jamais exigiriam os clientes de um banco a conversão total de seus bilhetes em espécies metálicas, sendo sempre esporádico o pedido de reembolso por necessidade pessoal, o que raramente aconteceria de modo simultâneo, ao menos enquanto aquele sistema despertasse confiança ${ }^{64}$. Observou argutamente as vantagens da unificação das várias espécies de moedas metálicas em circulação, sob a forma de uma nota representativa, findando as operações internas de câmbio e concentrando, assim, as diferentes espécies metálicas num caixa único de um banco central. Sem embargo, seu erro consistiu justamente em não se ater aos limites da emissão fiduciária, olvidando do efeito inflacionário dos investimentos, vez que não compreendia o mecanismos da inflação presentes na disparidade entre o incremento significativo do estoque de meios de pagamento e a taxa normal de crescimento da produção, sempre limitada a seus fatores reais (GUDIN, 1976, p. 193 e s.; HUGON, 1973, p. 78 e ss.).

Ainda nesse período pré-clássico, que se estende até a publicação, em 1776, da obra de SMITH (1984), ganha em relevo a obra de Richard Cantillon (apud HEIMANN ${ }^{65}$, 1965 , p. 49, n. 26), que fundamenta no trabalho e na terra a verdadeira riqueza de uma

63 A partir de 1718, o Estado francês adota suas ideias ao emitir grandes quantidades de papel-moeda através do Banco Real da França, fundado dois anos antes, pelo próprio Law, como banco privado, sobretudo para o financiamento dos empreendimentos monopolistas ultramarinos. Em 1729, apogeu de seu sistema, se opera a fusão entre aquela Companhia das Índias e o Banco. A superoferta monetária, decorrente da emissão continuada sem lastro metálico suficiente, sobretudo para viabilizar a capitalização da Companhia das Índias, finalmente despertam desconfiança no público e precipitam os pedidos de reembolso em espécie metálica, resultando na volatilização dos bilhetes bancários, não obstante o urgente estabelecimento de seu curso forçado, o que acaba redundando numa catástrofe sem precedentes.

64 Encontra-se precisamente nesse ponto o fundamento do multiplicador bancário, haja vista que uma nota de banco e um depósito à vista, em conta corrente, são fundamentalmente a mesma coisa (SCHUMPETER, 1964a).

65 Essai sur la nature du commerce em général, traduit de l'anglois, 1755 (publicação póstuma). A primeira versão da obra, em francês, se atribui ao próprio autor, banqueiro e financista internacional, de origem irlandesa, que vivia em Londres. Deve-se a Jevons o redescobrimento dessa literatura, que considerava como clássica, tendo sido republicada em 1931, em versão inglesa e francesa, por Higgs, enriquecida de ensaios biográficos tanto de Higgs como de Jevons. 
nação, libertando-se do complexo estritamente metalista. Explica as oscilações na balança comercial através dos mecanismos da teoria quantitativa, informando haver expansão no estoque metálico a partir do saldo beneficiário da balança comercial, resultando no incremento do nível dos preços que, por sua vez, elevam o custo da produção e o valor do produto final, ocasionando assim um déficit naquela balança. Tal processo tende a estabilizar a estrutura de preços inflacionada (HEIMANN, 1965; HUGON, 1973). Observe-se ainda sua acuidade ao defender as vantagens da liquidez, citando como exemplo dois senhores feudais, detentores de distintas formas e tamanhos de riqueza, ao mostrar que o possuidor de menor riqueza, porém de maior quantidade de moeda, tem poder imediato de aquisição de armamentos e contratação de mercenários, podendo assim derrotar mais facilmente o detentor de maior riqueza, porém menos líquida. Também logrou demonstrar, na esteira de Locke, que o incremento na velocidade de circulação monetária pode produzir efeito similar ao do aumento na oferta monetária (LOPES, 1980).

Uma das antecipações teóricas mais surpreendentes na evolução do pensamento econômico se deve a Ferdinando Galiani (apud SCHUMPETER ${ }^{66}, 1964$ a, p. 373 e ss.). No que tange à moeda, adepto do metalismo teórico, não a concebia de modo autônomo em relação aos metais nobres, não obstante nela identificasse duas espécies: ideal e real, pois que serve tanto para aferir os bens como para comprá-los. De maior alcance, no entanto, é sua contribuição científica para a solução do paradoxo do valor, conhecida mais tarde pela sua formulação clássica em SMITH, segundo a qual as coisas absolutamente necessárias atingiam um baixo preço enquanto que outras, quase inúteis, eram caras ${ }^{67}$. Obstinado pelo valor do ouro e da prata, considerados mercadorias, estudou o valor dessas. Partindo da cunha aristotélica, em que o valor se associa à utilidade, argumenta Galiani que o valor é uma razão entre a utilidade e a escassez, em que o grau de utilidade depende do grau de saciedade. Dessa forma, os bens não possuem valor econômico em si, mas apenas enquanto associados às necessidades presentes de seus usuários em potencial. Vislumbrou teoricamente muitos desenvolvimentos posteriores, faltando-lhe apenas a noção de margem para chegar à teoria do valor-utilidade marginal ${ }^{68}$ (HEIMANN, 1965, p. 115).

66 Della moneta, 1750. Há tradução para o português: Da Moeda. Curitiba: Segesta, 2000.

67 A contribuição de Galiani se deve antes a sua cientificidade e rigor de exposição do que a sua originalidade. Outros antes dele trataram de modo similar a questão em torno do valor - citem-se os escolásticos, tal como Davanzati ou Molina.

68 Teoria marginalista, predominante a partir da segunda metade do séulo XIX, e desenvolvida sobretudo por Jevons e Menger. Observe-se ainda a argumentação de Galiani no sentido de que a quantidade de trabalho é o único fator de produção e a única circunstância que dá valor às coisas, determinando seus diferentes preços, também em razão dos diferentes talentos pessoais, cujo equilíbrio (de preços) se dá 
Proeminente na transição entre o pensamento mercantilista e o liberalismo clássico é a obra do filósofo escocês David Hume (apud HEIMANN ${ }^{69}, 1965$, p. 53, n. 29), companheiro mais velho de SMITH na luta travada contra os monopólios mercantilistas e as teses relacionadas à acumulação de metais nobres como fundamento último da riqueza nacional $^{70}$. Não obstante, encampou a concepção fundamental da teoria quantitativa da

proporcionalmente a essa quantidade de trabalho. No essencial, essa teoria corresponde à de RICARDO e MARX, superando ainda a de SMITH (SCHUMPETER, 1964a).

69 Political discourses, 1752.

70 À guisa de excurso, cabe observar que o liberalismo clássico, em oposição à tese mercantilista, entendia consistir a riqueza nacional no volume de bens úteis ao povo, de nada adiantando o aumento do influxo monetário (metálico) se esse não se traduzisse num aumento do estoque de bens a serem comercializados, pois, do contrário, o resultado seria apenas um incremento no nível dos preços. Dessa forma, as trocas comerciais beneficiariam a todas as nações que delas participassem. Daí se origina a teoria das vantagens comparativas (SMITH, 1984), segundo a qual cada país teria vantagens maiores ou menores na produção de cada mercadoria, resultando numa diminuição proporcional de seu custo de produção e, assim, de seu valor, medido em tempo de trabalho (preço). Tais vantagens poderiam ser naturais ou adquiridas. Condição necessária para essa especialização produtiva seria a livre competição no mercado mundial, sem interferências governamentais (monopólios), de modo a se obter um barateamento das mercadorias. Nisso residiria justamente o ganho de todas as nações participantes, pois a riqueza nacional resultaria da obtenção dos bens necessários ao consumo da população, com o menor gasto possível de tempo de trabalho humano, promovida pelo livre comércio (tese do livre-cambismo). Os ganhos resultantes da especialização introduzida no livre comércio internacional são fundamentalmente análogos aos derivados da divisão social do trabalho no interior de uma economia local. Com efeito, a especialização induz ao aumento da produtividade do trabalho e à redução dos custos de produção, multiplicando a riqueza. $\mathrm{O}$ corolário político se expressa também na garantia das condições necessárias à expansão da divisão social do trabalho, eliminando-se as barreiras à livre circulação das mercadorias mediante o combate aos monopólios locais ou a eliminação dos direitos de passagem interna, tal qual ocorre com a supressão dos privilégios das companhias de comércio exterior ou das barreiras tarifárias às importações. Essa teoria foi aperfeiçoada por RICARDO (1984), ao demonstrar que cada país deveria se especializar na produção das mercadorias em que tivesse maior vantagem relativa, ainda que para isso tivesse de importar as demais mercadorias por valor superior ao de sua produção local. Pressuposto implícito do livre-cambismo é o de que os demais países também adotem essa política, de modo que a demanda externa pelos produtos especializados de um país seja elástica o suficiente para permitir seu escoamento e assim proporcionar o necessário superávit para aquisição das demais mercadorias de que necessite. Não obstante, a política mercantilista, ainda em voga na época de SMITH, objetivava justamente evitar que a balança comercial se tornasse deficitária, o que afastava do ponto de vista prático a objeção anterior. Não assim no decurso do século XIX, quando o livre comércio progredia e concomitantemente crescia a preocupação com o equilíbrio da balança comercial. RICARDO solucionou a questão a partir da adoção do monometalismo do ouro enquanto padrão monetário, pressupondo sua adoção pela comunidade internacional, de modo que os países deficitários saldariam suas obrigações mediante transferências daquele metal. Resultado dessa transferência seria a redução automática do volume de metal em circulação no país deficitário e, consequentemente, a contração dos meios de pagamento, gerando um processo deflacionário. Dessa forma, haveria um decréscimo forçado nos custos e preços, expressos em ouro, elevando assim as vantagens comparativas desses países, reduzindo-se na sequência os preços de sua pauta exportadora, redundando em reequilíbrio da balança comercial. Nos países superavitários, ao contrário, haveria uma elevação generalizada dos preços, redundando em decréscimo das exportações. A adoção irrestrita do padrão metálico único traria consigo um equilíbrio automático da balança comercial de todos os países envolvidos, suportando assim o livre-cambismo. Observe-se que o século XIX, durante um largo período, assistiu ao livre-cambismo no comércio internacional à luz da teoria exposta. Naturalmente se beneficiava dessa situação a Grã-Bretanha devido a suas enormes vantagens em termos de produtos manufaturados, resultado do avanço técnico trazido pela revolução industrial. As vantagens adquiridas eram tão amplas quanto a gama de produtos ali manufaturados, em contraposição a uma diversidade de países especializados na produção de certos produtos, em geral alimentos naturais e matérias-primas. Essa divisão internacional do trabalho fez com que Londres se tornasse o centro comercial e financeiro do 
moeda, da mesma forma que seus sucessores clássicos, ofertando análise penetrante dos possíveis efeitos dinâmicos do influxo de dinheiro. Seu mérito reside em ter confrontado de modo bastante rigoroso os estoques de mercadorias e de moedas, mostrando precisamente que os preços se formam a partir dessa interdependência (LOPES, 1980, p. $129)^{71}$.

A partir da segunda metade do século XVIII tem início o estudo científico da economia, predominando então o pensamento econômico dos clássicos. A chamada escola clássica dos economistas $^{72}$, que tem entre seus expoentes SMITH e RICARDO, e sob certos aspectos compreendendo MARX, apresenta basicamente duas características comuns, a saber, a refutação da ideia metalista de riqueza e o fato de que todos os seus representantes fizeram uso dos instrumentos analíticos apresentados na obra inaugural de SMITH (1984), Wealth of Nations, publicada em 1776. O mais relevante do ponto de vista científico é precisamente a continuidade e reinterpretação ${ }^{73}$ de seus instrumentos de análise, marcando historicamente essa escola (HEIMANN, 1965, p. 88).

Sem embargo, do ponto de vista da teoria monetária, a realização de SMITH ficou

Império Britânico e do mundo. Em consequência, a política monetária inglesa se tornava hegemônica, favorecendo naturalmente a adoção do padrão ouro britânico pelo restante da comunidade mundial, geralmente em substituição à prata, de modo a facilitar o comércio com o Reino Unido e a obtenção de empréstimos daquele país. A partir dessas políticas monetárias nacionais surge um sistema internacional de taxas de câmbio fixas. O sistema inteiro exigia, por sua vez, um clima intelectual no qual a estabilidade monetária e cambial gozasse de proeminência política. Para tanto, o ambiente político também deveria ser estável de modo a evitar orientação diversa das políticas públicas. Por último, mercados abertos e flexíveis eram condição necessária para a articulação dos fluxos de capital e mercadorias, evitando-se oscilações bruscas na oferta e na demanda por mercadorias e financiamentos. Assim que o livrecambismo, banhado a ouro monetário, perdurou praticamente até a eclosão da Grande Guerra, ainda que reformulado sob o argumento protecionista da indústria infante, o que permitiu a emergência de novas potências mundiais, a começar pelos Estados Unidos e a Alemanha unificada, ao menos no que dizia respeito às zonas comerciais sob influência das respectivas nações industrializadas. Fato é que muitas das condições anteriores já haviam sido minadas pela modernização econômica e política, resistindo o padrão ouro mais por circunstâncias conjunturais do que por sua solidez estrutural, mercê da solidariedade internacional em tempos de crise (EICHENGREEN, 2000, pp. 29 e s., 57 e ss.; SINGER, 2010, p. 146 e ss.).

71 Quanto ao fenômeno inflacionário, descobriu não somente a defasagem temporal na redistribuição das rendas entre os diversos segmentos da economia, mas sua vantagem enquanto estímulo à atividade produtiva, desde que esse aumento na quantidade de moeda circulante fosse gradual (HEIMANN, 1953, p. 54). Em sentido contrário, a interpretação dada por FRIEDMNAN (1994, p. 49).

72 Em regra suas obras têm origem na Grã-Bretanha, tendo como seu maior representante no continente europeu o economista francês Jean-Baptiste Say.

73 Essa reinterpretação ocorre sobretudo em razão de experiências dolorosas trazidas pela conjuntura histórica. O encaminhamento satisfatório da revolução industrial para a questão produtiva não se refletiu em ganhos para o conjunto da sociedade, pelo contrário, aprofundou o rasgamento do tecido social. $\mathrm{O}$ poder econômico, sob a égide dos ideais liberais, viu seus controles serem abolidos. Dessa forma, o individualismo sorveu daquele moinho não só o progresso econômico, mas também a dignidade social dos empregados fabris. O resultado não acompanhou a visão otimista trazida pela fé de SMITH, senão que se traduziu em crise social, o que vem sendo a regra na história do capitalismo (HEIMANN, 1965, p. 89; HUGON, 1973, p. 117). 
aquém de alguns dos seus antecessores, entre eles Cantillon, tendo ainda ignorado o caminho traçado por Galiani para a teoria do valor.

O alicerce da teoria smithiana se encontra na divisão do trabalho, fator básico do progresso humano, tendo induzido "o desenvolvimento da produtividade do trabalho, e o aumento do engenho, destreza e discernimento ao qual está ligado”. Essa divisão do trabalho não é fruto, todavia, da engenhosidade humana, tendo antes um caráter volitivo do que racional, "consequência necessária, se bem que lenta e gradual, de uma determinada tendência da natureza humana que tem como objetivo uma utilidade menos extensiva: a tendência para negociar e trocar uma coisa por outra”. Assim, "o contrato, a compra ou a troca nos permitem obter uns dos outros a maior parte dos serviços recíprocos de que necessitamos; foi ainda essa propensão para a troca que originariamente provocou a divisão do trabalho". Assim como as trocas originam a divisão do trabalho, também o desenvolvimento dessa divisão se condiciona pela extensão daquelas, ou seja, pela expansão dos mercados (SMITH, 1984, pp. 7, 13 e s., 17).

Estabelecida a correlação definitiva entre a divisão do trabalho e o mercado, seu corolário natural é a troca dos excedentes produzidos, pois que a especialização produtiva resulta na mercantilização daquilo que se produz em excesso de modo a se obter, em contrapartida, aquilo de que se tem falta. A sociedade como um todo tende dessarte a se comportar como uma sociedade mercantil. Esse progresso produtivo, no entanto, gera naturalmente uma dificuldade técnica, qual seja, a troca em espécie, pois que os produtos que se trocam nem sempre, e mesmo com frequência, não são úteis para ambas as contrapartes envolvidas no negócio. Dessa forma, em cada período da sociedade, efetuaram-se os negócios a partir da utilização não só do próprio produto do trabalho, mas também de certa quantidade de qualquer outra mercadoria facilmente negociável no mercado. Nos mais diversos países, em regra, se preferiram para essa utilização os metais a qualquer outra mercadoria. Além de manterem um valor tão estável quanto quaisquer outras mercadorias, são duráveis e ainda passíveis de fracionamento, sem desperdícios maiores, e de refundição. Essa característica dos metais é o que os torna, nesse particular, o melhor meio de troca e circulação. Para esse fim têm sido usados diversos metais, entre eles o ferro e o cobre, adotando-se o ouro e a prata pelas nações ricas (SMITH, 1984, p. 21 e s.).

O uso de metais apresentava, no entanto, dois graves inconvenientes no âmbito dos negócios: a avaliação do seu peso e a dificuldade de examiná-los. A pesagem do ouro, 
em particular, é uma operação de grande delicadeza, sendo sua análise ainda mais complicada. No intuito de prevenir os abusos decorrentes da adulteração dos metais, facilitando assim as trocas e o desenvolvimento industrial e comercial, viram-se obrigados os países de vanguarda a cunhar determinadas quantidades de metais geralmente usados na efetivação das trocas mercantis. Aqui reside a origem da moeda cunhada como das instituições públicas denominadas casas da moeda: "estas são exatamente da mesma natureza das instituições que hoje põem um selo de garantia nas roupas de linho e lã. Em ambos os casos se pretende garantir, por meio de um selo público, a quantidade e a qualidade uniforme das diferentes mercadorias levadas a mercado". Veja-se o exemplo dos antigos reis saxões da Inglaterra, cujas rendas eram pagas não em moeda mas sim em gêneros; somente com Guilherme, o Conquistador, se introduziu o costume de pagar com moeda - ainda assim, o valor dessa moeda se avaliava por peso ao dar entrada no erário. A instituição da cunhagem veio então definir tanto a qualidade quanto o peso do metal, de tal forma que as moedas passassem a ser avaliadas pela soma dos respectivos valores, não mais por seu peso. Dessa forma, tornou-se a moeda meio de troca universal, ao menos em todos os países civilizados, mediante o qual todas as mercadorias são compradas, vendidas e trocadas entre si (SMITH, 1984, p. 22 e ss.).

As lições smithianas a respeito da vetusta sequência divisão do trabalho - permuta - dinheiro, em que pese o rigor e a clareza de exposição, são tão originais quanto as aristotélicas, representando antes a síntese codificada das ideias amadurecidas ao longo da experiência social, e desde então repisadas pela quase totalidade dos estudiosos da economia.

No que tange particularmente à questão monetária, observa-se como traço fundamental a ideia de moeda vinculada à noção de mercadoria que, como qualquer outra, seja levada ao mercado. Dessa forma, a moeda enquanto dinheiro encontra seu valor no mercado, tal qual o metal que lhe serve de base ou, em última instância, a denota. Essa moeda-dinheiro tem valor intrínseco, enquanto valor de troca, correspondente ao do metal negociado no mercado, e somente nesse sentido o representa. A cunhagem enquanto técnica serve apenas de garantia oficial (pública) da qualidade e quantidade daquele metal circulante no mercado, que faz as vezes de mercadoria-dinheiro. A conclusão de que os metais sejam o "melhor meio de troca e circulação" implica, a partir das considerações anteriores, duas proposições: primeiramente, que o metal enquanto mercadoria é meio universal de trocas, pois somente mercadorias são levadas ao mercado, fazendo assim as 
vezes de dinheiro; em segundo lugar, que o metal enquanto moeda cunhada é meio circulante, representado esse mesmo dinheiro ao exprimir nominalmente seu valor de troca.

No que tange à questão do valor, supera SMITH seus antecessores ao distinguir, para a posteridade, entre valor de uso e de troca: expressando aquele a utilidade de determinado bem; enquanto esse, a possibilidade desse mesmo bem servir para comprar outras mercadorias. Surge, uma vez mais, a noção de mercadoria-dinheiro como meio de troca (compra), comparando-a ao diamante que, por sua vez, se distingue da água, nada mais útil, mas com o que nada se pode comprar. Com isso enuncia SMITH (1984, p. 25) o paradoxo do valor, mas sem sobre ele avançar, até porque seu objetivo era outro que não o de ferir o substrato do fenômeno do valor.

Com efeito, deve-se atentar para o objetivo verdadeiro do estabelecimento do conceito de valor de troca na teoria smithiana, a saber, o exame das regras normalmente observadas nas trocas de bens "por dinheiro ou entre si", e que determinam o "valor relativo ou variável das mercadorias" (p. 24). Assim que, após distinguir entre o valor de uso e o de troca, abandona aquele e parte desse último no caminho para estabelecer uma teoria dos preços ${ }^{74}$.

Como leciona SMITH (1984, p. 27 e ss.), o trabalho constitui o verdadeiro preço de qualquer mercadoria, devendo-se a esse elemento tanto aquilo que se compra com dinheiro ou com mercadorias como aquilo que resulta diretamente do próprio labor. Foi o trabalho, não o ouro ou a prata, o primeiro preço, a primeira moeda de troca que por tudo se pagou, a medida última da riqueza. O valor dessa última, ou seja, seu valor de troca se iguala exatamente à quantidade de trabalho que permite adquirir poder de compra. No dizer de Hobbes, a riqueza é poder. Esse poder, no entanto, reside unicamente na imediatidade do poder de compra, numa certa autoridade sobre o trabalho, ou seu produto, existente no mercado. A dimensão da riqueza se mede pela extensão do poder de compra,

74 Através dessa teoria busca determinar a verdadeira medida do valor das mercadorias, é dizer, o conteúdo de seu preço real, bem como diferenciar o verdadeiro preço das mercadorias (preço de mercado) de seu preço natural. Nesse sentido, conclusiva a lição de SMITH (1984, p. 44): "os salários, os lucros e as rendas são as três fontes originais de todo o rendimento assim como de todo o valor de troca [preço]". Sua teoria do valor nada mais é do que a denominada teoria dos custos de produção. Não obstante, "deve-se notar que o valor real de todas as partes componentes do preço é medido pela quantidade de trabalho que cada uma delas pode comprar ou trocar. $O$ trabalho não mede apenas o valor daquela parte do preço constituída pelo salário do próprio trabalho, mas também daquelas que são constituídas pela renda e pelo lucro. Logo, o trabalho é a medida real do valor de troca de todas as mercadorias" (pp. 27, 43). Além das referidas passagem, diversas outras indiciam uma teoria do valor-trabalho, antecipando, em certa medida, as teorias de RICARDO e MARX. 
em última instância, pelo produto do trabalho alheio que essa riqueza faculta adquirir. Dessa forma, "o valor de troca de todas as coisas deve ser precisamente igual à extensão do poder que os objetos possuídos permitem ao seu possuidor".

Sem embargo, a despeito de ser o trabalho o preço real de qualquer mercadoria, normalmente não é a ele que se recorre como unidade de aferição do valor de troca. De fato, todas as mercadorias são frequentemente permutadas, portanto comparadas, com outras mercadorias do que com trabalho. Não obstante, cessada a simples permuta, surge o dinheiro como instrumento regular do comércio, sendo ele o meio de troca preferencial a outra mercadoria qualquer. É portanto mais natural que se avalie o valor da mercadoria objeto da troca pela quantidade de dinheiro, ou seja, da mercadorias que imediatamente se recebe em troca, do que pela quantidade de mercadorias que só será obtida posteriormente "mediante a intervenção de outra mercadoria (moeda)". Assim que o valor de troca da mercadoria acaba sendo frequentemente avaliado pela quantia de dinheiro, não pela quantidade de trabalho ou de qualquer outra mercadoria que se obtenha em troca.

O ouro e a prata, todavia, como quaisquer mercadorias, têm um valor variável, dependendo sempre da riqueza ou esterilidade das minas. O trabalho, ao contrário, mantém sempre constante seu valor, pois em qualquer tempo e lugar têm as quantidades iguais de trabalho o mesmo valor para o trabalhador, vez que o trabalhador mediano deve sempre produzir a mesma quantidade de conforto, liberdades e felicidade. Em consequência, o trabalho é a derradeira medida universal de valor das mercadoria, constituindo o seu preço real; o dinheiro, por sua vez, é o seu preço nominal.

A diferença entre o preço real e o nominal das mercadorias, inclusive do trabalho, traz importantes consequências de ordem prática, considerando que o preço real encerra sempre o mesmo valor, enquanto que o preço nominal sofre oscilações constantes em seu valor em virtude das variações do valor do ouro e da prata. $\mathrm{O}$ arrendamento perpétuo de uma propriedade fundiária ilustra bem essa aplicação. Se o proprietário pretende conservar o mesmo valor ao longo do tempo, resulta que aquela renda não poderá consistir numa dada soma em dinheiro. Do contrário, a renda sofrerá dois tipos de variações: em primeiro lugar, aquelas que derivam das diferentes quantidades de metal contidas, ao longo do tempo, em moedas de mesma denominação; em segundo, as que resultam dos diferentes valores de uma mesma quantidade de metal ao longo do tempo. Observe-se que as rendas pagas em cereais preservam melhor o seu valor do que as pagas em dinheiro, mesmo onde a denominação das moedas não se alterou. 
Não obstante, dado que em diferentes regiões não exista uma proporção regular entre os preços real e nominal das mercadorias, o mercador que as transporta precisa somente considerar o seu preço em dinheiro, ou a diferença entre a quantidade de prata pela qual as comprou e aquela por que as pode vender. Dessa forma, sendo o preço nominal ou em dinheiro das mercadorias o instrumento de ponderação das possibilidades de compra e venda, regulando assim todo o tráfico em que intervém o dinheiro, tem esse atraído muito mais a atenção do que o preço real.

Observe-se que ao falar do preço em dinheiro das mercadorias, SMITH (1984, p. 39) se refere "sempre à quantidade de ouro ou prata puros pela qual são vendidas, sem qualquer consideração pela denominação da moeda".

O que se deve reter é que o substrato no qual se assenta a teoria smithiana é sempre uma economia consuntiva, que tem na satisfação das necessidades individuais seu escopo principal. Tal economia funciona a partir do processo básico de trocas, é dizer, trata-se de uma economia natural de trocas, ainda que faça uso da moeda (dinheiro). Nesse ponto reside o paradigma do pensamento econômico clássico, a saber, uma economia de trocas que utiliza dinheiro. Sua concepção enquanto mercadoria é corolário natural do sistema de trocas, mas enquanto dinheiro, em si mesmo, é de medida de valor. Com efeito. O dinheiro é necessariamente concebido como uma mercadoria levada a mercado, e como tal dotado de valor próprio (em regra, preço real e nominal dos metais nobres), conquanto também sirva de denominador comum. Nessa última função, o dinheiro se afigura como elemento neutro, que se traduz somente nos preços que nominam os valores de troca das mercadorias (preço nominal ou em dinheiro). Nessa concepção, portanto, se assenta a denominada teoria quantitativa da moeda (dinheiro), que nada mais é do que uma teoria dos $\operatorname{preços}^{75}$.

75 Decorre naturalmente da visão socioeconômica clássica a negação da riqueza fundada no dinheiro e, portanto, na acumulação metálica. No entender de SMITH (1984, p. 188 e ss.), essa ideia se relaciona ao sistema de economia política que entende a riqueza nacional centrada na abundância de ouro e prata, ou seja, o mercantilismo. Observa, na sequência, que o valor elevado dos metais preciosos traduz somente a esterilidade das minas que de momento abastecem o comércio mundial. O incremento simultâneo na quantidade de ouro e prata existente na Europa e nas suas manufaturas e agricultura são eventos determinados por causas distintas, naturalmente não relacionadas entre si. Aquele é consequência do mero acaso, não da sabedoria nem da política dos homens; esse, da queda do feudalismo e do incentivo governamental no sentido de ter dado à indústria a liberdade de gozo dos resultados de seu trabalho. Nesse sentido, é consequente SMITH, pois havia mostrado anteriormente ser a riqueza fundada no produto do trabalho, é dizer, na capacidade econômica de adquiri-lo. Dessarte, a partir da compreensão quantitativa das relações entre moeda e preços, assevera SMITH precisamente que o elevado ou baixo preço em dinheiro dos bens em geral, ou do trigo em particular, está condicionado pela fertilidade ou esterilidade das minas que produzem ouro e prata, nada dizendo a respeito da riqueza ou pobreza de um país. Por outro lado, do elevado ou baixo preço em dinheiro de certas espécies de bens proporcionalmente 
Na economia natural de trocas, paradigma do modelo clássico, não há lugar para o empreendedorismo orientado ao lucro, a não ser de modo esporádico, em regra restrito à classe dos negociantes, cujos interesses são vistos, aliás, como sempre conflitantes com os do público em geral, procurando elevar seus lucros acima dos valores naturais (SMITH, 1984, p. 198 e s.). Uma economia de trocas, que faz uso do dinheiro, difere fundamentalmente de uma economia lucrativa que tem no dinheiro um elemento central, ou seja, de uma economia monetária.

RICARDO (1984) é tido como o sistematizador da escola clássica, tendo como fundamento a teoria de valor baseada no trabalho, elaborando-a a partir da tese smithiana. Essa havia abandonado a questão da utilidade (valor de uso), logo após ter enunciado o paradoxo do valor, concentrando-se nos fatores e seus custos de produção de modo a desenvolver uma teoria dos preços, determinando finalmente o preço real das mercadorias em função do trabalho. A partir daqui se desenvolve a tese ricardiana, que encara a utilidade como elemento natural e portanto requisito prévio da economicidade dos bens, mas não como fonte ou determinante do valor de troca, ainda que a esse inerente: possuindo utilidade, as mercadorias derivam seu valor de troca de sua escassez e da quantidade de trabalho exigido para obtê-las. Tendo em vista sua preocupação com os produtos do trabalho, correspondentes à grande maioria das mercadorias levadas ao mercado, concentra sua análise na quantidade de trabalho como denominador comum do valor (RICARDO, 1984, p. 257) ${ }^{76}$.

A partir de uma ideia incidental de SMITH, entende RICARDO por trabalho todo o trabalho acumulado na produção de uma mercadoria, associando até certo ponto o trabalho ao capital. Assim que o valor de uma mercadoria, ou seja, a quantidade de outras mercadorias pela qual pode ela ser trocada, reside na quantidade relativa de trabalho encerrado em sua produção. O valor-trabalho se torna a única medida de todas as relações econômicas e, em última instância, seu princípio organizador.

ao de outros se pode inferir que muito provavelmente a maior parte das terras de um país está ou não melhorada, e que esse país atingiu ou não um estágio civilizatório elevado. Portanto, a terra constitui de longe a parte maior, mais importante e permanente da riqueza nacional.

76 Registre-se que o paradoxo do valor smithiano, ou seja, a aparente razão inversa entre valor (preço) e utilidade implicou logicamente a redução de dois dos três custos de produção (terra e capital) ao terceiro (trabalho) como fator elementar e fonte última do valor. A outra solução que se apresentava era a redução a um terceiro elemento subjacente a todos eles, qual seja, a utilidade, o que de fato ocorreu no desenvolvimento ulterior do pensamento econômico predominante, dando origem à teoria marginalista do valor-utilidade. A principal crítica de que padece essa teoria do valor da escola clássica reside justamente em olvidar da causa natural do valor (utilidade) e o explicar a partir de seu efeito, qual seja, o preço, daí construindo não uma teoria do valor, mas uma teoria dos preços (PRADO JR., 1966). 
Sendo o trabalho o fundamento de valor de todas as mercadorias, e sua quantidade comparativa, necessária à sua produção, a regra determinante de seu valor de troca, ou seja, de quanto de um bem se dá em troca de outro, surge a noção de preço primário ou natural, expressão daquele valor. Quando levadas ao mercado, sofrem as mercadorias com suas oscilações, sofrendo alterações em seu preço primário, o que também determinará as variações do capital alocado na sua produção. Dadas essas flutuações no capital investido em sua produção, sobretudo em razão da competição entre os investimentos, o valor de troca da mercadoria se ajusta às condições do mercado, determinando seu preço real, ou de mercado (RICARDO, 1984, p. 293 e ss.).

Após apontar a impossibilidade em se ter uma mercadoria que seja de fato uma medida invariável do valor das demais, de modo a aferir seus valores relativos e, portanto, a variação do seu valor real, assume RICARDO (1984, p. 274) ser o ouro um padrão monetário tão próximo do invariável quanto a conjuntura econômica o permite, postulado suficiente para o desenvolvimento de sua teoria monetária.

Com efeito. Partindo da lei do preço de mercado, o dinheiro mercadoria (ouro) sofre variações em seu valor (preço) na razão inversa de sua quantidade (oferta), sendo essa regulada pelo custo de produção do ouro ${ }^{77}$. Tendo em vista que ele é a mercadoria denominador comum, quantidades iguais de trabalho incorporadas à sua produção e à produção das demais mercadorias serão trocadas no mercado, em razão dos fluxos contrários de bens e dinheiro determinados pela natural migração dos investimentos em busca de maior rentabilidade. Em consequência, as variações dos preços das mercadorias serão inversamente proporcionais às variações do preço do dinheiro (mercadoria ouro), de modo que a oferta de ouro dependerá dos níveis relativos dos preços. Em suma, a teoria quantitativa da moeda é apresentada sob a forma da teoria do preço de mercado, nesse particular aplicada ao dinheiro ${ }^{78}$.

77 No curto prazo, a quantidade de ouro é regulada pelo custo de produção (curva normal), estabelecendo-se o equilíbrio em longo prazo simplesmente pela lei da oferta e da procura, ou seja, quando oferta e demanda se igualam, é dizer, quando a curva de oferta encontra o preço de mercado (curva de procura) essa é a síntese da teoria quantitativa clássica (SCHUMPETER, 1964a).

78 HUGON (1973, p. 142 e s.) critica a fórmula ricardiana por haver considerado exclusivamente a oferta (quantidade), olvidando da procura de moeda. Não obstante, a tese ricardiana permanece válida do ponto de vista da moeda metálica, cuja oferta regula a procura, resultado de ser o ouro uma mercadoria com valor real, o que lhe assegura uma procura equivalente no mercado mundial. A objeção permanece correta, no entanto, em relação à moeda fiduciária, conversível ou não, vez que não possui valor real e sua procura não é constante nem sempre internacional. De fato, RICARDO buscou superar essa dificuldade ao introduzir a regulamentação rígida da emissão monetária (vide nota seguinte), mantendo sempre a paridade com o ouro, da mesma forma que SMITH admitia a oferta monetária sem lastro, desde que bem regulada. Somente a partir de tais condições encontra aplicação possível a teoria quantitativa, tal qual 
Como assevera RICARDO (1984, p. 277), com base nos princípios que informam

o valor de troca e o preço, é mister que se diferencie as variações inerentes à própria mercadoria daquelas resultantes da oscilação no meio em que estima o valor ou se expressa o preço:

Sendo o dinheiro uma mercadoria variável, o aumento dos salários monetários será frequentemente ocasionado por uma queda no valor do dinheiro. Um aumento de salários resultante desta causa será, com efeito, acompanhado por uma elevação no preço das mercadorias, mas, em tais casos, verificar-se-á que o trabalho e todas as mercadorias não terão variado uns em relação aos outros, e que a variação se limitou à moeda [dinheiro $^{79}$.

formulada pelos clássicos, na regulagem da oferta de dinheiro, é dizer, substituindo à regulação automática pelo mercado a regulamentação oficial (política monetária). Dessa forma, mantém-se agora artificialmente exógena a oferta de moeda, que o era outrora automaticamente.

79 A partir desse sistema, a doutrina liberal se completa sob o prisma econômico. Assim, o suprimento de metal monetário ficaria a cargo da iniciativa privada, orientada pelo lucro, assegurando-se a proporção entre bens e moeda, conquanto a estabilidade dos preços restaria determinada pelo valor-trabalho. Esse equilíbrio automático entre preços e moeda (ouro) depende, obviamente, do livre intercâmbio internacional. Não obstante, RICARDO teve participação ativa na polêmica bulionista surgida em torno do papel-moeda não conversível, resultado da situação de penúria metálica que atingira a Inglaterra durante as guerras napoleônicas, resultando mais tarde, a partir de 1820, na lide entre as denominadas currency school e banking school. Mentor intelectual da primeira corrente, consentâneo com a teoria quantitativa da moeda, asseverava que a quantidade de notas emitidas (oferta monetária) era responsável pela sua depreciação, vez que o resgate das notas do Banco da Inglaterra por ouro em espécie fora suspenso sem que sua quantidade houvesse sido reduzida, ao contrário, permaneciam em circulação sem a paridade com o ouro. De fato, o esterlino se depreciou frente à cotação dos metais preciosos, tendência acentuada pelo entesouramento do ouro e a consequente necessidade de suplementação da oferta monetária por notas de emissão daquele banco. RICARDO acaba por identificar a moeda com um simples bilhete de troca qualquer que fosse sua forma, moeda metálica ou papel-moeda, conversível ou não. Na mesma linha de SMITH, acreditava que o abandono da moeda metálica pelo papel-moeda só traria vantagens, desde que sua oferta fosse bem regulada. Esse descrédito na moeda metálica, e sua identificação com um bônus de troca, nada mais é do que um reflexo tardio da reação da escola smithiana contra a concepção mercantilista de moeda enquanto fonte de riqueza. Com efeito, RICARDO propõe a resgatabilidade da moeda fiduciária a uma quantidade fixa de ouro, emitida contra a entrega do metal, impedindo assim sua depreciação em relação àquela paridade. Ademais, o resgate deveria se restringir ao ouro em espécie, não às moedas. Os saldos de importação em razão da desvalorização da moeda se compensariam mediante a remessa do metal ao exterior em seu pagamento. Evitar-se-ia dessa forma a emissão arbitrária pelo governo (inflação), mantendo-se a regulação (pretensamente) automática da quantidade de moeda em circulação (princípio da circulação) e assim do valor do papel-moeda por meio da livre produção dos metais e o livre-cambismo. Nessa hipótese, a nota bancária nada mais é do que um sucedâneo da moeda metálica, uma espécie de certificado de ouro. No entanto, de modo a preservar os ganhos de senhoriagem em poder público, advogava RICARDO a emissão oficial do papel-moeda por um órgão governamental. $\mathrm{O}$ entendimento monetarista da escola ricardiana pode se resumir na seguinte equação, onde $P$ representa o nível geral dos preços e $M$ a oferta de moeda: $P=f(M)$. Por seu turno, a banking school advogava a ideia de que a quantidade de moeda era determinada pelas necessidades dos negócios, ou seja, pelo lado da demanda, propondo a liberdade de emissão de forma a dar vazão ao crédito, caucionada pelas reservas metálicas do banco emissor, mercê dos empréstimos que essa proporciona. Segundo J. B. Say (CENECO, p. 79), esse princípio seria autorregulador, pois o excesso de emissão implicaria uma depreciação das notas bancárias e a consequente exigência de reembolso pelo público. Tal princípio foi adaptado pelo Banco de França, em 1802. Implicitamente segue dessa 
Em que pese sua crítica fundamental ao capitalismo e ao pensamento liberal, não há olvidar de que seja MARX (2004), em termos de teoria econômica pura, um tributário bastante fiel da escola clássica, em particular de RICARDO. Com efeito, sua teoria do valor parte do mesmos pressupostos adotados na exposição smithiana e, no que tange ao estudo da moeda, pouco acrescenta à teoria ricardiana (HEIMANN, 1965; HUGON, 1973; SCHUMPETER, 1958).

Sem embargo, o que lhe faltou em originalidade nessa seara, sobrou-lhe em termos de método, vigor e erudição. Partindo de uma concepção historicista, influenciado pela dialética hegeliana (SCHUMPETER, 1958) e sobretudo pelo materialismo de Feuerbach, traz para o centro de sua exposição econômica a noção de determinismo histórico, explicando sempre os fatos econômicos no sentido de uma progressão dialética. Ademais, apesar do naturalismo científico que inalam suas concepções, produto de seu tempo ${ }^{80}$, opera sua obra principal um amálgama entre a teoria econômica e a análise dos fatos sociais, introduzindo uma visão sociológica do fenômeno econômico a partir da concepção da materialidade (totalidade) fenomênica. A Economia Política é dessarte abordada por MARX sob a concepção materialista, no sentido de negação do idealismo, e dialética da história, portanto do sistema capitalista enquanto momento histórico (PRADO JR., 1966).

Com efeito. MARX (2004, p. 57 e ss.) adota, conquanto parcialmente, a teoria ricardiana do valor - quantidade relativa de trabalho -, enquanto explicação do valor econômico do produto social a partir da divisão social do trabalho, pois que "numa sociedade cujos produtos assumem, geralmente, a forma de mercadoria, (...) a diferença qualitativa dos trabalhos úteis executados leva a que se desenvolva um sistema complexo,

argumentação o entendimento de que a moeda é uma variável endógena, ou seja: $\mathrm{M}=\mathrm{f}(\mathrm{P})$. A tese ricardiana acabou por prevalecer não só em termos de doutrina econômica senão em virtude de sua adoção quase integral pelas leis bancárias (Peel Act), de 1819 e 1844, a partir do que o Banco da Inglaterra viu controlado seu poder emissor, permitindo-se, não obstante, a circulação de moedas paralelamente às notas bancárias. Do ponto de vista teórico, a teoria quantitativa conheceu posteriormente formulações matemáticas mais elaboradas, fundamentadas em testes empíricos. De fato, a análise das relações quantitativas entre moeda e preços se torna imprescindível sob um sistema monetário controlado do que num sistema de moeda livre, de modo a fornecer instrumental teórico para tal controle. Essa investigação resultaria na célebre "equação de trocas" de Fischer, segundo a qual o nível geral de preços (P) depende do volume de comércio (T), de um lado, e da quantidades (M) e velocidade (V) da moeda em espécie e do crédito, de outro: MV = PT (HEIMANN, 1965; LOPES, 1980; SCHWARTZ, 1989, pp. 418). Observa-se, finalmente, que o metalismo teórico, tal qual formulado por SMITH e RICARDO, nem sempre implica necessariamente sua adoção do ponto de vista prático, enquanto política monetária, como mostra a adesão ricardiana à tese da moeda fiduciária, vez que não raro contingências socioeconômicas impingem ao teórico formulações outras que sejam adequadas à realidade dos fatos.

80 O tomo primeiro de $O$ Capital foi publicado ainda em vida, em 1867. 
uma divisão social do trabalho". Portanto, "se prescindirmos do valor de uso da mercadoria, só lhe resta ainda uma propriedade, a de ser produto do trabalho". Sua grandeza de valor varia na razão direta da quantidade e na inversa da produtividade do trabalho aplicado em sua produção. É na relação de permuta das mercadorias que se revela seu valor de troca, totalmente independente de seu valor de uso: " o valor de troca é o modo necessário de expressar-se o valor ou a forma de este manifestar-se".

Observe-se que essa divisão social do trabalho se verifica na realidade histórica, se transforma ao longo da evolução econômica, se expandindo e assim influindo também sobre aquele valor. Essa expansão terminará por abarcar a atividade humana de modo geral, tornando-a econômica na medida em que se torna cada vez mais social (coletiva). Dessa forma, aquela divisão do trabalho não se opera de forma anacrônica, meramente lógica, para a satisfação das necessidades individuais, tal qual na teoria smithiana ou ricardiana, mas de modo histórico e para a satisfação das necessidades sociais, obtendo em contrapartida um produto equivalente, em termos de quantidade (tempo) de trabalho (social), dos demais membros da coletividade (SINGER, 2010, p 11 e ss.) ${ }^{81}$.

Da noção de valor (de troca ou econômico) segue a noção de dinheiro, segundo MARX (2004, p. 69 e s.):

Todos sabem, mesmo quem nada mais sabe, que as mercadorias possuem forma comum de valor, que contrasta com a flagrante heterogeneidade das formas corpóreas de seus valores de uso. Esta forma comum é a forma dinheiro do valor. Para isso se faz necessário acompanhar o desenvolvimento da expressão do valor contida na relação de valor existente entre as mercadorias, partindo da manifestação mais simples até chegar à esplendente forma dinheiro.

Com apoio na doutrina aristotélica, conclui $\operatorname{MARX}(2004$, p. 81 e s.) que a forma

81 Revelando a abordagem histórica de sua análise, assim se expressa MARX (2004, p. 83): "Em todos os estágios sociais, o produto do trabalho é valor de uso; mas só um período determinado do desenvolvimento histórico, em que se representa o trabalho despendido na produção de uma coisa útil como propriedade "objetiva", inerente a essa coisa, isto é, como seu valor, é que transforma o produto do trabalho em mercadoria". Observe-se, portanto, que a visão social marxista se difere fundamentalmente daquela dos economistas clássicos pelo fato de MARX entender o modo de produção capitalista da vida socioeconômica de seu tempo como um estágio do evolver histórico, rumo à coletivização, enquanto que os clássicos liberais veem a sociedade de seu tempo como modelo acabado, quase que a-histórico, se bem que passível de adaptações, mas no sentido do progresso do próprio modelo capitalista, sobretudo em razão da pressão concorrencial (HEIMANN, 1965). O marxismo, portanto, não propõe modificações do sistema capitalista em nome de qualquer princípio ou concepção ética, com o fim de sanar equívocos porventura existentes. Ao contrário, "aceita o capitalismo, como fato histórico que êle é, na suas integridade e por isso nas consequências que comporta; e é precisamente nessas consequências derradeiras e de última instância que o marxismo se funda para propor a transformação do sistema" (PRADO JR. 1966, p. 62). 
dinheiro da mercadoria é apenas a figura ulteriormente desenvolvida da forma simples do valor, isto é, da expressão do valor de uma mercadoria em outra qualquer, em razão de a troca implicar igualdade, e essa, pois, comensurabilidade. Essa equalização é estranha à verdadeira natureza das coisas, decorrendo assim de um simples expediente para atender às necessidades práticas ${ }^{82}$.

Observe-se, portanto, que a forma simples de valor da mercadoria é também a forma mercadoria elementar do produto do trabalho, sendo ainda a forma embrionária que atravessará uma série de metamorfoses para chegar à forma preço. Com efeito, ao se igualarem as quantidades de trabalho cristalizadas nas diversas mercadorias se encontrarão seus equivalentes recíprocos (entre as mercadorias), em valor (forma extensiva do valor) ${ }^{83}$. Não obstante, ao se determinar (historicamente) somente uma daquelas mercadorias (p. ex., o linho) como equivalente único a todas as outras, encontra-se uma forma comum de valor, sua forma geral (MARX, 2004, pp. 84-5, 87-9):

Então, o valor de cada mercadoria, igualado ao linho, se distingue não só do valor de uso dela mas de qualquer valor de uso, exprimindo-se assim de maneira comum a todas elas. Daí ser essa a forma que primeiro relaciona as mercadorias, como valores, umas com as outras, fazendo-as revelar, reciprocamente, valores de troca. $\mathrm{O}$ valor de uma mercadoria adquire expressão geral porque todas as outras exprimem seu valor através do mesmo equivalente. Evidencia-se, desse modo, que a realidade do valor das mercadorias só pode ser expressa pela totalidade de suas relações sociais, pois essa realidade nada mais é que a "existência social" delas, tendo a forma do valor, portanto, de possuir validade social reconhecida.

82 Observe-se que a caracterização da moeda (dinheiro) como expediente técnico resulta necessariamente que sua teorização implicará uma arte (política) monetária, que, no entanto, não se traduzirá plenamente na teoria marxista.

83 Evidencia-se, segundo MARX (2004, p. 85), que "não é a troca que regula a magnitude do valor da mercadoria, mas, ao contrário, é a magnitude do valor da mercadoria que regula as relações de troca". Nesse sentido, afastar-se-ia MARX da teoria quantitativa dos clássicos, na medida em que não faz da teoria do valor simplesmente uma teoria dos preços de mercado, ao estilo de RICARDO (1984), mas antes uma teoria do valor-trabalho, cuja fonte é a produção, não apenas a circulação das mercadorias. Não obstante, não desenvolveu plenamente no campo monetário as consequências possíveis de tal premissa, pois que requereria uma análise monetária específica da demanda monetária, o que de fato não empreendeu, em oposição à concepção liberal clássica da oferta enquanto determinante do valor da moeda circulante. Como se verá na sequência, o próprio MARX não se desvencilhará da concepção metalista da moeda-mercadoria (ouro), o que implica na aceitação do princípio da circulação ricardiano (regulação automática da oferta de ouro pelo mercado), não se podendo a ele atribuir, com efeito, a alcunha de verdadeiro opositor à teoria quantitativa da moeda, tal como pretendem LOPES (1980, p 131) e, de certa forma, SINGER (2010, p. 96). 
Daí se segue, na concepção marxista original, o dinheiro enquanto mercadoria, determinada socialmente, cabendo ao ouro tal privilégio (MARX, 2004, p. 91 e s.):

Então, mercadoria determinada, com cuja forma natural se identifica socialmente a forma de equivalente, torna-se mercadoria-dinheiro, funciona como dinheiro. Desempenhar o papel de equivalente universal se torna sua função social específica, seu monopólio social, no mundo das mercadorias.

Determinada mercadoria, o ouro conquista essa posição privilegiada entre as mercadorias. Ocorrem modificações substanciais na transição da forma simples para a forma extensiva de valor e dessa para a forma geral. Em contrapartida, a forma dinheiro do valor só difere da forma geral por possuir o ouro, em vez do linho, a forma de equivalente geral. O progresso consiste em ter identificado agora, definitivamente, a forma de direta permutabilidade geral ou forma de equivalente geral com a forma específica da mercadoria ouro, por força de hábito social.

Assim, a forma mercadoria, ou seja, a mercadoria equivalente da forma simples do valor, é o germe da forma dinheiro. A expressão simples e relativa do valor de uma mercadoria, tal como o linho, por meio de outra mercadoria que já esteja exercendo a função de mercadoria-dinheiro (ouro), é a forma preço. Recai-se novamente, portanto, na teoria clássica dos preços, que, aliás, $\operatorname{MARX}(2004$, p. 97) critica:

Refletir sobre as formas da vida humana e analisá-las cientificamente é seguir rota oposta à do seu verdadeiro desenvolvimento histórico. Começa-se depois do fato consumado, quando já concluídos os resultados do processo de desenvolvimento. As formas que convertem o produto do trabalho em mercadoria, constituindo pressupostos da circulação das mercadorias, já possuem a consistência de formas naturais da vida social, antes de os homens se empenharem em apreender, não o caráter histórico dessas formas, que eles, ao contrário, consideram imutáveis, mas seu significado. Assim, só a análise dos preços das mercadorias levava à determinação da magnitude do valor, só a expressão comum, em dinheiro, das mercadorias induzia a se estabelecer sua condição de valor. É porém essa forma acabada do mundo das mercadorias, a forma dinheiro, que realmente dissimula o caráter social dos trabalhos privados e, em consequência, as relações sociais entre os produtores particulares, 
ao invés de pô-las em evidência ${ }^{84}$.

O dinheiro serve, de fato, para equiparar os diferentes produtos do trabalho e, portanto, os converter em mercadorias. Dessa forma, ele se origina necessariamente do processo (histórico) de trocas, cujo desenvolvimento desdobra a oposição natural entre valor de uso e valor (de troca) das mercadorias. A permuta mercantil necessita exteriorizar essa oposição, o que requer uma forma independente para o valor da mercadoria, resultando finalmente na duplicação da mercadoria em mercadoria e dinheiro (MARX, 2004, p. 111 e s. $)^{85}$.

A expressão do valor de uma mercadoria em ouro é sua forma dinheiro ou seu preço. O dinheiro, em contrapartida, não tem preço pois, do contrário, teria a si próprio como referência, ou seja, equivalente de si mesmo. Enquanto forma do valor, o preço ou a forma dinheiro das mercadorias se distingue da sua forma corpórea, real e tangível, sendo puramente ideal ou mental. Em consequência, a expressão dos valores das mercadorias em ouro refere somente o ouro ideal ou imaginário. Em sua função de medida do valor serve o dinheiro apenas como dinheiro ideal ou figurado. Embora apenas o dinheiro idealizado sirva para medir o valor, depende o preço totalmente da substância real do dinheiro. O valor, ou seja, a quantidade de trabalho humano contida na mercadoria, é expresso numa quantidade imaginária da mercadoria ouro que encerra uma quantidade equivalente de trabalho (MARX, 2004, p. 122 e s.)

Por outro lado, na circulação monetária metálica, os nomes primitivos dos padrões de dinheiro, ou seja, dos estalões dos preços, provieram dos nomes que preexistiam de padrões de peso. Dessarte, medida dos valores e estalão dos preços são duas funções inteiramente diversas desempenhadas pelo dinheiro: a primeira segue da encarnação social do trabalho humano; a segunda de ser um peso fixo de metal. Como medida de valor, serve para converter os valores das diferentes mercadorias em preços, em quantidades

84 A crítica se dirige certamente à concepção liberal clássica da "moeda véu", na expressão de J. B. Say, ou seja, de que ela oculta a realidade econômica (CENECO, p. 283).

$85 \mathrm{O}$ processo de troca dá à mercadoria que transforma em dinheiro não o valor dela, mas sua forma específica de valor - reflexo das relações existentes entre todas as mercadorias. A confusão entre esses dois elementos, valor e sua forma, induziu ao erro de se considerar imaginário o valor do ouro e da prata. Além disso, por ser possível substituir o ouro em certas funções por meros símbolos dele mesmo, supôsse de modo errado que fosse mero símbolo. Nada obstante, cada mercadoria seria realmente um símbolo, pois, como valor, é apenas invólucro material do trabalho humano nela despendido. Ressalte-se ainda que, muito antes dos economistas, advogaram os juristas a ideia de ser o dinheiro apenas um símbolo, e pois o valor dos metais preciosos puramente imaginário, justificando assim o poder real de "falsificar moeda", como ocorreu ao longo de toda a Idade Média, fundamentando-o nas tradições do Império Romano e nos conceitos sobre moeda das Pandectas, pois consistia dogma jurídico o poder do imperador de decretar o valor do dinheiro, sendo expressamente proibido dar ao dinheiro o tratamento de mercadoria (MARX, 2004, p. 115 e s., n. 47). 
imaginárias de ouro; como estalão dos preços, mede essas quantidades de ouro. Da evolução socioeconômica se seguiu o costume de distinguir as designações monetárias das designações correntes dos preços dos metais. A despeito de ser o padrão monetário puramente convencional, necessita todavia de validade geral, o que resulta na sua regulamentação legal (MARX, 2004, p. 124 e ss.).

O preço implica finalmente a alienabilidade das mercadorias contra dinheiro e a necessidade dessa alienação por dinheiro. O ouro, de outra sorte, somente funciona como medida ideal do valor porque assim já operava, no processo de troca, como mercadoria dinheiro (MARX, 2004, p. 130 e s., nota à 2.ed.).

É mister que se retenha que a articulação resultante da divisão social do trabalho se realiza pelo ato de troca. A função precípua do sistema de trocas, portanto do mercado, reside na tarefa de coordenação e harmonização das atividades produtivas que, em última instância, se realiza através do processo de circulação de mercadorias (SINGER, 2010, p. 89 e ss.).

Nesse sentido, MARX (2004, p. 131 e s.) observou com precisão o mecanismo de autorregulação do sistema capitalista, ao afirmar que "o processo de troca realiza a circulação social das coisas". É dizer, as mercadorias entram no processo de troca que, de sua feita, produz uma bifurcação da mercadoria em mercadoria e dinheiro, estabelecendo entre ambos uma oposição externa na qual se espelha a oposição, imanente à mercadoria, entre valor de uso e valor. Na oposição externa, as mercadorias se confrontam, como valores de uso, com o dinheiro, como valor de troca.

O processo de troca se realiza através de duas metamorfoses opostas e reciprocamente complementares: a mercadoria se converte em dinheiro e o dinheiro se reconverte em mercadoria, ou seja: venda, troca da mercadoria por dinheiro; compra, troca do dinheiro por mercadoria, e unidade de ambas as transações, vender para comprar. Esquematicamente: Mercadoria (M) - Dinheiro (D) - Mercadoria (M).

$\mathrm{Na}$ circulação se rompem as limitações naturais de tempo e de lugar, como também as de caráter individual, impostas pela permuta de produtos, dissociando assim a identidade imediata que contrapõe à alienação do produto próprio a aquisição do alheio - a antítese entre venda e compra. Assume dessarte o dinheiro o papel de intermediário no processo de circulação, na função de meio circulante, pois que " a circulação poreja, continuamente, dinheiro" (MARX, 2004, p. 141).

Não se olvide, entretanto, que o dinheiro cumpre a função de meio de circulação 
apenas porque é o valor das mercadorias, como realidade independente. Daí seu movimento ser apenas o movimento das próprias mercadorias, ao mudarem suas formas, cujo reflexo aparente é o curso do dinheiro. Com efeito. O movimento das mercadorias constitui um circuito $(\mathrm{M}-\mathrm{D}-\mathrm{M})$ que imprime ao dinheiro o afastamento constante do ponto de partida, um fluxo: o seu curso (currency, cours de la monnaie). Esse curso é a repetição constante e monótona do mesmo processo: a mercadoria do lado do vendedor, o dinheiro do lado do comprador, com a função de meio de compra. Cumpre essa função ao realizar o preço da mercadoria. Realizando-o, a mercadoria se transfere do vendedor para o comprador e o dinheiro deste para aquele, a fim de repetir o mesmo processo com outra mercadoria. Encobre-se a circunstância de ser o movimento financeiro somente efeito da dupla forma do movimento da mercadoria, pois a própria circulação das mercadorias gera a aparência contrária. A continuidade do movimento cabe apenas ao dinheiro, permanecendo na esfera da circulação, onde desempenha, continuamente, sua função (MARX, 2004, p. 141 e ss. $)^{86}$.

86 Surge, assim, a questão de saber quanto dinheiro absorve, constantemente, essa esfera. A essa questão MARX (2004, p 144 e s.) esboça uma resposta aparentemente inversa à teoria quantitativa ricardiana, vez que assume "idealmente" equivalerem os preços das mercadorias às quantidades de dinheiro. Dessarte, "o montante de meios de circulação exigido pela circulação do mundo das mercadorias já está determinado pela soma dos preços das mercadorias. Com efeito, o dinheiro apenas representa, de maneira real, a soma ou montante de ouro já expresso idealmente na soma dos preços das mercadorias. As duas somas são, portanto, necessariamente iguais. Todavia, sabe-se que não se alterando os valores das mercadorias, seus preços variam com o valor do ouro (o material do dinheiro), subindo na proporção em que ele desce e descendo na proporção em que ele sobe. Assim, a massa do dinheiro circulante tem de subir ou descer, na mesma proporção. Nesse caso, a variação na massa dos meios de circulação provém, sem dúvida, do próprio dinheiro, mas não da sua função de meio de circulação, mas sim da sua função de medida de valor. Os preços das mercadorias variam, primeiro, na razão inversa do valor do dinheiro, e a massa dos meios de circulação varia na razão direta do preço das mercadorias. Considerando-se dado o valor do ouro, no momento de se fixarem preços, o montante dos meios de circulação é determinado pela soma dos preços a realizar das mercadorias. Admitindo-se dada a quantidade de mercadorias, o montante de dinheiro em curso oscila com as flutuações dos preços das mercadorias. A variação dos preços das mercadorias, quer corresponda a verdadeiras variações de valor ou a meras oscilações dos preços do mercado, exerce o mesmo efeito sobre o montante dos meios de circulação". Resumindo: $M=f(P)$, ou seja, a posição anteriormente referida de J. B. Say e da banking school, segundo a qual a quantidade de dinheiro em circulação se determina pela demanda de moeda (SCHWARTZ, 1989, p. 43). No entanto, observa-se a inversão arbitrária dos termos da equação $\mathrm{P}=\mathrm{f}(\mathrm{M})$, primeiramente, ao assumir MARX como dado o nível geral de preços, resultado de um procedimento de idealização na determinação prévia desses preços. Aliás, uma teoria em sentido próprio sobre o nível de preços ainda está para ser escrita (BRIDEL, 1989, p. 302). Ademais, concluir afirmando que a quantidade de dinheiro em curso decorre da variação dos preços das mercadorias, ou ainda, que "a lei segundo a qual a quantidade dos meios de circulação é determinada pela soma dos preços das mercadorias em circulação, pode ser expressa da seguinte maneira: dada a soma dos valores das mercadorias e dada a velocidade média de suas metamorfoses, a quantidade de metal precioso na função de dinheiro em curso depende do valor desse metal" (MARX, 2004, p. 149), é o mesmo que dizer, com RICARDO, que a quantidade de ouro-dinheiro, sua produção ou oferta, é determinada pelos custos de produção (valor do metal), em última instância, pelos preços de mercado. Essa nada mais é que a teoria quantitativa clássica, a saber, assumindo-se por hipótese uma demanda estável por dinheiro (ouro na função monetária), a procura por ouro monetário resulta de sua oferta (nível de produção do metal), é dizer, a produção de ouro cria sua própria demanda (lei das saídas ou lei de 
Reflete-se nessa exposição a concepção fundamental da economia capitalista, a saber, a presença da moeda enquanto elemento central desse sistema, cumprindo a função de informar (ao capitalista) sobre a viabilidade econômica da atividade produtiva face às possibilidades de circulação de seus produtos (SINGER, 2010, p. 95).

Outra consequência que MARX (2004, p. 151 e ss.) retira da circulação de mercadorias, e pois do curso financeiro, é a possibilidade da criação de moeda como símbolo de valor, em substituição ao dinheiro mercadoria (metal nobre). Reafirma nesse passo, mais uma vez, sua adesão ao metalismo teórico, na medida em que o próprio curso do dinheiro, ao separar a existência metálica da moeda de sua existência funcional, possibilita a substituição do dinheiro metálico, em sua função de moeda, por senhas feitas de outro material, ou meros símbolos. O caráter puramente simbólico está de algum modo dissimulado nas peças de dinheiro metálicas, revelando-se completamente no dinheiro de papel.

Não obstante, MARX (2004, p. 154) adverte que

Aqui aludimos apenas ao papel-moeda, o dinheiro papel do Estado, com curso compulsório. Origina-se diretamente do curso metálico ${ }^{87}$. O

Say), determinando assim proporcionalmente sua quantidade em circulação (procura), e pois inversamente seu valor (preço) (BRIDEL, 1989, p. 298), ou ainda, o nível geral de preços varia na razão direta da quantidade de moeda (ROBERTSON, 1969, p. 26). Dizer ainda, como quer SINGER (2010, p. 96), que na hipótese da moeda-mercadoria os preços não dependem da quantidade de moeda em circulação, mas do valor dessa moeda enquanto tempo de trabalho socialmente necessário à sua produção, o que afastaria a hipótese da adesão de MARX à teoria quantitativa, em nada altera a aplicação da tese ricardiana, pois, segundo essa última, a quantidade de trabalho se expressará sempre nos preços de mercado, refletindo a produção (oferta) do metal padrão monetário (ouro). SINGER na verdade identifica a teoria quantitativa com sua versão posterior, marginalista, pautada pelo valor-utilidade, todavia não é essa a teoria de RICARDO, na qual MARX muito provavelmente se havia inspirado. Outrossim, dizer que essa quantidade de moeda metálica se regula automaticamente pelas necessidades da circulação social (demanda por moeda) e ainda pelos custos de produção em termos de trabalho humano contido na mercadoria-moeda (SINGER, 2010), simplesmente alinha a tese da demanda monetária à tese clássica do custo de produção (RICARDO, 1984), o que equivale a dizer que a quantidade do meio circulante se determina tanto pela demanda como pela oferta de ouro, em suma, pela equação de oferta e procura (lei de Say-Mill), o que em última instância traduz a tese ricardiana desde a perspectiva de um equilíbrio em longo prazo regulado pela oferta e procura. Em conclusão, permitindo-se uma divagação de ordem matemática, em particular da teoria dos conjuntos, vez que a Economia é uma ciência social cuja peculiaridade reside na possibilidade de quantificação de seus resultados (SINGER, 2010, p. 11 e s.), pode-se dizer, grosso modo, que a lei de oferta e procura aplicada à moeda teria sido lida por MARX às avessas da leitura clássica, o que logicamente resulta no mesmo, pois que a equação de troca à base da teoria quantitativa da moeda implica uma relação reflexiva, simétrica e transitiva entre moeda e preços, portanto, uma relação de equivalência entre essas "quantidades", o que faculta sua leitura em sentidos opostos sem que se altere seu resultado, ou significado (SCHICK, 1982, p. 103 e s.).

87 Nesse sentido, MARX (2004, p. 154 e s.) identifica a moeda fiduciária com a metálica, e acaba por corroborar as teses de RICARDO (1984), apresentadas em nota anterior, e pois contraditando as suas próprias, não só no que tange às medidas e efeitos da política monetária de caráter metalista, mas sobretudo na admissão implícita da teoria quantitativa da moeda, o que se patenteia nas afirmações de que “o Estado lança em circulação pedaços de papel que levam impressas as respectivas denominações 
dinheiro de crédito pressupõe, ao contrário, condições que ainda nos são desconhecidas do ponto de vista da circulação simples de mercadorias. Mas, observemos de passagem, se o verdadeiro dinheiro-papel, o papelmoeda, nasce da função, exercida pelo dinheiro, de meio de circulação, o dinheiro de crédito tem sua raiz natural na função do dinheiro, de meio de pagamento.

Dessa forma, o papel-moeda é um símbolo que representa ouro ou dinheiro, pois representa simbolicamente as mesmas quantidades de ouro em que se expressam "idealmente" os valores das mercadorias, sendo essa a única relação existente entre o dinheiro de papel e esses valores: "o papel-moeda só é símbolo de valor por representar quantidade de ouro, a qual é quantidade de valor como todas as quantidades das outras mercadorias" (MARX, 2004, p. 155).

Finalmente, questiona MARX (2004, p. 155 e s.) da razão de o ouro poder ser substituído por meros símbolos sem valor (real). A essa indagação responde que tal substituição só pode ocorrer ao exercer o ouro exclusivamente a função de moeda ou de meio de circulação, e pois enquanto o dinheiro amoedado permanecer em curso. Nesse sentido, assevera que a mesma premissa é sempre válida para a quantidade mínima de ouro substituível por papel-moeda (padrão ouro = medida da paridade do papel com esse metal), uma vez que ela permanece continuamente na esfera da circulação, desempenhando continuamente a função de meio de circulação, sendo mesmo a razão de sua existência. Seu movimento representa o ininterrupto revezamento das mercadorias no circuito de trocas, lembrando que a existência autônoma do valor de troca da mercadoria é um elemento efêmero devido a sua imediata substituição como resultado da troca

monetárias. Ao circularem realmente no lugar da quantia de ouro de mesma denominação, por exemplo, cinco libras esterlinas, governam seu movimento apenas as leis do curso do dinheiro. Uma lei específica da circulação do papel só pode se originar da sua função de representar o ouro. Tal lei existe e diz que a emissão de papel-moeda tem de se limitar à quantidade de ouro que realmente circularia se não fosse substituída por símbolos [princípio da circulação decorrente da tese ricardiana, ou seja, controle de emissão e paridade com o ouro, portanto o mesmo posicionamento da currency school]. A quantidade de ouro que a circulação pode absorver oscila continuamente acima ou abaixo de certo nível médio. Todavia, a massa do meio circulante em dado país nunca desce abaixo de certo mínimo que a experiência revela. Por isso, pode essa massa mínima ser substituída por símbolos de papel. Se hoje está atendida de modo adequado a capacidade de absorção dos canais de circulação, podem amanhã se congestionar em virtude da mudança na circulação das mercadorias. Perde-se, então, toda a medida. Se o papel ultrapassa sua medida - a quantidade de moedas de ouro de igual nome que poderia circular -, expõe-se ao descrédito geral, mas ainda assim representa a quantidade de ouro determinada pela leis imanentes do mundo das mercadorias, portanto, só a quantidade de ouro suscetível de ser representada. Se a massa de papel-moeda for o dobro do que deve ser, uma libra esterlina, em vez de designar $1 / 4$ de onça, será a denominação monetária de 1/8 de onça. É como se o ouro houvesse experimentado uma alteração em sua função de medir os preços. Os mesmos valores que se expressavam antes por meio do preço de 1 libra esterlina, agora se expressam pelo preço de 2 libras". 
instrumentada por dinheiro (M - D - M). Dessa forma, basta a existência apenas simbólica do dinheiro num processo em que ele flui ininterruptamente, fazendo com que sua existência funcional de certa forma absorva a material: "reflexo objetivo, mas transitório dos preços das mercadorias, funciona somente como símbolo de si mesmo e, por isso, pode ser substituído por símbolos”. Não obstante, é mister que o símbolo do dinheiro mantenha a mesma validade social própria do dinheiro, o que ocorre somente através do curso forçado do papel-moeda imposto pelo Estado. Essa coerção todavia vigora apenas na esfera interna da circulação, é dizer, dentro das fronteiras nacionais, e só nela desempenha o dinheiro plenamente sua função de meio de circulação, passível assim de adquirir pura existência funcional por meio do papel-moeda, exteriormente distinta de sua existência metálica (material).

Na síntese de MARX (2004), o dinheiro é toda mercadoria que sirva de medida de valor e, diretamente ou por meio de representante, de meio de circulação. Tal mercadoria desempenha diretamente o papel de dinheiro quando se apresenta em sua materialidade metálica, como mercadoria-dinheiro, e não idealmente, como sucede em sua função de medida de valor, nem através de representação por símbolos, como ocorre em sua função de meio de circulação (meio de compra).

Do ponto de vista da sociologia econômica, realçando o aspecto institucional do dinheiro, MARX (2004, p. 158 e s.) afirma, com elevado grau de realismo, que

Não revelando o dinheiro aquilo que nele se transforma, converte-se tudo em dinheiro, mercadoria ou não. Tudo se pode vender ou comprar. A circulação se torna a grande retorta social a que se lança tudo, para ser devolvido sob a forma de dinheiro. No dinheiro desaparecem todas as diferenças qualitativas das mercadorias, e o dinheiro, nivelador radical, apaga todas as distinções ${ }^{88}$. Mas o próprio dinheiro é mercadoria, um objeto externo, suscetível de se tornar propriedade privada ${ }^{89}$ de qualquer indivíduo. Assim, o poder social se torna o poder privado de particulares.

Como ainda assevera MARX (2004, p. 160), “do ponto de vista da qualidade ou da forma, o dinheiro não conhece fronteiras: é o representante universal da riqueza material $^{90}$, pois é conversível em qualquer mercadoria". No entanto, adverte que "qualquer porção real de dinheiro é quantitativamente limitada, sendo meio de compra de eficácia

88 No mesmo sentido se pronunciaria, posteriormente, JHERING (1953).

89 De modo similar, WEBER (2011).

90 Também aqui antecipa argumentos de WEBER (2011). 
restrita”.

Enquanto objeto de riqueza, portanto meio de acumulação patrimonial, o ouro (mercadoria-dinheiro) é retido como dinheiro ou fator de entesouramento, para tanto é necessário que se impeça sua circulação ou que sirva de meio de compra, quando se transforma em artigo de consumo ${ }^{91}$.

O dinheiro entesourado, enquanto reserva de valor, portanto, cumpre importante função econômica no que diz respeito à própria circulação monetária, uma vez que "ora o dinheiro tem de ser atraído para servir de moeda, ora a moeda tem de ser atraída para servir de dinheiro acumulado". Dessa forma, "as reservas entesouradas servem de canais ao mesmo tempo adutores e de derivação do dinheiro circulante, o qual, por isso, nunca transborda os canais de seu curso" (MARX, 2004, p. 161).

O desenvolvimento do processo de circulação gera ainda determinadas condições em que a alienação da mercadoria se separa, por um intervalo de tempo, da realização de seu preço. Nessa hipótese, o vendedor se torna credor; o comprador, devedor. "A metamorfose da mercadoria, ou o desenvolvimento da forma do valor, assume então novo aspecto, e, em consequência, o dinheiro adquire nova função. Ele se torna meio de pagamento" (MARX, 2004, p. 161). O caráter de credor e de devedor decorre aqui da circulação simples das mercadorias. Não obstante, adverte MARX (2004, p. 162) que

(...) os papeis de credor e devedor podem vir à cena independentemente da circulação das mercadorias ${ }^{92}$. A luta de classes do mundo antigo se desenrola principalmente sob a forma de uma luta entre credor e devedor, e, em Roma, leva à ruína do devedor plebeu, convertido em escravo. $\mathrm{Na}$ Idade Média, a luta arruína o devedor feudal, que perde o poder político com a base econômica. A forma dinheiro, ou a relação monetária entre credor e devedor, reflete nessas lutas o antagonismo mais profundo das condições econômicas de existência das partes envolvidas.

A função do dinheiro como meio de pagamento a que MARX se refere é antes aquela de instrumento de pagamentos diferidos, ou promessas de pagamento (COSTA, 1999, p. 37). Nesse sentido se expressa MARX (2004, p. 163):

O comprador converte dinheiro em mercadoria, antes de ter convertido

91 Observe-se que SCHUMPETER (1964a) assevera que o meio final de pagamento é, por excelência, o bem de consumo.

92 A despeito de premissas históricas distintas, extrai WEBER (2011) conclusão similar à de MARX, no sentido de que o dinheiro enquanto meio de pagamento surgiu anteriormente à sua função de meio de troca. 
mercadoria em dinheiro, ou realiza a segunda metamorfose antes da primeira. A mercadoria do vendedor circula, mas realiza o preço apenas sob a forma de um direito sobre o dinheiro a receber ${ }^{93}$. É objeto do consumo de outra pessoa antes de se converter em dinheiro. Só posteriormente sucede a primeira metamorfose.

MARX (2004, p. 163 e s.) diferencia precisamente o sistema de circulação monetária daquele dos meios de pagamento. Com efeito. As obrigações vencidas em determinado período representam a soma dos preços das mercadorias cuja venda deu origem a essas obrigações. Por outro lado, a quantidade de dinheiro necessária para realizar tal soma depende sobremodo da velocidade do curso dos meios de pagamentos. Essa velocidade depende de duas circunstâncias: o encadeamento das relações entre credores e devedores e a duração dos intervalos entre as diversas datas de pagamento. Observe-se que a cadeia de pagamentos sucessivos se distingue fundamentalmente do entrelaçamento das séries de metamorfoses no circuito das trocas: o curso dos meios de circulação (troca) não expressa apenas a conexão entre vendedores e compradores, mas antes se origina daquele curso; o movimento dos meios de pagamento, ao contrário, expressa uma conexão social que existia antes dele ${ }^{94}$.

Igualmente, MARX (2004, p. 165) correlaciona, em pensamento de vanguarda, a função do dinheiro como meio de pagamento e o desencadeamento de crises financeiras, particularmente em mercados financeiros desenvolvidos, onde sobreleva a importância dos sistemas de pagamentos, antecipando assim aquilo que a contemporaneidade identifica como crise sistêmica:

A função do dinheiro como meio de pagamento envolve uma contradição direta: enquanto os pagamentos se compensam, ele serve apenas idealmente de dinheiro de conta ou de medida dos valores; quando têm de ser efetuados pagamentos reais, a função do dinheiro deixa de ser a de

93 Observe-se a similaridade dessa assertiva com o entendimento de SCHUMPETER (1964a) no sentido de que o dinheiro denota um direito ao dinheiro de curso legal.

94 Assim prossegue, acentuando a importância da centralização da liquidação de obrigações através de sistemas únicos de compensação de pagamentos: "Simultaneidade e contiguidade das vendas estabelecem limites à substituição da quantidade de moeda pela velocidade do curso. Mas, por outro lado, proporcionam nova alavanca à economia dos meios de pagamento. Com a concentração dos pagamentos num mesmo lugar, desenvolvem-se naturalmente organizações e métodos especiais para liquidá-los. Essa era, por exemplo, a função dos virements em Lyon, na Idade Média. Bastará se confrontar os créditos de A contra B, de B contra C, de C contra A, e assim sucessivamente, para, até certo ponto, se anularem reciprocamente como grandezas positivas e negativas. Assim, resta apenas um saldo a pagar. Quanto maior a concentração dos pagamentos, tanto menores, relativamente, o saldo e a quantidade dos meios de pagamento em circulação". (MARX, 2004, p. 164). 
meio de circulação, de forma transitória e intermediária do intercâmbio das coisas materiais, para ser a de encarnar o trabalho social, a existência independente do valor de troca, a mercadoria absoluta. Essa contradição se manifesta na fase especial das crises industriais e comerciais, chamada de crise de dinheiro. Ela só ocorre onde se desenvolveram plenamente uma cadeia de pagamentos simultâneos e um sistema de liquidação por compensação. Havendo perturbações gerais no funcionamento desse mecanismo, seja qual for a origem delas, deixa o dinheiro súbita e diretamente a forma ideal, de conta, para virar dinheiro em espécie.

Corolário da função do dinheiro como meio de pagamento é o dinheiro de crédito, circulando certificados de obrigações "com o fim de transferir aos outros o direito de exigir o pagamento delas", ou seja, a transmissão de direitos obrigacionais. À medida que se amplia o sistema de crédito, desenvolve-se a função de meio de pagamento exercida pelo dinheiro, adquirindo assim formas próprias de existência no domínio das grandes transações (MARX, 2004, p. 166 e s.):

Quando a circulação de mercadorias atinge certo nível e amplitude, a função de meio de pagamento que o dinheiro exerce ultrapassa a esfera da circulação de mercadorias. É a mercadoria universal dos contratos. Rendas e tributos se transformam de pagamentos em espécie em pagamentos em dinheiro. Essa transformação é determinada pela estrutura geral do processo de produção ${ }^{95}$.

O próprio desenvolvimento do sistema capitalista traz consigo a mutação funcional de determinados papeis exercidos pelo dinheiro, ao adaptar funções socialmente obsoletas às necessidades contemporâneas do sistema de circulação. Nesse sentido, assevera MARX (2004, p. 169) precisamente que a função do dinheiro como meio de pagamento acarreta cada vez mais a necessidade de acumulação financeira a fim de fazer frente às obrigações vincendas, enquanto o entesouramento, como forma autônoma de enriquecimento, tende a desaparecer com o progresso da "sociedade burguesa". Não obstante, o mesmo entesouramento, agora "sob a forma de fundo de reserva de meios de

95 Assim exemplificado por MARX (2004, p. 167): “É o que demonstra, por exemplo, o fracasso experimentado duas vezes pelo Império Romano em sua tentativa de coletar todos os tributos em dinheiro; também a miséria indescritível da população rural francesa durante o reinado de Luís XIV não decorreu apenas da elevação dos tributos, mas da conversão dos impostos em produtos em impostos em dinheiro. Na Ásia, a forma natural de renda da terra constitui o elemento principal da tributação do Estado e se fundamenta nas condições de produção, reproduzidas com a imutabilidade dos fenômenos naturais. Essa forma de pagamento reage no sentido de manter a estrutura arcaica de produção. É um dos segredos da conservação do Império Turco". 
pagamento, se expande com essa sociedade".

A síntese que denota a verdadeira superação da teoria clássica reside no encaminhamento que MARX (2004, p. 177 e ss.) oferece para a questão da transformação do dinheiro em capital.

Com efeito. A circulação de mercadorias é o ponto de partida do capital, uma vez que a sua produção e comercialização constituem as condições históricas que dão origem ao capital. O comércio e o mercado mundiais inauguram no século XVI a moderna história do capital.

Abstraindo-se todavia do conteúdo material do sistema de trocas (a troca dos diferentes valores de uso) de modo a se considerar apenas as formas econômicas engendradas por esse processo de circulação, encontrar-se-á o dinheiro como produto final. Esse produto final da circulação das mercadorias é a primeira forma em que aparece o capital.

Observe-se, porém, que o dinheiro que é apenas dinheiro se distingue do dinheiro que é capital através da diferença na forma de circulação (MARX, 2004, p. 177 e s.):

A forma simples da circulação de mercadorias é M - D - M, ou seja, vender para comprar. Ao lado dela, encontra-se uma segunda especificamente diversa, $\mathrm{D}-\mathrm{M}-\mathrm{D}$, conversão de dinheiro em mercadoria e de mercadoria em dinheiro, comprar para vender. O dinheiro que se movimenta de acordo com essa última circulação se transforma em capital, torna-se capital e, por sua destinação, é capital.

Nota-se claramente que na primeira forma de circulação é a mercadoria, enquanto na segunda é o dinheiro o ponto de partida e a meta final do movimento. Na primeira, serve o dinheiro de intermediário e, na segunda, a mercadoria. Em consequência, o circuito M - D - M tem como objetivo final o consumo, satisfação de necessidades, ou seja, valor de uso. O circuito $\mathrm{D}-\mathrm{M}-\mathrm{D}$, ao contrário, tem no próprio valor de troca, expresso em dinheiro (preço), o motivo que o impulsiona, o objetivo que o determina, ou seja, o lucro (MARX, 2004, p. 179 e s.).

No entanto, como ensina MARX (2004, p. 181), “o processo D - M - D não deve seu conteúdo a nenhuma diferença qualitativa entre seus extremos, pois ambos são dinheiro, mas à diferença quantitativa entre seus extremos". Na medida em que se retira mais dinheiro de circulação do que se lançou ao início, a forma completa desse processo assim se expressa: $\mathrm{D}-\mathrm{M}-\mathrm{D}^{\prime}$, onde $\mathrm{D}^{\prime}=\mathrm{D}+\Delta \mathrm{D}$. A esse acréscimo (excedente sobre o 
valor original) denomina MARX mais-valia (valor excedente): "O valor originalmente antecipado não só se mantém na circulação, mas nela altera a própria magnitude, acrescenta uma mais-valia, valoriza-se: esse movimento o transforma em capital".

Desse circuito próprio do dinheiro-capital se infere sua finalidade, a saber, sua própria reprodução, pois, ao contrário da circulação mercantil, a expansão do valor (dinheiro) somente ocorre nesse movimento continuamente renovado. Dessarte, o movimento do capital não tem limites ${ }^{96}$.

Conquanto representante consciente desse movimento, o proprietário do dinheiro se torna capitalista. O conteúdo objetivo da circulação em causa - a expansão do valor - é a sua finalidade subjetiva, e pois a apropriação crescente da riqueza abstrata resulta no único motivo que orienta suas operações, atuando como agente do sistema capitalista. $\mathrm{O}$ valor de uso jamais constituirá o objetivo imediato do capitalista, tampouco o lucro isolado, mas sobretudo o infindável processo de obtenção de lucros: "esse enriquecimento absoluto é comum tanto ao capitalista como ao entesourador, sendo o capitalista um entesourador racional" (MARX, 2004, p. 183) ${ }^{97}$.

Concluindo com MARX (2004, p. 185 e s.), "o valor se torna valor em progressão, dinheiro em progressão e, como tal, capital”. Dessa forma, comprar para vender mais caro $\left(\mathrm{D}-\mathrm{M}-\mathrm{D}^{\prime}\right)$ configura uma espécie de capital: o capital mercantil. Não

96 Nesse ponto, aliás, MARX (2004, p. 183) se iguala a ARISTÓTELES (1985, p. 26), a quem cita expressamente.

97 Os primeiros clássicos, atentos sobretudo ao sistema de trocas no qual assenta o capitalismo, não foram, e com razão nem o poderiam ser, capazes de superar a noção fundamental de que a atividade econômica se reduz àquele sistema. Dessa concepção segue naturalmente o entendimento do dinheiro enquanto mero instrumento de trocas, cuja neutralidade teórica se revela na apreciação geral das operações econômicas. Dessarte, a venda e compra se torna essencialmente um procedimento de troca, e essa pura e simplesmente exclui os momentos intermediários em que aparece a moeda. $\mathrm{O}$ preços permanecem primariamente como relações de troca, expressos em dinheiro enquanto roupagem monetária. $\mathrm{O}$ processo econômico é visto sob a perspectiva do modelo de escambo, logicamente completo e autônomo, a despeito das perturbações inflacionárias. A análise econômica é essencialmente real, não monetária, pois o modelo teórico de que lança mão concebe o dinheiro apenas como espécie de "lubrificante" dos negócios, sem que afete fundamentalmente outros componentes do processo, qual sejam a produção, o emprego ou a taxa de juros. Essa concepção clássica revela antes um anacronismo que projeta no sistema capitalista uma situação historicamente superada, é dizer, própria de economias estruturadas para prover a distribuição dos bens econômicos destinados à satisfação das necessidades individuais ou coletivas, em última instância, economias consuntivas. O regime capitalista, ao contrário, parte do sistema de circulação (trocas) como premissa estrutural para a consecução de um objetivo maior, qual seja, a formação e acumulação de capital, o que é peculiar a toda economia lucrativa. Nessa hipótese, a troca se desarticula em função da própria operação monetária, dantes simples momento da troca, mas que agora adquire uma individualidade própria, tornando-se um fim em si mesma de que nos fala MARX. A moeda, portanto, não apenas funciona como intermediária naquela circulação, mas constitui sobretudo a expressão final daquele capital, sempre tendente à forma monetária (LOPES, 1980, p. 139 e s.; PRADO JR., 1966, p. 73 e s.; SCHUPETER, 1964b, p. 395). Dessa forma, não é de todo incorreto se afirmar que MARX antecipa, em certa medida, o entendimento posterior de KEYNES no sentido de que a função precípua do dinheiro é a de reserva de valor, e pois a economia capitalista fundamentalmente uma economia monetária. 
obstante, o capital industrial também é dinheiro, que se converte em mercadoria e, com sua venda, se reconverte em mais dinheiro. Ressalte-se todavia que fatos ocorridos fora da esfera da circulação, no intervalo da compra e venda, não acarretam nenhuma mudança a essas forma de movimento. Ademais, no capital que rende juros se patenteia finalmente abreviada a circulação D - M - D', eliminando-se o estágio intermediário, restando apenas $\mathrm{D}-\mathrm{D}^{\prime}$, é dizer, dinheiro igual a mais dinheiro, valor que ultrapassa a si mesmo ${ }^{98}$.

\section{Keynes e o advento da ciência econômica monetária}

A natureza do regime econômico capitalista assenta fundamentalmente na lógica de extração da riqueza, mediante as atividades produtivas, sob a forma de capital. Essa extração, enquanto fluxo de produção excedente, não é todavia marca exclusiva desse sistema: as sociedades pré-capitalistas já o conheceram em algum estágio de sua evolução rumo ao marco civilizatório. A diferença quanto aquelas organizações sociais e aquela que preside o mundo ocidental, desde a revolução industrial, reside antes no fato de que os excedentes produtivos assumem no mundo pré-capitalista o aspecto de riqueza porque são objetos desejáveis a partir de suas características imanentes, em última instância, por refletirem a riqueza como valor de uso acumulado, como frisado não só em MARX, mas anteriormente em ARISTÓTELES e SMITH. No contexto capitalista, ao contrário, a riqueza é um conceito essencialmente funcional no sentido de atender ao propósito último do capitalismo, qual seja a acumulação de capital: "Trata-se do uso da riqueza de diversas formas concretas, não como um fim em si mesma, mas como meio para juntar mais riqueza" (HEILBRONER, 1988, p. 25).

O capital, conquanto entendido como bens produtivos, ou mesmo dinheiro, enfim como comando sobre os bens (produtivos) que movem logicamente o regime capitalista (SCHUMPETER, 1982), importa somente na medida em que desencadeia o processo de contínua metamorfose autoexpansiva (MARX, 1984), seja através de mercadorias, seja das próprias finanças, mas que deve resultar sempre (racionalmente) na acumulação de resultados financeiros, ou seja, o lucro. É, portanto, um processo dinâmico de acumulação de riquezas (HEILBRONER, 1988).

98 O "capital" enquanto criador de valor no âmbito das relações econômicas não se confunde com seu objeto, devendo antes ser compreendido como relação, ou seja, "um conjunto de valor que pode ser representado por qualquer bem econômico, inclusive dinheiro, mas não se confunde com nenhum desses bens em particular. Figura apenas como um título de valor que estabelece em favor de seu titular certa posição ou situação relativamente a outros indivíduos, e em geral, no complexo das relações econômicas" (PRADO JR., 1966, p. 66). 
Nesse contexto, observa-se que a análise econômica convencional (clássica e neoclássica) descura desse aspecto fundamental ao imprimir ao dinheiro um caráter puramente instrumental, tal como no modelo paradigmático do equilíbrio geral de WALRAS $(1983)^{99}$, não o considerando como o objetivo final da economia capitalista.

A visão teórica da economia capitalista como sistema mecânico e autorregulador, tendente ao equilíbrio (estacionário), e pois pautado por comportamentos racionais de mercado, resulta essencialmente numa concepção harmoniosa desse organismo. O confronto desse paradigma com a consideração acima a respeito do papel do dinheiro na economia capitalista (monetário-lucrativa) pode causar, no mínimo, certo desconforto. $\mathrm{Na}$ verdade, numa economia monetária, a despeito do entendimento de ser o processo produtivo o meio natural para a acumulação de riqueza, nem sempre constitui tarefa das mais fáceis a trilha por esse caminho. Outros há para o capitalista no contexto econômico do capitalismo hodierno, a saber, a arte das finanças, cujos artífices não raro dispõem de poder suficiente para controlar as condições de funcionamento do mercado do capital (senso largo). Outrossim, a criação artificiosa de escassez pode muitas vezes ser mais vantajosa do que a produção (real) de bens, conquanto apenas esses gozem de valor social. Essa visão resulta muito mais cética a respeito das possibilidades de eficácia e justiça social no regime capitalista de mercado do que aquela até então exposta (HEILBRONER, 1988; LIMA, 1997).

Essa visão das características reais do sistema capitalista, sob o contexto histórico da grande depressão do período entre guerras, constitui o substrato no qual KEYNES (2012) assenta sua Teoria geral do emprego, do juro e da moeda, de 1936. Os elementos essenciais dessa análise são a incerteza, a instabilidade e o desequilíbrio, aliados a duas instituições de grande poder - o dinheiro e o mercado monetário, de um lado, o salário monetário, de outro -, e pois todos esses elementos interagem numa visão orgânica da complexa realidade do capitalismo contemporâneo. A incerteza, enquanto dado da realidade econômica, decorre naturalmente da consideração temporal dessa realidade, resultante de sua indeterminação histórica. A esse aspecto fenomênico se correlacionam intimamente o dinheiro e o sistema financeiro na medida em que concomitantemente o determinam (causa) como dele resultam (efeito) enquanto meios de proteção contra incertezas futuras (LIMA, 1991).

99 Mesmo em WICKSELL (1986), como anteriormente mostrado, a despeito de sua inaugural teoria de juro monetário (bancário) enquanto elo com a economia real, o dinheiro ainda é concebido como "lubrificante" para o atrito típico do processo de troca. 
Como leciona LIMA (1997, p. 39), a teorização em torno da função da moeda numa economia monetária (capitalista) deve necessariamente principiar pela demonstração de sua não neutralidade no âmbito da produção. Essa parece ter sido a preocupação básica de KEYNES (2012, p. 15 e ss.) ao observar que o pensamento clássico, desde RICARDO (1984), se erige sob o princípio de que a oferta cria sua própria demanda (lei de Say), é dizer, que a totalidade dos custos de produção é de um modo ou de outro sempre gasta na compra do produto final. Sob essa premissa fácil é a conclusão de que "a moeda não faz realmente grande diferença, exceto de forma friccional", e pois que a teoria da produção e do emprego deve antes se calcar sobre o processo de trocas reais, refletindo o paradigma cognitivo de que o dinheiro é necessariamente sempre gasto. Essas conclusões, no entanto, partem de uma falsa analogia com uma economia isolada qualquer, sem trocas, portanto eminentemente consuntiva, na qual o rendimento consumido (poupado) pelos seus membros, resultante da atividade produtiva, é real e exclusivamente constituído pela produção em espécie dessa atividade. Como corolário desse sistema, em que o valor do rendimento global corresponde exatamente ao valor da produção, é natural a suposição do paralelismo entre poupança e investimento. Em consequência, a hipótese de igualdade entre o preço da procura da produção global e o preço da oferta pode ser considerada o "axioma das paralelas" da teoria econômica clássica, dele decorrendo todos os demais elementos de seu corpo teórico, a saber, as vantagens sociais da poupança, a taxa de juro real, a teoria clássica do desemprego, a teoria quantitativa da moeda ou ainda os inúmeros benefícios do livre cambismo. Não obstante, adverte KEYNES (2012, p. 18) que tal processo explicativo resulta falacioso na medida em que admite a existência de um nexo lógico entre as decisões de consumo presente e aquelas direcionadas a produzir consumo futuro, quando na realidade não há nenhuma relação simples entre as motivações que determinam ambas as decisões.

De modo a determinar as implicações monetárias, ou seja, o efeito do dinheiro sobre o capital produtivo, explicando assim a influência do dinheiro nas decisões de investimento, é necessário o estabelecimento de um elo entre ambos os processos, a saber, a taxa de juro. Esse entendimento, como declarado pelo próprio KEYNES (2012, p. 125), encontra seu fundamento teórico na concepção de FISHER (1984, p. 301 e ss.), anteriormente esboçada, que qualifica, a partir da análise do mercado de empréstimos, a taxa de juro como preço universal, e pois a correlaciona com o capital ao definir para esse a "taxa de retorno sobre o custo", isto é, o quociente que iguala o valor presente de todos 
os custos com o valor presente de todos os retornos. A expansão dos investimentos na economia como um todo se determinará então pela comparação dessa taxa de retorno com a taxa de juro, cujo papel indutor dos investimentos (novos) ocorrerá na hipótese de o retorno do capital investido superar a remuneração do capital no mercado monetário. A essa taxa de retorno sobre o custo adiciona KEYNES (2012, p. 120 e s.) o elemento "prospectivo" (futuro) à taxa de retorno fisheriana, denominando-a "eficiência marginal do capital", que define "como sendo a taxa de desconto que faria com que o valor presente da série de anuidades dadas pelos rendimentos esperados desse capital durante toda a sua existência fosse exatamente igual ao seu preço de oferta”. Dessa forma, o fluxo (corrente) de investimentos se encaminhará no sentido do consumo dos fluxos de bens de capital até que não haja mais nenhum capital cuja eficiência marginal supere a taxa de juro corrente, é dizer, "o investimento vai variar até aquele ponto da curva de procura de investimento em que a eficiência marginal do capital em geral é igual à taxa de juro do mercado".

Sem embargo, a taxa de juro não se identifica à eficácia marginal do capital, na medida em que "a curva da eficiência marginal do capital rege as condições em que se procuram fundos disponíveis para novos investimentos, enquanto a taxa de juro governa os termos em que esses fundos são correntemente disponibilizados" (KEYNES, 2012, p. 148). Ainda segundo KEYNES (2012, p. 174 e s.), tal identificação levou MISES (2005) e seus epígonos a conclusões falsas ${ }^{100}$.

Resta, portanto, mostrar como se determina a taxa de juro. A escola marginalista inglesa faz essa taxa resultar da interação entre a curva de eficiência marginal do capital e a propensão psicológica à poupança, ou em termos clássicos (teoria ricardiana), a taxa monetária de juro (de mercado) depende da taxa de lucro obtenível com a utilização do capital, não da taxa de juro bancário nem do volume de crédito emitido, e pois inteiramente independente da quantidade ou valo da moeda: o volume de crédito afetará assim somente o valor da moeda, mas não permanentemente a taxa de juro do mercado.

Na crítica de KEYNES (2012, p. 173), a hipótese convencional assenta sobretudo

100 No entanto, a assertiva de KEYNES é descabida no que tange à atribuição de tal confusão ao pensamento de MISES. Esse último parte da produtividade marginal do capital e da taxa de juro (real) do capital (Satz des Kapitalzinses), no sentido do juro natural do capital de WICKSELL (1986), consequente, aliás, com a teoria austríaca da imputação de valor ao fator produtivo a partir do valor do produto final (bem de consumo), e pois analisa as possibilidades de investimento em comparação à taxa bancária de juro ou taxa básica de empréstimo (Darlehenszinsfuss), mostrando as consequências sobre o processo produtivo em termos de postergação dessa atividade em razão da variação da taxa bancária de juro, cujo limite superior, sob condições de livre competição bancária, assenta justamente na taxa real do capital (MISES, 2005, pp. 347 e ss., 366 e ss.). 
na premissa do pleno emprego (dos fatores produtivos), pois sempre haverá apenas um nível possível de emprego no longo prazo. Dado que as expectativas (fator psicológico) não se alterem, e que qualquer variação se restrinja portanto apenas à quantidade de moeda (hipótese coeteris paribus), a teoria ricardiana permanece válida no sentido de haver “apenas uma taxa de juro compatível com o pleno emprego no longo prazo". No entanto, mesmo no longo prazo, adverte KEYNES que o emprego não estará necessariamente no nível máximo, podendo também variar, o que obviamente descarta o equilíbrio estacionário, e que esse nível variável de emprego dependerá ainda da política bancária, ou seja, o emprego variará em função das diversas políticas de juros adotadas pelas autoridades ao longo do tempo. Dessa forma, KEYNES introduz a moeda no nexo causal entre o investimento e a taxa de juro, de modo a mostrar que as variações da quantidade de moeda penetram e influem no sistema econômico.

No longo prazo, portanto, não se pode deduzir a taxa de juro apenas da procura de poupança em razão do investimento nem da propensão (psicológica) do público a poupar dada a taxa de juro (de equilíbrio). É mister, portanto, romper a circularidade cognitiva buscando a formação da taxa de juro em fatores externos a esse equilíbrio teórico, ainda que presentes nos fatores psicológicos que presidem a formação individual daquela poupança ao longo do tempo.

Nesse sentido, destaca KEYNES (2012, p. 149 e ss.) a "propensão ao consumo", definindo-a como a atitude individual orienta ao consumo parcial dos rendimentos (presente) e à reserva do restante "sob a forma de direito qualquer sobre o consumo futuro". Essa reserva prospectiva (de consumo) pode se operar sob a forma de um direito líquido e imediato (dinheiro ou seu equivalente), ou sob a forma de uma alienação temporária desse direito imediato em prol de um resgate futuro condicionado à situação do mercado. A alternativa entre essas duas hipóteses de conservação da renda (nominal), resultado do rendimento corrente ou da poupança prévia, determinará o nível da "preferência pela liquidez" do indivíduo, representada por uma curva de demanda por moeda para a satisfação de seu desejo em conservá-la sob diferentes circunstâncias.

No entendimento de KEYNES, o erro da teoria tradicional reside na consideração exclusiva da primeira forma de preferência psicológica temporal (liquidez imediata), olvidando portanto da segunda (prospectiva) na explicação da taxa de juro. $\mathrm{O}$ entesouramento de "dinheiro líquido" em resultado da poupança ou espera ou abstinência em si não implica nenhuma recompensa que possa denotar o juro, mas somente o ato de 
economizar. Ao contrário, a taxa de juro se traduz antes pela recompensa resultante da "renúncia à liquidez por um prazo determinado. Em si, a taxa de juro não é mais do que o inverso da relação existente entre uma soma de dinheiro e o que se pode obter desistindo do controle sobre esse dinheiro em troca de uma dívida, por um prazo determinado" $(\text { KEYNES, 2012, p. } 149 \text { e s. })^{101}$.

Conquanto recompensa pela renúncia à liquidez, a taxa de juro também serve de medida da relutância individual em alienar o direito de disponibilidade incondicional sobre o dinheiro. Assim, a taxa de juro não é o preço de equilíbrio entre as predisposições de investir e poupar, mas antes o preço de equilíbrio entre a propensão à liquidez e a quantidade (oferta) de dinheiro disponível. Na definição de KEYNES (2012, p. 150):

A preferência pela liquidez é uma potencialidade ou tendência funcional que fixa a quantidade de moeda que o público deterá quando a taxa de juro é dada; disso resulta que, se $r$ for a taxa de juro, $M$ a quantidade de moeda e $L$ a função da preferência pela liquidez, teremos $M=L(r)$. É aqui, e dessa forma, que a quantidade de moeda entra no esquema econômico.

A questão que ainda resta diz respeito à natureza dessa preferência pela liquidez. Recordando a distinção funcional básica entre o uso da moeda para a realização dos negócios correntes e o destinado à reserva de valor (riqueza), sob a hipótese de uma taxa de juro positiva e se supondo equivalente o risco de inadimplemento tanto para o depósito bancário como para a obrigação, a condição necessária para a existência dessa predisposição à conservação de riqueza por meio de dinheiro líquido reside na "incerteza" quanto à taxa de juro no futuro (KEYNES, 2012, p. 151).

Com efeito, se fosse dado ao público conhecer as taxas futuras, então as taxas futuras seriam deduzidas das taxas presentes para as obrigações com diferentes vencimentos, ajustando-se as últimas ao valor conhecido das taxas futuras. No entanto, dada a incerteza quanto ao valor da taxa de juro no longo prazo, na hipótese de haver uma

101 Observe-se que KEYNES (2012, p. 150, n. 1 e 2) adota deliberadamente um conceito fluido de dinheiro enquanto débito (obrigação) segundo a conveniência da questão em exame. Pode-se assim "considerar moeda [dinheiro] todo o direito a um poder geral de compra que o possuidor não aliena por um período superior a três meses, e "débito" o que se pode recuperar em períodos mais longos". Esse período pode todavia ser reduzido para um mês ou mesmo um dia, ou ainda se pode excluir do conceito de moeda tudo o que não seja dinheiro de curso legal, ou seja, dotado de poder liberatório imediato. Na prática, é muitas vezes conveniente se incluir no conceito de moeda os depósitos bancários a prazo e ainda certos instrumentos de crédito, tais como os certificados do Tesouro. De modo geral, a moeda é teoricamente coextensiva com os depósitos bancários. Ademais, no que tange ao prazo obrigacional é antes a taxa de juro um complexo das taxas correntes para obrigações com prazos diversos de maturidade. 
necessidade antecipada de liquidez, ou seja, antes do vencimento da obrigação em que se inverteu a renda individual, se incorrerá em risco de perda na aquisição dessa dívida de longo prazo em razão da possibilidade de sua conversão antecipada em dinheiro frente à hipótese de ter conservado o próprio dinheiro desde o início. Portanto, o lucro atuarial deve compensar suficientemente o risco de reveses na hipótese de inversão financeira.

Ressalte-se ainda que o aspecto atuarial da preferência pela liquidez se traduz da melhor maneira na presença de um mercado organizado de dívidas, portanto, só assim se verificará a determinação efetiva daquela preferência. Da mesma forma quanto à eficácia marginal do capital, a taxa de juro se fixa pela avaliação dos agentes de mercado quanto às expectativas da futura taxa de juro. Aqueles agentes que acreditam na elevação da taxa de juro acima da prevista pelo mercado se orientam no sentido do encaixe de dinheiro líquido, preferindo assim à inversão imediata a liquidez presente em prol de lucros futuros. Ao contrário, os agentes que apostam na queda da taxa de juro futura, estarão predispostos a assumir empréstimos no curto prazo de modo a adquirir obrigações de longo prazo. Dessa forma, o preço do mercado se fixará ao nível em que os preços de venda (de títulos obrigacionais) dos "baixistas" for equivalente ao de compra dos "altistas" (KEYNES, 2012, p. 152).

Em termos de causas subjetivas (motivos) da preferência pela liquidez, tendo em vista as referidas condutas individuais em relação aos usos (funções) da moeda frente à incerteza futura, distinguem-se, portanto, o motivo negocial ("transações correntes"), o motivo precaucional ("desejo de segurança") e o motivo especulativo ("propósito de lucro").

A questão em torno da adequação em se ter um mercado monetário organizado resulta num dilema, pois, de um lado, sua ausência aumentaria em muito a preferência pela liquidez em razão do motivo de precaucional, de outro, sua presença acarreta inevitavelmente amplas flutuações naquela preferência devido à especulação.

De qualquer maneira, como adverte KEYNES (2012, p. 155), a despeito da introdução teórica do elo monetário na cadeia econômica, não se há de olvidar dos percalços daí resultantes. Sempre sob a hipótese coeteris paribus, embora se infira que um aumento quantitativo da moeda reduza a taxa de juro, tal redução poderá se frustrar se a preferência pela liquidez crescer mais do que o incremento no volume monetário; não obstante se aguarde por um incremento positivo do investimento quando da redução da taxa de juro, tal não sucederá devido a uma diminuição mais rápida da escala de 
produtividade marginal do capital face àquela redução do juro; embora o investimento superior induza a um crescimento do nível empregatício, o mesmo pode se frustrar em razão de uma tendência de queda do consumo. Se o emprego de fato aumentar, os preços tenderão a se elevar, mas num grau que dependerá tanto da forma em que ocorre a oferta real como da tendência de elevação nominal dos salários. Dado o aumento da produção e dos preços, a preferência pela liquidez daí resultante acarretará o aumento da demanda de moeda para a manutenção de uma dada taxa de juro.

Não obstante os montantes de recursos líquidos na prática não se apartarem conforme os motivos anteriormente apresentados, é conveniente que sejam funcionalmente separados na abordagem teórica, do seguinte modo: $M 1$ para os recursos líquidos destinados aos negócios correntes e à precaução, e $M 2$ a soma destinada à especulação no mercado monetário. Em correspondência às classes de recursos anteriores há diferentes funções de liquidez, a saber: $L 1$ correspondente ao nível de rendimento $(Y)$, e $L 2$ à relação entre taxa de juro corrente $(r)$ e as expectativas. Portanto, resulta que $M=M 1+M 2=$ $L 1(Y)+L 2(r)$. O comportamento da equação anterior pode ser assim sumariado (KEYNES, 2012, p. 185 e s.):

dado qualquer estado de expectativas, há no espírito do público certo potencial para conservar recursos líquidos em quantidade superior à que requer a motivação das transações ou a motivação de precaução, e esse potencial se traduzirá em detenção efetiva de moeda, num grau que dependerá dos termos em que a autoridade monetária se acha disposta a criar recursos líquidos. É esse potencial que vem resumido pela função $L 2$.

Dessarte, a cada acréscimo da quantidade de moeda criada pela autoridade monetária corresponderá, mantidas as demais condições, uma determinada taxa de juro (complexo de taxas para dívidas com diversos prazos de vencimento) - o mesmo vale todavia para qualquer outro elemento isolado do sistema econômico. Esse postulado pressupõe, no entanto, que haja um nexo especial, direto e objetivo, entre as variações da quantidade de moeda e as da taxa de juro. A razão para tal suposição encontra KEYNES (2012, p. 186 e s.) no fato de que o sistema bancário e a autoridade monetária negociam com dinheiro e títulos obrigacionais, não com ativos ou bens de consumo. Na prática a autoridade monetária age sobre as obrigações de curto prazo na expectativa de que os preços das obrigações de longo prazo se ajustem sob a influência "retardada e imperfeita" das anteriores. 
Outrossim, KEYNES (2012, p. 189) estabelece a relação do postulado anterior com a teoria quantitativa da moeda da seguinte forma: no equilíbrio estático, ou seja, excluída qualquer incerteza em relação à futura taxa de juro, a função de liquidez L2 (propensão a entesourar) será sempre igual a zero. Em consequência, $M 2=0$ e $M=M 1$. Dessa forma, qualquer variação de $M$ resultará na flutuação da taxa de juro até que o rendimento atinja o nível de equilíbrio entre as supostas variações de $M 1$ e $M$. Não obstante, por definição, $M 1 . V=Y$, onde $V$ representa a velocidade-renda da moeda, e $Y$ o rendimento agregado. Face à possibilidade de medição da quantidade $O$ e do preço $P$ da produção corrente, então $Y=O P$, do que resulta $M V=O P$, relação análoga à forma tradicional da equação de troca.

Quanto à extensão aplicativa da teoria quantitativa, ainda observa KEYNES que sua possível falha frente às circunstâncias reais residiria em não distinguir entre as razões que influenciam as variações dos preços, a saber, as variações da produção e as resultantes das alterações nas unidades (monetárias) de salário ${ }^{102}$. Essa omissão pode decorrer sobretudo da absoluta ausência da propensão a entesourar, característica da economia catalática sob a hipótese analítica de equilíbrio (estacionário), como da expectativa de pleno emprego no equilíbrio (longo prazo), o que acarreta ser $O$ constante e $M 2$ igual a zero, e pois se supondo constante a velocidade-renda $V$, então a unidade salarial e o nível de preços variarão proporcionalmente na razão direta da variação da quantidade de moeda.

A taxa monetária de juro, ou seja, a taxa de juro sobre dinheiro, desempenha portanto um papel singular na economia capitalista (monetária) em razão de interferir no investimento na medida em que serve como referencial para a eficiência marginal do capital, é dizer, como nível a ser atingido pela produtividade marginal de um fator produtivo de modo a ser novamente produzido. Outrossim, atua necessariamente também na fixação de um limite ao nível quantitativo de emprego. Natural, portanto, a indagação de KEYNES (2012, p. 201) a respeito dessa singularidade do dinheiro em relação a outros ativos, o que implica o exame da questão da exclusividade da taxa de juro em relação dinheiro, ou seja, se também não há uma taxa de juro em relação aos bens de capital, e pois de seu corolário: o funcionamento da economia na ausência do dinheiro (economia não monetária).

A taxa de juro monetária se traduz no excedente (porcentagem) de um montante

102 Não se há de negar uma possível analogia da unidade monetária de salário de KEYNES com o conceito de "numerário" (moeda de conta) de WALRAS (1983). 
de dinheiro contratado para entrega futura (p. ex., no prazo de um ano), sobre o chamado preço spot ou à vista daquele montante objeto do contrato. Nesse sentido, a todo bem de capital pode corresponder uma taxa análoga à taxa monetária, desde que negociado (cotado) em mercado organizado, em última instância, uma taxa de juro calculada em termos do próprio bem. Assim, por exemplo, quanto à soja, a diferença entre os contratos "para o futuro" e "à vista" sobre essa mercadoria cotada no mercado se correlaciona com a taxa de juro dessa mercadoria. Não obstante, o contrato futuro dessa mercadoria (soja) está cotado em moeda para entrega futura, não em soja para entrega imediata, e pois essa diferença também integra a taxa monetária de juro. A relação anterior pode ser expressa pelo seguinte exemplo: supondo-se (irrealisticamente) que preço da soja para entrega imediata seja de 100 reais por 100 hectares, e seu preço futuro negociado para entrega em um ano seja de 107 reais por 100 hectares. Dada a taxa monetária de juro de 5\%, qual seria então a taxa de juro corrente da soja? Pois bem, a quantia de 100 reais comprará no momento 105 reais para entrega futura (juro do dinheiro no mercado monetário), e 105 reais para entrega futura comprarão 105/107.100 (=98) hectares de soja nas mesmas condições. Por outro lado, 100 reais comprarão hoje 100 hectares de soja para entrega imediata. Em consequência, 100 hectares de soja para pronta entrega comprarão 98 hectares a futuro. Portanto, a taxa de juro da soja é de $2 \%$ "negativa" ao ano.

Conclui-se do exposto não haver homogeneidade possível das taxas de juro próprias dos bens duráveis, dadas as peculiaridades de preços dos bens não fungíveis entre si. Suas cotações à vista e futuras conforme os negócios que lhes têm por objeto no mercado é notoriamente diferente para diferentes ativos. Nesse ponto, portanto, reside a chave keynesiana para a solução em prol da taxa monetária de juro como reguladora da produção. Em regra, será a taxa mais elevada entre todas as taxas específicas de juro (das mercadorias em si) que ditará a lei do investimento, pois é ela a maior das taxas a ser alcançada pelos fatores produtivos para que se tornem objeto de nova produção. A razão para isso se encontra na própria natureza econômica do dinheiro, que faz com que sua taxa de juro não se reduza da mesma maneira e na mesma proporção que as taxas naturais ${ }^{103} \mathrm{de}$ juro dos demais ativos (KEYNES, 2012, p. 202 e s.).

A singularidade do dinheiro em relação às demais mercadorias assenta sobretudo no fato de que sua taxa de juro declina mais lentamente do que as demais à medida que o estoque dos ativos em geral aumenta, resultando na eliminação da sua produção lucrativa. 
Isso ocorre em razão de que sua taxa específica de juro, expressa em termos da própria moeda como padrão de valor, seja mais resistente à queda face ao aumento da produção do que as taxas específicas dos demais ativos, expressas em termos dos próprios ativos. Essa peculiaridade do dinheiro se resume a duas características particulares, a saber: a) no curto ou longo prazo, o dinheiro tem uma elasticidade de produção igual ou muito próxima de zero, ou seja, o dinheiro não pode ser prontamente produzido, não se podendo desviar mão de obra de outras atividades, por vontade dos empresários, para acrescer sua produção, pois que seu preço também se elevará em unidades salariais, aliás, na hipótese de moeda fiduciária, a limitação é institucional e restrita às autoridades monetárias; e b) a despeito de haver outros fatores produtivos cuja elasticidade de produção também possa ser diminuta, o dinheiro também goza da propriedade de ter sua elasticidade de substituição (cruzada) praticamente nula, decorrente do fato de que sua utilidade se resume apenas a seu valor de troca, de modo que na medida em que seu valor se eleva não há motivo ou tendência, em circunstâncias estáveis e de inflação sob controle, para substituí-lo por outro fator, como sói ocorrer em relação aos demais ativos na economia (KEYNES, 2012, p. 208 e s.).

Não obstante, a despeito da impossibilidade de aumento da oferta monetária pelas forças de mercado, o grau de liquidez da economia poderia sofrer um acréscimo em razão de outros automatismos econômicos, tal como o afluxo de renda nominal decorrente da redução salarial que resulta da deflação de preços, liberando dinheiro para saldos ociosos, e aumentando assim o estoque de moeda em relação ao dividendo nacional. KEYNES (2012, p. 210 e s.) não nega tal possibilidade, mas entende não ser ela suficiente para descaracterizar o dinheiro e dessarte assegurar o pleno emprego. A principal razão para tanto é atribuída às propriedades do dinheiro relacionadas a sua elevada liquidez, por excelência, e a seu baixo custo de manutenção, particularmente quando a taxa monetária de juro atingir seu mínimo institucional, tornando a curva de preferência pela liquidez infinitamente elástica, é dizer, quando então o dinheiro se torna passível de troca quase ilimitada com outros ativos sem que como isso a relação de permuta seja desfavorável ao dinheiro como reserva de valor.

Dessa forma, dadas as características mencionadas, se pode afirmar com KEYNES (2012, p. 212 e s.) que uma elevação da taxa de juro retarda a produção de todos os demais bens duráveis sem que assim estimule a produção de dinheiro. A taxa monetária de juro, padrão para as demais taxas específicas dos ativos (mercadorias), paralisa o investimento produtivo direcionado a essas mercadorias, não o redirecionando ao aumento 
da oferta monetária, impossível por hipótese. Em consequência, face à ausência de dinheiro e de qualquer outro ativo com características similares à moeda, as taxas de juro atingiriam o equilíbrio somente ao nível de pleno emprego. O desemprego se desenvolve, portanto, devido ao desejo dos homens de atingir a lua, no sentido de que o emprego de mão de obra adicional para alcançar esse objetivo, que se traduz em dinheiro, não pode ser alcançado em razão de ser algo que não se produz e cuja procura não possa ser facilmente restringida, ou prontamente atendida. Não se apresenta assim alternativa senão o convencimento do público de que um pedaço de queijo suíço e a lua são praticamente a mesma coisa, criando-se finalmente um laticínio, ou seja, um banco central, sob controle do poder público.

A liquidez, portanto, caracteriza o dinheiro por sua utilidade, e pois justifica sua não neutralidade ao estabelecer um piso para o valor do investimento a partir da taxa de juro monetária. Não obstante, o próprio KEYNES (2012, p. 214 e s.) reconhece a insuficiência teórica desse elemento, pois que o fato de se admitir a liquidez do dinheiro por si só não explica a razão de ser o dinheiro em si líquido nem de ser sua taxa de juro a mais relevante na economia. Essa explicação encontra KEYNES no fato de ser a moeda o padrão de valor no qual normalmente se denominam os contratos e os salários. Ademais, a relativa rigidez salarial em termos monetários se explica em razão da liquidez do dinheiro, ou melhor, pelo fato de haver um bem que tenha as características de liquidez do dinheiro, isto é, a menor elasticidade de produção e o menor incremento de sua taxa de conservação sobre o prêmio de liquidez, e pois frente ao qual os salários serão necessariamente mais estáveis (viscosos).

$\mathrm{Na}$ verdade, as dificuldades apresentadas pelo raciocínio anterior se devem sobretudo à concepção ainda impregnada pelos elementos da análise econômica real, no sentido de não monetária, dos neoclássicos (marginalistas), visto que KEYNES parte do exame subjetivo (produtividade marginal) do dinheiro frente às demais mercadorias (LIMA, 1997).

A melhor solução para evitar tal circularidade de raciocínio em torno da liquidez monetária resulta da própria natureza inelástica do dinheiro relativa à sua produção e à cadeia dos demais bens produtivos, e pois mais adequada à análise monetária do fenômeno econômico, a saber, a inelasticidade da oferta monetária. Essa característica assegura ao dinheiro a qualidade de ter a garantia mais efetiva contra a desvalorização do que os demais ativos. Essa garantia resulta justamente das razões institucionais que asseguram a 
inelasticidade de sua oferta, em regra legalmente garantida. Como ensina LIMA (1997, p. 44 e s.):

A razão encontra-se na própria natureza das relações de produção que caracterizam uma economia monetária: a escassez do dinheiro em relação aos demais ativos é a forma de restringir seu acesso apenas a um grupo social, que em certo momento deve manter o monopólio de seu controle, isto é, o poder de contratar mais ou menos mão de obra e de obter lucro a partir do processo de assalariamento. Pode-se afirma que, em uma economia monetária, a moeda entra em circulação por meio da remuneração dos assalariados pelas firmas e não por um manah ou um "bombardeio de helicóptero" como querem os monetaristas.

Nesse sentido, o dinheiro se traduz num monopólio institucional que, em última instância, implica o controle de sua oferta. Dada a restrição inelástica do dinheiro, sua quantidade não pode se adequar à demanda por meio de sua produção, como ocorre com os demais bens de capital, resultando assim na elevação de seu preço, ou seja, da taxa de juros. Elevando-se seu preço, o investimento produtivo (real) tende naturalmente a se desviar de outros ativos (mercados), rumando na direção do dinheiro (mercado monetário), e pois se abstendo da utilização dos demais fatores produtivos existentes. O fenômeno monetário, que se manifesta através da taxa de juros, surge no espaço econômico como uma espécie de vetor, cujo ângulo de inclinação em relação à direção em que se encaminha o investimento produtivo (taxa de investimento) representa sempre um desvio de seu evolver, ou mesmo seu impedimento. Essa figura ilustra a ideia de KEYNES (2012, p. 213) de que na ausência do dinheiro as taxas específicas de remuneração dos demais ativos tendem a encontrar seu equilíbrio sob a condição de pleno emprego, ao contrário do que ocorre na presença do juro monetário.

A economia capitalista, monetária e lucrativa em si mesma, deve ser portanto analisada sob o enfoque dos fluxos e refluxos monetários, capazes de ilustrar circunstancialmente as possibilidades de realização monetária da produção, pois o retorno do capital na forma de lucro (excedente) constitui o objetivo último dessa economia (LIMA, 1997).

Num modelo econômico que gravita em torno da moeda, o fator limitativo de sua expansão reside antes na restrição da liquidez do que na insuficiência de poupança. $O$ ganho monetário (lucro) constitui assim a causa final do comportamento econômico, o qual pode se orientar tanto ao incremento produtivo (riqueza real) quanto ao incremento apenas 
financeiro, obstaculizando nessa segunda hipótese o investimento na medida em que lhe nega financiamento presente (crédito bancário de curto prazo, ou crédito rotativo) não raro em prol da especulação futura (títulos de curto ou longo prazo no mercado financeiro). Dessa forma, a restrição da liquidez caminha paralelamente à inelasticidade da oferta monetária, em última instância, ao caminho adotado por políticas monetárias restritivas, quaisquer que sejam seus propósitos (HUGON, 1976; LIMA, 1997; WEBER, 2011).

Advirta-se, no entanto, que certos países ainda em via de desenvolvimento têm suas economias apenas parcialmente monetárias, comportando situações de acentuado pluralismo, a despeito do desenvolvimento monetário decorrente dos acordos de Bretton Woods, em particular devido à atuação do Fundo Monetário Internacional no fomento à modernização da estrutura monetária e financeira, resultando assim no alargamento do uso das diversas formas de moeda, tal como a escritural (HUGON, 1976).

No contexto de subdesenvolvimento, as relações entre moeda e preços são marcadas por fenômenos inflacionários, sobretudo em razão da baixa elasticidade de sua produção (oferta), cuja expansão encontra sérios obstáculos resultantes de rigidezas fundamentais, a saber, fraca propensão à poupança como investimento, ou à preferência pela liquidez, e pois a forte propensão ao consumo. Na verdade, sob o prisma das unidades familiares, os motivos "keynesianos" de precaução e especulação praticamente não encontram guarida no seio social, sendo os encaixes individuais quase que inteiramente liquidados em transações correntes. Essa forte pressão pelo lado da demanda acaba por predominar no processo de crescimento dessas economias, cuja prodigalidade não raro avança sob condições favoráveis à forte expansão do crédito consuntivo, principalmente em prol da indústria de bens de consumo. Em consequência, o tipo de desenvolvimento schumpeteriano (SCHUMPETER, 1982), calcado na expansão da oferta real mediante o fomento ao empreendedorismo empresarial, resta seriamente prejudicado, retardando o verdadeiro progresso socioeconômico. O processo de crescimento dominado pela procura é marcado, portanto, "por uma tensão inflacionista contínua, que constitui, ao mesmo tempo, um fenômeno monetário, um desequilíbrio global e conjuntural entre oferta e procura, e um fenômeno estrutural” (HUGON, 1976, p. 113). 


\section{O FUNCIONAMENTO DO SISTEMA MONETÁRIO}

\section{As funções do dinheiro numa economia monetária}

Considerando os fundamentos articulados nas seções anteriores, frise-se novamente que o dinheiro (senso largo) é antes um fenômeno social, e pois institucional, cuja forma se representa pela "moeda" nacional ou oficial (curso legal), mas que não prescinde da aceitabilidade mercantil (social) para se tornar "dinheiro". A evolução da forma monetária no sentido da desmaterialização do dinheiro (WEBER, 2011), desde a moeda mercadoria, ou metálica, passando pela moeda conversível, até chegar à moeda fiduciária $^{104}$ e à bancária (escritural) ${ }^{105}$, resultou sobretudo da percepção de que a reconversão ao lastro (reservas bancárias) não era, em regra, simultaneamente solicitada por todos os clientes bancários, permitindo assim a consolidação do sistema bancário com ação monetário-creditícia. Não obstante, essa evolução e consolidação se lastreiam num arcabouço institucional que propicia, por exemplo, o uso generalizado de cheques ou ordens de transferência dos depósitos bancários, o funcionamento de câmaras de compensação ou o redesconto para provisão de liquidez.

O avanço da tecnologia da informação impele a forma monetária do dinheiro rumo à imaterialidade quase absoluta, restando praticamente só a moeda de cunho escritural na forma de cartões múltiplos (débito e crédito) e também de moeda eletrônica (armazenável em computador, ou aparelho celular).

Cumpre enfatizar que a chamada moeda eletrônica, se e quando emitida fora do controle do sistema bancário, pode provocar a erosão da receita proveniente da emissão monetária, ou seja, a perda de senhoriagem. Em regra, essa receita decorre do monopólio de emissão monetária (estatal), e pois do poder de compra do dinheiro posto em circulação através da moeda, num determinado período. No caso corrente de monopólio estatal, mede-se também pelo custo do financiamento público relativo à emissão de títulos da dívida pública em lugar de moeda ${ }^{106}$.

104 Dependente da confiança do público, dotada de curso forçado (não conversibilidade) e de poder liberatório compulsório, juridicamente garantido (curso legal), cuja circulação independe dos limites de lastro existentes.

105 Corresponde aos lançamentos contábeis de débitos e créditos bancários, sem existência física. Em regra, a moeda escritural goza de poder liberatório, mas sem curso legal, pois que não é compulsório seu recebimento em pagamento, isto é, mediante um depósito em conta corrente, podendo-se exigir o pagamento em espécie (CORTEZ, 2004, p. 114).

106 De forma geral, a senhoriagem equivale à diferença entre os custos de produção e emissão da moeda e seu poder de compra (HUBER, 2011). Trata-se do custo de oportunidade de investimento, ou seja, a 
Nesse sentido, é oportuno que se distinga da senhoriagem o chamado "imposto inflacionário", ou seja, a "arrecadação" governamental em razão da inflação elevada, resultante do contingenciamento orçamentário até ao final do prazo legal para liberação das verbas orçamentárias frente à arrecadação de receitas tributárias correntes, geralmente submetidas à correção monetária (indexadas ao índice ou à taxa de inflação). Esse “imposto" nada mais é do que a perda de poder aquisitivo sofrida pelo público, detentor da moeda nacional, devido à taxa de inflação, porque a retenção do mesmo estoque real de moeda requer um sacrifício das despesas em valor equivalente ao poder de compra perdido, resultando numa "poupança forçada” por parte do público (MISES, 2005) ${ }^{107}$.

Observa-se, outrossim, que pode haver senhoriagem mesmo na ausência de regime inflacionário, vez que um aumento da atividade produtiva demandará maior poder aquisitivo (renda nominal), e pois emissão monetária, aumentando também o poder de gasto governamental sem que a emissão primária de moeda tenha por fundamento uma acomodação inflacionária.

Essa distinção entre senhoriagem e imposto inflacionário remete à diferenciação conceitual entre dinheiro e moeda, na medida em que num regime de elevada inflação há a tendência de desaparecimento do "dinheiro" em prol do surgimento de várias "moedas". Assim, a "moeda oficial" continua a atuar como meio de pagamento nas relações de troca, e talvez ainda como unidade de conta (numerário walrasiano), ganhando a "moeda indexada" foros de padrão contratual, e não raro recebendo a "moeda estrangeira" a preferência pela liquidez (reserva de valor). A ameaça de hiperinflação resultará à moeda

captação da poupança social, que seria gerada pelo agregado monetário emitido, a juros de mercado via emissão de dívida pública (COSTA, 1999). Não obstante, como assevera HUBER (2011), a ciência das finanças tende a confundir a senhoriagem com o rendimento de juros em razão do fato de o dinheiro ser emitido contemporaneamente através da concessão de crédito (moeda escritural), o que conceitualmente não se justifica, na medida em que os juros decorrentes de empréstimos bancários geradores de moeda implicam uma emissão monetária a (render) juros e ilíquida, enquanto que a senhoriagem original significa emissão sem juros e plenamente líquida. Desde o final do medievo, cada vez mais, tal senhoriagem originária se encontra reduzida apenas à emissão (cunhagem) de moedas metálicas, uma vez que hodiernamente o próprio papel-moeda (nota bancária) estatal entra em circulação através de um mecanismo puramente escritural (contábil), pelo qual o banco central lança determinada soma a crédito na conta de reservas de um banco comercial em contrapartida a um depósito de papel-moeda em circulação ou títulos de crédito, criando uma relação obrigacional (empréstimo a juros) a ser liquidada entre o banco central (emissor) e o banco receptor, em que o banco central se obriga a dispor daquela soma em prol do banco receptor, e pois esse último ao resgate (pagamento) do mútuo contraído. Como se verá na sequência, a criação de moeda bancária (escritural) pelos bancos comerciais em suas relações com o público (clientela) resulta do mesmo mecanismo.

107 De modo simplificado, tendo em vista que a moeda representa uma dívida do emissor em prol daqueles que a detém, ao se desvalorizar em razão do processo inflacionário, ou da redução de sua cotação frente a outras moedas (câmbio) ou ativos, acarreta uma redução no valor real da dívida de seu emissor, portanto, um ganho que, em geral, é entendido como equivalente à senhoriagem (ESTRELA, 2011). 
estrangeira o valor de numerário da economia de trocas, passando a depender a carestia do aumento na cotação do câmbio estrangeiro, robustecido pela fuga de capitais. Esse processo inflacionário, particularmente na hipótese de indexação monetária, acarreta uma espécie de "fragmentação do padrão monetário" (CORTEZ, 2004, p. 187).

Em suma, "todo dinheiro é moeda, mas nem toda moeda é dinheiro" (COSTA, 1999, p. 36). Os atributos de liquidez que fomentam um ativo à condição de moeda representam um requisito necessário, mas não suficiente para torná-lo dinheiro. Segundo COSTA (1999, p. 37 e s.), uma moeda somente atinge a condição econômica de dinheiro integral quando cumpre ao menos as três "funções clássicas" do dinheiro, a saber: a) intermediário de trocas ou meio de circulação; b) medida de valor ou denominador comum das relações de troca, ou então padrão de contratos; e c) reserva de valor ou poder aquisitivo entesourado. Do contrário, desempenhando apenas parte dessas funções, seria ela algo como um "dinheiro parcial". Dessas três funções básicas decorreriam as demais funções econômicas: a função liberatória ou poder de liquidação de obrigações ${ }^{108}$, e a função de padrão de pagamentos diferidos ou promessa de pagamentos.

Não obstante, da mesma forma que os sistemas monetários sofreram mudanças ao longo do tempo, os ativos ${ }^{109}$ considerados dinheiro sempre variaram no devir histórico. A qualquer momento, portanto, um artigo pode estar a meio caminho de se transformar em moeda, ou mesmo dinheiro. A linha demarcatória entre moeda e não moeda, dinheiro e não dinheiro é tênue e imprecisa. Como leciona MAYER (1993, p. 14 e s.), a linha a ser traçada depende do campo econômico que se tenha em mira, em última instância, "da função de moeda que seja mais relevante para o problema em questão". Assim, se o problema central da análise econômica tiver por substrato o sistema de trocas (circulação), o fluxo circular real de bens e serviços, bastaria a definição de moeda como meio de troca, tal como na economia catalática de MISES (2005), ou então como unidade de conta (numerário) na economia (real) estacionária de WALRAS (1983). Em tais hipóteses, aqueles ativos que cumprissem a função econômica de meio circulante (intermediário de troca, ou padrão monetário de circulação) seriam intencionalmente entendidos como dinheiro.

Como anteriormente mostrado, o modelo neoclássico de análise econômica se

108 Sob o prisma estatizante, o poder liberatório de obrigações fiscais ou tributárias seria o elemento essencial do dinheiro de curso legal.

109 Todo objeto ou item que se introduz no âmbito da consideração econômica, incluam-se a capacidade laboral ou o capital intelectual, pode ser tratado como um ativo a partir do instante em que se trave o processo econômico, e proceda ao arrolamento de todos os seus elementos (SCHUMPETER, 1964b, p. 357 , n. 108). 
baseia, em regra, num sistema perfeito de troca (escambo), em regime de competição e simetria de informações acerca do futuro, sempre tendente ao equilíbrio. Nesse modelo, considerando a presença de outros ativos financeiros reais (bens de capital) que proporcionem rentabilidade positiva, racionalmente não há lugar para o dinheiro como reserva de valor, mas apenas como numerário (padrão walrasiano). Não sendo um elemento essencial à análise, a existência do numerário prescinde conceitualmente da função monetária tanto de reserva de valor como de meio de pagamento, na medida em que não se contempla a incerteza (risco) nem o diferimento, respectivamente ${ }^{110}$. A própria noção de equilíbrio é condicionada pela ideia de conciliação prévia de escolhas, não se distinguindo em tal modelo as decisões dos sujeitos econômicos ${ }^{111}$.

Suponha-se, no entanto, que a função de estoque de riqueza (reserva de valor) seja salientada, como na hipótese da economia monetária keynesiana. Ganharão preferência nessa abordagem os ativos que se apresentarem como extremamente líquidos, ou seja, que puderem ser gastos de imediato, uma vez que é a liquidez o que diferencia a moeda dos outros fundos de riqueza.

$\mathrm{Na}$ economia monetária e financeira, reprise-se, a clássica lei de Say ${ }^{112}$ não se aplica, pois a moeda (dinheiro) permite o adiamento das decisões relativas às despesas (gastos), enquanto o crédito faculta o adiantamento de poder aquisitivo. Desse modo, não há uma causalidade unilateral entre o dispêndio e a renda gerada na produção. Ao contrário do princípio clássico anterior, esse modelo se rege pelo princípio keynesiano da demanda efetiva, ou seja, são as decisões dos agentes econômicos quanto ao dispêndio, tornadas efetivas por meio de poupança própria ou de empréstimos de terceiros, que determinam a renda.

Dessarte, a simples presença da moeda, em razão da incerteza, permite o adiamento das decisões de gasto, afastando o princípio clássico do equilíbrio entre oferta e demanda. A moeda seria antes uma instituição defensiva, através da qual os eventos futuros

110 A análise real, não monetária, prescinde do meio de troca, pois, ainda que as operações colaterais de revenda sejam hipoteticamente realizadas em termos de numerário, se mantém a suposição de que esse tráfico se organiza sem qualquer desvio do ativo-padrão de seu uso próprio. Não obstante, como adverte SCHUMPETER (1964b, p. 358, n. 116), na hipótese de haver retenção de qualquer porção do ativo numerário, esse ativo se transformaria em dinheiro.

111 Daí se falar na presença teórica (fictícia) de um "leiloeiro walrasiano", inspirado no modelo de WALRAS (1983), que assegura o equilíbrio simultâneo e instantâneo a todo o momento do processo econômico (COSTA, 1999).

112 A chamada lei dos mercados, pilar básico da autorregulação do processo econômico, estabelece que toda oferta determina sua própria procura, ou seja, o valor adicionado à produção gera a renda para a aquisição do produto final, e pois, atingido o equilíbrio, a soma dos preços dos produtos seria equivalente à soma dos adquiridos (igualdade entre oferta e demanda totais). 
são afetados, cuja propriedade essencial reside na plena liquidez do dinheiro em sentido estrito, a saber, qualquer ativo dotado de inelasticidade de produção e substituição em relação aos demais ativos que se podem reproduzir facilmente por meio do emprego de trabalho (KEYNES, 2012).

Consigne-se, porém, que a liquidez de um ativo deriva dos seguintes fatores: facilidade negocial (compra e venda); custos negociais (de transação); e do grau de estabilidade e previsibilidade de seu preço. A moeda restrita, isto é, dinheiro de curso legal e depósitos bancários à vista, goza de liquidez perfeita, pois, em razão de já ser moeda, não incorre sua venda em custo e trabalho, não necessitando ser transformada em moeda, sendo seu preço constante. Na outra ponta da escala de liquidez há itens como imóveis, cuja venda implica demora, custo de corretagem e cujo preço pode resultar inferior às expectativas do vendedor. Dessa forma, todos os itens econômicos (ativos) se deixam classificar segundo o critério de liquidez, vale dizer, de acordo com seu grau de "moedicidade" (MAYER, 1993, p. 15). Ganha assim em relevo a questão de se saber em que ponto, ao longo do espectro de liquidez e moedicidade, se deve traçar a linha divisória entre moeda e não moeda.

Observa-se de antemão que o conceito de liquidez não é exato, pois que seus três componentes podem variar assimetricamente em relação aos ativos que se comparem: assim, por exemplo, um ativo pode ser vendido com mais facilidade, mas a custo negocial elevado (imposto sobre o ganho de capital auferido com a alienação); outro, no entanto, pode ser vendido mais tardiamente, mas quase sem custo negocial. Um terceiro, ainda, pode ser rapidamente vendido a um baixo custo negocial, mas cujo preço é muito volátil. Nessas circunstâncias, resta difícil a decisão em torno da liquidez maior ou menor dos ativos comparados.

Além disso, a liquidez também pode variar ao longo do tempo, como no caso dos lotes de ações negociadas em bolsa, além de apresentar um viés psicológico quanto à realização ou não do ativo em portfólio. Para fins analíticos, no entanto, podem ser ignoradas tais indefinições em prol do traçado de um espectro de liquidez, tendo num extremo a moeda restrita e noutro uma expectativa de direito a dinheiro de curso legal, digamos uma herança. Caso se decida por ampliar a definição de moeda restrita, infere-se desde logo que não há um ponto exato onde se possa demarcar precisamente o limite. Assim, independentemente da amplitude da definição de moeda (dinheiro) que se abrace, sempre haverá ativos que se aproximarão daquele limite, não obstante exclusos da 
definição inicial de moeda, pois a moedicidade é antes um moto contínuo. Esses ativos que muito se assemelham ou se aproximam da definição de moeda restrita se denominam quase-moedas, na medida em que são altamente líquidos, mas não tão líquidos quanto a moeda restrita ${ }^{113}$.

Na verdade, como enfatizado pelo próprio modelo keynesiano, a determinação do dinheiro e seus substitutos (ativos financeiros) passa necessariamente pelo estabelecimento da relação entre dinheiro e juros. Essa relação pode ser estabelecida a partir da consideração do tipo de título de crédito (ativo financeiro) que mais se assemelha ao dinheiro, sem que seja propriamente dinheiro. Com efeito, há ativos considerados como modalidades do próprio dinheiro de curso legal, entre eles os depósitos bancários, que são promessas de pagamento em dinheiro no futuro. Esses títulos que são dinheiro diferem daqueles que não são pelo fato de não renderem juros, ou seja, "seu valor presente é igual a seu valor nominal, em vez de cair abaixo de seu valor nominal, como é o caso das letras de câmbio" (HICKS, 1987, p. 137).

Desse modo, o dinheiro se assemelha ao tipo mais perfeito de título de crédito, enquanto os outros títulos, menos perfeitos, valem menos devido à sua imperfeição. Assim, a taxa de juros desses títulos seria uma medida de sua imperfeição, ou seja, de sua “monetização imperfeita", o que explica o paralelismo entre a natureza do dinheiro e a natureza dos juros.

No que tange aos títulos reais (notas promissórias, debêntures ou apólices governamentais), uma razão dos juros pagos reside no risco de inadimplência. Outra razão, em particular relacionada aos títulos de longo prazo, se atribui à incerteza quanto ao curso futuro das taxas de juros. Esses dois elementos constituem fatores de risco, de modo que se pode atribuir ao juro a característica de ser um ágio de risco. Como anteriormente mostrado, parece ser esse o fundamento da doutrina keynesiana da "preferência pela liquidez", na medida em que o juro se reduz a esses dois elementos de risco: inadimplemento e incerteza. Sem embargo, apenas a incerteza, sob a hipótese de títulos absolutamente seguros (p. ex., títulos da dívida pública de curto prazo), parece não ser suficiente para explicar o juro pago como prêmio pela aquisição de tais títulos, muito menos a razão de serem considerados quase-moeda.

A verdadeira natureza do juro pode ser investigada ao se considerar os títulos de

113 Em que pese a arbitrariedade conceitual aqui revelada, se aceita quase que universalmente a ideia de que os títulos de dívida pública, em particular os de curto prazo (vencimento em um ou dois anos), constituem espécie ordinária de quase-moeda. 
crédito muito próximos do dinheiro de curso legal, o que permite uma aproximação da própria natureza do dinheiro e seus substitutos, tal como um título de crédito de prazo muito curto e considerado absolutamente garantido contra o risco de inadimplência. Em geral, os títulos de crédito que não têm aceitação no pagamento de obrigações rendem juros porque não são propriamente "dinheiro". Não obstante, mesmo quando os emprestadores efetivos excluem a possibilidade de inadimplemento quanto a certos títulos obrigacionais, há ainda custos e riscos envolvidos quando os fundos disponíveis são mantidos em forma de títulos, em vez de dinheiro, pelos quais os mutuantes exigem uma compensação (HICKS, 1987).

Os diversos tipos de títulos de crédito se comportam de modo semelhante a uma cadeia de mercadorias substitutas, onde o dinheiro ocupa a primeira posição e os demais títulos sofrem, em regra, um desconto relativamente ao dinheiro, e em razão disso é que as taxas de juros são positivas. Na verdade, o que geralmente ocorre é que o sistema bancário e as autoridades monetárias, e ainda os grandes investidores, têm à sua disposição toda uma gama de títulos com diferentes prazos de vencimento. Nesse contexto, a substituição entre dinheiro e títulos de longo prazo resulta normalmente da mediação dos títulos de prazo mais curto ou mesmo de outros títulos cambiais que representem ordens de pagamento à vista. Assim, na hipótese de ser a taxa de longo prazo diminuta em comparação ao risco de perda de capital, há uma migração para os títulos de curto prazo; entretanto, caso essa taxa de curto prazo também seja pequena demais para compensar os riscos aqui envolvidos, há então retenção do dinheiro. Portanto, são esses investidores profissionais, em particular os bancos e os governos, operando com toda a gama de títulos e atentos às menores variações entre as taxas, que respondem em larga medida pela lógica do sistema de juros (HICKS, 1987).

No que tange, portanto, ao dinheiro e seus substitutos, frise-se que o funcionamento do sistema de taxas de juros nada mais é do que um reflexo da regra geral de substituição: "se duas mercadorias são substitutos perfeitos para uma importante seção do mercado, elas se comportarão como substitutos perfeitos para o mercado como um todo" (HICKS, 1987, p. 142), sendo essa capacidade de substituição perfeita uma propriedade essencial do dinheiro real, e pois fundamental para a economia dinâmica ${ }^{114}$.

114 Em regra, entende-se ser essa abordagem de HICKS (1987) um modo de conciliação entre a teoria keynesiana e a escola neoclássica, complementando, ou mesmo corrigindo, a ideia de liquidez por meio da introdução dos fundos disponíveis para investimento, e pois da diferenciação entre os ativos líquidos com base nas diferentes espécies de títulos de crédito (GUDIN, 1976). 
Mesmo sob o prisma da estrita análise econômica, resulta imprescindível o caráter social que deve revestir o dinheiro e sua forma monetária ${ }^{115}$, pois, no dizer de HICKS (1983, p. 139), “a "monetarização" [monetização] imperfeita das letras que não são dinheiro deve-se à falta de sua aceitação geral. Essa falta de aceitação geral provoca a dificuldade de investir nelas, e as leva a sofrer um desconto".

Desse modo, a própria eficácia técnico-jurídica dos meios monetários de pagamento não se lastreia meramente na validade formal, contrafática, conferida pelo ordenamento jurídico do sistema monetário, mas antes decorre de sua "sensibilidade sociológica", encontrando na realidade a ela subjacente "as condições sociais, econômicas, políticas, culturais e ideológicas" para seu reconhecimento e cumprimento por parte do público destinatário daquela ordenação, em última instância, para sua própria executabilidade jurídica (FARIA, 2004, p. 124). Nesse sentido, a própria “ordem monetária" se traduz num complexo de relações sociais lastreadas na existência de determinado padrão monetário, cuja ordenação jurídica resulta observada, sobretudo consensualmente, pelo corpo socioeconômico (CORTEZ, 2004, p. 125) ${ }^{116}$.

A despeito de a liquidez caracterizar o dinheiro por sua utilidade, e pois justificar sua não neutralidade ao estabelecer um piso para o valor do investimento a partir da taxa de juro monetária, o próprio KEYNES (2012, p. 214 e s.) reconhece a insuficiência teórica desse elemento. Como anteriormente esboçado, a liquidez do dinheiro por si só não explica a razão de ser o dinheiro em si líquido nem de ser sua taxa de juro a mais relevante na economia. Essa explicação buscará KEYNES no fato de ser a moeda o padrão de valor no qual normalmente se denominam os contratos e os salários. A despeito da função de reserva monetária enquanto acervo de poder geral de compra, o dinheiro é sobretudo o ativo cuja entrega ou transmissão sanciona os preços contratuais, garantindo a liquidação das obrigações resultantes.

Desse modo, a existência de contratos lavrados em termos monetários constitui elemento essencial do fenômeno monetário, e em particular as instituições do mercado financeiro onde ocorrem de fato a transmissão e os pagamentos à vista e a prazo relativos aos contratos (COSTA, 1999). A situação de liquidez do sujeito econômico se traduz sobretudo no poder de dispor dos meios financeiros necessários para o adimplemento de todas as suas obrigações contratuais em seus respectivos vencimentos (DE CHIARA,

115 Fundamento assaz destacado anteriormente por MISES (2005).

116 A respeito do entendimento jurídico e institucional do sistema monetário, vide novamente o articulado na Seção I deste trabalho. 
1986).

Com efeito, sendo o dinheiro de curso legal o único instrumento jurídico dotado de poder liberatório, representando a liquidez por excelência (KEYNES, 2012), qualquer outra reserva de valor que não seja moeda restrita (dinheiro de curso legal e depósitos bancários à vista), somente gozará de liquidez na medida em que possa ser negociada em troca dessa moeda, em última instância, no âmbito de um "mercado instantâneo" que lhe confira liquidez negocial imediata. Desse modo, um ativo líquido é antes um bem negociável em mercados permanentes e bem organizados, "o que depende das práticas e instituições sociais da economia” (COSTA, 1999, p. 47).

Segundo COSTA (1999, p. 47), “o fator mais importante dos mercados bemorganizados é a instituição de um regulador de mercado (market-maker)". A função econômica desse regulador reside fundamentalmente na sua atuação negocial de modo residual, ordenando os mercados a partir de sua posição como contraparte residual na compra e venda dos ativos financeiros, visando à estabilidade das cotações. Detentor de estoques consideráveis dos diversos ativos líquidos, em princípio, faz frente às flutuações de preços por meio da utilização desses fundos em negócios naqueles mercados. Justamente essa demanda de reservas por parte do regulador de mercado é o que ordena a escala de rigidez dos preços instantâneos dos ativos negociáveis ao longo do tempo.

O regulador desses mercados financeiros é essencialmente a autoridade monetária, ou seja, o banco central. Essa instituição mantém a continuidade e a ordem de tais mercados instantâneos a partir de sua atuação como prestamista de última instância, garantidor perene da liquidez dos ativos ali negociados. A sociedade se fia, portanto, na ordem jurídica para continuar denominando as obrigações contratuais no padrão monetário, utilizando o dinheiro do sistema monetário vigente (CORTEZ, 2004). Nesse sentido, a liquidez de uma economia monetária lucrativa, cuja atividade produtiva se organize por meio do instituto contratual a prazo em termos monetários, assenta fundamentalmente nas decisões e atividades dos bancos centrais (COSTA, 1999).

Ao contrário das razões institucionais que asseguram a inelasticidade da oferta monetária, em regra legalmente garantida pelo monopólio de emissão (LIMA, 1997; KEYNES, 2012), essa garantia institucional resulta sobretudo da atuação da autoridade estatal junto ao mercado monetário de ativos líquidos, garantindo-lhes a liquidez instantânea, e pois a já referida "moedicidade".

De fato, como se verá adiante, a flagrante evolução das técnicas inovadoras do 
mercado financeiro trouxe consigo um inevitável deslocamento da oferta monetária centralizada para a oferta bancária de quase-moedas, ou seja, produtos financeiros novos resultantes da administração dos passivos pelo sistema bancário, muitas vezes não regulamentados, e pois não submetidos às exigências de reservas da autoridade central.

Desse modo, numa economia monetária e creditícia, os ativos plenamente líquidos, enquanto substitutos socialmente reconhecidos do dinheiro de curso legal, resultam sobretudo das negociações realizadas em mercados organizados e instantâneos, presididos pela atuação imediata de um regulador institucional de mercado, em princípio um banco central, que garanta a estabilidade dos preços desses ativos financeiros (COSTA, 1999).

\section{0 sistema de crédito}

Ressalte-se novamente que o sistema monetário, em razão das características de atuação institucional dos mercados financeiros, onde se negociam ativos como o dinheiro e seus substitutos ${ }^{117}$, se revela basicamente pela atuação do banco central em conjunto com o sistema bancário, cuja importância reside fundamentalmente na administração do sistema geral de crédito, essencial à economia capitalista.

Frise-se, inicialmente, que o crédito não desempenha, em regra, a função de padrão de valor, mas participa, em diferentes graus, das demais funções monetárias. A despeito de não oferecer a seu beneficiário liquidez plena, não se deve olvidar de que o próprio mecanismo do crédito bancário faz nascer a chamada moeda escritural, em si multiplicadora de liquidez.

O crédito se qualifica precipuamente por incorporar ao universo das trocas econômicas bens a serem produzidos, rendimentos a serem obtidos e serviços a serem prestados no futuro (VIDIGAL, 1977). A operação de crédito consiste assim na "disposição efetiva e imediata de um bem econômico, em vista de uma contraprestação futura" (GUDIN, 1976, p. 55).

Não obstante o crédito configure juridicamente um direito realizável no futuro, uma vez concretizado, tem valor atual, por isso é permutável, implica poder aquisitivo, como a moeda ou dinheiro (NOGUEIRA, 1936, p. 382). Dessarte, seu gozo confere ao

117 Na lição de VIDIGAL (1977, p. 193), as operações financeiras são aquelas em que as contrapartes se obrigam a realizar prestação em moeda ou crédito, diferenciando-se das operações de cunho comercial, cujo objeto da prestação encerra mercadorias ou serviços. As obrigações, portanto, se classificam entre comerciais ou financeiras conforme o tipo de operação que as origine. 
beneficiário do crédito um poder de compra atual, ou seja, um comando genérico sobre os bens e serviços em circulação, realizando, em última instância, todas as operações essenciais do capital (NOGUEIRA, 1936; SCHUMPETER, 1982; VIDIGAL, 1977).

Considerando que a demanda efetiva global se relaciona objetivamente ao poder aquisitivo, essa procura oscilará em extensão no mesmo sentido das flutuações do crédito, cuja disciplina ou ordenação no seio do sistema monetário "pode influir decisivamente na determinação do processo de ajuste entre oferta e procura globais" (VIDIGAL, 1977, p. 193).

Nesse sentido, aliás, enquanto a quantidade de uma moeda mercadoria, tal como no padrão ouro, é "disciplinada" pela disponibilidade dessa mesma mercadoria, cabe ao sistema monetário o controle efetivo (institucional) da quantidade de crédito (MAYER, 1993). Portanto, “a disciplina quantitativa do crédito precisa implantar-se de forma a adaptar, no nível desejado, oferta e procura globais" (VIDIGAL, 1977, p. 194). Paralelamente a essa disciplina quantitativa, há ainda uma disciplina seletiva do crédito, resultado da arbitragem entre múltiplas pretensões econômicas ao crédito.

Retomando o exame da economia monetária de produção, pode-se afirmar que as forças produtivas especificamente capitalistas assentam basicamente na subsunção real do fator trabalho ao domínio do capital (MARX, 1984) e na concentração do capital financeiro (dinheiro e seus substitutos) no sistema de crédito (SCHUMPETER, 1982). Na lição de BELLUZZO (2013, p. 93), "são as variações nos gastos que determinam as variações na massa de lucros e na massa de salários, dado o grau de monopólio, uma proxy da taxa de exploração". Analogamente a essa visão de viés marxista, derivada da ideia central de que o monopólio dos bens de produção e o controle do sistema creditício (bancário) se encontram sob o domínio da classe capitalista, o princípio da demanda efetiva (KEYNES, 2012) também se encaminha, como anteriormente esboçado, no sentido de que o investimento e o crédito são as variáveis independentes que determinam a renda nominal (monetária), e pois "a distribuição do valor criado pelo gasto na produção de bens de consumo e bens de produção entre lucros e salários” (BELLUZZO, 2013, p. 94).

Nesse sentido, a economia monetária produtiva, ou capitalista, reflete grande concentração de capital fixo e dominância do sistema de intermediação bancária, cuja dinâmica de longo prazo se funda no aumento da produtividade marginal, ou social (MARX, 1984), do trabalho, fomentando simultaneamente a competição pela inovação tecnológica incorporada nos próprios fatores de produção (BELLUZZO, 2013). Essa 
elevada capacidade acumulativa (elasticidade de alocação) resulta sobretudo do sistema de crédito bancário, na medida em que esse sistema não só financia como participa dos empreendimentos empresariais, diversificando os riscos mediante a administração de seus passivos (bancários), ou seja, os depósitos escriturados, sob um regime monetário cuja estabilidade reside, em última instância, na fiança institucional de liquidez por meio da atuação da autoridade monetária (banco central).

Desse modo, "o sistema de crédito acelera as leis de movimento do regime do capital e governa o processo permanentemente inacabado de nivelamento da taxa de lucro sobre o qual repousa toda a produção capitalista" (BELLUZZO, 2013, p. 96) ${ }^{118}$.

\section{A intermediação financeira}

A etimologia do vocábulo "banco" muito diz de sua natureza e função. De um lado, primitivamente, o comércio cambiário, sobretudo nas feiras medievais das cidades italianas, era levado a cabo nas praças e mercados públicos e se operava sobre bancos (mochos) ou mostradores, donde se generalizou a referida expressão, seguindo sua natural evolução mercantil. Por outro lado, há quem derive a expressão não do vocábulo italiano banco (mocho), mas de outro, a saber, monte (acumulação, amontoação) (NOGUEIRA, 1936).

Narra-se que a cidade de Veneza, em 1171, em estado de beligerância contra o império romano, e pois para fazer frente à desordem financeira em que se encontrava, ordenou através de seu Conselho um empréstimo forçado de $1 \%$ a.a. sobre todos os cidadãos sob a promessa de um prêmio de $5 \%$ a.a. A esse empréstimo se denominou monte. Ainda naquele tempo, sob o domínio germânico, a palavra alemã bank também se empregava no sentido de monte, tendo sido italianizada em banco, de forma que os empréstimos ou dívidas públicas passaram a se chamar indiferentemente de monti ou banchi. No intuito de gerir essa dívida pública, o pagamento de juros e a transferência do respectivo fundo foram nomeados comissários. O Estado veneziano procedeu então à arrecadação do empréstimo compulsório, dando em troca a cada um dos contribuintes o chamado credito (certificados de depósito), passíveis de transmissão a terceiros. Essas transferências constituíam fundamentalmente negócios bancários, nominando-se

118 De certa forma, ao engendrar a concentração tanto das escalas produtivas como do capital, o sistema de crédito acarreta a promoção do poder de decisão e de influência do sistema bancário e, em última instância, do próprio sistema monetário, pois "o controle da riqueza sob a forma líquida reforça o poder do capital em geral sobre a força de trabalho e engendra consequências de natureza política" (BELLUZZO, 2013, p. 97). 
"banqueiros" aqueles que comerciavam com esses papeis, na medida em que compravam moeda de sua clientela e, em troca, lhe dava crédito, suscetível de transferência (NOGUEIRA $\left.^{119}, 1936\right)$.

Com efeito, os depósitos bancários podem ser considerados como uma espécie de estação geradora, ou de abastecimento, dos certificados emitidos, em última instância, dos cheques ou ordens de pagamento, tal como os cartões bancários de débito em conta corrente. Desse modo, a moeda bancária (escritural) não é criada pelo público depositante, mas antes pelos banqueiros, "quando concedem aos portadores de talões de cheque o direito de emiti-los". Ressalte-se ainda que a relação entre o volume total de depósitos e o volume total de meios de pagamento, a exemplo dos cheques, em determinado período traduz particularmente a "relação entre a quantidade de dinheiro existente e a quantidade de dinheiro que se torna disponível durante certo período" (ROBERTSON, 1969, p. 41).

Certamente, a economia consuntivo-produtiva pode empreender suas operações negociais sem intermediários, inclusive para as operações de crédito. Porém, os bancos contribuem prodigiosamente para o alargamento do crédito, formando centros apropriados para onde afluem a oferta e a demanda por capital, o que caracteriza o banco como "a instituição economica que tem por objecto o commercio de dinheiro", ou seja, "actos de mediação com fito de lucro para receber ou fornecer dinheiro" (NOGUEIRA, 1936, p. 409).

Como visto anteriormente, a propósito das notas de banco, a evolução do sistema bancário permitiu que se emprestasse não mais a moeda metálica (lastro) dos depósitos, mas as notas emitidas pelos próprios bancos. Esse foi o primeiro passo na organização do crédito bancário. Apercebendo-se de que as notas conversíveis em metal não eram, em geral, apresentadas para conversão pelos seus portadores, senão que permaneciam em circulação, compreenderam os banqueiros que poderiam conceder novos empréstimos, sob a forma de notas de banco, ou seja, moeda fiduciária, na certeza de que uma reserva metálica relativamente pequena seria suficiente para atender à demanda de seus clientes por conversão da moeda emitida (GUDIN, 1976).

Com efeito. Quando o prolongado domínio da moeda mercadoria (padrão-ouro) chegou ao fim, a partir da década de 1930, introduziu-se um sistema monetário bem mais flexível, baseado na moeda de crédito, que se tornou rapidamente o pilar da economia 
produtiva contemporânea. Liberada de seu limite metálico, a emissão de moeda, seja o papel-moeda estatal, seja a moeda bancária, sob a forma de operações de depósitos, cujo direito de saque se exerce através de ordens de pagamento, já estava a moeda intimamente relacionada à extensão do crédito no sistema bancário. Por meio do fracionamento da reserva bancária, os bancos comerciais passaram a captar depósitos do público, reservando uma parcela (reserva obrigatória) para fazer frente a retiradas, e emprestando o restante (reservas excedentes). Essa operações de empréstimo criavam dinheiro novo, sob a forma de novos depósitos em favor dos mutuários. Ademais, o Estado, em regra por meio de um banco central, provia liquidez aos bancos por meio do fornecimento de moeda fiduciária, garantida pelas reservas dos próprios bancos, para atender à procura do público por numerário. Esse vínculo entre criação monetária e extensão creditícia acabou por transformar a moeda mesma numa espécie de capital financeiro, ou simplesmente capital de empréstimo (a juros definidos pelos bancos comerciais). A transformação da moeda mercadoria (ouro) em relação obrigacional, creditícia, resultou na possibilidade de uma oferta elástica de moeda, podendo sempre atender às necessidades dos atores econômicos, sob a forma de liquidez e recursos (GUTTMANN, 1998).

Sob o prisma da técnica bancária, suponha-se que alguém levante um empréstimo num banco, no valor de dez mil reais. Esse fato jurídico se traduz contabilmente pelo fato de o banco registrar esse empréstimo como um depósito de mesmo valor. Em seu balanço, no passivo, os depósitos aparecerão aumentados de dez mil reais e, no ativo, a rubrica “empréstimos ao público" também. Portanto, o empréstimo criou depósito.

Não obstante, se o mesmo mutuário saca uma ordem de pagamento, tal como o cheque, em favor de um terceiro, seu credor, e esse último não sendo cliente do mesmo banco onde se levantou o empréstimo original, depositar aquele cheque em um segundo banco, nos livros desse segundo banco aparecerão os mesmos dez mil reais. Essa sequência pode se repetir, como de fato sói ocorrer, em larga medida, criando assim novos depósitos em diversos outros bancos no total de dez mil reais, em substituição ao depósito do primeiro cheque.

Observa-se então que sempre haverá um depósito correspondente nos livros de um ou outro banco, enquanto o mútuo original não tiver sido resgatado. Donde segue que um empréstimo concedido por um banco dá lugar a um depósito no sistema bancário como um todo, e pois esse depósito se extinguirá apenas quando o mútuo original for resgatado. Forma-se, assim, uma cadeia de empréstimos concedidos e depósitos efetuados pelo 
sistema bancário.

$\mathrm{O}$ encontro de contas entre os bancos, pelas ordens de pagamento sacadas e recebidas, ocorre normalmente nas chamadas câmaras de compensação, em que somente os saldos finais de todos os créditos e débitos originam pagamento em moeda corrente. Porém, havendo em regra um banco central onde todos os bancos mantêm contas correntes, ou de reserva, os pagamentos interbancários se liquidarão contra essas reservas bancárias centrais (GUDIN, 1976).

É mister que se observe, no entanto, que por meio desse mecanismo o banco comercial disponibiliza a seu cliente um dinheiro que resulta de um empréstimo a juros, criando assim uma dívida ilíquida de responsabilidade do cliente. Por meio desse mecanismo, portanto, não pode o banco por si mesmo emitir moeda, criando dinheiro, mas antes necessita tomar em empréstimo suas reservas de pagamento junto ao banco central, e pois contraindo também uma dívida a juros e ilíquida. À risca, essa obrigação não será liquidada, mas simplesmente renovada por meio de empréstimos subsequentes (HUBER, 2011).

De modo análogo, quando um banco emprega recursos disponíveis na aquisição de títulos para seu ativo, esse negócio se liquidará por meio de um pagamento que importa, em última instância, um crédito em favor do alienante daqueles títulos. Em consequência, no balanço haverá um ativo amentado do valor dos títulos adquiridos e um passivo aumentado desse mesmo valor. Desse modo, não só os empréstimos concedidos como também os investimentos realizados pelos bancos dão lugar à criação de depósitos, ou seja, moeda escritural (GUDIN, 1976).

Ressalte-se ainda que a operação conjunta do sistema bancário nas operações de empréstimos e investimentos não se limita à modificação da composição dos meios de pagamento, ao trocarem moeda corrente por moeda escritural, e vice-versa, mas sobretudo aumentam os meios de pagamento, criando moeda escritural em valor superior à moeda corrente que retiram de circulação (multiplicador bancário ou monetário).

Cai assim por terra o modelo dos "fundos existentes para empréstimos", cujo argumento básico reside na assertiva de que os bancos agem por conta de seus depositantes, poupadores, atribuindo a esses últimos uma influência sobre a oferta de crédito que absolutamente não possuem. Na lição de SCHUMPETER (1964a, p. 392):

Dos bancos não se diz mais que "emprestam seus depósitos" ou "o dinheiro alheio", mas que "criam" depósitos ou notas de banco: surgem 
como para fabricar dinheiro menos que para aumentar sua velocidade ou, o que é descabido, agir em nome de seus depositantes.

Desse modo, ao emprestar dinheiro, geram os bancos novos depósitos, tendo em vista o sistema bancário em seu conjunto. É justamente a moeda escritural, ao estabelecer uma íntima relação entre a moeda e o crédito, o elemento que sintetiza o momento das relações sociais em que o fluxo monetário, materializado nos depósitos bancários, instrumenta a multiplicação de trocas sociais, sob a égide dos mecanismos de crédito, permitindo assim a ampliação de toda a atividade econômica (DE CHIARA, 1977).

Sem embargo, essa dinâmica do mecanismo de multiplicador monetário encontra seu limite nas exigências da autoridade monetária de manutenção de depósitos compulsórios em relação a certa parcela dos depósitos à vista lançados a débito nos livros dos bancos comerciais. Com efeito, "a descontrolada criação de moeda escritural é um substancial estímulo inflacionário, e para os depositantes, de maneira particular" (DE CHIARA, 1977, p. 145).

Finalmente, como ressalta COSTA (1999, p. 43), "o multiplicador monetário depende de relações de comportamentos dos bancos e do público não-bancário", ou seja, da preferência do público quanto à espécie de moeda restrita de que fará uso em seus negócios (moeda corrente ou moeda escritural), portanto, do nível de uso (acesso) ao sistema bancário, e ainda do grau de confiança depositado nos bancos, que determinará, em última instância, o montante de reservas voluntárias (encaixe) que os próprios bancos proverão em cobertura de seus passivos.

Não se há de olvidar que a interação entre o sistema bancário e o público (investidor ou mutuário) ocorre basicamente sob a supervisão da autoridade monetária, a qual determina o nível de exigências de reserva bancária compulsória. Os empréstimos, por sua vez, são objeto de contratos privados, cujas vontades subjacentes são sempre conjunturalmente reavaliadas.

Nesse sentido, os contratos de empréstimo não se celebram apenas em função do diferencial entre a taxa de juros de captação (de clientes) por parte dos bancos e a taxa de juros das aplicações financeiras oferecidas pelos bancos, mas também em razão da expectativa do banco credor em relação ao grau de fragilidade financeira do devedor e das garantias ofertadas por esse último. Ademais, os próprios bancos são grandes investidores nos diversos mercados financeiros, exigindo portanto avaliações comparativas entre as possíveis receitas de operações de crédito e as rendas e lucros a serem auferidos a partir da 
aquisição de títulos e valores mobiliários (COSTA, 1999).

$\mathrm{O}$ estoque de moeda fiduciária, restrita à que normalmente serve de meio de pagamento, se traduz basicamente em papel-moeda em poder do público, criado pelo autoridade monetária, e em moeda escritural (depósitos à vista), criada pelos bancos. Do ponto de vista contábil, a moeda fiduciária nada mais é do que um débito do sistema monetário emissor para com o público (detentor de moeda), portanto, um crédito desse último contra aquele. Esses débitos das entidades emissoras, em razão da confiança da coletividade e da comodidade trazida pelos meios de pagamento (moeda corrente ou direitos de saque), em regra são utilizados nos negócios entre as unidades do restante da economia, transferindo-se de uma para outra unidade sem que se altere o débito total das entidades emissoras. Em última instância, a moeda restrita (dinheiro) traduz fundamentalmente uma relação de débito e crédito entre o sistema monetário e o resto da economia (GUDIN, 1976).

Esclareça-se, porém, que há outras espécies de depósitos bancários que também geram "agregados monetários" a partir da consolidação contábil do sistema emissor, portanto parte do débito em relação à sociedade, como sejam os depósitos de poupança, os depósitos a prazo, bem como os investimentos em títulos que também geram depósitos e se traduzem em documentos de dívida, tanto privada (p. ex., participações em fundos mútuos de investimento) como pública (apólices do Tesouro).

Internacionalmente, no entanto, apenas a moeda restrita (meio de pagamento) é de modo geral considerada como agregado contábil, havendo divergências quanto à conformação dos demais débitos consolidados (agregados monetários) (HUBER, 2011). No que tange à "moedicidade" desses débitos, repita-se, não se pode dizer com certeza o que configura dinheiro, pois há inúmeras definições e modelos, portanto, considerável arbitrariedade de critérios (TOBIN, 1989). Não obstante, consentâneo com a ideia do multiplicador bancário, e pois de que os banqueiros aumentam a quantidade de moeda restrita ou desses outros meios de pagamento que, em certa medida, "servem tão bem como dinheiro se se deseja reservar esse termo para moeda ou para o papel-moeda ou papel ou títulos do governo" (SCHUMPETER, 1964a, p. 392). Em última instância, a realidade da economia provoca nos credores dessas obrigações o sentimento de que dispõem de meios líquidos adicionais que são normalmente tão apropriados como o dinheiro.

Com efeito. Em termos jurídicos, boa parte das riquezas nacionais são apropriáveis, tanto pelos entes públicos como pelas pessoas físicas ou jurídicas de direito 
privado. Essa riqueza nacional, traduzida em ativos (bens), pode ser inventariada sem que muitas dessas pessoas possua esses ativos de modo tangível em seus acervos patrimoniais, desde que representados por moeda, depósitos bancários, direitos de participação (ações ou fundos de investimento, ou de pensão), debêntures, títulos de crédito, obrigações do Tesouro, opções e derivativos financeiros etc. Em termos de agregado contábil, excluída a participação governamental entre esses proprietários, tem-se a riqueza privada líquida. Essa riqueza privada líquida consiste basicamente em bens da riqueza nacional, em sua maior parte tangíveis, além de obrigações do Tesouro. A partir da noção anterior de obrigações bancárias consolidadas, portanto, de relações obrigacionais entre os sistema emissor e o público, pode-se dizer que essa riqueza privada líquida não se encontra na posse direta das pessoas jurídicas de direito privado, mas sim por meio de uma rede complexa de obrigações de dívida e pretensões. Aqueles bens podem ser chamados de ativos externos, pertencentes ao setor real da economia, enquanto esse complexo obrigacional que os espelha, de ativos internos (TOBIN, 1989).

Esses ativos internos se dividem basicamente em dívida pecuniária pública (obrigações do Tesouro e passivo da autoridade monetária - moeda de curso legal ou forçado, e reservas depositadas pelos bancos comerciais junto ao banco central) e demais obrigações privadas. Há autores que traduzem esses ativos na forma de moeda, constituindo as obrigações governamentais "moeda externa" (à economia privada) e o restante "moeda interna" (dívida interna, em foram de depósitos nos bancos comerciais) (MAYER, 1993; TOBIN, 1989) ${ }^{120}$.

Frise-se, porém, que esse complexo obrigacional - basicamente títulos e certificados de depósitos (ativo e passivo) -, que circula no âmbito do sistema monetário, tem, ou antes deveria ter, uma contrapartida (real) no chamado dividendo ou produto nacional.

Não obstante, não é o que sói ocorrer no mundo bancário contemporâneo, particularmente a partir da década de 1970, com o surgimento de mecanismos inventivos no setor financeiro, traduzidos basicamente em instrumentos financeiros, geralmente sucedâneos de moeda restrita, construídos a partir de modelos de administração de riscos (YAZBEK, 2009).

Essas "inovações financeiras" nada mais são que contratos financeiros, em regra

120 À moeda externa também se denomina de "moeda de alto poder de expansão" ou simplesmente "base monetária" (COSTA, 1999, p. 43). À moeda interna, "moeda de baixo poder de expansão" (TOBIN, 1989, p. 159). 
títulos e valores mobiliários ("produtos financeiros"), cuja conversão de documentos de dívida que fazem jus ao pagamento de juros em títulos transmissíveis por meio de saques (ordens de pagamento) ocorre a custos e prazos praticamente desprezíveis sob o prisma econômico. Não estando normalmente sujeitos a regulamentações específicas, esses instrumentos não se prestam somente à administração de riscos patrimoniais dos clientes bancários, muitas vezes resultantes do descasamento temporal de capitais necessários a, ou rendas de determinados processos produtivo-consuntivos, mas sobretudo à administração dos passivos bancários, não raro fruto de conluio entre tesourarias bancárias e de clientes, facultando aos bancos a possibilidade de acomodação das oscilações resultantes da procura por crédito face ao custo da assistência financeira de liquidez pela autoridade monetária, em regra elevado, e pois também se furtando a possíveis restrições regulamentares decorrentes de exigências de provisões extraordinárias de capital que comprometem a confecção regular de seus balanços contábeis (COSTA, 1999; HUBER, 2011).

De fato, o acentuado desenvolvimento das técnicas financeiras, como sejam os modelos de precificação de contratos de opções e o instrumental matemático aplicado à avaliação de riscos, bem como da tecnologia de processamento de dados (informação) forneceu o substrato material adaptativo, e pois criativo à conjuntura econômica em mutação a partir dos anos 1970, a saber, a crise do regime monetário internacional, construído em 1944, a partir do acordo de Bretton Woods (YAZBEK, 2009).

O sistema monetário inaugurado pelo referido acordo se baseava no lastro monetário internacional da moeda estadunidense (dólar), cujo preço se fixava em base do metal ouro, em última instância, um padrão ouro mitigado, cuja caixa de conversão residia nas reservas federais americanas (EICHENGREEN, 2000). Esse padrão, a despeito de problemas de rigidez nas políticas econômicas e das especulações do mercado de ouro, o que resultou finalmente no abandono da taxa de câmbio especial acordada, praticamente assegurou a estabilidade do intercâmbio comercial entre as nações ao longo de quatro décadas (SOLOMON, 2001).

Com efeito. O regime monetário acordado basicamente assentava na obrigatoriedade de fixação de uma paridade entre as moedas nacionais e o dólar americano, por parte dos membros do então criado Fundo Monetário Internacional, e pois a manutenção de taxas de câmbio oscilando no limite de um por cento em torno da paridade estabelecida. Quaisquer alterações na paridade dependiam da aprovação daquele Fundo. Não obstante, não havia regras preestabelecidas quanto à oportunidade em que se poderiam 
dar as variações das taxas de câmbio. Ademais, o acordo em si não proporcionava instrumentos que garantissem o incremento das reservas nacionais numa economia mundial ascendente. Sobretudo a partir da década de 1960, verificou-se considerável crescimento no fluxo internacional do capital em razão do acúmulo de diferenciais entre produtividade e inflação, em particular a favor dos países industrializados (Europa ocidental e Japão) e dos exportadores de petróleo, resultando num extraordinário incremento dos recursos externos em dólar, portanto em detrimento da balança de pagamentos dos Estados Unidos. A constrição do padrão ouro interno autoimposta à economia norte-americana, aliada à pressão deficitária em relação às reservas acumuladas pelos países superavitários (em torno de sete vezes o valor das reservas em ouro mantidas pelo Tesouro americano), e ainda a ameaça de conversão forçada exigida por alguns entes soberanos (p. ex., a França), resultaram naturalmente no rompimento dos termos do acordo, em 1971, por decisão soberana dos EUA, seguindo-se a desvalorização do dólar frente ao ouro e a suspensão da conversibilidade nesse metal ${ }^{121}$ (ESTRELA, 2011; SOLOMON, 2001).

A partir da extinção dessa padronização cambial, o movimento de flutuação cambial ganhou força no contexto econômico mundial, tendo início um período de forte instabilidade. Diante das incertezas crescentes no mercado de câmbio, surgiram "novos riscos para os agentes econômicos envolvidos em relações comerciais e financeiras internacionais" (YAZBEK, 2009). Segundo YAZBEK (2009, p. 62):

Aí, aliás, encontra-se uma das causas dos movimentos de
desregulamentação dos mercados financeiros, uma vez que a
flexibilização das restrições cambiais foi essencial para permitir aos
agentes econômicos com dívidas ou créditos em moeda estrangeira que
procurassem proteção contra o aumento da volatilidade. É lógico que essa

121 Registre-se que a desvalorização da moeda norte-americana representou perda de valor real para seus possuidores e apropriação de ganhos substanciais em "senhoriagem" para seu emissor, na medida em que se reduziu a dívida monetária (externa) norte-americana com o resto da economia mundial. Ressaltese ainda que todo o processo se desenvolveu de modo mais complexo, tendo havido acordos intermediários para a mitigação dos efeitos daquela ruptura, como o Acordo Smithsoniano, de 1971, que estabelecia margens mais amplas de flutuação cambial em relação às margens centrais, e a primeira emenda ao convênio constitutivo do Fundo Monetário Internacional, que permitia a utilização dos Direitos Especiais de Saque, criados em 1969 como moeda fiduciária, para a conversão de reservas internacionais, e ainda o financiamento dos países membros deficitários cujas reservas internacionais se encontrassem sob ameaça de escassez para fazer frente aos pagamentos correntes. A livre flutuação foi chancelada apenas em 1973, e as práticas cambiais desde então adotadas, em 1976, pela segunda emenda àquele convênio. Outrossim, tais emendas reforçaram a supervisão do Fundo Monetário sobre as economias nacionais, vez que a condução da política econômica doméstica se torna fundamental para a determinação da taxa cambial num sistema de câmbio flutuante (ESTRELA, 2011; YAZBEK, 2009). 
queda de barreiras está enquadrada também em um movimento ideológico, mas não há como negar, ao menos em um primeiro momento, o seu caráter funcional.

A despeito do desenvolvimento do mercado interbancário de moedas estrangeiras $^{122}$, e do surgimento dos derivativos de câmbio, outros desdobramentos daquelas mudanças econômicas que circunstanciaram o fim do padrão acordado em Bretton Woods se fizeram sentir em outros mercados, tal como o de mercadorias (commodities).

A anteriormente mencionada acumulação de superávits econômicos pelos países europeus e Japão, e ainda pelos países exportadores de petróleo (particularmente inflacionada pela primeira crise do petróleo, em 1974), afetaram de modo geral a formação de preços das mercadorias e os processos produtivos. Por um lado, os substanciais incrementos nos preços petrolíferos inflacionaram os preços dos fatores produtivos e dos produtos acabados. De outro, as reservas ociosas decorrentes do acúmulo de "eurodólares"123 e "petrodólares""124 foram investidas em bancos internacionais, aumentando assim a oferta de crédito para os países cronicamente deficitários, ainda em desenvolvimento. Esses últimos, aliás, em razão tanto dos processos inflacionários que atingiram os fatores produtivos como da excessiva liquidez fomentada pelo farto crédito internacional, se viram envolvidos em fortes crises de dívidas soberanas, sobretudo a partir

122 Como assevera KINDLEBERGER (1989, p. 45 e s.), um dos grandes problemas enfrentados pelas autoridades monetárias no período pós-guerra resultava do significativo aumento do vulto dos negócios cambiais de moeda estrangeira, tendo em vista que vários centros financeiros tiveram grande aumento de liquidez. As grandes empresas multinacionais, entre elas os bancos, passaram a operar de modo abrangente mundo afora. Adicione-se ao aumento real do PIB a elevação nominal do capital mobilizável em razão do processo inflacionário, bem como as facilidades trazidas pelos transportes e comunicações, alargando em muito os horizontes dos participantes do mercado monetário. Observe-se, por exemplo, que uma considerável fuga de capitais de uma importante praça financeira, antes da Segunda Guerra Mundial, girava em torno de cem milhões de dólares ao dia, enquanto que no auge da crises financeiras de 1964, 1967, 1971, 1979 e outras, a drenagem de divisas poderia esvaziar as reservas dos bancos centrais em muitos bilhões de dólares em uma única rodada de negociações. Esse fato remete ainda a outra ordem de ideias, sob os auspícios de GALBRAITH (1988), de que as decisões econômicas fundamentais, quais sejam a poupança e o investimento, se concentram basicamente num pequeno número de empresas, o chamado sistema de planejamento.

123 Assim chamados os dólares acumulados na Europa a partir da reconstrução do pós-guerra, e pois dos investimentos diretos ali realizados e dos crescentes superávits em relação à economia estadunidense, os quais passaram a ser negociados pelos bancos depositários europeus no chamado "euromercado". Esse hábil mecanismo de escrituração permitia aos bancos europeus disporem de dólares depositados nos EUA em favor de seus correntistas internos, atendendo-se assim a diversas demandas, quais sejam a criação de reservas internacionais, em particular para os países ditos comunistas, e a prestação de serviços de investimento a clientes internacionais, desenvolvendo-se ainda um considerável mercado de "eurotítulos" (YAZBEK, 2009; ESTRELA, 2011).

124 Esses dólares eram resultados dos superávits acumulados pelos países exportadores de petróleo e, em regra, também aplicados no "euromercado" acima citado (ESTRELA, 2011). 
da década de 1980, que se fizeram acompanhar de "novas oportunidades, novas necessidades e novos riscos para os mercados financeiros" (YAZBEK, 2009, p. 62).

Observe-se todavia que a esfera financeira, em princípio, se nutre da riqueza produtiva, resultante do investimento, e ainda da mobilização da força de trabalho multiplamente qualificada. Há certamente fortes vínculos entre a esfera consuntivoprodutiva internacional e as finanças, de grande alcance socioeconômico. Os capitais nascem em regra da esfera produtiva e do intercâmbio de bens e serviços, sendo seus rendimentos em seguida submetidos a processos de valorização econômica por meio das aplicações financeiras ou arbitragens entre diversos tipos de ativos. Somente após essa transferência e captação pela esfera financeira é que ocorrem através dos mecanismos técnicos das finanças os processos de valorização, em boa parte fictícios, resultando no incremento artificial dos ativos financeiros (CHESNAIS, 1998) ${ }^{125}$.

Particularmente a partir da década de 1980, de modo geral, a mobilidade internacional de capitais se incrementou quase que exponencialmente. $\mathrm{O}$ aumento da integração econômica e sobretudo financeira gerou, por sua vez, um crescente movimento de interdependência, resultando na disseminação semântica da expressão "globalização", conceito abrangente, assaz indeterminado, abrangendo não apenas os infindáveis tipos de negócios internacionais, além da própria revolução da tecnologia da informação, encurtando todas as distâncias (SOLOMON, 2001), mas também influenciando comportamentos econômicos e sociais (jurídico-institucionais) de modo reflexivo (BELLUZZO, 2013; FARIA, 2004) ${ }^{126}$.

125 Nesse sentido, por exemplo, os contratos de derivativos (títulos ou valores mobiliários), tais como opções, futuros, swaps e outros títulos lastreados em outros tantos substratos de cunho econômicofinanceiro como taxas de juros, câmbio, ações, índices de bolsas até mercadorias (produtos alimentícios e matérias-primas). O sentido original desses contratos financeiros consistia em fixar num termo futuro os preços de compra e venda de determinadas mercadorias, como forma de prevenção contra riscos eventuais. Isso se justifica plenamente para aqueles negócios mercantis suscetíveis a fortes oscilações de preços em razão do tipo de mercadoria negociada, como sejam as safras agrícolas ou as matérias-primas. Tais negócios existem de fato a centenas de anos, mas somente nas últimas décadas se expandiram desmesuradamente, tendo hodiernamente apenas uma pequena fração desses negócios a termo realmente um vínculo com o sistema produtivo e comercial. O restante, em sua grande maioria, se reduzem a contratos de jogo ou aposta em torno de preços futuros (HUBER, 2011, p. 38 e s.).

126 A crise da dívida externa, sobretudo na América Latina, acarretou algumas reformas básicas da política e da estrutura econômicas, reformas essas que se encaminharam no sentido do que John Williamson denominou "consenso de Washington" ("What Washington Means by Policy Reform", in Latin Amerian Adjustment: How much has happened?, Washington: IIE, 1990, pp. 1, 7 apud SOLOMON, 2001, p. 81 e s.). Basicamente constituem as políticas fomentadas pelo Fundo Monetário e Banco Mundial, pelo Executivo norte-americano (em particular, o Federal Reserve - banco central), e os assessores de alto nível, sumariados em dez instrumentos de política econômica: déficits físcais sob controle, prioridade de gastos públicos (corte de subsídios, investimento em educação, saúde e infraestrutura pública), reforma fiscal, taxas de juros, taxas cambiais estimulantes de exportações, política 
Nesse contexto, as restrições institucionais comumente impostas à movimentação de capitais se tornaram praticamente insustentáveis, ocasionando uma liberalização da chamada "conta de capital" como tendência entre os diversos países. Em razão dessa liberalização, o crescimento do afluxo de capitais e sua movimentação através do sistema financeiro internacional, sempre em busca do melhor rendimento e condicionado por patamares de risco, em base de operações de arbitragem e especulação ${ }^{127}$, naturalmente elevou a "volatilidade" dos mercados e do próprio sistema monetário internacional ${ }^{128}$. Assim, alterações nas rentabilidades dos ativos ou simplesmente na percepção de riscos passaram a gerar mudanças bruscas nas próprias posições contratuais, em dependência do tipo de ativo financeiro negociado, prazos de vencimento ou países onde os recursos financeiros se encontram aplicados (COSTA, 1999; ESTRELA, 2011).

A instabilidade assim instalada constituiu fator preponderante no desencadeamento das diversas crises financeiras (cambiais) que se sucederam ao final daquela década e na seguinte (1990), não mais em razão de desequilíbrios estruturais nas contas correntes (balanço de pagamentos), como até meados da década de 1980, mas sobretudo em função das alterações conjunturais, repentinas, nos fluxos da conta de capital. Em decorrência da internacionalização das "carteiras de investimento" e da integração dos sistemas de controle de risco em nível mundial, grandes investidores internacionais, como sejam os fundos de pensão ${ }^{129}$, os fundos de hedge (proteção) ou ainda os fundos soberanos de grandes exportadores de recursos naturais não renováveis (a exemplo do petróleo), passaram a ter em suas mão o poder de decisão quanto à redução

comercial, investimento direto estrangeiro, privatização, desregulamentação e direitos de propriedade, particularmente industrial e intelectual.

127 Sob o prisma do mercado financeiro, atribui-se o termo "arbitragem" à operação que visa à obtenção de lucro a partir de diferenciais entre títulos e moedas negociados em diferentes mercados, portanto interespaciais, enquanto que "especulação" diz respeito a operações lucrativas em razão dos prazos de aplicação, à vista e futuro, portanto intertemporais.

128 Segundo SOLOMON (2001, p. 177), “o resultado foi um aumento de saídas de capital bruto de catorze países industrializados - a maioria de uns para os outros - de cerca de 65 bilhões de dólares por ano em 1975-79 para cerca de 460 bilhões de dólares em 1989”. Em relação aos mercados emergentes, "o fluxo privado total atingiu cerca de 244 bilhões de dólares em 1996", dos quais 30\% em direção à América Latina e 45\% à Ásia, em especial dos chamados fluxos financeiros mobilizados, ou seja, "obrigações internacionais, ações e instrumentos de dívida de curto prazo" (SOLOMON, 2001, p. 184 e s.). Essas obrigações eram emitidas tanto nos mercados dos próprios países emergentes, adquiridas por investidores estrangeiros, como no exterior, sobretudo em Nova York, Tóquio, e no mercado de eurobônus. Os fluxos de ações em carteira se constituíam em emissões de debêntures no exterior por empresas em países em desenvolvimento, recibos de depósitos (instrumentos financeiros apoiados por cartéis contendo ações de empresas estrangeiras) e aquisições de ações locais naqueles países por investidores estrangeiros, em regra por meio de fundos mútuos.

129 Como noticia ESTRELA (2011, p. 49, n. 62), “os valores à disposição dos Pension Funds eram estimados em USD1 Trilhão no início de 2007, sendo USD275 Bilhões investidos na América Latina”. 
global do risco de seus investimentos. Assim, em face de restrições de liquidez num determinado mercado onde se negociavam ativos financeiros de um país considerado “vulnerável”, outros ativos, negociados em outros mercados, também se viam negociados para compensar os riscos daqueles, resultando na chamada "contaminação de carteiras"130. Jargões como "bons fundamentos macroeconômicos, comportamento de manada, irracionalidade dos mercados e incerteza" se tornaram frequentes nas discussões e decisões de política econômica nacional como do setor financeiro internacional (ESTRELA, $2011)^{131}$.

Nesse período, o Fundo Monetário desempenhou papel destacado como fonte de financiamentos de emergência, em especial por meio dos Direitos Especiais de Saque, complementados por financiamentos de infraestrutura aos países em desenvolvimento, levados a cabo pelo Banco Mundial, outro rebento de Bretton Woods. À medida que via aumentada sua importância como prestamista de última instância, experimentava o Fundo Monetário uma significativa obsolescência em termos de regulamentação do sistema monetário internacional, sobretudo em razão das taxas flutuantes de câmbio e da integração expansionista dos mercados financeiros globalizados, e pois em prol de uma maior importância e visibilidade dos bancos centrais dos países mais desenvolvidos (ESTRELA, 2011; SOLOMON, 2001).

Outrossim, a colaborar para a maior influência dos bancos centrais nas decisões econômicas internacionais, cabe mencionar o abandono pela Reserva Federal norte-

130 Através da estratificação dos investimentos em ativos conforme a classe de riscos, a minimização de perdas para determinado estoque de ativos tende a diminuir a exposição da carteira àquele segmento de risco de modo horizontal, afetando as cotações em todos os mercados em que se verifica aquela exposição, deflacionando-os em sequência, daí o termo "contaminação". A crise mexicana, entre 1994 e 1995, foi paradigmática nesse sentido. O então chamado "efeito tequila" fez com que outros países, ditos emergentes, sentissem os efeitos daquela crise na forma de deflação de ativos e desvalorização cambial, resultado do grande refluxo de capital em carteira, facilmente sacado. Na América Latina, Argentina e Brasil foram os mais atingidos, tendo os preços das ações na Argentina despencado em $40 \%$ e as reservas internacionais se reduzido à metade, além de uma "corrida bancária" que culminou na perda de fundos bancários da ordem de $18 \%$ nos primeiros três meses de 1995. No Brasil, os ativos se desvalorizaram praticamente na mesma proporção e as reservas internacionais se reduziram a um quarto.

131 Esse aspecto merece importante ressalva, como adverte CHESNAIS (1998, p. 12 e s.): “A integração internacional dos mercados financeiros nacionais tornou-se possível a partir de sua abertura regulamentar e de sua interligação em tempo real. Mas o efetivo contexto dessa integração decorre, de forma concreta, das decisões tomadas e das operações efetuadas pelos gestores das carteiras mais importantes e mais internacionalizadas. Não é irrelevante a "personificação" (antropomorfismo) dos mercados. Sem dúvida, é isso que permite revelar, ao mesmo tempo, pelo menos três dimensões da ascensão do setor financeiro. A primeira refere-se ao movimento de relativa autonomia da esfera financeira em relação à produção e, sobretudo, em relação à capacidade de intervenção das autoridades monetárias. A segunda tem a ver com o "fetichismo" (ressaltado por Marx e também por Keynes) das formas de valorização do capital de natureza especificamente financeira. A terceira remete ao fato de que são os operadores que delimitam os traços da mundialização financeira e que decidem quais os agentes econômicos, de quais países e para quais tipos de transação, que participarão desta". 
americana (banco central), em 1979, da política monetária direcionada a manter baixas as taxas de juros, a partir da fixação de uma taxa básica, optando-se pelo controle da quantidade de moeda em circulação (agregados monetários), de inspiração monetarista, a partir das ideias de FRIEDMAN (1994). Tendo tal decisão afetado as taxas de juro ao redor do mundo, basicamente em razão de ser o preço universal da moeda de circulação mundial e, portanto, numerário padrão de todas as operações de arbitragem internacionais, só fez aumentar a instabilidade financeira no plano internacional ${ }^{132}$.

Com efeito. Os países latino-americanos passaram por diversas reformas macroeconômicas e estruturais a partir da década de 1980, em decorrência dos procedimentos reestruturação das dívidas soberanas sob a supervisão do Fundo Monetário, debelando-se em grande parte os acentuados processos inflacionários outrora em descontrole. Mencione-se que a taxa de inflação média nesses países caiu vertiginosamente entre 1990 e 1996, a saber, de 400\% para 20,4\%, sobretudo em razão da eliminação da hiperinflação argentina e brasileira. Concomitantemente, os mercados financeiros foram liberalizados, facilitando o afluxo de novos investimentos. Acrescente-se a isso a franca possibilidade de operações de arbitragem com taxas de juros a partir da década de 1990, quando as taxas médias de juros de curto prazo nos sete maiores países industrializados diminuíram a menos da metade entre 1990 e 1996, atingindo a marca de 3,7\% naquele último ano. Assim também as taxas de longo prazo, estratificando-se em 5,8\% em 1996. Esses diferenciais de taxas de juros representaram novos incentivos aos investidores daqueles países, considerando a maior rentabilidade dos títulos negociados nos países em desenvolvimento, portanto, impulsionando a participação dos investimentos em carteira

132 Com efeito, o banco central norte-americano abandonou de modo ostensivo a política (keynesiana) de taxas de juros baixas, resultando numa desaceleração do crescimento da oferta monetária. Essa guinada na política monetária se deve basicamente a dois fatos, um de natureza interna e outro de natureza externa, distintos, mas intimamente correlacionados sob o prisma econômico. O primeiro se deve ao aumento excessivo dos agregados monetários e do crédito, alimentando a inflação interna, o que no entendimento daquele banco central resultara dos esforços direcionados à manutenção artificial de baixas taxas de juros. O segundo, por sua vez, sobretudo em decorrência da elevada inflação interna, se traduzia na ameaça de perda do estatuto de moeda internacional do dólar, cuja desvalorização, em última instância, provocara iniciativas internacionais nesse sentido, como sejam a ideia de uma cesta de divisas proposta pela Organização dos Países Produtores de Petróleo, a iniciativa do Fundo Monetário Internacional de recolher os excedentes em dólar em troca de dos Direitos Especiais de Saque, e ainda a criação do Sistema Monetário Europeu. Ressalte ainda que essa desregulamentação da taxa de juros se reforçou pela progressiva eliminação dos tetos para depósitos bancários e empréstimos, motivada pela constituição dos fundos de investimento, cujos rendimentos não regulamentados e elevada liquidez ocasionaram a retração dos depósitos bancários, regulamentados, de baixa rentabilidade. A despeito da queda dos índices inflacionários no início da década de 1980, a liberalização das taxas de câmbio e de juros, preços estratégicos da moeda, deixando-os à regulação de mercado, impulsionou a instabilidade financeira, repercutindo fortemente nos níveis de desenvolvimento dos Estados Unidos e do restante do mundo (GUTTMANN, 1998). 
por parte dos grandes investidores institucionais organizados em dezenas de fundos mútuos de mercados emergentes ao longo daquela década (SOLOMON, 2001) ${ }^{133}$.

Não obstante os fatos anteriormente narrados, e a despeito da aparente oposição entre o processo produtivo, baseado em ativos reais geradores de rendimentos, e o circuito de capital financeiro, baseado no crédito e em carteira de ativos, resultando também numa distribuição de rendas, é mister se frisar novamente que ambas as formas de capital implicam dispêndios imediatos na expectativa de se obter em retorno excedentes financeiros (dinheiro), seja sob a forma de lucro tradicional (capital produtivo), seja sob a forma de juros, dividendos ou ganhos de capital (capital financeiro). Essa é a dinâmica inerente à contemporânea economia lucrativa, ou economia monetária de produção, na acepção keynesiana.

Na economia monetária produtiva, os haveres monetários (exceto o papel-moeda em poder do público), ou seja, a moeda de crédito (bancária), não importa quem a detenha, permanece sempre em circulação no âmbito do sistema bancário, não sendo retida ociosamente além do necessário para atendimento às reservas compulsórias. Não há entesouramento no sentido de uma economia de trocas estrita, por meio de uma moeda mercadoria ou padrão numerário (WALRAS, 1983), e pois na ausência de um sistema

133 Em 1988, por meio de uma resolução do Conselho Monetário Nacional (CMN), sob influência do Banco Mundial, realizou-se no Brasil uma grande reforma do sistema bancário, eliminando-se a exigência legal de compartimentação das áreas específicas de atuação para cada tipo de instituição financeira, facultando assim a criação dos bancos múltiplos, além da extinção das cartas-patentes, e pois liberalizando o setor bancário - somente naquele ano foram criados 138 novos bancos. Com o processo de estabilização monetária, a partir do Plano Real (1994), muitos dos bancos existentes se viram ameaçados diante das exigências de reservas compulsórias, da inadimplência de clientes, e particularmente da queda de receitas com float (passivos não remunerados que se aplicavam a juros e correção monetária no mercado aberto). Não obstante, importante segmento do sistema bancário nacional se beneficiou das inovações financeiras internacionais e da arbitragem com taxas de juros para manter a rentabilidade patrimonial histórica. Isso se deu por meio da captação externa (eurobônus e commercial papers) e outras formas de securitização de passivos obrigacionais, eliminando de seus balanços aqueles passivos, diminuindo assim as exigências de capital impostas pelo Banco Central do Brasil, em especial a partir da adesão ao Acordo da Basileia (Resolução CMN no 2.099, de 1994), e suprindo ainda a demanda de crédito, sem as restrições dos depósitos compulsórios. A despeito das provisões suplementares para créditos de liquidação arriscada, em face daquele diferencial entre as taxas de captação no exterior e as de aplicação no mercado doméstico, um elevado lucro passou a ser auferido pelos bancos brasileiros. Esse movimento, contudo, foi levado a cabo pelos grandes grupos bancários nacionais, vez que se estima uma perda total para o sistema bancário equivalente a USD10 bilhões com o fim do ganho inflacionário gerado pelas operações de floating, tendo atingido fortemente a grande maioria dos chamados "pequenos bancos". A crise bancária que se seguiu à estabilização monetária levou a uma série de operações de resgate e assistência de liquidez por parte de Banco Central do Brasil, culminando em liquidações e falências bancárias, além de incentivos ao aumento da concentração bancária desde então, tendo em vista que muitos dos pequenos bancos, entre eles os criados a partir daquela liberalização, outrora apenas corretoras e financeiras, e ainda os bancos criados por grupos empresariais não financeiros, não tinham mais condições de se financiar no mercado interbancário por meio de operações diárias de tesouraria, de modo a aumentarem suas reservas de investimento para aplicação em títulos financeiros, resultando assim em acentuada perda das fontes de financiamento (COSTA, 1999; ESTRELA, 2011). 
bancário.

Recorde-se a propósito o ensinamento de SCHUMPETER (1982), anteriormente citado, corroborado ainda por TOBIN (1989, p. 164), de que a figura do banqueiro surge não como intermediária de poder de compra, mas sobretudo como produtora dessa mercadoria. Hodiernamente toda a poupança e fundos de reserva afluem para os bancos, neles se concentrando a procura por poder aquisitivo livre, já existente ou a ser criado, substituindo assim o banqueiro aos capitalistas privados ou se tornando seu agente, tendo ele próprio se tornado o capitalista por excelência. Abstraindo-se de qualquer autoridade central dirigente do processo social, assumem os bancos essa função enquanto agentes do desenvolvimento, como que autorizando às pessoas, em nome da sociedade capitalista, ao exercício da atividade empreendedora, sendo "o éforo da economia de trocas" (SCHUMPETER, 1982, p. 53).

A retenção de moeda (dinheiro e seus substitutos) em forma líquida (preferência pela liquidez), no presente sistema capitalista, se traduz sobretudo na detenção de direitos de crédito sobre o sistema monetário ${ }^{134}$. Os passivos bancários que espelham esses direitos creditórios são de forma direta ou indireta como que "ativados" pelo sistema bancário onde se armazenam. Ao transitarem pelo sistema bancário, a emissão de títulos de dívida, pública ou privada, se compõem em regra por títulos integralmente subscritos, tanto diretamente pelo público como por intermediação do próprio setor bancário. Do ponto de vista da demanda efetiva, isso significa que a oferta efetivamente contratada de dinheiro resulta da demanda por lançamento de títulos de dívida, ou por obtenção de crédito, em razão de decisões anteriores de gastos por parte do público (COSTA, 1999).

Desse modo, o sistema bancário detém permanentemente um passivo monetário em lastro de seus ativos, os quais se encontram em circulação consuntivo-produtiva, nas carteiras de empréstimos contratados para fins negociais (p. ex., capital de giro das empresas), ou em circulação financeira, nas carteiras de títulos adquiridos em aplicação dos encaixes ociosos (poupança, para a teoria econômica clássica) retidos pelos clientes bancários, tanto por motivo de precaução (expectativa de alteração da taxa de juros) quanto por motivo especulativo (expectativa de alteração da taxa de juros em determinado sentido). Essa demanda por liquidez para especulação assenta fundamentalmente na necessidade de encaixes disponíveis, temporariamente, para uso em operações de 
arbitragem com títulos, é dizer, no aguardo de diferenciais de juros entre os títulos $(\operatorname{COSTA}, 1999)^{135}$.

135 Essa questão remete a outra, com ela intimamente ligada, que é a da formação da taxa de juros no mercado de títulos. Enquanto a teoria convencional (neoclássica) entende aquela taxa simplesmente como outro preço qualquer, o qual se determina pela condições de oferta e procura marginais, é dizer, o preço de novos títulos de crédito negociados por dinheiro líquido (moeda restrita). Na acepção de HICKS (1987), pela simples equalização dos fluxos de poupança e investimentos líquidos. KEYNES (2012), no entanto, rejeita a ideia de um mercado onde a poupança (desejada), o investimento líquido (pretendido) e a taxa de juros mutuamente se determinam, na medida em que há outras forças operantes, e pois absolutamente preponderantes quando comparadas com tal mecanismo. Essas forças decorrem sobretudo da avaliação da riqueza por parte dos capitalistas (LIMA, 1997). Na hipótese da análise econômica pura, contudo, suprimidas essas forças, tal mecanismo funcionaria. Na concepção de SHACKLE (1969, p. 100 e ss.), interpretando o pensamento keynesiano, o equívoco cometido pela análise convencional do juro reside sobretudo no tratamento do mercado de títulos como se fosse determinado por fluxos, em vez de o ser por estoques. A despeito de haver naturalmente fluxos e refluxos sempre que títulos são comprados ou vendidos, seus efeitos são desprezíveis no processo de mudança de preços, o que evidentemente não seria verdade para um mercado de bens perecíveis, como o de "verduras frescas". Nesse último mercado, a transmissão de propriedade é essencial e necessária, pois se o ofertante não vender toda a sua produção, essa obviamente se deteriorará, de modo que o preço de venda e compra será o que puder ajustar diariamente a quantidade consumida (destruída) à quantidade amadurecida, ou seja, o volume ofertado às condições de demanda. Com títulos, todavia, o mesmo não ocorre, na medida em que um acréscimo líquido de alguns milhões correspondentes a novos títulos pode se juntar aos bilhões em valor do estoque existente de títulos sem que resulte em alterações expressivas no preço dos títulos. Na verdade, os preços dos títulos são inerentemente instáveis sobretudo porque dependem quase que exclusivamente de conjecturas a respeito de seu curso no futuro imediato. Acontecimentos de alguma importância ostensiva, como a iminente obrigação do Governo de retirar uma parcela de sua dívida e a substituir por outra, ou de tomar empréstimos a longo prazo no intuito de consolidar a dívida flutuante, não chegam a influenciar definitivamente no aumento ou na baixa dos preços dos títulos. Não obstante, a informação de que o Governo ou uma grande empresa lançarão títulos de dívida, então os seus termos serão antecipados conforme a suposição quanto à intenção do Governo em criar uma grande quantidade de dinheiro novo. $\mathrm{Na}$ hipótese dessas condições não corresponderem ao rendimento proporcionado pelos títulos existentes, presume-se que alguns de seus detentores os vendam ou, então, que outros que possuam disponibilidade em dinheiro os comprem por um preço mais próximo àquele dos novos títulos. Desse modo, os preços de todos os títulos existentes serão afetados, embora apenas uma fração pequena venha efetivamente a trocar de mãos. Observa-se, portanto, que o preço de algo que se conserva não se determina da mesma maneira que o preço de algo que se vende, compra ou usa em definitivo e a uma só vez. Nesse último caso, o vulto do fluxo de mercadorias perecíveis, consuntíveis, domina o mercado; já na primeira hipótese, o fluxo somente ocorre se o julgamento dos proprietários ou dos potenciais compradores das mercadorias permanentes (bens) em estoque se alterou em graus ou direções diferentes. Considerando dessarte que a todo o momento o estoque de títulos e o estoque monetário devem ser possuídos por alguém, os preços de todos esses ativos financeiros devem se ajustar, e as somas correspondentes, inclusive de dinheiro, devem estar de tal modo repartidas, em propriedade, que seus detentores momentâneos se nos apresentem como possuidores voluntários dessas quantidades ou somas. $\mathrm{Na}$ medida em que essas somas são retidas como riqueza armazenada, patrimônio financeiro (HUBER, 2011), em particular para fins especulativos, e não para algum propósito instrumental como o de efetuar pagamentos, as principais razões para a conservação desses ativos se relacionam, de um lado, a seus rendimentos futuros, e de outro, talvez primordialmente, às alterações no preço monetário desses ativos que parecem iminentes. Ressalte-se ainda que o preço monetário do dinheiro é imutável, mas não assim o preço dos títulos; os títulos serão portanto retidos apenas sob a suposição de que seus preços tendem a crescer ou pelo menos a não decrescer consideravelmente. O dinheiro, por sua vez, observada sua propriedade (função) de armazenar riqueza (reserva de valor), será retido por aqueles que esperam a baixa dos preços monetários dos outros valores mobiliários. Há basicamente dois grupos de investidores nos mercados de valores mobiliários, os que pensam que os preços dos títulos subirão e os que pensam que cairão. Ambos os grupos atuam, em realidade, por meio de investidores ou operadores profissionais, gestores de carteira (CHESNAIS, 1998), e pois sob aconselhamento, do que resulta naturalmente, em regra, a decisão de possuir concomitantemente títulos e dinheiro. Ressalve-se, portanto, que a preferência pela liquidez "keynesiana" 
A questão da especulação é inerente ao funcionamento do circuito monetário, não representando em si mesma um óbice econômico, uma vez que ao se efetivar a demanda por crédito (p. ex., produtivo), havendo disponibilidade sistêmica de encaixes ociosos reserva para investimento, no sentido de HICKS (1983), ou genericamente "poupança"136 , eles serão invertidos novamente no fluxo real de dispêndios (circuito produtivo) através justamente da intermediação financeira, cujo lucro resulta basicamente do diferencial de juros entre ativos e passivos, ou seja, entre os juros recebidos nos empréstimos ou inversões e os juros pagos sobre os recursos captados ${ }^{137}$.

Sob o prisma institucional, tendo em vista parâmetros sociovalorativos (normativos), ressalte-se todavia que a atuação bancária se direciona, ou deve se direcionar antes ao investimento e inovação, para além das poupanças (encaixes ociosos) anteriormente acumuladas em razão do desenvolvimento econômico passado (SCHUMPETER, 1982). Na prática, o aval do banqueiro geralmente auxilia seu cliente na obtenção de outras fontes de crédito ou ainda ao lançamento de títulos no mercado aberto

(dinheiro de curso legal, ou ainda moeda bancária, enfim, liquidez plena) se manifesta apenas como um dos lados possíveis desse processo, especialmente diante do temor de uma perda de capital cujo risco não se cobriria pela taxa de juros vigente (LIMA, 1997). Finalmente, a taxa de juros de mercado (preços dos títulos) dependerá fundamentalmente da avaliação e comportamento desses grupos, heterogêneos, de detentores do patrimônio financeiro, em última instância, da riqueza em sua forma desejada, em relação às possibilidades de ganho e perda de capital (lucro). Do que resultará sempre uma oscilação até que se reajustem as forças relativas dos dois campos (básicos), e se retenha por um dos grupos todo o dinheiro "flutuante" (aplicável), alcançando-se de fato "um equilíbrio, embora de uma qualidade fugidia e transitória" (SHACKLE, 1969, p. 106).

136 Advirta-se, no entanto, que as decisões de poupar e investir se concentram sobretudo no chamado "sistema de planejamento", ou seja, a esfera do sistema econômico dominada por um reduzido grupo de empresas, não havendo mecanismo que assegure ser o agregado das decisões de investimento suficiente para equilibrar o agregado das decisões de poupar. Configurando-se essa insuficiência, "o sistema estará sujeito a uma espiral descendente de produto e renda", afetando finalmente o próprio "sistema de mercado", em última instância, o público assalariado (GALBRAITH, 1988, p. 304 e ss.).

137 Não obstante, adverte veementemente KINDLEBERGER (1989, pp. 45, 47) quanto à capacidade desestabilizadora dos especuladores, especialmente no que tange aos chamados capitais de curto prazo, largamente utilizados nas negociações nos mercados de câmbio de moedas estrangeiras, ao contrário dos capitais de longo prazo, normalmente infensos a tais movimentos. Assim, esse fator desestabilizador depende, em última análise, da elasticidade das expectativas dos especuladores. Se as expectativas são inelásticas, idealizando que a taxa (p. ex., cambial) retornará ao nível anterior, os especuladores compram quando os preços baixam, e vendem ao subirem. Em face de expectativas elásticas, todavia, uma mudança no preço é entendida como um sinal de continuidade do movimento em dada direção, e pois os especuladores compram ao se elevar a taxa, e vendem na baixa. Há, porém, aqueles que negam a possibilidade de desestabilização por parte das operações especulativas, tal como Milton Friedman, e pois se baseiam na hipótese darwianiana de que os especuladores que compram na alta e vendem na baixa perderiam assim dinheiro e seriam naturalmente retirados dos negócios. Não obstante, a teoria convencional não se refere a qualquer tipo de especulador, mas antes ao investidor profissional, o qual opera em regra encaminhando a taxa no sentido de sua elevação para vender na alta, ou vice-versa, financiando suas vendas em curto prazo quando a taxa atingir um patamar baixo. Ressalte-se que aqueles que compram dos especuladores na alta, e vendem na baixa, perdem efetivamente dinheiro. Esses últimos investidores podem ser especuladores mal informados ou retardatários. Não raro, são eles os próprios bancos centrais, atuando nos mercados na tentativa inglória de estabilizar as taxas correspondentes. 
(TOBIN, 1989).

Ressalte-se ainda que a demanda por reservas de investimento, sobretudo destinada à especulação, implica naturalmente, como anteriormente mostrado, na assunção de riscos não só por parte do sistema bancário, mas em última instância pelo sistema monetário institucionalizado (incluso autoridades monetárias).

A evolução monetária, e pois as ocorrências aqui delineadas, demonstram por si sós o papel central da moeda nas sociedades capitalistas avançadas, dominando o processo econômico. Enquanto instituição social altamente complexa, as transmutações por que passa e ainda sua regulamentação institucional praticamente presidem os modos por que se processa o próprio desenvolvimento social.

Com efeito. O evolver monetário sob as circunstâncias temporais e espaciais, de ordem interna e externa, acompanhado pela estruturação monetário-produtiva, e por seus reflexos institucionais, revelam um complexo ao mesmo tempo integrativo e desagregador, que na realidade espelham nada além da própria contradição intrínseca ao fenômeno monetário, qual seja a de ser o dinheiro concomitantemente um bem público e uma mercadoria privada. Por um lado, as necessidades de circulação e produção, e portanto de estabilidade do próprio valor (poder aquisitivo), resultam em arranjos de ordem institucional (jurídica) no sentido de garantias públicas às importantes vantagens sociais da moeda. Nesse sentido, trata-se de bem público por afetação, na medida em que exerce a função de meio circulante entre os sujeitos econômicos, e sobretudo como padrão de valor $^{138}$ dos negócios, portanto, instrumento comum à sociedade em seu conjunto. Por outro lado, a moeda sempre traz consigo, inclusive em termos de psicologia social, aspectos inerentes à propriedade privada. Nesse último sentido, a simples realidade social, atual e largamente aceita, de que a moeda seja quase exclusivamente de crédito, manifestando-se portanto sob a forma preponderantemente bancária, implica um substrato fático irredutivelmente de ordem privada, pois os bancos, ainda quando públicos, atuam na qualidade de empresas em regime de mercado, portanto sujeitos ao objetivo de lucro. $\mathrm{O}$ sistema bancário como tal sempre oscilará entre os extremos de rentabilidade e segurança, cuja tendência natural é sempre responder de forma cíclica à conjuntura econômica. Vale dizer, o otimismo generalizado nos períodos expansionistas se fazem acompanhar do

138 Como adverte KINDLEBERGER (1989, p. 71), particularmente em contraponto às ideias de HAYEK (2011) e da escola austríaca que apregoam a desestatização (livre competição bancária) da emissão e circulação monetária, o dinheiro como padrão de valor revela um aspecto de bem público que do contrário seria perdido na hipótese de que cada negócio requeresse uma avaliação não só dos bens negociados, mas ainda da moeda a ser usada. 
respectivo incremento dos empréstimos, resultando não raro em excessos e consequentes pânicos, e pois em reduções drásticas de liquidez (crédito), encaminhando-se novamente no sentido de cautela (GUTTMANN, 1998; HUBER, 2011).

Portanto, na medida em que o dinheiro apresenta esse peculiar estatuto, aliás, similar à própria instituição do direito de propriedade, sua gestão exige cautela por parte da sociedade e suas instituições (POLANYI, 2000). Em particular, enquanto as funções de criação de dinheiro e distribuição de crédito continuarem acopladas, e pois o próprio sistema bancário, atuando economicamente em regime de mercado, determinar as quantidades reais de dinheiro em circulação, o dinheiro em si não constituirá nenhuma base ou fundamento estável para o bom funcionamento da economia. Ao contrário, o dinheiro constitui um ativo tão instável e variável quanto os ciclos econômicos (conjunturais) ou os ciclos bursáteis, é dizer, esses ciclos se formam de modo tão instável quanto a criação da moeda de crédito (bancária), não raro com consequências danosas ao conjunto ao bem comum da sociedade (HUBER, 2011).

Consequentemente, o dinheiro deveria permanecer estrutural e juridicamente, portanto material e formalmente como criação (emissão) e propriedade públicas, a despeito de ser sua posse ou detenção continuamente permutada. Nas sociedades contemporâneas, a ordem monetária é antes uma questão constitucional, cuja presidência e representação coletiva compete particularmente a um órgão estatal (constitucional), que responde pela disponibilização da base monetária e seu controle quantitativo em circulação, de modo que o estoque monetário total se alinhe ao desenvolvimento econômico.

Nesse sentido, ao menos parcialmente, se operou a evolução através da diferenciação entre os bancos centrais, em regra órgão estatais, e os bancos comerciais, em sua maioria privados, ocorrida sobretudo entre meados do século XIX e início do século XX. Desse modo, praticamente se reinstituiu a questão monetária no seio da ordem pública, permanecendo o negócio bancário na esfera privada (POLANYI, 2000). Não obstante, na medida em que a emissão monetária mesma se efetiva via crédito pelos próprios bancos centrais, por muito tempo aliás bancos privados em regime de monopólio, tal como no passado o Banco da Inglaterra, permaneceu esse arranjo institucional no mínimo ambivalente.

Com efeito, considerando que hodiernamente o tráfico mercantil operacionaliza seus pagamentos basicamente sem papel-moeda, ou seja, através de moeda escritural por meio do sistema bancário, o referido arranjo institucional simplesmente produz efeitos 
contrários, ou seja, atua muito mais em favor do interesse privado do sistema bancário do que no interesse público, na medida em que a coletividade acaba, por um lado, fazendo render aos bancos juros extras em razão de seu monopólio monetário de fato e, concomitantemente, os resgatando face à ameaça de insolvência por meio da geração de déficits públicos (HUBER, 2011) ${ }^{139}$.

O desenvolvimento dos mercados financeiros acabou por implicar também uma dificuldade conceitual no sentido de se definir operacionalmente o que seria o dinheiro. Como anteriormente exposto, tradicionalmente o dinheiro sempre foi visto como uma forma de riqueza, traduzida na sua função de reserva de valor, e pois se reduzindo a questão a quais formas de riqueza se identificariam ao dinheiro. Os critérios de segurança e liquidez do ativo, diante da incerteza futura (KEYNES, 2012), em função tanto de seu risco de inadimplemento quase insignificante como de sua facilidade de conversão, a certa taxa de câmbio, num meio de pagamento econômica ou juridicamente aceito (dinheiro de curso legal ou um seu substituto quase perfeito), sempre serviram como balizadores da análise econômica. No entanto, outra linha de entendimento, particularmente direcionada ao aspecto financeiro (creditício) dos ciclos econômicos (SCHUMPETER, 1982), passou a enfatizar a eficácia negocial propiciada pelo dinheiro, e consequentemente a defini-lo precipuamente como um ativo que seja aceito como meio de pagamento, sem que com isso se lhe negasse necessariamente a condição de reserva de valor.

De fato, a questão se complica sob as circunstâncias de um mercado financeiro altamente desenvolvido, principalmente em razão de que a vasta maioria dos negócios são liquidados sem a necessidade de se reter efetivamente alguma espécie de ativo identificável como dinheiro. Esse aspecto diz respeito a ambas as definições teóricas acima cotejadas, uma vez que ativos outros que não os meios de pagamento tradicionalmente assim considerados também podem servir à segurança e liquidez, dependendo antes do tipo de mercado, e ainda da conjuntura ou estrutura econômico-financeira em cujo âmbito esses ativos são negociados, podendo mesmo certo ativo constituir substituto perfeito ao dinheiro de curso legal (HICKS, 1983), a exemplo de alguns títulos obrigacionais altamente

139 Em sentido análogo, mas a partir de outros pressupostos teóricos, GALBRAITH (1988) afirma que a política monetária opera basicamente visando ao aumento ou à redução, direta ou indiretamente, dos agregados monetários disponíveis para empréstimo. Em regra, os sujeitos econômicos que menos necessitariam de recursos por serem os mais favorecidos pelas condições de financiamento compõem o sistema de planejamento (núcleo reduzido de capitalistas, financeiros ou não), enquanto os menos favorecidos pelos bancos e que justamente dependem de crédito se encontram no sistema de mercado, sendo pois aquele o componente altamente desenvolvido da economia, enquanto esse o menos desenvolvido. 
líquidos (quase-moeda).

As condições atuais dos mercados, ao fomentarem a pronta liquidação das operações à base do dinheiro de crédito, colocam em questão os modelos baseados exclusivamente na liquidez plena, ou sua preferência, como critério determinante das demais variáveis econômicas. Resta assim somente uma certeza nos mercados financeiros da atualidade, a saber, a de que existe sempre uma procura por dinheiro de modo a equalizar a oferta líquida de todos os outros ativos financeiros negociáveis, e pois uma oferta de dinheiro correspondente à procura líquida por ativos financeiros (FRIEDMAN, 1989).

Ressalte-se, todavia, que independentemente do viés teórico que se adote para o entendimento do dinheiro e suas funções na economia, a questão principal em torno da intermediação financeira, e pois dos mercados financeiros, também sob o prisma da análise macroeconômica, reside no padrão institucional em que se insere a estrutura financeira e dentro do qual se desenrola a política monetária, enquanto conjunto de programas e ações direcionadas ao controle da oferta monetária, tanto diretamente como por meio do sistema de intermediação financeira (FRIEDMAN, 1989).

\section{A política monetária}

A incontestável condição de bem público emprestada à moeda exige concomitantemente garantias a sua livre circulação e valor (poder de compra) estável, proporcionando "importantes vantagens sociais, das quais ninguém deveria ser espoliado" (GUTTMANN, 1998, p. 63).

A experiência histórica mostra, no entanto, que oscilações naquele valor, ainda que muitas vezes de curta duração (conjunturais), costumam ter larga amplitude de consequências, não raro influenciadas por movimentos de longo prazo (estruturais), mas cujas causas e explicação nem sempre coincidem. As oscilações no valor da moeda normalmente se prendem a oscilações similares no volume da produção, do consumo e do emprego, ademais de movimentos demográficos e dos ciclos empresariais, cujo âmbito de análise não raro envolve tamanha dificuldade sobretudo no que tange à distinção entre causas e efeitos. Em suma, a questão em torno do valor da moeda está intimamente ligada ao problema dos ciclos econômicos (ROBERTSON, 1969, p. 127 e ss.).

A expansão produtiva, a despeito de eventual caráter inovador ou empreendedor (SCHUMPETER, 1982), implica em regra um incremento significativo no capital 
circulante, e consequentemente da criação de moeda de crédito pelo sistema bancário. A essa pressão creditícia geralmente responde ciclicamente o sistema bancário, resultando em carestia e aumento da chamada "poupança forçada" imposta ao público (MISES, 2005). Iniciada a expansão inflacionária, inercial é a sua expansão. A velocidade de circulação monetária se acelera, as expectativas em torno da carestia se intensificam, a procura por fatores produtivos se incrementa, os estoques se avolumam no varejo, e mesmo o consumidor previdente faz concessões à prodigalidade. Mina-se assim qualquer disposição à poupança, em particular sob a forma monetária (liquidez), particularmente em razão das novas exigências impostas ao público pelo sistema produtivo-consuntivo.

Se o incremento monetário solapara a demanda real, a queda da procura como que fomenta novamente o acréscimo da oferta de moeda. Desse modo, os preços no atacado passam a ser determinados em função dos preços do varejo esperados para o futuro, ou seja, os preços no mercado se formam não a partir da renda nominal (moeda) atual, mas da futura, e pois cada vez mais o valor de negociação do dinheiro se dissocia de seu valor de renda. Em consequência, a renda nominal se eleva para fazer frente ao mesmo fluxo real (bens e fatores produtivos) presente (costumeiros), em razão da queda de poder aquisitivo da renda nominal. A pressão por poder de compra defasado buscará vazão em regra junto ao sistema bancário. Ao sistema bancário, portanto, o crescente vulto de empréstimos sempre aparece como resultado (efeito) da carestia, não pois como sua causa. Não obstante, sob outra perspectiva, observa-se que a conduta cíclica dos bancos não raro é condição essencial para o processo inflacionário.

Além disso, o problema relativo ao acúmulo de estoques se soluciona pelo natural prolongamento (retardamento) do processo produtivo, ajustando-se o ritmo de produção aos limites impostos pela saturação do capital fixo e da mão de obra existentes, afora os percalços da infraestrutura açodada. Consequentemente, e retornando ao início do ciclo, as solicitações de capital de giro ao sistema bancário se intensificam ainda mais.

A condescendência do sistema bancário, no entanto, atinge em regra seu limite na medida em que a pressão sobre suas reservas também se tornam insustentáveis. Mas, antes mesmo que se atinja esse limite, poupanças líquidas já se dissiparam, os períodos produtivos se alongaram demasiadamente, açambarcando as mercadorias, e inúmeros erros de julgamento e prognóstico já se cometeram, tudo enfim que caracteriza o curso de apogeu econômico. Nesse instante, é mister que o sistema monetário seja manejado de modo a corrigir os malefícios, em vez de fomentá-los (ROBERTSON, 1969). 
De modo conciso, a política monetária consiste no "processo pelo qual um determinado órgão tem o poder de afetar a economia de seu país, através de sua influência determinante sobre a expansão da moeda e do crédito" (VERÇOSA, 2005, p. 157).

Sob um prisma institucional (sociovalorativo), a finalidade última da política monetária, dada sua relação íntima com a política econômica em geral, assentaria na melhora do nível de vida da população. A questão se torna controversa, no entanto, ao se aferir quais as estratégias que melhor atenderiam a essa finalidade, e consequentemente ao nível ótimo de expansão monetária para determinada economia em dado momento histórico. Essa questão é fundamental a partir do entendimento de que a política monetária deve estar atrelada ao objetivo do desenvolvimento econômico ou do bem-estar da comunidade, na medida em que não raro os efeitos de tal política oscilam pendularmente entre a estabilidade monetária aliada a processos recessivos (deflacionários) e crescimento econômico sob regime inflacionário (VERÇOSA, 2005) ${ }^{140}$.

No que tange à sua formulação e execução, em regra busca a política monetária influenciar as decisões quanto ao dispêndio e os preços dos ativos em geral através do mecanismo da taxa de juros de curto prazo. Não obstante, a atuação dos bancos centrais se restringe a uma ordem de variáveis muito restrita em relação à magnitude das variáveis financeiras que busca atingir. Em sentido técnico, portanto, é muito incerta quanto a seus resultados, vez que atua praticamente sobre bases conjunturais. Trata-se aparentemente de um paradoxo a importância que se confere à política monetária e concomitantemente o instrumental reduzido que se apresenta para sua execução (COSTA, 1999; GALBRAITH, 1988).

Esse paradoxo se reflete teoricamente numa dicotomia quanto à forma de execução da política monetária, qual seja entre a discricionariedade e a fixação de uma regra para sua condução. Por um lado, seria ela conduzida conforme as condições prevalentes numa determinada conjuntura econômica. Por outro, sua condução se balizaria

140 Ainda sob esse prisma, trata-se apenas aparentemente de uma dicotomia, pois o enfoque primordial deveria ser antes a economia real do que seu aspecto meramente financeiro, portanto instrumental, considerando "o fato de que o dinheiro é um servo e não um senhor, um meio e não um fim. Os verdadeiros males econômicos da sociedade - produção inadequada e distribuição desigual - jazem muito profundos para serem curados unguento puramente monetário. A política monetária inadequada pode provocar dificuldades imerecidas e engendrar confusão desnecessária e desperdício: mas nem mesmo a política monetária sábia pode transformar um mundo injusto e pobre num mundo rico e justo. Nenhum conserto na estrada pela qual os produtos passam para ir ao mercado substitui o cultivo e a adubação da própria terra. Nenhuma arrumação de vitrinas e balcões nos levará muito longe em direção à descoberta de um sistema industrial que proporcione os incentivos adequados aos que arriscam e planejam e paz de espírito aos que suam e sofrem" (ROBERTSON, 1969, p. 148). 
por objetivos predeterminados (regra fixa), cabendo à autoridade monetária somente o cumprimento estrito desses objetivos, independentemente dos fatores conjunturais, restringindo-se ao mínimo sua discricionariedade (MODENESI, 2005) ${ }^{141}$.

Não bastassem os fatores relacionados à condução interna da política monetária, é mister que se tenha presente ainda o contexto financeiro internacional, determinado sobretudo pelas instituições, regras ou convenções a que aderem os diversos países desse concerto. Esse sistema compreende tanto regras explícitas como implícitas, sendo exemplo daquelas as regras contidas no Convênio Constitutivo do Fundo Monetário Internacional e do Banco Mundial, e pois dessas, os arranjos de câmbio, os fluxos de capital, ou ainda os sistemas internacionais de pagamentos onde se liquidam operações financeiras transnacionais. Como visto no tópico anterior ${ }^{142}$, entre as funções desse sistema monetário internacional se encontra o estabelecimento de regras de ajuste do balanço de pagamentos, e eventualmente de alteração das taxas de câmbio, de financiamento dos desequilíbrios entre países em razão da utilização de crédito, investimento ou reservas internacionais, ou ainda as regras de criação e fornecimento de moeda internacional (p. ex., os Direitos Especiais de Saque do Fundo Monetário) ${ }^{143}$.

141 Os defensores da adoção de uma regra fixa postulam a tendência irresponsável das autoridades monetárias na utilização dos instrumentos de política monetária, permitindo a expansão econômica no curto prazo, mas com sérios prejuízos à contenção da inflação no longo prazo. Os críticos da fixação de um regra, limitando a execução dessa política, se fiam no argumento de que a autoridade monetária deve ter maior liberdade na escolha dos instrumentos mais eficazes no combate aos diversos choques de oferta ou procura que conjunturalmente surjam na economia. O modelo que tem mundialmente prevalecido entre as grandes economias, sobretudo a partir de finais da década de 1990, inclusive no Brasil (1999), é o da adoção de uma regra balizadora da política monetária, estabelecendo-se uma âncora nominal para a economia - fixação de uma variável-chave nominal como elemento central dessa política (a taxa de câmbio, o estoque monetário ou a taxa de inflação) -, e assim um regime monetário. A adoção desse regime resulta basicamente no comprometimento da autoridade monetária em manter a economia ancorada numa daquelas variáveis eleitas a priori. A adoção de uma âncora se dirige sobretudo à coordenação das expectativas inflacionárias dos agentes econômicos, balizando a formação dos preços por partes desses agentes, auxiliando na promoção da estabilidade dos preços (MODENESI, 2005).

142 O sistema monetário de Bretton Woods e as regras do Fundo Monetário Internacional prevalecentes durante e após o abandono do padrão-ouro teórico (ouro-dólar) - mencione-se ainda como exemplo de consenso (regramento) implícito, o chamado "consenso de Washington".

143 Um exemplo de diretivas (regras) implícitas, pode ser encontrado na revelação de tendências dominantes pelos representantes dessas instituições internacionais, cujas opiniões emanadas não raro se traduzem numa espécie de consenso, geralmente não formalizado. Assim, por exemplo, as opiniões expressas por Alexandre Lamfalussy, outrora conselheiro econômico e posteriormente diretor geral do Banco de Compensações Internacionais, cujas observações têm sido ainda hoje de larga aceitação no conserto das políticas monetárias dos países membros. Como relatado por KINDLEBERGER (1989, pp. 61, 63), Lamfalussy expressou sua opinião, em 1985, a respeito das tendências inexoráveis do sistema monetário mundial, segundo a qual esse sistema experimentava quatro revoluções de uma só vez: um regime cambial flexível com tendência permanente, meios de transporte e de comunicação mais acessíveis de modo a promover a integração mundial dos mercados financeiros, grande variedade de instrumentos financeiros de tipo inovador a serem compreendidos, e ainda a crescente e veloz desregulamentação financeira. 
Dessa estreita relação sobretudo entre as políticas monetárias e cambiais dos diversos países, e pois diante do inexorável movimento internacional dos capitais, postulase, em princípio, um verdadeiro "trilema" para a condução da política econômica em nível nacional, a saber, a opção por parte das autoridades econômicas entre dois dos três objetivos seguintes: a) liberdade de movimentação de capitais transnacionais; b) fixação da taxa de câmbio monetário; e c) política monetária independente (ativa), direcionada a objetivos domésticos (ESTRELA, 2011) ${ }^{144}$.

Os objetivos estatutários dos bancos centrais trazem normalmente a estabilidade dos preços (poder de compra da moeda) como meta precípua (final) de suas políticas. Esse objetivo se apresenta todavia fugidio diante da tentativa de seu controle direto, sendo mister, portanto, a eleição de outras variáveis como objeto de controle (âncora nominal). Nesse sentido, estabelecem-se, em princípio, metas intermediárias em relação a algum agregado monetário hipoteticamente controlável, e pois correlacionado à meta principal. Sendo essa relação estável e previsível, as chamadas metas ou objetivos operacionais poderão ser estabelecidos de modo a assegurar o cumprimento da meta intermediária e, indiretamente, a consecução dos objetivos últimos da política monetária ${ }^{145}$. Em regra, os objetivos operacionais residem fundamentalmente no controle do nível de reservas bancárias $^{146}$ ou da taxa básica de juros ${ }^{147}$.

144 Desse modo, a opção (1) por afiançar a liberdade de capitais e a fixação da taxa de câmbio resulta na redução da capacidade de controle do banco central sobre a quantidade de moeda, tornando o estoque monetário endógeno (variável interna do modelo), determinada pois por outro fator, qual seja a oferta cambial num contexto de mobilidade internacional dos fluxos de capital. Na hipótese de se optar (2) pela liberdade de capitais concomitantemente à independência da política monetária, o resultado será a adoção de taxas cambiais flexíveis (câmbio endógeno, determinado pelas variações do estoque de moeda ao sabor do fluxo de capitais). Por último, ao se optar (3) pela fixação da taxa de câmbio e uma política monetária ativa, a restrição ao fluxo internacional de capitais se imporá necessariamente, tornando assim a mobilidade de capitais a variável endógena, ajustando-se às variações do estoque monetário sob uma taxa fixa de câmbio. Baseado nesse modelo de "trilema da política macroeconômica", é possível traçar um paralelo com a evolução do sistema monetário internacional, de modo que, por exemplo, o padrão ourolibra (1870-1914) correspondia basicamente à opção (1); o padrão ouro-dólar (Bretton Woods), à opção (3); e o padrão atual, à opção (2). O atual padrão (2), aliás, corresponde perfeitamente às tendências (ideias) apontadas por Lamfalussy, citadas na nota imediatamente anterior.

145 Os regimes monetários estabelecem normalmente as seguintes metas (âncoras nominais): meta cambial, meta monetária ou meta inflacionária - a depender da opção de política monetária. Registre-se, no entanto, que a meta inflacionária é a que fornece maior flexibilidade para a condução política em razão de considerar a informação sobre a conjuntura econômica, reduzindo muito o papel das metas intermediárias (praticamente restando apenas o cumprimento dos objetivos operacionais), além de conferir maior transparência e controle público. No entanto, a inflação é geralmente pouco previsível, além de estar fora do controle direto pela autoridade monetária, além da requerida flexibilidade cambial, sempre fator de forte instabilidade (MODENESI, 2005).

146 As reservas bancárias são recursos imediatamente disponíveis e que não rendem juros, sendo pois ociosos. Os bancos demandam esses recursos tanto para o cumprimento das exigibilidades compulsórias fixadas pela autoridade monetária como para a realização das negociações rotineiras entre si, em nome próprio ou de terceiros. O compulsório representa o encaixe obrigatório de um percentual dos depósitos à 
Esse modelo teórico de política monetária pressupõe sobretudo uma oferta exógena de moeda, em razão do monopólio estatal institucionalizado. Consequentemente, os meios de pagamento são antes considerados múltiplos da base monetária, definida como o somatório das reservas bancárias e do saldo de papel-moeda em circulação. Tendo em vista que esses agregados não apresentam na atualidade grande vulto em comparação com as reservas bancárias, podem ser desconsiderados em termos de operacionalidade da política monetária, resumindo-se pois a base monetária à própria conta de reservas bancárias no passivo dos bancos centrais.

Em princípio, considerando o fato anterior de que a base monetária nada mais é do que uma conta de passivo do banco central, presumir-se-ia que a autoridade monetária teria seu pleno controle, bastando para isso a administração de suas operações ativas (aplicações de recursos, por exemplo, em empréstimos líquidos aos bancos, eventualmente ao governo, administração das reservas internacionais e de sua carteira de títulos obrigacionais) e de seu passivo não monetário. Não obstante, a realidade se apresenta de outro modo, revelando neste passo o próprio caráter privado que se acentua no entendimento da moeda (MISES, 2005). De fato, o banco central não tem capacidade real de adicionar reservas bancárias ao sistema monetário sem que os bancos comerciais e o

vista, a prazo e de poupança a ser mantido sob a forma de reservas bancárias, cujas principais funções residem na manutenção de um nível mínimo de liquidez no sistema bancário, garantido sua solvência, no controle do volume de crédito, e na estabilização da procura por reservas bancárias. Os bancos comerciais também detêm reservas adicionais para cumprir suas obrigações, denominados encaixes voluntários. Os encaixes compulsórios e voluntários constituem a demanda por reservas bancárias. Em regra, as reservas bancárias constituem contas de depósito em espécie, mantidas junto ao banco central, mas no caso brasileiro, em vista das elevadas exigibilidades compulsórias, permite-se que uma parcela do compulsório seja retida sob a forma de títulos do Tesouro Nacional. Em razão de esses títulos renderem juros, essa parcela das reservas bancárias é também chamada de reservas bancárias secundárias, em oposição às reservas bancárias originais ou primárias. Ressalte-se ainda que esses encaixes, em princípio ociosos, representam riqueza estocada, portanto, têm para si um mercado próprio, o chamado mercado de reservas bancárias, destinado às negociações de reservas entre os bancos comerciais e entre esses e o banco central. No mercado primário, os negócios têm no banco central a contraparte principal, cujo resultado da operação dá azo à criação ou destruição de reservas, pois o banco central é o ofertante monopolista da "moeda dos negócios interbancários ou moeda de banco central". No mercado secundário, as operações são apenas interbancárias com as reservas já existentes, sem a participação do banco central, não havendo portanto alteração do estoque total de moeda, mas apenas permuta monetária (COSTA, 1999; MODENESI, 2005).

147 Há uma gama de taxas de juros na economia (de poupança, empréstimo, financiamento etc.), e pois de diferentes prazos (curto, médio e longo). A autoridade monetária controla diretamente somente a taxa de juros de curto prazo, qual seja a taxa primária de juros diariamente estabelecida no mercado de reservas bancárias. Vale dizer, essa taxa básica significa o custo incorrido pelos bancos comerciais ao levantarem em empréstimo por um dia reservas bancárias no chamado mercado interbancário, daí se denominar essa taxa de overnight. A partir da determinação dessa taxa primária, em razão das operações de arbitragem no mercado financeiro, se configuram as taxas de mais longo prazo na economia, pautando assim as decisões de investimento, poupança, produção e consumo de bens duráveis. Dessarte, as variações na taxa básica se propagam por toda a estrutura a termo da taxa de juros, ou seja, o conjunto das taxas de juros em relação a todos os prazos praticados nos negócios da economia (MODENESI, 2005). 
público assim o desejem. Desse modo, a decisão sobre o gerenciamento das contas do ativo do banco central fogem à sua alçada, restando-lhe apenas o controle indireto por meio da atuação no mercado de reservas bancárias de modo a influenciar a taxa de juros de curto prazo (primária) e assim a própria formação da estrutura a termo das taxas de juros da economia. Ressalte-se, portanto, que a impossibilidade de controle efetivo sobre as reservas bancárias não permite na realidade sua adoção como objetivo operacional da política monetária. Na prática, resta aos bancos centrais em geral atuarem somente sobre a formação da taxa primária de juros, influenciando as decisões de gasto dos sujeitos econômicos (COSTA, 1999; MODENESI, 2005).

Observe-se dessarte que a condição prévia do modelo teórico (geral) de política monetária, ou seja, a da oferta exógena da moeda em razão do monopólio estatal, perde espaço em razão da realidade (institucionalizada) da prática bancária e da criação (endógena) de moeda de crédito, sobretudo em tempos de desmesurada inovação financeira. Com efeito, sob o prisma da demanda efetiva (KEYNES, 2012), o dispêndio não se restringe pelo fluxo nominal (renda recebida e não consumida) nem pelo estoque líquido de riqueza (poupança), mas antes encontra vazão no próprio sistema bancáriocreditício enquanto provedor de liquidez, criador de moeda de crédito (meios de pagamento) (SCHUMPETER, 1982). No sistema de crédito contemporâneo, portanto, as autoridades monetárias não são capazes de fixar uma taxa de juros real a priori, ou seja, uma taxa de juros em termos de poder aquisitivo da moeda, pois que as taxas de juros próprias dos demais ativos (taxa natural de WICKSELL, 1986) se alinham, a posteriori, em base à taxa monetária (prêmio de liquidez do ativo monetário) (KEYNES, 2012). Outrossim, o estoque monetário anterior, aprioristicamente determinado, perde sua razão de ser em função da presença de uma demanda efetiva por financiamento para a realização de investimentos (geradora de renda), em princípio passível de ser atendida pela atividade cíclica do sistema bancário enquanto criador de meios de pagamento.

Frise-se novamente que em base às reservas bancárias criam os bancos comerciais meios de pagamento, ao concederem empréstimos sob a forma de depósitos à vista em nome dos tomadores de recursos (clientes), de forma que o banco central afeta a liquidez da economia ao expandir ou contrair o estoque dessas reservas.

Para o gerenciamento diário de liquidez desse mercado de reservas bancárias, utilizam-se os bancos centrais primordialmente das chamadas operações de mercado 
aberto $^{148}$. Em regra, atua a autoridade monetária através das operações de overnight, ou seja, cujo vencimento ocorre no dia seguinte à sua conclusão. Normalmente constituem operações compromissadas de venda e compra, por meio das quais o vendedor de um título obrigacional $^{149}$, ou tomador de reservas, se compromete a recomprar o mesmo título no dia seguinte, a um determinado preço pactuado (prêmio). Esse prêmio não se identifica necessariamente com a taxa de juros nominal inscrita no título negociado na operação overnight, de modo que o vendedor, ou mesmo um terceiro detentor original do título, tal como um banco comercial, prossegue auferindo os juros nele previstos. Já o detentor atual, mutuário das reservas, recebe a taxa pactuada na operação compromissada, que pode ser maior ou menor do que o prêmio pago pelo título que, na realidade, apenas lastreia ou garante aquela operação. Durante o contrato de compromisso não há transmissão de propriedade do título, sendo antes entregue como garantia, portanto não há alteração no conteúdo do direito à fruição dos juros originais por quem quer que seja seu proprietário ou atual detentor. Na realidade, o "dinheiro" (liquidez plena) é o único objeto do mercado de reservas (fluxos monetários em sentido estrito), onde os títulos servem apenas de caução (estoques de valor) (COSTA, 1999; MODENESI, 2005).

Dessarte, as operações de mercado aberto constituem o principal instrumento de política monetária da maioria dos bancos centrais no intuito de administrar a liquidez diária do mercado de reservas bancárias, onde se forma a taxa de juros de curto prazo. O mercado de reservas bancárias constitui assim a base de operações da política monetária na tentativa de influenciar a formação da taxa de juros de curto prazo, em última instância, a taxa básica de juros da economia ${ }^{150}$. Sua formação ocorre basicamente mediante o confronto entre a oferta de reservas bancárias, definida pela atuação do banco central e dos bancos comerciais com excesso de liquidez, e a procura por reservas pelos bancos comerciais para fazer frente às exigências de encaixes compulsórios e ainda aos compromissos voluntariamente assumidos com o público ou o setor não bancário da economia.

É mister que se tenha em mente que a movimentação financeira (dos fundos) dos

148 Em menor escala, atualmente, se utilizam o recolhimento compulsório e o redesconto de liquidez, instrumentos clássicos de política monetária, sendo que o redesconto ainda é muito utilizado pelo Banco do Japão (ESTRELA, 2011).

149 Em regra, títulos de elevada liquidez (quase-moeda) tal como os títulos da dívida pública.

150 Observe-se que a taxa básica de juros da economia brasileira se denomina taxa "Selic", em referência ao Sistema Especial de Liquidação e Custódia, o qual responde pelo registro da operações e pela custódia dos títulos públicos e depósitos interfinanceiros, objeto das operações compromissadas. Vale dizer, a taxa Selic corresponde à taxa (média) dos financiamentos diários contratados nos mercados primário e secundário de reservas bancárias, sempre sob caução de títulos públicos federais (MODENESI, 2005). 
sujeitos econômicos em geral, ou seja, de seus ativos e passivos, corresponde basicamente a um modelo de "fluxo de caixa", constituído de recebimentos (entradas) e pagamentos (saídas) de valores monetários. Ao final de cada dia, por ocasião da compensação desse fluxo de caixa, procuram seus titulares o manter equilibrado em termos de entradas e saídas ("zerado"), geralmente por meio de financiamento dos saldos deficitários ou aplicação dos saldos superavitários. Raramente ocorre o equilíbrio espontâneo, sobretudo em razão da natural ausência de sincronização dos fluxos de entrada e saída (incerteza).

Ressalte-se todavia que no contexto de economias monetárias, em regra é o sistema bancário que desempenha preponderantemente a tarefa de auxiliar na obtenção do equilíbrio dos fluxos de caixa dos sujeitos econômicos não bancários, sendo essa aliás sua função primordial (COSTA, 1999, p. 195).

O sistema bancário se desincumbe dessa tarefa ao fornecer ao mercado (clientela) a liquidez necessária ao bom funcionamento do (macro)processo de pagamentos, compensação e liquidação dos negócios (contratos). A aptidão bancária para essa tarefa reside basicamente no privilégio de captação de depósitos em conta corrente dos sujeitos econômicos, no fornecimento de crédito, de um mercado secundário para ativos líquidos de segunda linha ou ainda de facilidades de saques a descoberto (overdraft facilities, cheque especial), permitindo dessa forma a liquidação ou pagamento dos compromissos assumidos enquanto os fundos aguardados para esse fim ainda não se realizaram no âmbito dos fluxos de caixa. Ademais, atende ainda aos interesses dos agentes superavitários no que tange à aplicação das sobras de caixa, na medida em que a indústria bancária gera grande diversidade de produtos financeiros, de diferentes níveis de liquidez e maturação, propícios à canalização desses recursos ociosos.

Sem embargo, ao assumirem a tarefa de equilibrar os fluxos de caixa da economia, absorvem os bancos posições devedoras e credoras com diversos perfis correspondentes a diferentes prazos, quantidades e riscos, devendo assim empreender a difícil e custosa tarefa de conciliá-los. Há consequentemente elevado custo de manutenção da rede informacional que abarca as inúmeras necessidades individuais de caixa e a solvência dos mutuários. Sob um critério de economicidade, a operação bancária requer então escala operacional em nível elevado, encontrável apenas em instituições financeiras, sobretudo bancárias. Nesse mister reside ainda outra razão, talvez mesmo a principal, para a existência da intermediação bancária. De fato, negócios financeiros podem ser celebrados ainda que sem a participação direta dos bancos (típico fenômeno da desintermediação 
bancária), não obstante os procedimentos de liquidação daqueles negócios ainda se desenvolvem fundamentalmente no seio do sistema bancário.

Dessarte, é importante que se frise a fundamental convergência da generalidade dos negócios pecuniários e financeiros celebrados na economia na direção do sistema bancário, tornando-o assim a figura central do sistema de pagamentos (COSTA, 1999).

No processo de equilíbrio dos fluxos de caixa da economia, os agentes bancários acabam por desequilibrar os próprios fluxos de caixa, vez que raramente os empréstimos franqueados coincidem com as captações de depósitos, tornando-se também deficitários ou superavitários. Sob o prisma macroeconômico, ao desequilíbrio dos fluxos de caixa do setor bancário corresponde na realidade o equilíbrio do fluxo de caixa do setor real da economia. No entanto, o sistema bancário como um todo funciona sob o sistema contábil de partidas dobradas, portanto, a cada pagamento corresponderá sempre um recebimento de valor equivalente em termos consolidados, de sorte que diariamente haverá um conjunto de instituições deficitárias e outro de superavitárias. Nesse contexto se fecha o ciclo em torno do anteriormente apontado "mercado de reservas bancárias", onde se negocia a chamada "moeda de banco central".

Desse modo, todas os negócios financeiros celebrados diariamente na economia são como que "destilados" por meio dos negócios interbancários para fazer frente aos desequilíbrios dos fluxos de caixa do sistema bancário. Esse equilíbrio se obtém em regra pela negociação interbancária dos saldos em conta corrente mantidos nos bancos centrais, as já referidas "reservas bancárias".

Frise-se, portanto, que o mercado de reservas bancárias, base operacional da política monetária, representa basicamente o sorvedouro de praticamente todas as operações negociais realizadas nos diversos segmentos do sistema financeiro, funcionando como um verdadeiro "sistema de pagamentos", cujo instrumento final de pagamento é justamente a moeda (escritural) das reservas bancárias.

\section{A regulação financeira}

Tradicionalmente, a fragilidade do setor bancário é vista sob dois aspectos: no polo passivo, a vulnerabilidade bancária decorre da possibilidade de saques extemporâneos por depositantes ou aplicadores influenciáveis por quaisquer boatos; do lado ativo, os bancos podem sofrer perdas em razão da inadimplência de seus mutuários. Com efeito. A maior parte das obrigações do sistema bancário é resgatável a curto prazo, enquanto que 
suas próprias aplicações, em regra efetuadas a médio e longo prazos, enfrentam percalços em relação à capacidade de pagamento (solvência) de seus devedores, da conjuntura política, do comportamento do câmbio externo etc. Ademais, há os riscos de fraudes internas à gestão do próprio sistema bancário privado. O próprio comportamento prócíclico da atividade bancária gera naturalmente riscos quando da inversão do ciclo econômico, causando deflação de seus próprios ativos e daqueles oferecidos em garantia pelos mutuários (COSTA, 1999; ROBERTSON, 1969; VERÇOSA, 2005).

Em acréscimo, advirta-se que a própria estrutura político-institucional colabora para a fragilidade do sistema bancário, na medida em que não raro os diversos governos nacionais respondem às crises bancárias assumindo os riscos criados pelo próprio comportamento das instituições financeiras, na tentativa de minorar os prejuízos do público investidor. "Essa orientação apresentaria, como efeito direto, o encorajamento aos bancos para que continuem a se comportar sem grande cautela em suas operações" (VERÇOSA, 2005, p. 215).

Sob o prisma do funcionamento do circuito financeiro, resulta natural à atividade de intermediação bancária a assunção de riscos. Tais riscos são inerentes às finalidades perseguidas pelos bancos e pois às oportunidades lucrativas geradas por essa atividade, atraindo assim investidores de todo o gênero. Para os agentes de intermediação financeira, sobretudo a rede bancária, o principal risco reside na possibilidade de procura por fundos pelos depositantes ser efetivada a qualquer instante sem que o banco a possa satisfazer em absoluto, ou a satisfaça, mas a um custo extraordinário. Muitos dos ativos em poder dos bancos são ilíquidos ou não negociáveis em mercados, outros podem ser realizados a curto prazo, mas com substancial perda patrimonial. Além disso, má gestão, e às vezes má sorte, não raro acarretam a insolvência bancária. Portanto, as peculiaridades do próprio comércio bancário e ainda a estrutura patrimonial ${ }^{151}$ dos bancos são fundamentalmente aptos a gerar riscos que transcendem ao sistema bancário, e pois exterioridades ou efeitos colaterais de grande repercussão social (TOBIN, 1989; YAZBEK, 2009).

Ressalte-se mais uma vez que os bancos e outros intermediários financeiros possuem reservas, tanto em espécie como em determinados substitutos (p. ex., títulos da dívida pública), em regra depositadas nos bancos centrais, e ainda encaixes sob forma

151 A empresa bancária trabalha em regra de forma excessivamente alavancada, ou seja, é elevada a razão entre seu passivo (depósitos captados junto ao público) e seu ativo (reservas, empréstimos ou aplicações no mercado interbancário), e ainda com grande descompasso em termos de liquidez entre seus ativos e passivos (PINHEIRO, 2005). 
líquida como precaução contra resgates de sua clientela. Nesse sentido, o saque contra um banco específico normalmente significa apenas uma transferência de fundos para contas de depósito mantidas em outros bancos, através dos sistemas de pagamentos. Não obstante, o resgate generalizado dos depósitos bancários, tal como numa "corrida bancária", significa uma transferência pelo público dos depósitos bancários (moeda bancária ou escritural) para a "moeda corrente". Independentemente da chamada "assimetria informacional", a razão básica para a crise generalizada no sistema bancário reside fundamentalmente no comportamento do próprio investidor bem informado, que não podendo prever o comportamento do restante dos depositários, e pois diante da crença de que os outros correntistas estão sacando suas aplicações ou estão prestes a fazê-lo, irá ele próprio exigir o resgate de seus fundos depositados na rede bancária (TOBIN, 1989).

Os aspectos acima ressaltados, concomitantemente ao fato de que o sistema bancário desempenha o papel de transmissor da política monetária, como visto no tópico anterior em relação à atuação dos bancos centrais sobre a base monetária via reservas bancárias, compõem os fatores que comumente se identificam como razões macroeconômicas para justificar a atuação governamental na regulação ${ }^{152}$ financeira (PINHEIRO, 2005).

Sob o prisma da teoria microeconômica, justifica-se a atividade estatal de regulação no sentido de garantir ao público certa simetria de informações, a um baixo custo social, em relação aos investidores profissionais do mercado, e pois grandes empresas, uma vez que os correntistas incorreriam em custos imensuráveis na hipótese de terem de verificar por conta própria a reputação e a solidez financeira (liquidez) das instituições financeiras (p. ex., bancos, seguradoras ou fundos mútuos de pensão ou investimento), ou ainda calcular a probabilidade de sua quebra, além de não terem o incentivo e a competência necessários para exercer o monitoramento ou mesmo influenciar a administração dessas instituições. A essa forma de regulação se denomina informacional, ou do ponto de vista protetivo dos depositantes investidores, prudencial (PINHEIRO, 2005; TOBIN, 1989).

Ainda sob aspecto microeconômico, no que tange à regulação prudencial, entende-se como dever estatal a promoção, a um baixo custo social, de segurança e

152 De modo genérico, o termo "regulação" abrange a atividade normativa, a efetivação de controles em geral e ainda de medidas excepcionais (discricionariedade legal). Em correspondência ao gênero "regulação", pode-se entender que as atividades de "regulamentação, fiscalização ou supervisão" são espécies relativas a práticas específicas, restando assim à regulamentação uma ação de caráter normativo e à supervisão uma ação de caráter executivo (YAZBEK, 2009). 
eficiência à movimentação de valores (sistema de pagamentos), e ainda aos investimentos em ativos financeiros a todos os sujeitos econômicos que queiram investir (poupar) na unidade nacional de conta (padrão monetário). Os meios de pagamentos e os ativos financeiros de investimento podem ser oferecidos pelo sistema financeiro de modo a se obter eficiência econômica através da descentralização e competição privada, mas somente se o Estado atuar nessa esfera como regulador, assumindo ainda algum tipo de responsabilidade residual (PINHEIRO, 2005; TOBIN, 1989).

Desse modo, particularmente a atividade bancária, enquanto emissora de moeda de crédito, é afetada pelo risco de crédito ou de inadimplemento, é dizer, quando o devedor não resgata sua dívida (principal ou juros). Sob o aspecto microeconômico, o risco de crédito se traduz no risco comercial, ou seja, de que uma empresa ou pessoa física não consiga honrar o pagamento devido. Esse risco pode ser mitigado através da diversificação dos empréstimos e respectivos mutuários em larga escala (lei dos grandes números). No que tange ao aspecto macroeconômico, diante de um intenso processo deflacionário, em razão da contração econômica da renda, e pois do mercado de trabalho, um processo generalizado de inadimplência pode ser desencadeado. Portanto, o risco microeconômico de crédito recai no gerenciamento e controle cotidianos de risco por parte dos bancos, não havendo correlação entre os empréstimos individuais, enquanto o risco macroeconômico de crédito ou inadimplência, ou risco (sistêmico) de liquidez ${ }^{153}$, resulta de crise econômica (ciclos econômicos). Em contraponto, por exemplo, às empresas de seguro ou aos fundos de pensão, que normalmente administram apenas riscos microeconômicos, em regra os bancos enfrentam ambas as formas de risco de crédito. Dado que o sistema bancário, e pois monetário, assenta fundamentalmente na fidúcia, o contágio deflacionário (de ativos) e a inadimplência em larga escala podem acarretar a quebra de alguns bancos e, consequentemente, um risco para todo o sistema - o assim chamado "risco sistêmico"

153 O risco de liquidez é mais amplo que o risco de crédito, vez que é resultado direto da transmutação dos prazos dos ativos realizadas pelas instituições financeiras, particularmente os bancos, e do sistema de reservas fracionadas com que esses últimos operam. Essa transformação de prazos ocorre em razão da captação de depósitos e outras poupanças de elevada liquidez e sua garantia ou lastro em empréstimos ilíquidos, o que naturalmente implica um risco de falta de liquidez. $\mathrm{Na}$ realidade, os depósitos e empréstimos são contratos financeiros que em regra não podem ser facilmente revendidos, vez que são nominais e pois relevantes as pessoas das contrapartes, em contraste com os títulos financeiros (ações e títulos de renda fixa), cuja identidade dos titulares é basicamente irrelevante, importando antes sua cartularidade e circulação, daí serem facilmente negociáveis no mercado. Os contratos, por sua vez, necessitam em regra permanecer no balanço dos bancos até sua expiração, contando com liquidez imediata (depósitos à vista) ou resgatáveis em curto prazo (poupança), cujas somas superam em muito as reservas e encaixes mantidos pelos bancos, portanto, em caso de saques generalizados daqueles recursos, o branco atingido enfrentará uma crise de liquidez (PINHEIRO, 2005, p. 455 e s.). 
(PINHEIRO, 2005, p. 451 e ss.).

No âmbito do sistema de pagamentos, considerando o nível elevado de integração entre as atividades financeiras, o grande vulto de valores movimentados cotidianamente e ainda as necessidades de caixa das instituições financeiras durante o dia, qualquer atraso ou inadimplemento pode gerar problemas relacionados à liquidez do agente inadimplente, ou de outros indiretamente afetados, daí que "os riscos de crédito ou de liquidez apresentam uma dimensão sistêmica "em última instância", na medida em que uma falha isolada pode gerar instabilidade em todo o sistema financeiro" (YAZBEK, 2009, p. 190) ${ }^{154}$.

Ressalte-se ainda que essa interligação das atividades financeiras pode afetar ainda os sujeitos econômicos não financeiros, manifestando outro efeito colateral (exterioridade) da atividade bancária no que tange ao comportamento protetivo do mercado não bancário e à estrutura patrimonial dos bancos. Os excessos de caixa das empresas e indivíduos, como visto no tópico anterior, são depositados nas instituições bancárias, cuja relação com sua clientela se baseia quase exclusivamente na confiança em sua solidez. Quando há incertezas em relação à solvabilidade de alguma instituição bancária, nada mais natural do que a ocorrência de um refluxo nos depósitos nela mantidos.

Com efeito. Em regimes econômicos onde predomina a livre movimentação de capitais transnacionais e a flexibilidade cambial, como atualmente ocorre entre a maioria dos países membros do Fundo Monetário Internacional, incluso o Brasil, a realização de lucros em ativo cujo preço atingiu o patamar máximo segundo a estimativa dos especuladores (administradores de carteiras de investimento), pode provocar o efeito contágio, resultando numa série de vendas simultâneas de diferentes ativos, derrubando as cotações nos diversos mercados, de modo a também compensar prejuízos através das realização de lucros por meio de procedimentos de arbitragem entre mercados. Na hipótese de que algumas instituições bancárias venham a falir, um efeito de tipo dominó pode se espraiar ao longo do sistema bancário. Ao contrário, portanto, de uma empresa comercial

154 Nada obstante a conceituação anterior, em que prevalece o caráter sistêmico da liquidez bancária, e pois de seu risco, é admissível que se restrinja o conceito de liquidez do ponto de vista do direito obrigacional, assimilando-o então à mora no cumprimento da obrigação. Nesse sentido, assevera STURZENEGGER (2001, p. 231) que o risco de liquidez decorreria antes do "atraso" no pagamento de uma obrigação. Assim, somente no caso extremo desse atraso afetar a capacidade da contraparte de cobrir sua deficiência de fluxo de caixa qualquer que seja o custo de substituição da prestação inadimplida, é que então se delinearia a possibilidade de comprometimento generalizado de sua capacidade de pagamento perante terceiros. Desse modo, o risco de crédito decorreria residiria no inadimplemento absoluto e definitivo da obrigação de uma parte contratante no sistema. Em razão da dimensão da obrigação não adimplida e ainda da cadeia de obrigações coligadas, resultaria a possibilidade de risco de perdas para outros participantes (risco sistêmico). Essa terminologia se apresenta de fato mais adequada para o exame civilístico da matéria. 
ou industrial (não financeira), ao se verificar a falência súbita de um determinado banco, seus competidores também podem sofrer os efeitos de uma "corrida bancária". Esse efeito decorre tanto da suspeita generalizada de que outros agentes do sistema enfrentam o mesmo revés, ou ainda do efeito depreciativo causado nos ativos dos outros bancos em razão da liquidação do falido. Na realidade, a simples ameaça de saques generalizados resulta na liquidação antecipada de ativos por parte dos demais bancos de forma a robustecer seus encaixes face ao iminente refluxo dos depósitos em conta corrente ou investimentos especulativos, resultando num "processo deflacionário cumulativo" (COSTA, 1999, p. 335). Como adverte COSTA (1999, p. 336):

Este fenômeno de deflação dos ativos em garantia pode ter um efeito potencialmente devastador sobre a economia real. Os bancos pedem o pagamento de seus empréstimos pendentes, recusando-se a fazer refinanciamentos e novos empréstimos, o que cria uma escassez de crédito, a qual pode agravar o declínio dos preços dos ativos em geral.

Não obstante o exposto, é mister que se frise não se tratar apenas do perigo de contágio em razão do comportamento dos pequenos poupadores, no mercado financeiro de varejo. Não se deve olvidar do risco maior, a saber, os mercados financeiros de atacado, entre eles o mercado de empréstimos interbancários (bancos entre si), e ainda os sistemas de pagamentos, onde a rede bancária liquida suas próprias operações como aquelas por conta de terceiros. Os sistemas interbancários de pagamentos nacionais movimentam em regra o equivalente ao PIB anual no período de poucos dias. Na hipótese de retração do crédito no vital mercado interbancário, não restará alternativa senão a intervenção da autoridade reguladora máxima, o banco central.

De fato, como mostrado no tópico anterior, a liberalização financeira e o crescimento do comércio global reforçaram cada vez mais o entrelaçamento entre os bancos e os diversos mercados, entre eles o de crédito interbancário, o de câmbio externo e o de derivativos, tanto nacional como internacionalmente. Tendo em vista o vulto dos negócios sobretudo interbancários, na hipótese de que um dos grandes sistemas mundiais de pagamentos viesse a falhar em razão de insolvabilidade sistêmica, não só os bancos sofreriam incomensuráveis perdas, mas toda a economia.

Ressalte-se que as redes de pagamentos permitem aos bancos a transferência mútua de fundos de modo a compensar inúmeros acordos de câmbio externo ou valores mobiliários. Até o início da década anterior, muitos dos grandes sistemas gerais de 
pagamentos ou compensações ainda funcionavam à base da liquidação por diferença, ou seja, o sistema informacional acompanhava ao longo do dia a posição líquida de cada banco envolvido nos negócios celebrados, efetuando-se ao final do dia a compensação por diferença, transferindo assim a quantia devida da conta de reservas junto ao banco central (sistema público de pagamentos) ou da conta de liquidação junto à câmara de compensação (sistema privado) para a conta da contraparte bancária. Na hipótese de não haver pagamento, como já frisado, cria-se o risco de uma corrente de inadimplementos ao longo do sistema.

Outra ameaça ainda maior de "descompensação" poderia ocorrer no mercado de câmbio externo. Assim, pode um banco cumprir sua prestação no comércio de divisas estrangeiras ao entregar moeda, mas a contraparte não, o que somente vem à tona tardiamente em razão da diferença de fusos horários ${ }^{155}$.

Essa forma de funcionamento dos sistemas de pagamentos resultaram, ao longo dos anos de 1990, em movimentos articulados no âmbito dos organismos monetários internacionais no sentido de que os bancos centrais nacionais implantassem, ainda que a elevados custos, sistemas de pagamentos em tempo real. Observe-se que a liquidação imediata dos grandes negócios interbancários, ao se utilizar das disponibilidades junto ao banco central do país-sede da instituição devedora, reduziria o risco sistêmico, pois, em caso de falência do banco devedor, esse estaria pouco endividado em relação a outros bancos.

Frise-se ainda que as somas devidas no mercado interbancário superam não raro

155 Digno de nota é o caso do banco alemão Bankhaus Herstatt, de Colônia, nos idos da década de 1970. A partir da década de 1960, sobretudo em consequência da política norte-americana de redução consistente da taxa básica de juros, bem como da política em sentido contrário das autoridades alemãs, movimentos especulativos de arbitragem, ainda sob o regime monetário de Bretton Woods, se iniciaram com a fuga de capitais dos EUA em direção ao lucrativo mercado de eurodólares, tal como estabelecido na praça de Londres, a partir de onde migravam rumo ao mercado alemão. Desse modo, as autoridades financeiras alemãs se viram forçadas a restringir a liquidez interna, recolocando os fundos no mercado de eurodólares. Frise-se que a partir de então estavam dadas as condições não apenas para os empréstimos de liquidez à América Latina realizados por consórcios bancários, mas ainda para a especulação cambial com moedas estrangeiras em larga escala. Nesse contexto, bancos inexperientes sofreram severas perdas ao especularem nesse mercado. Em 1974, o banco Herstatt, posteriormente, em 1985, o Banco Nacional Franklin de Nova York. Ambos especularam de forma errônea quanto aos movimentos das taxas cambiais flutuantes. Observe-se ainda que o nível de exposição contratual (câmbio) do banco alemão correspondia a um décimo do banco americano, tratando-se esse último de um banco especulativo com desempenho ruim no mercado de créditos de risco em Nova York, buscando em Londres empréstimos para fazer caixa diante da ausência de uma base sólida de depósitos na matriz, e pois especulando no mercado cambial de forma altamente arriscada, cuja exposição chegou a alcançar a cifra de USD2 bilhões (KINDLEBERGER, 1989, p. 46 e s.). Esclareça-se novamente que o processo de especulação se traduz basicamente na conservação deliberada de posições contratuais de câmbio em aberto, é dizer, o especulador vende divisas sobre as quais se antecipa uma depreciação e compra aquelas sobre as quais se antecipa uma apreciação (COSTA, 1999, p. 330). 
as bases de capital dos bancos que nele atuam. Ademais, não se sabe ao certo quem são os devedores nem o que se deve, na medida em que os sistemas de pagamentos constituem uma cadeia de fluxos financeiros de extraordinária complexidade, resultando em inúmeras interdependências de crédito. Em razão dessa opacidade e também do volume das exposições creditícias envolvidas é que se cria justamente um "risco sistêmico potencial" (COSTA, 1999, p. 336; SCHUMPETER, 1964b).

Outro fator determinante da gravidade de uma ameaça sistêmica se traduz na extensão das conexões entre as instituições financeiras envolvidas. Na hipótese de o banco sob ameaça ser um grande agente num mercado específico, um prestamista de vulto a outros bancos, ou ainda um importante elo no sistema de pagamentos, o banco central deverá atuar sob pressão política e social, no sentido de evitar a escalada de tensão em torno da possível quebra de um banco que tenha em sua carteira de passivos quase a totalidade do patrimônio financeiro de milhares de clientes.

Desse modo, considerando a possibilidade de saques generalizados (corrida bancária) em razão da deflagração de processos deflacionários, também causados pela atual volatilidade dos mercados financeiros, bem como da estrutura e funcionamento dos sistemas de pagamentos, sobretudo em atenção aos mercados interbancários nacionais e internacionais, novos e acentuados riscos têm surgido a partir da reestruturação monetária internacional, justificando de modo amplo a atividade regulatória no âmbito dos Estados nacionais, particularmente sob a égide de diretivas emanadas dos organismos monetários internacionais $^{156}$.

A regulação prudencial dos riscos macroeconômicos de liquidez bancária, também

156 O órgão atualmente de maior relevo é indiscutivelmente o Banco de Compensações Internacionais (BIS, Bank for International Settlements), criado na década de 1930, com sede na Basileia, criado para tratar de questões relacionadas com as indenizações previstas no Tratado de Versalhes. Atuou fortemente durante o regime monetário de Bretton Woods, participando ainda de programas de auxílio e estabilização financeira mundo afora. Destaca-se sobretudo como privilegiado fórum de discussões e elaboração de políticas globais na seara financeira, cujas recomendações emanadas de seus diversos comitês são largamente adotadas pelos bancos centrais nacionais, tendo ainda como membros associados mais de cinquenta bancos centrais ao redor do mundo, entre eles o Banco Central do Brasil. Mencione-se, no âmbito do BIS, o Comitê de Regulação e Supervisão Bancária (Comitê da Basileia) do qual emanam as prescrições contidas no conhecido "Acordo da Basileia", de 1988, depois ampliado em 2004, e ainda em 2010, após a crise internacional deflagrada em 2007, de modo geral harmonizando as regras sobre regulação sistêmica e prudencial, particularmente o estabelecimento de requisitos de patrimônio mínimo para as instituições bancárias, formas de quantificação dos riscos de crédito, liquidez, operacional e sistêmico etc. Há também o importante Comitê de Sistemas de Pagamentos e Compensações (Committee on Payments and Settlements Systems), cujas recomendações se encontram no relatório Core Principles for Systemically Important Payment Systems, constituindo o substrato dogmático para a reformulação dos diversos sistemas de pagamentos pelos bancos centrais nacionais, incluso o BCB (ESTRELA, 2011; YAZBEK, 2009). 
chamada de regulação sistêmica em função do risco de contágio em larga escala gerado pelas exterioridades da atividade bancária (risco sistêmico), envolve sobretudo a criação de redes protetivas ou de mecanismos de blindagem destinados à administração das crises ou à resolução de problemas, de modo a afastar a possibilidade de alastramento da crise bancária. Entre os elementos que em regra compõem o arsenal regulatório "protetivo", ou prudencial (senso largo), estão os regimes especiais de liquidação extrajudicial, mecanismos garantidores de pequenos depósitos, a organização do sistema de pagamentos e, sobretudo, as atividades do banco central como provedor de liquidez (prestamista de última instância) (COSTA, 1999; YAZBEK, 2009).

De fato, o envolvimento dos bancos centrais inspira confiança generalizada, reduzindo assim as possibilidades de que se desencadeie uma crise do sistema bancário. Não obstante, a demasiada confiança no apoio incondicional da autoridade monetária também enseja a assunção de maiores riscos (alavancagem demasiada) ou a redução dos mecanismos internos de controle dos riscos de crédito e liquidez, resultando no chamado "risco moral" (moral hazard). No intuito de minimizar esse efeito e assegurar a confiabilidade do sistema a partir da higidez dos que nele operam, a atividade regulatória se complementa por mecanismos outros, de caráter prudencial (em sentido estrito), direcionados especificamente à adoção de boas práticas na gestão dos negócios financeiros e na organização empresarial das instituições financeiras, entre elas a obrigatoriedade do envio de informações, a prática de certos atos e ainda o estabelecimento de limites operacionais (COSTA, 1999; PINHEIRO, 2005; YAZBEK, 2009).

Sem embargo das razões acima expostas, há uma verdade econômica velada, de fundo eminentemente sociopolítico, na qual assenta a atuação dos bancos centrais enquanto provedores de liquidez de última instância. Enquanto os bancos, como quaisquer outros credores, minimizam o risco de crédito ou liquidez, em última instância, o risco de quebra através do oferecimento de garantias, o papel do banco central, ao exigir garantias dos bancos em contrapartida aos empréstimos de liquidez, não se apresenta de forma plenamente coerente. Na realidade, os bancos centrais se transformaram não somente em prestamistas de última instância, mas sobretudo em fontes de novas reservas bancárias, de primeira e última instâncias, e pois concomitantemente em "bombeiros" dos refinanciamentos sempre que os bancos se envolvem em situações negociais oblíquas ou duvidosas. Assim, à guisa de exemplo, na hipótese de insolvência de um cliente bancário que seja devedor imobiliário, o banco em regra executa as garantias ou retoma o imóvel, 
tal como na alienação fiduciária em garantia de imóveis. Em franco contraste a essa atitude diante do crédito garantido, na hipótese de ameaça de insolvência bancária, em regra a primeira atitude do banco central não se dirige de modo nenhum à constrição das reservas bancárias. Ao contrário, antes se oferecem novos recursos sob determinadas condições de adequação gerencial ou patrimonial, de acordo com as normas de regulação prudencial, e pois normalmente caucionados em títulos de dívida pública, ou eventualmente outros papeis de alta liquidez e segurança, portanto garantidos por mais endividamento público. Se a hipótese de insolvabilidade se restringir apenas a um caso isolado, normalmente atua o regulador de modo mais expedito e enérgico, do contrário, ao se tratar de grandes bancos, ou de um contágio sistêmico, assumem as autoridades monetárias comportamentos que vão muito além da permissividade racional, no limiar do pânico. Nesse contexto, como questiona HUBER (2011, p. 69), não fazem nenhum sentido as garantias ofertadas pelo sistema bancário em troca de recursos das reservas bancárias (moeda de banco central) disponibilizados pelo prestamista de última instância.

Vale lembrar, portanto, uma clássica lição, antecipada anteriormente ao se analisar a contribuição wickselliana à análise monetária, qual seja a de que a organização moderna do crédito, centralizada no sistema bancário, tenderia na realidade à redução do risco, em razão de sua dispersibilidade espacial. Dessa forma, o elemento subjetivo do risco desapareceria proporcionalmente à grandeza da riqueza que venha a constituir a garantia do crédito (em relação ao montante concedido), restando apenas o risco matemático (WICKSELL, 1986, p. 205).

É justamente esse risco de ordem atuarial que fundamenta racionalmente os conceitos e paradigmas regulatórios anteriormente descritos, no intuito de assimilá-lo à incerteza, de modo a se prevenir "cientificamente" diante dessa com base em instrumentos para a gestão daquele. Sem embargo, frise-se que os chamados "modelos estocásticos" utilizados hodiernamente na análise de risco se traduzem no cálculo da probabilidade de ocorrência de um evento, cujo resultado se reduz matematicamente a uma "certeza equivalente". Desse modo, verifica-se que não há incerteza em senso estrito, vez que essa se diferencia do "risco calculável" na medida em que implica possibilidades não quantificáveis por meio do cálculo probabilístico, pois que a incerteza se refere fundamentalmente a processos cujos resultados futuros não são predeterminados, mas antes múltiplos e multifacetados. Nesse sentido, esclarece COSTA (1999, p. 68):

O mundo econômico sob inovações é não-estacionário, possui um 
"espaço amostral" que varia ao longo do tempo e impossibilita cálculo de probabilidades. Não há sentido em leis de probabilidade quando há um experimento crucial, isto é, um evento que altera as condições iniciais de maneira irreversível. Comportamentos divergentes, devido a previsões que não coincidem, resultam num futuro incerto, cujas probabilidades não podem ser medidas.

Essas observações, eminentemente técnicas, lastreiam de modo análogo o pensamento sociológico hodierno no que tange à sociedade de risco. No centro da modernidade estão justamente as "incertezas fabricadas". $\mathrm{Na}$ verdade, são riscos fabricados, enquanto resultado de "decisões humanas", criados pela própria sociedade no seu funcionamento, e pois potencializadores de incertezas futuras. Esses riscos, mundialmente fabricados, sejam como mudanças climáticas ou crises financeiras, se caracterizam sobretudo pela onipresença, portanto não se limitando geograficamente, pela sua não calculabilidade, tratando-se na realidade de riscos hipotéticos ou "virtuais", assentados em "incógnitas cientificamente induzidas e dissensos normativos”, e ainda pela sua intangibilidade, visto não ser controlável científica nem juridicamente através dos mecanismos tradicionais de compensação (p. ex., seguro privado) (BECK, 2011, p. 363).

A partir dos contornos expostos a respeito do risco sistêmico nos mercados financeiros, particularmente diante dos processos de inovação e integração financeiras, observa-se que a propalada "ameaça de insolvência" do sistema bancário assenta antes em riscos gerados pela própria atividade bancária, lastreada na política monetária internacionalmente aceita e fomentada. $\mathrm{O}$ risco de atividade, racionalmente controlável ou compensável, tal qual o risco de crédito, nada diz com o risco sistêmico de liquidez, em princípio probabilisticamente incontrolável e não compensável por mecanismos tradicionais. Trata-se antes de "incerteza de liquidez sistêmica". Diante da eventualidade dessa última, não mais se aplicaria a lógica tradicional da compensação, fundada na crença moderna de segurança do século XIX, e pois baseada na utopia científica de tornar os perigos de decisão e a álea cada vez mais controláveis, permitindo-se sua ocorrência na medida da possibilidade de sua compensação. O princípio que passa a reger essa nova modalidade de "risco fabricado" passa a ser o da precaução através da prevenção (BECK, 2011). Note-se, aliás, que essa lógica da prevenção se encontra claramente entre os pressupostos da regulação prudencial anteriormente referida.

Logo, o risco de iliquidez generalizada é antes produto da atividade e decisões dos 
sujeitos sociais, gerador de incertezas e vulnerabilidades sociais que tornam o funcionamento do sistema monetário mundial imprevisível, porém, como risco voluntariamente produzido, escapa à sua caracterização o conceito de ameaça, de cunho fundamentalmente naturalístico, e pois não raro utilizado para justificar racionalmente a plêiade de medidas regulatórias de caráter protetivo.

A crescente cientificidade das ameaças, riscos e incertezas criados no evolver do processo socioeconômico hodierno constitui ainda preponderante fator de fomento econômico, visível sobremaneira no desenvolvimento dos correspondentes setores econômicos como seja o financeiro, resultando todavia no aumento dos gastos públicos com a proteção desses ramos de atividade econômica. Dessa forma, a expansão e mercantilização dos riscos não rompem com a lógica capitalista do crescimento econômico, apenas a elevam a outro patamar. O fenômeno do risco é antes um grande negócio, e se traduz em termos econômicos em necessidades insaciáveis, gerando assim um processo de permanente escassez. Nesse sentido, como adverte BECK (2011, p. 28), com os riscos a economia se torna "autorreferencial", independentemente da satisfação das necessidades humanas. Essa canibalização econômica dos riscos gera naturalmente ameaças, cuja imprevisibilidade naturalística tem todavia sua fonte última no processo econômico e social institucionalizado. Assim, “em lugar das necessidades preestabelecidas e manipuláveis como marco referencial para produção de mercadorias, entra em cena o risco autofabricável" (BECK, 2011, p. 68).

Com efeito. Da mesma forma que o capital reproduz a si mesmo no âmbito das relações de produção na economia capitalista, também assim o riscos gerados nessa produção. Nesse sentido, do mesmo modo que as relações produtivas pressupõem relações de dominação (poder), também assim as relações de definição dos riscos. As relações de definição dos riscos se apresentam sob formas particularmente institucionalizadas, enquanto conhecimento técnico-científico, regulamentações e portanto instâncias institucionais encarregadas da identificação dos riscos presentes nos vários contextos da vida de relação. As relações de poder envoltas nas estruturas sociais de risco seguem a mesma lógica do risco, ou seja, a lógica do processo decisório. Desse modo, analogamente às decisões de alocação dos fatores produtivos, também as decisões de alocação de risco são fundamentalmente assimétricas no sentido de que residem no monopólio de decisão por parte dos detentores sociais desse poder, que definem e lucram com as atividades aleatórias independentemente da participação daqueles que sofrem, direta ou 
indiretamente, os efeitos colaterais dos riscos criados e alocados (BECK, 2011).

Verifica-se empiricamente a partir das decisões de definição e distribuição dos riscos gerados que há sobretudo uma superação "simbólica" do risco, fazendo-os antes aumentar a partir de sua própria superação. Na realidade, como todo o processo de domínio econômico, também a atividade de risco não pode ser extinta com sua superação, mas antes justificada a partir de sua aparente superação. Nesse sentido, toda ação de definição e alocação dos riscos, precipuamente normativa, institucionalizada, se processa sobretudo "cosmeticamente", como sejam os rótulos preventivos nas embalagens de mercadorias, os filtros purificadores, a fixação de coeficientes de risco entre o patrimônio líquido e o ativo ponderado pelo risco ("índice de Basileia"), exigência obrigatória de garantias em operações compromissadas de provisão de liquidez (em regra, "sem custo") etc. Observase assim que a referida "lógica da prevenção", precaucional, substituta da tradicional "lógica da compensação", só aparentemente "previne" contra a realização dos riscos, tratando-se na realidade de uma indústria e uma política apenas "simbolicamente" destinadas à superação da possibilidade de multiplicação dos riscos. Em verdade, os riscos “não devem ser superados em suas causas, em suas fontes" (BECK, 2011, p. 68) ${ }^{157}$.

Com efeito, "na produção de riscos, o capitalismo tardio absorveu, generalizou e normalizou a força destrutiva da guerra” (BECK, 2011, p. 68). A partir da lógica da guerra (luta), a destruição de modos produtivos possibilita a superação de níveis ou processos produtivos ultrapassados e a consequente expansão dos mercados, trilhando-se assim o caminho da conquista não só de novos mercados, mas engendrando ainda novas formas de

157 A título de exemplo, uma forma de superação definitiva dos riscos gerados pela oferta de moeda de crédito através do sistema monetário calcado no sistema de reservas bancárias (fracionárias), oferta monetária endógena ao funcionamento do mercado bancário, seria sua extinção e consequente estatização (plena) da emissão monetária, é dizer, a decretação do fim do multiplicador bancário de moeda (escritural), e pois da captação de depósitos em conta corrente, permanecendo a atividade bancária restrita à captação de depósitos a prazo com o fito de investimento financeiro, cientes os depositários dos riscos das aplicações, e pois retomando integralmente o Estado para si a senhoriagem, desonerando assim o Tesouro em razão da redução natural da emissão de dívida (títulos de crédito públicos) (HUBER, 2011). Tal medida resultaria essencial e efetivamente na mitigação, senão eliminação, do próprio "risco do regulador", pois que se lhe diminuiria radicalmente o ônus financeiro de provedor último de liquidez, desonerando ainda o próprio erário, na medida em que reduziria a retroalimentação do endividamento público através do sofisticado mercado de dívida pública mobiliária (apêndice justamente do mercado de reservas bancárias), cujos títulos obrigacionais em regra só fazem avultar o ativo dos próprios bancos centrais. A despeito do "quixotismo" dessa medida, encontra paralelo nas propostas de reservas integrais em cobertura dos depósitos bancários (reservas de 100\%), surgidas particularmente na atribulada década de 1930, tendo entre seus expoentes nada menos que o grande economista norte-americano Irving Fisher. Curioso apenas é recordar que no Brasil, ainda recentemente, por ocasião da implantação do Plano Real (1994), como medida de remonetização forçada da economia na nova moeda ou novo padrão que se criava, se estabeleceu, mas somente em curto prazo, a compulsoriedade de reservas bancárias integrais para os depósitos bancários à vista, tendo sido prevista, no entanto, sua redução gradativa nos anos subsequentes, como de fato ocorreu. 
mercado. A produção de riscos e seus agentes cognitivos constituem sobretudo "uma forma normalizada e sistemicamente imanente do revolucionamento das necessidades" (BECK, 2011, p. 68), necessidades essas, vale novamente frisar, reflexivas, autorreferenciadas ao processo econômico que as engendra concomitantemente com os riscos que produz, tornando-se portanto tema e problema a um só tempo.

Sem embargo do embate empreendido no processo expansivo do mercado, a despeito dos riscos gerados e consabidos, prevalece contudo a possibilidade sintomática de sua superação, ainda que fundamentalmente assentada no plano da simbologia. Nesse plano simbólico, onde atuam institucionalmente os supostos mecanismos de prevenção (p. ex., regulação prudencial), à lógica da guerra substitui a lógica do jogo. De forma sumariada, a luta pressupõe a eliminação do adversário, enquanto o jogo constitui um conflito basicamente administrado, segundo regras que permitem a preservação do adversário e a própria continuidade do jogo (GRAU, 2011).

Em analogia à concepção de GRAU (2011, p 156 e s.), o jogo do mercado, em particular o mercado financeiro, pressupõe a garantia de que se continue operando em bases especulativas fundamentalmente geradoras de risco, como suporte da expansão e criação de mercados financeiros, sem contudo que esse jogo alcance um término definitivo. Nesse diapasão, seu regramento (mediação cognitiva e institucional) se traduz em medidas paliativas e, portanto, sancionadoras do comportamento de risco à base da atividade sobretudo bancária. Desse modo, o mais forte nesse jogo são simplesmente os detentores do capital financeiro, seja na qualidade de titulares ou representantes dos titulares dos patrimônios financeiros, divisando-o a coletividade como um todo, sobretudo assalariada, representada pelos órgãos estatais que atuam na mediação, mas também no próprio jogo, como seja no mercado aberto de títulos de crédito públicos, presentando a coletividade pois que essa constitui em última instância o devedor final.

Esse jogo fundamentalmente arriscado, sob a hipótese cogitada por BECK (2011) de que a superação apenas fomenta a autopropagação dos riscos, jamais alcança seu derradeiro término, pois tem como premissa a vitória permanente daquele que o inicia, qual seja o capitalista financeiro (sistema bancário) ao qual cabe a prerrogativa do primeiro lance. Aos órgãos reguladores não compete participar da luta, cujo resultado já se conhece previamente, senão cooperar com o jogador mais forte. Trata-se de um peculiar "jogo da velha" (GRAU, 2011), regrado (regulamentado) de modo a conduzir à vitória do sistema financeiro, a despeito de preservar, em tese, os vencidos (sociedade e instituições) a partir 
da aplicação da lógica da prevenção.

As regras que ordenam esse jogo garantem a cada etapa do jogo, vale dizer, a cada ciclo econômico e seu débâcle, a contínua preservação da posição "parasitária" do vitorioso em relação ao vencido. "Tais regras consubstanciam o que na sociedade capitalista denominamos de direito" (GRAU, 2011, p. 157).

A sociedade capitalista é essencialmente jurídica na medida em que suas relações de produção são específica e necessariamente mediadas pelo direito. $\mathrm{O}$ direito moderno, estatal, é fundamentalmente o direito do modo de produção capitalista, cuja função básica é disciplinar os mercados, viabilizando a circulação econômica, e pois a preservação dos meios, o seu fim. "Nesse sentido, o Estado põe um direito definidor das regras de um jogo cujo fim ou cujos fins são externos a ele, porque definidos pelo indivíduo, que se vale de suas formas para realizar os seus fins" (GRAU, 2011, p. 311).

O mercado financeiro, fundamental ao funcionamento do capitalismo, senão seu próprio cerne atualmente (capitalismo financeiro), enquanto atividade de risco, pressupõe o ordenamento de suas próprias relações de produção, é dizer, de definição e distribuição desses riscos, cujo regramento ainda depende da estrutura tradicional do direito (moderno), ou seja, o direito posto pelo Estado. Não obstante, o direito do mercado financeiro, como seja a regulação financeira, constitui antes uma "ordem jurídica do mercado, engendrada pelo mercado", que não encontrará seu derradeiro fim enquanto todas as forças produtivas (riscos) a ela inerentes não despertarem, e pois se desenvolverem em sua plenitude. Em sua fase atual de desenvolvimento, a "exceção" faz a regra, ou seja, "a razão do mais forte", porém acobertada pelo direito estatal (GRAU, 2011, p. 327), o qual pressupõe a lógica (violência) do mercado, mas a transforma em regra do jogo, ou seja, em direito positivado $^{158}$.

158 Ilustre-se, entre nós, a criação do Fundo Garantidor de Crédito, em 1995, por meio de Resoluções do Conselho Monetário Nacional. Esse Fundo resulta basicamente num seguro patrimonial, constituído sob a forma de sociedade civil sem fins lucrativos, criada para administrar a garantia aos depósitos bancários em conta corrente, custeado, em princípio, pelas entidades financeiras participantes. Originalmente, a norma do art. 192 da Constituição Federal, de 1988, previa sua criação por Lei Complementar, vedando o aporte de recursos pela União. Não obstante, como mencionado inicialmente, sua criação ocorreu no âmbito do poder normativo da Administração, tendo ainda incluído na composição patrimonial do Fundo recursos públicos, sejam como o Fundo de Garantia de Depósitos e Letras Imobiliárias e a Reserva para Promoção da Estabilidade da Moeda e do Uso do Cheque. Interposta junto à Suprema Corte a competente ação direta de inconstitucionalidade (ADIn $n^{\circ} 1.398$ ), aquela Corte reconheceu cautelarmente a violação à reserva parlamentar, não obstante mantivesse os efeitos do instrumento normativo administrativo, sob pena de causar tumulto e insegurança entre os investidores, restringindo-se apenas ao mandamento de retirada dos recursos públicos aportados ao patrimônio do referido Fundo. Posteriormente, em razão da Emenda Constitucional n 40, de 2003, alterando a redação do art. 192 da Carta Magna, a citada ação perdeu seu objeto, reincorporando-se, novamente por decisão administrativa, aqueles recursos públicos ao 
Com efeito. A soberania constitui antes um espaço juridicamente vazio, do ponto de vista formal, indiferente às esferas da violência e do direito, onde predomina a exceção, entendida como possibilidade de determinação conteudística conforme as circunstâncias socioeconômicas e políticas locais. A soberania política tradicionalmente se condiciona pelo nomos que lhe subjaz (pressuposto de juridicidade, ou simplesmente "direito pressuposto"), formado sobretudo a partir das circunstâncias geo-históricas e socioculturais que a conformam e, assim, a legitimam. Em contrapartida, as forças globalizadas de mercado também lograram alcançar uma condição soberana face aos próprios Estados nacionais, porém, não encontram sua justificação última na política nem no direito territoriais, mas antes nas estruturas ônticas nas quais assentam, a saber, a tecnologia e a economia. A conjunção de ambos os fatores fornece o substrato fático de onde retira o sistema capitalista hodierno, mundializado, sua força normativa (nomos), portanto, sua legitimidade (supranacional). Essa força normativa do sistema (internacional) de mercado irrompe fronteiras adentro, penetrando nas estruturas institucionais soberanas, e pois delas se utilizando para estruturar sua própria ordenação jurídica, tornando lei o fato do mercado (GRAU, 2011, p. 314 e ss.) $^{159}$.

Nesse sentido, assevera AGUILLAR (1999, p. 271 e s.):

$\mathrm{Na}$ prática, há uma concorrência entre a política pública econômica oficial nacional e uma difusa política pública econômica internacional, uma queda de braço silenciosa, mas de efeitos dramáticos. Entre a política de fato e a de direito há uma disparidade permanente, sinalizando a relativização cada vez mais acentuada da soberania interna, da capacidade de cada Nação autonomamente ditar os seus próprios rumos econômicos. Se esse fenômeno não é novo na ordem mundial, pode-se dizer que ele nunca foi tão explícito, nem tão intenso como hoje.

A violência do mercado, por definição, exceptiva em relação ao direito, se apodera da estrutura jurídica soberana, colocando-a a serviço de seus fins, e pois tornando regra a exceção. Desse modo, a situação excepcional, a despeito de não estar contemplada

patrimônio do mesmo Fundo (DURAN, 2012, p. 227, n. 361).

159 De fato, os países periféricos, incluam-se atualmente vários países europeus, em regra estão expostos à volatilidade dos mercados financeiros internacionais, em última instância, dependem de ajuda financeira internacional, concedida normalmente pelo Fundo Monetário Internacional. Ressalte-se ainda que as políticas de juros dos grandes bancos centrais, em particular da Reserva Federal norte-americana, são decisivas para a orientação das políticas econômicas do restante do sistema capitalista. Não raro se espera ansiosamente pela divulgação das taxas de juros a serem praticadas nos EUA, na medida em que determinam o sentido do fluxo financeiro mundial, portanto, o comportamento dos mercados financeiros locais (AGUILLAR, 1999). 
previamente pelas normas do direito posto, há de ser por esse coerentemente regrada, ainda

que ao se lhe aplicar à exceção, resulte dessa última a própria construção da norma aplicável $^{160}$.

160 A recente crise financeira internacional, desencadeada a partir de 2007, fornece um repertório nada desprezível de regulação financeira conjuntural, senão "emergencial", que se traduz essencialmente em medidas jurídicas de exceção. As autoridades monetárias dos países centrais, particularmente o Banco Central Europeu e a Reserva Federal norte-americana, basicamente dilataram os prazos de refinanciamento das reservas do sistema bancário, ampliaram o rol das contrapartes em suas operações de provisão de liquidez e ainda alargaram a gama de ativos normalmente aceitos em caução de suas operações compromissadas. Ademais, o banco central norte-americano celebrou contratos de swap cambial com diversos bancos centrais, entre eles o Banco Central Europeu e o Banco Central do Brasil, garantindo a liquidez em dólar para diferentes mercados financeiros, além da medida inédita de pagamento de juros sobre os depósitos compulsórios dos bancos comerciais. Através dessas medidas nada convencionais, discrepantes das medidas de política monetária tradicionais, como as operações de redesconto e as compromissadas sob a caução de títulos públicos de elevada liquidez, os bancos centrais mundo afora simplesmente adotaram a prática de intervenção direta nos mercados de crédito e títulos, dando suporte à liquidez dos mercados secundários pela aquisição de títulos obrigacionais de toda a sorte e qualidade, dando azo finalmente à temerária expansão de seus balanços patrimoniais sob a garantia direta do erário (Tesouros nacionais), na medida em que assumiam riscos típicos de mercado. Nesse sentido, ao final de 2008, a Reserva Federal norte-americana e o Banco Central Europeu haviam respectivamente triplicado e duplicado seus ativos. No Brasil, entre junho e novembro de 2008, foram editadas três Medidas Provisórias pelo Executivo, posteriormente convertidas em leis ordinárias (Leis ns. $11.803,11.882$ e 11.908 , de 2008), as quais facultam ao BCB o uso de instrumental invasivo, tanto no mercado como no erário, contemplando, entre outras, a possibilidade de utilização das reservas internacionais para empréstimos em moeda estrangeira às instituições financeiras em dificuldade e ampliação do rol de ativos caucionáveis em operações de liquidez, além de autorizarem a União à emissão de dívida pública mobiliária para a recomposição do balanço patrimonial do $\mathrm{BCB}$, cujos títulos poderão ser utilizados pela autarquia em operações de mercado aberto, ou seja, compromissadas para refinanciamento das reservas bancárias dos bancos comerciais. Com efeito, os pactos de retrovenda celebrados pelo BCB no mercado interbancário tiveram um aumento da ordem de $\mathrm{R} \$ 155$ bilhões no ano de 2008 (passivo), correspondente à ampliação de seu ativo em aproximadamente 43\% no mesmo exercício, dos quais $\mathrm{R} \$ 135$ bilhões em títulos públicos federais, de longo prazo, emitidos de acordo com o art. $5^{\circ}$ da Lei 11.803 , de 2008. Nesse mesmo diapasão, o BCB interveio no mercado de derivativos cambiais de modo a assegurar a liquidez em moeda estrangeira, garantindo assim a cotação cambial em patamar compatível com a cobertura das posições contratuais em aberto das tesourarias de bancos e sobretudo de empresas privadas não financeiras que especulavam nesse mercado. Acrescente-se que o Fundo Garantidor de Crédito, em princípio apenas garante dos depósitos bancários em conta corrente, também foi autorizado à época, por decisão do Conselho Monetário Nacional, à aquisição de carteiras de crédito e de certificados de depósitos bancários das instituições participantes, tendo ainda resolvido o mesmo Conselho sobre a criação do depósito a prazo com garantia especial, autorizando o mesmo Fundo à garantia de até $\mathrm{R} \$ 20$ milhões aos titulares desses depósitos lastreados em títulos de emissão das instituições depositárias, conforme as Resoluções CMN ns. 3.656, de 2008, e 3.692, de 2009, respectivamente. Ressalte-se ainda que o art. 192 da Constituição Federal veda a adoção de Medidas Provisórias na regulamentação do Sistema Financeiro Nacional, senão que exige lei complementar para o tratamento da matéria (DURAN, 2012, p. 223 e ss.). 
IV O SISTEMA DE PAGAMENTOS BRASILEIRO E O CÓDIGO CIVIL

\section{Noções fundamentais}

A eficiência da economia está indissociavelmente atrelada à velocidade e segurança dos negócios da circulação, e pois dos pagamentos que os liquidam. Como anteriormente delineado, as instituições financeiras, em particular os bancos, "centralizam a maior parte dos recursos movimentados na economia, tanto para guarda, quanto para aplicações e pagamentos diversos" (VERÇOSA, 2005, p. 221), independentemente aliás do processo de desintermediação financeira (COSTA, 1999).

Nesse sentido, entende-se por sistema de pagamentos

o conjunto de instrumentos por meio dos quais são efetuadas as transferências de valores e de outros ativos financeiros em razão de quaisquer operações econômicas. De um modo geral, as contratações realizadas entre agentes econômicos tendem a, em um determinado momento, refletir-se em transferências interbancárias, pela movimentação de reservas. Em caso de insolvência ou de atraso por uma instituição, a instituição beneficiária pode sofrer, também ela, problemas de liquidez, não conseguindo cumprir suas obrigações perante terceiros - o problema pode se alastrar, atingindo outras instituições e, em última instância, mesmo os clientes destas. É nos sistemas de pagamentos que fica mais evidente a interligação entre as diversas modalidades de risco, quando os riscos operacionais ou legais transformam-se em atrasos, postergações ou inadimplementos e quando os riscos de crédito e de liquidez assumem, mais flagrantemente, uma dimensão sistêmica (YAZBEK, 2009, p. 240).

Cumpre novamente frisar que as redes de pagamentos permitem aos bancos a transferência mútua de fundos de modo a compensar inúmeros acordos de câmbio em moeda estrangeira ou valores mobiliários. Até o início do presente século, muitos dos grandes sistemas gerais de pagamentos ou compensações ainda funcionavam à base da liquidação por diferença, ou seja, o sistema informacional acompanhava ao longo do dia a posição líquida de cada banco envolvido nos negócios celebrados, efetuando-se ao final do dia a compensação por diferença, transferindo assim a quantia devida da conta de reservas junto ao banco central (sistema público de pagamentos) ou da conta de liquidação junto à câmara de compensação (sistema privado) para a conta da contraparte bancária. Na 
hipótese de que algum participante não honrasse sua obrigação de pagamento, corria-se o risco de uma corrente de inadimplementos ao longo do sistema (risco sistêmico).

Essa forma de funcionamento dos sistemas de pagamentos resultaram em movimentos articulados, sobretudo a partir da década de 1990, no âmbito dos organismos monetários internacionais no sentido de que os bancos centrais nacionais implantassem, ainda que a elevados custos, sistemas de pagamentos em tempo real. Observe-se que a liquidação imediata dos grandes negócios interbancários, ao se utilizar das disponibilidades junto ao banco central (contas de reservas bancárias) do país-sede da instituição devedora, reduziria o risco sistêmico, pois, em caso de falência do banco devedor, esse estaria pouco endividado em relação a outros bancos.

Ressalte-se ainda que os montantes devidos no mercado interbancário superam não raro as bases de capital dos bancos que nele atuam. É mister que se retenha, particularmente em tempos de acentuada "desmaterialização" tanto da moeda como dos títulos de crédito em geral, que muitas vezes não se sabe ao certo quem são os devedores nem o que se deve, sobretudo em razão de constituírem os sistemas de pagamentos basicamente uma cadeia de fluxos financeiros (SCHUMPETER, 1964b), cuja extraordinária complexidade resulta em inúmeras interdependências de crédito. Em razão dessa "opacidade", bem como do vulto das exposições creditícias envolvidas, se potencializa o risco de contaminação do sistema de pagamentos, em última instância, da rede bancária (COSTA, 1999).

Outro fator determinante da gravidade de uma ameaça sobre o sistema bancário se traduz na extensão das conexões entre as instituições financeiras envolvidas. Na hipótese de o banco sob ameaça ser um grande agente num mercado específico, um prestamista de vulto a outros bancos, ou ainda um importante elo no sistema de pagamentos, o banco central deverá atuar sob pressão política e social, no sentido de evitar a escalada de tensão em torno da possível quebra de um banco que tenha em sua carteira de passivos quase a totalidade do patrimônio financeiro de milhares de clientes (COSTA, 1999).

Dessarte, considerando a possibilidade de saques generalizados (corrida bancária), sobretudo em razão da deflagração de processos deflacionários, dinamizados pela atualmente extremada integração, e consequente volatilidade dos mercados financeiros, novos e acentuados riscos surgiram a partir da reestruturação monetária internacional, justificando assim de modo amplo a atividade regulatória no âmbito dos Estados nacionais, legitimada sob a égide de diretivas emanadas dos organismos monetários internacionais, 
verdadeiros detentores do atual poder normativo de cunho tecnoeconômico (GRAU, 2011). A partir desses pressupostos normativos, reestruturam-se os sistemas de pagamentos sob novos princípios, basicamente direcionados à "prevenção pela precaução" (BECK, 2011, p. 68), atendendo assim à chamada regulação do risco sistêmico.

A esse respeito, assevera YAZBEK (2009, p. 231) ser a regulação sistêmica "implementada a partir da criação de uma "rede de proteção" para o sistema financeiro, destinada a impedir a ocorrência daquelas exterioridades relacionadas ao alto grau de integração entre as instituições, sobretudo no caso das instituições bancárias". Entre os mecanismos normalmente relacionados a essa regulação, destacam-se:

a criação de regimes excepcionais de intervenção e de liquidação de instituições, no lugar dos procedimentos típicos de reorganização e de quebra; a criação de fundos ou seguros garantidores de créditos; $a$ organização do sistema de pagamentos, com a outorga de mecanismos impeditivos do alastramento de crises [grifo nosso]; e a atuação do banco central como provedor de liquidez do sistema (YAZBEK, 2009, p. $232)^{161}$.

Prosseguindo no entendimento do atual nomos financeiro, a estabilidade do sistema financeiro exige uma regulamentação e estruturação dos sistemas de pagamentos no sentido de promover a solidez e eficiência das movimentações financeiras, permitindo ainda a redução dos custos das operações financeiras, a utilização eficiente dos recursos financeiros, a melhoria da liquidez do mercado financeiro e ainda a eficácia da política monetária (YAZBEK, 2009).

Sob o prisma da mundialização dos sistemas financeiros, e pois dos organismos que compõem o sistema monetário internacional, assevera ainda YAZBEK (2009, p. 240) que

A discussão sobre a matéria é recente, porém. Desde o início da década de 1990 o Committee on Payment and Settlement Systems do Bank for International Settlements, vem tratando da matéria, sendo que, até o presente momento, diversos países (dentre os quais o Brasil) adotaram as

161 Ainda segundo YAZBEK (2009, p. 232), "a regulação sistêmica se funda, no Brasil, na obrigação do CMN [Conselho Monetário Nacional] de implementar políticas que objetivem "zelar pela liquidez e solvência das instituições financeiras", conforme constante do art. $3^{\circ}$, VI, da Lei $n^{\circ} 4.595 / 1964$, assim como nas demais atividades a ele outorgadas. O BCB [Banco Central do Brasil], por sua vez, leva a efeito, na prática, a regulação sistêmica. Vez que tal modalidade de regulação diz respeito, fundamentalmente, à atuação dos bancos e à integridade dos fluxos de pagamentos, esta última autarquia acaba se afigurando como o regulador sistêmico por definição". 
recomendações dos Core Principles for Systemically Important Payment Systems (Bank for International Settlements, 2001), reestruturando seus sistemas de pagamentos. Tais princípios versam, de um modo geral, sobre a base legal adequada para o sistema de pagamentos, os riscos com que se defrontam as instituições financeiras e as formas de administrá-los e também sobre as regras, procedimentos e mecanismos para a criação e proteção de salvaguardas, regimes de contingências etc. O BCB [Banco Central do Brasil] iniciou as discussões para a reformulação do regime então vigente como uma forma de dar prosseguimento à reestruturação do Sistema Financeiro Nacional, fruto da estabilização econômica decorrente do Plano Real (...).

Nada obstante as observações anteriores, é mister se ressaltar que sua fundamentação teórica e ideológica é muito anterior aos estudos técnicos mencionados. Observe-se que MISES (2005), um dos ícones do neoliberalismo, já asseverava, em 1924, a grande importância da organização do sistema de pagamentos, particularmente através das caixas de liquidação, no sentido de se efetivar a redução da demanda por dinheiro em geral $^{162}$.

Com efeito. MISES (2005, p. 291 e ss.) pretendia demonstrar que a redução da procura por liquidez plena, ou seja, moeda restrita, particularmente moeda de curso legal ou depósitos nela lastreados, poderia ser efetivada pela expansão do uso dos sistemas gerais de compensação, alargando-se assim o uso da moeda escritural e outros valores mobiliários (instrumentos de crédito bancário), na medida em que esses últimos naturalmente substituiriam a moeda restrita (dinheiro estatal) no âmbito predominantemente escritural dos sistemas de liquidação por compensação ${ }^{163}$.

162 Assim, MISES (2005, p. 291): "Das Abrechnungssystem ist die wichtigste Institution zur Herabminderung des Geldbedarfes im weiteren Sinne”. Como anteriormente esboçado, entende o referido autor por dinheiro (senso largo) tanto a moeda corrente, e pois os efetivos depósitos bancários nela lastreados (depósitos em sentido estrito, sem criação de moeda bancária), como ainda sua substituta (moeda privada), de emissão bancária ou não, traduzida nos diversos meios de pagamento: moeda escritural ou de crédito, ou ainda valores mobiliários em geral, em última instância, instrumentos de circulação econômica (ou de crédito) (Umlaufsmittel) (MISES, 2005, p. 282).

163 Frise-se novamente que o papel central na teoria monetária da "escola austríaca", no sentido radicalmente neoliberal, cabe não só à procura por moeda (Geldbedarf), mas também à existência da moeda substituta (Geldsurrogat), em particular os instrumentos de crédito (Umlaufsmittel), de natureza eminentemente privada. Nesse sentido, o desenvolvimento da moeda substituta por meio da técnica bancária, paralelamente à criação de sistemas centralizados de liquidação (caixas de liquidação), resulta na diminuição generalizada da procura de dinheiro em sentido estrito (espécie e recebíveis), bem como no decréscimo da demanda por dinheiro em sentido largo (espécie e certificados bancários), na medida em que o sistema econômico de trocas se processa sem a utilização do dinheiro em espécie ou de seus substitutos. Dessa forma, verifica-se uma tendência à descompressão do valor objetivo de troca (poder de 
Outrossim, advogava a internacionalização dos sistemas de pagamentos, evitando assim os custos de transferência de fundos, a perda de juros e os riscos envolvidos. Desse modo, na hipótese de o sistema de compensações poder ser processado além das fronteiras soberanas, especialmente por meio de uma organização internacional para a transmissão de títulos de crédito e ordens de pagamento, tanto o meio circulante privado (moeda creditícia) como quaisquer outros substitutos do dinheiro poderiam prevalecer internacionalmente, desde que se criasse um banco mundial (Weltbank) de desconto, e pois emissor de instrumentos de crédito internacionais (moeda escritural) (MISES, 2005, p. 298 e ss.).

Ainda no sentido de privilegiar a circulação da moeda privada, outro ícone neoliberal, a saber, HAYEK (2011) funda no interesse privado, não na "benevolência" estatal, a legitimidade da moeda enquanto meio de troca geralmente aceito. Se a qualidade (valor) do dinheiro tem sido ruim ao longo do história monetária, gerando processos inflacionários, e dessarte cada vez mais sujeito ao controle estatal através de políticas monetárias, é porque a empresa privada não teve a permissão de fornecer à sociedade um dinheiro melhor, resultado da livre competição bancária, portanto, do interesse na manutenção do lucro privado na emissão monetária. Não foi assim o capitalismo, mas sobretudo a intervenção estatal, o principal responsável pelas repetidas crises monetárias $^{164}$.

No Brasil, a partir de 1994, com o advento do Plano Real e a normalização das relações financeiras internacionais, graças à renegociação da dívida externa (Plano Brady), acentuou-se consideravelmente o afluxo de capitais internacionais tanto a título de empréstimos como de investimentos. Após a eclosão da crise financeira mexicana, introduziu-se o regime monetário de bandas cambiais, ao lado de um sistema de controle de fluxos de capital de curto prazo. A partir de 1997, a taxa de câmbio assumiu o papel de âncora da estabilização. Desse modo, sujeitava-se a política monetária às amarras do cupom cambial, ou seja, limitava-se a manter elevadas taxas de juros no sentido de atrair

compra) do dinheiro no sentido de compensar o grande aumento da demanda por moeda (senso largo) em razão do contínuo progresso da economia de mercado. O sistema de crédito e o refinamento da técnica bancária resultam, portanto, no aumento da elasticidade dos meios de pagamento, em particular dos instrumentos creditícios, equalizando oferta e demanda monetárias sem influir nas relações de troca entre mercadorias e dinheiro, portanto, no nível de preços (MISES, 2005, p. 302 e ss.)

164 Tecnicamente, a emissão privada de moeda não distingue entre o que é ou não dinheiro, sendo antes a norma legal que o faz arbitrariamente. O que caracteriza um objeto (ativo) como dinheiro é sobretudo seu grau de liquidez, formando os diversos ativos assim dotados uma espécie de continuum. Na realidade, o dinheiro é antes um "adjetivo" do que um "substantivo", pois que qualifica os diferentes objetos assim utilizados, em graus diversos (HAYEK, 2011, p. 66). 
capitais externos, e pois possibilitando a conservação da taxa de câmbio dentro do intervalo de flutuação fixado. Para o bom funcionamento dessa política, era mister a manutenção do afluxo ilimitado de divisas, subtraindo-se assim quaisquer resistências internas. Não obstante, as circunstâncias internacionais minaram as linhas de defesa interna da moeda, a saber, as crises asiática (1997) e russa (1998). Devido sobretudo à moratória russa, a manutenção da âncora cambial se tornou insustentável. Em 1999, a despeito de contar com substancial auxílio internacional para a sustentação do regime cambial, o país abandona a âncora cambial e adota o regime de câmbio flutuante, corolário natural da opção pela liberdade de fluxos de capitais concomitantemente à independência da política monetária, e pois restando o câmbio determinado pelas variações do estoque de moeda, ao sabor do fluxo de capitais internacionais (MOURA, 2000). Nesse contexto, portanto, projetou-se a reestruturação do Sistema de Pagamentos Brasileiro.

\section{Panorama do Sistema de Pagamentos Brasileiro (SPB)}

Desde o final da década de 1980, a questão em torno do risco em sistemas de pagamentos tem sido objeto de indagações por parte dos organismos financeiros internacionais, a exemplo do Banco de Compensações Internacionais (BIS), do Fundo Monetário Internacional, do Banco Internacional para a Reconstrução e Desenvolvimento e dos grandes bancos centrais nacionais.

O Brasil, em particular, buscou dar vazão a esse substrato normativo internacional, adequando a estrutura do seu sistema de pagamentos ao gerenciamento de riscos, de modo a corresponder não só às realidades e demandas internas, mas sobretudo à almejada integração dos mercados financeiro e de capitais no âmbito da mundialização dos interesses econômicos e financeiros.

As principais diretrizes para a reestruturação foram lançadas pela diretoria colegiada do Banco Central do Brasil, através do Voto BCB 214, de 1999. Nele restaram assentadas as características fundamentais que o sistema de pagamentos deveria revestir, observadas as recomendações e práticas internacionais, entre elas as que se encontram no relatório produzido pela Força Tarefa para Práticas e Princípios em Sistemas de Pagamentos, formada pelo Comitê de Sistemas de Pagamentos e Liquidação do BIS. Daí surgiu a decisão de se estabelecer uma sólida base legal e regulamentar, capaz de garantir irreversível e incontestavelmente a satisfação dos compromissos assumidos nos mercados financeiro e de capitais, "mesmo em caso de o obrigado ver-se assujeitado a regimes de 
execução concursal, judiciais ou administrativos” (AGUIAR JÚNIOR, 2001, p. 52).

Com efeito. O mercado financeiro opera em rede, de modo que antes da criação do SPB as instituições financeiras realizavam operações interbancárias de crédito, financiando a si mesmas, geralmente em cadeia, elevando o grau de risco sistêmico em caso de quebra de uma delas (VERÇOSA, 2005).

Também nesse sentido leciona YAZBEK (2009, p. 241):

Até a efetiva implantação do Sistema de Pagamentos Brasileiro, o BCB assumia os riscos em última instância das atividades bancárias ao promover a movimentação de reservas mesmo quando a instituição solicitante não dispunha de fundos, de modo a evitar a transformação de algum problema de liquidez em uma eventual crise. Neste caso, a instituição ficava com a sua conta Reservas Bancárias negativa até que cobrisse o valor faltante (o que usualmente se dava ao final do dia).

Em razão daquela posição pragmática do $\mathrm{BCB}$, não são raros os casos de instituições que foram liquidadas com as suas reservas negativas, hipótese em que a autarquia, por haver concedido crédito, tornava-se credora quirografária, precisando habilitar-se perante a massa liquidanda. Era inequívoca, também aqui, a existência de moral hazard, vez que o $\mathrm{BCB}$ de certa forma garantia a priori todas as operações realizadas, assim como a própria liquidez do mercado.

De fato, o BCB não possuía um sistema de transferências interbancárias de fundos com liquidação bruta em tempo real e as câmaras e os prestadores de serviços de compensação e liquidação (clearing houses, ou apenas clearings - caixas de liquidação) não dispunham de instrumentos de controle e gerenciamento de riscos que pudessem garantir a liquidação das operações realizadas em seus sistemas. Além disso, não havia uma base legal adequada que pudesse evitar o risco de crédito e de liquidez.

No intuito de eliminar a situação descrita, necessário seria o trancamento do mecanismo indireto de assistência automática, exigindo-se assim que as instituições financeiras mantivessem as suas contas com saldo sempre positivo ou, ao menos, zerado. Não obstante, essa medida implicaria sobretudo a redução da liquidez do mercado financeiro. Nesse sentido, elaborou-se a Medida Provisória $\mathrm{n}^{\mathrm{o}}$ 2.008, de 1999, sucessivamente reeditada, e finalmente convertida na Lei $\mathrm{n}^{\mathbf{0}}$ 10.214, de 2001, fundamentando-se legalmente a organização do Sistema de Pagamentos Brasileiro, por meio do qual se erigiram as câmaras e os prestadores de serviços de compensação e de 
liquidação (clearings) em coadjuvantes do sistema financeiro nacional, particularmente aquelas cujas operações passaram a ser consideradas sistemicamente importantes, portanto capazes de gerar risco sistêmico (AGUIAR JÚNIOR, 2001; YAZBEK, 2009).

Sob o prisma institucional, o Conselho Monetário Nacional (CMN), órgão de cúpula do Sistema Financeiro Nacional (SFN), tem entre seus objetivos "propiciar o aperfeiçoamento das instituições e dos instrumentos financeiros, com vista à maior eficiência do sistema de pagamentos e de mobilização de recursos", devendo ainda "zelar pela liquidez e solvência das instituições financeiras" (art. 3º, V e VI, da Lei n 4.595, de 1964).

Assim, no intuito de cumprir os objetivos de sua política ao exercer suas atribuições legais, o CMN

há de estabelecer regras capazes de responder prontamente aos anseios de aprimoramento de um mercado financeiro e de capitais totalmente seguro no que concerne ao adimplemento das obrigações oriundas dos negócios jurídicos neles celebrados (ou seja, que praticamente eliminem os riscos de liquidez e de crédito). É que a introdução de regras que tais no ordenamento jurídico favorece uma redução significativa, senão drástica, da possibilidade de ocorrência de uma crise sistêmica, que, como se sabe, sempre termina por representar grave comprometimento do interesse público, com indesejáveis desdobramentos de ordem política, econômica, financeira e, no fundo, também social (AGUIAR JÚNIOR, 2001, p. 54).

Observe-se que o CMN exara as normas regulamentares, de caráter geral e relativa permanência, sobre o SPB. Por outro lado, compete ao Banco Central do Brasil (BCB) o cumprimento das disposições legais em vigor e das normas emanadas do CMN (Lei $n^{\circ} 4.595$, de 1964, arts. $9^{\circ}$ e 10, IX). Em razão de a operacionalização técnica exigir maiores detalhamentos e, portanto, maior flexibilidade quanto a eventuais modificações e ajustes, deixa o $\mathrm{CMN}$ “que as regras jurídicas a respeito sejam traçadas pelo Banco Central do Brasil e pela Comissão de Valores Mobiliários, assegurada a coordenação de esforços entre ambas as autarquias" (AGUIAR JÚNIOR, 2001, p. 55).

O SPB, na definição de AGUIAR JÚNIOR (2001, p. 55), é um sistema preordenado à liquidação de obrigações contraídas no âmbito dos mercados financeiro e de capitais. No que tange a estas obrigações, que se entrelaçam com muitas outras, formando uma verdadeira cadeia de trocas, o pagamento é momento jurídico crítico 
[grifo nosso]: se ocorre em relação a uma delas, será possível honrar as demais, que dependem de seu adimplemento; se não ocorre, a câmara ou o prestador de serviços de compensação e de liquidação adota as providências necessárias e suficientes a que o ativo ou a importância devida seja entregue ao participante, evitando, assim, a deflagração de uma crise sistêmica.

O desenvolvimento e a sustentação dos mercados financeiro e de capitais dependem, em última instância, da credibilidade quanto a seu funcionamento (pressuposto político e normativo). Nesse contexto se desenvolveram ao longo do tempo as câmaras (caixas) de liquidação e custódia (clearings), ou seja, sociedades (departamentos ou sistemas) cujo objeto é a prestação de serviços relacionados à liquidação de obrigações contrapostas entabuladas entre determinados sujeitos que dela participarem, colocando-se como pagadora de cada recebedor e recebedora de cada pagador, ou seja, como contraparte de todos os participantes.

Em princípio, qualquer bem ou direito pode ser objeto de liquidação no âmbito de uma clearing. O SPB, por sua vez, também contempla uma série de caixas de liquidação segmentadas por objeto negociado, como será examinado mais adiante.

Observe-se ainda que qualquer entidade pode ter por objeto a liquidação de obrigações geradas por negócios realizados entre pessoas a ela associadas. No entanto, o legislador e os órgãos regulamentares têm autonomia para indicar quais câmaras de liquidação são sistemicamente importantes, conferindo-lhes um estatuto diferenciado.

Os sistemas de liquidação visam precipuamente (i) à liquidação financeira das operações, referente ao pagamento dos valores monetários devidos em razão do negócio financeiro celebrado (bancária ou bursátil); (ii) à liquidação física, quando cabível, caracterizada pela entrega efetiva dos ativos negociados (não obstante, essa entrega seja marcada sobretudo pela imaterialidade de caráter escritural); e (iii) ao gerenciamento dos níveis de garantias das operações realizadas.

Com efeito, dispõe o art. $2^{\circ}$ da Lei $n^{\circ} 10.214$, de 2001, que o SPB compreende as entidades, os sistemas e os procedimentos relacionados com a transferência de fundos e de outros ativos financeiros, ou com o processamento, a compensação e a liquidação de pagamentos em qualquer de suas formas. De acordo com o $\S$ único e incisos ao mesmo artigo, integram esse sistema, além do serviço de compensação de cheques e outros papeis, os seguintes subsistemas: I - de compensação e liquidação de ordens eletrônicas de débito 
e de crédito; II - de transferência de fundos e de outros ativos financeiros; III - de compensação e de liquidação de operações com títulos e valores mobiliários; IV - de compensação e de liquidação de operações realizadas em bolsas de mercadorias e de futuros; e V - outros, inclusive envolvendo operações com derivativos financeiros, cujas câmaras ou prestadores de serviços tenham sido autorizados na forma deste artigo.

\section{Princípios fundamentais do SPB}

Os sistemas de compensação e liquidação são fundamentais para o bom funcionamento da economia, na medida em que através do sistema de pagamentos se interligam o setor real da economia, as instituições financeiras e o banco central. Como anteriormente mencionado, a busca por sua eficiência tem sido objeto constante de estudos e proposições emanados de organismos internacionais, em especial do Bank for International Settlements (BIS), estabelecendo-se normas e princípios a esse respeito (BIS, $1992,2001)^{165}$. Na sequência, portanto, se expõe o nomos financeiro internacional que fundamenta a estrutura legal do SPB.

Diante da possibilidade de que um distúrbio nos sistemas de liquidação de transações com títulos possa ocasionar um colapso no mercado financeiro em geral, propagando-se para o setor real da economia, os bancos centrais têm se empenhado em fortalecer os dispositivos de compensação e liquidação de títulos e fundos, verificando-se, ainda, uma tendência de se harmonizar e aprimorar os sistemas de liquidação de títulos públicos e privados.

Os sistemas de compensação e liquidação de títulos são projetados de forma a minimizar os riscos inerentes às respectivas operações. Dos vários princípios para o projeto e operação de sistemas de pagamentos, a entrega contra pagamento recebeu ampla aceitação (BIS, 1992, 2001). Esse princípio tem por objetivo a redução ou eliminação do risco de crédito, ou seja, que o vendedor não receba o pagamento ao entregar o título, ou que o comprador pague pelo título e não o receba. Considera-se o risco de perda do valor da transação, total ou parcial (risco do principal ou principal risk), como o principal fator de potencialização do risco sistêmico, isto é, o risco de que a insolvência de uma

165 As diversas medidas contidas nesses projetos de estruturação dos meios de pagamento se referem originalmente ao chamado Relatório Lamfalussy, publicado pelo Comitê de Sistemas de Pagamento e Liquidações do Banco para Compensações Internacionais (BIS) da Basileia, em 1990 (SALOMÃO NETO, 2007, p. 244, n. 163). Recordando, apenas, que se trata do nome do antigo diretor dessa instituição, o Sr. Alexandre Lamfalussy, nome tantas vezes mencionado nos diversos relatórios e recomendações resultantes do assim chamado "consenso de Washington". 
instituição participante seja transferida para outras instituições, ocasionando instabilidade no sistema de pagamentos como em todo o sistema financeiro.

\subsection{As etapas}

Conforme estudo do BIS (1992), o processo de compensação e liquidação envolve as seguintes etapas: a) o casamento dos termos da negociação com o cálculo das obrigações das contrapartes (compensação); b) a baixa dessas obrigações (liquidação) mediante a transferência definitiva de títulos (entrega) e fundos (pagamento). O estudos dessas etapas permitirá o exame da natureza e das fontes de risco a que o operador e outros participantes do sistema de liquidação estão expostos.

O processo de compensação e liquidação de títulos se origina de uma negociação. As negociações são realizadas através de bolsa de valores, cujo ambiente é centralizado e de livre apregoação, ou do mercado de balcão, em que os participantes negociam entre si por meio de telefone ou sistemas eletrônicos (ANDIMA, 2002). Em seguida à negociação, realiza-se o casamento ou comparação de negociação ou, ainda, verificação de negócio, visando assegurar que as contrapartes concordam com os termos da negociação, tendo-se em conta o título envolvido, o preço, a data de liquidação e a contraparte. Em sistemas automatizados, em regra, as contrapartes acordam que os negócios sejam liquidados conforme registrados no momento de sua execução. Em outros sistemas de execução de negociações, a verificação do negócio é efetuada por uma bolsa, uma entidade de compensação ou ainda pelo sistema de liquidação. Os participantes diretos do mercado efetuam negociações por conta própria e também por conta de clientes. No caso de negócio por conta de clientes, pode-se solicitar aos participantes diretos do mercado que notifiquem a seus clientes, ou aos agentes desses, sobre os detalhes da negociação, a fim de que esses possam efetuar a confirmação do negócio. Cabe salientar que existem sistemas automatizados que não permitem que haja distinção entre contrapartes, não sendo possível a escolha entre diferentes contrapartes com base nas diferenças de risco de crédito de cada um dos participantes.

A etapa seguinte é a compensação, ou seja, o cálculo das obrigações das contrapartes para a efetivação de entregas ou pagamentos na data da liquidação. As obrigações decorrentes de negócios com títulos são muitas vezes reunidas e utilizadas para a apuração de saldos. Realizadas de diversas formas, as apurações de saldos precisam estar revestidas de eficácia legal para não gerar riscos potenciais no caso de falência de uma das 
partes, mantendo, assim, a credibilidade do sistema. Saliente-se que os sistemas de apuração de saldos são escolhidos de acordo com o volume de negócios e a característica de mercado, de modo que os benefícios assim propiciados compensem os custos. As obrigações dos participantes podem ser calculadas em bases brutas, líquidas bilaterais ou líquidas multilaterais.

Na sequência, as contrapartes transmitem instruções de transferência de títulos e fundos (recursos) à entidade ou entidades que operam o sistema de liquidação. Essas instruções podem ser transmitidas pelas contrapartes ou por uma bolsa ou por um sistema de compensação.

Atualmente, as transferências ocorrem cada vez mais de forma escritural, sendo cada vez menos frequente a movimentação física de certificados. Utilizam-se depositários centrais de títulos que fornecem instrumentos para sua guarda, tanto na forma certificada quanto na forma não certificada (desmaterializada), permitindo, assim, a transferência da titularidade por meio escritural.

As transferências de fundos podem ocorrer através de contas em um depositário central ou em outras instituições como um banco comercial ou banco central. Em alguns casos, o banco central pode exercer a função de depositário central de títulos (títulos públicos), em outros essa função é exercida por uma entidade privada.

A realização das instruções de transferência se caracteriza por várias etapas. Frequentemente, a transferência é provisória ou condicional, quando uma ou mais partes têm direito a rescindi-la. Quando puder ser rescindida pelo remetente da instrução, então é dita revogável. Se a transferência for irrevogável, mas alguma outra parte (em regra, operador do sistema) a puder rescindir, poderá ainda ser considerada provisória. Apenas em um estágio posterior a transferência se torna definitiva, ou seja, irrevogável e incondicional. Dessa forma, somente quando se transfere definitivamente um título do vendedor ao comprador há entrega, enquanto que a transferência definitiva de fundos do comprador ao vendedor perfaz o pagamento. O processo de liquidação se encerra quando ocorrer a entrega e o pagamento.

\subsection{Os riscos}

Os tipos e as fontes de risco em sistemas de compensação, a proteção contra risco e as implicações de vínculos transnacionais são questões a serem tratadas ao se projetar e operacionalizar um sistema de pagamentos. Por meio da liquidação de títulos ocorre a 
transferência definitiva e incondicional dos títulos de propriedade do vendedor alienante ao comprador adquirente (entrega), bem como dos fundos pertencentes a esse último ao vendedor (pagamento). Nessa etapa de encerramento do processo liquidante surgem os maiores riscos financeiros.

Como nos faz recordar SOUZA (2001), eventos ocorridos ao final do século XX mostraram de que modo crises financeiras podem se desencadear e propagar em razão de problemas na estrutura dos sistemas de pagamentos.

Assim, por exemplo, ocorreu quando da insolvência, em 1974, do Bankhaus Herstatt, pequeno banco alemão que atuava intensamente no mercado de câmbio. Ao ser posto em regime de liquidação após o fechamento diário do sistema de pagamentos, houve a suspensão dos pagamentos em dólares às contrapartes que já haviam transferido os valores, em marcos alemães, àquele banco. Dessarte, as contrapartes tiveram não apenas sua liquidez comprometida como o risco de perda do principal.

Há lembrar ainda a falha, em 1985, no sistema computacional do Bank of New York, um dos maiores bancos liquidantes dos EUA. Em razão da falha, houve impossibilidade de liquidação das posições em aberto do banco, fazendo-se necessário um empréstimo do Federal Reserve, o banco central norte-americano, a fim de que se eliminasse o risco de perdas a que se expuseram os credores daquele banco.

Em 19 de outubro de 1987, após cinco anos consecutivos de alta, ocorreu um colapso nos preços das ações negociadas na Bolsa de Valores de Nova York, ocasionando a perda de 22,6\% no valor do índice Dow Jones Industrial. Tal fato suscitou dúvidas a respeito da capacidade de os intermediários financeiros honrarem suas obrigações e as de seus clientes.

Tais acontecimentos ensejaram a discussão e o exame dos riscos a que estão expostos os participantes dos sistemas de pagamentos e liquidação de ativos, em especial os riscos de crédito, de liquidez, operacional e sistêmico.

a) Riscos de crédito e de liquidez

O risco de crédito é o risco de que uma contraparte não receba, total ou parcialmente, o valor devido pela outra parte (BIS, 1992, 2001). Esse risco compreende, portanto, o risco de perda do valor da transação, total ou parcial (risco do principal), e o risco de perda de lucros não realizados em razão de atrasos no recebimento do valor da transação (risco de custo de reposição). 
Tanto o comprador quanto o vendedor estão expostos ao risco de principal, pois a possível perda do valor total dos títulos ou fundos se relaciona a contratos cuja liquidação esteja programada para data futura, podendo ocorrer a inadimplência de qualquer das contrapartes.

O risco de custo de reposição, ou de perda de lucros não realizados, está relacionado ao fato de que o preço futuro dos ativos financeiros (títulos) é sempre incerto, sujeitando, portanto, ambas as partes do negócio. As receitas não realizadas de um contrato são calculadas pela diferença entre o preço de mercado do título e o preço do contrato no momento da inadimplência. Esse risco depende diretamente da volatilidade do preço do título e do intervalo de tempo entre a negociação e a liquidação. A reavaliação dos títulos a preços correntes de mercado enquanto não liquidadas as transações ("marcação a mercado") como a exigência de transferência de fundos ou garantias correspondentes ao valor dos ganhos ainda não realizados ao sistema de compensação ou liquidação são medidas que reduzem o risco de custo de reposição.

O risco de liquidez, por sua vez, é o de que uma contraparte não cumpra sua obrigação na data de vencimento, mas o faça somente no futuro, em mora, ocasionando assim dificuldades momentâneas de liquidez, ou seja, obrigando a instituição credora a recorrer a empréstimos de emergência, frequentemente de elevados custos, ou ainda prejudicando sua imagem e reputação no mercado.

Ademais, ao se constatar alguma falha na liquidação, muitas vezes não se sabe se o evento decorre de inadimplência ou de transação falha. Essa última ocorre quando uma contraparte não cumpre sua obrigação por razão técnica ou temporária. A falha técnica pode causar perda de confiança na contraparte que falhou na liquidação, podendo causar a retenção, por suas contrapartes, da liquidação de outras transações, principalmente em momentos de grande volatilidade nos preços.

Em regra, falhas na liquidação de transferências de fundos causam maior desconfiança do que falhas na liquidação de obrigações de transmissão de títulos, pois é consabido que os mercados de títulos e seus empréstimos são ilíquidos em certa medida, podendo uma contraparte financeiramente sólida ser temporariamente incapaz de comprar ou tomar por empréstimo os títulos necessários para a completude da liquidação. Nesse caso, quando não ocorrer a entrega de títulos por parte do vendedor, o comprador se verá obrigado a tomar por empréstimo títulos a fim de adimplir outras obrigações de entrega de títulos a terceiros. Esses eventos geram certamente um custo adicional aos participantes, o 
qual depende diretamente da liquidez do mercado em questão.

b) Risco operacional

Entende-se por risco operacional a possibilidade de erro humano ou de falha de equipamentos, programas de computador ou sistema de telecomunicações imprescindíveis para o funcionamento de determinado sistema.

c) Risco de insolvência do banco liquidante

Os participantes de um sistema de liquidação de títulos estão sujeitos ao risco de insolvência, ou falência, da entidade que mantém as contas de fundos utilizados para se efetuar pagamentos.

Tal risco pode ser eliminado quando se utilizar contas do banco central para a transferência de recursos. No entanto, algumas instituições não bancárias, participantes dos mercados de títulos, não têm acesso a essas contas, seja por razões legais, seja por decisão do próprio banco central de não competir com os bancos comerciais. Nesse caso, as contas de fundos devem ser fornecidas pelo próprio sistema de transferência de títulos ou por um banco comercial.

d) Risco sistêmico

O risco sistêmico consiste na situação em que o não cumprimento das obrigações por parte de um participante possa provocar a incapacidade de o coparticipante também cumprir suas obrigações, e assim sucessivamente, gerando uma crise que não se limita ao sistema de pagamentos específico, mas que se expande para o sistema financeiro e, quiçá, para a economia real (BIS, 1992, 2001).

Dessa forma, evidencia-se que deficiências técnicas em liquidações de títulos e, particularmente, inadimplências podem acarretar risco sistêmico, uma vez que se a liquidez dos mercados de empréstimo de títulos for muito limitada ou inexistente, a falha na entrega de um título pelo vendedor poderá acarretar a falha do comprador no cumprimento de sua obrigação de repassar o título a um terceiro.

Aos bancos centrais cabe zelar pela estabilidade do sistema financeiro e, consequentemente, atuar no sentido de mitigar deficiências técnicas e inadimplências de amplo alcance, pois essas não podem ser administradas apenas pelos participantes do sistema. 
Aos participantes do mercado, por sua vez, cabe a utilização de instrumentos contratuais e bancários aptos a superar pressões de liquidez decorrentes de deficiências técnicas.

\subsection{O princípio da "entrega contra pagamento" (EcP)}

O princípio da entrega contra pagamento implica que só haja a entrega do título quando houver pagamento. Esse princípio, quando aplicado na liquidação dos ativos financeiros (títulos), elimina a maior fonte de risco de crédito e sistêmico, a saber, o risco do principal, possível de ocorrer na data aprazada para liquidação. Eliminado o risco do principal, reduz-se também a probabilidade de que os participantes retenham entregas e pagamentos quando os mercados estiverem sob pressão, ou seja, reduz-se o risco de liquidez.

Dessa forma, o sistema de entrega contra pagamento é altamente recomendável no âmbito dos procedimentos de liquidação, embora não elimine o risco de custo de reposição nem o de liquidez, que, por sua vez, também podem criar risco sistêmico.

Corolário desse princípio é naturalmente o do pagamento contra pagamento, tal como na hipótese de operações de câmbio em moeda estrangeira.

Além da adoção do princípio da entrega contra pagamento, é conveniente que também se controlem de forma adequada os riscos de liquidez e de custo de reposição (lucros cessantes) das contrapartes, devendo ainda ser controlada a probabilidade como os potenciais efeitos da insolvência do banco liquidante, a não ser que o banco central garanta as liquidações como prestamista de última instância (BIS, 1992).

Assim, por exemplo, se os saldos monetários transferidos para as contas de liquidação, a fim de que se efetue os pagamentos, forem fundos diários, podem, então, ser utilizados para liquidação (transferidos) no mesmo dia de seu recebimento, mitigando os riscos de uma eventual quebra do banco liquidante. Nesse sentido, merece ainda atenção o risco de insolvência de um garantidor na hipótese de que as obrigações liquidandas dos participantes estejam garantidas por terceiros.

\subsection{Os modelos de liquidação}

Identificam-se basicamente três modelos estruturais de liquidação de títulos sob a égide do princípio da entrega contra pagamento (BIS, 1992): a) a liquidação bruta em tempo real; b) a liquidação bruta de títulos e diferida de fundos; c) a liquidação diferida 
pelo valor líquido.

a) Liquidação bruta em tempo real (LBTR)

O modelo LBTR apresenta liquidação bruta para instruções de transferência de títulos e fundos, em que a transferência definitiva de títulos do vendedor para o comprador ocorre no mesmo instante da transferência definitiva de fundos do comprador ao vendedor.

Assim, o sistema mantém as contas de títulos e de fundos, executando simultaneamente as transferências de forma escritural. Caso as contas de fundos estejam alocadas em outra entidade, essa necessita informar em tempo real a respeito da conclusão das transferências de fundos.

As transferências, por sua vez, apresentam caráter irrevogável e incondicional a partir dos lançamentos de débito e crédito simultâneos. Não ocorrem saques a descoberto nas contas de títulos, mas podem ocorrer nas contas de fundos. No intuito de se eliminar o risco do principal, exige-se saldos monetários elevados para que se assegure a conclusão das liquidações, em particular se não houver a possibilidade de ajuste dos saldos monetários ou de títulos durante o ciclo de processamento.

Não havendo tal ajuste, os participantes deverão manter valor suficiente para cobrir o maior saldo devedor durante o processamento (BIS, 1992). Do contrário, poderá ser elevado o índice de falhas nas transações, aumentando o risco de custo de reposição. Ressalte-se que é de difícil previsão o montante do maior saldo devedor durante o processamento, pois não se pode prever a ordem na qual as transferências ocorrem, dependendo da disponibilidade de saldos em títulos.

Notificadas as partes envolvidas, no caso de falha, essas poderão tomar por empréstimo os fundos ou títulos necessários para a liquidação da transação. O sistema recicla as instruções repetidamente, observado o critério de fila, ou seja, de que o primeiro a entrar seja o primeiro a sair, até que os participantes sanem as deficiências de saldo. A quantidade de transações falhas também pode ser minimizada por meio de empréstimos automáticos de títulos previamente autorizados.

Em sistemas com elevado número de transações há um dilema entre a opção por elevada disponibilidade de saldo ou por elevado índice de transações falhas. No intuito de mitigar a necessidade de saldos como as falhas, alguns sistemas oferecem crédito intradiário, podendo assumir às vezes valores substanciais, permitindo saques a descoberto em suas contas de fundos, e reduzindo, assim, os riscos de custo de reposição e de liquidez, 
mas criando uma nova fonte de risco, a saber, a falha de um participante no reembolso do crédito concedido. Tal falha, por sua vez, também gera riscos de reposição e de liquidez. Aliás, em caso de não serem garantidos, aqueles empréstimos tendem a criar riscos de principal. Nesse caso, os riscos de crédito e de liquidez dependem de controles que minimizem a probabilidade de falha no reembolso dos créditos intradiários concedidos. Nesse sentido, normas de admissão ao sistema como gravames sobre as posições em títulos são utilizadas para limitar o risco de crédito (BIS, 1992).

O operador do sistema, ao garantir o pagamento dos títulos transferidos, assegurase também por meio de linhas de crédito com bancos comerciais ou o banco central. Caso seja o próprio banco central o operador do sistema, então ele mesmo poderá atender às demandas por liquidez decorrentes de falhas no reembolso de créditos de cobertura concedidos. No entanto, limitam-se tais concessões no intuito de se estimular as partes a gerir os próprios risco de crédito e liquidez, reduzindo ainda as medidas necessárias para contrabalançar os efeitos de suas intervenções sobre a base monetária.

No presente modelo se pode também limitar os saques dos fundos recebidos, até o dia seguinte, limitando, assim, eventuais demandas por liquidez. Esse procedimento, contudo, aumenta a exposição dos participantes ao risco de uma falha do próprio operador do sistema. Tal risco ganha relevo se o operador do sistema não estiver fortemente capitalizado ou estiver atuando em outros ramos mais arriscados do mercado financeiro.

b) Liquidação bruta de títulos e diferida de fundos

Nesse modelo se liquidam as transferências de títulos pelo valor bruto seguida pela liquidação das transferências de fundos pelo valor líquido ao final do ciclo de processamento. As contas de títulos dos participantes são custodiadas pelo administrador do sistema, já os fundos são mantidos, em regra, em contas junto a bancos comerciais ou ao banco central. Os títulos se transferem escrituralmente, por meio de débito na conta de títulos do vendedor e crédito na conta do comprador, de modo definitivo ao serem registrados nos livros ou planilhas do sistema. As transferências de fundos, embora irrevogáveis, não são definitivas. Os saldos credores e devedores de fundos são calculados ao longo do ciclo de processamento, e as posições liquidadas ao final desse ciclo por meio de lançamentos nas contas de fundos.

Dessa forma, tem-se que a entrega definitiva de títulos precede o pagamento definitivo. Aqui não ocorrem saques a descoberto de títulos, já os saques a descoberto de 
fundos são aceitos de modo tácito ao se permitir que haja saldos devedores líquidos. Rejeita-se a transferência de títulos somente se não houver títulos suficientes à disposição na conta do vendedor.

O sistema em questão requer garantias adicionais para que não se exponham os vendedores de títulos ao risco do principal. Os riscos de custo de reposição e de liquidez, por seu lado, restam potencialmente reduzidos em razão da característica própria a esse modelo, que é a de permissão de liquidação das transferências de fundos em bases líquidas, reduzindo, portanto, a frequência de falhas nas transações. Transações falhas em razão de saldo insuficiente de títulos poderão ainda ocorrer, indicando a necessidade de dispositivos de enfileiramento e de o sistema ser capaz de optar pela ordem direta da fila ou pela alteração nessa ordem de modo a minimizar o número de transações deficientes.

No intuito de se assegurar o pagamento, em troca do título entregue há promessa irrevogável de pagamento do comprador ao final do ciclo de processamento. Isto elimina o risco do principal, mas não o risco de insolvência do garantidor de um ou mais participantes. A instituição garantidora, por sua vez, protege-se contra riscos de crédito por meio de gravames sobre os títulos dos participantes custodiados no sistema. Não obstante o gravame sobre títulos dos participantes, a instituição garantidora ainda enfrenta risco de crédito análogo ao risco de custo de reposição e ao de liquidez porventura o participante falhe na cobertura de uma posição devedora líquida de fundos. Pode-se impor ainda um limite para o montante de posições devedoras líquidas de fundos, mitigando os efeitos de eventual quebra de um garantidor.

Quanto ao risco de insolvência do banco por meio do qual um participante opera, pode-se limitá-lo através da exigência de serem disponibilizados diariamente os saldos creditados em razão de pagamentos por títulos vendidos.

c) Liquidação diferida pelo valor líquido (LDL)

Aqui há simultaneidade na liquidação das transferências de títulos e fundos pelo valor líquido. As contas de títulos dos participantes são custodiadas pelo administrador do sistema, já os fundos são mantidos, em regra, em contas junto a bancos comerciais ou ao banco central. Os títulos se transferem escrituralmente, debitando-se a conta de títulos do vendedor e se creditando a do comprador. Os saldos correntes de débitos e créditos das contas de títulos e de fundos são calculados durante o processamento, dado disponível ou não aos participantes, sendo provisórias as transferências escriturais de títulos até que se 
complete o ciclo de processamento. Ao final do ciclo são consolidadas as posições credoras e devedoras líquidas e a disponibilidade de saldos para encerrá-las. Se uma contraparte não tiver saldo suficiente, poderá tomar em empréstimo os títulos ou fundos necessários. As transferências definitivas somente serão executadas se todos os participantes tiverem saldos suficientes em títulos e fundos.

Ao seguirem o princípio da entrega contra pagamento, eliminar-se-á o risco do principal. No entanto, também aqui os riscos de custo de reposição e de liquidez não são eliminados. Caso as contas de fundos não sejam alocadas no banco central, o risco de insolvência do banco liquidante também se faz presente.

No presente modelo sói ocorrer o fenômeno da reversão, ou seja, a revogação total ou parcial das transferências realizadas por um participante que tenha falhado na liquidação de sua posição líquida devedora de fundos, ocasionando o recálculo das obrigações dos demais participantes. Por precauções de ordem legal, opta-se geralmente por reversões completas, em que pese o aumento do risco sistêmico em razão da pressão por liquidez originada.

Dessa forma, o evento da reversão na apuração multilateral de saldos de transferências de fundos e títulos poderá acarretar aos participantes, contrapartes daquele que causou a falha, créditos líquidos menores ou débitos líquidos maiores, dependendo da liquidez dos mercados sua agilidade para a superação de tal evento, não se descartando, inclusive, que reversões adicionais venham a ocorrer.

No intuito de se evitar o evento da reversão, adotam-se, em regra, diversos controles de risco. Em princípio, o administrador do sistema atua como contraparte central, garantindo a completude das liquidações e se protegendo por meio de controles do risco de crédito como, por exemplo, requisitos de admissão, exigência de garantias completas e contribuições compulsórias a um consórcio garantidor.

O risco de liquidez, por sua vez, é comumente limitado por meio de instrumentos de liquidez disponibilizados por terceiros (p. ex., financiamento no mercado interbancário, com participação do banco central), ou ainda por meio de limites operacionais determinados pelo administrador do sistema.

\section{Evolução do SPB}

O Sistema Financeiro Nacional (SFN) teve um salto qualitativo a partir de 1945, com o aparecimento das sociedades de crédito, financiamento e investimento, as chamadas 
financeiras, pois era centrado, até então, quase que exclusivamente em banco comerciais privados, como reflexo da incipiente modernização do País (ALMEIDA, 2009, p. 53).

A atual arquitetura institucional do SFN se desenvolveu de modo significativo somente entre 1964 e 1965, a partir da promulgação da Lei de Reforma Bancária (Lei n ${ }^{\circ}$ 4.595, de 31 de dezembro de 1964), criando o Banco Central do Brasil e ordenando o sistema financeiro. Sua evolução se alicerçou basicamente em dois períodos. O primeiro, durante as décadas de inflação, até o início da década de 1990, no qual se enfatizava a eficiência técnica nas transações financeiras, sem que se observassem os riscos do sistema de pagamentos, em particular aqueles inerentes à atuação da autoridade monetária como garante e prestamista de última instância. O segundo, a partir da Constituição Federal de 1988, sob o influxo da estabilidade econômica interna trazida pelo Plano Real (1994) como de uma nova realidade financeira internacional, mais célere e volátil, em que se nota amadurecimento e sofisticação do sistema financeiro brasileiro (ALMEIDA, 2009).

\subsection{A estrutura anterior à reforma do SPB}

Em que pese o avanço tecnológico experimentado pela indústria financeira, propiciando maior velocidade no processamento das transações, a arquitetura do SFN se encontrava às voltas com certos gargalos, que limitavam a celeridade e a segurança das transações, impondo-se também sérias dificuldades e grandes riscos ao BCB.

Em linhas gerais, o SPB anterior se baseava em quatro grandes sistemas, a saber, o Sistema Especial de Liquidação e Custódia (Selic), a Central de Custódia e Liquidação Financeira de Títulos (Cetip), a Central de Compensação de Cheques e outros Papeis (Compe) e o Sistema de Câmbio (Sisbacen-Câmbio).

Esses sistemas tinham seus resultados diários lançados diretamente na conta de reserva de cada participante junto ao BCB. Além dos sistemas mencionados, a movimentação de numerário em espécie, realizada pelo Departamento do Meio Circulante (Mecir) do BCB ou pelo Banco do Brasil S.A., também tinha sua contrapartida direta em contas de reserva bancária (BCB, 2009).

No sistema anterior não havia separação dos pagamentos de varejo dos demais, e a liquidação ocorria pelo sistema LDL, de modo multilateral. Ao permitir saques a descoberto ao longo do dia, o BCB agia somente ex post, assumindo o risco de crédito e de liquidez, ou seja, obrigando-se a arcar com a eventual inadimplência de um participante a fim de evitar um possível contágio de todo o sistema (BCB, 2009). 
O enfoque dado à informatização e automação na estruturação anterior do SPB pressupunha um contexto inflacionário, que exigia um aumento da celeridade de processamento dos negócios. A partir da estabilização econômica advinda com o Plano Real (1994), impuseram-se novas necessidades e, portanto, novos rumos, em particular no que tange à administração de riscos e à segurança jurídica (BCB, 2009).

As mudanças visavam assegurar, em novas bases legais, tanto a compensação multilateral como a execução das garantias constituídas pelos participantes, possibilitando que os mecanismos de proteção pudessem ser operacionalizados de forma juridicamente eficaz.

Ademais, procurou-se retirar o setor público a obrigatoriedade de assunção dos riscos inerentes à atividade financeira do setor privado, fortalecendo o sistema financeiro por meio de um sistema de pagamentos moderno, reduzindo-se, assim, a percepção de risco do país pelos investidores internacionais (BCB, 2009).

\subsection{A reestruturação do $S P B$}

Após a superação dos problemas econômico-financeiros gerados pela alta inflacionária e o saneamento do sistema financeiro, o BCB teve condições materiais de implantar um projeto de reestruturação do SPB, pois somente num cenário de estabilidade monetária e instituições financeiras saudáveis haveria condições de adequação do SFN às novas exigências tecnológicas (SOUZA, 2001; BCB, 2009). Em razão das diversas deficiências apontadas, o BCB reestruturou finalmente o sistema de pagamentos, surgindo, a partir de 22 de abril de 2002, o novo SPB.

No âmbito do novo sistema, as transferências de fundos interbancários passaram a ser liquidadas em tempo real e de modo irreversível (irrevogável), segundo o modelo LBTR. Por meio de nova regulamentação da conta de reservas das instituições financeiras (Reservas Bancárias) restaram impedidos os saques a descoberto (Circular BCB nº 3.101, de 28 de março de 2002).

Ressalte-se ainda que a conta Reservas Bancárias registra as disponibilidades mantidas no BCB, em moeda nacional, por seus titulares, sendo obrigatória para os bancos comerciais, múltiplos com carteira comercial e caixas econômicas, e opcional para os bancos de investimento e os múltiplos sem carteira comercial.

Grosso modo, o negócio financeiro passou a ser processado da seguinte maneira: a instituição financeira a ser debitada elabora a mensagem desejada, estabelecendo, se for o 
caso, um nível de preferência para a liquidação; essa mensagem, por sua vez, é encaminhada ao BCB através da Rede do Sistema Financeiro Nacional (RSFN), sendo então processada no âmbito do Sistema de Transferência de Reservas (STR). Havendo saldo suficiente na conta de reserva da devedora junto ao $\mathrm{BCB}$, aquela mensagem é imediatamente liquidada, sendo a instituição credora notificada pelo $\mathrm{BCB}$ a respeito do lançamento a crédito efetuado em sua conta de reserva, encerrando-se, assim, o ciclo financeiro com as devidas providências internas de cada instituição financeira (em regra, bancária). Se não houver saldo suficiente na conta de reserva do banco a ser debitado, a mensagem entrará numa fila de espera, havendo, no entanto, duas exceções a essa regra: i) caso a transferência de fundos decorra de negociações envolvendo o sistema Selic; ou ii) caso a mensagem emitida provenha de entidades administradoras de sistemas de compensação e liquidação. Nessas duas hipóteses, será a mensagem imediatamente rejeitada pelo STR.

O STR configura assim o centro de liquidação das operações interbancárias, em decorrência dos seguintes fatores: primeiramente, por disposição legal (Lei no 4.595, de 1964), todas as instituições bancárias (instituições que captam depósitos à vista) têm de manter suas disponibilidades de recursos no Banco Central do Brasil; em segundo lugar, por determinação regulamentar (Circular BCB n 3.057, de 2001), os resultados líquidos apurados nos sistemas de liquidação considerados "sistemicamente importantes" devem ter sua liquidação final junto ao Banco Central do Brasil, em contas exclusivamente de liquidação; finalmente, também por disposição regulamentar (Circular BCB no 3.439, de 2009), todas as transferências de fundos entre contas de reservas bancárias têm de ser feitas por meio do STR (BCB, 2009).

A implantação do STR criou a possibilidade de se efetuar um pagamento, em tempo real, entre quaisquer regiões do país, de modo a possibilitar uma melhor integração dos mercados financeiros regionais tendo em vista a estruturação de um mercado monetário de curto prazo mais eficiente.

A plataforma tecnológica utilizada para o acesso ao SPB é a RSFN: uma estrutura de comunicação de dados em rede, cuja finalidade é dar suporte ao tráfego de mensagens entre todos os participantes do sistema. Operacionalmente, ela é formada por duas redes independentes de telecomunicação, sendo cada participante usuário obrigatório de ambas as redes (uma principal, outra secundária, acionada em caso de falha da primeira), por onde tramitam as mensagens em padrão XML (Extensible Markup Language), em conformidade 
com a regulamentação estabelecida em manuais e normativos específicos divulgados pelo BCB.

A nova estrutura ainda prevê a criação de câmaras privadas de compensação e liquidação (clearings), operando na modalidade LDL. Essas entidades podem atuar nos mais diversos segmentos do sistema, respeitadas as normas estabelecidas para seu funcionamento, em particular a condição de serem contraparte central nas negociações e, quando consideradas sistematicamente importantes, possuírem mecanismos de salvaguardas (garantias), que lhes possibilitem assegurar a liquidação nelas cursadas, mesmo na eventualidade de inadimplência simultânea de alguns de seus maiores clientes. No regulamento anexo à Circular BCB n 3.057, de 31 de agosto de 2001, estabeleceramse os critérios para a caracterização de um sistema, ou câmara, como "sistemicamente importante":

- sistemas de liquidação de transações com ativos financeiros, títulos, valores mobiliários, derivativos financeiros e moedas estrangeiras, independentemente do valor individual de cada operação e do giro financeiro diário; e

- sistemas de liquidação de transferências de fundos e de outras obrigações interbancárias não relacionadas com as transações identificadas no item anterior, se possuírem giro financeiro diário médio superior a $4 \%$ do giro financeiro diário médio do Sistema de Transferência de Reservas (STR), ou se forem sistemas de liquidação diferida que utilizam compensação multilateral e existir a possibilidade de que a inadimplência de um participante afete outros de modo a provocar interrupções em volumes significativos de pagamentos do SPB.

Em razão de sua importância para a continuidade dos pagamentos, os sistemas de liquidação sistemicamente importantes devem atender sobretudo aos seguintes requisitos:

- o resultado compensado das operações aceitas por sistemas de liquidação diferida deve ser liquidado pelo STR em contas de liquidação ou em contas de reservas bancárias;

- os prazos para a liquidação de operações, em relação ao momento da aceitação da operação, devem ser os seguintes: a) para transferências de fundos: até ao final do dia; b) para operações à vista com títulos e valores mobiliários, exceto ações: até um dia útil; e c) para operações à vista com ações realizadas em bolsa de valores: até três dias úteis;

- recomenda-se realizar mais de uma sessão de liquidação ao longo de cada dia; e 
- o prestador de serviços de compensação e de liquidação, ou câmara, deve assumir a posição de contraparte central, na liquidação das obrigações realizadas por seu intermédio, ressalvado o risco de emissor, e assegurar a liquidação das obrigações relativas às operações aceitas, constituindo patrimônio especial e adotando mecanismos e salvaguardas adequados, tais como a definição de limites operacionais, a instituição de mecanismos de compartilhamento de perdas entre os participantes, a constituição de garantias pelos participantes, a constituição de fundo de garantia de liquidação, a contratação de seguro de garantia de liquidação e a contratação de linhas de crédito bancário.

Atualmente, o SPB se encontra segmentado em sistemas de liquidação, na sequência os discriminando de acordo com a forma de liquidação adotada e os mecanismos de segurança utilizados para conter a propagação de efeitos da eventual inadimplência dos participantes (BCB, 2009; TABAK, 2012, p. 7 e ss.).

a) Sistemas de transferência de fundos

STR - realiza transferência entre contas de reservas bancárias, ou contas de liquidação, com liquidação bruta em tempo real (LBTR). É o núcleo do SPB, por meio do qual são realizadas todas as transferências entre contas de reservas bancárias. Circulam ainda por esse sistema as transferências associadas a operações de política monetária e cambial do BCB, a arrecadação de tributos e as emissões primárias, resgates e pagamentos de juros dos títulos da dívida pública federal pelo Tesouro Nacional. Ademais, são liquidados no STR os resultados líquidos apurados nos sistemas de liquidação considerados sistemicamente importantes.

Sitraf - realiza transferências entre contas de liquidação de titularidade de instituições possuidoras de contas de reservas bancárias. É um sistema que utiliza compensação contínua, operado pela Câmara Interbancária de Pagamentos (CIP), processando ordens de transferência para liquidação no mesmo dia, de valor inferior a $\mathrm{R} \$ 1$ milhão. A partir desse valor, as transferências devem ser feitas pelo STR. Possui características de sistema LBTR e de sistema com liquidação diferida líquida (LDL), podendo considerar a ordem de transferência de fundos tanto isoladamente como no contexto de uma compensação bilateral ou multilateral. Nesse sistema são realizadas as transferências somente se houver fundos nas contas de liquidação dos participantes pagadores. Para tanto, ao início de cada dia, o Sitraf determina, para cada participante, o 
valor do depósito prévio a ser transferido para a sua conta de liquidação. Participantes que emitiram ordens de transferência de fundos ainda pendentes ao final do dia devem efetuar depósitos adicionais para possibilitar a execução das ordens. As ordens de pagamento não executadas até ao final do dia são canceladas.

O Siloc (Sistema de Liquidação Diferida das Transferências Interbancárias de Ordens de Crédito), também operado pela CIP, bem como a Compe (Centralizadora da Compensação de Cheques) e a Câmara TecBan (Tecnologia Bancária S.A.) são sistemas LDL com compensação multilateral de obrigações. No Siloc são liquidadas as obrigações interbancárias relacionadas a Documentos de Crédito, Transferências Especiais de Crédito e boletos de cobrança. Para todos esses instrumentos, o valor é limitado a $\mathrm{R} \$ 5$ mil entre participantes detentores de conta Reservas Bancárias. Na Compe são liquidadas obrigações concernentes a cheques de valor inferior a $\mathrm{R} \$ 250$ mil entre participantes titulares de contas de reservas bancárias, ou de liquidação, com depósitos movimentáveis por cheques. Na TecBan, por fim, são efetivadas transferências interbancárias de fundos entre contas de liquidação dos participantes, relacionadas principalmente a pagamentos efetuados com cartões de débito e a saques em redes de atendimento automático de uso compartilhado, como a rede Banco24Horas. No caso do Siloc e da Compe, a liquidação é em D+1 (dia seguinte à operação), e no caso da Câmara TecBan, D ou D+1 (no mesmo dia ou no seguinte), a depender do horário em que se originar a ordem de transferência de fundos.

b) Sistemas de liquidação de operações com títulos e valores mobiliários, derivativos e de câmbio interbancário

Esses sistemas são considerados sistemicamente importantes pela Circular $n^{\circ}$ 3.057, de 2001. Neles se efetua a liquidação financeira interbancária nas contas de reservas bancárias através do STR. Na liquidação se observam os princípios de entrega contra pagamento $(\mathrm{EcP})$ e de pagamento contra pagamento $(\mathrm{PcP})$.

Selic (Sistema Especial de Liquidação e de Custódia): processa a emissão, o resgate, o pagamento de juros e a custódia de títulos emitidos pelo Tesouro Nacional e pelo $\mathrm{BCB}^{166}$. Também processa, em LBTR, a liquidação de operações no mercado secundário registradas no seu ambiente, liquidando assim as obrigações financeiras por meio do STR.

166 Observe-se que, desde o advento da Lei de Responsabilidade Fiscal (Lei Complementar $n^{\circ} 101$, de 4.5.2000), o BCB já não está mais autorizado a emitir títulos próprios, restando apenas aqueles de emissão do Tesouro Nacional. Os anteriores, emitidos pelo BCB e que ainda se encontravam em circulação no mercado secundário (aberto), já foram integralmente resgatados, não havendo mais títulos do BCB em circulação (ESTRELA, 2011). 
Esse sistema é administrado pela Andima (Associação Nacional das Instituições do Mercado Aberto) (SALOMÃO NETO, 2007, p. 236).

BM\&FBOVESPA $^{167}$ (Bolsa de Mercadorias e Futuros) - Câmara de Ativos: liquida operações financeiras que tenham por objeto títulos públicos federais. Nesse sistema se efetua a liquidação em D ou D+1, conforme o horário da negociação, por meio de compensação multilateral, atuando a câmara como contraparte central. A câmara estabelece limites operacionais com base em garantias depositadas. No caso de inadimplência, dispõe de um fundo operacional constituído com recursos da própria BM\&FBOVESPA, podendo ser usado para concluir o processo de liquidação em caso de inadimplência de algum participante.

BM\&FBOVESPA - Câmara de Derivativos ${ }^{168}$ : liquida obrigações financeiras relacionadas a operações com contratos à vista, a termo, de futuros, de opções e de swaps $^{169}$. A liquidação é feita por compensação multilateral (D+1), através do STR, em contas de reservas bancárias, atuando a BM\&FBOVESPA como contraparte central. $\mathrm{Na}$ hipótese de inadimplência, as posições contratuais, em aberto, do participante são encerradas. Após serem compensados os valores dos contratos, caso seja apurado resultado líquido negativo, a BM\&FBOVESPA executa, de ofício (diretamente), as garantias prestadas pelo participante. Mostrando-se insuficientes as garantias previamente depositadas, a câmara utiliza recursos disponíveis em diferentes fundos constituídos para esse fim e que contam com recursos das corretoras, dos membros de compensação e da

167 Sociedade empresarial formada a partir da integração entre as operações da Bolsa de Valores de São Paulo (BOVESPA) e da Bolsa de Mercadorias e Futuros (BM\&F).

168 Sob o prisma financeiro, o derivativo se caracteriza como instrumento cujo valor "deriva" ou depende de uma variável básica, ou seja, o preço de um determinado ativo subjacente, podendo ser um bem, uma taxa ou um índice. Juridicamente, seu traço comum reside no pacto entre as partes contratantes relativo a um preço para o bem (ativo) subjacente, em uma data futura, contrapondo esse preço ao de mercado na data de execução do contrato, e pois transferindo finalmente apenas as diferenças entre si. Todo derivativo constitui, portanto, um contrato diferencial (Código Civil, art. 816). Originalmente, vinculavam-se à proteção de riscos ligados às oscilações de preços e taxas (riscos de mercado), constituindo sobretudo operações de hedge (proteção), de modo a compensar reciprocamente os efeitos da álea. Sem embargo, sobretudo na atualidade, esse fundamento precaucional dos contratos de derivativos cede lugar à atuação de investidores profissionais que não se encontram expostos às condições do mercado físico do ativo subjacente, mas que atuam exclusivamente com o fito de lucro financeiro, a saber, os especuladores. O fundamento especulativo predomina hodiernamente nos mercados financeiro e de capitais mundializados, incluindo-se nesse contexto as operações de arbitragem em diversos mercados com o objetivo de auferir ganhos decorrentes de diferenciais de preços entre mercados distintos (YAZBEK, 2009).

169 Os swaps são na verdade um gênero de negócio financeiro a designar uma diversidade de negócios de troca efetiva tanto de ativos como de fluxos financeiros. Nesse último sentido tem sido seu desenvolvimento recente, enquanto operações destinadas à liquidação em data futura cujo efeito se resume à troca de resultados financeiros decorrentes da aplicação, sobre valores ativos e passivos, de taxas ou índices utilizados como referenciais (Resolução CMN n ${ }^{\circ} 2.873$, de 2001, art. $1^{\circ}, \S 1^{\circ}, \mathrm{I}$ ). 
própria câmara. Se, ainda assim, os recursos não forem suficientes, a câmara pode solicitar novos aportes de recursos aos seus participantes e, em último caso, utilizar o próprio patrimônio.

BM\&FBOVESPA - Câmara de Câmbio: liquida operações interbancárias de câmbio realizadas no mercado de balcão organizado pela BM\&FBOVESPA. As obrigações correspondentes são compensadas multilateralmente e a BM\&FBOVESPA atua como contraparte central. A Câmara de Câmbio dispõe de linhas de crédito em moeda nacional e em moeda estrangeira, a serem utilizadas na conclusão tempestiva do ciclo de liquidação acaso se torne inadimplente algum de seus participantes (bancos). A liquidação das operações é assegurada primeiramente pelas garantias constituídas individualmente pelos participantes. Na hipótese de os recursos obtidos com a execução (direta) das garantias prestadas pelo inadimplente não forem suficientes para a liquidação de suas posições contratuais em aberto, a soma faltante é custeada por rateio entre os demais participantes adimplentes que contrataram operações para liquidação na data em que ocorreu a inadimplência.

Companhia Brasileira de Liquidação e Custódia (CBLC): liquida operações com títulos de renda variável (mercados à vista e de derivativos) e títulos privados de renda fixa (operações definitivas do mercado à vista). A liquidação usualmente é feita por compensação multilateral de obrigações ${ }^{170}$, tendo a BM\&FBOVESPA como contraparte central, assegurando a liquidação das operações cursadas. Havendo inadimplência de algum participante, o sistema utiliza os seguintes recursos, nesta ordem: recursos obtidos com a execução (direta) de garantias depositadas pelo "agente de compensação" (mandatário de investidores) inadimplente ou por investidor a ele vinculado; recursos do fundo de liquidação, correspondentes à participação do agente de compensação inadimplente; recursos do fundo de liquidação correspondentes à participação dos demais agentes de compensação; recursos do fundo de liquidação correspondentes à contribuição institucional da CBLC; e recursos do patrimônio especial do sistema.

Câmara de Custódia e Liquidação - antiga Central de Custódia e de Liquidação Financeira de Títulos (Cetip): processa a emissão, o resgate, o pagamento de juros e a custódia de títulos de renda fixa privados, títulos públicos estaduais e municipais e ainda títulos representativos de dívidas de responsabilidade do Tesouro Nacional. As operações no mercado primário são geralmente liquidadas por compensação multilateral de 
obrigações, ressalvando-se que a Cetip não atua como contraparte central. A compensação bilateral é utilizada na liquidação das operações com derivativos, já as operações com títulos negociados no mercado secundário são liquidadas em tempo real (LBTR). Na hipótese de inadimplemento, a compensação multilateral é novamente processada.

Central de Cessões de Crédito (C3): registra, compensa e liquida contratos de cessão de crédito $^{171}$. Para a realização de uma operação de cessão de crédito, os créditos a serem cedidos e os contratos de cessão devem ser, inicialmente, registrados nessa central, que posteriormente processa a compensação e liquidação dos respectivos contratos. A transferência de fundos é feita através do STR, simultaneamente à transferência de titularidade dos créditos registrados. Havendo inadimplência de um participante, a entidade, que não atua como contraparte central, processa novamente a compensação.

\subsection{O risco de contágio sistêmico no SPB}

Um sistema de pagamentos pode influenciar os riscos de contágio ${ }^{172}$ e sistêmico do sistema financeiro, uma vez que por seus dutos corre o fluxo de recursos financeiros da economia. A depender de sua estrutura, as interrupções de transferências de fundos ocasionadas por inadimplências das contrapartes que em seu âmbito negociam podem ser tanto atenuadas como acentuadas (TABAK, 2012).

Frise-se, nesse sentido, que os sistemas de liquidação que integram o SPB utilizam os modelos de liquidação anteriormente apresentados: os processos de LBTR $^{173}$, de LDL $^{174}$ ou combinações de ambos.

171 Em regra, esse sistema tem operado sobretudo a transferência de contratos de financiamento de veículos automotores e de crédito consignado.

172 No contexto do sistema de pagamentos, contágio significa efeito imediato e restrito, ou seja, o fato de uma instituição falhar em cumprir suas obrigações faz com que outra instituição também incida em inadimplemento. Por outro lado, o contágio pode ter um caráter sistêmico ao afetar uma porção significativa do sistema financeiro.

173 Em sistemas de liquidação LBTR, reprise-se, uma transação só é aceita se os recursos a serem transferidos estiverem disponíveis na conta da instituição pagadora. As transações aceitas são executadas imediatamente. Nesse caso, o sistema de pagamentos não interfere no risco sistêmico, pois não modifica o fluxo de recursos entre as partes. No entanto, a exigência de disponibilidade de recursos como condição para a realização das transferências faz com que seja necessária maior liquidez e ainda acesso a linhas de crédito intradia de maior volume pelos participantes do sistema do que seria necessário no caso de sistemas de liquidação por diferença (líquida), ou seja, por compensação.

174 Vale novamente frisar que na hipótese de sistemas de liquidação LDL, as instituições efetuam depósitos nas contas de liquidação e registram ordens de transferência até um horário limítrofe, determinando o fim do ciclo liquidante. Ao final do ciclo se efetiva a compensação: a posição de cada empresa é calculada e os valores líquidos resultantes são transferidos. A transferência pode se dar no mesmo dia do registro da ordem ou em dia posterior, caso em que se diz que a liquidação é diferida. Se houver inadimplência de algum participante do ciclo, as ordens de liquidação emitidas por ele são canceladas, o que pode deixar as contrapartes com saldo negativo, levando também ao cancelamento de 
No que se refere à transferência de fundos, o já mencionado $\mathrm{STR}^{175}$ constitui a espinha dorsal do Sistema de Pagamentos Brasileiro. Por seu intermédio se efetivam todas as transferências líquidas finais de sistemas de liquidação, sistemicamente importantes, entre as contas de reservas bancárias sob a titularidade das contrapartes negociais, por determinação regulamentar. Como adverte TABAK (2012, p. 12):

Dado que é um sistema LBTR, não amplifica os riscos de contágio e sistêmico em caso de inadimplência. O Sitraf também realiza transferência de fundos, no entanto essas transferências são realizadas somente entre contas de liquidação. Esse sistema executa ciclos de liquidação durante o dia. Os participantes inadimplentes, ao final de um ciclo, são chamados a depositar, em suas contas de liquidação, os recursos necessários à execução de suas transferências. Caso esse depósito não seja feito até o final do dia, as transferências pendentes são canceladas, podendo originar uma cadeia de cancelamentos de transferências.

Ressalte-se que desde junho de 2011, a partir da vigência da Circular BCB no 3.534, de 6 de maio de 2011, as Transferências Eletrônicas Disponíveis (TED) com valor igual ou superior a um milhão de reais passaram a ser liquidadas por meio do sistema administrado pelo BCB. Essa determinação teve por objetivo justamente reduzir a importância sistêmica do Sitraf, operado pela CIP (Câmara Interbancária de Pagamentos). Desse modo, transferências de valores a partir de um milhão de reais deixaram o ambiente liquidante do Sitraf e passaram a ser efetuadas pelo STR, operado diretamente pelo BCB. Assim, a maior parte do volume financeiro das transações interbancárias migraram de um sistema de liquidação por diferença (LDL), desprovido de garantias institucionais para absorver o impacto de inadimplência, elevando assim o risco de contágio sistêmico, para um sistema de liquidação em tempo real (LBTR), em que esse risco é mitigado, sobretudo pela presença direta do prestamista de última instância ${ }^{176}$.

suas respectivas ordens e propagando a situação de inadimplência para participantes que originalmente possuíam recursos. Essa é uma situação que eleva potencialmente o risco de contágio do sistema de pagamentos: o risco se eleva porque os participantes credores dos que estavam inicialmente inadimplentes não têm tempo hábil para suprir as deficiências financeiras de suas posições contratuais em aberto. Por outro lado, esse tipo de processo de liquidação tem a vantagem de exigir menor disponibilidade de liquidez para os participantes. Sistemas de liquidação LDL com contraparte central, limites e exigências de garantias podem atenuar riscos de contágio resultantes de inadimplementos, pois essas características possibilitam a absorção e, em última instância, o compartilhamento de eventuais perdas.

175 Sistema de Transferência de Reservas vinculado às contas de reservas bancárias mantidas junto ao BCB e por esse administrado.

176 Como revela TABAK (2012, p. 13), em junho de 2011, a composição das transferências 
Nesse sentido, advirta-se que o fornecimento de liquidez intradia pelo BCB, por meio de operações compromissadas sem custos (redesconto), abraçado pela reestruturação do SPB, garante a liquidez dos pagamentos diários, suprindo a elevada necessidade de liquidez exigida em sistemas LBTR. Como assevera ESTRELA (2011, p. 216):

No que tange aos prazos, embora as operações do Redesconto do Banco Central prevejam prazos de 1 até 359 dias, somente as operações intradia são relevantes na oferta de liquidez aos participantes do sistema de pagamentos. Essas operações só existem na modalidade de compra com compromisso de revenda, e são realizadas com custo zero. A única limitação de valor para estas operações é o tamanho da carteira de títulos públicos [federais] livre. Ao final do dia, essas operações podem ser convertidas em operações com prazo de 1 dia, quando então passam a pagar juros punitivos.

\section{Arcabouço institucional do SPB}

Vale novamente frisar que a busca de ordenação e unidade interior (de sentido) nas relações entre os elementos presentes no ordenamento jurídico implica necessária adequação valorativa, pois que se trata de emanações e postulados inerentes à ideia de Direito, devendo um sistema, no âmbito jurídico, refletir e realizar tal desiderato, sempre em busca de solução aos problemas. Ressalte-se que a unidade valorativa é sempre de tipo material e historicamente determinada, portanto permeável à realidade circundante (CANARIS, 1989; FREITAS, 2002).

Nesse sentido, é mister que se adote um conceito mais largo de sistema jurídico, configurando-o como

uma rede axiológica e hierarquizada topicamente de princípios fundamentais, de normas estritas (ou regras) e de valores jurídicos cuja função é a de, evitando ou superando antinomias em sentido amplo, dar cumprimento aos objetivos justificadores do Estado Democrático, assim como se encontram consubstanciados, expressa ou implicitamente, na Constituição (FREITAS, 2002, p. 61).

Esse conceito de sistema franqueia epistemologicamente a faculdade de síntese

interbancárias de fundos se repartia em $57 \%$ para o Sitraf e $43 \%$ para o STR. A partir daquele mês, a composição começa a se alterar e, ao final de 2011, o STR já era responsável por $77 \%$ das operações, enquanto o SITRAF respondia por 23\%. Pode-se inferir, portanto, que o risco sistêmico do SPB diminuiu consideravelmente, não só em vista da diminuição do volume dos pagamentos processados pelo Sitraf, mas também das somas negociadas nesse sistema. 
hermenêutica entre os pensamentos sistemático e tópico, em sede de necessária e desejável interpenetração e complementação mútuas, e pois assevera a natureza tópica e sistemática dos princípios componentes do ordenamento jurídico. Assim, a abordagem jurídica deve antes amalgamar metodológica e concomitantemente estruturas e funções, superando dicotomias de modo a se obter uma visão empiricamente adequada do objeto a ser interpretado (CANARIS, 1989; FREITAS, 2002). Consequentemente,

a interpretação sistemática deve ser entendida como uma operação que consiste em atribuir, topicamente, a melhor significação, dentre várias possíveis, aos princípios, às normas estritas (ou regras) e aos valores jurídicos, hierarquizando-os num todo aberto, fixando-lhes o alcance e superando antinomias em sentido amplo, tendo em vista bem solucionar os casos sob apreciação (FREITAS, 2002, p. 80).

Resulta plausível se admitir uma complementaridade entre o posicionamento crítico e o hermenêutico, de modo a orientar a interpretação do texto, contexto e pretexto, no sentido de superara antinomias, inclusive valorativas, rumo a um plano axiologicamente superior. Nesse sentido, evidencia-se uma hierarquia, ainda que não inteiramente apriorística, dos princípios, máxime daqueles que fundamentam a ordem constitucional, na medida em que toda interpretação sistemática é, em última instância, interpretação constitucional. Outrossim, reforça-se a noção de que os valores supremos decorrentes da força normativa da Constituição devem sempre ser examinados em sede de fundamentação da interpretação ou aplicação jurídica. Nessa linha de pensamento, corrobora PERLINGIERI (2002, p. 12) a relevância a ser atribuída à eficácia

da norma constitucional frente às relações pessoais e socioeconômicas. A norma constitucional frente às relações torna-se a razão primária e justificadora (e todavia não a única, se for individuada uma normatividade ordinária aplicável ao caso) de relevância jurídica de tais relações, constituindo parte integrante da normatividade na qual elas, de um ponto de vista funcional, se concretizam.

No que tange ao sobrepassamento das antinomias jurídicas em senso largo, essa noção alargada de sistema enquanto totalidade axiológica e normativa, hierarquizável, implica uma prevalência tópica que viabiliza a resolução de questões envolvendo o conflito de normas que se encontram no mesmo patamar formal. Desse modo,

o critério hierárquico axiológico deve preponderar sobre a regra da especialidade, sob pena de se perder a ideia de que os princípios estão 
situados no topo do ordenamento jurídico e que as normas de vários escalões devem a eles restar harmonicamente subordinadas (FREITAS, 2002, p. 100).

Portanto, o critério hierárquico e principista deve finalmente prevalecer na hipótese de conflito aberto e insanável entre uma lei superior geral e uma norma especial inferior, ainda que por hipótese prepondere, ao fim e ao cabo, a norma inferior, na medida em que a hierarquização formal deve ceder à substancial.

Em síntese, deve-se entender as antinomias jurídicas fundamentalmente como incompatibilidades possíveis ou instauradas entre regras, valores ou princípios jurídicos, pertencentes, validamente ao mesmo sistema jurídico, tendo de ser vencidas para a preservação da unidade e coerência sistemática e para que se alcance a efetividade máxima da pluralista teleologia constitucional (FREITAS, 2002, p. 102).

Não obstante, é mister que a interpretação sistemática, a despeito dos moldes acima abraçados, evite a natural recaída na armadilha do autorreferenciamento e intimismo próprios da dogmática legalista, é dizer, na tendência histórica ao positivismo. Como adverte SALOMÃO FILHO (2012, p. 541):

A teoria jurídica é uma teoria social e exige, portanto, influxos,
informações e comparação com outras teorias que pretendem organizar o
funcionamento social. Não se dissocia e não pode ser compreendida ou
interpretada sem a contribuição e o diálogo com outras teorias sociais.
(...) a interdisciplinaridade é essencial para sua análise (da realidade) e
aplicação (à realidade).

Dessarte, somente através da identificação das estruturas jurídicas e econômicas, bem como de sua formação histórica, é que se franqueia a possibilidade de construção e reconstrução da totalidade do sistema jurídico em sede interpretativa, afastando-se da circularidade viciosa do positivismo dogmático, que basicamente beneficia as estruturas de poder dominante: ora se aplicando literalmente as regras em favor dessas estruturas, ora os princípios superiores, gerais, quando as regras não beneficiam as mesmas estruturas.

Também PERLINGIERI (2002, p. 72) realça a importância de se considerar o sistema jurídico em sua totalidade e complexidade, e pois a necessidade de concatenação de seus vários elementos, na medida em que

O princípio da legalidade não se reduz ao respeito aos preceitos individuais, implicando, ao revés, de um lado, a coordenação entre eles 
(além da harmonização com os princípios fundamentais de relevância constitucional) e, de outro, o confronto e o contextual conhecimento do problema concreto a ser regulado, isto é, do fato, individuado no âmbito do inteiro ordenamento - o conjunto das proposições normativas e dos princípios -, de maneira a individuar a normativa mais adequada e mais compatível com os interesses e com os valores em jogo.

Consequentemente, assevera SALOMÃO FILHO (2012, p. 544) a urgência de se "complementar as tradicionais declarações de princípios por uma identificação dos interesses a serem protegidos pelos princípios e normas". A despeito do valor fundamental presente nos princípios regentes da vida sociojurídica, devem ser eles antes "acompanhados de corajosa e clara identificação dos interesses envolvidos em sua aplicação, bem como da identificação de instrumentos para a mediação entre esses vários interesses".

Em sentido análogo, preleciona PERLINGIERI (2002, p. 106):

De um ponto de vista objetivo, a situação é um interesse que, essencial à sua existência, constitui o seu núcleo vital e característico. Interesse que pode ser ora patrimonial, ora de natureza pessoal e existencial, ora um e outro juntos (...). No ordenamento dito privatístico encontram espaço sejam as situações patrimoniais e entre essa a propriedade, o crédito, a empresa, a iniciativa econômica privada; sejam aquelas não patrimoniais (os chamados direitos de personalidade) às quais cabe, na hierarquia das situações subjetivas e dos valores, um papel primário.

Vale frisar que raramente se procura nos próprios princípios fonte de identificação dos interesses envolvidos. Na perspectiva da dogmática tradicional, são os princípios antes utilizados como guias interpretativos das regras, assumindo assim caráter residual e quase disfuncional na interpretação construtiva do ordenamento jurídico.

Não obstante, PERLINGIERI (2002, p. 211) adverte que

A jurisprudência dos valores constitui, sim, a natural continuação da jurisprudência dos interesses, mas com maiores aberturas para com as exigências de reconstrução de um sistema de 'Direito Civil constitucional', enquanto idônea a realizar, melhor do que qualquer outra, a funcionalização das situações patrimoniais àquelas existenciais, reconhecendo a estas últimas, em atuação dos princípios constitucionais, uma indiscutida preeminência.

Não se deve olvidar, portanto, de que o conhecimento jurídico é eminentemente 
valorativo. É dizer, em última instância, que os valores de uma determinada sociedade influenciam fundamentalmente o conhecimento que dela se tem. Do mesmo modo que a opinião dominante assevera a permanente presença de uma pretensão ou interesse a proteger por detrás de uma norma, ou seja, de um valor subjacente, também a sociedade objeto de conhecimento realiza na prática seus valores ao cumprir as regras do ordenamento jurídico. A sociedade que se observa nada mais é que uma representação dos valores sociais democraticamente estabelecidos, e pois cristalizados em sua Constituição (SALOMÃO FILHO, 1999).

Considerando, portanto, que as regras jurídicas não são simples generalizações de fatos observáveis nas relações socioeconômicas, requer a teoria jurídica não somente a observação empírica dos suportes fáticos concretizados pela aplicação dedutiva das regras jurídicas e seus efeitos, mas antes a concretização dos valores sociais desejados, observados os fatos da vida de relação (SALOMÃO FILHO, 1999).

\subsection{A Constituição brasileira face ao nomos financeiro}

Tendo em vista a natureza política da Constituição, em que se consignam os fundamentos definidores do ordenamento jurídico, revela-se a ordem jurídico-políticoeconômica de determinada nação, e pois seus elementos ou fatos econômicos e os princípios que os regem. A ordem econômica, ao ser disciplinada pela ordem jurídica constitucional, assume necessariamente uma condição ideológica, configurando o regime político econômico juridicamente regulamentado para aquela nação durante a vigência de sua Constituição (SOUZA, 2005).

No plano legal infraconstitucional, a ordem jurídico-político-econômica exprime sobretudo a política econômica praticada. Tais medidas de caráter legal abrangem toda a vida econômico-jurídica nacional, como sejam a atividade produtiva e seus elementos, passando pelo sistema de circulação e distribuição da riqueza, e finalmente o consumo. Assim, a exemplo dos princípios de justiça social, resultantes da ideologia constitucional, enquanto objetivos da política econômica, pretende-se garantir a posição do indivíduo como consumidor, como usuário da qualidade de vida, e pois se justificando todo o esforço produtivo da sociedade. Igualmente, outro dado ideológico, peculiar à ordem jurídicopolítico-econômica brasileira, a saber, o "desenvolvimento", tem em sua garantia todo o complexo legislativo que traduz a política econômica direcionada a seu fomento (SOUZA, 2005). 
O caráter instrumental dessas medidas já fora acentuado, de modo inaugural, em ensaio de COMPARATO (2012, p. 52), onde o direito econômico encontra sua natureza no fim a que colima: "traduzir normativamente os instrumentos da política econômica do Estado". O direito econômico visa assim atingir as estruturas do sistema econômico, no sentido de seu aperfeiçoamento ou transformação. No caso do Brasil, a tarefa do direito da política econômica sempre foi o da transformação das estrutura socioeconômicas, no sentido da superação do subdesenvolvimento.

Nesse sentido, adverte BERCOVICI (2012, p. 61) a respeito do desafio da reestruturação do Estado brasileiro, desafio esse a exigir "uma reflexão sobre os instrumentos jurídicos, fiscais, financeiros e administrativos necessários ou à disposição do Estado para a retomada do projeto nacional de superação do desenvolvimento".

Observe-se todavia a clássica lição de $\operatorname{VIDIGAL}$ (1977, p. 44), em que esse instrumental jurídico-econômico (direito econômico) encontra seu sentido na organização dos mercados, enquanto "disciplina jurídica de atividades desenvolvidas nos mercados, visando a organizá-los sob a inspiração dominante do interesse social".

Com efeito, esse "direito da organização dos mercados" só se perfaz mediante uma simbiose entre os ramos público e privado do Direito. Já o sentido e conteúdo do interesse social dominante só pode ser buscado, em última instância, nos princípios colimados pela ordem socioeconômica constitucional (SOUZA, 2005).

Não obstante, cabe mencionar a severa advertência lançada por BERCOVICI (2012, p. 62) a respeito da tarefa a ser desempenhada sobretudo pelo direito econômico no Brasil, mas que certamente a esse ramo jurídico não se deve restringir:

ao mesmo tempo em que oferece instrumentos para a organização do processo econômico capitalista de mercado, o direito econômico pode ser utilizado pelo Estado como um instrumento de influência, manipulação e transformação da economia, vinculado a objetivos sociais ou coletivos, incorporando, assim, os conflitos entre a política e a economia. Para repensar as bases e estrutura do Estado brasileiro, não se pode deixar de levar em consideração a questão central da atualidade: a prevalência das instituições democráticas sobre o mercado e a independência política do Estado em relação ao poder econômico privado, ou seja, a necessidade de o Estado ser dotado de uma sólida base de poder econômico próprio. $\mathrm{O}$ fundamento desta visão, consubstanciado no texto constitucional vigente, é o de que não pode existir um Estado democrático forte sem que sua 
força também seja ampliada do ponto de vista econômico, para que ele possa enfrentar os interesses dos detentores do poder econômico privado. Afinal, seguindo a síntese de Hermann Heller ${ }^{177}$, a partir do fim da Idade Média, o poder político lutou para ganhar autonomia em relação ao poder religioso. Esta luta, desde o início do século XX, vem se travando contra o poder econômico privado.

A atual Constituição brasileira, promulgada em 1988, inovou tanto na técnica como na abrangência do regramento da ordem econômica e financeira. Com efeito, o art. 170 e incisos definiram os "fundamentos" e os "princípios" sobre os quais assenta a ordem jurídico-político-econômica que se colima efetivar, a saber, o "trabalho humano" e a "livre iniciativa". O "fim" a ser alcançado, por sua vez, repousa na "existência digna conforme os ditames da justiça social".

Ressalte-se ainda que a composição ideológica a que estão atrelados esses "fundamentos" e "fins" se exprimem pelos "princípios" enumerados nos diversos incisos ao mesmo artigo. Porém, seu discurso ideológico original sofreu, posteriormente, fundamentais modificações por meio de Emendas Constitucionais, em movimento pendular neoliberal para o lado do liberalismo (SOUZA, 2005).

Não obstante, ao intérprete não cabe olvidar de que sempre haverá uma "ideologia constitucionalmente adotada", determinando os "parâmetros" e oferecendo os "fundamentos" para a interpretação. Desse modo, é mister se ter presente que a Constituição se compõe fundamentalmente dos "princípios" nela consagrados, independentemente dos "tipos ideológicos puros". A despeito dos possíveis conflitos entre princípios constitucionais, sobretudo em sua forma pura, resta ao intérprete, senão por dever de ofício, mas ao menos por questão de "economicidade", decidir por uma ou outra regra, sem afastar definitivamente aquela que fora ocasionalmente preterida, mesmo porque jamais as excluirá do "conjunto constitucional” (SOUZA, 2005, p. 232 e s.).

Nesse sentido, vale frisar ser a Constituição "a ordem jurídica fundamental de uma sociedade em um determinado momento histórico; e, como ela é um dinamismo, é contemporânea à realidade". Na verdade, é dizer que não há de fato a Constituição de 1988, mas “o que realmente hoje existe, aqui e agora, é a Constituição do Brasil, tal como hoje, aqui e agora, está sendo interpretada/aplicada" (GRAU, 2012, p. 356).

A despeito, portanto, das ideologias ocasionais e dos movimentos políticos 
pendulares ao sabor dessas mesmas ideologias, o dirigismo econômico, no sentido de oposição à Constituição meramente política e organicista, permanece sendo a marca institucional da vigente Constituição brasileira. Com efeito, assim preleciona GRAU (2012, p. 356):

Deveras, a Constituição do Brasil não é um mero "instrumento de governo", enunciador de competências e regulador de processos; mas, além disso, enuncia diretrizes, fins e programas a serem realizados pelo Estado e pela sociedade. Não compreende tão somente um "estatuto jurídico do político", mas sim um "plano global normativo" da sociedade e, por isso mesmo, do Estado Brasileiro.

Portanto, a Constituição vigente não significa apenas a Constituição (política) da República Federativa do Brasil, mas desempenha sobretudo a tarefa de ser a "Constituição do Brasil". Dessarte, "os fundamentos e os fins definidos em seus arts. $1^{\circ}$ e $3^{\circ}$ são os fundamentos e os fins da sociedade brasileira", estando também e principalmente o próprio legislador "vinculado pelos seus preceitos, ainda que sob distintas intensidades vinculativas" (GRAU, 2012, p. 357).

Retrata assim a nossa Constituição, sobretudo na projeção de sua ordem econômica, a realidade nacional, a sociedade política em sua heterogeneidade de interesses os mais diversos e contraditórios, coexistindo estrutural e funcionalmente através dos muito modos de produção da vida socioeconômica (GRAU, 2012, p. 341).

Nos quadrantes acima esboçados é que se deve ler a norma que restou ao caput do art. 192 da Constituição Federal, sobretudo após o ferimento causado pela Emenda Constitucional $\mathrm{n}^{\circ} 40$, de 2003, revogando integralmente esse artigo, seus incisos e parágrafos, mantendo somente a sua introdução.

Na lição de SOUZA (2005, p. 230):

Tratava dos mais importantes temas como as condições para a participação do capital estrangeiro nas instituições financeiras nacionais, criação de um "fundo de seguro" para proteger a economia popular, estabelecia critérios para a transferência de poupanças de regiões com renda inferior à nacional, para outras de maior desenvolvimento e outros, além de estabelecer a taxa de juros em $12 \%$ ao ano.

Fortes reações, especialmente levadas a efeito pelos Bancos e instituições financeiras particulares, culminaram na revogação de todos os seus dispositivos, pela Emenda Constitucional n. 40, de 29 de maio de 2003. 
Restaram apenas os dizeres do caput que sem os dispositivos perdem toda objetividade.

Nada obstante, vale frisar que ainda restam, de um lado, os fundamentos e princípios esposados no citado art. 170, diretriz fundamental para o conjunto da ordem econômica e financeira constitucional, e de outro, a própria regra do art. 192, rica em conteúdo e eficácia, ao menos para aqueles que a souberem ler:

O sistema financeiro nacional, estruturado de forma a promover o desenvolvimento equilibrado do País e a servir aos interesses da coletividade, em todas as partes que o compõem, abrangendo as cooperativas de crédito, será regulado por leis complementares que disporão, inclusive, sobre a participação do capital estrangeiro nas instituições que o integram.

Verifica-se, portanto, que "ainda onde o direito mudou muito, muito se há de inquirir do que não mudou. O direito muda muito onde em muito deixou de ser o que era" (PONTES DE MIRANDA, 1999, p. 20).

Sem embargo, é forçoso se admitir que a hegemonia das tendências neoliberais que sucederam a ruptura do padrão de financiamento da economia do segundo pós-guerra, a desarticulação das ordens financeira e econômica nas constituições reflete a contradição do novo padrão sistêmico de acumulação com o paradigma da constituição dirigente, implicando o surgimento de um novo fenômeno: a constituição dirigente invertida (BERCOVICI, 2006, p. 3 e s.).

Com efeito, a articulação do direito financeiro com o econômico convergiu historicamente no sentido da organização jurídica da acumulação econômica, enquanto situada também no espaço político, conforme o regime econômico e a tarefa atribuída ao Estado na estruturação da economia. Nesse sentido, o constitucionalismo do século XX evoluiu na direção estruturante de uma ordem econômico-financeira integrada, e pois assentada no planejamento como principal instrumento de política econômica, observada assim a organização estatal do modo de produção capitalista (BERCOVICI, 2006).

Porém, ainda no final do século XX, dando sequência à desestruturação do padrão (keynesiano) de financiamento público da economia, impulsionado nos pós-guerra pelo sistema de Bretton Woods, a reação neoliberal avança fronteiras, rompendo as linhas de defesa constitucionais que até então sustentavam o chamado "Estado Social". 
Consequentemente, questões historicamente superadas retornaram à pauta da política econômica, quais sejam "a cisão entre a economia e as finanças públicas, a abstenção do Estado no domínio econômico e a pretensa neutralidade financeira propugnada pelos liberais" (BERCOVICI, 2006, p. 5 e s.).

Consequentemente, a integração outrora estruturante do paradigma dirigente foi substituída por novo fenômeno, desagregador por definição, no sentido da crescente instrumentalização da Constituição financeira, particularmente do orçamento, pela política econômica liberal, em detrimento do planejamento econômico estatal e socialmente orientado conforme os ditames da Constituição econômica (dirigente). No Brasil, a Constituição dirigente de 1988 e a política econômica posta em prática em período posterior refletem particularmente esse ponto de inflexão.

Não é despiciendo o relato a respeito do movimento de reestruturação financeira que presidiu a reformulação constitucional de 1988 (BERCOVICI, 2006, pp. 10-2):

Com a redemocratização, a crise econômica profunda herdada da Nova República leva à aceleração do processo de reestruturação financeira. Em 1986 é criada a Secretaria do Tesouro Nacional, que passa a administrar os fundos e programas de fomento até então gerenciados pelo Banco Central. Por meio do Voto $n^{\circ} 45 / 86$, promulgado em 31 de janeiro de 1986 pelo CMN, é congelado o saldo da conta-movimento do Banco do Brasil, que, na prática, tem encerrada suas atividades, e, em 1987, com o "Plano Bresser" (Decretos no 94.443 e no 94.444, ambos de 12 de Junho de 1987), e o Decreto-Lei no 2376, de 25 de Novembro de 1987, a gestão da dívida pública sai da esfera de competências do Banco Central, passando para o Ministério da Fazenda. Além disto, o Banco Central também deixa de ser financiador do Tesouro Nacional e são extintas suas funções de fomento, medidas que, posteriormente, seriam consolidadas no artigo 164 da Constituição de 1988. Afinal, o próximo e definitivo passo no rumo da centralização monetária e orçamentária seria dado pela nova Constituição em discussão na Assembléia Nacional Constituinte de 1987-1988.

Com o objetivo de ampliar a participação do Poder Legislativo na elaboração, aprovação e execução do orçamento e de aumentar a transparência dos gastos públicos, a Constituição de 1988 consagra a unificação orçamentária. No artigo 165 preveem-se três leis orçamentárias distintas: o Plano Plurianual (PPA), a Lei de Diretrizes 
Orçamentárias (LDO) e a Lei Orçamentária anual (o Orçamento Geral da União, que engloba o Orçamento Fiscal, o Orçamento Monetário, o Orçamento das Empresas Estatais e o Orçamento da Previdência Social). O processo de centralização e unificação orçamentária só vai se encerrar durante a década de 1990, após a privatização dos bancos estaduais, com a consolidação da centralização da autoridade monetária no Banco Central e com a aprovação da peça legislativa final, a Lei de Responsabilidade Fiscal (Lei Complementar $n^{\circ}$ 101, de 2000), diploma que, ao contrário da opinião corrente, encerra um processo iniciado na década de 1970, não inicia uma fase nova das finanças públicas brasileiras.

A questão que sobreleva nesse devir reside fundamentalmente no esgotamento da capacidade de intervenção econômica do Estado brasileiro, sobretudo em razão da cruzada empreendida na reestruturação das finanças públicas. A degradação financeira do Estado e o consequente rompimento da funcionalidade do pacto desenvolvimentista resultaram em ampla revisão de todo o arcabouço institucional. A despeito de proporcionar, em certa medida, uma maior transparência das contas públicas, as alterações substanciais sofridas pelo aparato financeiro institucional não forjaram novas formas de intervenção estatal, aliás, pelo contrário. A Constituição financeira de 1988, a qual deveria dar suporte à consecução dos objetivos da ordem econômica e social, se viu neutralizada pela política econômica posteriormente praticada, esterilizando assim a capacidade de intervenção do Estado no domínio econômico-financeiro.

De fato, a função do orçamento público (fundo público) sofreu transformações concomitantemente às mudanças ocorridas no capitalismo sobretudo a partir da década de 1970. Durante o período do chamado "consenso keynesiano" (1945-1973), ainda sob o regime de Bretton Woods, o papel do fundo público residia fundamentalmente na garantia de direitos sociais e na prestação de serviços públicos para a maioria da população. Nesse sentido, através do crescimento do "salário indireto", se investia na força de trabalho e indiretamente se fomentava o processo de acumulação capitalista.

Sem embargo, o próprio processo de acumulação capitalista sofre uma guinada no sentido das finanças, a partir da mesma década de 1970, como mostrado anteriormente. Paralelamente, o desenvolvimento tecnológico em larga escala afasta a necessidade de investimentos maciços, particularmente por parte do Estado, no fator produtivo trabalho. Nesse contexto, obviamente, se altera a própria função do fundo público no que tange à 
reprodução das condições básicas do capitalismo acumulativo. É dizer, o fundo público ainda tem papel preponderante no fomento dos fatores produtivos, não obstante, se afasta do fator trabalho em direção à formação do próprio capital, no sentido de garantir sua remuneração.

Com efeito, e pois como também já visto em tópicos anteriores, a década de 1980 assiste ao avanço do discurso neoliberal de repúdio ao Estado, tendo como corolário natural as exigências de controle eficaz do déficit público sobretudo por meio de políticas econômicas deflacionárias, vale dizer, políticas monetárias sustentadas por elevadas taxas de juros. Desse modo, o crescente déficit público resultante das despesas geradas pelo pagamento de juros aos credores das dívidas soberanas substitui largamente as políticas fiscais deficitárias de outrora, geradoras de despesas públicas como resultado de políticas de pleno emprego. Em última instância, o déficit público passou a garantir a remuneração do capital financeiro.

Nesse diapasão, o direito financeiro passa a tutelar juridicamente a renda do capital, sancionando os "ganhos financeiros privados, a partir da alocação de garantias estatais ao processo sistêmico de acumulação liderado pelo capitalismo financeiro" (BERCOVICI, 2006, p. 15).

No Brasil, consolida-se a supremacia do orçamento monetário, ou seja, "a garantia do custo da moeda (definido pelo Banco Central e pelo Conselho de Política Monetária Copom, à margem do Congresso Nacional), voltado para a estabilidade monetária, sobre o orçamento fiscal” (BERCOVICI, 2006, p. 16).

O controle do orçamento monetário passa assim a presidir a formulação da política fiscal, determinando portanto o próprio orçamento fiscal. Dessarte, as políticas fiscais e o chamado "orçamento-programa" basicamente se subordinam à política de estabilização monetária implementada sobretudo a partir do Plano Real (1994).

Com o advento da Lei de Responsabilidade Fiscal, bem como das sempre presentes "metas de superávit primário", em complemento às metas de política monetária, não raro impostas pelo mercado e no interesse do poder econômico privado que tem por objetivo precípuo o lucro financeiro sem riscos. Nesse contexto, portanto, a implementação da ordem socioeconômica constitucional tem sido alijada dos instrumentos financeiros (orçamentários) a ela necessários, restando-lhe as sobras orçamentárias.

Como esboçado na seção anterior, o padrão regulatório que sustentou o mundo do pós-guerra até meados da década de 1970 foi completamente remodelado no âmago do 
capitalismo central. Essa nova ordem econômica mundial, concêntrica à moeda norteamericana, e pois à sua política fiscal e monetária, se traduz basicamente no alinhamento mundial das políticas cambial, de taxa de juros, monetária e fiscal de todos os países desenvolvidos, vale dizer, o espectro das taxas de crescimento, câmbio e juros, enfim, os preços básicos da economia, são referenciados pelo desempenho dessas variáveis internas à economia norte-americana.

Nesse sentido, o direito financeiro deixa a órbita de organização da expansão material (real) do sistema capitalista de acumulação produtiva, de viés keynesiano, ou ainda schumpeteriano, transmudando sua função normativa no sentido de assegurar a organização da expansão financeira do processo capitalista de acumulação, é dizer, adaptando seu instrumental para a realização da segunda etapa de um dos modelos acumulativos proposto por MARX (1984), qual seja o lucro financeiro especulativo (D $\left.D^{\prime}\right)$.

Consequentemente, o fundo público permanece na retaguarda do financiamento da acumulação de capital. Não obstante, assume novas formas e funções, considerando sobretudo a referência generalizada da moeda de crédito à moeda norte-americana e o advento de um novo padrão de riqueza, fundado na acumulação patrimonial financeira. Ao contrário do processo verificado na ordenação econômica mundial do segundo pós-guerra, os detentores do capital financeiro ou seus mandatários, situados na interface entre o poder e o capital do sistema mundial, assumiram o comando da expansão capitalista sob a forma puramente financeira, resultando na imposição pelo poder econômico privado de uma adaptação dos ordenamentos jurídicos nacionais a seus interesses (BERCOVICI, 2006; HUBER, 2011).

Parafraseando KEYNES (2012, p. 142), essas considerações não devem estar além da alçada do jurista ${ }^{178}$. Ao revés, devem ser enquadradas na correta perspectiva. Assim, o celebre economista lança mão do termo "especulação" para definir a atividade consistente na previsão da psicologia do mercado, enquanto reserva a expressão "empreendimento" à atividade que busca prever o rendimento provável dos bens durante toda a sua vida útil.

Com efeito, o mercado especulativo se caracteriza pela demanda por ativos apenas em razão da expectativa de que seus preços se mantenham em elevação, basicamente sem que se considere, por parte do especulador, nenhuma relação entre aqueles preços e seus 
fundamentos econômicos, é dizer, os rendimentos prospectivos (dividendos) graças ao empreendimento econômico (real) que lastreia os mesmos ativos (COSTA, 1999).

Advirta-se, porém, não se poder inferir imediatamente da argumentação anterior que a especulação prevaleça sempre sobre o empreendimento. Não obstante, à medida que a organização de mercados de investimentos "líquidos" se torna cada vez mais efetiva, provendo liquidez de forma plenamente eficaz, eleva-se potencialmente o risco de predomínio da atividade especulativa sobre a empreendedora (KEYNES, 2012) ${ }^{179}$.

Nesse sentido, vale frisar a advertência de KEYNES (2012, p. 142):

Os especuladores podem não causar dano quando são apenas bolhas numa corrente estável de empreendimento. Mas a situação torna-se grave quando o empreendimento se converte numa série de bolhas no turbilhão especulativo. Quando o desenvolvimento do capital de um país passa a ser um subproduto das atividades de um cassino, a obra sairá provavelmente torta [grifo nosso]. As proporções assumidas pelo êxito de Wall Street, encarada como uma instituição cuja adequada finalidade social seria conduzir os novos investimentos pelos canais mais produtivos em termos de rendimento futuro [grifo nosso] ${ }^{180}$, não podem ser apontadas como um dos mais brilhantes triunfos do capitalismo do tipo laissez-faire - o que não é surpresa, se for verdadeiro, como penso, que os mais brilhantes cérebros de Wall Street se orientam de fato para um fim diferente.

No âmbito dessa evolução do capitalismo financeiro, impõe-se contextualizar o ordenamento econômico-financeiro face à legislação de política econômica (monetária) que vem sendo adotada pelos governos brasileiros, situando-se indubitavelmente nesse âmbito o Sistema de Pagamentos Brasileiro, não somente enquanto "parte" do sistema financeiro nacional (Constituição Federal, art. 192), mas sobretudo em razão da sua própria formatação material (conteudística), anteriormente esboçada.

Desse contexto, aliás, não se deve olvidar ao se ler o texto da regra contida no art. 192 da Constituição Federal, sem o que

Não se poderia situar, no tempo, na evolução jurídica, cada enunciado do sistema lógico; nem se colheria o que estava na psique dos elaboradores da lei, porque estava no ambiente social (e continuou de estar), e se supôs

179 A analogia com a estruturação hodierna dos sistemas de pagamentos se impõe por si própria.

180 É indubitável a analogia desse pensamento com a teoria do desenvolvimento de SCHUMPETER (1982). 
incluso nos textos, ou entre os textos; nem se poderiam fixar certos conceitos, nem se determinariam certas categorias, que têm os seus limites marcados pelos fios históricos. Ainda onde o direito mudou muito, muito se há de inquirir do que não mudou. $\mathrm{O}$ direito muda muito onde em muito deixou de ser o que era (PONTES DE MIRANDA, 1999, p. 20).

Nesse diapasão, a ordem econômica e financeira esposada pela Constituição Federal tem sua ratio legis antes alicerçada nos princípios e fundamentos que compõem a ordem constitucional, cujas regras, constitucionais ou legais, encontram seu sentido último não nas alterações queridas pelo legislador nem no que o texto legal quer agora, mas sobretudo no que está na lei, regrado ou enunciado conforme o sistema jurídico (constitucional), pois

Interpretar é revelar as regras jurídicas que fazem parte do sistema jurídico, pode ter sido escrita e pode não estar escrita, mas existir no sistema, pode estar escrita e facilmente entender-se e apresentar certas dificuldades para ser entendida (PONTES DE MIRANDA, 1999, p. 17).

Dessarte, ao se ler a lei, é mister que se tenha presente "o sistema jurídico, em que ela entra, e se ler na história, no texto e na exposição sistemática" (PONTES DE MIRANDA, 1999, p. 18).

\subsection{O Código Civil face à ordem constitucional}

O Direito Civil tem acompanhado uma série de alterações axiológicas desde o advento de sua codificação. A aristocracia rural e o modo de produção escravista da vida de relação ainda dominavam o Brasil que se tornara independente da metrópole portuguesa. Embora Portugal tenha absorvido em sua legislação civil o ideário da Revolução Francesa, de viés liberal, e a despeito de ter o movimento abolicionista logrado certo sucesso ainda no período imperial, a própria República que se fundara contemplou ainda por muito tempo os antigos valores impregnados no ordenamento filipino. Com efeito,

Nos primeiros trinta anos da República - 1889 a 1919 - a contradição resultante do desenvolvimento desigual do capitalismo do país, que, grosso modo, pode ser expressa no contraste entre o litoral e o interior, não provocou crises profundas, porque o setor mais ponderável da camada social superior - o dos fazendeiros - utilizou, em proveito próprio, a classe média urbana, que por sua vez, adstrita ao serviço burocrático e militar, por falta de desenvolvimento industrial, a ela se 
submeteu docilmente, para alargar as suas possibilidades. Esses interesses coincidiam, por outro lado, com os da burguesia mercantil, agindo todos em detrimento da massa rural, cujas condições de vida não permitiam, sequer tivesse consciência de sua miserável situação (GOMES, 2003, p. 11 e ss.).

O modelo edificador do Código Civil de 1916, da lavra de Beviláqua, residia na valorização do individualismo no âmbito da dicotomia entre o público e o privado, justificando assim teoricamente a supremacia da codificação civil na regência das relações de ordem privada. Consequentemente, seus marcos teóricos assentavam no direito de propriedade e na família patriarcal, refletindo a própria hierarquia da sociedade brasileira (GOMES, 2003).

A codificação civil representava o eixo central da vida de relação, dado o primado liberal do privado sobre o público, protegendo a propriedade e o contrato sob a égide patrimonialista, e calcada na ideia de que a subsunção do fato à norma civil bastaria à tutela de todos os fatos sociais. A Constituição Federal, embora formalmente reconhecida como lei maior, tinha seu papel relegado a repositório de ideais e princípios, entendida assim como documento essencialmente político, enquanto o Código Civil, sim, denotava a efetividade das normas a serem seguidas em sociedade.

Nesse sentido esclarece PEDRO (2012, p. 81):

Nesse sistema dicotômico, o espaço público representa a coletividade com suas normas de regência, sendo a preponderante a Constituição Federal. Em outro extremo observa-se o espaço privado também com suas normas de regência e a norma que predomina é o Código Civil. A partir dessa concepção, verifica-se de um lado os publicistas e de outro lado os privatistas com concepções axiológicas diversas, estruturando o ordenamento não em um sistema de eixos, mas em um sistema de paralelas.

Ao longo do século XX, entretanto, verificou-se uma clara mudança de paradigma no sentido de se atribuir às normas constitucionais o estatuto de "norma jurídica" efetiva. Essa noção se desenvolve sobretudo a partir da Constituição alemã de Weimar, no primeiro pós-guerra, onde o projeto de ordenação socioeconômica encontra guarida. No Brasil, a Constituição de 1934 já incorporava a semente de uma organização social, não meramente política, cujo ápice se atinge obviamente no dirigismo socioeconômico da Constituição de 1988. 
Por esse encaminhamento, natural foi a publicização crescente experimentada de um modo geral pelo Direito, e particularmente pelo Direito Civil, cujos institutos como, propriedade ou família adentraram a agenda da ordem pública, a eles também se irradiando os efeitos dos princípios e regras constitucionais. Com efeito,

a partir da interferência da Constituição no âmbito antes reservado à autonomia privada, uma nova ordem pública há de ser construída, coerente com os fundamentos e objetivos fundamentais da República. Afinal, o código civil é o que a ordem pública constitucional permite que possa sê-lo. E a solução interpretativa do caso concreto só se afigura legítima se compatível com a legalidade constitucional (TEPEDINO, 2009, p. 4).

Sem embargo, como adverte PEDRO (2012, p. 83),

cumpre salientar que não se trata de uma desintegração do individualismo humano, mas sim, do primado do bem comum sobre a necessidade individual. É nesse contexto que se pode perceber que, embora todos os diplomas legais contemplem o direito do indivíduo ter a propriedade, fica bem clara a noção de que esta propriedade deve atender a seus fins sociais. Tal pensamento não representa em si mesmo um antagonismo, mas no plano axiológico, tem-se uma complementaridade que denota o estágio social-democrático da sociedade em contraposição ao estágio do apogeu do liberalismo que norteou o Código Civil de 1916 entre outros dispositivos legais.

De fato, a nova proposta interpretativa não objetivava subtrair ao direito privado seu espaço de incidência, ao contrário, visava à sua mudança qualitativa, "potencializandoo e redimensionando-o, mediante a funcionalização de seus institutos e categorias à realização dos valores constitucionais" (TEPEDINO, 2009, p. 4).

Desse modo, a autonomia privada tem sua noção remodelada por valores não patrimoniais, antes existenciais, próprios da noção de ordem pública e social. Institutos como a propriedade, a empresa, a família, relações contratuais se funcionalizam no sentido de atender concretamente aos valores constitucionais, particularmente da dignidade da pessoa humana. O próprio princípio da autonomia privada deixa de ser um valor em si, também não se subtraindo "ao controle de sua correspondência e funcionalização ao sistema de normas constitucionais” (PERLINGIERI, 2002, p. 277).

Floresce assim o fenômeno conhecido como "diálogo das fontes", tendo como 
premissa o entendimento flexível do sistema jurídico por parte do operador do Direito, cuja principal tarefa reside na compatibilização entre os normativos existentes, observados os postulados constitucionais sobretudo no sentido de lhes dar efetividade na tutela das relações jurídicas (PEDRO, 2012).

No mesmo sentido, assevera TEPEDINO $(2009$, p. 7) que

A atenção, portanto, se volta para a indispensável unidade interpretativa exigida no cenário de pluralidade de fontes normativas, a partir dos valores constitucionais, cuja utilização direta na solução das controvérsias do direito privado assegura, a um só tempo, a abertura do sistema e a sua unidade.

Não se há todavia de olvidar da inflação legislativa que flagela o nosso tempo, na medida em que

numerosas leis especiais têm disciplinado, embora de modo fragmentado e por vezes incoerente, setores relevantes. O Código Civil certamente perdeu a centralidade de outrora. $\mathrm{O}$ papel unificador do sistema, tanto nos seus aspectos mais tradicionalmente civilísticos quanto naqueles de relevância publicista, é desempenhado de maneira cada vez mais incisiva pelo Texto Constitucional. Falar de descodificação relativamente ao Código vigente não implica absolutamente a perda do funcionamento unitário do ordenamento, de modo a propor a sua fragmentação em diversos microordenamentos e em diversos microssistemas, com ausência de um desenho global. Desenho que, se não aparece no plano legislativo, deve ser identificado no constante e tenaz trabalho do intérprete, orientado a detectar os princípios constantes na chamada legislação especial, reconduzindo-os à unidade, mesmo do ponto de vista de sua legitimidade (PERLINGIERI, 2002, p. 6).

Considerando, portanto, a força normativa dos princípios constitucionais, resultado sobretudo do entendimento unitário do ordenamento jurídico, pois que a Constituição sobreleva incontestavelmente na hierarquia das fontes, não resta dúvida que nem o tamanho ou importância efetiva do Estado e tampouco a renovação infralegal têm o condão de alterar a normatividade constitucional, em que pese a menor racionalidade normativa dos dispositivos constitucionais. Pelo contrário, as normas constitucionais integram fundamentalmente a própria dogmática civilista, no sentido de remodelar e revitalizar os institutos do Direito Civil concentricamente à sua força integrativa (unificadora) do sistema jurídico (TEPEDINO, 2009). 
Não obstante, é mister que não se recaia no equívoco de se entender o processo hermenêutico como via de mão dupla, enquanto corolário da visão unitária do ordenamento, pretendendo-se assim justificar a influência recíproca entre normas constitucionais e normas de hierarquia inferior. Ao revés, tendo em vista ser antes axiológica do que lógica a fundamentação hermenêutica, deve ela se manifestar necessariamente num único sentido, qual seja a prevalência dos valores constitucionais diante dos julgados, núcleos legislativos ou categorias de direito infraconstitucional.

Nesse diapasão, importante a ressalva feita por TEPEDINO (2009, p. 31 e s.), no sentido de que

as categorias jurídicas (tais como contrato, propriedade, empresa, negócio jurídico e família) são essencialmente históricas. Cuida-se de noções relativas, não já neutras ou absolutas, forjadas nas tensões dialéticas da atividade interpretativa. $\mathrm{O}$ intérprete não se pode deixar influenciar pela minúcia analítica do legislador infraconstitucional, supondo que tal detalhamento regulamentar vincule mais do que as cláusulas gerais veiculadoras de princípios hierarquicamente superiores.

De fato, quanto mais baixa na hierarquia normativa mais detalhada a norma se apresenta. E justamente por possuir maior concretude, mostramse certos autores tentados a adaptar o preceito constitucional ao comando pormenorizado da regra raquítica, lendo a norma constitucional à luz da norma infraconstitucional - e não o contrário -, de modo a fazer com que a regra específica prevaleça sobre a determinação constitucional, e subvertendo, assim, a hierarquia de valores do ordenamento, no âmbito do qual os princípios constitucionais devem sempre prevalecer. Trata-se de uma espécie de técnica de interpretação conforme às avessas, oblíqua, intolerável do ponto de vista hermenêutico.

\subsection{A legislação (financeira) especial}

Frise-se novamente que a Lei $\mathrm{n}^{\circ} 10.214$, de 27 de março de 2001, representa o marco legal do SPB. Ao regrar a atuação das câmaras de compensação e de liquidação, estabelece, em seu art. $2^{\circ}$, que as entidades, os sistemas e os procedimentos relacionados à transferência de fundos e de outros ativos financeiros, ou ao processamento, a compensação e a liquidação de pagamentos em qualquer de suas formas compõem o sistema de pagamentos brasileiro. 
Nesse sentido, instituiu o referido diploma legal as seguintes inovações (AGUIAR JÚNIOR, 2001; VERÇOSA, 2005):

a) a compensação multilateral de obrigações no ambiente de um sistema integrado de compensação e de liquidação de obrigações;

b) assunção da posição de contraparte central pela câmara de compensação e liquidação considerada sistemicamente importante;

c) a exigência de serem adotados mecanismos e salvaguardas para garantir a liquidação dos negócios cursados nos ambientes sistemicamente importantes;

d) a execução direta de posições em custódia, contratos e garantias aportadas pelos participantes;

e) segregação de patrimônio especial destinado exclusivamente à garantia do cumprimento das obrigações cursadas em ambiente sistemicamente importante;

f) tornou impenhoráveis os bens oferecidos em garantia no âmbito dos sistemas de compensação e de liquidação;

g) afastou do adimplemento das obrigações cursadas em ambiente sistemicamente importante a incidência e os efeitos dos regimes de insolvência, administrativos ou judiciais.

Segundo VERÇOSA (2005, p. 223),

verifica-se que, dentro de uma área reconhecida como de relevo sistêmico, é imprescindível operar com garantias absolutamente eficazes quanto ao seu papel de resguardar o credor. Para este efeito foi criada uma regra excepcional de afastamento de qualquer credor externo ao sistema de compensação e de liquidação de obrigações quanto a pretensões que pudesse ter contra o mesmo credor. Assim sendo, não poderá o síndico de uma instituição financeira sob liquidação extrajudicial ou falência arrecadar aqueles bens para a massa liquidanda ou falida.

Com efeito, conforme o texto da Exposição de Motivos que acompanhava a Medida Provisória n ${ }^{\circ}$ 2.008, de 1999, sucessivamente reeditada, portanto, fonte legislativa do atual diploma legal do SPB (Lei no 10.214, de 2001),

todo o nosso sistema de pagamentos foi criado e desenvolvido sob a suposição de liquidação financeira certa das transações junto ao Banco Central do Brasil. A eventual rejeição de débitos por parte deste leva a que a iliquidez de determinada instituição se transfira às demais, gerando 
a possibilidade de crise sistêmica, pois as principais câmaras de compensação e de liquidação não estão adequadamente instrumentalizadas para garantir a finalização das operações contratadas, até por falta de amparo legal. (...) Pretende-se que, mais do que pólos de tramitação de operações financeiras (as câmaras de compensação e de liquidação) sejam pólos de contenção de riscos potencialmente sistêmicos, tudo com o escopo principal de possibilitar redução drástica da álea hoje suportada pelo Banco Central do Brasil. Ou seja, quer-se que os riscos sejam devolvidos ao próprio mercado, que, em contrapartida, passa a beneficiar-se de regras que garantem a finalização das operações contratadas nos mercados financeiro e de capitais, mesmo nas hipóteses de insolvência civil, concordata, intervenção, falência e liquidação extrajudicial de um participante (apud STURZENEGGER, 2001, p. 233 e s.) $)^{181}$.

Contribuem ainda para a formatação institucional do SPB outras normas de caráter infralegal, editadas pelo Conselho Monetário Nacional (CMN) e pelo Banco Central do Brasil (BCB), destacando-se entre elas:

- Resolução $\mathrm{CMN}^{\mathrm{o}}$ 2.882, de 30 de agosto de 2001, dispõe sobre o sistema de pagamentos e as câmaras e os prestadores de serviços de compensação e de liquidação que o integram; e

- Circular BCB no 3.057, de 31 de agosto de 2001, aprova o regulamento disciplinar do funcionamento dos sistemas operados pelas câmaras e pelos prestadores de serviços de compensação e de liquidação que integram o SPB.

Dessarte, as inovações introduzidas buscam dar suporte institucional sólido ao SPB de modo que as câmaras de compensação e liquidação, mesmo na hipótese de

181 A despeito da dicção legiferante, e pois como mostrado no tópico anterior, na realidade se verifica que a provisão de liquidez ilimitada por meio de operações diárias de redesconto, sem custos e somente condicionadas à disponibilidade de títulos da dívida pública federal, não afasta a álea inerente aos negócios interbancários em rede, senão que a mantém sob controle, na medida em que se lhe garante o financiamento rotativo por meio de operações financeiras lastreadas (indiretamente) pelo erário, é dizer, garantidas pela contínua aquisição em mercado dos títulos de crédito públicos - aliás, o maior e mais sofisticado mercado financeiro existente -, onerando em última instância toda a sociedade. Vale novamente frisar, trata-se sobretudo de riscos "criados" pelo próprio sistema financeiro, fomentados pela elevada liquidez institucionalizada nos modernos sistemas de pagamentos, dando azo à preponderância econômica da atividade especulativa sobre os investimentos empreendedores (KEYNES, 2012). Esses riscos financeiros são basicamente mantidos sob controle, no sentido de restarem assegurados sob os auspícios da legalidade institucional (BECK, 2011), e pois onerando continuamente o erário, ainda que de forma oblíqua, ao robustecer a emissão de dívida pública, garantindo, em última instância, a valorização real dos ativos financeiros em prol dos estratos socioeconômicos dominantes (BERCOVICI, 2006; HUBER, 2011). 
inadimplência, insolvência civil, intervenção administrativa, falência ou liquidação extrajudicial de um partícipe, possam liquidar as obrigações decorrentes de negócios por ele celebrados no mercado financeiro e no de capitais, lançando mão dos ativos negociados e, se necessário, do produto da excussão direta (específica) das garantias recebidas, sem prejuízo, ainda, de outros mecanismos de salvaguarda, tais como a definição de limites operacionais, a constituição de fundo de garantia de liquidação, a contratação de seguro de garantia de liquidação, a aplicação do regime de compartilhamento de perdas, a utilização de linhas de crédito bancário e ainda a constituição de patrimônio apartado (BCB, 2009).

\section{Negócios jurídicos bancários}

O Código Comercial de 1850, revogado, se referia aos atos de comércio praticados pelos banqueiros como "operações de banco" (arts. 119 e 120). Com efeito, todas essas operações podem ser classificadas como contratos, na medida em que nelas há acordo entre as partes criando obrigações. Na realização de seu objetivo de criação e circulação de riquezas sob a forma financeira (moeda escritural ou de crédito), os estabelecimentos bancários ora se tornam devedores, ora credores das pessoas com quem negociam. À primeira categoria pertencem as chamadas "operações passivas"; à segunda, “operações ativas”. Entre as operações passivas de crédito, mencionem-se o depósito e o redesconto; como operações ativas, o empréstimo, a abertura de crédito (cartões de crédito), o desconto de títulos de terceiros, entre outras (MARTINS, 2010, p. 396 e ss.).

Além das operações passivas e ativas, os bancos podem praticar outras, em geral atuando como intermediários ou prestadores de serviços. De fato, "o que caracteriza a atividade bancária é a função de intermediariedade na circulação do dinheiro" (PONTES DE MIRANDA, 1966, p. 3). Desse modo, cobram os bancos comissões, donde o lucro dessas operações. Entre as diversas operações de intermediação, é mister se mencionar as operações de câmbio de moedas estrangeiras, as cobranças, as transferências de somas (pagamentos), compras e vendas de valores mobiliários etc.

Nesse sentido, a lição de PONTES DE MIRANDA (1966, p. 3 e s.):

O ser bancário o negócio jurídico não resulta de elemento essencial ou de caráter intrínseco. Não atende sòmente ao objeto da operação, nem há objeto essencial à bancariedade do negócio jurídico. A legislação mais se influenciou pela qualidade subjetiva, de modo que se apresenta o problema de ser só concluível por banco, ou entre bancos, o negócio 
jurídico bancário. Não há resposta a priori, porque alguns negócios jurídicos, em que banco é figurante, podem ser feitos por pessoas, jurídicas ou físicas, que não são bancos. Em tais casos, porque não há a qualificação subjetiva, o negócio jurídico não é bancário. Por aí se vê quão afastada da verdade seria qualquer teoria que ligasse às espécies dos negócios jurídicos o serem bancários os negócios jurídicos. Leis especiais é que prendem à profissionalidade empresarial a exclusividade de operações ditas bancárias.

Algumas operações bancárias são sôbre dinheiro. Outras, sôbre guarda. Êsses não se prendem à intermediação na circulação do dinheiro, pôsto que a posse, mesmo duradoura, do dinheiro, como ocorre quando se guarda dinheiro, seja fato da vida circulatória dêle. Alguns contratos de guarda, em que figuram bancos, não são de dinheiro, mas de bens de valia, tais como jóias, ações e debêntures.

Os contratos concernentes à intermediariedade na circulação do dinheiro têm como eficácia o dever de prestar, desde logo ou futuramente, às vezes eventualmente, soma de dinheiro, com dever de restituição; porém não é estranha à função qualquer contrato em que alguém deposita dinheiro, ou empresta dinheiro ao banco ou ao banqueiro. Há operações ativas de crédito e operações passivas de crédito.

A relação entre banco e cliente se rege pelo "contrato de banco", em que o banco se vincula a operar para o cliente, seja em relação a dinheiro, seja com respeito a título de crédito ou títulos representativos, quais sejam depósitos, custódia e administração de ações e debêntures, compra e venda de títulos ou desconto cambiário. Como assevera PONTES DE MIRANDA (1966, p. 5), "a relação jurídica entre o cliente e o banco é relação de confiança. Não tem conteúdo típico. A relação jurídica contratual é duradoura".

Esclareça-se, de antemão, que não se devem confundir contrato de banco e contrato de giro, sendo esse uma espécie daquele. Também o contrato de conta corrente não é contrato de banco, embora possa ser um contrato auxiliar desse último. Por meio da conta corrente se consigna o que ocorreu, ou seja, "a entrada e a saída do que se pôs em conta corrente; portanto, os resultados, são as vinculações a que as operações levaram" (PONTES DE MIRANDA, 1966, p. 5).

O negócios jurídicos de crédito, enquanto os negócios mais frequentes dos bancos, correspondem basicamente às duas espécies de operações bancárias anteriormente apontadas, quais sejam: os negócios jurídicos de crédito bancariamente ativos, em que o 
banco se faz credor na medida em que dá ou presta; e os negócios jurídicos de crédito bancariamente passivos, em que o banco se faz devedor na medida em que o cliente é quem dá ou presta. Respectivamente, a abertura de crédito ou o desconto e o depósito bancário pecuniário. (PONTES DE MIRANDA, 1966).

De ordinário, os negócios jurídicos bancários são de duração, seja por prazo determinado ou, mais comumente, indeterminado. Quanto à prestação, podem os negócios jurídicos bancários encerrar prestação única e instantânea, bem como uma ou mais prestações. $\mathrm{Na}$ última hipótese, a pluralidade prestacional pode recair sobre o banco, o cliente ou ambos. Assim, por exemplo, o depósito em conta corrente acompanhado do negócio jurídico pelo qual o banco se encarrega do recebimento de quantias de terceiros com o dever de as lançar na conta corrente do cliente. Outrossim, podem ser as prestações repetidas, como na hipótese de abertura de crédito em que o efeito da relação jurídica existente faculta ao cliente sacar ou exigir a quantia prometida.

No que tange às exigibilidade e satisfação do crédito bancário, é ele suscetível de ser exigido ou satisfeito a qualquer momento, ou com as duas suscetibilidades, ou ainda sem elas. Na hipótese de exigibilidade a líbito do credor, têm-se todos os créditos que se originam de comodato, ou de mútuo sem prazo para pagamento. Na hipótese de satisfação a cada momento, mencione-se a abertura de crédito, restando ao acreditado o poder de prestar, total ou parcialmente, o que era devido. Também pode a exigibilidade ser repetida, na hipótese de caber ao banco dizer as datas dos pagamentos parcelares, ou se se fixaram previamente as datas a serem efetuados os pagamentos.

Como adverte PONTES DE MIRANDA (1966, p. 7),

as quantias que o cliente leva a depósito no banco não são prestações a que correspondam negócios jurídicos sucessivos. Nem há outros negócios jurídicos que resultem das retiradas. Só há um negócio jurídico. Só há uma dívida e só há um crédito, a despeito das variações. Por isso mesmo não se podem invocar regras jurídicas sôbre imputação de pagamento, nem regras jurídicas sôbre compensação. Também por isso não há tantos prazos de prescrição quantos os sucessivos débitos, porque êsses, salvo cálculo liquidativo, são um só.

O procedimento, no tocante ao registro contábil, tinha de ser especial e com duas colunas, a do crédito e a do débito.

Se o cliente entrega, gratuitamente, ao banco título de crédito, com poder de uso e dever de restituïção, há comodato bancário de título de crédito. 
A propriedade continua com o comodante, e o banco não pode dispor dos títulos, mesmo a despeito da sua fungibilidade. No depósito regular, não há o uso pelo depositário, o que o distingue do comodato. No depósito irregular, o fim de custódia não se apaga com a transferência da propriedade: usa, porque recebeu e tem de restituir; no comodato, o comodatário tem direito ao uso, e tão só. Não há comodato irregular, de modo que se não pode transferir a propriedade do bem comodato.

\subsection{O depósito e a conta corrente}

O depósito constitui o negócio bancário básico que subjaz, ou sobrejaz, a todas as outras operações bancárias que compõem as diversas relações jurídicas entre banco e cliente. Na definição de MARTINS (2010, p. 397), consiste na operação bancária

segundo a qual uma pessoa entrega ao banco determinada importância em dinheiro, ficando o mesmo com a obrigação de devolvê-la no prazo e na condições convencionadas. Pela utilização das importâncias que lhe são entregues, o banco às vezes, pagará juros, podendo, inclusive, ser estes capitalizados $^{182}$.

Em regra,

as contas de depósito não se limitam a receber valores, mas podem ser movimentadas pelos bancos, segundo acordo destes com os correntistas, para efetuar pagamentos e receber dívidas. A conta com tais características pode também ser usada para a realização de empréstimo pela instituição financeira, permitindo-se saques a descoberto (SALOMÃO NETO, 2007, p. 227 e s.).

Considerando a convenção entre as partes sobre o modo de devolução da quantia objeto de depósito, surgem as diversas modalidades de depósitos. Na hipótese básica de retirada livre e sem aviso prévio por parte do depositante (exigibilidade a líbito do credor, ou simplesmente depósito à vista), tem-se o chamado "depósito em conta corrente". Na lição de MARTINS (2010, p. 397 e s.),

À importância inicialmente depositada poderão acrescer outros depósitos, que naturalmente aumentarão o saldo credor do depositante perante o banco; cada vez que o depositante retira uma importância do banco faz-se a dedução no seu saldo. Para controle das retiradas de numerário, o banco

182 A partir do advento da Resolução CMN no 15 , de 1966, foi abolido o pagamento de juros sobre os depósitos à vista, restando somente nos casos de depósitos a prazo fixo. 
fornece aos depositantes extratos bancários, por onde se verificará, a cada momento, o estado da conta do depositante; esses extratos servem, também, de comprovação das importâncias entregues pelos depositantes aos bancos. Em regra, faz-se a retirada das importâncias depositadas mediante a emissão de cheques contra os bancos (...). podem, entretanto, os depositantes retirar as importâncias depositadas por meio de recibos ou outras modalidades.

Igualmente, há depósitos cuja movimentação da conta só pode ocorrer decorrido certo prazo - são os chamados "depósitos a prazo fixo", normalmente abonando juros aos correntistas depositantes. A depender do tipo de investimento financeiro carreado junto ao depósito, sua exigibilidade pode ainda estar condicionada a um aviso prévio por parte do depositante.

Muito comum, também, que os depositantes condicionem a movimentação dos respectivos depósitos a determinados fatos. A esses depósitos se denominam "vinculados", servindo sobretudo "de garantia a outras operações a serem realizadas pelos bancos" (MARTINS, 2010, p. 398).

A qualificação do negócio jurídico de depósito bancário em conta corrente tem se prestado a diversas discussões. A primeira versa em torno da natureza do negócio que lastreia o depósito de fundos junto à instituição bancária. A outra questão gira em torno da figura da conta corrente bancária enquanto contrato acessório ao depósito bancário.

Preliminarmente, cabe a observação de que o depósito é um contrato real, assim como o mútuo, o comodato e o penhor, cujo início é marcado pela entrega do bem objeto de depósito. Segundo o art. 627 do Código Civil, pelo referido contrato "recebe o depositário um objeto móvel, para guardar, até que o depositante o reclame”. Normalmente recai o depósito sobre bens não fungíveis, permanecendo a propriedade com o depositante (depósito regular). Não obstante, pode ser o depósito irregular, ou seja, aquele em que o depositário, recebendo um bem para guarda e conservação, se obriga a restituir não o próprio bem recebido, mas outro do mesmo gênero, qualidade e quantidade. Esse depósito é regido pelas mesmas regras atinentes ao mútuo (CC, art. 645). O depósito irregular tem por objeto, em regra, o dinheiro.

Como adverte SALOMÃO NETO (2007, p. 228), há entendimento de que o depósito bancário não se equipararia ao depósito em sentido estrito nem ao mútuo. Em relação àquele, porque o depósito é contrato em favor do depositante e gratuito; quanto a esse, o mútuo exige que se convencione expressamente o prazo durante o qual os recursos 
permanecem à disposição do mutuário (CC, art. 592; MARTINS, 2010, p. 353), enquanto o depósito bancário permite o saque à vista do valor depositado.

Não obstante, assevera SALOMÃO NETO (2007, p. 228 e s.) o contrário, entendendo que o depósito pode, sim, remunerar o depositante:

É verdade que normalmente não o faz, porque a causa do depósito, no sentido de substrato econômico do negócio, é normalmente uma vantagem para o depositante quando são coisas infungíveis que se depositam. O mesmo não ocorre com o depósito de dinheiro ou outra coisa infungível que possa o depositário usar: nesse caso, também ele auferirá vantagem pelo uso, e assim poderá ter interesse em remunerar o depósito. É precisamente isso que ocorre no depósito bancário, que serve como modalidade de captação de recursos pela instituição financeira.

Nesse sentido, a regra é ser o contrato de depósito bancário "real e oneroso" (PONTES DE MIRANDA, 1966, p. 78).

No que tange à equiparação ao mútuo, ressalte-se que o art. 645, do Código Civil, não equipara ambos os contratos quanto ao fundamento, mas somente dispõe que o depósito de coisas fungíveis se rege pelas regras do mútuo. Ademais, o contrato de mútuo não requer necessariamente um prazo mínimo de permanência do bem mutuado na posse do devedor. Com efeito, é clara a regra do art. 592, II, do Código Civil, ao afirmar, supletivamente, que na ausência de convenção expressa o mútuo de dinheiro será, ao menos, de trinta dias. Desse modo, é perfeitamente razoável entender o depósito (irregular) como centro da figura contratual do depósito bancário (SALOMÃO NETO, 2007).

De fato, os depósitos bancários, sejam a termo fixo ou à vista, sempre implicam a dação de dinheiro ao banco, mesmo que as entradas sejam feitas pelo próprio banco, como na hipótese de abertura de crédito, em conta corrente, a favor do depositante. Por se tratar de bem fungível, há transmissão de propriedade ao banco. Na lição de PONTES DE MIRANDA (1966, p. 75):

Com a transmissão da propriedade do dinheiro, o banco pode dispor, no que entenda, como, onde e quando entenda, do recebido, sem que o cliente depositante se possa envolver nas operações que vão ser feitas, para o interêsse da emprêsa bancária, inclusive se essa transfere à filial, agência ou à sede a quantia depositada. Na figura do depósito bancário, há a estrutura do depósito irregular e algo de mútuo (...).

Portanto, no depósito bancário se trata de depósito, não de mútuo. Há diferenças 
entre o depósito irregular e o mútuo, sendo a mais relevante para o negócio bancário a regra segundo a qual o depositante pode exigir a restituição da res deposita a qualquer tempo, o que não ocorre no mútuo, salvo cláusula expressa (CC, art. 592; PONTES DE MIRANDA, 1966).

Outrossim, o efeito do depósito irregular é extinguir inteiramente a posse do depositante, não restando a esse último nenhum poder fático sobre o bem depositado, nem mesmo a título precário. Nesse sentido, assevera PONTES DE MIRANDA (1966, p. 77) que

Todos os depósitos bancários têm como elemento comum a entrega de soma de dinheiro, da qual o banco adquire a posse própria e a propriedade, com o dever de restituïção na mesma espécie de moeda, quando exigida de acôrdo com a convenção e a lei. A convenção pode resultar de uso bancário. O banco pode dispor como entenda do que foi depositado, porque é seu. Não tem dever de conservar, porque restitui o tantundem eiusdem generis ac qualitas, e não a eadem res. Não se pode dizer, portanto, (...) que se trate de depósito ad uso. O depositante transferiu mais do que o uso.

O que distingue o depósito bancário enquanto espécie de depósito irregular é precisamente a presença da empresa bancária, cuja atividade se direciona ao recebimento de depósitos, havendo assim a pluralidade de entradas (depósitos-parcelas). O que faz do depósito irregular depósito bancário é justamente a série de creditamentos e debitamentos. As operações bancárias constituem, em última instância, "negócios jurídicos de massa" (PONTES DE MIRANDA, 1966, p. 77).

De fato, o substrato econômico-financeiro dos negócios jurídicos bancários de depósito reside fundamentalmente em angariar o número máximo de clientes no sentido de multiplicar a moeda de crédito (escritural ou bancária), lastreada apenas de modo fracionário nas reservas bancárias junto ao banco central (HUBER, 2011).

Na grande maioria dos casos, o depósito bancário acarreta a abertura de uma conta corrente. O depósito em conta corrente, em sentido próprio, é aquele do qual se retira livremente, ou a termo, o que cabe no saldo, seja mediante saque físico ou em caixa eletrônico, seja por meio de ordens de pagamento (cheques ou ordens eletrônicas de débito). Na hipótese de caderneta de poupança, lança-se o que se deposita e o que se retira, como se a conta fosse do cliente, mas como atividade contabilística do banco (PONTES DE MIRANDA, 1966; SALOMÃO NETO, 2007). 
Com efeito, a relação bancária geral surge com o contrato de abertura de conta bancária. Esse contrato, tipicamente bancário, ainda que não desenvolvido legalmente, compreende entre seus efeitos o aparecimento de uma relação jurídica básica, qual seja a relação bancária duradoura. Seu conteúdo advém dos usos e das cláusulas contratuais gerais, cuja vocação é a multiplicação crescente de atos jurídicos conexos a essa relação.

Desse modo, a partir do primeiro negócio significativo entre o banco e seu cliente, normalmente a abertura de conta por meio do depósito bancário, se estabelece uma relação socioeconômica, tendente à continuidade. Ao surgirem mais negócios entre ambos, ela se intensificará. Daí surgirem para ambas as partes deveres de conduta, derivados da boa fé, dos usos ou de acordos parciais que eventualmente celebrem. Assim, "todos esses deveres surgem num conjunto que tem uma unidade económica e social evidente: há uma relação bancária contínua, susceptível de ser preenchida com os mais diversos negócios" (CORDEIRO, 1999, p. 342).

Consumado assim o contrato bancário básico, qual seja o depósito bancário em conta corrente (abertura de conta), há entre ambas as partes deveres de lealdade, em especial para o profissional: o banqueiro. Além disso, é mister não se olvidar de que essa relação tem sua origem num contrato. A despeito de todo um conjunto de regras legais, usuais ou assentes em cláusulas contratuais gerais, resultantes do acordo básico celebrado, a natureza contratual não se perde (CORDEIRO, 1999).

Nesse sentido, esclarece SALOMÃO NETO (2007, p. 229),

A conta corrente é estruturalmente um registro efetuado nos sistemas da instituição financeira, relativamente a créditos detidos pelo depositante, mas podendo também incluir obrigações para com o depositante, geralmente ligadas à prestação de serviços. Tais obrigações são em regra de duas naturezas. A primeira se refere à efetuação de pagamentos na forma e periodicidade solicitada pelo depositante, como por exemplo para quitar débitos junto a concessionários de serviços públicos (água, luz, telefone etc.). A segunda família de obrigações da instituição financeira em benefício do correntista se refere a cobrança de créditos a favor dele, serviço este mais comumente prestado em benefício de pessoas jurídicas detentoras de créditos empresariais contra clientes. Os valores assim pagos ou recebidos transitam em regra pela conta corrente, isto é, dela saem através de débitos no primeiro caso, e para ela são vertidos no segundo. $\mathrm{O}$ ajuste de conta corrente entre cliente e instituição financeira 
abrange ainda a possibilidade de que a última compense diretamente contra valores na conta taxas pela prestação de seus serviços. Eventualmente, pode ainda ser prevista a abertura de crédito em conta corrente, permitindo-se ao cliente sacar além de seu saldo, até um limite.

As características anteriormente indicadas podem levar à conclusão de que no depósito bancário em conta corrente haveria paralelamente ao contrato de depósito um contrato autônomo de conta corrente. De fato, a despeito de não tipificado na legislação atual nem no antigo Código Comercial, ora revogado, nada impediria, sob a égide do novo Código Civil, de 2002, a existência de tal contrato (inominado), em razão do princípio da livre estipulação contratual.

Na lição de MARTINS (2010, p. 366), o contrato de conta corrente

é o contrato segundo o qual duas pessoas convencionam fazer remessas recíprocas de valores - sejam bens, títulos ou dinheiro -, anotando os créditos daí resultantes em uma conta para posterior verificação do saldo exigível, mediante balanço. As partes contratantes têm o nome de correntistas ou correspondentes; desses correntistas denomina-se remetente o em favor de quem é lançado o crédito; recipiente é aquele que recebe o crédito e o lança, na conta a seu débito. As remessas são as operações praticadas pelos correntistas para alimentar a conta. Podem constar essas remessas de dinheiro, bens ou títulos de crédito; deverão, sempre, ter um valor determinado, para que possam servir de base aos lançamentos que são feitos na conta.

Quando duas pessoas convencionam fazer este contrato, as operações que vão realizar têm início com uma abertura da conta corrente. Para isso, em geral, há uma escrituração especial, que é feita do mesmo modo que se faz a escrituração mercantil da conta corrente contábil, simples anotação em livro próprio registrando a posição de um determinado freguês que fez compras sucessivas e pagamentos parciais em um estabelecimento empresarial. Mas, no contrato de conta corrente, se a escrituração é idêntica à conta corrente contábil, há uma especialidade; as remessas se fundem em um todo, não se compensando, formando esse todo uma massa homogênea; só quando, posteriormente, se faz a liquidação dessas remessas (...) é que se verificará o saldo, sabendo-se, então, qual dos correntistas é o credor e qual o devedor.

Nota-se, portanto, uma diferença fundamental entre a conta corrente contrato e a 
conta corrente gráfica ou contábil: nessa, significa somente a anotação gráfica de créditos e débitos; naquela, as partes se colocam em estado de conta corrente, ou seja, configura-se um estado total, de débitos e créditos, sem haver, antes de seu encerramento, um credor ou um devedor,embora se possam contar juros sobre as remessas, ativas ou passivas (BULGARELLI, 1991).

No que tange à existência de um eventual "contrato de conta corrente bancária", o Projeto de Código Civil ( $\mathrm{n}^{\circ}$ 634, de 1975) na verdade o conceituava como o contrato pelo qual "estipula-se a obrigação, para ambas as partes ou uma delas, de inscrever, em partidas de débito e crédito, os valores monetários correspondentes às suas remessas" (art. 869), perdendo esses valores a sua exigibilidade autônoma (BULGARELLI, 1991, p. 567).

Em relação ao citado Projeto de Código Civil, crítica é a lição clássica de Philomeno Costa (1973, p. 11 e ss. apud BULGARELLI ${ }^{183}$, 1991, p. 567 e s.):

Parece que toda esta matéria deve ser reformulada, porque a 'conta corrente', em matéria bancária, deve ser apenas 'método de contabilidade, forma contável de anotação das remessas e das retiradas em dever e haver'. O contrato de conta corrente não é contrato de banco. 'Ajuda, auxilia, o contrato de banco'. Deve dar-se explicação mais detalhada. Conta corrente pode duas coisas distintas. Aquela, que é mais comum, não é um contrato. É, como acentuou acertadamente Carvalho de Mendonça, uma forma de se escrever, de se grafar uma movimentação recíproca de bens e valores entre duas pessoas. É facilitação unitária de registro de tudo quanto um mandou para o outro e deste para aquele, como escreveu corretamente Pontes de Miranda. É o empilhamento lado a lado do que os dois se enviaram reciprocamente. É forma gráfica de registro unificado de coisas diferentes. E a conta corrente é um contrato com que duas pessoas se abrem crédito mutuamente; como cada uma das suas utilizações é anotada numa conta só, acontece que esta registra valores ora a favor de um contratante, ora a favor de outro; como essa conta não é estática, como ela se presume em continuidade, em movimento durante o tempo do contrato, essa conta continua, ou melhor, ela é conta corrente, isto é, que corre; mas, neste caso, ela é gráfico representativo de um contrato de duas aberturas de crédito cruzadas ou traçadas reciprocamente entre os dois comerciantes. Isto não costuma

183 Philomeno J. Costa. “As Atividades Bancárias no Anteprojeto do Código Civil”. In: RDM n 10, 1973. 
ocorrer normalmente com os bancos. Eles trabalham com dinheiro, que é a sua mercadoria, e eles trabalham com o crédito, que é sabidamente a confiança de que seja futuramente liquidada a contraprestação de um contrato. O contrato de conta corrente configura-se notadamente quando os dois contratantes trabalham entre si com coisas e com valores, isto é, um envia mercadorias para o outro e este faz o mesmo em relação ao primeiro. No fim, ambos apuram o saldo. Com os bancos, as entregas ou remessas são apenas de dinheiro. Quando se combina que o cliente remeterá ao banqueiro títulos de crédito, estes se entendem recebidos normalmente em garantia ou em cobrança, não sendo assim escritos no gráfico da conta... indivisível ou ordinária. Só excepcionalmente o banqueiro credita o cliente pelos valores dos títulos dele recebidos. Quando é aberto pelo banqueiro um crédito a favor do cliente, este 'avança' nas retiradas. Se acontece de devolvê-las em excesso, o saldo a mais é considerado automaticamente como depósito bancário. O que acontece no comércio bancário é que a conta corrente não é contrato com este nome; é apenas o gráfico da movimentação das retiradas e dos depósitos. É comuníssimo. Pode concluir-se rapidamente que não há normalmente contrato de conta corrente feito por banco. Existe sempre, sim, o emprego do gráfico de uma conta que corre, de uma conta corrente que não é o contrato deste nome. Para isto, o legislador italiano de 1942 não consagrou uma atividade bancária chamada conta corrente bancária, como se pretende no anteprojeto do Código Civil. Ele estabeleceu (e parece que acertadamente) as 'operações bancárias em conta corrente', como se lê no título da Seção V, do Capítulo XVII (operações bancárias), do Título III (Contratos em espécie), do Livro IV (Obrigações) do Codice Civile. O texto do seu art. 1.852 revela logo a grande diferença que existe no assunto, e que aconselha antecipadamente que o nosso futuro projeto do Código Civil admita: 'Toda vez que o depósito, a abertura de crédito e outras operações bancárias sejam reguladas em conta corrente, o correntista (ou o cliente) pode dispor, em qualquer momento que seja, das quantias existentes a seu crédito, salva a observação do termo do aviso prévio combinado eventualmente'. Parece que o anteprojeto do Código Civil, no tocante à pretendida 'conta corrente bancária' deve ser reformulado. (...). O resumo do problema pode ser enunciado assim: a conta corrente, como contrato, não é de índole bancária. Logo, deve 
figurar destacadamente numa espécie à parte dos contratos enumerados. A conta corrente como gráfico é comuníssima. Deve ser referida nos contratos bancários. Mas deve figurar, enfim, aí, não como contrato e sim como gráfico. Como os bancos prestam serviços auxiliares aos seus clientes e como estes continuam a ser aqueles que têm gráficos de conta corrente, poder-se-ia imitar o Codice Civile, no depósito pelo seu art. 1.856, que fixa a responsabilidade do banqueiro, como mandatário, pelo seu encargo de executar os serviços bancários auxiliares.

Com efeito, a conta corrente bancária se origina de cláusula ou pacto, às vezes somente de uso, que regula certas operações, tais como o depósito (em conta corrente), a abertura de crédito (em conta corrente), ou a antecipação (em conta corrente). Não importa se há contrato único ou coligado a outros contratos, nem se há pluralidade de documentos ou de prestações diversas, ou ainda pluralidade de motivos. A causa contratual é única, qual seja a relação bancária básica, socioeconômica, tornada jurídica pela incidência de regra legal ou contratual (CORDEIRO, 1999; PONTES DE MIRANDA, 1966).

Dessarte, a conta corrente bancária não se confunde com o "contrato de conta corrente", pois esse último pressupõe essencialmente a reciprocidade. Na conta corrente bancária somente o cliente tem função ativa, na medida em que

o banco apenas registra, isto é, credita e debita, sem poder fazer remessas ao outro figurante. Por outro lado, no contrato de conta corrente, os créditos são inexigíveis e indisponíveis, até que se feche a conta corrente, ao passo que, na conta corrente bancária, o cliente pode sempre dispor do crédito (PONTES DE MIRANDA, 1966, p. 51).

Do exposto, destacam-se como principais efeitos do "contrato de conta corrente" a indivisibilidade dos créditos e débitos lançados em conta (remessas), bem como a novação. Quanto a esses efeitos, esclarece SALOMÃO NETO (2007, p. 230 e s.) que,

O primeiro efeito é o de causar novação, de forma que os créditos comerciais inscritos na conta deixam de ter natureza autônoma e passam a ser devidos tendo por causa o próprio contrato de conta corrente. Em nosso sistema, o fundamento de direito positivo para isto está no artigo 360, inciso I, do Código Civil, em cujos termos há novação quando o devedor contrai com o credor nova dívida, para extinguir e substituir a anterior. $\mathrm{O}$ segundo efeito é o da indivisibilidade de débitos e créditos lançados na conta corrente, enquanto lá permanecem. Isto quer dizer que, na conta corrente, não só desaparecem os débitos e créditos originais, mas 
também são substituídos por uma relação jurídica complexa que não permite distinguir os débitos e créditos lançados na conta, para efeito de cobrança, compensação ou qualquer outro, até o momento da liquidação final da conta. Só então serão levados em consideração e a diferença paga ao favorecido.

Os efeitos acima elencados não se coadunam com diversos efeitos reconhecidos aos contratos de depósito bancário em conta corrente, sobretudo em razão da indivisibilidade dos créditos e débitos lançados em conta corrente, caractere principal do "contrato de conta corrente". Com efeito, mencione-se a ineficácia que o termo legal da falência impinge ao pagamento de obrigações não vencidas realizado nesse mesmo termo (Lei $\mathrm{n}^{\mathrm{o}}$ 11.101, de 2005, art. 129, I). Desse modo, na hipótese de pagamento antecipado realizado por um cliente de débito vincendo com o banco, resultante, por exemplo, de saque a descoberto permitido pelos termos do contrato bancário, o pagamento seria plenamente eficaz diante da admissibilidade de existência de um contrato autônomo de conta corrente, uma vez que por esse contrato o depósito de recursos em conta corrente de modo nenhum implica pagamento em sentido estrito, mas antes novação, mantendo assim os débitos e créditos indivisíveis (SALOMÃO NETO, 2007).

Com efeito, o depósito irregular caracterizaria precipuamente o negócio jurídico básico de conta corrente bancária, definindo-lhe a natureza. Desse modo, o pagamento de contas, recebimento de valores e outros pactos adjetos denotariam basicamente a existência de obrigações de prestação de serviços acessórias ao contrato de depósito, não raro amparadas por mandato conferido pelo depositante correntista ao banco. Haveria fundamentalmente "um contrato de depósito irregular, cumulado com prestação de serviços e mandato, no depósito bancário com abertura de conta corrente" (SALOMÃO NETO, 2007, p. 232).

Ressalte-se ainda que a diversidade interna dos atos a serem praticados pelo banco segundo as cláusulas contratuais não retiram ao depósito bancário, ou conta corrente bancária, o caráter de unicidade do contrato. As regras jurídicas a que está adstrito cada ato praticado pelo banco nada têm com a conta bancária em si, permanecendo um só o contrato básico, na medida em que não se desce ao interior dos atos de solução, a despeito da multiplicidade de encargos assumidos pelo banco. Tais atos constituem antes o objeto da conta corrente bancária, qual seja o giro bancário, cuja operação depende da regulação dos encargos (PONTES DE MIRANDA, 1966). 


\subsection{As operações bancárias (pecuniárias)}

As operações bancárias são fundamentalmente operações pecuniárias, cujo objeto principal é a aquisição, troca, depósito ou empréstimo de dinheiro. Nesse sentido, cabe dar um passo atrás na exposição, ainda que brevemente, de modo a se definir o que se pode entender por dinheiro no atual quadrante da evolução socioeconômica, permitindo assim seu adequado enquadramento jurídico.

No que tange à questão, preliminar, de se saber se existe dualidade de conceitos a respeito do dinheiro, a saber, um conceito econômico, e outro, jurídico, cabe a advertência de PONTES DE MIRANDA (1966, p. 22):

A Sociologia sói mostrar-nos casos em que em dois ou mais processos sociais de adaptação, e. g., Economia e Direito, Moral e Direito, Economia, Moral e Direito, os conceitos e o que se conceitua num dêles se diferenciam dos conceitos e do que se conceitua no outro, ou nos outros. Não se pode dizer, portanto, ab initio, que a distinção não existe. Tão-pouco, que deve existir.

Tradicionalmente, a teoria econômica, bem como as doutrinas monetárias, definem o dinheiro a partir do critério funcional, indicando geralmente sua função principal conforme o viés teórico que se adota. Frisem-se novamente as funções típicas da moeda: a) ser instrumento geral de troca ou câmbio; b) ser medida comum dos valores, denominador geral dos bens e seus preços; c) ser meio geral de pagamento; e d) ser instrumento de conservação e transmissão de valores.

Procedendo a análise de caráter eliminatório, assim as examina PONTES DE MIRANDA (1966, p. 23):

A função $d$ ) é, evidentemente, secundária, e não poderia ser considerada como principal, menos ainda como exaustiva, ou suficiente, para definir o dinheiro. A função $c$ ) constitui parte da função $a$ ), pois que, em vez de se aludir a instrumento geral de câmbio, de tráfico, se alude a instrumento geral de pagamento, com o que se lhe reconhece, não o papel de única prestação em paga (o que valeria dizer-se que todo pagamento consiste, necessàriamente, em entrega de soma de dinheiro), mas papel resultante de que qualquer obrigação se pode reduzir à obrigação de se pagar soma de dinheiro.

Tal é a atitude que, ao definirem dinheiro, preferiram: $F$. 
KLEINWÄCHTER (Lehrbuch der Nationalökonomie, $2^{\mathrm{a}}$ ed., 320); EUGEN PHILIPPOVICH VON PHILIPPSBERG (Grundriss der politischen Ökonomie, I, $8^{\text {a }}$ ed., 320); PAUL LABAND (Das Staatsrecht des deutschen Reichs, $5^{\mathrm{a}}$ ed., 170); e G. F. KNAPP (Staatliche Theorie des Geldes, 31). A função a) pareceu principal e típica a CARL MENGER (Geld, Handwörterbuch der Staatswissenschaft, IV, $3^{\text {a }}$ ed., 567); a L. v. MISES (Theorie des Geldes und Umlaufsmittel, 3 s.); a MARTIN WOLFF (Das Geld, Handbuch des gesamten Handelsrechts, IV, 570).

Alguns escritores há que põem em relêvo duas ou mais funções.

Todos os sistemas monetários se basearam em unidade fundamental, que é o divisor comum; de modo que cada sistema é independente das expressões, ainda que se adotem particularidades espaciais ou geográficas, e da própria substância dos signos monetários (ouro, prata, níquel, papel). O sistema varia, sem se tornar incompatível ou estranho, quando se admite nova unidade, ou se passa a nova unidade, mediante norma de redução (...). Aliás, em vez de regra de redução, o legislador pode aceitar regra de câmbio, estabelecendo, no tempo, o que sói ser no espaço, ou no espaço anunciado a tempo, mas tempo da prestação, e não da moeda mesma.

Nada obstante a lição anterior, dizer que a função $d$ ), qual seja a de ser reserva de valor (monetário), seja apenas secundária é olvidar de que um dos efeitos da moeda reside justamente na situação jurídica (econômica) de liquidez, enquanto direito (poder) sociojurídico face ao dividendo nacional (DE CHIARA, 1986; SCHUMPETER, 1982). Atualmente, o patrimônio financeiro representa a instância prevalecente de riqueza social. A depender, aliás, do tipo de mercado que se tenha em exame, o que prepondera não são os fluxos (transferências) de valores, mas justamente os estoques financeiros, em última instância, as reservas monetárias para fins de poupança ou especulação (KEYNES, 2012). Assim, por exemplo, nos mercados de valores mobiliários (títulos de crédito em senso largo), a situação de liquidez que se traduz em poder econômico-financeiro sobre tais mercados é influenciada fundamentalmente pelos estoques monetários, determinantes para a formação da taxa de juros no mercado monetário (SHACKLE, 1969) ${ }^{184}$. Considerando,

184 Vale assim novamente examinar o mecanismo de formação da taxa de juros no mercado de títulos. Enquanto a teoria convencional (neoclássica) entende aquela taxa simplesmente como outro preço qualquer, o qual se determina pela condições de oferta e procura marginais, é dizer, o preço de novos 
títulos de crédito negociados por dinheiro líquido (moeda restrita). Na acepção de HICKS (1987), pela simples equalização dos fluxos de poupança e investimentos líquidos. KEYNES (2012), no entanto, rejeita a ideia de um mercado onde a poupança (desejada), o investimento líquido (pretendido) e a taxa de juros mutuamente se determinam, na medida em que há outras forças operantes, e pois absolutamente preponderantes quando comparadas com tal mecanismo. Essas forças decorrem sobretudo da avaliação da riqueza por parte dos capitalistas (LIMA, 1997). Na hipótese da análise econômica pura, contudo, suprimidas essas forças, tal mecanismo funcionaria. Na concepção de SHACKLE (1969, p. 100 e ss.), interpretando o pensamento keynesiano, o equívoco cometido pela análise convencional do juro reside sobretudo no tratamento do mercado de títulos como se fosse determinado por fluxos, em vez de o ser por estoques. A despeito de haver naturalmente fluxos e refluxos sempre que títulos são comprados ou vendidos, seus efeitos são desprezíveis no processo de mudança de preços, o que evidentemente não seria verdade para um mercado de bens perecíveis, como o de "verduras frescas". Nesse último mercado, a transmissão de propriedade é essencial e necessária, pois se o ofertante não vender toda a sua produção, essa obviamente se deteriorará, de modo que o preço de venda e compra será o que puder ajustar diariamente a quantidade consumida (destruída) à quantidade amadurecida, ou seja, o volume ofertado às condições de demanda. Com títulos, todavia, o mesmo não ocorre, na medida em que um acréscimo líquido de alguns milhões correspondentes a novos títulos pode se juntar aos bilhões em valor do estoque existente de títulos sem que resulte em alterações expressivas no preço dos títulos. Na verdade, os preços dos títulos são inerentemente instáveis sobretudo porque dependem quase que exclusivamente de conjecturas a respeito de seu curso no futuro imediato. Acontecimentos de alguma importância ostensiva, como a iminente obrigação do Governo de retirar uma parcela de sua dívida e a substituir por outra, ou de tomar empréstimos a longo prazo no intuito de consolidar a dívida flutuante, não chegam a influenciar definitivamente no aumento ou na baixa dos preços dos títulos. Não obstante, a informação de que o Governo ou uma grande empresa lançarão títulos de dívida, então os seus termos serão antecipados conforme a suposição quanto à intenção do Governo em criar uma grande quantidade de dinheiro novo. $\mathrm{Na}$ hipótese dessas condições não corresponderem ao rendimento proporcionado pelos títulos existentes, presume-se que alguns de seus detentores os vendam ou, então, que outros que possuam disponibilidade em dinheiro os comprem por um preço mais próximo àquele dos novos títulos. Desse modo, os preços de todos os títulos existentes serão afetados, embora apenas uma fração pequena venha efetivamente a trocar de mãos. Observa-se, portanto, que o preço de algo que se conserva não se determina da mesma maneira que o preço de algo que se vende, compra ou usa em definitivo e a uma só vez. Nesse último caso, o vulto do fluxo de mercadorias perecíveis, consuntíveis, domina o mercado; já na primeira hipótese, o fluxo somente ocorre se o julgamento dos proprietários ou dos potenciais compradores das mercadorias permanentes (bens) em estoque se alterou em graus ou direções diferentes. Considerando dessarte que a todo o momento o estoque de títulos e o estoque monetário devem ser possuídos por alguém, os preços de todos esses ativos financeiros devem se ajustar, e as somas correspondentes, inclusive de dinheiro, devem estar de tal modo repartidas, em propriedade, que seus detentores momentâneos se nos apresentem como possuidores voluntários dessas quantidades ou somas. $\mathrm{Na}$ medida em que essas somas são retidas como riqueza armazenada, patrimônio financeiro (HUBER, 2011), em particular para fins especulativos, e não para algum propósito instrumental como o de efetuar pagamentos, as principais razões para a conservação desses ativos se relacionam, de um lado, a seus rendimentos futuros, e de outro, talvez primordialmente, às alterações no preço monetário desses ativos que parecem iminentes. Ressalte-se ainda que o preço monetário do dinheiro é imutável, mas não assim o preço dos títulos; os títulos serão portanto retidos apenas sob a suposição de que seus preços tendem a crescer ou pelo menos a não decrescer consideravelmente. O dinheiro, por sua vez, observada sua propriedade (função) de armazenar riqueza (reserva de valor), será retido por aqueles que esperam a baixa dos preços monetários dos outros valores mobiliários. Há basicamente dois grupos de investidores nos mercados de valores mobiliários, os que pensam que os preços dos títulos subirão e os que pensam que cairão. Ambos os grupos atuam, em realidade, por meio de investidores ou operadores profissionais, gestores de carteira (CHESNAIS, 1998), e pois sob aconselhamento, do que resulta naturalmente, em regra, a decisão de possuir concomitantemente títulos e dinheiro. Ressalve-se, portanto, que a preferência pela liquidez "keynesiana" (dinheiro de curso legal, ou ainda moeda bancária, enfim, liquidez plena) se manifesta apenas como um dos lados possíveis desse processo, especialmente diante do temor de uma perda de capital cujo risco não se cobriria pela taxa de juros vigente (LIMA, 1997). Finalmente, a taxa de juros de mercado (preços dos títulos) dependerá fundamentalmente da avaliação e comportamento desses grupos, heterogêneos, de detentores do patrimônio financeiro, em última instância, da riqueza em sua forma desejada, em relação às possibilidades de ganho e perda de capital (lucro). Do que resultará sempre uma oscilação até que se reajustem as forças relativas dos dois campos (básicos), e se retenha por um dos grupos todo o dinheiro 
portanto, que a taxa de juros constitui, ao lado do câmbio, preço básico da economia, essa situação jurídica de liquidez (reserva de valor financeiro) reflete o poder econômico que se faz presente na sociedade.

Conferir relevo somente à função $a$ ), ou seja, instrumento geral de troca, como o faz MISES (2005) em sua teoria catalática da moeda, tendo a função $c$ ), meio geral de pagamento, como seu corolário jurídico (GUDIN, 1976), é reducionismo que ainda se prende à presença física da moeda enquanto meio circulante (papel-moeda), descurando assim da moeda de crédito (bancária) enquanto forma prevalecente na economia hodierna.

Com efeito, em tempos de riqueza (patrimônio) financeira integralmente desmaterializada, tanto em termos estritamente monetários (moeda escritural ou bancária) quanto em termos de instrumentos financeiros sob a forma predominantemente escritural (valores mobiliários), antes se traduz o patrimônio financeiro em complexo jurídico de bens e direitos denominados, em última instância, na unidade monetária oficial (padrão monetário legalmente adotado).

Nesse sentido, diante do fato da desmaterialização em larga escala da moeda, a Lei $\mathrm{n}^{\mathrm{o}}$ 10.192, de 2001 ("Plano Real"), ao estabelecer, em seu art. 1º, o curso legal da moeda (REAL) para as estipulações de pagamento de obrigações pecuniárias, não deve mais ser interpretada no sentido de restringir o curso legal somente à moeda em espécie, mas sobretudo como abrangente do padrão monetário nacional.

Nos sistemas monetários modernos, assaz nos sistemas de pagamentos informatizados, e pois nos mercados financeiro e de capitais cujos negócios jurídicos se perfazem e cujas obrigações pecuniárias se liquidam no âmbito (imaterial ou escritural) desses mesmos sistemas, a única função relevante da moeda que ainda subsiste é justamente a função $b$ ), qual seja a de denominador comum dos valores (fluxos e estoques financeiros) eletronicamente negociados.

\subsection{O giro bancário}

Frise-se novamente que a diversidade interna dos atos a serem praticados pelo banco, segundo as cláusulas contratuais, não retiram ao depósito bancário, ou conta corrente bancária, o caráter de unicidade do contrato. As regras jurídicas a que está adstrito cada ato praticado pelo banco nada têm com a conta bancária em si, permanecendo um só

"flutuante" (aplicável), alcançando-se de fato "um equilíbrio, embora de uma qualidade fugidia e transitória” (SHACKLE, 1969, p. 106). 
o contrato básico, na medida em que não se desce ao interior dos atos de solução, a despeito da multiplicidade de encargos assumidos pelo banco. Tais atos constituem antes o objeto da conta corrente bancária, qual seja o giro bancário, cuja operação depende da regulação dos encargos (PONTES DE MIRANDA, 1966).

Nesse sentido, define CORDEIRO (1999, p. 494) o giro bancário como "o conjunto das operações escriturais de transferência de fundos, realizadas por um banqueiro, a pedido do seu cliente ou a favor dele".

A própria etimologia da palavra giro, do latim gyrus, traduz a ideia de circularidade, própria do dinheiro enquanto elemento cerne das operações de giro bancário, sobretudo no sentido de que "o dinheiro circula, em torno do banqueiro, sem que, propriamente, haja qualquer movimento material" (CORDEIRO, 1999, p. 494).

$\mathrm{O}$ giro bancário tem por fundamento um contrato bancário, em termos expressos ou como resultado de cláusulas contratuais inseridas no contrato básico (inerente) de conta corrente bancária (depósito bancário). Esse contrato pressupõe, portanto, a prévia celebração de uma abertura de conta bancária. Como a maioria dos contratos bancários, trata-se de um contrato-quadro no âmbito do qual se perfazem variados negócios jurídicos simples e se praticam diversos atos bancários. As ordens concretas de transferência constituem assim atos de execução do negócio (contrato) de giro bancário (CORDEIRO, 1999; PONTES DE MIRANDA, 1966).

Ressalte-se ainda que

A possibilidade de acordar com o banqueiro um esquema imaterial de circulação do dinheiro ascende às primeiras experiências bancárias, com raízes na Antiguidade. Passos significativos dar-se-iam na passagem do século XIX para o século XX. Seria, no entanto, no último quartel do século XX, designadamente com a informatização, que o giro bancário atingiria proporções predominantes. Os últimos passos vêm sendo dados mediante operações conduzidas através de cartões e do denominado home banking, que permite, por telefone ou por computador, desencadear, de casa, as mais diversas operações relativas a fundos, os quais, fisicamente, nunca são deslocados (CORDEIRO, 1999, p. 494 e s.).

Como observa PONTES DE MIRANDA (1966, p. 150), com razão, trata-se de transferência de "quantia, porque é id quod plerumque fit. Mas o objeto pode ser título ou moeda estrangeira, como res".

As ordens de transferência são pura e simplesmente executadas, desde que haja 
fundos. Não se cogita aqui de manifestação da vontade por parte do banqueiro, não havendo assim nenhum elemento contratual nas ordens de pagamento dadas ao banco. Aliás, essas ordens sói serem executadas por meio exclusivamente informático, sem mediação de qualquer elemento humano (volitivo), a não ser quanto ao contrato subjacente, ou sobrejacente (CORDEIRO, 1999).

Outrossim, o regime jurídico de cada operação de giro bancário, no que tange às relações com o banco, tem por fundamento a "abstração", portanto, independe da fonte ou causa da operação (CORDEIRO, 1999).

O giro pode ser de moeda corrente, moeda estrangeira ou títulos. A relação jurídica de giro entre correntista e banco pode ser subjacente, então a operação bancária de execução do giro implica em manifestação unilateral de vontade do correntista, similarmente ao que se passa com uma ordem de pagamento (p. ex., o cheque). Assim, quem tem conta corrente tem o pressuposto para emitir ordens de pagamento, ou incumbir o banco de efetuar pagamentos, ou ainda de creditar a alguém, ou de efetuar remessas em pagamento. São esses, aliás, os meios mais frequentes de utilização da conta corrente, além da eventual vinculação do banco a saques a descoberto, ou conforme abertura de crédito.

Ao contrário de CORDEIRO (1999, p. 497), que observa serem as ordens concretas de transferência de fundos meros atos de execução do negócio jurídico (contrato) de giro bancário, entende PONTES DE MIRANDA (1966, p. 150) que a manifestação da vontade do correntista no sentido de ordenar o creditamento de alguma quantia a terceiro é antes "negócio jurídico unilateral de giro". A despeito de tal negócio subjacente, caso o interessado, ainda que correntista, deseja "ordem de prestação a alguém", mas sem ter que levantar de sua conta a quantia a ser creditada a outrem, então, sim, teria ele de concluir negócio jurídico bilateral de giro (contrato de giro bancário). Desse modo, assumiria a figura de ofertante, celebrando com o banco contrato pelo qual aquele recebe a quantia que será creditada a outrem, vinculando-se o banco.

Não obstante, a última hipótese, apresentada por PONTES DE MIRANDA (1966), constituiria situação pontual, enquanto objeto de um negócio individualizado, não parecendo razoável se admitir a existência de um negócio jurídico, muito menos um contrato, numa ordem de transferência dada ao banco, sendo pois simplesmente executada diante da existência de fundos, coberta pela relação jurídica substancial (CORDEIRO, 1999).

Observe-se que o giro bancário pressupõe atualmente suportes tecnológicos 
consideráveis, capazes de canalizar e operar um número abundante de operações financeiras. Nesse sentido, portanto, é que se fala em "sistemas de pagamento". Na lição de CORDEIRO (1999, p. 496),

Os sistemas de pagamento não são inóquos. Aparentemente, eles limitarse-iam a melhorar os suportes materiais (ou energéticos) das operações jurídicas comuns. $\mathrm{Na}$ realidade, eles vêm promover alterações substanciais: determinados tipos de operações vêm a suplantar outros, surgindo, num paralelo simultâneo, novos produtos financeiros. Institutos consagrados, como o das falências, por exemplo, devem ser repensados. Basta atentar em que a situação líquida e patrimonial duma empresa pode alterar-se completamente, num lapso muito curto de tempo, através de operações de giro bancário.

Entre as atividades mais frequentes que compõem o giro bancário estão a de cobrança e a do pagamento bancário por giro em conta (clearance, compte de virement).

$\mathrm{Na}$ cobrança fica o banco investido do poder de receber. O negócio jurídico que origina o crédito do cliente pode ser cambiário, cambiariforme ou, ainda, não cambiário.

Quanto ao pagamento, "o banco pratica ato-fato jurídico (paga) e recebe o título da dívida ou o recibo, ou exige quitação se até aí vai a incumbência" (PONTES DE MIRANDA, 1966, p. 41).

Desse modo, para a compreensão da figura jurídica do pagamento pelo banco é mister se abstrair de qualquer negócio jurídico subjacente, justaposto ou sobrejacente. Com efeito, há outorga de poderes para o adimplemento, que podem resultar de negócios jurídicos bancários, sejam como o depósito ou a abertura de crédito, porém essa vinculação não é requisito necessário àquela outorga de poderes. Sem embargo, particularmente no giro bancário, o pagamento por giro em conta resulta do negócio jurídico básico de giro em conta corrente.

Falou-se anteriormente de ato abstrato no pagamento (CORDEIRO, 1999). Não obstante, o banco paga em nome próprio e por conta do cliente, sendo antes o pagamento um ato-fato jurídico, não um ato ou negócio jurídico, ao qual se pudesse antepor uma causa. Nesse sentido, portanto, não cabe a alusão a qualquer forma de abstração (da causa) no pagamento (PONTES DE MIRANDA, 1966, p. 42).

Assim, o banco prometeu o ato-fato jurídico como efeito da outorga de poder para pagar, tal como na ordem de pagamento. O fato do pagamento é, portanto, efeito jurídico da execução por parte do banco de seu dever negocial de pagar por conta do cliente. 


\subsection{O pagamento}

O direito moderno, a partir da última fase do pandectismo, amalgamado no Código Civil alemão, reelaborou a teoria da causa a partir da doutrina medieval. Sob a influência escolástica, as causae da condictio e da traditio concorreram para a concepção da causa finalis, de modo que a finalidade do contrato seria a prestação que se pretende obter (SÖLLNER, 1958 apud COUTO E SILVA ${ }^{185}$, 2012, p. 48). Os conceitos objetivo e subjetivo de causa resultaram na função objetiva do negócio jurídico, por meio da qual o ato jurídico antecedente se vincula ao subsequente. Trata-se, portanto, de função propriamente, não de fim, em razão de ser a transmissão da propriedade ato final (FLUME, 1965 apud COUTO E SILVA ${ }^{186}, 2012$, p. 48).

No direito alemão, o acordo de transmissão da propriedade de bens móveis e imóveis é abstrato, visto ser a causa legalmente irrelevante. Em contraponto, o direito francês, ou o italiano, atribui ao próprio contrato de venda e compra o efeito translatício, em que pese a necessidade do registro para o efeito em relação a terceiros. O Código Civil brasileiro adotou posição intermédia, ao vincular a eficácia da tradição à do negócio jurídico que a antecede, princípio que se estendeu à transferência de imóveis em razão de construção jurisprudencial (COUTO E SILVA, 2012).

O direito comum exigia negócio obrigacional (titulus) e tradição ou transcrição (modus adquirendi) para a transferência da propriedade. A partir da doutrina de SAVIGNY (1840 apud COUTO E SILVA ${ }^{187}$, p. 49), classificou-se a tradição como contrato de direito real, quando importasse adimplemento, exigindo-se declaração de vontade das contrapartes. Os planos obrigacional e real se distinguem nitidamente no direito alemão, mas tendo no negócio jurídico fonte comum de efeitos. Dessa forma, o negócio jurídico de disposição (acordo de transmissão) é abstrato e se situa no plano dos direitos reais. A compra e venda, por sua vez, é causal. O poder de disposição é, portanto, requisito de eficácia dos negócios jurídicos de direitos reais, não o sendo para a celebração dos negócios obrigacionais.

Ressalte-se, porém, que mesmo no direito alemão tem havido ressalvas à separação absoluta entre os planos obrigacional e real, em especial nos negócios ilícitos

185 SÖLLNER, Alfred. Die causa im Kondiktionen- und Vertragsrecht des Mittelalters bei den Glossatoren, Kommentatoren und Kanonisten. Frankfurt a.M., 1958. p. 36 e s.

186 FLUME, Werner. Allgemeiner Teil des Bürgerlichen Rechts. Berlin: Springer, 1965. v. II: Das Rechtsgeschäft. p. 24.

187 SAVIGNY, FC von. System des heutigen römischen Rechts. Berlin, 1840. v. III. p. 312 e s. 
antecedentes à disposição, naqueles cuja fonte negocial resulte de ato volitivo unitário, ou, em se tratando de bens móveis, admitindo-se o condicionamento das eficácias obrigacional e real - não assim quanto à transmissão imobiliária, em razão da incondicionalidade estabelecida no $§ 925$ II BGB (COUTO E SILVA, 2012).

A separação de planos é corolário da distinção entre negócios obrigacionais e reais, imposto pela própria lógica do direito obrigacional ao situar o adimplemento, ato de extinção da obrigação, em fase diversa da do nascimento do vínculo obrigacional. Do ponto de vista conceitual (operacional), tal discrime se impõe.

O dimensionamento conceitual entre os campos obrigacional e real não implica, necessariamente, a abstração dos negócios jurídicos de transmissão de direitos reais. Nesse sentido, a separação de planos será relativa (COUTO E SILVA, 2012). Esse é o caso típico da sistemática do direito civil brasileiro, em que se confere caráter causal (funcional) ao negócio dispositivo.

No sistema alemão, de separação absoluta, o acordo de transmissão tem existência autônoma, exigindo-se a comunhão de vontades em relação à transferência em si da propriedade, além da tradição ou transcrição ( $§ 925,929$ BGB).

No sistema brasileiro, de separação relativa, considera-se codeclarada no negócio obrigacional a declaração de vontade direcionada ao adimplemento, conteúdo do negócio jurídico de disposição (COUTO E SILVA, 2012). Na promessa obrigacional estaria embutida, portanto, a vontade de adimplir o prometido.

A questão concernente à causa na transmissão se revelou peculiarmente importante no âmbito dominial, na medida em que o art. 859 do Código Civil anterior, de 1916, dizia da presunção de titularidade do direito real daquele em cujo nome se registrou. Prevaleceu a corrente doutrinária e jurisprudencial que entendia ser o ato de transmissão causal, portanto relativa a presunção de propriedade dada pelo registro (COUTO E SILVA, 2012). Esse entendimento se cristalizou no $\S 2^{\circ}$ ao art. 1.245 do Código Civil vigente.

Em verdade, a discussão doutrinária aqui havida se cingiu ao exame da natureza da presunção normativa e da boa fé do adquirente do domínio, independentemente do posicionamento dogmático em torno do relacionamento entre o negócio obrigacional e a aquisição dele derivada (negócio de adimplemento ou pagamento).

A doutrina brasileira, ainda afeta aos conceitos do direito comum, desenvolve o tema do pagamento, em geral, apenas como modo de aquisição, ou forma de liberação do devedor, conceituando-o de forma estanque, apenas em correlação à fonte negocial do ato 
dispositivo (derivado), sem a presença necessária da vontade geradora do negócio jurídico dispositivo. Não raro, entende-se o pagamento como efeito natural da obrigação, resumindo-o à execução voluntária da obrigação ou à entrega da prestação devida, simples fato jurídico (MONTEIRO, 2011, p. 287, com ressalvas à p. 288; PEREIRA, 2011; vacilante nesse sentido, VENOSA, 2012, p. 173). Deve-se isso, talvez, à influência da legislação civil anterior, que referia apenas o ato jurídico.

No direito brasileiro, haja vista a codeclaração da vontade de transmitir o bem no âmbito do negócio de compra e venda, as regras a respeito da capacidade incidirão no momento da realização do negócio obrigacional, vigorando também para o pagamento (COUTO E SILVA, 2012).

Com efeito. O Código Civil vigente traz algumas regras que corroboram a existência e o caráter causal do negócio jurídico de disposição, a saber, os arts. 307 e 1.268 (CC/1916, arts. 933 e 622). No art. 307, § único, que trata de quem deve pagar, alude-se ao poder de disposição (direito de alienar) do solvens, como requisito de eficácia do pagamento. Assim, também, no legado de coisa certa, cuja ineficácia da transmissão (saisina) retroage ao próprio negócio de direito sucessório (CC, art. 1.912). A causalidade (funcionalidade) do negócio de transmissão exsurge da regra do $\S 2^{\circ}$ ao art. 1.268 do Código Civil, que trata da tradição (modo de aquisição da propriedade móvel).

Resta claro que somente por meio da declaração volitiva de caráter negocial se poderá transferir de esfera jurídica o direito real de propriedade, alienando-o. Esse acordo, porque implica comunhão de vontades ao modificar a esfera patrimonial do adquirente, tem seu efeito no campo dos direitos reais. Não só. Vincula-se ao pagamento, cujo efeito seja a transmissão da propriedade, a titularidade e exercício do direito de disposição, portanto, a eficácia da própria transmissão dominial (CC, art. 307). Nesse caso, o pagamento (adimplemento) seria, portanto, negócio jurídico de eficácia real direta, ao contrário dos negócios obrigacionais (CC, art. 1.267). Aliás, a opinião dominante é de que o pagamento seria contrato (MONTEIRO, 2011, p. 288).

Equivoca-se o argumento de que a tradição seja em si ato jurídico dispositivo, portanto de natureza negocial. A tradição é ato real, ato-fato jurídico, não condicionável; a transcrição, por sua vez, é ato de direito público: ambas não têm conteúdo volitivo como condição de validade (COUTO E SILVA, 2012). A disposição, alienação, ao contrário, pode ser objeto de condição, como na venda com reserva de domínio.

Ademais, o negócio dispositivo permite representação, já a tradição, somente 
posse ou detenção. Nesse sentido, aliás, subentende-se a tradição (ficta) quando há o constituto possessório, cessão de direito à restituição da coisa possuída por terceiro, ou quando o adquirente já está na posse da coisa por ocasião do próprio negócio obrigacional (CC, art. 1.267, § único). Vê-se, portanto, que a declaração de vontade destinada à transferência dominial, portanto de eficácia real, se encontrava previamente declarada no âmbito da obrigação.

A tradição em si, enquanto entrega do objeto negocial, é apenas condição de eficácia do acordo de transmissão (negócio dispositivo), com ele não se confundindo, mas o complementando. Quando contemporâneos as declarações de vontade, geradoras do negócio obrigacional e real, e a entrega do objeto prometido (tradição), então será instantânea (comum) a eficácia.

Não fosse assim, a validade da tradição (modo de aquisição) seria também condição de validade do negócio jurídico obrigacional. No entanto, a teor da regra do art. 307 do Código Civil, o direito de alienar do solvente (poder de disposição) é requisito do pagamento, não do negócio obrigacional. Nesse caso, ou se admite ser o pagamento negócio jurídico dispositivo, de direito real, ou se transforma a própria tradição em negócio jurídico translatício. A última hipótese, no entanto, não prospera tanto em face da doutrina como da lógica do sistema.

Com efeito, o $\S 1^{\circ}$ do art. 1.268, do Código Civil, esclarece a regra do caput ao estabelecer que a transferência se considera realizada no momento da tradição, portanto, não através dessa última. Além disso, seria tamanha a incongruência ao se admitir a tradição como negócio jurídico de alienação, pois que se estaria também admitindo, por força da regra do art. 1.267, § único, ser ficta a própria declaração negocial destinada à transmissão do direito de propriedade.

Em atenção aos princípios, conclui-se, portanto, pela existência jurídica do acordo de transmissão, como requisito a integrar o negócio jurídico de pagamento. Trata-se de conceito funcional, apto a operacionalizar o efeito translatício do pagamento no campo do direito das coisas, observada a distinção sistemática entre as obrigações e os direitos reais.

Consequência fundamental do princípio da separação dos planos diz respeito à determinação do objeto da dívida, que incide no plano obrigacional, pois "a obrigação se dirige à prestação, ao ato que a satisfaça", uma vez que a relação jurídica obrigacional se caracteriza por ser determinada a sua prestação (COUTO E SILVA, 2012, p. 59 e s.; MONTEIRO, 2011; PONTES DE MIRANDA, 1959c). 
A determinação do credor se prende à formação do vínculo obrigacional, podendo, no entanto, ocorrer posteriormente, máxime nos negócios realizados em ambientes automatizados ou informatizados. No entanto, tal indeterminação é apenas relativa, devendo haver sempre a possibilidade de individuação, em particular na ocorrência de vícios do objeto de adimplemento.

Quanto ao objeto da prestação, sua determinação também ocorre no plano obrigacional no que tange às obrigações de dar coisa genérica e às alternativas. Sua individuação se insere, no entanto, entre os requisitos do pagamento.

A determinação do objeto seria, assim, requisito do negócio jurídico de disposição. O pagamento, no entanto, não pertence à construção do vínculo obrigacional, sendo antes sua solução, desde que eficaz. Dessa forma, constitui a determinação do objeto elemento de eficácia do pagamento. Na dimensão do pagamento se inserem, portanto, as regras atinentes ao objeto da obrigação, incidindo ainda aquelas concernentes aos modos de aquisição quando o pagamento importar transmissão, ou oneração, da propriedade (CC, art. 307). A eficácia do adimplemento, seja no plano obrigacional ou no dos direitos reais, repercutirá ainda na tipologia das eventuais demandas processuais.

Nada obstante a doutrina exposta, é mister que se ressalte a possibilidade de se entender o pagamento independentemente de seu vínculo ao negócio jurídico dispositivo (acordo de transmissão funcional). Com efeito, o pagamento entendido como ato-fato jurídico, na esteira da doutrina de PONTES DE MIRANDA (1959a, p. 77 e ss.), uma vez efetuado (existente), poderá ser somente eficaz ou ineficaz, mas não válido ou inválido, vez que o suporte fático do ato-fato prescinde do elemento volitivo como condição de eficácia do ato. $\mathrm{O}$ pagamento assim considerado constitui ato que somente corresponde à prestação devida, não sendo mister a presença da vontade de aceitar, por parte do credor, nem a de pagar, do devedor. Assim, o pagamento poderia ser realizado pelo devedor de modo eficaz, ainda que sem vontade de o fazer, ou contrariamente a ela, na medida em que aquele que paga dívida existente e sua, ainda que incidente em erro quanto a ser outra a dívida quitada, cumpre e extingue a obrigação que não tencionava adimplir. "A solução ou adimplemento pode ser definido pelo efeito, e é a solutio dos textos, a extinção do dever ou da obrigação sòmente, liberando" (PONTES DE MIRANDA, 1959a, p. 71). Sem embargo, na hipótese de haver negócio jurídico, unilateral ou bilateral, quando do pagamento, pois que a esse justaposto, faz-se necessário distinguir entre o pagamento em si e o seu objeto.

Nesse sentido, esclarece SILVA (2007, p. 55 e s.): 
No direito brasileiro, não há norma que exija a vontade específica de pagar, sendo, aliás, extraível do ordenamento a sua desnecessidade. Se, por exemplo, o devedor pagou dívida prescrita pensando que adimplia dívida exigível, o seu ato extingue a obrigação. Tendo sido correto e perfeito, este pagamento não poderá ser repetido. Do mesmo modo, se alguém possui duas dívidas com dois credores distintos e deposita na conta de um pensando estar fazendo-o na conta de outro, terá com isso extinguido a dívida para com o primeiro. Independentemente da sua vontade, o pagamento terá sido bem feito, igualmente inexistindo espaço para repetição. Vontade específica só se faz relevante em casos pontuais, que, dadas as suas particularidades, não motivam generalizações.

Entre as situações específicas, mencione-se o caso do pagamento por terceiro, em que se faz necessário o animus solvendi, pois, do contrário, poderá o terceiro repetir o que erroneamente pagou (CC, art. 877). Não obstante essa particularidade, ainda assim o pagamento por terceiro (p. ex., o banco) seria pagamento em sentido amplo, portanto, a vontade de adimplir não seria elemento necessário do ato. A vontade de adimplir, portanto, ainda que exista como regra nos negócios paritários, constitui plus ao suporte fático, não sendo relevante para a eficácia do pagamento.

Segundo esse entendimento, deve-se distinguir o ato de pagar e o objeto do ato de pagar. Assim, por exemplo, nas obrigações pecuniárias, a entrega do dinheiro constituiria o ato de pagamento, enquanto que o dinheiro em si o seu objeto. Portanto, na hipótese de obrigação de dar coisa certa, o ato de pagamento ocorreu exatamente no prazo convencionado, não obstante o defeito do objeto dado em pagamento, então não incidirão as regras sobre inadimplemento, senão as concernentes aos vícios redibitórios.

Desse modo, o pagamento efetivado por quem não possua o poder de disposição não seria considerado inválido, a despeito de sua ineficácia (CC, art. 307). $\mathrm{O}$ ato de pagamento em si terá sido perfeitamente legítimo, mas ineficaz em razão da impossibilidade de se concretizar a transferência da propriedade. Nesse sentido, pode-se entender a regra do art. 1.268, $\S 1^{\circ}$, do Código Civil, segundo a qual, na presença de boa-fé (subjetiva) do credor alienante, caso esse adquira posteriormente a propriedade, tem-se por realizada a transferência desde o momento da tradição. Não fosse o ato do pagamento somente ineficaz, mas inválido, não incidiria tal regra, a teor do $\S 2^{\circ}$ ao referido artigo.

Ressalte-se todavia que ambas as doutrinas anteriormente esboçadas são aptas a explicar o funcionamento e os efeitos das regras de direito civil atinentes às obrigações 
pecuniárias e, portanto, à transferência (da propriedade) do objeto do pagamento.

\subsection{As obrigações pecuniárias}

A entrega ou restituição de uma coisa constitui objeto das obrigações de dar. As obrigações chamadas de pecuniárias são, em verdade, aquelas que têm por objeto uma prestação pecuniária, ou seja, a entrega (pagamento) de uma soma em dinheiro (ASCARELLI, 1969; PEREIRA, 2011), não de determinadas moedas ou certa quantidade de espécies monetárias (FARIA, 1990), corolário, aliás, do princípio nominalista, prevalecente ao longo da história das doutrinas jurídicas (ASCARELLI, 1969, p. 178 e ss.).

Entendia-se, tradicionalmente, ser a obrigação pecuniária uma modalidade muito particular de obrigação genérica, de prestar espécie ou coisa incerta, uma vez que se considerava a moeda algo similar à mercadoria, como bem fungível e consumível por excelência. Nessa modalidade, o bem será indicado ao menos pelo gênero e quantidade, devendo o devedor prestar objeto de qualidade média, cabendo-lhe, em princípio, a escolha (CC, arts. 243 e 244; COUTO E SILVA, 2010; FARIA, 1990; GOMES, 1988).

$\mathrm{Na}$ doutrina alemã se tem aclarado sobremaneira a especificidade das obrigações pecuniárias em relação às genéricas, salientando-se as diferenças quanto à transmissão do risco através da concentração (necessária concretização para a circulação da dívida, em função do princípio da determinação), e à aplicação do critério da escolha, uma vez que não se há de prestar objeto de qualidade média, mas antes a própria moeda estipulada (BROX, 1962 apud FARIA ${ }^{188}$, 1990, p. 210, n. 4).

Com efeito. Segundo alguns doutrinadores de escol, à relação obrigacional cujo objeto da prestação seja dinheiro não se aplicam as regras comuns às obrigações de dar (transferir) coisa corpórea, dada sua extrema fungibilidade e consuntibilidade, assim como sua função econômica. Sendo o dinheiro, portanto, meio legal de pagamento, a ele não seria adequado o sistema de transmissão dos direitos reais (KASER, 1944 apud COUTO E SILVA $^{189}, 2012$, p. 139 e ss.).

Ressalte-se que a dívida pecuniária, não obstante seja de valor nominal (CC, art. 315), ao ser considerada genérica, requer ainda sua concretização (escolha), em atenção ao princípio da determinação (COUTO E SILVA, 2012). Nesse sentido, ESSER (1969 apud

188 BROX, Hans. Allgemeines Schuldrecht. 1980, p. 62.

189 KASER, Max. Das Geld im Sachenrecht. Archiv f. die civilistische Praxis. Tübingen: Mohr, 1944. v. 143. p. 6. 
COUTO E SILVA ${ }^{190}$, 2012, p. 144) a chamou de dívida genérica em sentido formal, pois materialmente seria dívida de valor ou de soma, portanto, não haveria sentido prático em tê-la por genérica.

Em verdade, a doutrina dominante a entende apenas como obrigação específica de dar certa quantia em dinheiro, ou, ainda, obrigação de soma de valor (nominal) (GOMES, 1988; MONTEIRO, 2011; VENOSA, 2012).

PONTES DE MIRANDA (1959c, p. 291 e ss.) a entende como prestação de espécie, sempre, cuja nota diferencial de outras dívidas genéricas seria o valor nominal. Esse valor nominal afastaria, portanto, a incidência dos arts. 244 e 245, do Código Civil, regrando-a somente os arts. 243 e 246.

As dívidas pecuniárias seriam dívidas de prestação concreta, cujo objeto é um bem ou um ato, omissivo ou comissivo. Ao contrário, as dívidas de valor são aquelas de prestação abstrata. Assim, a dívida de dinheiro é dívida de coisa; já a dívida de valor, adaptativa.

A dívida de soma de dinheiro tem por objeto a prestação de moeda, devendo-se o importe nominal. Deve-se o valor patrimonial incorporado no título, suscetível a oscilações, podendo se incorporar em cheque ou dinheiro depositado em banco, à disposição do credor. Entrega-se, portanto, o signo monetário, ou aquilo que se credite na conta do credor, conforme o preestabelecido. Essas outras formas de prestação, além da entrega de cédulas, devem também ser acolhidas (PONTES DE MIRANDA, 1959c, p. 293).

As dívidas de valor, por sua vez, têm por objeto prestação de valor, determinável em dinheiro, ou em outro objeto. A diferença entre a promessa de coisa, inclusive dinheiro, e a de valor, afere-se por meio de interpretação da declaração negocial, precisando-se qual a prestação prometida, independentemente da presença de cláusula de correção (PONTES DE MIRANDA, 1959c, p. 294).

Desde o Decreto $\mathrm{n}^{\mathrm{o}} 23.501$, de 1933, consolidado pelo Decreto-lei $\mathrm{n}^{\mathrm{o}}$ 857, de 1969, e, ainda, pela Lei $\mathrm{n}^{\circ}$ 10.192, de 2001 ("Plano Real”), restou proibida qualquer estipulação em ouro, ou moeda estrangeira, cominando-se a pena de nulidade (ineficácia). Dessa forma, a regra do nominalismo rege todas as obrigações que tenham por objeto o pagamento em dinheiro (CC, art. $315 \mathrm{c} / \mathrm{c}$ art. 318).

Não obstante poder se entender a moeda em razão de suas funções, como já 
anteriormente indicado, resta classificá-la entre as diversas categorias de bens estabelecidas na lei civil.

Tradicionalmente, vê-se o dinheiro como algo ligado à sua forma perceptível no mundo social, qual seja, o papel-moeda. Dessa forma, seria ele bem móvel, fungível e consumível (CC, arts. 85 e 86), sujeito, portanto, às regras de transmissão da propriedade (tradição).

Além do meio circulante em si, moeda em espécie, há que se classificar também as chamadas quase-moedas, tanto a moeda escritural como outros ativos financeiros (agregados monetários), todos eles havidos como instrumentos de pagamento devido à sua liquidez, por exemplo, no mercado secundário de títulos crédito (de renda fixa), públicos ou privados. São assim reconhecidos também sob o prisma institucional, ainda que não dotados, em princípio, de curso legal (CC, art. 315) ${ }^{191}$.

Dessarte, a moeda, como objeto do direito potestativo liberatório, de caráter público, classificar-se-ia, do ponto de vista do direito privado, entre os direitos pessoais patrimoniais, ou seja, bens móveis para os efeitos legais (CC, art. 83, III).

Ressalte-se ainda que os ativos financeiros representados pelos títulos de crédito da praxe bancária, como o cheque ou os certificados de depósito bancário (CDB), são utilizados como dinheiro em razão de sua liquidez, na medida em que representam meios de pagamento, cujos valores são objeto de compensação bancária. Não obstante, o pagamento realizado diretamente através deles, sem a intermediação bancária, se traduz em cessão de crédito (COUTO E SILVA, 2012).

Não há se olvidar de que a moeda escritural, gerada pelo depósito bancário (à vista), também deixa de ser propriedade do titular do depósito, tornando-se esse último apenas credor em razão de que ao depósito bancário, dada a fungibilidade da moeda, se aplicam as regras atinentes ao mútuo, configurando-se o chamado depósito irregular (CC, art. 645). Esse, por sua vez, implica transmissão da propriedade ao mutuário, ou seja, o banco depositário (CC, art. 587).

Dessa forma, constitui a moeda escritural, enquanto agregado monetário de primeira ordem, principalmente devido à sua elevada liquidez (ALMEIDA, 2009), um direito de crédito do titular do depósito em relação ao banco (SALOMÃO NETO, 2007).

191 Não obstante, a Lei no 10.192, de 2001 ("Plano Real”), estabelece, em seu art. 1', o curso legal da moeda (REAL) para as estipulações de pagamento de obrigações pecuniárias. Assim, não se restringiria o curso legal apenas à moeda em espécie, antes abrangendo o padrão monetário nacional. Diante do fato da desmaterialização da moeda em larga escala, parece-nos ser essa hodiernamente a melhor opção doutrinária. 
Registre-se também que as contas bancárias não se limitam à custódia de valores, mas podem ser movimentadas pelos bancos, mediante acordo com o correntista, para a realização de pagamentos e recebimento de dívidas. Tem-se, portanto, a abertura de uma conta corrente, registro contábil relativo a créditos e obrigações de ambas as partes. Entre as obrigações do banco há a realização de pagamentos (SALOMÃO NETO, 2007).

Os créditos mencionados são objeto de transferências (pagamentos) no âmbito do SPB. Assim, por exemplo, o CDB, anteriormente objeto de cartularidade (art. 30 da Lei $\mathbf{n}^{\circ}$ 4.728, de 1965), é hoje mantido em registros eletrônicos, inclusive na Cetip. Aliás, já circulava através de simples cessão de crédito, visto ter sido ao longo do tempo substituído por simples documento de legitimação (recibo de depósito bancário), representando a relação jurídica de depósito, mas sem incorporação do direito creditório.

Sobreleva ainda em importância os depósitos interbancários - também denominados interfinanceiros -, cujos depositantes e depositários são, em regra, as instituições financeiras bancárias. Essas operações não são objeto de certificados, mas são registradas e liquidadas financeiramente em sistema de registro e liquidação pertencente ao SPB, a saber, o Sistema de Transferência de Reservas (STR).

As transferências desses créditos são objeto de pagamentos (indiretos) realizados no sistema financeiro. No entanto, ocorrem por meio de câmaras de compensação, como, por exemplo, a Compe, administrada pelo Banco do Brasil. Realiza-se, assim, a compensação multilateral de cheques e outros papéis, na medida em que se contrapõem cheques e outras ordens de pagamento interbancárias (DOC), emitidos por clientes de um banco, a ordens de pagamento a favor de clientes do mesmo banco. Nesse processo, cada banco receberá somente a diferença entre ambos os valores a seu favor, ou pagará a diferença a seu desfavor. A própria Compe possui sua conta de liquidação junto ao BCB, alimentada diariamente pelos bancos por meio de depósitos, contra a qual se lançam, posteriormente (a partir do dia seguinte), a crédito ou débito, os resultados financeiros apurados diariamente.

Observe-se todavia que os cheques de valor igual ou superior à $\mathrm{R} \$ 250$ mil (VLBCheque) e os bloquetos de cobrança de valor igual ou superior a $\mathrm{R} \$ 5$ mil (VLB-Cobrança) passaram a ser liquidados por meio do STR, onde a liquidação é bilateral entre os bancos, por valores brutos agregados (sem compensação). Dessa forma, retirou-se do âmbito da Compe os pagamentos de quantias elevadas, pois que não havia proteção contra o risco de principal. 
Do exposto, a moeda, representada por direitos creditórios (moeda escritural), e pois ainda a quase-moeda, eventualmente representada por títulos de crédito públicos de elevada liquidez, todos sob a forma desmaterializada (intangível), não raro fungíveis entre si, é aceita como meio de pagamento em contexto socioeconômico cada vez mais amplo, equivalendo, portanto, à chamada moeda de curso legal (unidade de conta oficial). Tal fato se concretiza de modo institucional, em particular com o advento da Lei $n^{\circ} 10.214$, de 2001, que dispõe sobre o SPB.

Nessa mesma ordem de ideias, seria legítimo se expandir doutrinariamente o conceito de moeda de modo a abranger toda forma de moeda fiduciária, em particular a moeda escritural dos bancos e ainda a "moeda de banco central" (reservas bancárias), como complexo de normas que regulamentam a circulação monetária e o pagamento das obrigações pecuniárias. Dessa forma, todas essas formas de moeda seriam veículos de transmissão da moeda de curso legal, incorporando sobretudo direitos a essa moeda. Vale dizer, são dinheiro em sentido largo, enquanto direitos ao dinheiro de curso legal (SCHUMPETER, 1982).

A teoria dos títulos de crédito tem por finalidade precípua a aplicação aos créditos do regime de transmissão da posse e propriedade das coisas móveis, incorporando-os, assim, em documentos físicos. Na falta desses, impossível a existência do título de crédito (SALOMÃO NETO, 2007).

Nesse sentido, também a lição de COELHO (2011, p. 410):

O registro da concessão e circulação do crédito em meio eletrônico tornou obsoletos os preceitos do direito cambiário intrinsecamente ligados à condição de documento dos títulos de crédito. Cartularidade, literalidade (em certa medida), distinção entre atos "em branco" e "em preto" representam aspectos da disciplina cambial desprovidos de sentido, no ambiente informatizado.

$\mathrm{O}$ único dos três princípios da matéria que não apresenta incompatibilidade intrínseca com o processo de desmaterialização dos títulos de crédito é o da autonomia das obrigações cambiais, e os seus desdobramentos no da abstração e inoponibilidade das exceções pessoais aos terceiros de boa-fé. Será a partir dele que o direito poderá reconstruir a disciplina da ágil circulação do crédito, quando não existirem mais registros de sua concessão em papel.

De fato, as informações arquivadas em banco de dados eletrônico são a base para 
a expedição de alguns documentos físicos a respeito das operações bancárias. A partir do banco de dados, emitem os bancos, por exemplo, o instrumento para a quitação de dívida ("guia de compensação bancária”). Esses documentos, entretanto, não configuram títulos de crédito. Dessa forma, "quando a obrigação registrada por processo informatizado vem a ser satisfatoriamente cumprida, em seu vencimento, ela não chega jamais a ser materializada num título escrito" (COELHO, 2011, p. 409).

Não obstante, a presença da intermediação bancária, por meio da movimentação eletrônica dos créditos, via regime de conta corrente, torna os créditos circuláveis, passíveis de transmissão por meio de pagamento, ainda que por um de seus modos particulares, como a compensação multilateral (interbancária), através dos sistemas de compensação centralizados, operando-se, em princípio, a novação.

Os pagamentos realizados pelo depositário são feitos em adimplemento às obrigações de prestação de serviços acessórias ao contrato de depósito, por meio de mandato conferido pelo depositante à instituição bancária.

Nesse diapasão, a moeda fiduciária, não obstante sua natureza creditícia, se transmite, por meio do pagamento, ao (banco) depositário onde os credores do depositante devedor são titulares de contas bancárias, creditando-se a soma devida em nome dos credores, para solução da dívida monetária, sem que ocorra a cessão desse crédito.

A intermediação bancária, em princípio, importa a tradição de moeda bancária, crédito, por meio do pagamento, subtraindo essa obrigação ao regime de transmissão que lhe é próprio, a cessão de crédito.

O regime de compensação centralizada, próprio ao SPB, vem a corroborar o entendimento anteriormente esboçado de que a obrigação pecuniária se insere, de modo peculiar, entre as dívidas genéricas, de espécie ou de dar coisa incerta. Nesse caso, ainda que se afaste a concretização (determinação) por meio de escolha do devedor (CC, art. 244), cabe a analogia com as obrigações ilíquidas, em razão da determinação dos saldos financeiros finais por meio da liquidação (MONTEIRO, 2011; VENOSA, 2012).

Finalmente, a tradição eletrônica tanto de fundos como de ativos financeiros corrobora o argumento de que tal modo de transmissão não é mais do que ato real, ou ainda, ato-fato jurídico. No que tange ainda ao conceito de negócio jurídico de disposição, ato volitivo de solução, caso se entenda a sua presença, continuará ele a ser prestigiado como codeclaração no negócio gerador de obrigações, antecedente, portanto, à própria solução da obrigação. 


\section{Fundamentos do SPB sob o prisma do Código Civil}

Recapitulando a estrutura de liquidação adotada pelo SPB, frise-se que os sistemas de transferência de fundos seguem a regra da Liquidação Bruta em Tempo Real, não obstante se liquidarem os negócios financeiros cursados nas câmaras de compensação e liquidação pelo valor líquido de cada participante - Liquidação Diferida pelo Líquido (LDL), através de lançamentos de débito e crédito envolvendo as contas Reservas Bancárias dos participantes e a conta de liquidação das câmaras, todas mantidas junto ao Banco Central do Brasil.

Cada câmara componente do SPB liquida suas operações em determinado período do dia, também chamado de "janela de liquidação". Como contrapartida, exigem elas o depósito de garantias por parte de seus participantes. Assim, em caso de inadimplemento tanto das obrigações pecuniárias como das obrigações de entrega (transferência de titularidade) dos ativos financeiros (p. ex., títulos e valores mobiliários), haverá a execução direta (específica) das garantias pela câmara. Regem-se as câmaras pelo princípio da entrega contra pagamento (EcP), vale dizer, ocorrem de modo simultâneo a efetiva transferência de fundos entre as contas Reservas Bancárias dos bancos que realizam operações em determinada câmara e a conta de liquidação dessa câmara no Banco Central, bem como a contrapartida da transferência da titularidade dos ativos negociados entre os participantes, custodiados na mesma câmara. Desse modo, na "janela de liquidação" transfere a câmara as quantias coletadas aos participantes vendedores (líquidos), bem como redistribui os ativos entre os compradores (líquidos).

Observa-se, portanto, que há basicamente duas espécies de sistemas operacionais no âmbito do SPB, a saber, os sistemas de liquidação de transferência de fundos interbancários e os sistemas de liquidação de transferência de ativos financeiros.

No que tange à transferência de fundos, representa o Sistema de Transferência de Reservas (STR) o centro de liquidação das operações interbancárias ${ }^{192}$. Operando o sistema de liquidação LBTR, onde as obrigações são incondicional e irrevogavelmente liquidadas, esse sistema é de propriedade do Banco Central do Brasil, sendo por esse administrado.

Basicamente, responde o STR pela liquidação de negócios interbancários realizados nos mercados monetário (títulos de crédito públicos), financeiro (cambial) e de

192 Entre os sistemas de liquidação de transferências de fundos interbancários, mencionem-se ainda a Compe, a CIP e a Tecban, descritas em tópico anterior. 
capitais, das transferências de fundos do Tesouro Nacional (recolhimento de tributos e pagamentos de despesas governamentais), das transferências de fundos das contas de liquidação das câmaras de compensação, das transferências de fundos em nome e por conta dos clientes bancários etc.

O acesso ao STR é obrigatório a todas as câmaras e prestadores de serviços de compensação e liquidação considerados sistemicamente importantes (a critério do BCB), aos bancos comerciais, bancos múltiplos com carteira comercial e às caixas econômicas, sendo facultativo às restantes câmaras de compensação (não consideradas sistemicamente importantes pelo $\mathrm{BCB}$ ), aos bancos de investimento, entre outras instituições financeiras $^{193}$.

Sob o prisma monetário, particularmente da moeda escritural das reservas bancárias (moeda de banco central), é mister que se destaquem as principais fontes de liquidez do sistema liquidante de fundos: a) saldos mantidos pelas instituições financeiras junto ao $\mathrm{BCB}$, incluindo os recolhimentos compulsórios; b) transferências interbancárias; c) concessões de crédito pelo BCB (operações diárias de redesconto, sem custo); e d) empréstimos interbancários (por meio da emissão, pela instituição mutuária, de certificados de depósitos interbancários - CDI).

Ressalte-se ainda que o STR funciona em meio a uma estrutura de comunicação de dados em rede, a chamada Rede do Sistema Financeiro Nacional, interligando o BCB, as instituições financeiras, as câmaras de compensação e liquidação e ainda a Secretaria do Tesouro Nacional. Essa tecnologia permite a comunicação direta entre os computadores dos participantes do SPB. Observe-se que o processamento contínuo da informação, sem intervenção humana, não só veio a prevenir a ocorrência de erros operacionais, como também a permitir as inovações no mercado financeiro brasileiro (ESTRELA, 2011).

No que tange aos sistemas de liquidação de transferência de ativos financeiros, vale frisar que respondem pela negociação, compensação e liquidação de títulos de crédito públicos e privados, moedas estrangeiras, ações, derivativos, entre outros valores mobiliários. Ressalte-se que esses sistemas são quase que totalmente automatizados,

193 A teor do art. $2^{\circ}$, XXIII, do Regulamento anexo à Circular BCB nº 3.057, de 31.8.2001, define-se como sistemicamente importante todo "sistema de liquidação em que o volume ou a natureza dos negócios, a critério do Banco Central do Brasil, é capaz de oferecer risco à solidez e ao normal funcionamento do Sistemas Financeiro Nacional". Nesse sentido, de acordo como o art. $8^{\circ}$, I, do mesmo Regulamento (com redação dada pela Circular no 3.539, de 2.6.2011), atualmente "são considerados sistemicamente importantes pelo Banco Central do Brasil os sistemas de liquidação de transações com ativos financeiros, títulos, valores mobiliários, derivativos financeiros e moedas estrangeiras, independentemente do valor individual de cada transação e do giro financeiro diário". 
consequentemente são os ativos financeiros mencionados, em sua grande maioria, desmaterializados, existindo apenas sob a forma de registros eletrônicos. O sistema de entrega contra pagamento é observado em todos os sistemas de liquidação de títulos e valores mobiliários, e pois seu equivalente, pagamento contra pagamento, se opera pela Câmara de Câmbio da BM\&FBovespa.

Entre os sistemas de liquidação de transferência de títulos e valores mobiliários, destaca-se o Sistema Especial de Liquidação e de Custódia (Selic), pertencente ao Banco Central do Brasil. Trata-se de sistema informatizado, destinado à custódia centralizada de títulos escriturais de emissão do Tesouro Nacional e do BCB, bem como ao registro e à liquidação de negócios tendo por objeto os referidos títulos. Responde assim pelo processamento da emissão, resgate, pagamento de juros e custódia daqueles títulos, sendo todos eles escriturais, vale dizer, emitidos exclusivamente sob a forma eletrônica ${ }^{194}$.

O Selic e o STR estão interligados de modo a permitir a efetivação do regime de entrega contra pagamento (EcP). Observe-se que por ser um sistema de liquidação em tempo real (LBTR), a efetiva liquidação dos negócios de compra e venda de títulos está condicionada à disponibilidade do título negociado na conta de custódia do vendedor, registrada no Selic, e ainda à disponibilidade de recursos financeiros na conta Reservas Bancárias do comprador, registrada no STR. Na hipótese de a conta de custódia do vendedor não apresentar saldo suficiente de títulos, suspende-se a operação de liquidação pelo prazo máximo de sessenta minutos, ou até às $18 \mathrm{~h} 30$, o que primeiramente se der, excetuados os negócios de venda e compra de títulos adquiridos em leilão primário realizado no mesmo dia de sua celebração. Frise-se ainda que somente se encaminha a operação negocial ao STR para a liquidação do lado financeiro (obrigação pecuniária) após o evento de bloqueio dos títulos negociados, observada ainda a suficiência de fundos na conta Reservas Bancárias, pois, do contrário, não se opera a liquidação da operação, sendo rejeitada pelo STR e, em seguida, pelo Selic.

Outra instituição importante do SPB é a Câmara de Custódia e Liquidação

194 O Selic é administrado pelo BCB e operado em parceria com a Associação Nacional das Instituições de Mercado Aberto (Andima). Participam do Selic, na qualidade de titulares de contas de custódia, além do $\mathrm{BCB}$ e da Secretaria do Tesouro Nacional, bancos comerciais, bancos múltiplos, bancos de investimento, caixas econômicas, distribuidoras e corretoras de títulos e valores mobiliários, entidades que operam os serviços de compensação e liquidação, fundos de investimento, entre outras tantas instituições que integram o SFN. Os participantes se diferenciam entre liquidantes e não liquidantes, sendo os primeiros, $\mathrm{BCB}$ e bancos titulares de contas Reservas Bancárias junto ao $\mathrm{BCB}$, diretamente responsáveis pelas liquidações das operações, enquanto os segundos liquidam seus negócios por meio dos primeiros, conforme contrato celebrados entre as instituições, observados ainda os limites financeiros impostos pelos liquidantes às operações no âmbito da administração de riscos (ESTRELA, 2011). 
$(\text { Cetip })^{195}$. Criada nos moldes da Selic, mantém sistemas próprios de negociação, registro, custódia computadorizada e liquidação, a despeito de não desenvolver atividades de clearing (contraparte central) no âmbito do SPB. Administra a negociação e, conforme o caso, o registro de negócios com títulos de captação emitidos por instituições financeiras e não financeiras ("obrigações societárias" em geral, registradas no "Sistema Nacional de Debêntures"), bem como certos títulos públicos não registrados no Selic e ainda alguns derivativos de balcão.

Mencione-se finalmente as operações de câmbio, outro preço básico da economia, cursadas em ambiente pertencente ao SPB, a saber, a Câmara de Câmbio da BM\&FBovespa. Nessa câmara se liquidam operações interbancárias de câmbio realizadas no mercado de balcão organizado pela BM\&FBovespa. As obrigações correspondentes são compensadas multilateralmente, atuando a câmara como contraparte central, ou ainda mediante liquidação pelo valor bruto, diretamente junto ao STR. Nesse último caso, as contrapartes são responsáveis pela liquidação em moeda nacional através do STR e pela liquidação em moeda estrangeira junto a bancos correspondentes no exterior, observandose que nessa hipótese o risco recai sobre as contrapartes. Atualmente são cursadas operações cujo objeto se restringe ao dólar americano.

\subsection{A natureza jurídica da "entrega contra pagamento"}

A Resolução $\mathrm{CMN}^{\circ}{ }^{\circ} 2.882$, de 30.8.2001, que a teor do art. 10 da Lei ${ }^{\circ}$ 10.214, de 2001, dispõe sobre o sistema de pagamentos e as câmaras e os prestadores de serviços de compensação e de liquidação que integram o SPB, estabeleceu em seu art. $3^{\circ}$, inciso IV, a "regra geral" (norma) de que "a tradição do ativo negociado e a efetivação do correspondente pagamento devem ser mutuamente condicionadas", traduzindo normativamente, portanto, o princípio da entrega contra pagamento $(\mathrm{EcP})$.

Independentemente da descrição anterior do regime EcP, restrita ao modo operacional, é mister que se identifique juridicamente a natureza dos elementos envolvidos no modelo, a saber, do título objeto da tradição e ainda do pagamento efetuado quando da

195 A Cetip processa a emissão, o resgate, o pagamento de juros e a custódia de títulos de renda fixa privados, títulos públicos estaduais e municipais e ainda títulos representativos de dívidas de responsabilidade do Tesouro Nacional. As operações no mercado primário são geralmente liquidadas por compensação multilateral de obrigações, ressalvando-se que a Cetip não atua como contraparte central. A compensação bilateral é utilizada na liquidação das operações com derivativos, já as operações com títulos negociados no mercado secundário são liquidadas em tempo real (LBTR). Na hipótese de inadimplemento, a compensação multilateral é novamente processada. 
ocorrência sincronizada desses eventos (BENJAMIN, 2000, p. 192).

Com efeito, o art. $8^{\circ}$, inciso I, da Lei $\mathrm{n}^{\circ} 10.214$, de 2001, a liquidação das obrigações ocorrerá "com a tradição dos ativos negociados ou a transferência dos recursos, no caso de movimentação financeira".

Por liquidação, no âmbito do SPB, se deve entender o processo de extinção das obrigações (Regulamento anexo à Circular BCB n 3.057, de 2001, art. $2^{\circ}$, IX).

Outrossim, explicitando a norma do art. $3^{\circ}$, inciso III, da Resolução CMN n ${ }^{\circ}$ 2.882, de 2001, o art. $2^{\circ}$, inciso VII, do Regulamento anexo à Circular BCB n ${ }^{\circ} 3.057$, de $2001^{196}$, define como sendo "definitivo" qualquer evento que ocorra em caráter irrevogável e incondicional, sejam como "a liquidação e a transferência de fundos ou de títulos e valores mobiliários".

Observe-se ainda que o citado Regulamento (anexo à Circular $\mathrm{n}^{\mathrm{o}} 3.057$, de 2001), em seu art. 33, ao explicitar a norma do art. $3^{\circ}$, inciso IV, da Resolução CMN nº 2.882, de 2001, estabelece que "a transferência definitiva do ativo negociado deve ocorrer simultaneamente à liquidação financeira".

\subsubsection{Os valores mobiliários e sua tradição}

No que tange aos títulos em geral (valores mobiliários), é possível os distinguir entre títulos de participação (ações) e títulos de dívida. Os títulos de dívida podem ser emitidos tanto por empresas comerciais (debêntures), bancos e ainda entes governamentais.

No Brasil, o título acionário não é definido legalmente, sendo apenas identificado como uma parte ideal da sociedade anônima (Lei $n^{\circ}$ 6.404, de 1976, art. 11). A Lei $\mathrm{n}^{\circ}$ 6.385, de 1976, em seu art. $2^{\circ}$, inciso I, caracteriza as ações como valores mobiliários.

A disciplina dos valores mobiliários brasileiros constitui na realidade um amálgama entre a definição tradicional, do direito francês, e as inovações trazidas pelas securities do direito anglo-americano. Tradicionalmente, os valores mobiliários designam os títulos negociáveis emitidos por pessoas jurídicas, transmissíveis por registro ou por tradição, conferindo a seus titulares direitos de participação ou de abono.

Porém, como esclarece YAZBEK (2009, p. 83),

o conceito de valor imobiliário, que a lei evita, adotando apenas uma relação de instrumentos, cada vez mais ampliada, destina-se muito mais a

196 Regulamento aprovado pela Diretoria Colegiada do BCB, que disciplina o funcionamento dos sistemas operados no âmbito do SPB, tendo em vista o disposto na Lei $\mathrm{n}^{\circ} 10.214$, de 2001, e no art. 11 da Resolução CMN no 2.882, de 2001. 
estabelecer o campo de incidência das regras estabelecidas pelo diploma. Originariamente, procurava-se colocar sob tal rubrica aqueles títulos que, emitidos em massa, representassem o recurso à poupança popular (...). Com o tempo, porém, a categoria passou a abranger instrumentos financeiros bastante distintos, que nada têm a ver com atividades de investimento e financiamento, como os derivativos. Assim, a Lei $\mathrm{n}^{\circ}$ 6385/1976 apenas permite o reconhecimento da negociabilidade dos títulos acionários, nada mais.

Tendo em vista a negociabilidade dos títulos acionários, inegável seu parentesco com os títulos de crédito. Nesse sentido, identificada como o documento ou certificado que corporifica e representa o direito de participação societária. Sem embargo, a situação jurídica do acionista e a do detentor do título de crédito são obviamente distintas. Com efeito, as ações constituem instrumentos de investimento ou de exercício de poder de controle, enquanto os títulos de crédito somente são instrumentos de pagamento. Ademais, o título acionário não traz alguns dos requisitos tradicionais dos títulos de crédito, assaz em razão da informatização e desmaterialização que atinge a própria conceituação de título de crédito, como anteriormente referido ${ }^{197}$.

Com efeito, como relata YAZBEK (2009, p. 84):

A maior parte das objeções à posição tradicional surgiu em face da existência de ações nominativas (em contraposição aos títulos ao portador) e da larga adoção, hoje, das chamadas ações escriturais, de que não se emitem certificados (sendo apenas mantidas como registros, nos termos do art. 34 da Lei $n^{\circ}$ 6.404/1976). Esse tipo de posição ganhou reforço no Brasil, ainda, quando da vedação, pela Lei n ${ }^{\circ}$ 8.021/1990, da emissão de ações ao portador, motivo pelo qual, hoje, tais títulos devem ser sempre nominativos, com o registro de seu titular nos livros da companhia ou com a forma escritural supra referida.

De fato, a emissão cartular de títulos assume contemporaneamente caráter excepcional no âmbito do mercado de valores mobiliários. As ações são em regra custodiadas em contas de depósito junto às instituições financeiras autorizadas pela Comissão de Valores Mobiliários (CVM) a ofertar serviços de ações escriturais. Desse

197 Vale repetir a lição de COELHO (2011, p. 410): “O registro da concessão e circulação do crédito em meio eletrônico tornou obsoletos os preceitos do direito cambiário intrinsecamente ligados à condição de documento dos títulos de crédito. Cartularidade, literalidade (em certa medida), distinção entre atos "em branco" e "em preto" representam aspectos da disciplina cambial desprovidos de sentido, no ambiente informatizado". 
modo, "a propriedade da ação escritural presume-se pelo registro na conta de depósito das ações", cuja transferência se efetua mediante lançamentos a débito e a crédito nas respectivas contas de ações do alienante e do adquirente (Lei $n^{\circ}$ 6.404, de 1976, art. 35, § $\left.1^{\circ}\right)$.

Mencione-se ainda a possibilidade de emissão, por instituições financeiras, de certificados de depósito de ações, que legalmente constituem valores mobiliários (Lei $\mathrm{n}^{\mathrm{0}}$ 6.835, de 1976, art. $2^{\circ}$, III). A partir do título acionário fundamental, portanto, surgem outras operações financeiras, não se restringindo apenas a operações de compra e venda a vista, mas ainda a operações de mútuo, negócios a termo, e instrumentos derivativos, tal como os certificados mencionados.

Desse modo, as inovações financeiras não erodem as categorias formais consolidadas somente no sentido da desmaterialização definitiva dos títulos acionários, mas sobretudo ao incorporarem novos conteúdos a esses títulos, muito mais amplos do que aqueles típicos ao regime original (YAZBEK, 2009).

Quanto aos títulos de dívida ("obrigações"), a modalidade típica são as debêntures, enquanto instrumentos de financiamento da atividade empresarial emitidos massivamente no sentido de sua circulação (negociação) no mercado de capitais. Conferindo a seus titulares direito de crédito contra a companhia emissora, são majoritariamente emitidos sob a forma escritural (Lei $\mathrm{n}^{\circ}$ 6.404/1976, art. 52), e pois tipificadas legalmente como valores mobiliários. Como mencionado anteriormente, são registradas no "Sistema Nacional de Debêntures", negociadas também no mercado secundário, como seja no âmbito da Cetip. Aliás, independentemente da configuração legal original, de mútuo, podem as debêntures ser emitidas em garantia de operações de financiamento, lastreando-as.

Entre as obrigações comerciais, importa ainda citar aquelas que compõem o grande mercado interbancário, sistemicamente importante no âmbito do SPB. Destacam-se o Certificado de Depósito Bancário (CDB) e o Certificado de Depósito Interbancário (CDI), ambos "formalmente" considerados cambiariformes (YAZBEK, 2009).

O CDB é tradicionalmente o instrumento bancário típico para a captação de recursos pelos bancos comerciais, de investimento e múltiplos (Decreto-lei no ${ }^{\circ}$, de 1966). Em sua essência constituem depósitos bancários a prazo, formalizados enquanto instrumentos cambiários, e ainda abonados por juros e correção monetária.

Registre-se que o CDB, anteriormente objeto de cartularidade (art. 30 da Lei $n^{\circ}$ 
4.728, de 1965), é hoje mantido em registros eletrônicos, inclusive na Cetip. Aliás, já circulava através de simples cessão de crédito, visto ter sido ao longo do tempo substituído por simples documento de legitimação - Recibo de Depósito Bancário (RDB) -, representando a relação jurídica de depósito, mas sem a incorporação do direito creditório (SALOMÃO NETO, 2007).

Ainda mais importante para a dinâmica do mercado financeiro é o CDI, pois que diretamente ligado ao mercado de reservas bancárias, onde se forma a taxa de juros - preço básico de toda a economia -, emitido pelos bancos sobretudo em razão das operações de empréstimo realizadas no mercado interbancário. Na lição de YAZBEK (2009, p. 96):

Tais operações, que geralmente têm prazo de um dia (o "CDI-over"), são realizadas diretamente entre os bancos interessados e registradas por meio eletrônico, tendo sido desenvolvidas, em meado da década de 1980, para promover uma mais eficiente distribuição de recursos entre as instituições. Estas, com efeito, podem durante o dia estar superavitárias ou deficitárias em suas reservas bancárias, em razão de operações diversas e das demandas e seus clientes - tal mercado deveria, desta forma, permitir a "zeragem" do sistema bancário, com a transferência de reservas dos agentes superavitários para os agentes deficitários.

No topo da estrutura econômico-financeira contemporânea se encontram obviamente os títulos da dívida pública, negociados no ambiente do Selic. Tradicionalmente emitidos para fazer às necessidades de financiamento governamental, passaram ao longo do tempo a fomentar o surgimento de sofisticados mercados secundários (mercado aberto - open market), a cargo dos bancos centrais. Essa estruturação financeira em torno desses títulos assenta basicamente no reduzido risco de crédito, inerente às dívidas soberanas, nas condições privilegiadas de negociação e ainda, como no caso do Brasil, nos valores ofertados a título de remuneração (juros). Nesses mercados, a compra e venda desses títulos tendo como contrapartes os bancos centrais e determinadas instituições financeiras bancárias, tem por finalidade a gerência de liquidez do sistema de pagamentos e ainda a indicação ao mercado financeiro da taxa de juros tida em mira pela autoridade monetária.

Tradicionalmente, fundamentam-se as operações de mercado aberto "na circunstância de que, quando o público compra títulos, paga seu valor mediante saque de depósitos bancários, gerando desmultiplicação de créditos e de moeda escritural" (VIDIGAL, 1977, p. 196). Traduzindo em termos mais simples, a venda de títulos implica 
restrição da circulação de dinheiro (liquidez) na economia, reduzindo assim a capacidade econômica do público em geral no que tange às situações de liquidez individuais.

Não obstante, é mister se destacar outras repercussões da existência do mercado de títulos públicos, a saber,

ele pode estimular tais atividades [do mercado financeiro], criando uma referência para a precificação de outros instrumentos (um benchmark) ou outorgando hedge aos agentes que neles operam (como ocorre, por exemplo, quando da emissão de títulos atrelados à variação cambial), mas também pode impedir o desenvolvimento daquelas, atraindo a liquidez do mercado para si (o chamado efeito crowding-out) (YAZBEK, 2009, p. $98)^{198}$.

A importância dos mercados de títulos públicos reside não só na segurança que oferece ao investidor, mas sobretudo por ser, de fato, um "mercado de dinheiro", ou seja, mercado monetário em sentido estrito, onde os bancos obtêm financiamento de curto prazo, particularmente através das operações de venda e compra a vista cumuladas com compromissos de revenda ou recompra (operações compromissadas - repurchase agreements), nas quais os títulos são dados em garantia do mútuo aprazado. Ressalte-se todavia que tais negócios não se destinam à alienação de títulos, mas antes ao estabelecimento de uma relação creditícia, subjacente ao negócio jurídico (YAZBEK, 2009) ${ }^{199}$.

Quanto aos derivativos, amplamente negociados no âmbito das distintas câmaras que compõem o SPB, são também definidos legalmente como "valores mobiliários", como sejam "os contratos futuros, de opções e outros derivativos, cujos ativos subjacentes sejam

198 Diga-se, aliás, que o último efeito mencionado é justamente aquele que se tem verificado no Brasil, não apenas em prejuízo de outros segmentos do mercado financeiro, principalmente do mercado de capitais, mas antes atingindo toda a estrutura produtiva da economia, no sentido de seu não financiamento.

199 Esses negócios são tradicionalmente chamados de reporte, vale dizer, a compra de títulos representativos de valor a vista acompanhada da retrocessão a termo (SALOMÃO NETO, 2007, p. 326). Não obstante, entende PONTES DE MIRANDA (1966, p. 291 e ss.) ser o reporte contrato real, não consensual, a termo final (resilição), distinto, portanto, da compra e venda. Há, assim, apenas uma alienação, não dois contratos de compra e venda, estipulando-se o retorno ao alienante em razão do termo final. O contrato é único, translativo de propriedade (real) e oneroso. É, ademais, contrato de especulação, não apenas contrato de crédito, de modo que as operações de reporte supõem a existência de mais títulos à venda do que à procura nos mercados, ou ainda que haja mais especuladores de baixa do que de alta. Em sentido contrário, entende MARTINS (2010, p. 138 e s.) haver no reporte duas compras e duas vendas simultâneas, às mesmas pessoas, sendo um contrato à vista e outro a termo, ou seja, para entrega dos títulos e pagamento do preço em época futura. Frise ainda que o comprador à vista não se obriga, pela venda a termo, à entrega dos mesmos títulos comprados. Assim, o contrato deve ter por objeto títulos da mesma espécie dos adquiridos à vista, substituíveis por outros que não os adquiridos. Observe-se ainda que o reporte era regrado pelos arts. 106 a 109 do Decreto $n^{\circ} 2.745$, de 13.3.1897. 
valores mobiliários", ou "outros contratos derivativos, independentemente dos ativos subjacentes" (Lei n ${ }^{\circ} 6.385 / 1976$, art. $2^{\circ}$ ).

Originariamente se prestavam os contratos de derivativos à proteção contra determinados riscos financeiros, particularmente os decorrentes de variações de preços e taxas, assumindo a característica de operações de hedge (proteção). A interdependência fatual entre as atividades empresariais desempenhadas pelas contrapartes contratantes da proteção e a álea inerente a essas atividades, no sentido de compensar reciprocamente os eventuais efeitos refletidos no contrato, sempre foi a marca dessas avenças. Assim, por exemplo, uma empresa de comércio exterior, que detenha créditos ou débitos em moeda estrangeira, pode naturalmente buscar proteção contra as oscilações do câmbio, comprando ou vendendo moeda para data futura, por meio de contratos a termo, ao preço que julgar adequado.

A despeito da natureza protetiva desses contratos, o avanço econômico dos mercados financeiros trouxe uma série de inovações, tornando cada vez mais estritamente financeiro o motivo presente nesses negócios. Nesse sentido, se tornaram cada vez mais contratos assemelhados ao jogo ou aposta, em que não se faculta nenhuma tradição do bem, mas apenas o lucro financeiro. De fato, na grande maioria dos contratos derivativos não se efetua a tradição dos ativos negociados para entrega futura, mas somente o pagamento das somas correspondentes à diferença entre o preço avençado e o preço de mercado no evento da liquidação, de modo que a própria eficácia protetiva, quando presente, assenta nessa movimentação financeira (YAZBEK, 2009).

Os contratos derivativos têm, portanto, a natureza de contratos diferenciais puros, anteriormente classificados entre os contratos de jogo, ou aposta, fonte apenas de obrigações naturais (CC/1916, art. 1.479). O Código Civil em vigor, alterando esse entendimento, excepcionou as dívidas oriundas desses contratos da incidência da regra sobre a não obrigatoriedade do pagamento das dívidas de jogo ou de aposta (art. 814), não se aplicando assim "aos contratos sobre títulos de bolsa, mercadorias ou valores, em que se estipulem a liquidação exclusivamente pela diferença entre o preço ajustado e a cotação que eles tiverem no vencimento do ajuste" (art. 816).

Observe-se, nesse sentido, que o negócio diferencial "em que só se admite a prestação por diferença não é contrato de compra-e-venda. O objeto supostamente vendido seria dinheiro, parte do preço ou excedente do preço. A álea estaria evidente" (PONTES DE MIRANDA, 1966, p. 270). 
Ressalte-se ainda que a natureza estritamente financeira dos derivativos dá azo a toda sorte de operações especulativas e de arbitramento entre diferentes mercados, tendo fomentado, aliás, o crescimento vertiginoso dos respectivos mercados. Desse modo, atualmente os elementos de proteção, especulação e arbitragem se entremeiam nas estratégias dos investidores financeiros, sobretudo em razão da criação de produtos mais complexos e da crescente competição entre intermediários financeiros, tendo a própria função protetiva adquirido novo sentido, antes designando estratégias operacionais mais elaboradas e soluções mais complexas, a exemplo da atuação dos chamados fundos de hedge, investidores institucionais que operam concomitante e agressivamente em diferentes mercados (YAZBEK, 2009).

Entre as espécies de derivativos, citem-se, por exemplo, as opções ${ }^{200}$ sobre valores mobiliários lançados em bolsa, também consideradas valores mobiliários pela norma do art. $1^{\circ}$ da Resolução CMN nº 1.907, de 26.2.1992. Como ensina SALOMÃO NETO (2007, p. 355):

As opções sobre ações negociadas em pregão podem ser padronizadas ou não padronizadas, conforme sejam ou não negociadas na forma de lotespadrão previamente determinados pela bolsa. Em ambos os casos, entretanto, vemos presente a necessidade de prévio registro da emissão ou das características das opções, diante do regime imposto pela Lei $n^{\circ}$ 6.385/76. No caso de opções não padronizadas - que, além de ações de emissão de companhia aberta, podem ter por objeto debêntures e notas promissórias registradas para distribuição pública -, há regramento específico sobre a distribuição pública. A distribuição de tais opções depende de prévio registro na Comissão de Valores Mobiliários, de acordo com o art. $4^{\circ}$ da Instrução $n^{\circ}$ 223, de 10 de novembro de 1994, da Comissão de Valores Mobiliários. No caso de opções padronizadas, cabe à bolsa de valores definir previamente as características da operação, estabelecendo lotes-padrão para negociação e determinando os valores mobiliários que poderão se constituir em objeto das operações com opção, a quantidade de ações do lote-padrão, o preço de exercício, a data e os meses (...).

200 O negócio de opção constitui basicamente um negócio jurídico pré-contratual, de modo que origina a uma das partes contratantes o direito de exigir de outrem a celebração de contrato de compra e venda definitivo no futuro. Difere, portanto, da venda a termo, com liquidação futura a preço desde logo determinado, pois que seu efeito obrigacional é apenas uma obrigação de fazer (contratar), enquanto a compra e venda a termo gera obrigação de dar. 
É mister que se retenha dessarte que os negócios jurídicos de bolsa são na realidade contratos em que mais se considera onde se concluem (ambiente bursátil) e mediante atos de alguém, sem ser figurante (corretagem), do que sua finalidade. Não haveria, em princípio, peculiaridade estrutural. Há na verdade "atinência a determinado mercado, em que se concluem, com frequência, contratos que não são especificamente de bolsa, como a venda a termo e o reporte" (PONTES DE MIRANDA, 1966, p. 223).

Nesse sentido, particularmente no que tange à eventual aleatoriedade dos contratos de bolsa, não se pode generalizar a álea enquanto característica comum a todas as operações dos mercados financeiro e de capitais, pois se assim o fosse, então aleatórios seriam todos os contratos mercantis. A aleatoriedade exige que haja probabilidades, quase equivalentes, de vantagem e de perda, tal qual se passa na aposta ou no seguro. A álea deve ser essencialmente jurídica, presente no suporte fático negocial, não apenas econômica, vez que essa última pode ocorrer em quase todos os negócios jurídicos. Na lição de PONTES DE MIRANDA (1966, p. 223):

Nos contratos de bolsa, sabe-se o que se compra e o que se vende. Se foi mau negócio, a álea não resulta da estrutura negocial, mas sim de fatos econômicos, que eram ignorados pelo figurante, ou pelos figurantes, ou foram fortuitos. De qualquer modo, fora do mundo jurídico, como elementos do contrato. A comutatividade ressalta. Oscilam os valores, não os títulos e as mercadorias.

No que tange à natureza jurídica dos títulos (valores mobiliários) negociados nos mercados financeiro e de capitais, independentemente da sua atual desmaterialização, apenas o fato de serem negociados enquanto valores já os fazem assentar sobretudo em quantidades. A despeito de conterem os títulos elementos de não fungibilidade, a própria operação financeira, de bolsa ou assemelhada, os trata como "gênero". Assim, a certidão ou recibo extraído dos registros onde se encontram escriturados os valores mobiliários têm apenas valor probante, não corporificando nenhum direito (PONTES DE MIRANDA, 1966, p. 249 e s.).

Nesse sentido, ao se referir ao caráter genérico e incorpóreo dos títulos escriturados nominativos, assevera BENJAMIN (2000, p. 25) que

registered securities are intangible assets, comprising bundles of claims. (The physical certificate issued in respect of a registered security merely evidences, and does not constitute, the security). Therefore, the elimination of paper certificates and transfer forms in relation to 
registered securities is merely a procedural matter, and does not fundamentally alter the legal nature of the security, which is intangible in both dematerialised and non-dematerialised form.

Não obstante, os modernos sistemas de pagamentos, entre eles o SPB, já estão institucionalmente amparados no que tange à escrituração informatizada, fomentando-se legalmente a própria desmaterialização dos títulos negociados, como anteriormente descrito.

Os registros de títulos e valores mobiliários são essencialmente formas gráficas de escrituração unificada.

Desse modo, em razão mesma de sua destinação econômico-social, são em regra fungíveis os valores mobiliários escriturais, desmaterializados, em sua ampla maioria negociados nos ambientes que compõem o SPB (CC, art. $85 \mathrm{c} / \mathrm{c}$ art. 82). Em última instância, são bens incorpóreos, representativos de direitos pessoais de caráter patrimonial (direitos creditórios) (CC, art. 83, III): são direitos de crédito de pessoa a pessoa, que se dirigem à prestação de valor pecuniário (PONTES DE MIRANDA, 2000, p. 49).

Podem ser entendidos ainda como consumíveis, no sentido de que sua emissão sempre visa à venda, ou alienação, servindo portanto à circulação no âmbito dos mercados financeiros em que são negociados (CC, art. 86 in fine).

Com efeito, a fungibilidade implica a possibilidade de substituição qualitativa e quantitativa, atendendo-se antes ao gênero (classe) do que à individualidade da coisa. Frise-se que a determinação da classe advém sobretudo do tráfico jurídico (socioeconômico), não da discricionariedade negocial (PONTES DE MIRANDA, 2000, p. $55)$.

A fungibilidade se liga, pois, aos bens móveis, sendo particularmente relevante à conceituação do mútuo, do depósito irregular e da assinação (Anweisung). Dessa forma, as moedas correntes, os cereais ou os papeis de valor (títulos de crédito em sentido largo) são fungíveis. Outrossim, a regra especial do art. 86, $2^{\text {a }}$ parte, do Código Civil, imprime ao dinheiro e aos títulos de valor a consuntibilidade por destino (a venda) (PONTES DE MIRANDA, 2000, p. 55 e s.).

Os valores mobiliários, particularmente quando em circulação nos mercados financeiro e de capitais, adquirem natureza jurídica análoga à do meio circulante (moeda). Na lição de PONTES DE MIRANDA (2000, p. 59 e s.):

Discute-se se o dinheiro é coisa consumível, ou se o não é. $\mathrm{O}$ direito 
romano tinha-o como consumível (L. 32, D., de minoribus viginti quinque annis, 4, 4; L. 13, D., de rebus creditis, 12, 1; § 2, I., de usu fructu, 2, 4). A sua assidua permutatio dá-lhe a natureza de coisa consumível: "in ipso usu assidua permutatione quodammodo extinguitur". Destina-se à alienação. Não se consome o metal, ou o papel; mas consome-se o valor, que é o dinheiro. Serve de meio de troca, de mercadoria e de meio de transporte. Os juristas romanos viram bem quanto o destino a ser alienado tornava consumível o dinheiro (...). No texto justinianeu, a pecunia numerata é chamada "próxima" das coisas consumíveis (...). Mas tal consumibilidade pode cessar, se a destinação à alienação cessa (e.g., coleção de moedas), ou se, tratando-se de dinheiro metálico, intervém a má-fé, que permite a reivindicação (...). O dinheiro como valor não é suscetível de comistão, ou confusão (...).

Sob o prisma dos negócios financeiros em sentido estrito, frise-se que os valores mobiliários representariam sobretudo valores (quantias), máxime nos contratos diferenciais puros (derivativos). São assim valores em curso, do mesmo modo que o dinheiro, quando em comparação com a moeda estrangeira ou alguma moeda nacional, podendo ser o valor comum do tráfico ou ainda o valor de bolsa (PONTES DE MIRANDA, 2000, p. 59).

Ainda no que tange à fungibilidade dos valores mobiliários negociados em ambiente de bolsa, recorde-se da operação de (venda com) reporte, negócio jurídico outrora regrado pelos arts. 106 a 109 do Decreto $n^{\circ}$ 2.745, de 1897. Por essa operação, similar às operações compromissadas atualmente realizadas nos mercados financeiros, se compra certa quantidade de títulos mediante pagamento à vista, vendendo-os simultaneamente à mesma contraparte, por determinado preço, certa quantidade de títulos, da mesma espécie, para entrega em data futura. Frise-se que o comprador à vista não se obriga, pela venda a termo, à entrega dos mesmos títulos comprados. Assim, o presente contrato deve ter por objeto títulos da mesma espécie dos adquiridos à vista, substituíveis por outros que não os adquiridos (MARTINS, 2010).

Observe-se que as dívidas de valor são aquelas que têm por objeto prestação de valor, determinável não apenas em dinheiro, mas também em outro objeto (bem). A diferença entre a promessa de coisa, inclusive dinheiro, e a de valor, afere-se por meio de interpretação da declaração negocial, precisando-se qual a prestação prometida, independentemente da presença de cláusula de correção (PONTES DE MIRANDA, 1959c, p. 294). 
De ordinário, os negócios jurídicos financeiros se resumem a contratos de compra e venda, à vista ou a termo, firme ou a prêmio, reporte e ainda os negócios diferenciais (derivativos). Esses negócios originam em regra obrigações de dar coisa incerta, cujo objeto é a entrega de uma quantidade de certo gênero, não especificada (CC, art. 243). Não se trata de indeterminação, mas antes de uma determinação genericamente feita, suscetível de determinação, ou seja, determinável. O termo "gênero" expresso na regra do art. 243 deve ser lido como "espécie", por analogia aos bens fungíveis (CC, art. 85). Trata-se assim de obrigação genérica (VENOSA, 2012, p. 73).

Com efeito, gênero designa um grupo de espécies, que oferecem caracteres comuns, enquanto espécie represente uma divisão do gênero, caracterizada por certo sinal distintivo e específico. Assim, o gênero encerra diversas espécies, e essas, um grupo individuado. Não obstante, em linguagem jurídica, desde o direito romano, gênero constitui um conjunto de seres semelhantes que, isoladamente, se denominam espécies. A coisa individuada, portanto, determinada, essa, sim, configura espécie jurídica (MONTEIRO, 2011, p. 100).

Não se faz necessária a indicação do objeto da prestação obrigacional desde o início, bastando que se indique os elementos necessários à sua determinação no vencimento da obrigação. Nessa hipótese, a prestação

é determinável ou determinada pelos caracteres comuns a outros bens, vale dizer, pelo gênero. Por isso, chama-se obrigação genérica aquela cujo objeto consiste na dação de coisa indicada pelo gênero. O grau de indeterminação é, porém, mais forte nas que não têm por objeto coisas fungíveis, mas, não obstante, é impossível fixar, desde o começo, a quanto montará o pagamento.

Em regra, as prestações determináveis compreendem os bens que podem ser substituídos por outro da mesma espécie, qualidade e quantidade, isto é, suscetíveis de serem pesados, medidos ou contados (GOMES, 1988, p. 43 e s.).

Nesse sentido também é a lição de ENNECCERUS (1947, p. 30 e s.):

Constituye un caso especial de obligación con prestación indeterminada, pero determinable, la obligación genérica, o sea aquella en la cual el objeto de la prestación está determinado por características genéricas. $\mathrm{Su}$ contrafigura es la obligación específica, que se refiere a una prestación determinada por notas particulares. Por regla general, el 
objeto de las obligaciones genéricas está constituído por cosas fungibles, pero esto no es indispensable, ya que también pueden ser objeto de una deuda de género las cosas no fungibles (un caballo de silla, un auto), e igualmente una cosa fungible (este ejemplar de un libro difundido en una gran edición) puede ser debida como especie. A estos efectos es decisiva la determinación de las partes, mientras que la fungibilidad depende de la opinión del tráfico.

Las partes (o el testador) pueden determinar el género con mayor o menor amplitud, mediante características discrecionales (vino, vino blanco, vino del Rhin, vino Josephshöfer, ...), y especialmente también estableciendo que las cosas objeto de la prestación hayan de extraerse de una determinada gran porción (la produción de una finca o de una fábrica determinadas). En tales casos se habla de obligación genérica delimitada (limitada).

No que tange à fungibilidade da obrigação em exame, praticamente se confundem [as obrigações fungíveis] com as de coisa incerta. Nestas, é impossível não falar em coisas fungíveis, como na entrega de sementes, posto que a obrigação centra-se mais no gênero e quantidade dos bens. Desde o momento em que me refiro aos objetos que se encontram no escritório, ou ao maquinário de uma indústria, não se caracteriza a incerteza. A obrigação será de dar ou entregar coisa certa. Mas, se trata, no negócio, de um computador de marca especificada, não se está referindo a um computador já existente, e sim de uma espécie, ou de uma coisa de determinado gênero. A obrigação, aqui, é relativa a coisa incerta, que não deixa de ser fungível, eis que perfeitamente admitida a substituição por outra. Se não vier o computador acertado para a data aprazada, nada impede que se aguarde outro, distinto daquele que estaria fabricado na primeira data. Nota-se, daí, o cunho intrínseco da substituição da coisa por outra.

Ora, desde que a coisa incerta compreende aquela que pode ser substituída por outra da mesma espécie (...), qualidade e quantidade, não resta dúvida a nenhuma distinção entre coisa incerta e coisa fungível, para os efeitos do objeto da obrigação em exame (RIZZARDO, 2006, p. 110).

Advirta-se, no entanto, que a "fungibilidade, por si só, não caracteriza a obrigação genérica, pois existem coisas fungíveis que são adquiridas $u t$ singuli, em razão de assim 
haverem sido escolhidas, como uma joia, no joalheiro" (COUTO E SILVA, 2012, p. 150).

Ao revés, há certas obrigações de dar coisa certa que, aparentemente, se dirigem à prestação de coisas indeterminadas. Mencione-se, como exemplo, a obrigação que tenha por objeto da prestação uma universitas rerum, tal como uma fábrica ou empresa determinada, ou ainda um lote não padronizado de títulos de dívida (p. ex., debêntures, Letras do Tesouro Nacional e ainda opções sobre esses valores mobiliários) para negociação em mercado de balcão. A despeito de ser essa universalidade constituída por bens móveis ou imóveis, direitos reais, ou somente direitos pessoais, ainda assim a obrigação permanecerá sendo de dar coisa determinada.

Ressalte-se que as obrigações genéricas se estabelecem em variados graus, exigindo consequentemente "a concretização do vínculo jurídico no iter do adimplemento. In thesi, o objeto das prestações desse tipo de deveres, no momento em que o ato jurídico se torna eficaz, só existe idealmente" (COUTO E SILVA, 2012, p. 150).

Dessarte, a prestação de obrigação genérica requer, em regra, a individualização a fim de que seja adimplida. A essa determinação do objeto da prestação de gênero se denomina "concentração do débito", ou simplesmente "escolha": concentrada a prestação, depois de feita a escolha, em regra pelo devedor, se o contrário não resultar do título da obrigação, a obrigação genérica se converte em específica (CC, art. 244; GOMES, 1988, p. 44).

Na lição de MONTEIRO (2011, p. 103),

A escolha efetua-se mediante ato jurídico unilateral denominado concentração, que é a individuação da coisa manifestada no ato do pagamento, ou do cumprimento da obrigação. Exterioriza-se por meio de atos apropriados, como a separação (compreendendo pesagem, medição e contagem, conforme o caso) e a expedição. Com esses atos (...), passa-se de um primeiro momento, menos determinado, para um segundo, mais determinado; depois dele, torna-se certa a res devida.

Não obstante, em razão dessa circunstância mesma, prévia ao cumprimento, é possível se distinguir entre as obrigações puramente genéricas e as obrigações genéricas restritas (delimitadas ou mistas). Essas últimas comportam, por sua vez, diferentes graus de restrição, a depender da interpretação que se dê ao negócio jurídico concreto. Assim, 
unidades existentes dentro de depósito de uma fábrica, indicadas, apenas, pelo gênero e quantidade. Não o é, porém, a que resulta da venda em sua totalidade de provisões depositadas em certo lugar, devendo-se verificar o preço dessas mesmas provisões pelo número, quantidade ou peso de cada uma das unidades existentes (emptio ad mensuram). A dívida é de coisa certa, porque a determinação diz respeito apenas ao preço. Conclui-se, pois, que, para caracterizar a dívida genérica restrita, se faz necessário que a disposição se refira a algumas unidades (quantidade), indicadas pelo gênero, existentes dentro de um círculo espacialmente determinado (v.g., depósito, fábrica, empresa).

A restrição pode resultar da atividade exercida por quem aliena. De modo geral, o fabricante vincula-se pela mercadoria que ele produz ou tem em depósito. Sendo o objeto das dívidas genéricas indicado apenas idealmente, vige o princípio de que o risco corre sempre por conta do devedor, que não se libera em virtude de caso fortuito ou de força maior [CC, art. 246]. Daí o adágio: genus perire non censetur.

Nas dívidas genéricas restritas, já não se pode dizer o mesmo. Se a mercadoria, que estava no depósito, queimou, libera-se o devedor, ainda antes da concretização, se não sobrou nenhuma do gênero que se prometeu prestar (COUTO E SILVA, 2012, p. 150 e s.).

A expressão "restrita" ou "delimitada" não se apresenta de todo correta, na medida em que a restrição deve referir unicamente o "gênero", não a obrigação (genérica) em si mesma (ENNECCERUS, 1947, p. 34, n. 11). Como exemplifica ENNECCERUS (1947, p. 34, n. 12):

El que me debe una botella de vino de esta cuba, no me debe un algo concreto (¿qué botella sería ésta?), sino una cantidad de líquido aun por determinar, que ha de tomarse de esa cuba. El vino que se encuentra en la cuba constituye el género determinado por las partes y del cual se ha extraer el vino que debe entregarse.

Sob o prisma legislativo, advirta-se que o Código Civil não contempla em seus quadros as obrigações genéricas delimitadas (mistas). Nesse caso, serão genéricas ou alternativas, conforme as circunstâncias de caso particular (MONTEIRO, 2011, p. 101 e s.).

Um exemplo de obrigação genérica delimitada, ou alternativa, gerada por uma operação do mercado financeiro a ser cursada em ambiente de bolsa, tal como na Câmara 
de derivativos da BM\&FBovespa, também vinculada ao sistema de pagamentos do SPB, seria aquela resultante da celebração de um contrato de opção, ou melhor da aquisição de tal contrato de derivativo (posição contratual), registrado naquele ambiente, versando sobre ações de determinada companhia, cuja emissão foi registrada em bolsa, garantida a subscrição por um renomado banco de investimento, ainda pendentes, portanto, de subscrição. A opção ofertada por esse mesmo banco de investimento, contra o pagamento do prêmio (preço), teria por objeto convencional o direito à subscrição, ou aquisição, de determinada quantidade daquelas ações (gênero), ou de certa classe das mesmas, segundo os lotes padronizados, em data futura. Alternativamente, a obrigação de liquidação por diferença em razão da revenda do direito convencionado. Observe-se ainda a necessidade de especificação (padronização) desses lotes acionários que compõem as opções registradas em bolsa, seus caracteres específicos (classes) e quantidades de títulos depositados, conforme a regulamentação vigente. Na data aprazada, optará o investidor (credor) pela subscrição, ou aquisição, das ações, ou ainda pela revenda do direito de opção (liquidação por diferença), sob pena de perda do prêmio pago. Note-se a alternatividade de obrigações, uma genérica (mista) e outra específica, aquela, de dar bem fungível, essa, pecuniária e a termo (dívida de valor, de mercado ou de bolsa - CC, art. 486), cuja concentração cabe ao credor. Ressalte-se ainda que em caso de recair a escolha na entrega efetiva dos títulos, as ações que serão escrituralmente transferidas ao credor, na espécie (classe) e quantidade aprazadas, restarão, portanto, determinadas a partir dos referidos lotes (padronizados).

A partir do exposto, é mister que se note não decorrer da concretização (“concentração do débito") nenhuma modificação na prestação ou no vínculo obrigacional. Essa determinação do objeto da prestação não constitui negócio jurídico, mas antes espécie de ato real, requerendo para sua eficácia apenas critérios objetivos, de modo a tornar clara a vinculação do objeto da prestação à finalidade contratual (COUTO E SILVA, 2012, p. 154).

Não obstante, o Código Civil em vigor, ainda afeto ao direito comum, optou pela concentração por meio da escolha do devedor (art. 244), determinando a consequente notificação do credor (art. 245) como ato prévio à incidência das regras sobre prestações determinadas (obrigações de dar coisa certa). Andou melhor, nesse aspecto, o Código Beviláqua, pois que somente aludia à escolha "feita", incidindo, sem solução de continuidade, as regras das obrigações de dar coisa certa (CC/1916, art. 876). 
Ainda assim, o melhor entendimento assenta na objetivação do ato de escolha, vale dizer, na mera especificação fática, fazendo-a depender não somente do devedor, mas ainda das circunstâncias do negócio jurídico. Nesse sentido, aliás, a própria regra do art. 244, do Código Civil, afasta a necessidade do ato do devedor quando o contrário resultar do título da obrigação (COUTO E SILVA, 2012, p. 155; GOMES, 1988, p. 44).

Uma vez determinado o objeto das prestações genéricas, não se deve olvidar da necessidade de sua transferência ao adquirente. Com efeito, a obrigação específica e característica do contrato de compra e venda é a da transmissão do domínio, que, por se tratar de bem móvel, vez que os contratos de bolsa (senso largo), quando translatícios de propriedade (negócios jurídicos de alienação), sempre versam sobre valores mobiliários, se efetiva mediante a "tradição" ou entrega da coisa, segundo dispõe o art. 1.226 do Código Civil.

Em regra, os negócios financeiros são consensuais, até porque a própria eficácia translativa da prestação é, não raro, alternativa à liquidação por diferença, resultando sobretudo em obrigações conjuntivas, disjuntivas ou complexas.

Com efeito, a tradição configura modo de transmissão da propriedade de bens móveis, transfigurando o direito creditório em direito real. $\mathrm{O}$ vendedor se obriga a transferir o domínio de certa coisa (CC, art. 481). Trata-se, portanto, de obrigação pessoal. O cumprimento dessa obrigação implica a realização de um segundo ato, que é a tradição. De forma eclética, o Direito Civil brasileiro imputa ao contrato apenas o efeito obrigacional, resultado do consenso, que se integrará pela tradição ou registro (MARTINS, 2010; ROSENVALD, 2009).

Sem embargo,

mantém-se acesa grande polêmica instaurada pelo genial Darcy Bessone ao discordar da compra e venda como mera obrigação de dar. Para o insigne doutrinador, o registro apenas conclui o ato complexo de formação progressiva pela qual toda manifestação de transmissão do direito real já se exauriu no negócio jurídico. Vale dizer que o registro apenas concederia eficácia real à compra e venda, pois é desnecessária uma segunda manifestação de vontade do alienante, ao contrário do que se sucede no direito alemão [acordo de transmissão como negócio abstrato, de eficácia real]. Com efeito, a obrigação demanda uma futura atuação do devedor, todavia, com a emissão da escritura de compra e venda, o alienante não precisará praticar uma nova conduta, eis que toda 
a carga recairá sobre o adquirente, no sentido de promover unilateralmente o registro do título, concluindo o ato complexo com a chancela estatal.

Nada obstante, a doutrina pátria mantém a tese obrigacional da compra e venda como negócio jurídico bilateral, no qual a obrigação do alienante consiste na entrega da coisa, enquanto a prestação do adquirente se traduz no pagamento de um preço. Assim como a troca e a doação, trata-se de contrato translativo, funcionando como título ou causa, enquanto a tradição e o registro são os modos de transmissão da propriedade (ROSENVALD, 2009, p. 516).

Desse modo, para a transferência do domínio, se faz necessária a entrega do bem móvel, operando sua tradição (CC, art. 1.226 c/c art. 1.267). Segundo LOUREIRO (2009, p. 1159),

Diz o artigo em exame [CC, art. 1.226] que as aquisições a título derivado e inter vivos somente transmitem-se com a tradição. A tradição, em tais casos, tem caráter constitutivo do direito real. Antes da tradição, existe um simples título, que confere apenas direito pessoal, ou de crédito, a seu titular. A tradição, mediante entrega da coisa alienada ao adquirente, é que converte o direito de crédito em direito real. Lembre-se de que nem toda entrega de coisa móvel a outrem caracteriza tradição, como, por exemplo, ocorre no comodato, ou na locação, em que há mera transmissão da posse direta. Exige-se para a tradição um título que exteriorize negócio translativo da propriedade ou outros direitos reais. A tradição é a entrega da coisa ao adquirente, em obediência à obrigação assumida no título.

Nosso sistema de aquisição da propriedade e de outros direitos reais segue a tradição do Direito romano, exigindo título mais modo, consistente em uma providência suplementar que, somada ao título, provoca a aquisição do direito real (...).

Extraem-se daí as duas marcas da tradição em nosso sistema jurídico: é constitutiva da propriedade e de outros direitos reais sobre coisas móveis e é causal, por se encontrar ligada ao título que lhe deu origem. Desfeito o título, desfaz-se a tradição que dele proveio, salvo exceções previstas em lei (...).

Sob o prisma dos negócios jurídicos financeiros, espécies mercantis que são, cabe, no entanto, a seguinte advertência: 
A tradição não é o único meio, na compra e venda mercantil, pelo qual o vendedor cumpre a obrigação assumida de transferir o domínio da coisa vendida. Apesar do disposto no art. 1.226 do Código Civil, que dá a tradição como o modo comum de se fazer a transferência do domínio das coisas móveis (...), há, em Direito Comercial, algumas exceções que merecem ser lembradas, pois nelas, a transferência do domínio não se faz pela entrega da coisa.

Assim, por exemplo, nos títulos cambiais nominativos à ordem, considerados coisas móveis para os efeitos comerciais, a transferência de propriedade se faz pelo endosso (...). Nas ações nominativas das sociedades anônimas a transferência de propriedade se faz mediante termo lavrado em livros especiais (...). A transferência de propriedade do navio também se dará mediante registro em cartório especial (...) (MARTINS, 2010, p. 146).

Nesse sentido, mencione-se novamente que a propriedade da ação escritural, atualmente a regra no mercado de capitais, se presume pelo registro na conta de depósito das ações, aberta em nome do acionista nos livros (registros eletrônicos) da instituição financeira depositária, sem a emissão cartular. O traslado (da propriedade) do valor mobiliário se opera apenas por meio de lançamento contábil, a crédito e a débito, nos respectivos registros, sempre à vista de ordem escrita do alienante, em documento hábil apresentado ao depositário. Esse último, ao menos uma vez por ano, deve fornecer ao acionista extrato da conta de depósito das ações escriturais (Lei $\mathrm{n}^{\circ}$ 6.404, de 1976, art. 35, $\S \S 1^{\mathrm{o}}$ e $\left.2^{\circ}\right)$.

Com efeito, a tradição pode ser real, simbólica ou ficta (consensual). Na tradição real, a entrega da coisa se perfaz materialmente; na simbólica, a despeito de não haver entrega física do bem, o comportamento concludente das partes, valorado pelos usos e costumes, efetiva a tradição (p. ex., a entrega de chaves de um veículo automotor). Já a tradição meramente consensual resulta somente da avença, sem conduta ou sinais exteriores que indiquem a transferência dominial (LOUREIRO, 2009, p. 1234).

No que tange particularmente à tradição simbólica ou virtual, a entrega do bem se realiza por meio de um símbolo, ou sinal gráfico, que represente esse mesmo bem. Nesse diapasão, a lição de MARTINS (2010, p. 147):

O Código Comercial de 1850, no art. 200, citava vários casos de tradição simbólica, mas de fato nem todos esses casos são, hoje, considerados 
como tais. A entrega, mencionada no $\mathrm{n}^{\circ} 1$, das chaves do armazém em que se encontra a mercadoria, por exemplo, é tida atualmente como tradição real, pois nesse caso o comprador, ao receber as chaves, como que se transforma no proprietário do armazém. Como regra geral, entretanto, faz-se a diferença entre a tradição real e a simbólica, considerando-se a primeira como aquela em que a coisa é efetivamente, materialmente entregue, e a simbólica como sendo a em que a mercadoria não é efetivamente entregue ao comprador, e sim representada por um documento, um ato (averbação nos livros ou despachos das estações públicas, e favor do comprador, com concordância de ambas as partes Código Comercial, art. 200, nº 5; Código Civil, art. 529), ou um fato (pôr o comprador suas marcas nas mercadorias compradas, com o consentimento do vendedor) que atestam haver sido transferido o domínio da coisa do vendedor para o comprador.

O citado art. 529 do Código Civil trata da venda sobre documentos, ou contra documentos, constituindo uma espécie de tradição simbólica. Substitui-se assim a entrega do objeto pela tradição de documentos que o representem (ROSENVALD, 2009, p. 553).

Com efeito, a regra do art. 529 estabelece tradição documental da coisa, mediante a entrega do título representativo do bem vendido conforme o contrato ou, na falta de estipulação expressa, segundo os usos do tráfico.

Essa possibilidade de tradição virtual do objeto da prestação seria, em princípio, aplicável aos valores mobiliários escriturados por meio eletrônico (desmaterializados), cuja tradição se processa de modo gráfico, ou seja, por meio de lançamentos, a débito e a crédito, em conta de depósito (custódia), a exemplo do que ocorre com as ações escriturais, conforme anteriormente mostrado.

Nada obstante a solução para a questão da tradição a partir da aplicação da regra do art. 529 do Código Civil, resta ainda solucionar o difícil problema em torno do próprio ato (fato jurídico) do adimplemento (pagamento), na medida em que a instituição custodiante dos valores mobiliários (escriturais) é de fato a pessoa que o efetua, tendo em vista configurar regra a presença das instituições financeiras ou das caixas de custódia e liquidação como intermediárias na liquidação dos negócios financeiros.

Com efeito, a Lei $\mathrm{n}^{\mathrm{o}}$ 6.385, de 1976, dispondo sobre o mercado de valores mobiliários, estabelece em seu art. 24, § único, caber exclusivamente às instituições financeiras e às entidades de compensação e liquidação a atividade de custódia de valores 
mobiliários, considerando tal atividade como depósito para guarda, recebimento de dividendos, resgate ou reembolso, e ainda o exercício de direitos de subscrição, entretanto, sem conferir ao depositário qualquer poder de alienação sobre os valores mobiliários sob custódia, salvo autorização expressa do depositante em cada caso.

Essa forma de depósito em custódia tradicionalmente se encontra entre as principais operações comumente realizadas pelos bancos, mas não se restringindo necessariamente a essas instituições financeiras. Consistem basicamente no fato de se confiar aos bancos, para depósito, títulos ou valores móveis, ficando os bancos responsáveis pela boa guarda dos mesmos, em regra se convencionando ainda a administração dos valores mobiliários custodiados, encarregando-se o banco de praticar determinados atos, tais como a cobrança de dividendos de ações ou o recebimento de juros (MARTINS, 2010, p. 405).

O depósito de títulos em administração é, com efeito, contrato único, no qual o custodiante assume duplo dever, a saber, de custódia e de administração. Trata-se de depósito aberto, no sentido de normalmente não restar excluída a disponibilidade por parte do depositante, a não ser que haja empenhado o objeto depositado, além de ser oneroso (CC, art. 628) e real tal espécie de contrato (de prestação duradoura). Desse modo, por ter como objeto títulos com interesses ou dividendos e outros direitos que requerem exercício durante a custódia, tornou-se esse contrato de mais amplo cuidado, dilatando-se o conceito de custódia.

Em regra, não se há cogitar de mandato, mas de representação, incluída na custódia, na medida em que se trata de espécie de depósito que se tornou negócio jurídico bancário: não se resume à prestação contínua de custódia, mas também de atos relativos a efeitos (PONTES DE MIRANDA, 1966).

Considerando que os valores mobiliários negociados nos mercados financeiro e de capitais são normalmente custodiados de modo universal, particularmente pelas caixas de custódia e liquidação, surge nesse caso espécie de depósito em administração a que se poderia denominar "depósito global de títulos em administração". Nesse sentido, vale lembrar a lição de PONTES DE MIRANDA (1966, p. 88):

O banco [entidade custodiante] pode misturá-los com outros do mesmo conteúdo e valor, sem que tenha sobre eles direito de propriedade. Não se assimila ao depósito bancário de dinheiro, nem ao depósito de outro bem fungível, porque fica entre eles e o depósito de títulos em administração, 
a que chamaríamos depósito ordinário de títulos em administração. A irregularidade é parcial.

Com efeito, os valores móveis custodiados, em regra, sob a forma escritural, são naturalmente fungíveis (títulos-gênero), como anteriormente mostrado, e ainda divisíveis (CC, art. 87). Note-se, aliás, que a prestação de dar coisa fungível é normalmente divisível (MONTEIRO, 2011, p. 166). Não obstante, nada impede que se convencione, ou resulte da lei, sua indivisibilidade (CC, art. 88). Nessa hipótese, é possível que da própria natureza do negócio jurídico resulte o condomínio em frações ideais (pro partibus indivisis), dentro de certo tempo, que aproveite à qualidade da coisa (L. 14, § 2, D., communi dividundo, 10, 3 apud PONTES DE MIRANDA, 2000, p. 566; CC, art. 1.320, § $1^{\circ}$ ).

A figura que melhor se adapta a essa espécie de depósito é, portanto, a de "comunhão em partes ideais" dos títulos depositados pelos seus titulares, cabendo-lhes individualmente a respectiva cota-parte (CC, art. 639). Assemelha-se ao depósito de grãos, criando-se espécie de comunhão pro indiviso. Dessarte, pode o depositário administrar os valores móveis como se fossem fungíveis, mas sem poder dispor das cotas alheias, daí a necessidade de outorga especial de poder para a alienação (PONTES DE MIRANDA, 1966).

Afasta-se, portanto, a aplicação da regra translativa de domínio, concernente ao mútuo (CC, art. 587), à presente hipótese de depósito. Com efeito, cabe ainda mencionar a possibilidade de incidência da regra contida no art. 17 da Lei $n^{\circ} 4.595$, de 31.12.1964, que se refere à "custódia de valor de propriedade de terceiros" enquanto atividade privativa de instituições financeiras (senso largo) ${ }^{201}$.

Desse modo, a depender da atividade exercida pela instituição financeira, e no caso em exame não se trata necessariamente de banco nem de atividade bancária específica, no sentido de captação de depósitos pecuniários e realização de operações ativas de crédito (criação de moeda de crédito), a restrição dominial contida no referido dispositivo legal se prestaria a afastar a regra concernente à transferência de propriedade do objeto de mútuo, tendo em vista que, ali, se trata necessariamente de bens móveis “infungíveis", passíveis, portanto, de individualização e separação, por exemplo, através de numeração em série ou de outras características. Apenas em relação a essa espécie de bens é possível a menção à propriedade de terceiro que não seja o custodiante (CC, art. 1.228),

201 A definição de instituição financeira abarcada pelo referido dispositivo legal é bastante ampla, pois envolve o exercício das atividades de coleta, intermediação ou aplicação de recursos próprios ou de terceiros. 
pois aos bens fungíveis caberia a sua apropriação pelo custodiante (CC, art. 587).

Nesse sentido, também a lição de SALOMÃO NETO (2007, p. 29):

Essa interpretação dada ao art. 17 da Lei $n^{\circ}$ 4.595/1964 é consentânea com a linguagem adotada pela regulamentação legal e administrativa da custódia. De fato o artigo 24, parágrafo único, da Lei $\mathrm{n}^{\circ} 6.385$, de 7 de dezembro de 1976, define a custódia de valores mobiliários (...).

Por outro lado, não são quaisquer bens que podem levar ao enquadramento como instituição financeira, uma vez custodiados. Por valores devem-se entender títulos de crédito em sentido amplo, ou seja, quaisquer documentos necessários e suficientes para o exercício dos direitos patrimoniais neles contidos. Deste tipo são os títulos negociáveis no mercado de capitais (...), bem como os títulos e papeis do mercado financeiro (...).

Ressalte-se ainda a possibilidade de atuar o custodiante na condição de contraparte central (clearing), estabelecendo-se uma espécie de "contrato de conta corrente", em que os títulos escriturados se fundem num todo indissolúvel, perdendo sua individualidade por efeito mesmo da novação que se opera (MONTEIRO, 2011, p. 165), de modo a serem liquidadas por diferença as obrigações (fungíveis) e, ao final, redistribuídas individualmente as respectivas cotas de títulos, mediante lançamentos contábeis.

De fato, além da custódia há uma série de atos intermitentes de recebimento, subscrições e satisfações (adimplementos), operações negociais que devem constar do mesmo contrato de custódia. Assim, o serviço prestado, ou a outorga de poderes, não se configura acessório da custódia, mas antes elemento integrativo. Essa forma de depósito é sobretudo eficacial. No exercício regular desses poderes, age o custodiante em nome e por conta do cliente (PONTES DE MIRANDA, 1966, pp. 87-9).

Desse modo, cabe essencialmente ao titular dos valores mobiliários, registrados em conta de depósito, determinar à instituição depositária a realização do pagamento, que se opera mediante a tradição virtual, como já assentado.

O pagamento a ser realizado pelo depositário, em cumprimento da obrigação de transferir a propriedade do título custodiado, traz à baila, portanto, a questão relativa à pessoa que deve efetuar o pagamento (solvens).

Em regra, o pagamento se pode realizar por qualquer interessado, mas, precipuamente, pelo próprio devedor, que, pagando, cumpre a prestação a que se obrigara, constituindo esse último o "pagamento verdadeiro e próprio" (MONTEIRO, 2011, p. 288), 
também chamado de "pagamento real” (MARTINS, 2010, p. 24).

Não obstante, o direito do terceiro interessado em solver a dívida encontra previsão legal no art. 304 do Código Civil, segundo o qual "qualquer interessado na extinção da dívida pode pagá-la, usando, se o credor se opuser, dos meios conducentes à exoneração do devedor".

Trata-se, na hipótese anterior, de interesse jurídico, direta ou indiretamente ligado à relação obrigacional estabelecida entre credor e devedor originais, no sentido de legitimar também aqueles que venham eventualmente a suportar os efeitos do inadimplemento (BDINE JR., p. 272). Nesse sentido, estariam juridicamente legitimados, por exemplo, o fiador, o coobrigado, o herdeiro, outro credor do devedor e o adquirente do imóvel hipotecado. Ao fazê-lo, sub-rogam-se de pleno direito em todos os direitos creditórios (CC, art. 346).

Igualmente, cabe ao terceiro não interessado o direito de solução, se o fizer em nome e por conta do devedor, salvo oposição deste (CC, art. 304, § único).

Com efeito, na hipótese de pagamento por terceiro "não interessado", há presunção legal de que a solução do vínculo obrigacional venha sempre em prol do credor. Esse último teria assim não apenas o direito, mas também o dever de receber a prestação, independentemente de quem a execute. Desse modo, completar-se-ia o ciclo obrigacional, tendo em vista que toda obrigação se destina, em regra, à solução (COUTO E SILVA, 2012; MONTEIRO, 2011, p. 289).

Ressalte-se ainda que ao terceiro "não interessado" faculta a lei civil o pagamento em nome próprio, conferindo-lhe pretensão ao reembolso, mas sem que se opere qualquer sub-rogação nos direitos do credor (CC, art. 305). Cabe-lhe somente uma simples ação de cobrança por aquilo que foi pago.

Porém, não se deve olvidar da ideia do núncio e da representação, pois, excetuados os casos de obrigação personalíssima, o pagamento pode ser feito não só pelo devedor, mas também por seus auxiliares ou ajudantes, prepostos a esse fim, ou por terceiros que o representem, de modo voluntário ou legal. Seja através de representante, ou mandatário, seja por intermédio de auxiliares, quem cumpre a obrigação é o próprio devedor - aqueles outros executam apenas o ato material de pagar (GOMES, 1988, p. 115; VENOSA, 2012, p. 174).

Em regra, portanto, são transferíveis os direitos e as dívidas, incluso o direito de adimplir. De modo que "estar o interesse patrimonial adstrito ao titular do direito, da 
pretensão, da ação ou da exceção, ou ao sujeito passivo da dívida, da obrigação, da ação, ou da exceção, é excepcional" (PONTES DE MIRANDA, 1959a, p. 12).

Assim, sendo transmissível a dívida, a sucessão à título particular depende da incidência dos princípios que regem a assunção de dívida alheia, ou a transferência da posição subjetiva no negócio jurídico (PONTES DE MIRANDA, 1959a).

Observe-se todavia que as hipóteses são muitas vezes fronteiriças, não raro levando o exegeta a equívocos. Nesse sentido cita VENOSA (2012, p. 175) o exemplo

de um pai que paga a dívida de um filho. Seu interesse não é jurídico. Faz o pagamento com interesse altruístico, moral ou familiar. Contudo, fá-lo em nome e por conta do filho devedor. Não há representação, nem mesmo autorização ou quiçá ciência do devedor. O pagamento, porém, deve ser aceito. E o solvens, aqui, tem a mesma legitimidade de consignar, se houver resistência.

Nesse sentido também é a lição de ENNECCERUS (1947, p. 118), segundo a qual el deudor puede ejecutar la prestación por medio de otra persona, salvo pacto en contrario. E incluso cualquier tercero, sin necesidad de ser representante del deudor, puede cumplir la obligación de éste y, en consecuencia, si el acreedor rechaza la prestación que le es ofrecida por un tercero, incurre en mora accipiendi frente al deudor. Únicamente si el deudor se opone a la prestación, el acreedor podrá negarse a aceptarla, pues, como es natural, no puede incurrir en mora accipiendi por seguir las indicaciones del deudor. Pero si recibe la prestación a pesar de la prohibición del deudor, el derecho de crédito se extingue de todos modos en virtud del pago (\$267) [BGB].

Ressalte-se ainda que o terceiro que paga a dívida "em nome e por conta do devedor" (CC, art. 304, § único), ou recebeu poderes do devedor, ou não, sendo então gestor de negócios, ou doador. É mister, portanto, que se caracterize a relação jurídica entre devedor e terceiro, também denominada “interna”. Nesse sentido, poderá o terceiro reclamar aquilo que lhe cabe segundo o negócio jurídico celebrado com o devedor, desde que tenha atuado de acordo com a vontade manifestada, ou presumível desse último, tal como no mandato, ou se apenas houve gestão de negócios, conforme o art. 869 do Código Civil. Outrossim, o terceiro não interessado, que solve, não se sub-roga nos direitos, pretensões, ações ou exceções que haveria o credor satisfeito contra o devedor original, cabendo-lhe todavia as ações resultantes da relação jurídica interna (PONTES DE 
MIRANDA, 1959a, pp. 95, 98).

A substituição do devedor por outrem no cumprimento da prestação obrigacional pode muitas vezes ocorrer mesmo na ausência de convenção expressa, tal como no mandato, no depósito, ou na prestação de serviços. Ainda que não se trate de bem fungível o objeto da prestação, nada impediria que o devedor se fizesse coadjuvar por auxiliares no seu cumprimento. Sobretudo na hipótese de prestação fungível, pode o devedor se fazer mesmo substituir por outrem no cumprimento. Em certa medida, equiparam-se a esses casos aqueles em que o devedor "delega" a terceiro o ato (operação) de pagamento, no sentido de que o terceiro atue à sua ordem, tal como no pagamento efetuado por meio de cheque ou outra ordem de pagamento (crédito) dada ao banco no qual o devedor tem em depósito fundos suficientes para a cobertura da operação (VARELA, 1999, p. 26 e s., n. 1).

Cite-se ainda como hipótese de prestação fungível, objeto de ordem de adimplemento, aquela consistente na transferência do valor mobiliário por lançamento a crédito do adquirente (credor), conforme ordenado pelo alienante (devedor) ao depositário do título, a exemplo da regra do referido art. 35, $\S 1^{\circ}$ a $3^{\circ}$, da Lei $n^{\circ} 6.404$, de 1976, podendo ainda resultar de contrato de prestação de serviço $\left(\S 3^{\circ}\right)$.

Frise-se que a figura jurídica da "delegação" encontra previsão legal no diploma civil italiano, ao lado da expromissão e da acollatio de dívida alheia (contrato entre o antigo e o novo devedor).

A delegação, prevista no art. 1.268 do Código Civil italiano, "consiste na convenção pela qual uma pessoa (delegante) incumbe uma outra (delegado) de realizar certa prestação a terceiro (delegatário), que é autorizada a recebê-la em nome próprio" (VARELA, 1999, p. 370). Verifica-se comumente na hipótese do depositante bancário que ordena ao banco a entrega de determinada quantia de sua conta a outrem, a quem se pretende fazer um empréstimo, uma doação ou um pagamento.

No caso de ser o delegante devedor do delegatário, e pois visar o negócio à substituição do devedor original, ou somente ao acréscimo do delegante ao polo passivo da obrigação, configura-se a chamada delegação passiva, a qual pode resultar em verdadeira sucessão singular na obrigação (VARELA, 1999).

Mencione-se ainda a figura da expromissão, em que não há delegação do devedor, pois que o terceiro (expromitente) assume diante do próprio credor original a obrigação de adimplemento devida por outrem.

Observe-se ainda a transmissão singular de dívida consequente à avença 
contratual entre o primitivo e o novo devedor, obrigando-se esse último ao cumprimento, e ainda o assumindo perante o credor original (acollo).

As categorias acima mencionadas resultam, em última instância, na transmissão singular da dívida obrigacional. A despeito da diversidade estrutural das diversas operações negociais que implicam a sucessão no débito, o resultado comum a todas elas é a “assunção de dívida".

Os diversos modos de sucessão no débito estão regulados entre nós, da mesma forma que na legislação civil portuguesa, numa única categoria jurídica, a saber, a assunção de dívida (CC, art. 299 e ss.).

De fato, durante muito tempo prevaleceu a concepção personalista da obrigação, com fulcro na doutrina romanista, e pois avessa a qualquer modificação subjetiva singular da relação de crédito afora os casos de sucessão universal, sobretudo em razão da importância central conferida à qualidade pessoal e patrimonial do devedor. A ideia tradicional de substituição do devedor assentava essencialmente na figura da novação subjetiva, vale dizer, na extinção da obrigação anterior, desonerando o devedor original, com a consequente oneração do novo devedor por meio da constituição de um novo vínculo obrigacional, por delegação do antigo devedor (delegatio), ou sem essa (expromissio).

A reação a essa concepção se deu a partir da doutrina pandectista alemã, a ponto de o Código alemão ter já consagrado abertamente, nos $\S \S 414 \mathrm{e}$ seguintes, a possibilidade de um terceiro tomar para si a posição jurídica do devedor dentro da relação obrigacional (Übernahme).

E foi na esteira deste diploma e do Código italiano de 1942 - mais inspirado no primeiro do que no segundo - que o novo Código civil português abriu, no capítulo que trata da transmissão das obrigações, uma secção subordinada à epígrafe "Transmissão singular de dívidas", em cujos preceitos se prevê e regula, com bastante desenvolvimento, a figura da assunção de dívida.

Como o próprio nome indica, a assunção de dívida é a operação pela qual um terceiro (assuntor) se obriga perante o credor a efectuar a prestação devida por outrem (VARELA, 1999, p. 360 e s.).

Desse modo, o devedor anterior se libera, sub-rogando-se um novo devedor, mas a obrigação segue sendo a mesma (ENNECCERUS, 1947, p. 404).

Com efeito, na assunção de dívida alheia assume o terceiro (assumente) a posição 
jurídica do devedor, não obstante permaneça a mesma a relação obrigacional, tal como é a mesma a relação jurídica se o credor cede o crédito. Pela assunção de dívida se permite que "alguém se faça devedor em vez de outrem, que o era e saiu da relação jurídica; mas essa continua a mesma” (PONTES DE MIRANDA, 1959b, p. 86).

Note-se a diferença básica com a novação subjetiva, vez que nessa não há "assunção" de obrigação alheia, pois o devedor assume dívida e obrigação próprias, em razão da nova relação jurídica que se funda após a outra, que se extingue. Portanto, o efeito do negócio jurídico novativo é o de extinguir a dívida, não a inserção de novo devedor na obrigação.

Na assunção de dívida, portanto, a "relação jurídica obrigacional passa a ter novo devedor, liberando-se, ou não, o antigo. Um se exime e o outro se obriga, ou um entra sem que o outro saia" (GOMES, 1988, p. 259).

Opera-se a assunção por dois modos, a saber, mediante contrato entre terceiro e o credor (expromissão), ou entre terceiro e o devedor (delegação). Não há confundir, como anteriormente delineado, com as formas de novação expressas pelos mesmos nomes.

Considerando a hipótese de cumprimento mediante a transferência de propriedade dos valores mobiliários escriturais, prestação (de bem) fungível que sói ocorrer por meio da ordem de lançamento a crédito (do credor) dada pelo devedor à instituição financeira ou câmara de compensação depositária do título, sobreleva o modo delegatório para o exame preliminar desse particular adimplemento por substituição.

Nesse sentido, valioso é o ensinamento de GOMES (1988, p. 263 e s.) a respeito da definição dessa categoria de assunção de dívida:

Para definir a delegação nos seus termos exatos, importa, em primeiro lugar, afastar a ideia de que é meio técnico de efetuar a novação. Desde os estudos de SALPIUS, vem-se admitindo que a delegação é instituto autônomo, que tem campo funcional independente da novação, tornandose incontestável a assertiva de que pode haver delegação sem novação. Pela novação surge nova obrigação, extinguindo-se a obrigação anterior, enquanto a delegação não tem efeito extintivo, residindo nessa particularidade, precisamente, sua superioridade. Para se distinguir essa forma de delegação da delegatio novativa, chamam-na imperfeita, indicando-se, com esse qualificativo, a sucessão particular no débito.

Assentado que a delegação não se confunde com a novação, cumpre, de imediato, descrever seu mecanismo. Para compreender a complicada 
entrosagem do instituto, nada melhor do que figurá-la, exemplificativamente, na sua forma mais simples. Se sou devedor de alguém e, ao mesmo tempo, credor de outra pessoa, posso mandar que meu devedor pague ao meu credor, desde que estejamos todos de acordo. Com essa operação, suprimo um circuito desnecessário, que consistiria em receber do meu devedor e pagar ao meu credor. A utilidade do processo se revela, por exemplo, quando meu credor e meu devedor não moram na mesma cidade. Evito, por esse modo, ter de receber e a pagar fora do meu domicílio. Por esse processo, suprime-se o dúplice giro de dinheiro. $\mathrm{O}$ mecanismo não é tão simples, porém, quanto se apresenta nessa forma da delegatio. Não raro, a pessoa a quem o devedor delega o débito se compromete a pagá-lo futuramente, assumindo a sua posição. Verifica-se, assim, a sucessão singular no débito, conservando a obrigação sua individualidade. Esta é a verdadeira delegação, porque implica assunção de uma dívida.

Há, em suma, delegação, quando o devedor transfere a terceiro, com o consentimento do credor, o débito com este contraído. O devedor-cedente chama-se delegante; aquele a quem transfere o débito, delegado, e o credor, delegatário.

O art. 299, caput, do Código Civil parece ter se encaminhado no sentido da delegação ao delinear o conceito de assunção de dívida, na medida em que faculta a terceiro assumir a obrigação de devedor, com o consentimento expresso do credor, exonerando-se por esse modo o devedor primitivo. Nesse sentido, "apresenta-se na mesma esteira do código alemão" (VENOSA, 2012, p. 149).

Ressalte-se ainda a necessidade do assentimento "expresso" do credor para a eficácia da delegação, ao contrário da legislação portuguesa, a qual exige somente "ratificação" do contrato de transmissão de dívida, admitindo ainda a assunção no silêncio do credor (CC português, art. 595, 2 ). Contudo, nessa última hipótese, o delegado responderá solidariamente com o delegante (VARELA, 1999).

Dessa forma, somente na presença de uma declaração expressa do credor haveria assunção de dívida em sentido próprio, acarretando, portanto, o efeito liberatório do delegante. Ao revés, restaria apenas uma cumulação passiva da obrigação, uma espécie de reforço, ou garantia da obrigação existente. Tendo em vista que a solidariedade não se presume, devendo resultar da lei ou do negócio jurídico (CC, art. 265), seria então de garantia a relação jurídica do novo devedor da obrigação, na hipótese de se admitir, entre 
nós, a possibilidade dessa assunção imperfeita de dívida, diante do silêncio do credor (VENOSA, 2012, p. 150).

Também a admitem BDINE JR. (2009, p. 259) e RIZZARDO (2006, p. 280), tratando-a como espécie de obrigação solidária. Nesse sentido, tratando-a de "adesão à dívida”, com efeito de solidariedade, ENNECCERUS (1947, p. 407). Porém, em relação ao atual direito brasileiro, não assiste razão aos defensores desse entendimento.

A despeito da permanência do vínculo com respeito ao devedor original, a esse caberia como que um benefício de ordem, não podendo ser compelido ao pagamento senão quando o novo devedor deixar de cumprir a obrigação assumida. Trata-se sobretudo de adesão à dívida por parte do delegado, enquanto reforço pessoal da obrigação (GOMES, 1988, p. 264). Não se há de confundir essa espécie de garantia com a fiança, vez que essa última visa à garantia de dívida "alheia", o que não resulta da delegação cumulativa (VENOSA, 2012, p. 150).

O direito alemão admite a aceitação tácita, sobretudo porque se trata de ratificação do contrato firmado, desde que o credor trate efetivamente ao novo devedor como assumente da dívida, como no caso de acioná-lo em juízo (ENNECCERUS, 1947, p. 405).

Não obstante, diante da dicção do art. 299, § único, do Código Civil brasileiro, em que o silêncio por parte do credor, após o decurso do prazo que lhe fora assinado, é tido como recusa à delegação, parece indubitável que somente diante de um comportamento concludente, consistente, como seja o recebimento parcial de pagamentos, ou juros, por parte do credor, seria possível se interpretar como assentimento essa forma de conduta (BDINE JR., 2009, p. 260 e s.).

Nesse sentido, se o credor do valor mobiliário escritural recebe do custodiante extrato de sua conta, e desse recibo consta o creditamento do objeto de pagamento, sem que haja qualquer impugnação, a aceitação do credor quanto à delegação decorrerá da própria quitação da dívida. O extrato de conta servirá como recibo de quitação regular ao devedor que pagou por delegação (CC, art. 320).

Com efeito, a quitação regular compreende a quitação dada por meio eletrônico ou outras formas de comunicação à distância, desde que aptas à conclusão do negócio jurídico ou para a prática de atos jurídicos sem a presença corpórea simultânea das partes ou de seus representantes (MONTEIRO, 2011, p. 298, n. 28) ${ }^{202}$. Valerá dessarte a quitação, vez

202 Nesse sentido também é o enunciado no 18 aprovado pela I Jornada de Direito Civil, realizada pelo Conselho da Justiça Federal, em 2002. 
que de seus termos ou das circunstâncias resulta o cumprimento da prestação obrigacional (CC, art. 320, § único).

Importante ainda que se atente à função do instrumento delegatório, sendo corrente a distinção entre delegação de cumprimento (solvendi) e delegação de promessa (de cumprimento) (promittendi). Nessa, há a verdadeira delegação, enquanto sucessão singular, ou ao menos cumulação passiva, com a promessa feita por terceiro ao credor de que cumprirá a obrigação; naquela, ao revés, não há promessa de pagamento por parte do terceiro em relação ao credor, mas apenas a promessa de efetuar o pagamento à ordem do devedor primitivo. Com efeito, assim leciona GOMES (1988, p. 265):

A primeira, também chamada delegação de cumprimento ou, ainda, delegação de pagamento, consiste numa ordem dada pelo devedor originário a outra pessoa para que, em seu lugar, pague a dívida. A pessoa a quem se dirige a ordem não assume a obrigação do devedor, pois que se limita a pagar. Obriga-se simplesmente a solver a obrigação do devedor que cometeu esse encargo. Uma vez que não implica assunção de dívida ao lado do devedor ou substituição deste na relação obrigacional, não configura verdadeira delegação, senão espécie afim, chamada, no Direito suíço, assunção interna de dívida, a que Von Tuhr, como visto, prefere chamar promessa de liberação. A pessoa a quem o devedor ordena que pague, compromete-se, tão só, a efetuar o pagamento, liberando-o, por via de consequência. É claro, porém, que, se esta pessoa é, por sua vez, devedora do devedor, haverá delegação, embora não se verifique sucessão passiva na relação obrigacional que este travara com o credor.

A delegatio promittendi é a figura autêntica de delegação, seja liberatória ou cumulativa. Há delegação de débito quanto o terceiro contrai a obrigação, sucedendo a devedor ou a ele se unindo, com a promessa, feita ao credor, de que a cumprirá. (...) Nesta figura, patenteia-se a modificação subjetiva no lado passivo da relação obrigacional. Ou o devedor originário é substituído, dando ingresso a outro, o delegado, ou este se junta a ele, ocupando, supervenientemente, a mesma posição.

Nota-se, portanto, que na "promessa de liberação" não há substituição no polo passivo da obrigação, havendo apenas negócio jurídico entre promitente e devedor original. $\mathrm{O}$ credor não pode se dirigir ao promitente, aliás, não raro nem toma conhecimento dessa promessa. O devedor continua obrigado, não resultando nenhuma transmissão de dívida. O promitente não assume a dívida, isolada ou cumulativamente, 
mas somente o adimplemento. A essa figura, como mencionado anteriormente, denomina o direito italiano acollo (GOMES, 1988, p. 260).

O direito alemão também a conhece, chamando-lhe "assunção de cumprimento" (Erfüllungsübernahme). O Código Civil português também a recepcionou do direito alemão, encontrando guarida no art. 444º, 3 (VARELA, 1999, p. 363). Resta ao devedor apenas pretensão contra o promitente, seguindo assim obrigado em relação ao credor. Importa que se pague, liberando o devedor, não sendo mister o modo pelo qual se pague. Ao credor, por sua vez, não resulta nenhuma pretensão contra o promitente do pagamento, a não ser que se justaponha à promessa de liberação uma adesão à dívida originária por parte do promitente do pagamento. Na dúvida, deve se interpretar como havendo apenas a promessa de liberação (ENNECCERUS, 1947, p. 407 e s.).

Observe-se ainda que não há na promessa de liberação nenhum contrato de prestação a favor de terceiro, vez que tal avença obrigaria o devedor perante o credor (da promessa) a pagar, não a esse último, mas ao seu credor. É dizer, restaria configurada a delegatio promittendi, antípoda da assunção de cumprimento (adimplemento).

$\mathrm{Na}$ assunção de adimplemento é essencial que haja “dever de executar", obrigação que resulta em face do devedor primitivo, a quem a assunção aproveita. Por essa razão, pode resultar de negócio jurídico unilateral, enquanto "promessa abstrata de dívida" feita por terceiro ao devedor originário. Nessa hipótese, não se necessita da aceitação desse último para o efeito negocial de adimplemento. Não obstante, se bilateralmente avençado, pode o contrato ser oneroso ou gratuito. Naquele, a obrigação de solver a dívida é contraprestação; nesse, a assunção de cumprimento denota doação, mas não promessa de doação. Quanto aos modos de pagamento, seriam os mesmos que estariam à disposição do devedor originário; sem embargo, como não há substituição passiva, não pode o assumente do pagamento alegar compensação com crédito seu (PONTES DE MIRANDA, 1959a, p. 99 e s.).

Não obstante, não se deve olvidar de que há certa interdependência funcional entre as diversas relações jurídicas envolvidas na delegação de pagamento. Em princípio,

Há três negócios estreitamente coligados: entre delegante e delegado, entre delegado e delegatário, e entre delegante e delegatário. A divergência reside apenas na qualificação de um desses negócios, precisamente o que se conclui entre delegante e delegado. Para alguns é unilateral, para outros, bilateral. Importa, no entanto, frisar que a teoria 
atomística define a estrutura da delegação em termos mais ágios e simples, afirmando que há apenas uma conexão funcional entre negócios que se conservam estruturalmente autônomos. De fato, o sujeito de uma das relações permanece estranho à outra, como é o caso do delegante em relação ao vínculo estabelecido entre delegado e delegatário (GOMES, 1988, p. 268 e s.).

Por esse argumento é possível se entender do porquê de não se misturar eventual defeito jurídico na relação entre delegante e delegado com a relação entre delegado e delegatário, na medida em que o delegatário é considerado pessoa alheia à estipulação entre os primeiros. Assim, por exemplo, se o devedor primitivo obtém dolosamente o consentimento de terceiro (delegado), esse último não poderá se escusar perante o credor a efetuar o pagamento sob a alegação de vício do consentimento (GOMES, 1988).

Retornando à hipótese em torno do traspasso do valor mobiliário pela entidade custodiante do título, o que há é o adimplemento por terceiro, resultado de prestação de serviço por parte do depositário. Em princípio, a instituição depositária é estranha à relação jurídica entre devedor e credor. O depositário paga, portanto, em nome, ou em nome e por conta do devedor. Em regra, deve haver ao menos representação, ainda que não haja mandato. Em princípio, não há falar em reembolso, pois a remuneração resulta do próprio contrato de prestação de serviço de custódia (global) de títulos em administração, essencialmente oneroso e executado de modo profissional (CC, art. 638, caput), não do fato do pagamento. Portanto, há de ser normalmente excluída a aplicação do art. 305, caput, do Código Civil, sob pena de se configurar enriquecimento sem causa, devendo antes incidir a regra do $\S$ único ao art. 304 do mesmo diploma.

Não é necessário que ainda se fale de ato abstrato em relação ao pagamento realizado pela entidade de custódia dos valores mobiliários, bastando que se pense no pagamento como ato-fato jurídico, independente de sua causa, não havendo, portanto, do que se abstrair (PONTES DE MIRANDA, 1966, p. 42).

Com efeito, entre o devedor originário e o depositário, o pagamento representa execução do dever desse perante aquele, resultante do vínculo negocial que, em regra, traz consigo a promessa de liberação (assunção de cumprimento). O depositário atua somente como delegado no cumprimento da obrigação do devedor delegante. O objeto da promessa é o ato-fato jurídico do pagamento. Trata-se sobretudo de ordem de pagamento, que compreende outorga de poder para adimplemento da dívida. 
Considerando que a ordem, em estudo, se dirige ao lançamento a crédito em prol do credor da prestação de traspasse do título, há nessa hipótese espécie de giro em conta (de títulos), ou quiçá negócio jurídico de giro. De qualquer modo, configurar-se-ia, aqui, espécie de pagamento por giro em conta, similar ao pagamento bancário por giro. $\mathrm{O}$ depositário assumiria assim o dever de creditar na conta do credor (adquirente dos valores mobiliários negociados). Tal dever, vale novamente frisar, se configura, em princípio, perante o devedor originário, não em relação ao credor; do contrário, ter-se-ia verdadeira assunção de dívida, com substituição, ou cumulação passiva.

Obviamente, o traspasse dos títulos de uma conta a outra supõe que devedor e credor originários (delegante e delegatário) tenham conta de depósito junto ao custodiante (delegado).

Desse modo, entre o devedor e o depositário dos títulos, permanece a relação jurídica causal, ou seja, a promessa (unilateral ou bilateral) de liberação, assumindo o depositário a obrigação de realizar o pagamento mediante a transferência gráfica (lançamento contábil) do título. O depositário assume dessarte o dever de cuidar do ato (fato) jurídico do pagamento. A incumbência de avisar o credor, caso haja, é do devedor, não do depositário. O pagamento em si é ato-fato jurídico; o negócio que origina o dever de executar o pagamento é causal em relação ao pagamento efetivado, pois acarreta ao depositário a incumbência de extinguir a dívida.

Por outro lado, entre o credor da prestação de traspasso do valor mobiliário e o depositário surge relação jurídica somente no momento mesmo em que o depositário conclui o negócio de assunção de adimplemento, na medida em que o lançamento com o respectivo crédito configura apenas elemento contabilístico. O depositário se vinculou a lançar, e o eventual extrato da conta de títulos, com o demonstrativo do trespasse (lançamento), denota a própria execução, tendo tal documento mera eficácia declaratória. Nem se faz mister a comunicação do depositário ao beneficiário do lançamento (credor originário), pois, na hipótese em exame, o crédito do beneficiário do lançamento é abstrato (PONTES DE MIRANDA, 1966, p. 155).

O pagamento ora em exame importa a transmissão dominial dos valores mobiliários. Sua eficácia depende assim da existência do poder de alienar, a ser outorgado pelo devedor ao assumente do dever de solver (CC, art. 307). Se, porém, se tratar de pagamento de coisa fungível, uma vez realizado e quitado (recebido), não se pode mais reclamar a coisa do credor que, de boa fé, a consumiu, ou alheou (CC, art. 307, § único c/c 
art. 86 , in fine).

Ainda que sejam os valores mobiliários escriturais, em regra, espécies de títulosgênero, pode se tratar de um lote padronizado desses valores, contendo, por exemplo, determinada classe de ações, não podendo mais ser substituído por outro equivalente. Caso já renegociado pelo adquirente de boa fé, caberá tão só o substitutivo indenizatório, resolvendo-se entre o delegado e o delegante da ordem de pagamento viciada (sem outorga de poder), excluindo-se, portanto, o direito de repetição perante o credor originário (VENOSA, 2012, p. 178).

Observe-se ainda que não se deve ter por válido nenhum dispositivo contratual, ou pacto adjeto ao contrato de custódia, que exclua a responsabilidade do custodiante por não cumprimento do dever de solver, ou ainda que a restrinja em caso de culpa. Ao custodiante, enquanto prestador do serviço de custódia de títulos em administração, desde que se lhe outorgue o devido poder de solver (delegação), incumbe cuidar do ato jurídico do pagamento, para tanto devendo extinguir a dívida na forma devida (PONTES DE MIRANDA, 1966, pp. 89, 155).

Cogite-se ainda da hipótese de transferência indevida de títulos, não em razão da ausência do legítimo poder de solver (alienar) por parte do custodiante (delegado), mas devido à execução errônea (culposa) da ordem de crédito. Assim, a despeito do lançamento indevido a crédito de terceiro que não o credor originário, pode o terceiro estar de boa fé ao renegociá-lo no mercado de valores mobiliários, máxime em razão de o recebimento daquele lote indevido (de valores escriturais) ter se confundido com o de tantos outros a ele creditados, ao final do mesmo dia, após a liquidação por diferença dos créditos (clearing). Nessa hipótese, não haveria razão para se cogitar da existência do direito de repetição, devendo-se-lhe aplicar analogamente a citada regra do § único ao art. 307 do Código Civil. A questão se resolverá, portanto, entre o delegado (depositário), que indevidamente pagou, e o devedor (titular dos valores indevidamente transmitidos em pagamento).

\subsubsection{A transferência eletrônica de fundos}

Frise-se novamente que o art. $2^{\circ}$, inciso VII, do Regulamento anexo à Circular BCB n ${ }^{\circ} 3.057$, de 2001, define como sendo "definitivo" qualquer evento que ocorra em caráter irrevogável e incondicional, sejam como "a liquidação e a transferência de fundos ou de títulos e valores mobiliários".

Outrossim, estabelece o mesmo Regulamento, em seu art. 33, que nos sistemas de 
liquidação de transferência eletrônica de fundos "a transferência definitiva do ativo negociado deve ocorrer simultaneamente à liquidação financeira".

No que tange à transferência eletrônica de fundos, o referido Regulamento determina ainda que essa transferência deve ser efetivada mediante "ordens de crédito" (art. 31), definindo-a como "ordem de transferência de fundos da conta do participante emitente para a conta do participante favorecido" (art. $\left.2^{\circ}, \mathrm{XIV}\right)$.

Com efeito, a liquidação no âmbito do SPB, enquanto "processo de extinção de obrigações" (art. 2, IX, do Regulamento anexo à Circular BCB n 3.057, de 2001), implica a transmissão dominial dos valores móveis negociados concomitantemente ao pagamento em moeda corrente (objeto da obrigação pecuniária). A transferência de fundos trata, portanto, de extinguir a dívida de dinheiro.

No que se refere à transferência "eletrônica" de fundos, vale lembrar que o STR 203 constitui a espinha dorsal do SPB. Por seu intermédio se efetivam todas as transferências líquidas finais de sistemas de liquidação, sistemicamente importantes ${ }^{204}$, entre as contas de reservas bancárias, ou contas de liquidação, mantidas junto ao Banco Central do Brasil, sob a titularidade das contrapartes negociais, por determinação regulamentar (Regulamento anexo à Circular BCB no 3.057, de 2001).

A esse respeito, esclarece ainda TABAK (2012, p. 12):

Dado que é um sistema LBTR, não amplifica os riscos de contágio e sistêmico em caso de inadimplência. O Sitraf também realiza transferência de fundos, no entanto essas transferências são realizadas somente entre contas de liquidação. Esse sistema executa ciclos de liquidação durante o dia. Os participantes inadimplentes, ao final de um ciclo, são chamados a depositar, em suas contas de liquidação, os recursos necessários à execução de suas transferências. Caso esse depósito não seja feito até o final do dia, as transferências pendentes são canceladas, podendo originar uma cadeia de cancelamentos de transferências.

Ressalte-se novamente que, a partir da vigência da Circular BCB $n^{\circ} 3.534$, de

203 Sistema de Transferência de Reservas vinculado às contas de reservas bancárias mantidas junto ao BCB e por esse administrado.

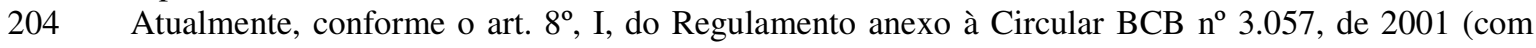
redação dada pela Circular n $n^{\circ} 3.539$, de 2011), "são considerados sistemicamente importantes pelo Banco Central do Brasil os sistemas de liquidação de transações com ativos financeiros, títulos, valores mobiliários, derivativos financeiros e moedas estrangeiras, independentemente do valor individual de cada transação e do giro financeiro diário". 
6.5.2011, as Transferências Eletrônicas Disponíveis (TED) com valor igual ou superior a um milhão de reais passaram a ser liquidadas por meio do sistema administrado pelo BCB. Essa determinação teve por objetivo justamente reduzir a importância sistêmica do Sitraf, operado pela CIP (Câmara Interbancária de Pagamentos). Desse modo, transferências de valores a partir de um milhão de reais deixaram o ambiente liquidante do Sitraf e passaram a ser efetuadas pelo STR, operado diretamente pelo BCB. Assim, a maior parte do volume financeiro das transações interbancárias migraram de um sistema de liquidação por diferença (LDL), desprovido de garantias institucionais para absorver o impacto de inadimplência, elevando assim o risco de contágio sistêmico, para um sistema de liquidação em tempo real (LBTR), em que esse risco é mitigado, sobretudo pela presença direta do prestamista de última instância.

A normatização regulamentar do pagamento eletrônico de dinheiro traz à baila sobretudo a questão da qualidade do objeto de pagamento, ou seja, da moeda a ser transferida em adimplemento da obrigação pecuniária. Nesse sentido vale observar a lição de BENJAMIN (2000, p. 192):

On the cash side, it is important to remember that in the financial markets money is debt. When $A$ is said to have paid $£ 1,000$ to $B$, in practice A has arranged for a bank or other credit institution to make a credit entry to an account recorded in its books in favour of $B$. This credit entry has the effect that $A$ creates or increase an existing debt to $B$ to the extent of $£ 1,000$. The quality of the 'payment' of $A$ to $B$ depends on the credit rating of the credit institution which maintains this account. The credit institutions whith the best credit ratings are central banks (and in particular the central banks of OECD countries). Therefore the best quality of payment is a credit to an account maintained in the books of such a central bank, or 'central bank money'.

$\mathrm{O}$ argumento apresentado levanta duas questões, aparentemente distintas, mas essencialmente correlacionadas: primeiramente, o pagamento enquanto ordem de crédito dada à instituição depositária, encarregada de efetuá-lo; em segundo lugar, o tipo de conta na qual se efetua o pagamento, cujo corolário é a natureza da própria moeda de pagamento.

A questão em torno da ordem de pagamento, a ser efetuado mediante lançamento a crédito na conta do beneficiário (credor), quanto à forma em nada difere da delegação de pagamento anteriormente estudada (tradição de valor mobiliário em cumprimento da obrigação genérica de dar). Não obstante, é mister que se diferencie a condição do titular 
da conta de depósito na qual se extingue a dívida pecuniária.

Com efeito. No âmbito do SPB, as transferências pecuniárias devem ser liquidadas em contas mantidas junto ao $\mathrm{BCB}$, a saber, as de reservas bancárias e as contas de liquidação. Essas têm como titulares, entre outros, as câmaras de liquidação e custódia de valores mobiliários, instituições financeiras não bancárias; aquelas, são principalmente de titularidade dos bancos (comerciais, múltiplos com carteira comercial e caixas econômicas).

No que tange às contas de liquidação, cuja abertura é obrigatória às câmaras e prestadores de serviços de compensação e liquidação (inclua-se a custódia) que operam os sistemas de liquidação de transações com ativos financeiros, títulos, valores mobiliários, derivativos financeiros e moedas estrangeiras, independentemente do valor individual de cada transação e do giro financeiro diário. Outrossim, os sistemas de liquidação de transferências de fundos e de outras obrigações interbancárias que não as anteriormente citadas, desde que o giro financeiro diário médio seja superior a $4 \%$ do giro médio diário do STR, ou que os efeitos da inadimplência de um participante em relação aos demais (efeito-contágio), em sistemas de liquidação diferida que utilizem a compensação multilateral, a critério do $\mathrm{BCB}$, coloquem em risco a fluidez dos pagamentos no âmbito do SPB (art. 8, I, II, “a” e “b” do Regulamento anexo à Circular BCB no 3.057, de 2001).

Por meio das contas de liquidação podem as entidades de liquidação operar diretamente no STR, reduzindo assim custos na realização e no recebimento de pagamentos. A razão para isso reside no fato de que sendo a instituição titular de uma conta junto ao $\mathrm{BCB}$, não mais dependerá de um intermediário bancário (banco liquidante) detentor de conta Reservas Bancárias -, para o cumprimento de das obrigações negociadas no mercado financeiro e de capitais, sejam como negócios com títulos públicos, realizados no Selic, ou com outros valores mobiliários, na BM\&FBovespa ou Cetip. Outrossim, as instituições detentoras dessas contas, a depender de sua atividade, poderão executar operações de pagamento ou recebimento de transferências de crédito à ordem de seus clientes, podendo ainda participar da compensação de cheques, no âmbito da Compe, e do Meio Circulante.

Particularmente no âmbito do SPB, destinam-se as contas de liquidação essencialmente à realização de movimentações financeiras, a crédito e a débito, vinculadas aos eventos de custódia relativos à liquidação de obrigações de transferência de ativos (Regulamento anexo à Circular BCB n 3.057, de 2001, art. 13, I e II). Vale dizer, nessas 
contas se executam as prestações de dinheiro em solução das obrigações pecuniárias resultantes dos negócios jurídicos, onerosos, translativos da propriedade de valores mobiliários, ou ainda daqueles liquidados por diferença (derivativos).

Esse giro financeiro compreende exclusivamente lançamentos a crédito, em contrapartida a débito ordenado por titular de conta Reservas Bancárias, e lançamentos a débito, ordenados pelo titular da conta de liquidação, em contrapartida a crédito em conta Reservas Bancárias (Regulamento anexo à Circular BCB no 3.057, de 2001, art. 13, § $1^{\circ}$, I e II).

Em razão de sua particular finalidade, qual seja a liquidação, as mencionadas contas devem apresentar saldo igual a zero ao final de cada dia (Regulamento anexo à Circular BCB n $3.057 / 2001$, art. 13, § $2^{\circ}$ ).

Frise-se, portanto, que as entidades que as operam não são bancos comerciais, não se lhes outorgando poder de disposição dos fundos custodiados na qualidade de proprietários, afastando-se, portanto, a incidência da regra do art. 587 do Código Civil, a despeito de se tratar de depósito de dinheiro. É dizer, não se trata de depósito bancário, mas antes deve ser tratado à semelhança do que ocorre com o depósito para a custódia de títulos em administração, examinado no tópico anterior.

Com efeito, apesar de a hipótese presente configurar depósito irregular, vez que se trata de numerário o objeto de custódia (moeda de curso legal), portanto, bem fungível, a diferença decorre da própria teleologia desse depósito em relação ao depósito bancário. Enquanto o banco tem seu patrimônio acrescido pelo empréstimo (CC, art. 587), com a obrigação de restituir no prazo avençado (depósito a prazo) ou, então, no termo legal (CC, art. 592), o depositário em exame não adquire poder de disposição sobre o numerário custodiado, não podendo assim utilizá-lo em operações ativas, tal como fazem os bancos (ROSENVALD, 2009, p. 637).

Dessarte, a despeito da fungibilidade da moeda utilizada para a liquidação das dívidas pecuniárias nas contas de liquidação, ela decorre de destinação socioeconômica diversa daquela que se dá à mesma moeda (de curso legal) objeto de depósito bancário (CC, art. 82, in fine).

Vale recordar que a fungibilidade implica a possibilidade de substituição qualitativa e quantitativa, atendendo-se antes ao gênero (classe) do que à individualidade da coisa. Frise-se todavia que a determinação da classe advém sobretudo do tráfico jurídico (socioeconômico), não somente da discricionariedade negocial (ENNECCERUS, 1947, p. 
30; PONTES DE MIRANDA, 2000, p. 55).

Nesse sentido, os fundos movimentados em contas de liquidação do SPB, diferentemente dos depósitos bancários de dinheiro, se destinam exclusivamente às operações de pagamento à ordem do participante devedor, segundo a própria dicção regulamentar. Sua custódia deve ser interpretada analogamente àquela dos títulos objeto de custódia global para administração, na medida em que a entidade custodiante pode misturá-los com outros do mesmo conteúdo e valor, dado seu caráter essencialmente fungível, sem que tenha sobre eles, no entanto, direito de propriedade. Assim, configura-se somente de modo parcial a irregularidade dessa espécie de depósito (PONTES DE MIRANDA, 1966, p. 88).

A despeito de também ser moeda escritural, a moeda que circula nas contas de liquidação não pode ser objeto de multiplicação por meio de operações bancárias ativas, uma vez que seus titulares não só não estão autorizados a isso, como a função dessas contas difere essencialmente daquela atinente às Reservas Bancárias. Desse modo, não podem criar seus custodiantes a chamada "moeda de crédito" através de empréstimos ao público, a partir da criação de depósitos à vista. Resta claro, portanto, que o fundamento socioeconômico do depósito irregular, que marca as contas de liquidação, difere frontalmente do depósito irregular a cargo dos titulares de contas de reservas bancárias, o que afasta daquele a aplicação da regra do art. 587, todavia incidente nesse último.

Nesse sentido, resultaria legítima a aplicação da regra do art. 17 da Lei no 4.595, de 31.12.1964, que se refere à "custódia de valor de propriedade de terceiros" enquanto atividade privativa de instituições financeiras (senso largo).

Em relação à ordem de crédito emitida contra a entidade titular da conta de liquidação, deve ser ela acompanhada de outorga especial de poder de solver, decorrente do negócio de assunção de pagamento, ou de pagamento por giro em conta corrente contábil, mas não em virtude de lei (CC, art. 587). A realização do pagamento é feita, portanto, em nome e à conta do devedor (CC, art. 304, §único).

Note-se ainda que seria absurdo, em nosso sistema, se pensar em cessão de crédito, não só por afrontar a própria natureza da prestação pecuniária, mas simplesmente por não se transferir ao credor da dívida de dinheiro o mesmo crédito contra o titular da conta de liquidação, vez que ao lançamento a débito nessa conta corresponde o lançamento a crédito em conta Reservas Bancárias (de titularidade de um banco). O devedor da obrigação pecuniária não é, portanto, o titular da conta de liquidação (delegado para o 
pagamento), mas o delegante do pagamento, tal como o adquirente de um lote de valores mobiliários.

No que tange à assunção de dívida, é de se afastar que o titular da conta de liquidação assuma a posição passiva da obrigação pecuniária, ainda que ao lado do devedor originário, toda vez que sempre age à ordem do devedor primitivo, não dispondo de nenhum poder de alienação em razão do depósito (parcialmente) irregular, a exemplo do que determina a parte final do $\S$ único ao art. 24 da Lei $\mathrm{n}^{\circ} 6.385$, de 1976, anteriormente citado.

Como anteriormente citado, a restrição dominial do art. 17 da Lei $\mathrm{n}^{\circ} 4.595$, de 31.12.1964 (custódia de valores de terceiros), se prestaria suficientemente a afastar a regra concernente à transferência de propriedade do objeto de mútuo, tendo em vista que a destinação socioeconômica e regulamentar da moeda de pagamento em exame (circulante nas contas de liquidação) implica seu tratamento como bem móvel não fungível (CC, art. 82 , in fine).

Assim, somente em atenção à não fungibilidade resultante da sua destinação exclusiva (liquidação de prestação pecuniária), dada pela regulamentação do SPB, é possível a menção à propriedade de terceiro que não seja o custodiante (CC, art. 1.228), pois, do contrário, ao lhe emprestar o caráter irrestrito de bem fungível, apenas por se tratar de dinheiro, caberia a sua apropriação pelo custodiante (CC, art. 587).

Quanto aos pagamentos de dinheiro realizados pelos bancos liquidantes, titulares de contas Reservas Bancárias, é mister que novamente se explique, sumariamente, a natureza e o funcionamento dessas contas, bem como da moeda escritural bancária nelas circulante.

Criadas a partir da edição da Circular BCB n 492, de 1980, as contas Reservas Bancárias se destinam essencialmente à centralização da movimentação de débitos e créditos do mercado interbancário, seja entre as instituições financeiras (mercado secundário), seja entre essas e o BCB (mercado primário), incluso os lançamentos a crédito e a débito resultantes da liquidação financeira dos negócios cursados no Selic ${ }^{205}$.

205 Mencionem-se ainda os resultados financeiros lançados nessas contas em razão das operações de compensação de cheques realizadas pela Compe, das operações com valores mobiliários no mercado financeiro, das operações de compra e venda de moeda estrangeira realizadas fora do ambiente da Câmara de Câmbio da BM\&FBovespa, ou ainda dos saques e depósitos de papel-moeda no BCB e no Banco do Brasil S.A. (custodiante de numerário) como da movimentação de numerário entre as instituições financeiras bancárias, além dos recolhimentos compulsórios, multas e custos financeiros instituídos pelo BCB (ESTRELA, 2011, p. 197). 
Com efeito, os bancos comerciais, múltiplos com carteira comercial e as caixas econômicas devem manter as suas disponibilidades em moeda nacional nas respectivas contas Reservas Bancárias, cujo saldo ao final de cada dia deve ao menos corresponder aos depósitos compulsórios a que estão regulamentarmente obrigados ${ }^{206}$.

Vale recordar que paralelamente à moeda fiduciária (geralmente identificada com o papel-moeda), de emissão não lastreada (daí o elemento fidúcia), objeto de monopólio estatal, de curso forçado, e legalmente dotada de poder liberatório das obrigações (curso legal), há a moeda chamada bancária ou escritural (sinal gráfico).

Historicamente, a moeda escritural avança sobretudo a partir do século XIX, em razão da progressiva utilização dos serviços bancários para a liquidação (pagamento) de obrigações, incluso a compensação interbancária. Para tanto, cada vez mais se passaram a utilizar os fundos depositados em bancos de depósitos (depósitos à vista), daí a alcunha “moeda bancária". Resultado da escrituração levada a efeito nos registros contábeis das contas correntes dos bancos (conta corrente contábil), corresponde essencialmente aos lançamentos a débito e a crédito nessas contas.

Outrossim, considerando a influência inglesa no mundo econômico e financeiro de então, o desenvolvimento da moeda escritural também se precipitou devido à falta de compreensão do fenômeno de multiplicação de moeda por parte dos dirigentes do Banco da Inglaterra, sobretudo em razão da independência das instâncias decisórias correspondentes aos departamentos bancário e monetário daquele banco, consequentemente se permitindo a livre expansão dos meios de pagamento através da criação de depósitos bancários enquanto forma de moeda movimentável por meio de cheques ou ordens de pagamento. Atualmente, é consabido que os fundos depositados cada vez mais se movimentam por meio de transferências eletrônicas, cartões de débito ou crédito, e ainda comandos eletrônicos remotos (moeda digital) (ESTRELA, 2011).

Frise-se ainda que a moeda escritural consiste essencialmente nos depósitos à vista mantidos junto ao sistema bancário ou instituições de crédito, constituindo-se majoritariamente da moeda criada pelo mecanismo da multiplicação bancária, a saber, a partir da possibilidade conferida a determinados bancos de manter em caixa apenas uma

206 Esclareça-se, porém, que a partir da nova regulamentação dessas contas, sobretudo em razão da estruturação do SPB, em 2002, também foi facultada a bancos de investimento, e múltiplos sem carteira comercial, a abertura de contas de reservas bancárias, observando-se todavia a necessidade de monitoramento em tempo real dessas particulares contas, pois que não podem ter saldo devedor ao longo do dia, pois essas instituições não estão sujeitas ao compulsório, vez que não captam depósitos à vista do público, não participando, portanto, da criação de moeda escritural (ESTRELA, 2011, p. 196). 
fração do total de depósitos sob sua guarda, emprestando o restante sob a forma de negócios de crédito. A criação dessa "moeda de crédito" resulta matematicamente do comportamento conjunto das entidades bancárias autorizadas à captação de depósitos à vista junto ao público (ESTRELA, 2011).

Desse modo, a moeda escritural do sistema bancário comercial tem origem tanto no depósito pecuniário realizado por sua clientela como, sobretudo, nas operações de crédito bancário, lembrando que essas últimas também geram depósitos bancários (contábeis). Em ambos os casos, adiante-se, se trata de depósito bancário de dinheiro, espécie irregular de depósito voluntário, regulado pelas regras atinentes ao contrato de mútuo (CC, art. 645), devendo ter o banco, em princípio, inteiro poder de disposição sobre o dinheiro depositado.

Por outro lado, é mister que se ressalte a criação da moeda nacional a partir de sua emissão estatal. Entre nós, o monopólio de emissão pertence à União (CF, art. 21, VII), cuja competência para emitir moeda se exerce exclusivamente por meio do banco central (CF, art. 164). Essa competência se encontra regrada na legislação do Sistema Financeiro Nacional, que atribui ao Banco Central do Brasil a competência para emitir moeda-papel (ou papel-moeda) e moeda metálica, nas condições e limites autorizados pelo CMN, bem como executar os serviços do meio circulante (Lei n 4.595, de 1964, art. 10, I e II).

A competência exclusiva de emissão deve ser entendida à luz da legislação monetária em vigor, vale dizer, segundo o disposto na Lei $\mathrm{n}^{\circ}$ 9.069, de 1995 ("Plano Real"), cujo art. $1^{\text {o }}$ estabelece que "a unidade do Sistema Monetário Nacional passa a ser o Real, que terá curso legal em todo o território nacional". Em complemento às regras do sistema monetário vigente, prescreve o art. $1^{\circ}$ da Lei $n^{\circ} 10.192$, de 2001 , que as estipulações de pagamento das obrigações pecuniárias, cujo cumprimento se der no Brasil, deverão ser feitas pelo seu valor nominal em REAL.

Outrossim, o art. $3^{\circ}$ da Lei no 9.069, de 1995, determina que o "Banco Central do Brasil emitirá o REAL mediante prévia vinculação de reservas internacionais em valor equivalente".

O mencionado serviço do meio circulante, a cargo do $\mathrm{BCB}$, se destina fundamentalmente ao atendimento das necessidades de numerário do sistema bancário, consequentemente, do público, e pois executado através dos mecanismos de emissão e recolhimento de moeda.

$\mathrm{O}$ ato jurídico de emissão de moeda reside essencialmente em sua introdução no 
meio circulante. A entrada em circulação pode resultar da substituição de numerário desgastado, ou do atendimento à maior procura de moeda em espécie ${ }^{207}$, monetizando-se as reservas bancárias para fazer frente à demanda monetária por parte do público.

A emissão está essencialmente ligada às reservas bancárias mantidas pelos bancos (senso estrito) junto ao BCB. As reservas bancárias, acrescidas do papel-moeda emitido, compõem o conceito econômico de Base Monetária. Resta claro que as contas Reservas Bancárias representam moeda escritural, enquanto o papel-moeda se refere ao dinheiro em espécie (numerário). A transformação recíproca não representa emissão nem recolhimento, mas somente alteração na composição da Base Monetária.

A emissão de "moeda escritural" pelo BCB resulta do aumento da quantidade de dinheiro (fundos) depositados nas contas Reservas Bancárias. Essa emissão primária é efeito de pagamento pecuniário realizado pelo BCB em cumprimento de obrigações resultantes de negócios financeiros celebrados no mercado interbancário primário, ou seja, entre o $\mathrm{BCB}$, atuando por conta própria, ou da União, e os titulares das contas de reservas. Assim, por exemplo, os fundos transferidos em pagamento de um resgate de títulos vincendos da dívida mobiliária federal, efetuado pelo BCB enquanto depositário da conta única do Tesouro Nacional, no interesse desse último; também o pagamento efetuado pelo BCB em razão da venda de valores móveis de sua própria carteira de títulos (operação compromissada, ou reporte), em típica operação de mercado aberto; pagamentos em razão da compra de moeda estrangeira pelo BCB; ou ainda operações de concessão de crédito direto aos bancos pelo BCB (redesconto) ${ }^{208}$, típica operação bancária que implica a criação da chamada "moeda de crédito" (escritural) (COSTA, 1999; ESTRELA, 2011).

Ressalte-se ainda que as operações interbancárias do mercado secundário, ou seja, entre os bancos comerciais, ou ainda entre esses e outros entes de direito privado, tal como a compra e venda de valores mobiliários, a despeito de girarem a moeda escritural de suas contas de reservas, não denotam emissão ou recolhimento oficiais, uma vez que os fundos creditados e debitados não alteram as quantias consolidadas, em última instância, não há criação nem destruição de moeda (REAL) pelo BCB.

A entrada em circulação, junto ao público, da moeda emitida pelo BCB ocorre

207 Observe-se que as moedas metálicas e o papel-moeda são apenas fabricados pela Casa da Moeda, tornando-se moeda (REAL) somente na hipótese de serem introduzidos no meio circulante pelo BCB.

208 A concessão desse crédito é discricionária e exclusiva para os titulares de contas Reservas Bancárias. Não obstante, foi estabelecido o acesso automático a linhas de crédito intradia e de um dia útil sob a garantia de títulos públicos federais custodiados no Selic. Instituições titulares somente de contas de liquidação, ressalte-se, não têm acesso ao redesconto ofertado pelo BCB. 
através da movimentação das contas Reservas Bancárias para atender às operações passivas dos bancos comerciais. Vale dizer, em atendimento à procura de numerário por parte dos clientes bancários, as instituições bancárias efetuam saques em suas contas Reservas Bancárias de modo a fazer frente a essa demanda, introduzindo dessarte o papelmoeda em circulação. Assim, a emissão se destina ao atendimento da procura privada (pelo público) de moeda (COSTA, 1999; ESTRELA, 2011) $)^{209}$.

Dessa forma, as instituições bancárias autorizadas ao recolhimento de depósitos à vista do público em geral $^{210}$ integram o sistema monetário, coadjuvando o BCB na emissão monetária, na medida em que não apenas participam do processo de criação de moeda na economia, como também colaboram na realização do ato jurídico de emissão final da moeda.

Esses bancos comerciais, coadjuvantes na emissão monetária oficial, agem ainda na condição de bancos emissores de moeda escritural a partir da criação de depósitos contábeis (de moeda). Nesse sentido, têm eles por objetivo a captação de recursos, a vista e a prazo, para proporcionar o suprimento adequado dos recursos necessários ao financiamento do comércio, da indústria, das empresas prestadoras de serviços e das pessoas físicas. Esse financiamento se realiza basicamente por meio de abertura de crédito e desconto de títulos, entre outras modalidades (Resolução CMN nº 469, de 7.4.1978, itens 16-2-1, 16-7-1-1, "b").

Além das operações anteriores, podem os bancos comerciais realizar as seguintes operações: a) negócios com câmbio, mediante autorização do BCB (Resolução CMN n ${ }^{\circ}$ 3.265, de 4.3.2005); b) custódia de títulos e valores (Resolução CMN nº 469, de 1978, item 16-7-1-1, “c”); c) reporte de títulos públicos, debêntures, letras de câmbio e outros com promessa de recompra, ou revenda (Regulamento anexo à Resolução CMN no 2.950, de 17.4.2002); e d) prestação de fiança e outras garantias bancárias, bem como a prestação de serviços diversos como recebimento, pagamento e transferência de fundos (Resolução CMN no 469, de 1978, item 16-7-1-1, “c" e “d”).

Após essa exposição preliminar, cumpre então examinar as circunstâncias

209 Ressalte-se todavia o importante detalhe de que as quantias "monetizadas" das reservas bancárias, ou seja, sacadas em espécie dos bancos comerciais pelo público, ou contabilmente debitadas das contas bancárias dos clientes, permanecem contabilizadas como ativo (propriedade) dos bancos, por meio do seu lançamento na conta caixa.

210 Vale lembrar, mais uma vez, que esse grupo é composto pelos bancos comerciais, múltiplos com carteira comercial, caixas econômicas e ainda as sociedades cooperativas de crédito, sem bem que essas últimas estejam aptas à emissão de moeda escritural (Lei Complementar no 130, de 2009), na prática operam como correspondentes bancários, repassando recursos dos bancos (ESTRELA, 2011). 
jurídicas do pagamento efetuado pelos titulares das contas Reservas Bancárias, determinadas fundamentalmente pela natureza jurídica da moeda de pagamento utilizada no cumprimento das obrigações pecuniárias a serem liquidadas nessas contas.

Como anteriormente observado, a atividade bancária específica dos bancos comerciais, titulares de contas Reservas Bancárias, estão ligadas ao ato de emissão (criação) de moeda, configurando assim institucionalmente a destinação socioeconômica, e pois regulamentar, dessas contas. Assim, a moeda aqui utilizada representa não só moeda bancária (escritural), senão particularmente "moeda de banco central” (CORTEZ, 2004).

Primeiramente, essa moeda bancária deve ser tratada como moeda de crédito, ou seja, bem fungível por destinação própria à atividade bancária, enquanto emissora ou criadora de moeda em decorrência da natureza econômica do depósito bancário (destinação socioeconômica - CC, art. 82), aplicando-se-lhe consequentemente as regras do mútuo (CC, art. $645 \mathrm{c} / \mathrm{c}$ art. 587).

Somente nesse contexto se justifica o entendimento da doutrina e da jurisprudência pátrias a respeito da irregularidade típica do depósito bancário, no qual o banco é depositário de quantia em dinheiro (coisa fungível), podendo dispor da coisa em seus negócios jurídicos bancários (ROSENVALD, 2009, p. 637). Nesse sentido é assente a jurisprudência superior:

No contrato de depósito bancário, o depositante transfere à instituição financeira depositária a propriedade do dinheiro, passando esta a ter sobre ele total disponibilidade. Esse contrato, por construção doutrinária e jurisprudencial, é equiparado ao contrato de mútuo. É chamado de depósito irregular (depósito de coisas fungíveis) (STJ, Resp n. 492.956/MG, Proc. n. 2003/0012673-5, 1ª T., rel. Min. José Delgado, j. 06.03.2003, DJ 26.05.2003, p. 628 apud ROSENVALD, 2009, p. 637).

O pagamento em questão, efetuado no referido STR, e pois junto à conta Reservas Bancárias, ocorre por meio de ordem de pagamento dada ao banco liquidante, a ser realizada mediante lançamento à debito da mesma conta.

Ao contrário do pagamento realizado a partir das contas de liquidação, trata-se nessa segunda hipótese de pagamento por meio de banco em senso estrito. A esse respeito, observe-se a lição de PONTES DE MIRANDA (1966, p. 42):

Os bancos prestam serviços aos clientes no tocante ao adimplemento por terceiro. Aí, em vez da função ativa, é passiva a função do banco. Há outorga de poderes, que pode resultar, porém não necessariamente, de 
depósito, de abertura de crédito ou de adiantamento bancário. $\mathrm{O}$ depósito bancário pode ser sem tal outorga; a abertura de crédito pode ser com os simples levantamentos pelo cliente. Por onde se vê que perturba a compreensão da figura jurídica do pagamento pelo banco (...) não se abstrair de qualquer negócio jurídico subjacente, justajacente ou sobrejacente.

Em princípio, o banco é estranho e permanece estranho à relação jurídica entre cliente, devedor, ou cliente, que tem outorga de poderes do devedor, e o credor, a quem o banco vai pagar. O pagamento é ato-fato jurídico, e mais uma vez havemos de frisá-lo.

O banco paga em nome próprio e por conta do cliente (...).

Entre o cliente e o banco, o pagamento foi execução do dever do banco, que se vinculara a isso. $\mathrm{O}$ banco prometeu o ato-fato jurídico (...).

Por onde se vê que, tal qual exposto anteriormente, se trata também da figura da delegação de pagamento (assunção de adimplemento), mas com algumas peculiaridades que a afastam da simples "promessa de liberação", enquanto a aproximam da assunção de dívida, sob a forma de "delegação cumulativa".

No que tange à diferença da simples promessa de liberação (delegação de pagamento), ressalte-se que o poder a ser outorgado não necessita conter poder de disposição, mas tão somente o essencial poder de solver, na medida em que as quantias presentes nas reservas bancárias são objeto de depósito irregular junto ao BCB, gozando essa autarquia de poder de disposição sobre a moeda de adimplemento, por equiparação ao mútuo (CC, art. 587). Desse modo, paga o BCB em nome próprio, mas por conta do banco liquidante (delegante), da mesma forma que esse último tradicionalmente o faria ao executar serviços de pagamento por meio de ordens de pagamento, cujo lançamento a débito se perfaria na conta do cliente.

Portanto, difere a presente delegação de pagamento daquela existente no pagamento efetuado por titular de conta de liquidação, em que a ordem especial, em razão da quase irregularidade do respectivo depósito, deve necessariamente outorgar ao custodiante o poder de disposição do numerário a ser transferido dessa conta.

A despeito de ser pagamento em nome próprio, não incide a regra do art. 305 do Código Civil, mas antes a do art. 304 desse diploma, vez que o BCB atua no âmbito do SPB como terceiro interessado na extinção das obrigações. Com efeito, por força de disposição regulamentar, a liquidação das obrigações, em caráter irrevogável e 
incondicional, deve ocorrer em conta mantida nessa autarquia (contas de liquidação e de reservas bancárias), devendo o $\mathrm{BCB}$ ainda promover a solidez (financeira) e o normal funcionamento do SPB, de acordo com o estabelecido na Resolução CMN no 2.882, de

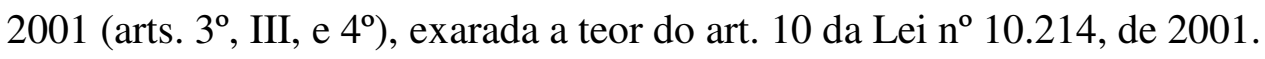

Tradicionalmente, citam-se entre os interessados aqueles que estão expostos a eventual execução judicial, sobretudo em razão de garantias prestadas ao devedor originário, mas não só. Assim, por exemplo, o fiador, o coobrigado, o herdeiro ou sucessor, outro credor do devedor ou ainda o adquirente do imóvel hipotecado, ao pagarem, subrogam-se nos direitos creditórios do devedor (CC, art. 346; MONTEIRO, 2011, p. 289). Não obstante,

censura-se modernamente a tese de que só serão interessados na extinção da dívida os que têm sub-rogação legal, tendendo-se, por interpretação extensiva, que basta para legitimar a intervenção de terceiro, um interesse puramente econômico (GOMES, 1988, p. 115 e s.).

$\mathrm{Na}$ presente hipótese, portanto, o interesse do BCB no pagamento se apresenta juridicamente legitimado, na medida em que a autarquia deve estar empenhada na sua realização, por disposição de norma regulamentar.

Ademais, sob o prisma econômico e institucional, como anteriormente acentuado, sobreleva o interesse jurídico no pagamento por parte dessa autarquia em razão das operações de concessão de crédito às instituições bancárias (titulares de reservas bancárias), de modo a atender à procura de liquidez no âmbito do STR (solidez financeira do SPB). Essas operações de empréstimo constituem essencialmente contratos de venda com reporte (compra de títulos da dívida mobiliária federal com o compromisso de revenda) e redesconto (mútuo).

Com efeito, nesse sentido também dispõe o art. 10, incisos V e XII, da Lei $\mathrm{n}^{\circ}$ 4.595, de 1964, ao atribuir ao BCB a realização de operações de redesconto e empréstimo a instituições financeiras bancárias, bem como operações de compra e venda de títulos públicos federais, como instrumento de política monetária.

Em última instância, trata-se, portanto, da circulação da "moeda de banco central" nesse sistema de pagamentos, conferindo aos participantes uma espécie de "reforço pessoal" das obrigações a serem liquidadas, em razão da presença da autoridade monetária na condição de prestamista de última instância.

A hipótese de sub-rogação, conforme a regra do art. 346, III, do Código Civil, a 
despeito da possibilidade teórica de sua aplicação, resta afastada na prática, na medida em que o acesso automático a linhas de crédito intradia e de um dia útil (reporte ou redesconto) ocorre somente sob a dação de garantia de títulos públicos federais, custodiados no Selic. Não obstante, em caso de falência ou liquidação extrajudicial do devedor (banco liquidante), incidiria a referida regra de modo a permitir a habilitação do direito creditório, sub-rogado, perante a massa liquidanda.

A presente questão em torno do interesse da autarquia federal no pagamento, uma vez assente sua presença, traz à baila a consideração a respeito do mencionado "reforço pessoal" das obrigações a serem extintas pelo pagamento por delegação. Nesse sentido, aproxima-se a presente delegação da chamada "delegação cumulativa", espécie de assunção de dívida (CC, art. 299), da qual já se tratou anteriormente.

Vale novamente frisar que apesar da permanência do vínculo com respeito ao devedor original, sem que haja, portanto, sucessão passiva na relação obrigacional, entende-se que a esse último caberia uma espécie de benefício de ordem, não podendo ser compelido ao pagamento senão quando o novo devedor deixar de cumprir a obrigação assumida (GOMES, 1988).

$\mathrm{Na}$ presente hipótese, no entanto, a presença da autoridade monetária enquanto garante das obrigações, em razão não só de afiançar a moeda de pagamento, a ser girada nas contas do STR, mas sobretudo devido à sua atuação político-institucional, implica se tratar de hipótese de "adesão à dívida" por parte do delegado (BCB), enquanto reforço pessoal da obrigação (ENNECCERUS, 1947, p. 407; GOMES, 1988, p. 264).

Advirta-se, como já frisado, que essa espécie de garantia não se identifica com a fiança, vez que essa última visa à garantia de dívida "alheia", o que não resulta da delegação cumulativa (VENOSA, 2012, p. 150).

Sem embargo, caso se entenda que as mencionadas linhas (automáticas) de crédito, concedidas pelo BCB para o financiamento das liquidações no STR, configuram espécie de abertura de crédito aos bancos liquidantes, então nada impede que as obrigações resultantes dessa "promessa de mútuo" sejam garantidas por meio de fiança. Observe-se todavia que o objeto da fiança a ser hipoteticamente prestada (aos bancos liquidantes) teria por objeto as obrigações pecuniárias surgidas em razão da efetivação dos mútuos (SALOMÃO NETO, 2007, p. 223).

Na prática, porém, a abertura de crédito de que aqui se cogita tem como creditante dos desembolsos futuros, na forma de mútuo, o prestamista de última instância, fiador 
institucional do próprio sistema de pagamentos. Ademais, como visto, os mútuos realizados através de reporte têm como contraprestação (garantia) os títulos da dívida pública depositados no Selic, também pertencente ao SPB.

No que tange ao consentimento do credor, diante da dicção do art. 299, § único, do Código Civil, em que o silêncio por parte do credor, após o decurso do prazo que lhe fora assinado, é tido como recusa à delegação, somente diante de um comportamento concludente, consistente, por parte do credor, seria possível se interpretar como assentimento essa forma de conduta (BDINE JR., 2009, p. 260 e s.). De qualquer forma, a simples presença do credor na condição de participante institucional do SPB, autorizado pela autarquia federal a negociar e liquidar suas obrigações no STR, já traduz um comportamento concludente, em respeito à regra do citado dispositivo da lei civil.

Trata-se, portanto, de figura negocial híbrida, relação jurídica de delegação de pagamento que surge da própria adesão dos bancos liquidantes às normas regulamentares e aos contratos de adesão aos ambientes de custódia, negociação e liquidação de obrigações financeiras que compõem o SPB.

Dessa relação não só contratual, mas sobretudo institucional, máxime em relação à posição assumida pelo $\mathrm{BCB}$ como garante (funcional) do sistema de pagamentos em exame, surge a aproximação de sua atuação delegada, no sentido da efetivação dos pagamentos por conta dos bancos liquidantes, à posição de assumente da dívida pecuniária, atraindo para a presente hipótese a possibilidade de acumulação passiva na obrigação pecuniária liquidanda, dado seu interesse institucional, por força da Lei ${ }^{\circ} 4.595$, de 1964, na condição de executor da política monetária.

Garante-se, dessarte, a liquidação definitiva da obrigação, em caráter irrevogável e incondicional, conforme a "regra geral" (norma regulamentar) contida no art. $3^{\circ}$, III, da Resolução $\mathrm{CMN}^{\mathrm{o}}$ 2.882, de 2001, em respeito ao mandamento legal de se assegurar a certeza da liquidação no âmbito do SPB (Lei no 10.214 , de 2001, art. $4^{\circ}, \S 2^{\circ}$ ).

\subsubsection{Excurso: A moeda nacional como bem púbico}

Frise-se novamente que a entrada em circulação, junto ao público, da moeda emitida pelo $\mathrm{BCB}$, no exercício de sua competência constitucional, ocorre através da movimentação das contas Reservas Bancárias para atender às operações passivas dos bancos comerciais. Vale dizer, em atendimento à procura de numerário por parte dos clientes bancários, as instituições bancárias efetuam saques em suas contas de Reservas 
Bancárias de modo a fazer frente a essa demanda, introduzindo dessarte o papel-moeda em circulação. Assim, a emissão se destina ao atendimento da procura privada (pelo público) de moeda (COSTA, 1999; ESTRELA, 2011) ${ }^{211}$.

Dessa forma, as instituições bancárias autorizadas ao recolhimento de depósitos à vista do público em geral integram o sistema monetário, coadjuvando o BCB na emissão monetária, na medida em que não apenas participam do processo de criação de moeda na economia, como também colaboram na realização do ato jurídico de emissão final da moeda.

Os bancos comerciais assim autorizados, coadjuvantes na emissão monetária oficial, agem ainda na condição de bancos emissores de moeda escritural a partir da criação de depósitos contábeis (de moeda). Nesse sentido, têm eles por objetivo a captação de recursos, a vista e a prazo, para proporcionar o suprimento adequado dos recursos necessários ao financiamento do comércio, da indústria, das empresas prestadoras de serviços e das pessoas físicas. Esse financiamento se realiza basicamente por meio de abertura de crédito e desconto de títulos, entre outras modalidades (Resolução $\mathrm{CMN} \mathrm{n}^{\circ}$ 469, de 7.4.1978, itens 16-2-1, 16-7-1-1, “b”).

Desse modo, a moeda escritural do sistema bancário comercial tem origem tanto no depósito pecuniário realizado por sua clientela como sobretudo nas operações de crédito bancário, lembrando que essas últimas também geram depósitos bancários (contábeis). Em ambos os casos, adiante-se, se trata de depósito bancário de dinheiro, espécie irregular de depósito voluntário (de bem fungível), regulado pelas regras atinentes ao contrato de mútuo (CC, art. 645), devendo ter o banco, em princípio, inteiro poder de disposição sobre o dinheiro depositado.

Da moeda enquanto bem considerado em si mesmo, é dizer, da fungibilidade (consuntibilidade e divisibilidade) do dinheiro, já se tratou anteriormente ao referir a qualificação jurídica do depósito de dinheiro.

Não obstante, importa ainda qualificar juridicamente a moeda escritural quanto à classe de bens na qual se insere. Portanto, o que se busca solucionar no presente tópico diz respeito à sua eventual inserção na classe de bens públicos (CC, art. 98 e ss.).

A questão se torna relevante tendo em conta o modo de emissão da moeda,

211 Vale ainda lembrar o importante detalhe de que as quantias "monetizadas" das reservas bancárias, ou seja, sacadas em espécie dos bancos comerciais pelo público, ou contabilmente debitadas das contas bancárias dos clientes, permanecem contabilizadas como ativo (propriedade) dos bancos, por meio de lançamento na conta caixa. 
resultado do exercício da competência constitucional da União. Nesse sentido, vale lembrar a criação da moeda nacional a partir de sua emissão estatal.

Com efeito, o monopólio de emissão pertence à União (CF, art. 21, VII), cuja competência para emitir moeda se exerce exclusivamente por meio do Banco Central (CF, art. 164). Essa competência se encontra regrada na legislação do Sistema Financeiro Nacional, que atribui ao Banco Central do Brasil a competência para emitir moeda-papel (ou papel-moeda) e moeda metálica, nas condições e limites autorizados pelo CMN, bem como executar os serviços do meio circulante (Lei n 4.595, de 1964, art. 10, I e II).

A competência exclusiva de emissão deve ainda ser entendida à luz da legislação monetária em vigor, vale dizer, segundo o disposto na Lei no 9.069, de 1995 ("Plano Real"), cujo art. $1^{\text {o }}$ estabelece que "a unidade do Sistema Monetário Nacional passa a ser o Real, que terá curso legal em todo o território nacional". Em complemento às regras do sistema monetário vigente, prescreve o art. $1^{\circ}$ da Lei $n^{\circ} 10.192$, de 2001, que as estipulações de pagamento das obrigações pecuniárias, cujo cumprimento se der no Brasil, deverão ser feitas pelo seu valor nominal em REAL.

Outrossim, é mister que se observe a regra do art. $3^{\circ}$ da Lei $n^{\circ} 9.069$, de 1995, segundo a qual o "Banco Central do Brasil emitirá o REAL mediante prévia vinculação de reservas internacionais em valor equivalente".

De acordo com o respectivo titular do bem, distingue o Código Civil (art. 98) entre bens públicos e privados, aqueles pertencentes às pessoas jurídicas de direito público interno (art. 41), enquanto esses, a outras pessoas, físicas ou jurídicas.

De fato, o domínio público se traduz em direitos de soberania e direitos de propriedade. Assim, distinguem-se o domínio eminente e o domínio patrimonial, no sentido de que

O domínio eminente é manifestação da soberania e é em razão dele que o Estado firma limitações sobre a propriedade privada e mantém um poder sobre todas as coisas encontradas em seu território. O domínio patrimonial é direito de propriedade, embora sujeito a regras de direito público (DUARTE, 2009, p. 91).

Ademais, bens públicos são aqueles regidos pelo direito público $(\mathrm{CC}$, art. 99, I e II) e ainda os regidos pelo direito privado, se pertencentes ao Estado (CC, art. 99, III). A presente distinção é própria do Direito brasileiro, atendendo à tradição das Ordenações (PONTES DE MIRANDA, 2000). 
Ressalte-se que os bens de uso comum do povo (CC, art. 99, I) constituem aqueles a que todos têm acesso, de modo gratuito ou não (CC, art. 103); enquanto os bens de uso especial são aqueles destinados a atividades inerentes ao serviço público (CC, art. 99, II). Há ainda os bens dominicais, integrantes do domínio patrimonial do Estado (CC, art. 99, III), vez que não se encontram afetados ao uso coletivo nem ao serviço público.

Vale esmiuçar o conteúdo do art. 99 do Código Civil (com redação essencialmente similar à do art. 66 do Código Civil de 1916), segundo a lição de PONTES DE MIRANDA (2000, p. 191):

Os bens de que cogita o art. 66, I, são as coisas públicas em senso estritíssimo, porque quem quer que seja tem acesso ao uso delas. Em senso estrito, elas e as de que se fala no art. 66, II, são as coisas públicas, porque ou o uso toca a qualquer pessoa, ou foram destinadas a algum serviço ou obra administrativa. Porém tal sentido engloba duas classes, de modo que se apaga a separação entre elas, que é exatamente a titularidade do uso. O que se destina a fim administrativo não é, por definição, destinado a todos. Os bens, de que se cogita no art. 66, III, distinguem-se entre si por seu valor de capital. Os de que trata o art. 66, I e II, pelo valor do seu uso imediato, ali, de todos, aqui, de administração. Os bens do art. 66, I, são utilizáveis por todos (...); os do art. 66, II, só se destinam a certa execução de serviço público (...). A linha discretiva entre os bens do art. 66, I, e os do art. 66, II, nem sempre é fácil de se determinar.

Os dois conceitos, de bem particular e de bem público, não correspondem, exatamente, à precipuidade da satisfação dos interesses privados, ou públicos. Há caminhos abertos ao público que pertencem a particulares e deveres e obrigações de direito público que se integram no conteúdo do direito de propriedade e, pois, o limitam. O problema de se distinguirem os bens particulares e os bens públicos é, pois, de solução $a$ posteriori.

Preliminarmente, é mister que se observe que a tricotomia colocada pelo art. 99 do Código Civil atende à diferença de uso, não à de titularidade. A questão da titularidade e sua fonte é pressuposta à questão da destinação. Assim, a dicotomia entre bens públicos a título de direito privado e bens públicos a título de direito público requer a solução prévia do modo de adquirir iure publico.

Nesse sentido, o titular do direito sobre os bens do art. 99, I, não é pessoa de direito público, mas o próprio povo, cabendo ao Estado o dever de cuidado 
(regulamentação). O art. 99, II, indica o uso público dos bens, entendidos como públicos em razão de sua função especial (titularidade pública por destinação). Os bens referidos no art. 99, III, pertencem, em direito privado, ao Estado.

Dessa forma, "a disciplina da propriedade, que se constrói no direito civil, prevê que se publicize a destinação dos bens ditos públicos" (PONTES DE MIRANDA, 2000, p. 171 e s.).

A solução da questão da titularidade reside, portanto, na determinação do conceito de pertença a que se refere o art. 98 do Código Civil. Com efeito, no Direito Romano o populus romanus era senhor das res publicae (populicae), distintas das res privatae, observando-se que o povo romano não se identificava a nenhuma pessoa privada, sequer sendo pessoa. Daí resultar a identificação entre coisa do povo como sendo de todos, ou seja, o que por direito público a todos pertence, por direito privado a ninguém pertence. Cessada, no entanto, a identificação original entre povo e Estado, mister a separação dominial entre o que ao povo pertence e o que ao Príncipe pertence (patrimonium Caesaris). A regra da inalienabilidade permaneceu em relação às res communes omnium, bem como aos bens do patrimônio régio (CC, art. 100), apartados os últimos, porém, do poder coletivo, do incertum corpus (povo). Nesse sentido também os bens do art. 99, II, que por direito público pertencem ao Estado, designados no passado como bens da Coroa, daí sua titularidade caber à pessoas de direito público, como sejam a União e os Estados Federados, e pois suas autarquias. Outrossim, não há distinguir quanto a serem móveis ou imóveis, fungíveis ou infungíveis, consumíveis ou inconsumíveis (PONTES DE MIRANDA, 2000).

No que tange à moeda nacional (REAL), a emissão compete à União (CF, art. 21, VII), devendo ser exercida exclusivamente pelo Banco Central do Brasil (CF, art. $164 \mathrm{c} / \mathrm{c}$ art. $3^{\circ}$ da Lei ${ }^{\circ}$ 9.069, de 1995).

$\mathrm{O}$ ato jurídico de emissão da moeda nacional configura ato de soberania, vale dizer, exercício do domínio eminente sobre coisa fungível de interesse público (dinheiro) ${ }^{212}$, configurando assim modo de aquisição (originário) de propriedade de direito público, na medida em que se reconhece doutrinariamente a possibilidade de aquisição iure publico (PONTES DE MIRANDA, 2000).

Desse modo, a moeda nacional, a partir da sua emissão pelo Banco Central do Brasil, passa a pertencer à União, por atribuição constitucional, incidindo na espécie a 
regra do art. 20, I, da Constituição Federal.

Em razão da própria destinação socioeconômica da moeda, objeto de emissão, frise-se poder "dar-se que bens do patrimônio do Estado sejam destinados ao uso comum, sem se tornarem bens de todos, razão por que há bens do art. 66, I [art. 99, I], que são do patrimônio público do Estado" (PONTES DE MIRANDA, 2000, p. 173). Com efeito,

A destinação ao uso comum do povo ou resulta da natureza da coisa, e então não pode haver desdestinação; ou provém de manifestação de vontade da entidade de direito público a que pertence o bem público. Então a destinação - negócio jurídico unilateral - importa em passagem do bem ao uso comum do povo. Poder-se-ia discutir se essa destinação é negócio jurídico, ato jurídico stricto sensu, ou ato-fato jurídico; mas, por certo, é de negócio jurídico unilateral que se trata (...) (PONTES DE MIRANDA, 2000, p. 179).

De fato, a disponibilidade de moeda nas contas de reservas bancária pode resultar tanto do fornecimento do numerário (espécie) novo, normalmente em substituição do antigo, como das operações no mercado interbancário primário, ou seja, entre o BCB e os titulares das contas Reservas Bancárias. Essas hipóteses de movimentação das contas de reservas podem configurar, portanto, adimplemento, pela referida autarquia, de negócio jurídico unilateral (de emissão), bem como de contratos de troca (de moeda corrente) ou de compra e venda (reporte) de títulos públicos.

Ressalte-se ainda que a procura de numerário por parte dos clientes bancários resulta em que as instituições bancárias efetuem saques em suas contas Reservas Bancárias, de modo a fazer frente a essa demanda, introduzindo, portanto, o papel-moeda em circulação - o que traduz economicamente a emissão monetária.

Assim, a emissão se destina ao atendimento da procura coletiva por moeda (operações bancárias passivas), bem como à realização de operações ativas dos bancos comerciais (abertura de crédito, mútuo), colocando-a, portanto, à disposição das pessoas para a utilização em seus negócios jurídicos (Resolução CMN n 469, de 7.4.1978, itens 16-2-1, 16-7-1-1, “b”).

Nesse sentido também reza o art. 103 do Código Civil, ao dispor que "o uso comum dos bens públicos pode ser gratuito ou retribuído, conforme for estabelecido legalmente pela entidade a cuja administração pertencerem".

Dessarte, as regras de direito público que incidem na presente hipótese dizem respeito à circulação ou utilização pública, do mesmo modo no que tange às regras, ou aos 
regulamentos que disciplinam o serviço do meio circulante pelo BCB (autarquia federal), ou a supervisão do sistema bancário e suas operações no mercado financeiro (PONTES DE MIRANDA, 2000, p. 192; Lei no 4.595, de 1964).

No que tange à inalienabilidade, essa é peculiar aos bens do art. 99, I e II (CC, art. 100). Não obstante, essa questão deve ser interpretada conforme a destinação do bem, "entendendo-se que os produtos e frutos que, segundo o tráfico, se apanham ou colhem para a alienação, não estão clausulados” (PONTES DE MIRANDA, 2000, p. 177).

Com efeito, em razão da destinação socioeconômica da moeda (circulação), em atendimento aos princípios da livre iniciativa e da função social da propriedade $(\mathrm{CF}$, art. 170, III), a moeda emitida é utilizada no tráfico jurídico, comercial e financeiro, de modo a gerar frutos civis (juros e lucros), particularmente como resultado dos contratos de mútuo bancário (operações bancárias ativas), ou dos contratos diferenciais (CC, art. 816).

Cabe ainda uma última consideração em relação à moeda nacional como bem público. Do ponto de vista do Direito Econômico, o corolário natural da titularidade pública da moeda nacional seria a restrição das operações passivas de captação de depósitos à vista (em conta corrente) por parte dos bancos comerciais, restringindo-se dessarte a criação de moeda escritural por essas instituições financeiras.

Nesse sentido, bastaria a aplicação do parâmetro compulsório máximo, a teor da regra contida no art. 10, III, da Lei $\mathrm{n}^{\circ}$ 4.595, de 1964, que atribui ao BCB a competência de determinar o recolhimento de até cem por cento do total de depósitos a vista dos bancos comerciais. Em consequência, restaria garantido o retorno do bem público (moeda) às contas de depósito mantidas no BCB (reservas bancárias), de propriedade pública (depósito irregular - CC, art. 645 c/c art. 587), anulando-se o efeito da emissão bancária (privada, ou no exercício de atividade privada), sob a forma escritural, por bancos comerciais ${ }^{213}$.

Não obstante, é mister não se olvidar de que a moeda nacional, ou padrão monetário nacional, é dizer, o "REAL" constitui objeto da emissão de competência da União, tendo em conta o seu exercício exclusivo pelo Banco Central do Brasil (CF, art. 164 c/c art. $3^{\circ}$ da Lei $n^{\circ} 9.069$, de 1995). Portanto, a regra do citado art. $3^{\circ}$ da legislação federal,

213 Vale frisar que a hipótese aventada encontra sua razão econômica nas propostas de reservas integrais, em cobertura dos depósitos bancários (reservas de 100\%), surgidas particularmente na atribulada década de 1930, tendo entre seus expoentes nada menos que o grande economista norteamericano Irving Fisher. Observe-se ainda que no Brasil, recentemente, por ocasião da implantação do Plano Real (1994), como medida de remonetização forçada da economia na nova moeda, ou novo padrão que se criava, se estabeleceu, mas somente em curto prazo, a compulsoriedade de reservas bancárias integrais para os depósitos bancários à vista, tendo sido prevista, no entanto, sua redução gradativa nos anos subsequentes, como de fato ocorreu. 
que rege o sistema monetário nacional, é norma fundamental do regime monetário vigente, e pois se refere genericamente à unidade monetária nacional (REAL), não restringindo a emissão apenas ao "papel-moeda e moeda metálica", como o faz a Lei no 4.595, de 1964, em seu art. 10, I.

Estar-se-ia, portanto, diante de erro de direito ao se permitir, por meio de norma regulamentar (Resolução CMN no 469, de 7.4.1978, itens 16-2-1, 16-7-1-1, “b”), a captação de recursos a vista pelos bancos comerciais, ainda que em razão do financiamento da economia, vez que as operações ativas também criam moeda escritural por meio da abertura de depósitos bancários em conta corrente, tal como na abertura de crédito bancário, configurando ato jurídico (quiçá negócio jurídico unilateral) de emissão.

Desse modo, a moeda escritural "emitida" pelos bancos comerciais, cuja titularidade se origina de modo de aquisição "privado" de propriedade, se traduz essencialmente no padrão monetário nacional, ou seja, o REAL. Viola-se, em princípio, as regras do art. 164 da Constituição Federal e do art. $3^{\circ}$ da Lei no 9.069 , de $1995^{214}$.

A moeda escritural assim emitida, objeto de negócio jurídico de direito privado, poderia ser interpretada como objeto negocial ilícito, ou ainda o próprio negócio jurídico, que tenha por efeito a emissão de REAL, não estaria a revestir a forma prescrita em lei, tendo por consequência a nulidade do negócio jurídico (privado) que originou o padrão monetário nacional, sob qualquer que seja a sua forma (CC, art. 166).

Vale finalmente frisar o excesso de poder regulamentar atribuído ao Conselho Monetário Nacional em matéria financeira, não raro conferido pela própria legislação ordinária, no sentido de facultar a esse órgão do Executivo a edição de regras jurídicas, ou seja, normas de caráter geral.

214 Sob o prisma econômico, mas também tendo em conta a questão da titularidade estatal da emissão (aquisição originária) da moeda nacional, é mister se frisar, mais uma vez, que a superação definitiva dos riscos gerados pela oferta de moeda de crédito, através do sistema monetário calcado no sistema de reservas bancárias (fracionárias) - oferta monetária endógena ao funcionamento do mercado bancário -, seria sua extinção, e consequente estatização (plena) da emissão monetária, é dizer, a decretação do fim do multiplicador bancário de moeda (escritural), portanto, da captação de depósitos (a vista) em conta corrente, permanecendo a atividade bancária restrita à captação de depósitos a prazo com o fito de investimento financeiro, cientes os depositários dos riscos das aplicações, e pois retomando integralmente o Estado para si a senhoriagem, desonerando ainda o Tesouro Nacional, em razão da redução natural da emissão de dívida (títulos da dívida mobiliária federal) (HUBER, 2011). Tal medida resultaria, essencial e efetivamente, na mitigação, senão eliminação, do próprio "risco do regulador" (risco de crédito da autoridade monetária), pois que se lhe diminuiria radicalmente o ônus financeiro de provedor último de liquidez, desonerando ainda o próprio erário, na medida em que reduziria a retroalimentação do endividamento público através do sofisticado mercado de dívida pública mobiliária (mercado Selic apêndice justamente do mercado de reservas bancárias), cujos títulos obrigacionais, em regra, só fazem avultar o ativo contábil do Banco Central. 
Observe-se, outrossim, o exemplo da Resolução n 2.882, de 2001, que dispõe sobre o sistema de pagamentos, editando "regras gerais" a serem observadas no SPB (art. $3^{\circ}$ ), embora seja clara a dicção da Lei $n^{\circ} 10.214$, de 2001, ao dispor em seu art. 10 que o CMN baixará "as normas e instruções necessárias ao cumprimento desta Lei”.

Não deixa de ser lastimável a omissão do Congresso Nacional em legislar sobre moeda e sistema financeiro, de modo adequado e específico, delegando, pelo menos desde 1964, sua competência constitucional nessa matéria aos órgãos regulamentares do Executivo. Nesse sentido é também a lição de PONTES DE MIRANDA (1966, p. 228), válida hoje tanto quanto outrora: "O que se tem por fito, evidentemente, é a ditadura financeira".

\subsection{A compensação}

A compensação (multilateral) se encontra prevista no art. $3^{\circ}$ da Lei $n^{\circ} 10.214$, de 2001, nos seguintes termos: "É admitida a compensação multilateral de obrigações no âmbito de uma mesma câmara ou prestador de serviços de compensação e de liquidação". Sua definição decorre do parágrafo único ao mesmo dispositivo, como sendo "o procedimento destinado à apuração da soma dos resultados bilaterais devedores e credores de cada participante em relação aos demais".

Trata-se, portanto, do processo de abatimento de créditos e obrigações resultantes das ordens de transferência de recursos ou de ativos (ordens de pagamento) entre os participantes dos sistemas de compensação e liquidação, de modo que, ao final, se os possa reduzir a um único crédito ou a uma única obrigação, cabível a cada participante.

Desse modo, opera-se uma redução dos direitos e obrigações oriundos de negócios jurídicos celebrados nos mercados financeiro e de capitais, por meio de uma multiplicidade de operações de compensação, a um único direito ou obrigação de cada contraparte.

Nesse sentido também é a explicação de AGUIAR JÚNIOR (2001, p. 60):

Assim, se, por exemplo, três participantes houvessem celebrado, dois a dois, negócios jurídicos de que se originassem direitos e deveres, o resultado da compensação do débito de $A$ contra o débito de $B$, do débito de $B$ contra o crédito de $C$, e do débito de $C$ contra o crédito de $A$, sendo cada um dos créditos e débitos do mesmo valor, seria nulo em cada operação de compensação (haveria a extinção das obrigações de $A$ em relação a $B$, de $B$ em relação a $C$, e de $C$ em relação a $A$ ). Mas, para os 
efeitos de liquidação financeira na conta Reservas Bancárias, seria necessário apurar uma única posição jurídica (credora ou devedora) para cada participante relativamente aos demais. Donde se desenvolveu a noção de compensação multilateral, definida como o procedimento pelo qual se calculam os valores correspondentes aos direitos e deveres de cada participante em relação aos demais, para em seguida, abatê-los até a extensão em que se eliminarem mutuamente.

Desse modo, em hipóteses de multilateralidade, ou seja, diante da presença de três ou mais participantes, a câmara de compensação e de liquidação, assumindo ou não a posição de contraparte central, se posiciona entre os participantes de forma a apurar os créditos e débitos recíprocos, realizando seu abatimento, e pois reduzindo acentuadamente o vulto das movimentações interfinanceiras, na medida em que o que se lança a crédito ou a débito em conta Reservas Bancárias de cada participante envolvido é apenas a diferença entre todas as suas operações ativas e passivas.

Assim, fornecem as clearings posições líquidas dos participantes de seus sistemas, resultantes da compensação da totalidade de créditos e de débitos decorrentes dos negócios jurídicos em seu âmbito realizados, em regime de reciprocidade.

Em realidade, os procedimentos de compensação multilateral, abraçados pelo modernos sistemas legais de pagamento, entre eles o SPB, têm sua origem na prática bancária, no âmbito da chamada administração do risco de crédito, ou seja, o risco de descumprimento da obrigação pela contraparte devedora. Assim, leciona YAZBEK (2006, p. 332) que

tais acordos, firmados entre os bancos e seus clientes, dispõem sobre o vencimento antecipado das operações entre eles existentes, em caso de quebra de uma das partes, permitindo a compensação (o set-off, para os autores de língua inglesa) dos valores correspondentes a tais operações. Eles ganham importância, sobretudo, no caso de clientes que mantêm com a instituição financeira relações diversas, com a contratação de operações de hedge (no mais das vezes, contratos a termo ou swaps) ao lado das operações bancárias mais tradicionais.

A administração do risco de crédito neste tipo de arranjo é operada a partir da criação de um saldo líquido, onde antes haveria posições credoras e devedoras de diferentes status perante a massa falida. Ao invés de habilitar-se para procurar receber seu crédito e de ser demandada a pagar seu débito quando do vencimento da operação (...), a instituição 
financeira obtém, por compensação, a redução de sua exposição - seus créditos são quitados por seus débitos, daí decorrendo apenas uma posição residual a ser paga ou para a qual a instituição deva habilitar-se.

Do mesmo modo, a compensação já era permitida no Direito Romano préjustinianeu quando se tratava de ação do banqueiro (argentarius) contra seu cliente. Ao banqueiro cabia primeiramente fazer o balanço da conta do cliente, podendo então cobrar somente o saldo em juízo - daí a expressão cum compensatione agere (AZEVEDO, 1920, p. 11).

Da mesma forma que a compensação bilateral da lei civil, busca-se com a multilateralidade a eliminação do risco de eventual insolvência do credor pago (MONTEIRO, 2011).

Nesse sentido também é a lição do Direito Romano clássico, quando o patrimônio de um insolvável (defraudator) tinha sido adquirido por um terceiro (bonorum emptor), podia este, como successor in universum jus, proceder à cobrança das dívidas ativas da massa, mas era obrigado a permitir que se fizesse a compensação do que a massa devia àquele a quem acionava, recebendo apenas a diferença. Era a isto que se chamava-agere cum deductione.

Diferentemente do caso do argentarius, para o qual a compensação deveria ser feita de antemão, incluindo-se desde logo na intentio, para o bonorum emptor a compensação tinha lugar na condemnatio, por via de deductio. Daí decorre que o emptor não sofria a pena consistente na perda de seu direito creditório, como acontecia com o primeiro, e isto porque não incorria em plus petitio.

Aliás, era razoável que fosse tratado com menos rigor, não se lhe podendo exigir o conhecimento exato dos negócios de um insolvável.

Por outro lado, como era de interesse a liquidação completa de todos esses negócios, permitia-se a deductio mesmo tratando-se de dívidas não vencidas e daquelas que não tinham por objeto coisas do gênero das reclamadas pelo bonorum emptor (AZEVEDO, 1920, p. 12 e s.).

Assim, fornecem as clearings posições líquidas dos participantes de seus sistemas, resultantes da compensação da totalidade de créditos e de débitos decorrentes dos negócios jurídicos em seu âmbito realizados, em regime de reciprocidade, tanto na hipótese de compensação multilateral sem contraparte central, como naquela em que também haja a assunção da qualidade de parte contratante central pela clearing. 


\subsubsection{A compensação multilateral}

A compensação configura modo indireto de extinção das obrigações, vez que o devedor não realiza efetivamente a prestação. Nesse sentido, define a regra do art. 368 do Código Civil que "se duas pessoas forem ao mesmo tempo credor e devedor uma da outra, as duas obrigações extinguem-se, até onde se compensarem”.

A compensação pode ainda resultar de disposição legal, operando-se independentemente da vontade das partes (compensação legal). Exemplo de compensação ope legis é a prevista no art. 122 da Lei $\mathrm{n}^{\circ} 11.101$, de 9.2.2005, que dispõe sobre a compensação das dívidas do falido vencidas até o dia da declaração de falência. Também pode resultar da vontade das partes, sendo então denominada convencional.

Nesse sentido é a lição de MARTINS (2010, p. 30 e s.):

As regras contidas nos arts. 368 a 380 do Código Civil referem-se à compensação legal. Seguimos, nesse sentido, a orientação do Código Civil francês, que, no art. 1.290, estabeleceu que a compensação legal se realiza de pleno direito, mesmo à revelia dos devedores, extinguindo-se reciprocamente as dívidas no momento em que se opera a compensação. Daí resulta que, para que se verifique a compensação legal, não é necessária a declaração do juiz nem o requerimento das partes; a própria renúncia à compensação legal deverá ser manifestada por uma das partes (...), ou excluída por ambas, de mútuo acordo.

Essa foi, também, a orientação tomada pelo atual Código Civil italiano de 1942, ao estatuir, no art. 1.242, que a compensação extingue os dois débitos, a partir do dia de sua coexistência, não podendo o juiz relevá-la ex officio. Mas a verdade é que existe uma outra corrente legislativa, encabeçada pelo Código Civil alemão e seguida pelo Código Suíço das Obrigações, segundo a qual a compensação, para poder surtir efeito, deverá ser declarada por uma das partes. Assim sendo, é indispensável a manifestação do juiz para que a compensação se possa verificar, passando, contudo, ela a ter efeito retroativo, o que não acontece com o sistema francês ou o brasileiro, em que não há retroatividade de efeitos da compensação, já que essa se opera independentemente da vontade das partes. O Código Suíço das Obrigações, seguindo a orientação do alemão, estatui, no art. 124, que "a compensação não tem lugar senão quando o devedor dá a conhecer ao credor sua intenção de invocá-la". 
A compensação legal é, em regra, bilateral e se refere a dívidas vencidas e líquidas, cujos credores são ao mesmo tempo devedores um do outro. Deve haver, portanto, identidade entre credor e devedor, a teor do art. 368 do Código Civil. Outrossim, deve haver reciprocidade de dívidas líquidas, vencidas, e homogêneas. No que tange à fonte das dívidas, é requisito fundamental que essas se originem de títulos diversos. Presentes os requisitos, a compensação se opera de pleno direito, não obstante haver a possibilidade de compensação convencional (GOMES, 1988; MONTEIRO, 2011; VENOSA, 2012).

Na modalidade convencional, por sua vez, há plena liberdade das partes em não se reger pelos dispositivos da lei civil, dispensando-se os requisitos legais acima mencionados. Desse modo, a compensação objeto de avença contratual pode se efetuar entre dívidas ilíquidas ou de coisas infungíveis, ao revés do que dispõe o art. 369 do Código Civil, que exige esses requisitos para que possa haver compensação legal. Assim, o único limite imposto à compensação convencional é o de ordem pública (MARTINS, 2010).

Nesse sentido é a dicção do art. $3^{\circ}$ da Lei $n^{\circ} 10.214$, de 2001: "É admitida a compensação multilateral de obrigações no âmbito de uma mesma câmara ou prestador de serviços de compensação e de liquidação". Assim, a compensação multilateral é facultativa, do que decorre ser necessariamente convencional.

Nesse sentido também é o entendimento de GOMES (1988, p. 157): “Modalidade especial da compensação voluntária é a facultativa, que pressupõe renúncia de um dos interessados ao obstáculo que a impediria”.

Com efeito. O requisito fundamental da compensação legal é a própria diversidade de títulos que originam as obrigações a serem compensadas. Se assim não fosse, todo contrato bilateral poderia ser extinto por compensação, vez que estruturalmente torna cada contratante credor e devedor do outro. Absurdo se admitir que dívidas provenientes do mesmo título possam ser compensadas, contrariando a própria finalidade do contrato. De fato, caso o vendedor pudesse se recusar a efetuar a tradição da coisa vendida sob a alegação de que essa obrigação se compensa com o preço a ser pago pelo comprador, o próprio fundamento do contrato seria falacioso (GOMES, 1988).

Não obstante, na compensação multilateral o que ocorre é justamente a possibilidade de identidade entre os títulos obrigacionais, vez que não raro os próprios contraentes originais têm suas dívidas reciprocamente compensadas a partir da mesma 
avença pactuada (p. ex., contrato de compra e venda de um lote de valores acionários). Ademais, os contratos não raro são padronizados, e pois repetitivos nos ambientes de negócios das clearings.

Assim, frise-se novamente o seguinte exemplo: acaso três participantes houvessem celebrado, dois a dois, negócios jurídicos de que se originassem direitos e deveres, o resultado da compensação do débito de $A$ contra o débito de $B$, do débito de $B$ contra o crédito de $C$, e do débito de $C$ contra o crédito de $A$, sendo cada um dos créditos e débitos do mesmo valor, seria nulo em cada operação de compensação (haveria a extinção das obrigações de $A$ em relação a $B$, de $B$ em relação a $C$, e de $C$ em relação a $A$ ). Porém, para os efeitos de liquidação financeira na conta de liquidação, ou Reservas Bancárias, seria necessário apurar uma única posição jurídica (credora ou devedora) para cada participante relativamente aos demais.

Dessa forma, a despeito da fungibilidade de valores mobiliários e do dinheiro, além da homogeneidade das dívidas, não incidiria a regra da compensação legal em razão da frequente identidade de títulos como fonte das obrigações a serem compensadas. Tratase, na compensação multilateral, fundamentalmente da modalidade facultativa de compensação voluntária.

Nesse sentido, vale ressaltar o entendimento de GOMES (1988, p. 159):

$\mathrm{Na}$ compensação voluntária, os pressupostos da homogeneidade e liquidez podem ser dispensados de comum acordo. Nada obsta a que estipulem a extinção das dívidas recíprocas, mediante compensação, sob as condições que lhes convenham, mas a reciprocidade das duas dívidas é, obviamente, necessária.

Advirta-se, no entanto, que a homogeneidade se liga ao conceito de fungibilidade, uma vez não bastar

que as duas coisas sejam fungíveis por si mesmas, consideradas separadamente, mas que sejam fungíveis entre si, de sorte que com uma ou com outra, poderia qualquer das duas obrigações ser satisfeita. De onde se vê que não basta atender ao gênero, mas igualmente à qualidade (...). É que, na compensação se compreende (...) um duplo pagamento fictício, devendo cada credor, por efeito da compensação, encontrar-se na mesma situação em que estaria se recebesse o pagamento real de seu crédito. Não pode, por isso, haver compensação, quando uma das obrigações é alternativa, contra a vontade da parte a quem pertence a 
escolha. Assim também quando é facultativa uma das obrigações (ESPINOLA, 1951, p. 213).

Com efeito, quem compensa solve, mas não juridicamente nem economicamente, senão que realiza dois pagamentos inversos, ainda que não completamente. Assim,

na compensação não há só dois pagamentos, separados (o terceiro pode pagar; não pode compensar); há, de um lado, pagamento e recebimento, e, do outro, recebimento e pagamento, porém sem existir, talvez, no patrimônio de um e no patrimônio do outro, aquilo com que um e outro solvem. Essa dificuldade levou, diretamente, a pensar-se em dação em soluto, ou em remissão bilateral. Em verdade, a compensação extingue os créditos, como o extinguiriam duas dações em soluto, dois pagamentos, duas remissões: o elemento comum é a extinção; portanto, o efeito. Em comparação com o pagamento, ela e os seus efeitos são determinados, distintivamente, pelo fato de não receber o credor o objeto do débito (PONTES DE MIRANDA, 1959a, p. 363).

A presente modalidade de compensação se destina, portanto, à apuração da soma dos resultados bilaterais, devedores e credores de cada participante de uma caixa de liquidação em relação aos demais. Resulta assim do abatimento dos créditos e débitos objetos das ordens de pagamento entre os participantes (transferência do valor mobiliário contra pagamento pecuniário), de modo que, ao final, reduzam-se a um único crédito, ou débito, atribuível a cada participante, cujo valor mobiliário negociado será escrituralmente lançado a débito ou a crédito na conta de custódia, e pois a quantia em dinheiro será lançada numa conta de liquidação mantida junto ao banco central ${ }^{215}$.

$\mathrm{Na}$ hipótese de multilateralidade, em que há envolvimento de diversos participantes, a câmara de compensação se posiciona entre eles, de modo a apurar globalmente os créditos e débitos bilaterais, abatendo-os até a extensão em que se eliminarem mutuamente.

Trata-se, portanto, de modalidade avançada de compensação interbancária, estendida às câmaras de custódia e liquidação que atuam nos diversos segmentos dos mercados financeiro e de capitais, do mesmo modo que tradicionalmente se faz com a compensação de cheques ${ }^{216}$. Nessa hipótese, ressalte-se que

\footnotetext{
215 Em caso de compensação de créditos e débitos originados de negócios de câmbio (dólar), certamente se trata de lançamentos contábeis recíprocos de pecúnia.

216 Vale lembrar que as operações de compensação de cheques, no âmbito do SPB, são realizadas pela Compe.
} 
não há relação jurídica entre os bancos, um é devedor e credor e outro credor e devedor, sem que haja a identidade de devedor e credor recíprocos. Um cheque, por exemplo, é de A contra o Banco de Crédito Real de Minas Gerais, entregue ao Banco Andrade Arnaud S.A., e outro cheque é de B contra o Banco Andrade Arnaud S.A., entregue ao Banco Crédito Real de Minas Gerais. Títulos abstratos, a situação que se estabelece é de pessoas jurídicas insertas na linha circulatória. Se o Banco que tem o cheque de A fosse recebê-lo no Banco que tem o depósito bancário de A, sem saber, ou sabendo, que o Banco depositário tem cheque de cliente do Banco portador ou endossatário do cheque, não haveria compensação.

Diante da multiplicidade de bancos, tem-se de pensar em lugar, escritório, repartição, ou empresa, a que se hajam de remeter os títulos para pluralisticamente se passar à compensação, diminuindo-se o trabalho e as dificuldades das apresentações separadas para recebimento e das compensações, quase sempre ignoradas. Mediante essa eliminação de percursos e de investigações, estabelece-se a compensação coletiva, com a liquidação global, mediante outorga - ex lege, ou contratual - de poderes para apresentação, verificação e compensação entre os diversos bancos (PONTES DE MIRANDA, 1966, p. 163).

Independentemente de ser o agente de compensação sociedade de direito privado, ou autarquia, a que a lei, ou contrato atribuiu funções compensativas em caráter de multiplicidade, deve o Estado exercer vigilância, sobretudo em razão da relevância da função compensativa diante da massa de créditos e de débitos.

Desse modo,

O excesso de crédito é creditado ao banco credor, que não devia o mesmo; o excesso de débito é debitado ao banco, que não era credor de igual quantia. Pode ser lançado todo o crédito, ou todo o débito, por ser sem débito o banco, ou faltar ao banco algum crédito. Supõe-se que o banco devedor tenha ativo na Câmara de Compensação (PONTES DE MIRANDA, 1966, p. 164).

A finalidade operacional da câmara de compensação é a de extinguir os créditos e os débitos, até onde haja concorrência, cujo requisito fundamental é a objetividade entre todos os remetentes dos títulos (PONTES DE MIRANDA, 1966).

Com efeito, a câmara de compensação 
foi e é uma das criações mais eficientes da economia. Supõe conhecimento, organização e propósito de simplificar, na base de atos contabilísticos e atos-fatos jurídicos, pois que os pagamentos o são, as permanentes emissões e negociações de títulos. Em vez de intervir em relações de A e B, faz contatos entre multiplicidade de credores e de devedores, em vez de os por em contato. De certo modo, faticamente se substitui aos credores e aos devedores, para simplificar, o mais possível, a solução das dívidas entre muitos bancos (PONTES DE MIRANDA, 1966, p. 166).

$\mathrm{Na}$ verdade, há pluralidade de legitimados entre os credores e devedores dos valores mobiliários e das quantias em dinheiro, na medida em que as operações não são apenas entre os credores e devedores imediatos. Trata-se de "ato-fato jurídico complexivo", como seria o do pagamento ordinário, ou de pagamentos ordinários, por meio de operação contabilística de câmara de compensação.

A adesão contratual ao serviço de compensação da clearing, de modo a se liquidarem os futuros créditos e débitos oriundos dos negócios financeiros nela cursados, não implica negócio jurídico fiduciário, mas somente a "outorga de poder de compensar", ou seja, para a prática dos atos necessários à compensação interbancária (PONTES DE MIRANDA, 1966).

Há, portanto, delegação de pagamento, já estudada anteriormente, cujo efeito é a solução das dívidas por meio de compensação multilateral.

\subsubsection{A contraparte central}

Outro aspecto jurídico fundamental do SPB reside na assunção da qualidade de parte contratante pela câmara de compensação e liquidação, desde que considerada sistemicamente importante pelo BCB (Lei ${ }^{\circ} 10.214$, de 2001, art. $4^{\circ}$ ).

São considerados sistemicamente importantes, pelo $\mathrm{BCB}$, as câmaras e prestadores de serviços de compensação e liquidação (inclua-se a custódia) que operam os sistemas de liquidação de transações com ativos financeiros, títulos, valores mobiliários, derivativos financeiros e moedas estrangeiras, independentemente do valor individual de cada transação e do giro financeiro diário. Outrossim, os sistemas de liquidação de transferências de fundos e de outras obrigações interbancárias que não as anteriormente citadas, desde que o giro financeiro diário médio seja superior a $4 \%$ do giro médio diário do STR, ou que os efeitos da inadimplência de um participante em relação aos demais 
(efeito-contágio), em sistemas de liquidação diferida que utilizem a compensação multilateral, a critério do $\mathrm{BCB}$, coloquem em risco a fluidez dos pagamentos no âmbito do SPB (art. 8, I, II, “a” e “b” do Regulamento anexo à Circular BCB no 3.057, de 2001).

Por definição legal, o resultado da compensação multilateral, no presente caso, corresponde ao resultado de cada parte em relação à câmara de compensação e liquidação que assuma a posição de parte contratante para fins de liquidação das obrigações, realizada por seu intermédio (Lei ${ }^{\circ} 10.214$, de 2001, art. $4^{\circ}, 2^{\mathrm{a}}$ parte).

Em razão do posicionamento central da câmara, eliminando o risco de crédito, compensam-se créditos e débitos de contraparte eventualmente insolvente para com a câmara, uns contra os outros. Tal não se daria em caso de contratação direta das operações financeiras entre várias partes diferentes, pois se romperia o princípio da identidade entre credor e devedor. Vale novamente lembrar que a compensação da lei civil exige a reciprocidade de sujeitos da relação creditícia, com exceção ao fiador, ou seja, o devedor principal não pode compensar seu débito com o do credor para com o fiador, mas esse último pode compensar sua dívida com a de seu credor ao devedor principal (afiançado) (CC, art.371; MONTEIRO, 2011; SALOMÃO NETO, 2007).

Em razão da assunção da posição de parte contratante pela câmara, sustenta-se haver, nesse caso, espécie subjetiva de novação (CC, art. 360, II e III), na medida em que credor e devedor originais passam à condição de credor e devedor da câmara, espécie de "fiadora" da liquidação, vale dizer, da incondicionalidade e irrevogabilidade dos pagamentos (AGUIAR JÚNIOR, 2001).

Ressalte-se, no entanto, que não haveria solidariedade entre a câmara e o emissor do título ou devedor da obrigação, objeto de liquidação ou compensação. Ressalva-se, assim, o chamado risco de emissão, ou seja, a câmara não responde pelo adimplemento das obrigações originárias do emissor, de resgatar o principal e os acessórios de seus títulos e valores mobiliários objeto de compensação e de liquidação (Lei n ${ }^{\circ} 10.214$, de 2001, art. $4^{\circ}$, $\left.\S 1^{\circ}\right)$.

$\mathrm{Na}$ presente hipótese, a câmara toma a titularidade dos direitos e deveres obrigacionais dos participantes originais, passando esses últimos a ter aquela entidade como sua credora ou devedora, a qual se encarregará de receber o que se lhe deve e de pagar o que se lhe é exigível. Nesse sentido, leciona AGUIAR JÚNIOR (2001, p. 62):

Note-se que, com esse modus operandi, tem-se o seguinte curso: suponha-se que o participante $A$ vende a $B$ o ativo $a$ ao preço de 
$\mathrm{R} \$ 1.000,00$; este, de sua vez, paga o preço de $\mathrm{R} \$ 1.000,00$ pela venda do ativo $a$, de titularidade do participante $A$. Celebrado o negócio jurídico, que é solo consensu, os participantes $A$ e $B$ registram-no numa câmara ou prestador de serviços de compensação e de liquidação, que, se considerada sistemicamente importante pelo Banco Central do Brasil, passará a responder perante $A$ pelo pagamento do preço e perante $B$ pela entrega do ativo. Ou seja, a sorte das obrigações (adimplemento, inadimplemento), daí em diante, não mais dependerá, para $A$, das vicissitudes inerentes ao cumprimento da obrigação de $B$, e vice-versa. Tanto $A$ quanto $B$ se reportarão, desde o momento inicial da novação, à câmara e ao prestador de serviços de compensação e liquidação, que encaminhará aquelas obrigações à liquidação, repassando a $B$ o ativo $a$, recebido de $A$, e a $A$ o preço de $\mathrm{R} \$ 1.000,00$, recebido de $B$. Feito isto, as obrigações se extinguirão e nada mais poderá ser exigido de $A$, de $B$ ou da câmara ou do prestador de serviços de compensação e de liquidação, sendo certo, ainda, que esta procederá ao encaminhamento das informações referentes a todos os lançamentos efetuados, bem assim ao resultado financeiro apurado ao final do dia, que será creditado e debitado na conta Reservas Bancárias [ou na conta de liquidação] de $A$ e de $B$ (...).

Na novação há o ajuste entre credor e devedor de nova obrigação com a intenção deliberada (ânimo de novar) de substituir a obrigação anterior. Observe-se que nem a prestação original nem a nova prestação assumida são cumpridas, havendo antes substituição de uma obrigação pendente por outra também pendente, ou seja, ainda devida pelo devedor. Ainda assim, aceita o credor que seja considerada extinta a obrigação originária, podendo só exigir o adimplemento da obrigação que a substituiu. Trata-se, portanto, de modo extintivo, mas não satisfativo das obrigações, sendo sempre contratual sua natureza (BDINE JR., 2009, p. 350).

Nesse sentido, são requisitos da novação: a) a existência de obrigação originária; b) uma nova obrigação; e c) a intenção de novar.

$\mathrm{Na}$ hipótese em estudo, entendido haver novação, seria essa então subjetiva, em razão de o novo devedor (câmara liquidante) suceder ao antigo, ficando esse quite com o credor, e, ainda em razão da obrigação nova, substituir a câmara o antigo credor, ficando o devedor quite com esse último. Assim, seria a novação concomitantemente passiva e ativa.

Observe-se, no entanto, que a novação subjetiva passiva (devedor) (CC, art. 360, 
II) pressupõe não apenas um novo devedor, mas também que esse assuma uma nova obrigação em relação ao credor, distinta da original. Sem embargo, se a obrigação for a mesma, a hipótese será de assunção de dívida (CC, arts. 299 e ss.).

Vale recordar que na assunção de dívida o devedor anterior se libera, sub-rogandose um novo devedor, mas a obrigação segue sendo a mesma (ENNECCERUS, 1947, p. 404).

Com efeito, na assunção de dívida alheia assume o terceiro (assumente) a posição jurídica do devedor, não obstante permaneça a mesma a relação obrigacional, tal como é a mesma a relação jurídica se o credor cede o crédito. Pela assunção de dívida se permite que "alguém se faça devedor em vez de outrem, que o era e saiu da relação jurídica; mas essa continua a mesma" (PONTES DE MIRANDA, 1959b, p. 86).

Note-se a diferença básica com a novação subjetiva, vez que nessa não há "assunção" de obrigação alheia, pois o devedor assume dívida e obrigação próprias, em razão da nova relação jurídica que se funda após a outra, que se extingue. Portanto, o efeito do negócio jurídico novativo é o de extinguir a dívida, não a inserção de novo devedor na obrigação.

De qualquer modo, tanto na assunção como na novação subjetiva passiva, a lei civil requer essencialmente a vênia do credor, sob pena de invalidade do negócio, em razão do interesse do credor na solvência de seu devedor. Ao revés, a novação subjetiva ativa (credor) (CC, art. 360, III) pode ocorrer sem anuência do devedor original (CC, art. 362), se amparando na substituição do credor original por outro, mas sempre em razão de nova obrigação, sob pena de se configurar cessão de crédito (CC, arts. 286 e ss.). Em ambos os casos de novação subjetiva, deve haver substancial modificação da prestação obrigacional original, caso contrário, não terá lugar a novação, mas antes assunção de dívida ou cessão de crédito. Nessa última a mesma obrigação se transfere ao credor, enquanto na novação ativa a obrigação original se extingue (BDINE JR., 2009, p. 351).

No que tange ao ânimo de novar, entende-se presente quando há intenção inequívoca, ainda que tácita, de extinguir a obrigação original, sem adimplemento, mas por meio de sua substituição por outra. Em regra, identifica-se essa intenção na incompatibilidade entre a antiga e a nova obrigação. Desse modo, alterações de prazos de pagamento, mudanças de taxas de juros e cláusula penal, ou ainda reforço de garantias não revelam a mencionada intenção. Portanto, sendo de pouco significado para o conteúdo da prestação, ou não havendo mudança substancial na natureza da obrigação, não se falar em 
novação. Em caso contrário, a segunda obrigação apenas confirmará a primeira $(\mathrm{CC}$, art. 361; BDINE JR., 2009; MONTEIRO, 2011).

Nada obstante as lições anteriores, AGUIAR JÚNIOR (2001, p. 62) assevera que a assunção pela câmara liquidante da qualidade de parte contratante consiste em "novação subjetiva de obrigações, imposta por ato político com força de lei”, referindo-se à Medida Provisória $\mathrm{n}^{\mathrm{o}}$ 2.040-12, de 23.11.2000, cujos termos de seu art. $4^{\circ}$ foram fielmente reproduzidos na regra do art. $4^{\circ}$ da Lei $n^{\circ} 10.214$, de 2001. Nesse sentido é a sua lição:

De ver-se que, em verdade, não há mudança das partes contratantes, pois isto seria atingir o plano da existência do negócio jurídico. Vale dizer, ao fazer-se menção à parte contratante, agrega-se que a assunção desta posição jurídica pela clearing é para fins de liquidação das obrigações relativas às operações nela registradas e aceitas. Está-se, aí, no plano da eficácia, posterius em relação ao da existência. Está-se, portanto, no plano das relações jurídicas, direitos, deveres e obrigações, cuja titularidade a câmara ou prestador de serviços de compensação e de liquidação assume ope legis, extinguindo as obrigações existentes entre os participantes pela substituição por outras obrigações, em que estes figuram como credores e devedores em relação à clearing e esta, como devedora e credora em relação a cada um dos participantes (AGUIAR JÚNIOR, 2001, p. 63 e s.).

No que tange ainda à possibilidade teórica da novação, seria possível vislumbrar na hipótese uma espécie de contrato de contra corrente, atípico em nosso sistema. Nessa hipótese, tanto os valores mobiliários como os créditos escriturados se fundem num todo indissolúvel, perdendo sua individualidade por efeito mesmo da novação que se opera (MONTEIRO, 2011, p. 165), de modo a serem liquidadas por diferença as obrigações (fungíveis) e, ao final, redistribuídas individualmente as respectivas cotas de títulos, mediante lançamentos contábeis.

Com efeito, as obrigações escrituradas na conta de liquidação da câmara deixariam de ter natureza autônoma, ao contrário do que ocorre, por exemplo, no depósito bancário ordinário (irregular), passando então a ser devidos em razão do próprio contrato de conta corrente. Desse modo, pode-se vislumbrar o efeito da novação que se opera ao se inserir a instituição liquidante como contraparte de todos os participantes ("correntistas"), incidindo a regra do art. 360, I, do Código Civil. Outro efeito resultante do desaparecimento dos débitos e créditos originais, lançados na conta única de liquidação, é 
sua indivisibilidade, ao menos temporariamente. Em verdade, são substituídos por uma relação jurídica complexa, não se lhes permitindo distinguir para efeito de cobrança, compensação ou outro qualquer, até o momento da liquidação final da conta, que sói se realizar diariamente no caso do SPB.

Ressalte-se todavia que a compensação em exame, multilateral, não implica essencialmente nenhuma novação, não decorrendo esse entendimento necessariamente do texto legal, anteriormente reproduzido. Equivoca-se tal entendimento não somente em razão de se repelir espécie de "novação legal”, em razão de disposição "tácita" da lei especial, e pois ao arrepio do Código Civil.

Não obstante, a melhor opção doutrinária se encaminha no sentido de se rejeitar a novação, toda vez que não há intenção de extinguir a dívida pelo fato da intermediação da câmara, mas antes de reforçar a dívida existente por meio de garantia ao pagamento das obrigações oriundas do negócio jurídico registrado na câmara.

Com efeito, a assunção da posição de parte contratante é somente "para fins de liquidação das obrigações”, portanto, destina-se ao adimplemento (Lei n 10.214, de 2001, art. $4^{\circ}$ in fine). Não se cria nova dívida, vez que não há modificação substancial da relação jurídica obrigacional. Em regra, identifica-se essa intenção na incompatibilidade entre a antiga e a nova obrigação, o que não ocorre na presente hipótese.

Observe-se novamente que a novação subjetiva passiva (devedor) (CC, art. 360, II) pressupõe não apenas um novo devedor, mas também que esse assuma uma nova obrigação em relação ao credor, distinta da original. Sem embargo, a obrigação permanece sendo a mesma, assumindo a câmara liquidante a obrigação de pagamento perante ambas as partes, pois não há cessão de crédito, de um lado, e assunção de dívida, de outro, mas assunção do dever de adimplir para ambos os lados, ou seja, transferindo a titularidade dos valores mobiliários paralelamente à transferência de fundos.

Note-se, outrossim, que as obrigações originárias do emissor permanecem, sem que se opere sua extinção em razão da assunção de parte contratante para o pagamento (Lei $\mathrm{n}^{\mathrm{o}} 10.214$, art. $\left.4^{\mathrm{o}}, \S 1^{\mathrm{o}}\right)$.

Vale recordar que na assunção de dívida o devedor anterior se libera, sub-rogandose um novo devedor, mas a obrigação segue sendo a mesma (ENNECCERUS, 1947, p. 404).

$\mathrm{Na}$ realidade, há pluralidade de legitimados entre os credores e devedores dos valores mobiliários e das quantias em dinheiro, na medida em que as operações não são 
apenas entre os credores e devedores imediatos. Trata-se de "ato-fato jurídico complexivo", como seria o do pagamento ordinário, ou de pagamentos ordinários, por meio de operação contabilística de câmara de compensação (PONTES DE MIRANDA, 1966).

Não obstante, na presente hipótese, tendo em conta que a câmara se substitui aos devedores das prestações de dar assumidas pelas contrapartes, passa a câmara liquidante à condição de verdadeiro responsável pelo pagamento, não havendo somente outorga para compensar, solvendo, mas assunção do pagamento, com a consequente exoneração do credor e devedor originais.

Para tanto, as câmaras deverão contar com o depósito de garantias para assegurar a liquidação das obrigações compensadas, permitindo-se inclusive a execução direta dessas garantias (Lei $n^{\circ} 10.214$, de 2001, art. $4^{\circ}, \S \S 2^{\circ}$ e $3^{\circ}$ ).

Nesse sentido, aliás, restaria também excluída a hipótese de novação, anteriormente afastada, tendo em conta que esse modo indireto de adimplemento em regra extingue as garantias da dívida (CC, art. 364), o que também não se coaduna com as mencionadas regras da lei especial.

Haveria, portanto, delegação de pagamento, já estudada anteriormente, cujo efeito é a solução das dívidas por meio de compensação multilateral.

Vale lembrar, nesse sentido, as modalidades de instrumento delegatório, sendo corrente a distinção entre delegação de cumprimento (solvendi) e delegação de promessa (de cumprimento) (promittendi). Nessa, há a verdadeira delegação, enquanto sucessão singular, ou ao menos cumulação passiva, com a promessa feita por terceiro ao credor de que cumprirá a obrigação; naquela, ao revés, não há promessa de pagamento por parte do terceiro em relação ao credor, mas apenas a promessa de efetuar o pagamento à ordem do devedor primitivo. Com efeito, assim leciona GOMES (1988, p. 265):

A primeira, também chamada delegação de cumprimento ou, ainda, delegação de pagamento, consiste numa ordem dada pelo devedor originário a outra pessoa para que, em seu lugar, pague a dívida. A pessoa a quem se dirige a ordem não assume a obrigação do devedor, pois que se limita a pagar. Obriga-se simplesmente a solver a obrigação do devedor que cometeu esse encargo. Uma vez que não implica assunção de dívida ao lado do devedor ou substituição deste na relação obrigacional, não configura verdadeira delegação, senão espécie afim, chamada, no Direito suíço, assunção interna de dívida, a que Von Tuhr, como visto, prefere 
chamar promessa de liberação. A pessoa a quem o devedor ordena que pague, compromete-se, tão só, a efetuar o pagamento, liberando-o, por via de consequência. É claro, porém, que, se esta pessoa é, por sua vez, devedora do devedor, haverá delegação, embora não se verifique sucessão passiva na relação obrigacional que este travara com o credor.

A delegatio promittendi é a figura autêntica de delegação, seja liberatória ou cumulativa. Há delegação de débito quanto o terceiro contrai a obrigação, sucedendo a devedor ou a ele se unindo, com a promessa, feita ao credor, de que a cumprirá. (...) Nesta figura, patenteia-se a modificação subjetiva no lado passivo da relação obrigacional. Ou o devedor originário é substituído, dando ingresso a outro, o delegado, ou este se junta a ele, ocupando, supervenientemente, a mesma posição.

A despeito de se configurar na presente hipótese autêntica delegação liberatória (assunção de dívida), diante da dicção do art. 299 do Código Civil, em que se exige a vênia do credor, parece indubitável que somente diante de um comportamento concludente, consistente, seria possível se interpretar como assentimento essa forma de conduta (BDINE JR., 2009, p. 260 e s.).

Com efeito, a adesão dos contraentes ao serviço de liquidação da câmara sistemicamente importante implica igualmente adesão aos termos da regra contida no citado art. $4^{\circ}$ da Lei $n^{\circ} 10.214$, de 2001 , em que a responsável pela liquidação assume a posição de parte contratante em relação a cada um dos contraentes, de modo a executar o pagamento, liberando-os.

Nesse sentido, vale reproduzir a lição de GOMES (1988, p. 264) quanto à delegação privativa (liberatória):

É privativa quando tem efeito liberatório. O delegante exonera-se, assumindo o delegado inteira responsabilidade pelo débito, não respondendo, sequer, pela insolvência deste. Cria-se, no entendimento geral, novo laço, e, por isso, embora se reconheça que teoricamente é figura distinta da novação subjetiva, são equivalentes, na prática, pela identidade da função.

\subsection{A não sujeição das obrigações aos efeitos da execução}

De modo a garantir a liquidação no âmbito da câmara liquidante, na condição de contraparte central, limitando os riscos de crédito e liquidez, tanto a Lei $\mathrm{n}^{\mathrm{o}} 10.214$, de 
2001, em seu art. $4^{\circ}, \S \S 2^{\circ}$ e $3^{\circ}$, como seu regulamento (anexo à Circular BCB $n^{\circ}$ 3.057/2001), determinam, entre outras medidas de salvaguarda, a constituição de garantias pelos participantes e a criação de fundos de garantia de liquidação.

Desse modo, segregam-se as obrigações de fundo financeiro, a cuja liquidação se dará curso normal, e as demais obrigações dos participantes das referidas câmaras. Nesse sentido, vale transcrever a lição de AGUIAR JÚNIOR (2001, p. 64 e s.):

Note-se que as câmaras e os prestadores de serviços de compensação e de liquidação estão aparelhados à liquidação de um avantajado volume de obrigações. A eles acorrem, por si ou por seus clientes, as instituições participantes, após a realização de operações de compra e venda de títulos, de opções e de swap, ou tendo em vista a transferência de recursos, só para ficar em alguns poucos exemplos de cometimentos financeiros que estão vocacionadas a liquidar. Por isso se concluiu que as clearings, conquanto fossem polos de tramitação de operações financeiras, por sua maior proximidade da trepidância negocial também poderiam ser, como são agora, polos de contenção de riscos potencialmente sistêmicos.

Tratava-se, portanto, de se conferir maior autoridade à sua atuação, parecendo ser esta a razão por que se lhes quis impor, na qualidade de partes contratantes, responsabilidade pela liquidação financeira das obrigações pactuadas, ainda que o participante inicialmente obrigado tenha inadimplido ou tenha sido impedido de adimplir em decorrência do assujeitamento a regimes de insolvência civil, intervenção, liquidação extrajudicial, concordata e falência.

De fato, revela a prática que, estando as obrigações de fundo financeiro geralmente ajustadas por elos bem firmes, a inexistência de pagamento quanto a uma resulta na impossibilidade ou extrema onerosidade de satisfação dos compromissos que, mesmo remotamente, a ela se vincula. É isso o que vê quem olha de fora: os negócios entram e saem a todo o momento dos ambientes e sistemas de negociação disponíveis no mercado, formando cadeias que só se completam se cada um deles for terminado com sucesso. Nesse panorama, dando-se o inadimplemento de uma obrigação, não tinham as câmaras e prestadores de serviços de compensação e de liquidação título jurídico, que não pudesse ser facilmente contestado, para exigir a continuidade e a finalização das 
operações pendentes, o que, em muitos casos, abria espaço à probabilidade de transbordamento dos riscos ao Sistema Financeiro Nacional, com os prejuízos em cadeia tomando o lugar do esperado sucesso dos negócios. Aí, em razão das distorções estruturais do sistema de pagamentos brasileiro, que se vão eliminando a pouco e pouco, o Banco Central do Brasil era compelido a intervir, honrando, com injeção de recursos públicos, compromissos de ordem eminentemente privada.

Dessa forma, a Lei $\mathrm{n}^{\circ} 10.214$, de 2001, atribui às câmaras de liquidação sistemicamente importantes um título jurídico de expressão legal (CC, art. 957) e, por isso, indutor da segurança e da confiabilidade necessárias à tranquilidade dos mercados financeiro e de capitais. Ficam assim as câmaras dotadas de faculdade legal para finalizar, no mesmo dia, os negócios cuja liquidação está a seu encargo, utilizando-se tanto da compensação multilateral como da possibilidade de execução direta de posições em custódia, contratos e garantias aportadas, particularmente em situações de suspensão de pagamento decorrente dos regimes de insolvência civil ou falência (Lei no 10.214, de 2001, art. $7^{\circ}, \S$ único; AGUIAR JÚNIOR, 2001).

Assim, restam legalmente arredadas da eficácia decorrente da execução concursal as obrigações objeto de pagamento no âmbito das mencionadas câmaras. Se um dos participantes tiver decretada sua liquidação extrajudicial, como no caso dos bancos, os créditos contra ele constituídos, desde que guardem relação com tais obrigações, não reverterão à respectiva massa, para pagamento posterior segundo a ordem de preferências e privilégios creditórios. Ao revés, a câmara de compensação e liquidação solverá as obrigações usando as garantias oferecidas, bem como os valores mobiliários e outros ativos objeto das correlatas obrigações.

Com efeito, estabelece o art. $8^{\circ}$, II, da Lei $n^{\circ} 10.214$, de 2001, entre as modalidades de liquidação das obrigações, "a entrega do produto da realização das garantias", sempre que "inexistentes ou insuficientes os ativos negociados ou os recursos a transferir”. Como esclarece AGUIAR JÚNIOR (2001, p. 67):

Há, aí, a definição do como, ou seja, dos passos a serem seguidos pelas clearings no sentido de efetuarem o pagamento das obrigações levadas à liquidação por seu intermédio. Primeiramente, verifica-se se existe o ativo negociado ou, então, se há os recursos a transferir. Se a resposta for afirmativa, a liquidação dar-se-á com a entrega dos ativos ou com a transferência dos recursos. Caso inexistam ou sejam insuficientes os 
ativos negociados ou os recursos a transferir, o passo alternativo é o da entrega, ao parceiro negocial, do produto da realização das garantias prestadas pelo participante obrigado. Tudo, note-se, após a realização de compensação multilateral, daí podendo resultar saldo positivo, que será transferido ao participante, integrando a respectiva massa, se houver; ou, então, saldo negativo, que constituirá crédito da câmara ou do prestador de serviços de compensação e de liquidação contra o participante.

Dessa forma, ficam as câmaras legalmente obrigadas à finalização compulsória dos pagamentos pendentes, até ao final do dia, de modo a se evitar o efeito contágio. As garantias depositadas configurariam assim um título legal especial, justificado a partir da consideração de que o inadimplemento particularizado implicaria uma onda de dificuldades de adimplemento, com prejuízo à solidez e ao normal funcionamento do Sistema Financeiro Nacional. Nessa hipótese, o BCB seria obrigado a assumir os riscos inerentes às obrigações inadimplidas, de modo a evitar que outras instituições tivessem o mesmo destino da que ruiu, o que "não convém ao interesse público" (AGUIAR JÚNIOR, 2001, p. 66).

Os ativos depositados em garantia, preferencialmente líquidos (art. 17 do Regulamento anexo à Circular BCB no 3.057, de 2001), poderão ser assim alienados diretamente pela câmara, de forma a saldar as obrigações dos inadimplentes (Lei $\mathrm{n}^{\circ}$ 10.214, de 2001 , art. $8^{\circ}$, II c/c art. $4^{\circ}, \S 3^{\circ}$ ).

A referida regra especial se sobrepõe, em princípio, aos dispositivos da lei civil que impedem a alienação de coisa empenhada (CC, art. 1.428). Ressalte-se ainda que essa regra do Código Civil recebe tratamento extensivo por parte da jurisprudência, abrangendo todas as hipóteses de garantia ao pagamento de mútuo (SALOMÃO NETO, 2007).

Com efeito, o § único ao art. 1.428 prevê a possibilidade de o devedor, no vencimento da obrigação ou após, dar o bem objeto de garantia real em pagamento ao credor. Trata-se de dação em pagamento, conforme o art. 356 do Código Civil, a qual exige, outrossim, que o consentimento do devedor nunca seja contemporâneo à constituição da garantia real, mas somente no momento do vencimento da obrigação ou após. A promessa de dação, manifestada concomitantemente à constituição da garantia real, ofende a vedação de cláusula comissória (CC, art. 1.428, caput), proibição essa de ordem pública, segundo jurisprudência pacífica do Superior Tribunal de Justiça, abrangente tanto do ato constitutivo da garantia como de convenção posterior (LOUREIRO, 2009, p. 1477).

A doutrina dominante entende que as garantias constituem depósito irregular, ou 
penhor, a depender da fungibilidade dos bens que as compõem. No entanto, há os que as veem como arras, mas, em princípio, sem razão, pois não haveria aí nenhum indício de início de pagamento (CC, arts. 417 e 418; SALOMÃO NETO, 2007).

Com efeito, em regra os ativos líquidos a que se refere o art. 17 do Regulamento anexo à Circular BCB n 3.057, de 2001, constituem garantias pecuniárias ou valores mobiliários que gozam de total liquidez no mercado, normalmente os títulos-gênero, fungíveis, de que são o maior exemplo os títulos da dívida mobiliária federal. Nesse sentido também estabelece o mesmo regulamento, em seu art. 19, que em atenção ao disposto no art. $5^{\circ}$ da Lei $\mathrm{n}^{\mathrm{o}} 10.214$, de 2001, ou seja, para a constituição de patrimônio especial pela câmara sistemicamente importante, sejam oferecidos ao menos $\mathrm{R} \$ 10$ milhões, sob a forma exclusiva de títulos públicos federais, a serem custodiados no Selic em conta de titularidade da respectiva câmara.

Dessarte, a dicção legal e a praxe regulamentar indicam se tratar de depósito de coisa fungível, portanto, depósito irregular, por meio do qual se transfere a propriedade do bem dado em garantia (depositado) ao titular da conta de custódia, ou seja, a câmara de compensação e liquidação, assumente da posição de parte contratante (CC, art. 645 c/c art. 587).

Não obstante a dicção da lei especial, motivada por questão de política legislativa voltada ao interesse de proteção dos mercados financeiro e de capitais, cumpre se notar o "efeito transindividual" do adimplemento levado a efeito nas mencionadas câmaras sistemicamente importantes, no sentido de repercussão negativa nas esferas jurídicas dos credores alheios aos negócios ali cursados, tendo em conta que as garantias depositadas, independentemente de sua forma, não constituem títulos legais de preferência, previstos no art. 958 do Código Civil, a saber, privilégios (direitos pessoais) ou direitos reais de garantia (p. ex., o penhor), mas verdadeiras exceções àqueles títulos de propriedade dos demais credores.

Com efeito, o patrimônio do devedor, enquanto conjunto de bens suscetíveis de penhora, responde por suas obrigações (princípio da universalidade patrimonial). Trata-se de uma garantia geral, efetivada mediante meios técnicos processualmente previstos, como sejam o arresto, penhora, sequestro e arrecadação. A partir do preço obtido com a excussão daqueles bens, em hasta pública, o credor satisfaz seu crédito. Vale dizer, os credores que não gozem de qualquer direito de preferência sobre os demais, são pagos em pé de igualdade (plena proporcionalidade) (LOUREIRO, 2009, p. 1463; ESPINOLA, 1951, p. 
313; VARELA, 1999, p. 430).

A presente regra excepciona, portanto, o princípio da par condicio creditorum, em grau ainda mais elevado em relação aos próprios direitos reais de garantia. Desse modo, cria obrigação de garantia não com caráter subsidiário à obrigação principal $(\mathrm{CC}$, art. 1.419), mas sobretudo com caráter independente e principal, tal como no aval ou na fiança com vínculo de solidariedade (ESPINOLA, 1951, p. 314).

A ratio legis da lei especial reside essencialmente no interesse de proteção dos mercados financeiro e de capitais, enquanto verdadeira exigência de interesse e ordem pública, limitando assim o princípio da universalidade patrimonial. Somente diante de tal interesse, independentemente da questão de sua legitimidade, é que se pode entender o afastamento, em grau superior ao previsto pela lei civil (CC, art. 1.419 c/c art. 1.422).

Ressalte-se ainda que o próprio § único do art. 1.422 do Código Civil apenas ressalva que a preferência do crédito com garantia real não supera o privilégio decorrente diretamente de lei. Nesse sentido, reconhece-se somente o estabelecimento legal de "outros privilégios" que os realmente garantidos, de modo que diante da execução coletiva contra o patrimônio do devedor, o crédito com garantia real deve ser habilitado e não executado em via própria (LOUREIRO, 2009, p. 1469).

$\mathrm{Na}$ realidade, o mencionado efeito (transindividual) do adimplemento, autorizado pela regra do art. $8^{\circ}$, II, da Lei $\mathrm{n}^{\circ} 10.214$, de 2001, cria verdadeira lex comissoria specialis, ao arrepio da tradição civilista (CC, art. 1.428), anteriormente citada, e que só pode ser legitimado enquanto princípio de ordem pública.

Vale observar a seguinte lição de VARELA (1999, p. 427):

Dentro do campo das relações obrigacionais disponíveis (nomeadamente das obrigações ex contractu), a limitação da responsabilidade a uma parte do patrimônio do devedor há-de naturalmente, para ser válida, corresponder a um interesse sério e justificado das partes. Deve, por um lado, especificar os bens sobre que recai a garantia, de acordo com o próprio texto da lei. E deve a limitação corresponder, por outro lado, a uma real necessidade ou conveniência do devedor, compatível com a coercibilidade do vínculo obrigacional, visto às partes não ser lícito criar obrigações naturais (deveres de prestar destituídos de real coercibilidade) fora dos termos em que a lei prevê a sua existência e implantação.

Observe-se, nesse contexto, que Código Civil português não abraçou a regra que permitia ao credor e devedor excluírem, por convenção, o recurso do credor às vias 
judiciárias, tal qual prevista no Anteprojeto do Direito das obrigações, de Vaz Serra (VARELA, 1999, p. 427, n. 2).

Sob o prisma do ordenamento jurídico brasileiro, entendido como ordem axiológica ou teleológica topicamente hierarquizada em função dos princípios constitucionais (FREITAS, 2002), não se pode olvidar de que a estrutura socioeconômica, subjacente à regra jurídica, implica um todo de valorações a serem informadas pelos princípios e valores expressos na Constituição brasileira, particularmente no que tange aos valores próprios da ordem econômica constitucional, na qual também se insere o Direito Civil.

Desse modo, o princípio da proporcionalidade deve ser observado enquanto princípio que preside o ordenamento jurídico em sua integralidade, apresentando-se na esfera privada como dever de proporcionalidade. Com efeito, a própria autonomia privada se desloca de seu papel central na disciplina obrigacional, cedendo espaço ao caráter transindividual que marca o atual o direito obrigacional, e pois a disciplina do adimplemento, na medida em que

não mais centrado e concentrado na relação relativa a dois sujeitos, que liga apenas duas esferas jurídicas patrimoniais, mas verdadeiramente um fenômeno complexo, no qual são "interessados" não apenas os dois protagonistas da relação, o titular da relação, o titular da situação creditória e o da situação debitória, mas também outros sujeitos particularmente qualificados, titulares de uma situação jurídica considerada relevante, e inerte restaria, neste campo, a diretriz constitucional da solidariedade social (MARTINS-COSTA, 2005, p. 373, n. 60).

Nesse panorama, frise-se novamente que o Sistema Financeiro Nacional deve ser estruturado de modo "a servir aos interesses da coletividade, em todas as partes que o compõem" (CF, art. 192). Como sobejamente mostrado, o Sistema de Pagamentos Brasileiro constitui parte integrante, assaz relevante, do sistema financeiro brasileiro.

Com efeito, a finalização compulsória dos pagamentos pendentes, de modo a se evitar o efeito contágio, só se legitima enquanto compreendida no contexto do interesse coletivo. Assim, as garantias depositadas configurariam um título legal especial, justificado a partir da consideração de que o inadimplemento particularizado implicaria uma onda de dificuldades de adimplemento, com prejuízo à solidez e ao normal funcionamento do Sistema Financeiro Nacional. Nessa hipótese, o "pacto comissório" legalmente 
fundamentado evitaria a assunção pelo $\mathrm{BCB}$ dos riscos inerentes às obrigações inadimplidas, a ser evitado em prol da coletividade.

Nada obstante esse entendimento, e pois como inúmeras vezes aventado ao longo do presente escrito, resta questionável a essencialidade de tais medidas excepcionais, ainda que revestidas por regras jurídicas, e não encontradas apenas no seio da regulamentação normativa. Com efeito, não raro é justamente no seio da regulamentação financeira que se encontra a verdadeira ratio iuris da lei especial, a despeito de vestir regra legislativa ordinária.

Nesse sentido, observe-se novamente o exemplo dos "ativos líquidos" a que se refere o art. 17 do Regulamento anexo à Circular $\mathrm{BCB} \mathrm{n}^{\circ}$ 3.057, de 2001, em regra consubstanciados em garantias pecuniárias ou valores mobiliários que gozam de total liquidez no mercado, normalmente os títulos-gênero, fungíveis, de que são o maior exemplo os títulos da dívida mobiliária federal. Assim também o art. 19 do mesmo regulamento, que em atenção ao disposto no art. $5^{\circ}$ da Lei $n^{\circ} 10.214$, de 2001, ou seja, para a constituição de patrimônio especial pela câmara sistemicamente importante, prescreve sejam oferecidos ao menos $\mathrm{R} \$ 10$ milhões, sob a forma exclusiva de títulos públicos federais, a serem custodiados no Selic em conta de titularidade da respectiva câmara.

Desse modo, mais uma vez, recai-se na circularidade, anteriormente evidenciada (HUBER, 2011), de se fomentar um sistema de reservas bancárias como lastro (público) da moeda escritural de crédito, fruto do multiplicador bancário enquanto instrumento de emissão (privada) da moeda nacional (REAL), ao arrepio das normas monetárias constitucionais e ordinárias. O mencionado lastro é público na medida em que se forma, conforma e fomenta no âmbito do ambiente negocial da dívida pública nacional, particularmente da dívida mobiliária federal (Selic), parte integrante do SPB e, portanto, do sistema financeiro constitucional.

Onde se encontra a verdadeira razão jurídica, de ordem pública, a fundamentar a legislação financeira, que o busque o jurisconsulto pátrio nos textos do ordenamento brasileiro, pois o legislador do Direito especial a tem buscado, de fato, nas "relações da vida" (econômica) (GIERKE, 1936, p. 44 apud FREITAS ${ }^{217}$, 2002, p. 107, n. 6). Na realidade, "o que se tem por fito, evidentemente, é a ditadura financeira" (PONTES DE MIRANDA, 1966, p. 228). 


\subsection{O patrimônio especial}

Como mostrado no tópico anterior, o patrimônio, tradicionalmente compreendido como universalidade indivisível (unidade autônoma), ou seja, complexo das relações jurídicas de uma pessoa com valor econômico, que em regra responde, em sua integralidade, pelas dívidas de seu titular (princípio da universalidade patrimonial), em consequência da teoria subjetiva clássica (CC/1916, art. 57; CC, art. 91).

Como assevera STURZENEGGER (2001, p. 237):

A unidade do patrimônio se evidencia particularmente na responsabilidade que o afeta pelas obrigações do titular. Responde pelas dívidas deste último todo o conjunto de ativos, e, na forma em que se apresenta em cada instante, toda a unidade patrimonial (sem que importe o momento do ingresso dos bens ao patrimônio) responde por toda a dívida, sem que tampouco importe o momento em que esta nasça. $\mathrm{O}$ credor conta com o patrimônio do devedor, ainda que nenhum dos bens que o compõem existisse na época em que nasceu o seu direito de crédito. Em outras palavras, o credor tem todo o patrimônio do devedor, indistintamente apresentado (incluindo-se seus incrementos), a qualquer momento acessível para a satisfação de seu crédito.

Segundo alguns doutrinadores, no entanto, não teria caráter coletivo, de universalidade, sendo, antes, um conjunto atomístico de relações jurídicas de valor pecuniário (PINTO, 1990). Nesse sentido, aliás, se encaminha a regra do art. 91 do Código Civil, segundo a qual "constitui universalidade de direito o complexo de relações jurídicas, de uma pessoa, dotadas de valor econômico".

Desse modo, "a universalidade de direito se identifica pela submissão a regras estabelecidas em lei” (DUARTE, 2009, p. 87), vale dizer, o vínculo unitário e funcional resulta exclusivamente da lei. Daí resultar, outrossim, a sub-rogação real (in iudicis universalibus res succedit in loco pretii et praetium in loco rei), como princípio de Direito Civil, é dizer, a substituição patrimonial (de valor) dos bens que deixam a universalidade, em razão de qualquer ato ou negócio jurídico, por outro valor que tenha sido adquirido concomitantemente àquela perda dos bens (CC/1916, art. 56; CC, art. 39; DUARTE, 2009, p. 87).

Não obstante, alguns juristas de nomeada entendem ser perfeitamente aceitável uma segregação patrimonial em razão de um encargo imposto a certos bens, postos a serviço de um fim determinado. Dessa forma, o patrimônio seria um conjunto de bens 
coesos pela afetação a uma finalidade econômica. Coexistindo com o patrimônio geral, cujos elementos se unem pela relação subjetiva com seu titular, haveria um patrimônio especial, cuja unidade resultaria da destinação que lhe concedeu o mesmo titular. Esse patrimônio separado responde somente e exclusivamente por aquelas dívidas a que foi afetado (GOMES, 1997, p. 203 apud STURZENEGGER ${ }^{218}$, 2001, p. 236; VARELA, 1999).

Não se deve igualmente olvidar de que a afetação do patrimônio autônomo à satisfação exclusiva de certos débitos também se rege pelo mencionado princípio da subrogação real ou de vínculo, ou seja, a substituição patrimonial (de valor) dos bens que deixam aquele acervo separado, em razão de qualquer ato ou negócio jurídico, por outro valor que tenha sido adquirido concomitantemente àquela perda dos bens vinculados (PINTO, 1990).

Essa construção doutrinária em torno do destacamento de alguns bens da unidade abstrata do patrimônio (geral), afetos a um destino específico, e pois limitando a ação dos credores sobre os bens destacados, se materializa no chamado patrimônio de afetação (STURZENEGGER, 2001). Com efeito,

A teoria do patrimônio autônomo, nessa concepção, admite que as pessoas possam ser titulares de mais de uma massa patrimonial, com tratamento e finalidades diferentes, com capacidade para estabelecer relações jurídicas e dívidas próprias, mantendo-se essa massa patrimonial destacada completamente afastada das vicissitudes a que esteja sujeito o patrimônio geral.

A utilização dessa nova teoria apresenta-se como um instrumento de conteúdo inovador na tendência de modernização de alguns dos principais institutos jurídicos de origem romana. É possível desenvolver em países com essa tradição, por exemplo, pela afetação do patrimônio, a assimilação dos benefícios do instituto do trust, de origem saxônica. A melhor expressão dessa assimilação encontra-se na doutrina que altera e expande o conceito do direito romano de negócio fiduciário, para formular a teoria moderna do fideicomisso legal (STURZENEGGER, 2001, p. 239).

Cite-se, nesse sentido, o exemplo trazido pela legislação canadense, particularmente o Código Civil da Província de Quebec, que regra o patrimônio especial 
fiduciário como patrimônio sem titular. Dessarte,

após definir, o seu art. 1.260, o fideicomisso como "a consequência de uma ato pelo qual uma pessoa, o instituidor, transfere do seu patrimônio a outro patrimônio, que ele constitui, bens afetados a uma finalidade particular, e que um fiduciário se obriga, pelo fato de aceitá-lo, a guardar e a administrar", o art. 1.261, complementando a norma do artigo antecedente, define o patrimônio fiduciário nos seguintes termos:

“O patrimônio fiduciário, formado pelos bens transferidos em fideicomisso, constitui um patrimônio de afetação autônomo e distinto do patrimônio do instituidor, do fiduciário e do beneficiário, sobre o qual nenhum deles tem direito real".

A configuração de um patrimônio sem titular distingue o fideicomisso de Quebec do fideicomisso hispano-americano [mexicano] em geral. Observe-se que (...), também na configuração anglo-americana, o fiduciário, ou trustee, é o proprietário dos bens objeto do fideicomisso, com as limitações decorrentes do caráter fiduciário da propriedade, enquanto que na lei de Quebec é o fiduciário um mero administrador dos bens constantes de um patrimônio independente (STURZENEGGER, 2001, p. 241).

No Brasil, há exemplo de segregação funcional de patrimônio, legalmente estabelecida, tendo sido introduzida no âmbito da legislação de direito imobiliário, particularmente no que tange à incorporação imobiliária.

Com efeito, a Lei $\mathrm{n}^{\mathrm{o}} 10.931$, de 2.8.2004, introduziu nesse particular moderno mecanismo de segregação de riscos em relação às aquisições de imóveis "na planta", incluindo os arts. 31-A a 31-F na Lei $\mathrm{n}^{\circ}$ 4.591, de 1964, assim definindo o patrimônio de afetação:

Art. 31-A. A critério do incorporador, a incorporação poderá ser submetida ao regime de afetação, pelo qual o terreno e as acessões objeto da incorporação imobiliária, bem como os demais bens e direitos a ela vinculados, manter-se-ão apartados do patrimônio do incorporador e constituirão patrimônio de afetação, destinado à consecução da incorporação correspondente e à entrega das unidades imobiliárias aos respectivos adquirentes.

Pelo regime da afetação se separam, portanto, os bens e direitos da incorporação para a satisfação dos créditos a ela vinculados. Esse conjunto de bens e direitos não pode 
ser destinado ao pagamento de créditos estranhos à incorporação afetada. Os credores vinculados à incorporação afetada não se submetem aos efeitos de eventual falência, ou insolvência do incorporador, assumindo, nessa hipótese, a Comissão de Representantes a administração da incorporação, dando assim prosseguimento à obra com autonomia em relação à massa concursal (ELIAS FILHO, 2006, p. 271).

Vale lembrar que o patrimônio de afetação da referida legislação imobiliária também se relaciona à política legislativa de incentivo à formação de um mercado financeiro imobiliário, sobretudo de um mercado secundário, no âmbito do chamado Sistema Financeiro Imobiliário (ELIAS FILHO, 2006). Nesse sentido, também prevê a sub-rogação legal dos compromissários compradores, em regra, investidores (especuladores) daquele mercado (incluam-se os fundos de investimento), nos direitos e obrigações da incorporação, inclusive naqueles decorrentes do contrato de financiamento da obra (Lei no 4.591, de 1964, art. 31-F, § 11).

No que tange ao SPB, como visto anteriormente, os mecanismos garantidores utilizados na hipótese de inadimplemento de obrigações nos negócios cursados nos ambientes sistemicamente importantes (clearings), se resumem: a) aos bens dados pelos participantes em garantia das obrigações pactuadas; e b) aos recursos dos fundos especiais depositados pelos membros de compensação em garantia das operações realizadas.

Em caso de insuficiência das garantias anteriores, em obediência ao mandamento legal de certeza da liquidação das operações (Lei $n^{\circ} 10.214$, de 2001, art. $4^{\circ}$, § $2^{\circ}$ ), deve ser utilizado o patrimônio das próprias clearings em garantia da extinção das obrigações.

Consoante já mencionado, a questão em torno do efeito contágio também se faz presente nessa hipótese, tendo em conta a possibilidade de que um mesma câmara de compensação e liquidação seja responsável pela certeza de liquidação dos negócios celebrados em mais de um ambiente sistemicamente relevante, desde que não haja identidade entre os universos de negociação envolvidos. Nesse contexto, observado o princípio da universalidade patrimonial, o alastramento dos efeitos do inadimplemento ocorrido em um subsistema de negociação teria lugar em outros ambientes negociais do SPB.

Nesse particular, a partir do princípio da segregação de riscos, ou seja, de que os problemas surgidos em cada subsistema negocial devam nele se confinar, tem-se um caráter transindividual das relações jurídicas de adimplemento, no sentido de afetarem todo o sistema de pagamentos. Desse modo, 
torna-se imperioso destacar, do conjunto de bens do patrimônio da clearing house, um ou mais subconjuntos - dependendo do número de ambientes de atuação dessa clearing -, cuja destinação última será garantir a certeza da liquidação em cada um desses ambientes (STURZENEGGER, 2001, p. 244).

No sentido de programar a referida política, o art. $5^{\circ}$ da Lei $\mathrm{n}^{\circ} 10.214$, de 2001, determina que as câmaras de compensação e liquidação deverão separar patrimônio especial para garantir exclusivamente o cumprimento das obrigações existentes nos sistemas por elas operacionalizados. $O \S 1^{\circ}$ ao mesmo artigo estabelece ainda a incomunicabilidade desses bens, como de seus frutos e rendimentos, com o patrimônio geral. $\mathrm{O}$ art. $6^{\circ}$ do mesmo diploma estabelece a impenhorabilidade dos referidos bens.

$\mathrm{O}$ art. 19 do Regulamento anexo à Circular BCB n 3.057, de 2001, estabelece patrimônio especial mínimo de dez milhões de reais, constituído exclusivamente por títulos públicos federais, devendo-se-lhes transferir a uma conta vinculada específica de cada sistema, no Selic, permanecendo bloqueados à negociação. Os rendimentos auferidos em razão desses títulos também devem integrar o patrimônio separado.

Porém, nota-se que a legislação relativa ao SPB não trouxe regra quanto à possibilidade de sub-rogação de vínculos. Ademais, em que pese a lei não haver determinado expressamente a inalienabilidade dos bens que integram o patrimônio especial, o citado regulamento autárquico assim o fez (Regulamento anexo à Circular BCB $n^{\circ} 3.057$, de 2001, art. 19). Em princípio, houve delegação legislativa na matéria em exame, contida na regra do art. $5^{\circ}$ da Lei $n^{\circ} 10.214$, de 2001, ao prescrever a obrigatoriedade de instituição de patrimônio especial, “obedecida a regulamentação baixada pelo Banco Central do Brasil”.

Com efeito. A inalienabilidade cria um ônus real sobre a coisa, que impede, temporariamente, a possibilidade de transferência do bem, pesando sobre o titular do domínio. Não há, no entanto, um direito real, mas uma mutilação do direito de propriedade, ou seja, uma indisponibilidade real do bem, restringindo-se o poder de disposição inerente ao domínio, ou propriedade. Incide, portanto, nos bens, ou os atinge de forma objetiva, quanto à eficácia. Somente a eficácia perante terceiros depende de formalidades registárias. Por fim, não impõe nenhuma condição ao negócio jurídico de transmissão, não o subordina a termo, nem lhe anexa modo ou encargo (VENOSA, 2009; PONTES DE MIRANDA, 1954). 
No que tange aos direitos reais de garantia, esses representam início de alienação, restando, portanto, proibida sua instituição sobre os bens inalienáveis, por resultarem ineficazes aqueles direitos diante da inexcutibilidade futura (FUJITA, 2006, p. 1318; ALMEIDA, 2003, p. 259).

Do ponto de vista do patrimônio, a inalienabilidade implicaria, portanto, espécie de paralisação patrimonial (AZEVEDO, 1977, p. 48; MALUF, 1986, p. 39).

Ainda que se entenda ser a inalienabilidade restrição lícita, a despeito de estabelecida em sede (de norma) regulamentar, não se deve ter por consequência automática sua eficácia real, nem a evicção do bem. O direito real de propriedade, cujo conteúdo é fixado integralmente por lei, não pode, em princípio, sofrer vinculações negativas ou restrições de conteúdo, impostas em benefício ou interesse de uma das partes do negócio jurídico, senão nos casos em que a lei o prevê. Com efeito, na hipótese de se impor alguma restrição negocial do direito de propriedade, além da estabelecida em norma regulamentar quanto aos títulos gravados, deve aquela esgotar sua eficácia em sede obrigacional, apenas inter partes, sem que se reconheça a uma vinculação dessa ordem eficácia erga omnes (MESQUITA, 1990).

Diante dos contornos legais que a inalienabilidade apresenta em nosso sistema, em analogia aos arts. 1.848, $\S 2^{\circ}$, e 1.911, § único, do Código Civil, poder-se-ia entender que os bens restariam separados do restante do patrimônio do proprietário, não sendo alienáveis nem penhoráveis para satisfação de qualquer outro interesse patrimonial de seu titular, a não ser em razão de dívidas próprias daqueles bens, como no caso do adimplemento das obrigações cursadas na própria câmara de liquidação (Lei n 10.214 , de 2001 , art. $5^{\circ}$ ), ou eventualmente por força de lei federal, derrogatória (p. ex., em solução de dívidas fiscais relativas ao bem vinculado, ou em caso de expropriação pelo poder público). Não obstante essa última hipótese, o produto da alienação ainda ficaria sujeito à sub-rogação do vínculo (MONTEIRO, 2010, p. 181 e s.).

Com efeito. Trata-se, na presente hipótese, de "ativos líquidos" os bens a que se refere o art. 17 do Regulamento anexo à Circular BCB nº 3.057, de 2001, os quais, em regra, gozam de integral liquidez no mercado financeiro, sendo antes títulos-gênero, fungíveis, de que são o maior exemplo os títulos da dívida mobiliária federal. Como anteriormente exposto, a regra da fungibilidade e consuntibilidade, por alienação, decorre sobretudo da natureza socioeconômica desses valores mobiliários (CC, arts. 85 e $86 \mathrm{c} / \mathrm{c}$ art. 82), dada pelo tráfico (ENNECCERUS, 1947), tendo ainda em conta que a doutrina 
financeira e econômica os considera como "quase-moeda".

Nesse sentido, a despeito do "bloqueio" regulamentar imposto à sua circulação ("negociação"), em caso de serem objeto de transferência efetiva - não somente de negócio jurídico diferencial (CC, art. 816) -, o produto da alienação ainda ficaria sujeito à subrogação do vínculo, dada a essencial fungibilidade e consuntibilidade dos títulos que compõem a presente hipótese de patrimônio especial.

Outrossim, dada a fungibilidade e consuntibilidade dos títulos em estudo, depositados em contas de custódia específicas do Selic, não podem fugir à incidência da regra do art. 645 do Código Civil, concernente ao depósito irregular, restando juridicamente possível, ao menos do ponto de vista doutrinário, a negociação desses títulos, particularmente em razão da regra do art. 587 do diploma civil, restando o produto de sua alienação sujeito à sub-rogação do vínculo patrimonial, afeto ao cumprimento das obrigações assumidas pela câmara de compensação e liquidação na qualidade de parte contratante (Lei $\mathrm{n}^{\mathrm{o}} 10.214$, de 2001 , art. $6^{\circ} \mathrm{c} / \mathrm{c}$ art. $4^{\mathrm{o}}$, caput).

Nesse sentido, dá-se efeito aos princípios da doutrina civil, compatibilizando-os com o mandamento legal, evitando-se dessarte a incidência sem reservas da norma regulamentar que proíbe a negociabilidade (alheabilidade) dos referidos bens (valores).

Outrossim, somente nesse contexto interpretativo se pode aceitar o estabelecimento de tal normativo financeiro, a despeito de exarado em sede de competência regulamentar, por delegação legislativa (Lei 10.214, de 2001, art. $5^{\circ}$ ), sobretudo tendo em conta a existência no ordenamento jurídico pátrio da reserva legal contida na regra do art. 22, I, da Constituição Federal. 


\section{CONCLUSÃO}

A juridicidade dos meios de pagamento presentes nos mercados financeiro e de capitais, em que adquirem funcionalidade através do sistema de pagamentos, se deve precipuamente à sua presença efetiva na instrumentação das operações em curso, possibilitando sua normatização em caráter difuso. As normas que os dimensionam nas relações do sistema monetário se legitimam em razão da materialidade fenomênica tornada substrato normativo, interagindo com esse sistema e seus elementos, e pois dando ao dinheiro, enquanto riqueza financeira circulante, o caráter jurídico de moeda.

Nesse panorama, o entendimento do sistema de pagamentos requer previamente a caracterização do fenômeno monetário tanto no âmbito da evolução socioeconômica como da própria ciência econômica (análise monetária), dado o papel central desse sistema na economia monetária contemporânea, cujo funcionamento permeia a própria ordem econômica e, portanto, os arranjos institucionais que dão efetividade ao sistema monetário, sobretudo através das políticas econômica e monetária.

Nesse sentido, o dinheiro se traduz num monopólio institucional que, em última instância, implica o controle de sua oferta. Dada a restrição inelástica do dinheiro, sua quantidade não pode se adequar à procura por meio de sua produção, como ocorre com os demais bens de capital, resultando assim na elevação de seu preço, ou seja, da taxa de juros. Elevando-se seu preço, o investimento produtivo (real) tende naturalmente a se desviar de outros ativos (mercados), rumando na direção do dinheiro (mercado monetário), e pois se abstendo da utilização dos demais fatores produtivos existentes. $\mathrm{O}$ fenômeno monetário, que se manifesta através da taxa de juros, surge no espaço econômico como uma espécie de vetor, cujo ângulo de inclinação em relação à direção em que se encaminha o investimento produtivo (taxa de investimento) representa sempre um desvio de seu evolver, ou mesmo seu impedimento. Essa figura ilustra a ideia keynesiana de que na ausência do dinheiro as taxas específicas de remuneração dos demais ativos tendem a encontrar seu equilíbrio sob a condição de pleno emprego, ao contrário do que ocorre na presença do juro monetário.

A economia capitalista, essencialmente monetária e lucrativa, deve antes ser examinada sob o enfoque dos fluxos e refluxos monetários, capazes de ilustrar circunstancialmente as possibilidades de realização monetária da produção, pois o retorno do capital na forma de lucro (excedente) constitui o objetivo último desse regime econômico. 
Num modelo econômico que gravita em torno da moeda, o fator limitativo de sua expansão reside antes na restrição da liquidez do que na insuficiência de poupança. $\mathrm{O}$ ganho monetário (lucro) constitui assim a causa final do comportamento econômico, o qual se pode encaminhar tanto no sentido do incremento produtivo (riqueza real), quanto no do incremento estritamente financeiro, nessa última hipótese impondo obstáculos ao investimento, na medida em que lhe nega financiamento presente (crédito bancário), geralmente em prol da especulação futura (nos mercados financeiros). Dessa forma, a restrição da liquidez caminha paralelamente à inelasticidade da oferta monetária, vale dizer, ao caminho adotado por políticas monetárias restritivas, quaisquer que sejam seus propósitos.

No contexto de economias periféricas (subdesenvolvimento), advirta-se que as relações entre moeda e preços são marcadas por fenômenos inflacionários, sobretudo em razão da baixa elasticidade de sua produção (oferta), cuja expansão encontra sérios obstáculos sobretudo devido a rigidezas fundamentais, a saber, fraca propensão à poupança como investimento, ou à preferência pela liquidez, traduzida em grande propensão ao consumo. Na realidade, os motivos "keynesianos" de precaução e especulação praticamente não encontram guarida nesse panorama social, na medida em que os encaixes individuais são quase que inteiramente liquidados em transações correntes. Essa forte pressão pelo lado da demanda acaba por predominar no processo de crescimento dessas economias, cuja prodigalidade não raro avança sob condições favoráveis à forte expansão do crédito consuntivo, principalmente em prol da indústria de bens de consumo. Em consequência, o tipo de desenvolvimento schumpeteriano, calcado na expansão da oferta real mediante o fomento ao empreendedorismo empresarial, resta seriamente prejudicado, retardando o verdadeiro progresso socioeconômico. O processo de crescimento dominado pela procura é marcado, portanto, por uma tensão inflacionista contínua, que constitui, ao mesmo tempo, um fenômeno monetário, um desequilíbrio global e conjuntural entre oferta e procura, e um fenômeno estrutural.

Sob o prisma institucional, a sociedade capitalista é essencialmente jurídica, na medida em que suas relações de produção são específica e necessariamente mediadas pelo direito. O direito moderno, estatal, é fundamentalmente o direito do modo de produção capitalista, cuja função básica é disciplinar os mercados, viabilizando a circulação econômica, e pois a preservação dos meios, o seu fim. Nesse contexto, o Estado estabelece um direito definidor das regras de um jogo contínuo, cujos fins são externos a ele, porque 
definidos pelo indivíduo, que se vale de suas formas para realizar seus objetivos.

Nesse sentido, o mercado financeiro, fundamental ao funcionamento do capitalismo, sobretudo na atual forma do capitalismo financeiro, enquanto atividade essencialmente de risco, pressupõe o ordenamento de suas próprias relações de produção, é dizer, de definição e distribuição desses riscos, cujo regramento ainda depende da estrutura tradicional do direito (moderno), ou seja, o direito posto pelo Estado. Não obstante, o direito do mercado financeiro, como seja a regulação financeira, constitui antes uma ordem jurídica do mercado, por esse último engendrada, que não encontrará seu derradeiro fim enquanto todas as forças produtivas (riscos) a ela inerentes não despertarem, e pois se desenvolverem em sua plenitude. Em sua fase atual de desenvolvimento, a exceção faz a regra, porém acobertada pelo direito estatal (legislação especial), o qual pressupõe a lógica (violência) do mercado, mas a transforma em regra do jogo, ou seja, em direito positivado.

No que tange à operacionalização dos mercados financeiro e de capitais, ressaltese que a eficiência da economia capitalista está indissociavelmente atrelada à velocidade e segurança dos negócios jurídicos da circulação, portanto, dos pagamentos em solução das obrigações deles resultantes. Nesse contexto, as instituições financeiras, em particular os bancos, centralizam a maior parte dos recursos movimentados na economia, tanto para guarda quanto para aplicações e pagamentos diversos.

Frise-se que as redes de pagamentos permitem aos bancos a transferência mútua de fundos, de modo a compensar inúmeros acordos de câmbio em moeda estrangeira ou valores mobiliários. Até o início do presente século, muitos dos grandes sistemas gerais de pagamentos ou compensações ainda funcionavam à base da liquidação por diferença, ou seja, o sistema informacional acompanhava ao longo do dia a posição líquida de cada banco envolvido nos negócios celebrados, efetuando-se ao final do dia a compensação por diferença, transferindo assim a quantia devida da conta de reservas junto ao banco central (sistema público de pagamentos) ou da conta de liquidação junto à câmara de compensação (sistema privado) para a conta da contraparte bancária. Na hipótese de algum participante não honrar sua obrigação de pagamento, corria-se o risco de uma corrente de inadimplementos ao longo do sistema (risco sistêmico).

Essa forma de funcionamento dos sistemas de pagamentos resultaram em movimentos articulados, sobretudo a partir da década de 1990, no âmbito dos organismos monetários internacionais no sentido de que os bancos centrais nacionais implantassem, ainda que a elevados custos, sistemas de pagamentos em tempo real. Observe-se que a 
liquidação imediata dos grandes negócios interbancários, ao se utilizar das disponibilidades junto ao banco central (contas de reservas bancárias) do país-sede da instituição devedora, reduziria o risco sistêmico, pois, em caso de falência do banco devedor, esse último estaria pouco endividado em relação a outros bancos. Ressalte-se ainda que os montantes devidos no mercado interbancário não raro superam as bases de capital dos bancos que nele atuam.

No panorama (ideológico e jurídico) da mundialização dos sistemas financeiros, a estabilidade desses sistemas exige regulamentação e estruturação dos sistemas de pagamentos no sentido de promover a solidez e eficiência das movimentações financeiras, permitindo ainda a redução dos custos das operações, a utilização eficiente dos recursos, a melhoria da liquidez do mercado e ainda a eficácia da política monetária. Resta caracterizado, nesse sentido, o nomos financeiro, vale dizer, a ratio iuris do Direito que o abraça e assegura.

Nesse sentido, de modo a fazer frente à eventualidade de que um distúrbio nos sistemas de liquidação dos negócios com valores mobiliários possa ocasionar um colapso no mercado financeiro em geral, propagando-se para o setor real da economia, os bancos centrais se empenharam em fortalecer os dispositivos de compensação e liquidação de títulos e fundos, verificando-se, ainda, uma tendência de se harmonizar e aprimorar os sistemas de liquidação de títulos públicos e privados.

No âmbito dessa evolução do capitalismo financeiro, impõe-se contextualizar o ordenamento econômico-financeiro face à legislação de política econômica (monetária) que vem sendo adotada pelos governos brasileiros, situando-se indubitavelmente nesse âmbito o Sistema de Pagamentos Brasileiro, não somente enquanto "parte" do sistema financeiro nacional, mas sobretudo em razão da sua própria formatação material. Nesse panorama, portanto, deve ser entendida a estrutura institucional do Sistema de Pagamentos Brasileiro.

Não obstante o citado contexto institucional, não se há de olvidar da força normativa dos princípios constitucionais, resultado sobretudo do entendimento unitário do ordenamento jurídico, pois que a Constituição sobreleva incontestavelmente na hierarquia das fontes, não restando dúvida que nem o tamanho ou importância efetiva do Estado e tampouco a renovação infralegal têm o condão de alterar a normatividade constitucional, em que pese a menor racionalidade normativa dos dispositivos constitucionais. Pelo contrário, as normas constitucionais integram fundamentalmente a própria dogmática civilista, no sentido de remodelar e revitalizar os institutos do Direito Civil 
concentricamente à sua força integrativa (unificadora) do sistema jurídico

Sob o prisma operacional, as transferências de fundos interbancários passaram a ser liquidadas em tempo real, de modo irreversível. Por meio de nova regulamentação da conta de reservas das instituições financeiras (Reservas Bancárias) restaram impedidos os saques a descoberto. Além disso, a nova estrutura ainda prevê a criação de câmaras privadas de compensação e liquidação (clearings), nas quais as obrigações contraídas são liquidadas (solvidas) pela diferença.

Nesse contexto técnico e institucional se deve situar, portanto, o Direito Civil, em particular o seu aspecto obrigacional.

Ressalte-se todavia que o próprio dinheiro ainda é visto doutrinariamente como algo ligado à sua forma perceptível no mundo social, qual seja, o papel-moeda. Dessa forma, seria ele um bem móvel, fungível e consumível, portanto, sujeito às regras de transmissão da propriedade (tradição).

Não obstante, além do meio circulante em si, moeda em espécie, há que se classificar também as chamadas quase-moedas, tanto a moeda escritural como outros ativos financeiros (agregados monetários), todos eles havidos como instrumentos de pagamento devido à sua liquidez, por exemplo, no mercado secundário de títulos crédito (de renda fixa), públicos ou privados (valores mobiliários). São assim reconhecidos também sob o prisma institucional, ainda que não dotados, em princípio, de curso legal.

Dessarte, a moeda, como objeto do direito potestativo liberatório, de caráter público, classificar-se-ia, do ponto de vista do direito privado, entre os direitos pessoais patrimoniais, ou seja, bens móveis para os efeitos legais.

Ressalte-se ainda que os ativos financeiros representados pelos títulos de crédito da praxe bancária, como o cheque ou os certificados de depósito bancário, são utilizados como dinheiro em razão de sua liquidez, na medida em que representam meios de pagamento, cujos valores são objeto de compensação bancária.

Outrossim, não deve olvidar de que a moeda escritural, gerada pelo depósito bancário (à vista), também deixa de ser propriedade do titular do depósito, tornando-se esse último apenas credor em razão de que ao depósito bancário, dada a fungibilidade da moeda, se aplicam as regras atinentes ao mútuo, configurando-se o chamado depósito irregular. Esse, por sua vez, implica transmissão da propriedade ao mutuário, ou seja, o banco depositário.

Dessa forma, constitui a moeda escritural, enquanto agregado monetário de 
primeira ordem, principalmente devido à sua elevada liquidez, um direito de crédito do titular do depósito em relação ao banco.

Registre-se também que as contas bancárias não se limitam à custódia de valores, mas podem ser movimentadas pelos bancos, mediante acordo com o correntista, para a realização de pagamentos e recebimento de dívidas. Tem-se, portanto, a abertura de uma conta corrente, registro contábil relativo a créditos e obrigações de ambas as partes. Entre as obrigações do banco há a realização de pagamentos.

Os créditos mencionados são, portanto, objeto de transferências (pagamentos) no âmbito do Sistema de Pagamentos Brasileiro.

Sobreleva ainda em importância os depósitos interbancários, cujos depositantes e depositários são, em regra, as instituições financeiras bancárias. Essas operações, em regra não certificadas (desmaterializadas), são registradas e liquidadas financeiramente em sistema de registro e liquidação pertencente ao Sistema de Pagamentos Brasileiro, qual seja o Sistema de Transferência de Reservas.

As transferências desses créditos são objeto de pagamentos (indiretos) realizados no sistema financeiro. No entanto, ocorrem por meio de câmaras de compensação. Realizase, assim, a compensação multilateral de cheques e outros papéis, na medida em que se contrapõem cheques e outras ordens de pagamento interbancárias, emitidos por clientes de um banco, a ordens de pagamento a favor de clientes do mesmo banco. Nesse processo, cada banco receberá somente a diferença entre ambos os valores a seu favor, ou pagará a diferença a seu desfavor.

Nesse panorama, é mister se notar que os sistemas de pagamento não são inócuos. Aparentemente se limitam a melhorar os suportes materiais das operações jurídicas comuns. Na realidade, porém, promovem alterações substanciais, no sentido de que determinados tipos de operações vêm a suplantar outros, surgindo paralelamente novos produtos financeiros. Institutos consagrados, como no âmbito do Direito Civil, devem ser repensados. Basta observar que a situação líquida e patrimonial de uma empresa pode se alterar completamente, num lapso muito curto de tempo, através de operações de giro interbancário.

Nesse sentido, observe-se a nova caracterização jurídica que assume a própria moeda no âmbito da doutrina civilista. Desse modo, conferir relevo somente à função monetária de instrumento geral de troca, vale dizer, meio geral de pagamento (corolário jurídico), é reducionismo que ainda se prende à presença física da moeda enquanto meio 
circulante (papel-moeda), descurando-se assim da moeda de crédito (bancária) enquanto forma prevalecente na economia hodierna.

Com efeito, em tempos de riqueza (patrimônio) financeira integralmente desmaterializada, tanto em termos estritamente monetários (moeda escritural ou bancária) quanto em termos de instrumentos financeiros sob a forma predominantemente escritural (valores mobiliários), o patrimônio financeiro se traduz essencialmente em complexo jurídico de bens e direitos, denominados na unidade monetária oficial (padrão monetário legalmente adotado).

Nesse sentido, diante do fato da desmaterialização em larga escala da moeda, o curso legal da moeda nacional (REAL) para as estipulações de pagamento de obrigações pecuniárias, não deve mais ser interpretado no sentido de restringir o curso legal somente à moeda em espécie, mas sobretudo como abrangente do padrão monetário nacional.

Nos sistemas monetários modernos, assaz nos sistemas de pagamentos informatizados, e pois nos mercados financeiro e de capitais cujos negócios jurídicos se perfazem, e cujas obrigações pecuniárias se liquidam no âmbito (imaterial ou escritural) desses mesmos sistemas, a única função relevante da moeda que ainda subsiste é fundamentalmente a de denominador comum dos valores (fluxos e estoques financeiros) eletronicamente negociados.

Nesse panorama, a moeda fiduciária, não obstante sua natureza creditícia, se transmite, por meio do pagamento, ao (banco) depositário, onde os credores do depositante devedor são titulares de contas bancárias, creditando-se a soma devida em nome dos credores, para solução da dívida monetária, sem que ocorra a cessão desse crédito.

A intermediação bancária, em princípio, importa a tradição de moeda bancária, crédito, por meio do pagamento, subtraindo essa obrigação ao regime de transmissão que lhe é próprio, a cessão de crédito.

O regime de compensação centralizada, próprio do Sistema de Pagamentos Brasileiro, corrobora, por exemplo, o entendimento de que a obrigação pecuniária se insere, de modo peculiar, entre as dívidas genéricas, de espécie ou de dar coisa incerta. Nesse caso, ainda que se afaste a concretização (determinação) por meio de escolha do devedor, cabe a analogia com as obrigações ilíquidas, em razão da determinação dos saldos financeiros finais por meio da liquidação por diferença.

Igualmente, a tradição eletrônica tanto de fundos como de ativos financeiros corrobora o argumento de que tal modo de transmissão não é mais do que ato real, ou 
ainda, ato-fato jurídico. No que tange ainda ao conceito de negócio jurídico de disposição, ato volitivo de solução, caso se entenda a sua presença, continuará ele a ser prestigiado como codeclaração no negócio gerador de obrigações, antecedente, portanto, à própria solução da obrigação.

No que tange à solução das obrigações no âmbito do Sistema de Pagamentos Brasileiro, a liquidação das obrigações ocorrerá com a tradição dos ativos negociados ou a transferência dos recursos, no caso de movimentação financeira. Outrossim, por liquidação se deve entender o processo de extinção das obrigações segundo a legislação especial que regula esse mesmo sistema.

Uma vez determinado o objeto das prestações genéricas, não se deve olvidar da necessidade de sua transferência ao adquirente. Com efeito, a obrigação específica e característica do contrato de compra e venda é a da transmissão do domínio, que, por se tratar de bem móvel, vez que os contratos de bolsa (senso largo), quando translatícios de propriedade (negócios jurídicos de alienação), sempre versam sobre valores mobiliários, se efetiva mediante a "tradição" ou entrega da coisa.

Com efeito, a tradição pode ser real, simbólica ou ficta (consensual). Na tradição real, a entrega da coisa se perfaz materialmente; na simbólica, a despeito de não haver entrega física do bem, o comportamento concludente das partes, valorado pelos usos e costumes, efetiva a tradição; enquanto a tradição meramente consensual resulta somente da avença, sem conduta ou sinais exteriores que indiquem a transferência dominial.

Diante da imaterialidade não só da moeda, mas também dos valores mobiliários, sob a forma escritural, resta assim doutrinariamente caracterizada a possibilidade de tradição virtual do objeto da prestação, aplicável aos valores mobiliários escriturados por meio eletrônico (desmaterializados), cuja tradição se processa de modo gráfico, ou seja, por meio de lançamentos, a débito e a crédito, em conta de depósito (custódia), a exemplo do que ocorre com as ações escriturais.

Ainda nesse sentido, esses valores móveis, depositados (custodiados) sob a forma escritural, têm caracterizada sua fungibilidade (títulos-gênero) e divisibilidade. Não obstante, nada impede que se convencione, ou resulte da lei, sua indivisibilidade. Nessa hipótese, é possível que da própria natureza do negócio jurídico resulte o condomínio em frações ideais (pro partibus indivisis), dentro de certo tempo, que aproveite à qualidade da coisa.

A figura que melhor se adapta a essa espécie de depósito seria a de "comunhão em 
partes ideais" dos títulos depositados pelos seus titulares, cabendo-lhes individualmente a respectiva cota-parte. Assemelha-se ao depósito de grãos, criando-se espécie de comunhão pro indiviso. Dessarte, pode o depositário administrar os valores móveis como se fossem fungíveis, mas sem poder dispor das cotas alheias, daí a necessidade de outorga especial de poder para a sua alienação.

Desse modo, cabe essencialmente ao titular dos valores mobiliários, registrados em conta de depósito, determinar à instituição depositária a realização do pagamento, que se opera mediante a tradição virtual. O pagamento a ser realizado pelo depositário, em cumprimento da obrigação de transferir a propriedade do título custodiado, implica ainda a questão relativa à pessoa que deve efetuar o pagamento (solvens).

Nesse sentido, observe-se que no traspasso do valor mobiliário pela entidade custodiante do título, o que há é o adimplemento por terceiro (delegação de pagamento), resultado de prestação de serviço por parte do depositário. Em princípio, a instituição depositária é estranha à relação jurídica entre devedor e credor. O depositário paga, portanto, em nome, ou em nome e por conta do devedor. Em regra, deve haver ao menos representação, ainda que não haja mandato. Em princípio, não há falar em reembolso, pois a remuneração resulta do próprio contrato de prestação de serviço de custódia (global) de títulos em administração, essencialmente oneroso e executado de modo profissional, não do fato do pagamento.

Com efeito, entre o devedor originário e o depositário, o pagamento representa execução do dever desse perante aquele, resultante do vínculo negocial que, em regra, traz consigo a promessa de liberação (assunção de cumprimento). O depositário atua somente como delegado no cumprimento da obrigação do devedor delegante. O objeto da promessa é o ato-fato jurídico do pagamento. Trata-se sobretudo de ordem de pagamento, que compreende outorga de poder para adimplemento da dívida.

No que tange à transferência de fundos bancários (prestação pecuniária), essa se traduz essencialmente em ordem de pagamento, a ser efetuado mediante lançamento a crédito na conta do beneficiário (credor), não se diferindo, quanto à forma, da delegação de pagamento anteriormente mencionada. Não obstante, é mister que se diferencie a condição do titular da conta de depósito na qual se extingue a dívida pecuniária.

A atividade bancária específica dos bancos comerciais, titulares de contas Reservas Bancárias, estão ligadas ao ato de emissão (criação) de moeda, configurando assim institucionalmente a destinação socioeconômica, e pois regulamentar, dessas contas. 
Assim, a moeda aqui utilizada representa não só moeda bancária (escritural), senão particularmente "moeda de banco central".

Trata-se também na presente hipótese de delegação de pagamento (assunção de adimplemento), mas com algumas peculiaridades que a afastam da simples "promessa de liberação", enquanto a aproximam da assunção de dívida, sob a forma de "delegação cumulativa".

No que tange à diferença da simples promessa de liberação (delegação de pagamento), ressalte-se que o poder a ser outorgado não necessita conter poder de disposição, mas tão somente o essencial poder de solver, na medida em que as quantias presentes nas reservas bancárias são objeto de depósito irregular junto ao Banco Central do Brasil, gozando essa autarquia de poder de disposição sobre a moeda de adimplemento, por equiparação ao mútuo. Desse modo, paga o referido Banco Central em nome próprio, mas por conta do banco liquidante (delegante), da mesma forma que esse último tradicionalmente o faria ao executar serviços de pagamento por meio de ordens de pagamento, cujo lançamento a débito se perfaria na conta do cliente.

Dessa relação não só contratual, mas sobretudo institucional, máxime em relação à posição assumida pelo Banco Central do Brasil como garante (funcional) do Sistema de Pagamentos Brasileiro, surge a aproximação de sua atuação delegada, no sentido da efetivação dos pagamentos por conta dos bancos liquidantes, à posição de assumente da dívida pecuniária, atraindo para a presente hipótese a possibilidade de acumulação passiva na obrigação pecuniária liquidanda, dado seu interesse institucional, na condição de executor da política monetária.

Garante-se, dessarte, a liquidação definitiva da obrigação, em caráter irrevogável e incondicional, conforme a "regra geral" (norma regulamentar), em respeito ao mandamento legal (lei especial) de se assegurar a certeza da liquidação no âmbito do Sistema de Pagamentos Brasileiro.

No que tange à compensação realizada pelas câmaras de compensação e liquidação pertencentes ao Sistema de Pagamentos Brasileiro, fornecem essas clearings posições líquidas dos participantes de seus sistemas, resultantes da compensação da totalidade de créditos e de débitos decorrentes dos negócios jurídicos em seu âmbito realizados, em regime de reciprocidade, tanto na hipótese de compensação multilateral sem contraparte central, como naquela em que também haja a assunção da qualidade de parte contratante pela clearing. 
A presente modalidade de compensação se destina essencialmente à apuração da soma dos resultados bilaterais, devedores e credores de cada participante de uma caixa de liquidação em relação aos demais. Resulta assim do abatimento dos créditos e débitos objetos das ordens de pagamento entre os participantes (transferência do valor mobiliário contra pagamento pecuniário), de modo que, ao final, reduzam-se a um único crédito, ou débito, atribuível a cada participante, cujo valor mobiliário negociado será escrituralmente lançado a débito ou a crédito na conta de custódia, e pois a quantia em dinheiro será lançada numa conta de liquidação mantida junto ao banco central.

$\mathrm{Na}$ hipótese de multilateralidade, em que há envolvimento de diversos participantes, a câmara de compensação se posiciona entre eles, de modo a apurar globalmente os créditos e débitos bilaterais, abatendo-os até a extensão em que se eliminarem mutuamente.

Trata-se, portanto, de modalidade avançada de compensação interbancária, estendida às câmaras de custódia e liquidação que atuam nos diversos segmentos dos mercados financeiro e de capitais, do mesmo modo que tradicionalmente se faz com a compensação de cheques.

Ressalte-se haver pluralidade de legitimados entre os credores e devedores dos valores mobiliários e das quantias em dinheiro, na medida em que as operações não são apenas entre os credores e devedores imediatos. Trata-se de "ato-fato jurídico complexivo", como seria o do pagamento ordinário, ou de pagamentos ordinários, por meio de operação contabilística de câmara de compensação.

A adesão contratual ao serviço de compensação da clearing, de modo a se liquidarem os futuros créditos e débitos oriundos dos negócios financeiros nela cursados, implica fundamentalmente a "outorga de poder de compensar", ou seja, para a prática dos atos necessários à compensação interbancária. Há, portanto, delegação de pagamento, cujo efeito é a solução das dívidas por meio de compensação multilateral.

Quanto à hipótese de assunção da qualidade de parte contratante (contraparte central) pela clearing, a assunção dessa posição deve ser entendida somente "para fins de liquidação das obrigações", portanto, destina-se ao adimplemento. Não se cria nova dívida, vez que não há modificação substancial da relação jurídica obrigacional. Em regra, identifica-se essa intenção na incompatibilidade entre a antiga e a nova obrigação, o que não ocorre na presente hipótese.

Observe-se ainda que a novação subjetiva passiva (devedor) pressupõe não apenas 
um novo devedor, mas também que esse assuma uma nova obrigação em relação ao credor, distinta da original. Sem embargo, a obrigação permanece sendo a mesma, assumindo a câmara liquidante a obrigação de pagamento perante ambas as partes, pois não há cessão de crédito, de um lado, e assunção de dívida, de outro, mas assunção do dever de adimplir para ambos os lados, ou seja, transferindo a titularidade dos valores mobiliários paralelamente à transferência de fundos.

Note-se, outrossim, que as obrigações originárias do emissor permanecem, por determinação da lei especial que rege o Sistema de Pagamentos Brasileiro, sem que se opere sua extinção em razão da assunção de parte contratante para o pagamento.

Vale ainda recordar que na assunção de dívida o devedor anterior se libera, subrogando-se um novo devedor, mas a obrigação segue sendo a mesma.

$\mathrm{Na}$ realidade, há pluralidade de legitimados entre os credores e devedores dos valores mobiliários e das quantias em dinheiro, na medida em que as operações não são apenas entre os credores e devedores imediatos. Frise-se novamente que se trata de "atofato jurídico complexivo", como seria o do pagamento ordinário, ou de pagamentos ordinários, por meio de operação contabilística de câmara de compensação.

Não obstante, tendo em conta que a câmara se substitui aos devedores das prestações de dar assumidas pelas contrapartes, passa a câmara liquidante à condição de verdadeiro responsável pelo pagamento, não havendo somente outorga para compensar, solvendo, mas assunção do pagamento, com a consequente exoneração do credor e devedor originais.

Para tanto, as câmaras deverão contar com o depósito de garantias para assegurar a liquidação das obrigações compensadas, permitindo-se inclusive a execução direta dessas garantias, conforme lhes faculta a lei especial. Nesse sentido, aliás, restaria também excluída a hipótese de novação, tendo em conta que esse modo indireto de adimplemento, em regra, extingue as garantias da dívida, o que também não se coaduna com as mencionadas regras da lei de regência.

No que tange às garantias dadas pelos participantes das câmaras de compensação, restam essas legalmente arredadas da eficácia decorrente da execução concursal as obrigações objeto de pagamento no âmbito das mencionadas câmaras. Se um dos participantes tiver decretada sua liquidação extrajudicial, como no caso dos bancos, os créditos contra ele constituídos, desde que guardem relação com tais obrigações, não reverterão à respectiva massa, para pagamento posterior segundo a ordem de preferências e 
privilégios creditórios. Ao revés, a câmara de compensação e liquidação solverá as obrigações usando as garantias oferecidas, bem como os valores mobiliários e outros ativos objeto das correlatas obrigações.

A referida regra especial se sobrepõe, em princípio, aos dispositivos da lei civil que impedem a alienação de coisa empenhada.

Esse efeito (transindividual) do adimplemento, autorizado por regra jurídica contida em lei especial, cria verdadeira lex comissoria specialis, ao arrepio da tradição civilista, e que só pode ser legitimado enquanto princípio de ordem pública.

Ainda no que tange aos mecanismos garantidores, utilizados na hipótese de inadimplemento de obrigações nos negócios cursados nos ambientes sistemicamente importantes (clearings), aqueles se resumem aos bens dados pelos participantes em garantia das obrigações pactuadas; e aos recursos dos fundos especiais depositados pelos membros de compensação em garantia das operações realizadas.

Em caso de insuficiência das garantias anteriores, em obediência ao mandamento legal de certeza da liquidação das operações (lei especial), deve ser utilizado o patrimônio das próprias clearings em garantia da extinção das obrigações.

Não obstante, a questão em torno do efeito contágio também se faz presente nessa hipótese, tendo em conta a possibilidade de que um mesma câmara de compensação e liquidação seja responsável pela certeza de liquidação dos negócios celebrados em mais de um ambiente sistemicamente relevante, desde que não haja identidade entre os universos de negociação envolvidos. Nesse contexto, observado o princípio da universalidade patrimonial, o alastramento dos efeitos do inadimplemento ocorrido em um subsistema de negociação teria lugar em outros ambientes negociais do Sistema de Pagamentos Brasileiro.

Nesse particular, a partir do princípio da segregação de riscos, ou seja, de que os problemas surgidos em cada subsistema negocial devam nele se confinar, tem-se um caráter transindividual das relações jurídicas de adimplemento, no sentido de afetarem todo o sistema de pagamentos.

No sentido de programar a referida política, a lei especial de regência determina que as câmaras de compensação e liquidação deverão separar patrimônio especial para garantir exclusivamente o cumprimento das obrigações existentes nos sistemas por elas operacionalizado, estabelecendo a incomunicabilidade desses bens, como de seus frutos e rendimentos, com o patrimônio geral, bem como a impenhorabilidade dos referidos bens. 
A despeito de a lei especial não haver determinado expressamente a inalienabilidade dos bens que integram o patrimônio especial, o regulamento autárquico assim o fez, em sede de competência delegada, contida em regra jurídica da lei especial de regência.

Frise-se ainda que a finalização compulsória dos pagamentos pendentes, de modo a se evitar o efeito contágio, só se legitima enquanto compreendida no contexto do interesse coletivo. Assim, as garantias depositadas, bem como o patrimônio especial, configurariam um título legal especial, justificado a partir da consideração de que o inadimplemento particularizado implicaria uma onda de dificuldades de adimplemento, com prejuízo à solidez e ao normal funcionamento do Sistema Financeiro Nacional. Nessa hipótese, o "pacto comissório" legalmente fundamentado, ou o patrimônio de afetação, evitariam a assunção pelo Banco Central do Brasil dos riscos inerentes às obrigações inadimplidas, a ser evitado em prol da coletividade.

Nada obstante esse entendimento, e pois como tantas vezes frisado ao longo do presente trabalho, resta questionável a essencialidade de tais medidas excepcionais, ainda que revestidas por regras jurídicas, quando não estabelecidas apenas no seio da regulamentação normativa. Na realidade, resta muitas vezes claro que é justamente no seio da regulamentação financeira que se encontra a verdadeira ratio iuris da lei especial, a despeito de vestir regra legislativa ordinária.

Nesse sentido, observe-se novamente o exemplo dos "ativos líquidos" a que se refere a norma regulamentar, consequente à lei especial de regência do Sistema de Pagamentos Brasileiro, ativos consubstanciados em garantias pecuniárias ou valores mobiliários que gozam de total liquidez no mercado, normalmente os títulos-gênero, fungíveis, de que são o maior exemplo os títulos da dívida mobiliária federal. Assim também para a constituição de patrimônio especial pela câmara sistemicamente importante, prescreve-se que sejam oferecidos recursos financeiros sob a forma exclusiva de títulos públicos federais, a serem custodiados em sistema de negociação e custódia destinado a esse fim (Selic), em conta de titularidade da respectiva câmara.

Desse modo, mais uma vez, recai-se na circularidade, tantas vezes evidenciada ao longo deste trabalho, de se fomentar um sistema de reservas bancárias como lastro (público) da moeda escritural de crédito, fruto do multiplicador bancário enquanto instrumento de emissão (privada) da moeda nacional (REAL), ao arrepio das normas monetárias constitucionais e ordinárias. $\mathrm{O}$ mencionado lastro é público na medida em que 
se forma, conforma e fomenta no âmbito do ambiente negocial da dívida pública nacional, particularmente da dívida mobiliária federal, que integra o Sistema de Pagamentos Brasileiro e, portanto, o próprio sistema financeiro constitucional.

Onde se encontra a verdadeira razão jurídica, de ordem pública, a fundamentar a legislação financeira, que o busque o jurisconsulto pátrio nos textos do ordenamento brasileiro, pois o legislador do Direito especial a tem buscado, de fato, nas relações da vida econômica. 


\section{REFERÊNCIAS}

AGUIAR JÚNIOR, Nelson Alves de. "Aspectos jurídicos fundamentais do Sistema de Pagamentos Brasileiro". In: Revista de direito bancário, do mercado de capitais e da arbitragem. n. 11. São Paulo: RT, 2001.

AGUILLAR, Fernando Herren. "Direito econômico e globalização". In: SUNDFELD, Carlos; VIEIRA, Oscar (coords.). Direito global. São Paulo: Max Limonad, 1999.

ALMEIDA, J. L. Gavião de; AZEVEDO, Álvaro Villaça (coord.). Código civil comentado: arts. 1784 a 1856. São Paulo: Atlas, 2003. v. 18

ALMEIDA, J. R. Novaes de. Economia monetária: uma abordagem brasileira. São Paulo: Atlas, 2009.

ARISTÓTELES. Ética a Nicômaco. Trad. 4.ed. São Paulo: Nova Cultural, 1991.

ARISTÓTELES. Política. Trad. Brasília: Editora UnB, 1985.

ASCARELLI, Tulio. Problemas das sociedades anônimas e direito comparado. 2.ed. São Paulo: Saraiva, 1969.

ASSOCIAÇÃO NACIONAL DAS INSTITUIÇÕES DE MERCADO ABERTO (ANDIMA). Sistema de Pagamentos Brasileiro. Rio de Janeiro, 2002.

AZEVEDO, Álvaro Villaça. "Cláusula de inalienabilidade, impenhorabilidade e incomunicabilidade”. In: Enciclopédia Saraiva do Direito. São Paulo: Saraiva, 1977. v. 15.

AZEVEDO, Laurentino. Da compensação. São Paulo: Globo, 1920.

BANCO CENTRAL DO BRASIL (BCB). Sistema de Pagamentos Brasileiro. Brasília: Departamento de Operações Bancárias e de Sistema de Pagamentos, 2009.

BANCO DE COMPENSAÇÕES INTERNACIONAIS (BIS). Delivery versus Payment in Securities Settlement Systems. Basel, 1992.

BANCO DE COMPENSAÇÕES INTERNACIONAIS (BIS). Princípios fundamentais para sistemas de pagamento sistemicamente importantes. Trad. Basileia, 2001.

BDINE JR., Hamid Farah. "Arts. 233 a 420 - Obrigações”. In: Código Civil comentado: doutrina e jurisprudência (coord. Cezar Peluso). 3.ed. Barueri: Manole, 2009.

BECK, Ulrich. Sociedade de risco: rumo a uma outra modernidade. Trad. 2.ed. São Paulo: Ed. 34, 2011. Unesp, 2013.

BELLUZZO, Luiz Gonzaga. O capital e suas metamorfoses. São Paulo: Ed.

BENJAMIN, Joanna. Interests in Securities. A Proprietary Law Analysis of the 
International Securities Markets. Oxford: Oxford University Press, 2000.

BERCOVICI, Gilberto. "O direito como instrumento da política econômica". In: Revista dos Tribunais. Ano 101; vol. 923; setembro/2012.

BERCOVICI, Gilberto; MASSONETO, Luis Fernando. A Constituição dirigente invertida: a blindagem da constituição financeira e a agonia da constituição econômica. Separata de Boletim de Ciências Económicas. v. 49, p. 1-23. Coimbra, 2006.

BRIDEL, P. "Price level". In: The New Palgrave. Money (eds. Eatwell, Milgate e Newman). New York - London: Norton, 1989.

BULGARELLI, Waldírio. Contratos comerciais. 6.ed. São Paulo: Atlas, 1991.

CANARIS, Claus-Wilhelm. Pensamento sistemático e conceito de sistema na ciência do direito. Trad. Lisboa: Fundação Calouste Gulbenkian, 1989.

CENECO. Dicionário dos economistas. Trad. Porto: Rés, s.d.

CHESNAIS, François. "Introdução geral". In: A Mundialização Financeira: gênese, custos e riscos (coord. François Chenais). São Paulo: Xamã, 1998. 2011. v. 1

COELHO, Fábio Ulhoa. Curso de direito comercial. 15.ed. São Paulo: Saraiva,

COMPARATO, Fábio Konder. "O indispensável direito econômico". In: Revista dos Tribunais. Ano 101; vol. 923; setembro/2012.

CORDEIRO, António Menezes. Manual de direito bancário. 1.reimp. Coimbra: Almedina, 1999.

CORTEZ, Tiago Machado. Moeda, Estado e Direito: o Papel do Estado na Ordem Monetária e seu Controle. Tese de doutorado. São Paulo: FDUSP, 2004.

COSTA, Fernando Nogueira. Economia monetária e financeira: uma abordagem pluralista. São Paulo: Makron Books, 1999. Ed. FGV, 2012.

COUTO E SILVA, Clóvis. A obrigação como processo. 1.ed. 6.reimp. São Paulo:

DE CHIARA, José Tadeu. "MOEDA - III". In: FRANÇA, Rubens Limongi (coord.). Enciclopédia Saraiva do Direito. São Paulo: Saraiva, 1977, v. 53.

DE CHIARA, José Tadeu. Moeda e Ordem Jurídica. Tese de doutorado. São Paulo: FDUSP, 1986.

DUARTE, Nestor. "Arts. $1^{\mathrm{o}}$ a 232 - Parte Geral”. In: Código Civil comentado: doutrina e jurisprudência (coord. Cezar Peluso). 3.ed. Barueri: Manole, 2009.

DURAN, Camila Villard. A moldura jurídica da política monetária: um estudo de caso. Tese de Doutorado. São Paulo: FDUSP, 2012. 
EICHENGREEN, Barry. A globalização do capital: uma história do sistema monetário internacional. Trad. São Paulo: Editora 34, 2000.

ELIAS FILHO, Rubens Carmo. "O sistema financeiro imobiliário e o patrimônio de afetação". In: FONTES; WAISBERG (coord.). Contratos bancários. São Paulo: Quartier Latin, 2006.

ENNECCERUS, Ludwig; LEHMANN, Heinrich. Derecho de obligaciones. Trad. 35.ed. Barcelona: Bosch, 1947. v. 1

ESPÍNOLA, Eduardo. Garantia e extinção das obrigações. São Paulo: Freitas Bastos, 1951.

ESTRELA, M. A. Moeda, sistema financeiro e banco central. Brasília: Banco Central do Brasil, 2011.

FARIA, J. L. A. Ribeiro de. Direito das Obrigações. Coimbra: Almedina, 1990. v.

FARIA, José Eduardo. O direito na economia globalizada. 1.ed. 4.reimp. São Paulo: Malheiros, 2004. 1978.

FERRAZ JR., Tercio Sampaio. Teoria da norma jurídica. Rio de Janeiro: Forense,

FREITAS, Juarez. A interpretação sistemática do direito. 3.ed. São Paulo: Malheiros, 2002.

FRIEDMAN, Benjamin M. "Capital, credit and money markets". In: The New Palgrave. Money (eds. Eatwell, Milgate e Newman). New York - London: Norton, 1989. 1994.

FRIEDMAN, Milton. Episódios da história monetária. Rio de Janeiro: Record,

FUJITA, Jorge S. “Art. 1.848”. In: Comentários ao Código Civil: artigo por artigo. Coordenadores C. E. Nicoletti Camillo [et al.]. São Paulo: RT, 2006.

GALBRAITH, John K. A economia e o interesse público. Trad. São Paulo: Pioneira, 1988.

GOMES, Orlando. Obrigações. 8.ed. 1.tir. Rio de Janeiro: Forense, 1988.

GOMES, Orlando. Raízes históricas e sociológicas do Código Civil. São Paulo: Martins Fontes, 2003.

GOMES, Orlando. Transformações gerais no direito das obrigações. 2. ed. São Paulo: RT, 1980.

GOODE, Roy. Commercial Law. 3.ed. London: Penguin Books, 2004.

GRAU, Eros. A ordem econômica na Constituição de 1988. 15.ed. São Paulo: 
Malheiros, 2012.

GRAU, Eros. O direito posto e o direito pressuposto. 8.ed. São Paulo: Malheiros, 2011.

GUDIN, Eugênio. Princípios de economia monetária. 9.ed. rev. Rio de Janeiro: Agir, 1976. v. 1

GUTTMANN, Robert. "As mutações do capital financeiro". In: A Mundialização Financeira: gênese, custos e riscos (coord. François Chenais). São Paulo: Xamã, 1998. Brasil, 2011.

HAYEK, F. A. Desestatização do dinheiro. Trad. 2.ed. São Paulo: Instituto Mises

HEILBRONER, Robert. A natureza e a lógica do capitalismo. Trad. São Paulo: Ática, 1988.

HEIMANN, Eduard. História das doutrinas econômicas (Uma introdução à teoria econômica). Trad. Rio de Janeiro: Zahar, 1965.

HICKS, J. R. Valor e capital. Trad. 2.ed. São Paulo: Nova Cultural, 1987.

HUBER, Joseph. Monetäre Modernisierung. Zur Zukunft der Geldordnung. 2.ed. Marburg: Metropolis, 2011.

HUGON, Paul. A Moeda. 4.ed. São Paulo: Pioneira, 1976.

HUGON, Paul. História das doutrinas econômicas. 13.ed. São Paulo: Atlas, 1973.

JANSEN, Letácio. A moeda nacional brasileira. Rio de Janeiro: Renovar, 2009.

JHERING, Rudolf. A evolução do direito (Zweck im Recht). Salvador: Progresso, 1953.

KEYNES, John Maynard. Teoria geral do emprego, do juro e da moeda. Trad. São Paulo: Saraiva, 2012.

KINDLEBERGER, Charles P. International capital movements. Cambridge: Cambridge University Press, 1989.

LIMA, L. A. Oliveira. Estudo sobre a economia capitalista. Uma visão keynesiana. São Paulo: Bienal, 1997.

LOPES, João do Carmo; ROSSETTI, José Paschoal. Moeda e bancos: uma introdução. São Paulo: Atlas, 1980.

LOUREIRO, Francisco Eduardo. "Arts. 1.196 a 1.510 - Coisas". In: Código Civil comentado: doutrina e jurisprudência (coord. Cezar Peluso). 3.ed. Barueri: Manole, 2009.

MALUF, Carlos Alberto Dabus. Das Cláusulas de Inalienabilidade, Incomunicabilidade e Impenhorabilidade. São Paulo: Saraiva, 1986. 
MANN, F. A. The legal aspect of money. Oxford: Clarendon Press, 1992.

MARTINS, Fran. Contratos e obrigações comerciais. 16.ed. rev. e aum. Rio de Janeiro: Forense, 2010.

MARTINS-COSTA, Judith. "O adimplemento e o inadimplemento das obrigações no Novo Código Civil e o seu sentido ético e solidarista". In: NETTO, Domingos Franciulli; MENDES, Gilmar; MARTINS FILHO, Ives Gandra (coords.). O Novo Código Civil: Homenagem ao Prof. Miguel Reale. 2.ed. São Paulo: LTr, 2005.

MARX, Karl. O capital: crítica da economia política. livro I. 22.ed. Rio de Janeiro: Civilização Brasileira, 2004. v. 1

MAYER, Thomas; DUESENBERRY, J.; ALIBER, R. Moeda, bancos e a economia. Trad. 4.ed. Rio de Janeiro: Campus, 1993.

MENDES, J. M. Amado. História económica e social dos séculos XV a XX. 2.ed. Lisboa: Calouste Gulbenkian, 1997.

MESQUITA, Manuel Henrique. Obrigações reais e ónus reais. Coimbra: Almedina, 1990.

MISES, Ludwig. Theorie des Geldes und der Umlaufsmittel. 2.ed. Berlin: Duncker \& Humblot, 2005.

MODENESI, André de Melo. Regimes monetários: teoria e experiência do real. Barueri: Manole, 2005.

MONTEIRO, Washington de Barros; MALUF, C. A. Dabus. Curso de direito civil. São Paulo: Saraiva, 2010. v. 6

MONTEIRO, Washington de Barros; MALUF, C. A. Dabus. Curso de direito civil. São Paulo: Saraiva, 2011. v. 4

MOURA, Alkimar. “Apresentação”. In: EICHENGREEN, Barry. A globalização do capital: uma história do sistema monetário internacional. Trad. São Paulo: Editora 34, 2000. Zahar, 1962.

MYRDAL, Gunnar. Aspectos políticos da teoria econômica. Trad. Rio de Janeiro:

NAPOLEONI, Claudio. O pensamento econômico do século XX. Trad. Rio de Janeiro: Paz e Terra, 1979.

NOGUEIRA, J. L. Almeida. Curso didático de economia política ou sciencia do valor. 5.ed. rev. São Paulo: Graphica São José, 1936.

NUSDEO, Fábio. Curso de economia. 3.ed. São Paulo: RT, 2001.

NUSSBAUM, Arthur. Das Geld in Theorie und Praxis des deutschen und ausländischen Rechts. Tübingen: Mohr Siebeck, 1925. 
NUSSBAUM, Arthur. Uma história do dólar. Trad. Rio de Janeiro: Zahar, 1967. 2012.

OLIVECRONA, Karl. Linguagem jurídica e realidade. São Paulo: Quartier Latin,

PEDRO, Fábio de Freitas. "As diretrizes teóricas do Código Civil brasileiro de 2002 e o neoconstitucionalismo". In: Revista dos Tribunais. Ano 101; vol. 925; novembro/2012.

PEREIRA, Caio Mário da Silva. Instituições de direito civil. Rio de Janeiro: Forense, 2011. v. 2

PERLINGIERI, Pietro. Perfis do Direito Civil: introdução ao direito civil constitucional. 2.ed. Rio de Janeiro: Renovar, 2002.

PINHEIRO, Armando Castelar; SADDI, Jairo. Direito, Economia e Mercados. Rio de Janeiro: Elsevier, 2005.

PINTO, C. A. da Mota. Teoria geral do direito civil. Coimbra: Coimbra Ed., 1990.

PIRENNE, Henri. História econômica e social da idade média. Trad. São Paulo: Mestre Jou, 1963.

PLATÃO. A República. Trad. São Paulo: Nova Cultural, 1997.

POLANYI, Karl. A grande transformação: as origens de nossa época. Trad. 2.ed. Rio de Janeiro: Elsevier, 2000.

PONTES DE MIRANDA, F. C. Tratado de Direito Privado. Campinas: Bookseller, 1999. t. 1

PONTES DE MIRANDA, F. C. Tratado de Direito Privado. Campinas: Bookseller, 2000. t. 2

PONTES DE MIRANDA, F. C. Tratado de Direito Privado. Rio de Janeiro: Borsoi, 1954. t. 56

PONTES DE MIRANDA, F. C. Tratado de Direito Privado. Rio de Janeiro: Borsoi, 1959a. t. 24

PONTES DE MIRANDA, F. C. Tratado de Direito Privado. Rio de Janeiro: Borsoi, 1959b. t. 25

PONTES DE MIRANDA, F. C. Tratado de Direito Privado. Rio de Janeiro: Borsoi, 1959c. t. 26

PONTES DE MIRANDA, F. C. Tratado de Direito Privado. Rio de Janeiro: Borsoi, 1966. t. 52

PRADO JR., Caio. Esbôço dos fundamentos da teoria econômica. 4.ed. São Paulo: Brasiliense, 1966. 
RICARDO, David. Princípios de economia política e tributação. Trad. 3.ed. São Paulo: Abril Cultural, 1984. 2006.

RIZZARDO, Arnaldo. Direito das obrigações. 2.ed. Rio de Janeiro: Forense,

ROBERTSON, Dennis. A Moeda. Trad. 3.ed. Rio de Janeiro: Zahar, 1969.

ROSENVALD, Nelson. "Arts. 481 a 652 - Contratos (em espécie)". In: Código Civil comentado: doutrina e jurisprudência (coord. Cezar Peluso). 3.ed. Barueri: Manole, 2009.

SALOMÃO FILHO, Calixto. "Globalização e teoria jurídica do conhecimento econômico". In: SUNDFELD, Carlos; VIEIRA, Oscar (coords.). Direito global. São Paulo: Max Limonad, 1999.

SALOMÃO FILHO, Calixto. "Novo estruturalismo jurídico: uma alternativa para o direito?". In: Revista dos Tribunais. Ano 101; vol. 926; dezembro/2012. 2007.

SALOMÃO NETO, Eduardo. Direito bancário. 1.ed. 2.reimpr. São Paulo: Atlas,

SAMUELSON, Paul A. Fundamentos da análise econômica. Trad. 5.ed. São Paulo: Nova Cultural, 1997.

SCHICK, Karl. Wirtschaftsmathematik im Grundstudium. Paderborn - München Wien - Zürich: Schöningh, 1982.

SCHUMPETER, Joseph A. A teoria do desenvolvimento econômico. Trad. São Paulo: Abril Cultural, 1982.

SCHUMPETER, Joseph A. Dez grandes economistas. Trad. Rio de Janeiro: Civilização Brasileira, 1958.

SCHUMPETER, Joseph A. História da análise econômica. Trad. Rio de janeiro São Paulo - Lisboa: Fundo de Cultura, 1964a. v. 1

SCHUMPETER, Joseph A. História da análise econômica. Trad. Rio de janeiro São Paulo - Lisboa: Fundo de Cultura, 1964b. v. 3

SCHWARTZ, Anna. "Banking School, Currency School, Free Banking School”. In: The New Palgrave. Money (eds. Eatwell, Milgate e Newman). New York - London: Norton, 1989.

SHACKLE, G. L. S. Um esquema de teoria econômica. Trad. Rio de Janeiro: Zahar, 1969.

SICSÚ, J. “A URV e sua função de alinhar preços relativos”. In: Revista de Economia Política 16(2), abr.-jun 1996.

SILVA, Jorge Cesa Ferreira da. Adimplemento e extinção das obrigações. São 
Paulo: RT, 2007.

SINGER, Paul. Curso de introdução à economia política. 17.ed. Rio de Janeiro: Forense Universitária, 2010.

SMITH, Adam. Investigação sobre a natureza e as causas da riqueza das nações. Trad. 3.ed. São Paulo: Abril Cultural, 1984.

SOLOMON, Robert. Dinheiro em movimento. Rio de Janeiro: Record, 2001.

SOUZA, Leandro Alves. Sistema de pagamentos brasileiro: nova estrutura e seus impactos econômicos. São Paulo: Saraiva, 2001.

SOUZA, Washington Peluso Albino de. Primeiras linhas de direito econômico. 6.ed. São Paulo: LTr, 2005.

STURZENEGGER, Luiz Carlos. "A doutrina do patrimônio de afetação". In: Revista de Direito Bancário, Mercado de Capitais e Arbitragem. São Paulo: RT, 2001.

TABAK, Benjamin; MIRANDA, Rodrigo; SOUZA, Sergio. Conectividade e risco sistêmico no sistema de pagamentos brasileiro. Trabalhos para discussão ${ }^{\circ} 300$. Brasília: Depep/BCB, 2012. 2009.

TEPEDINO, Gustavo. Temas de direito civil - Tomo III. Rio de Janeiro: Renovar,

TOBIN, James. "Financial intermediaries". In: The New Palgrave. Money (eds. Eatwell, Milgate e Newman). New York - London: Norton, 1989.

II

VARELA, Antunes. Das obrigações em geral. 7.ed. Coimbra: Almedina, 1999. v.

VENOSA, Sílvio de Salvo. Direito Civil. 12. ed. São Paulo: Atlas, 2012. v. 2

VENOSA, Sílvio de Salvo. Direito Civil. 9. ed. São Paulo: Atlas, 2009. v. 7

VERÇOSA, Haroldo Malheiros Duclerc. Bancos Centrais no Direito Comparado - O Sistema Financeiro nacional e o Banco Central do Brasil. São Paulo: Malheiros, 2005. 1977.

VIDIGAL, Geraldo Camargo. Teoria geral do direito econômico. São Paulo: RT,

WEBER, Max. Historia económica general. Trad. 3.ed. México: FCE, 2011.

WICKSELL, Knut. Lições de economia política. Trad. 5.ed. São Paulo: Nova Cultural, 1986.

YAZBEK, Otavio. "O risco de crédito e os novos instrumentos financeiros". In: FONTES; WAISBERG (coords.). Contratos bancários. São Paulo: Quartier Latin, 2006.

YAZBEK, Otavio. Regulação do mercado financeiro e de capitais. 2.ed. Rio de Janeiro: Elsevier, 2009. 
ANEXO (Legislação extravagante) 
LEI N $\mathbf{N}^{0}$ 10.214, DE 27 DE MARÇO DE 2001

Conversão da MPv nº 2.115-16, de 2001

Dispõe sobre a atuação das câmaras e dos prestadores de serviços de compensação e de liquidação, no âmbito do sistema de pagamentos brasileiro, e dá outras providências.

Faço saber que o PRESIDENTE DA REPÚBLICA adotou a Medida Provisória $n^{\circ}$ 2.115-16, de 2001, que o Congresso Nacional aprovou, e eu Jader Barbalho, Presidente do Senado Federal, para os efeitos do disposto no parágrafo único do art. 62 da Constituição Federal, promulgo a seguinte Lei:

Art. $1^{0}$ Esta Lei regula a atuação das câmaras e dos prestadores de serviços de compensação e de liquidação, no âmbito do sistema de pagamentos brasileiro.

Art. $2^{\underline{0}} \mathrm{O}$ sistema de pagamentos brasileiro de que trata esta Lei compreende as entidades, os sistemas e os procedimentos relacionados com a transferência de fundos e de outros ativos financeiros, ou com o processamento, a compensação e a liquidação de pagamentos em qualquer de suas formas.

Parágrafo único. Integram o sistema de pagamentos brasileiro, além do serviço de compensação de cheques e outros papéis, os seguintes sistemas, na forma de autorização concedida às respectivas câmaras ou prestadores de serviços de compensação e de liquidação, pelo Banco Central do Brasil ou pela Comissão de Valores Mobiliários, em suas áreas de competência:

I - de compensação e liquidação de ordens eletrônicas de débito e de crédito;

II - de transferência de fundos e de outros ativos financeiros;

III - de compensação e de liquidação de operações com títulos e valores mobiliários;

IV - de compensação e de liquidação de operações realizadas em bolsas de mercadorias e de futuros; e

V - outros, inclusive envolvendo operações com derivativos financeiros, cujas câmaras ou prestadores de serviços tenham sido autorizados na forma deste artigo.

Art. $3^{\circ}$ É admitida a compensação multilateral de obrigações no âmbito de uma mesma câmara ou prestador de serviços de compensação e de liquidação.

Parágrafo único. Para os efeitos desta Lei, define-se compensação multilateral de obrigações o procedimento destinado à apuração da soma dos resultados bilaterais devedores e credores de cada participante em relação aos demais.

Art. $4^{\underline{0}}$ Nos sistemas em que o volume e a natureza dos negócios, a critério do Banco Central do Brasil, forem capazes de oferecer risco à solidez e ao normal funcionamento do sistema financeiro, as câmaras e os prestadores de serviços de compensação e de liquidação assumirão, sem prejuízo de obrigações decorrentes de lei, regulamento ou contrato, em relação a cada participante, a posição de parte contratante, para fins de liquidação das obrigações, realizada por intermédio da câmara ou prestador de serviços. 
$\S 1^{\circ}$ As câmaras e os prestadores de serviços de compensação e de liquidação não respondem pelo adimplemento das obrigações originárias do emissor, de resgatar o principal e os acessórios de seus títulos e valores mobiliários objeto de compensação e de liquidação.

$\S 2^{0}$ Os sistemas de que trata o caput deverão contar com mecanismos e salvaguardas que permitam às câmaras e aos prestadores de serviços de compensação e de liquidação assegurar a certeza da liquidação das operações neles compensadas e liquidadas.

$\S 3^{0}$ Os mecanismos e as salvaguardas de que trata o parágrafo anterior compreendem, dentre outros, dispositivos de segurança adequados e regras de controle de riscos, de contingências, de compartilhamento de perdas entre os participantes e de execução direta de posições em custódia, de contratos e de garantias aportadas pelos participantes.

Art. $5^{\circ}$ Sem prejuízo do disposto no $\S 3^{\circ}$ do artigo anterior, as câmaras e os prestadores de serviços de compensação e de liquidação responsáveis por um ou mais ambientes sistemicamente importantes deverão, obedecida a regulamentação baixada pelo Banco Central do Brasil, separar patrimônio especial, formado por bens e direitos necessários a garantir exclusivamente o cumprimento das obrigações existentes em cada um dos sistemas que estiverem operando

$\S 1^{\circ}$ Os bens e direitos integrantes do patrimônio especial de que trata o caput, bem como seus frutos e rendimentos, não se comunicarão com o patrimônio geral ou outros patrimônios especiais da mesma câmara ou prestador de serviços de compensação e de liquidação, e não poderão ser utilizados para realizar ou garantir o cumprimento de qualquer obrigação assumida pela câmara ou prestador de serviços de compensação e de liquidação em sistema estranho àquele ao qual se vinculam.

$\S 2^{\circ}$ Os atos de constituição do patrimônio separado, com a respectiva destinação, serão objeto de averbação ou registro, na forma da lei ou do regulamento.

Art. $6^{\circ}$ Os bens e direitos integrantes do patrimônio especial, bem como aqueles oferecidos em garantia pelos participantes, são impenhoráveis, e não poderão ser objeto de arresto, seqüestro, busca e apreensão ou qualquer outro ato de constrição judicial, exceto para o cumprimento das obrigações assumidas pela própria câmara ou prestador de serviços de compensação e de liquidação na qualidade de parte contratante, nos termos do disposto no caput do art. $4^{\circ}$ desta Lei.

Art. $7^{\circ}$ Os regimes de insolvência civil, concordata, intervenção, falência ou liquidação extrajudicial, a que seja submetido qualquer participante, não afetarão o adimplemento de suas obrigações, assumidas no âmbito das câmaras ou prestadores de serviços de compensação e de liquidação, que serão ultimadas e liquidadas pela câmara ou prestador de serviços, na forma de seus regulamentos.

Parágrafo único. O produto da realização das garantias prestadas pelo participante submetido aos regimes de que trata o caput, assim como os títulos, valores mobiliários e quaisquer outros seus ativos, objeto de compensação ou liquidação, serão destinados à liquidação das obrigações assumidas no âmbito das câmaras ou prestadores de serviços.

Art. $8^{\underline{0}}$ Nas hipóteses de que trata o artigo anterior, ou quando verificada a inadimplência de qualquer participante de um sistema, a liquidação das obrigações, observado o disposto nos regulamentos e procedimentos das câmaras ou prestadores de serviços de compensação e de liquidação, dar-se-á:

I - com a tradição dos ativos negociados ou a transferência dos recursos, no caso de movimentação financeira; e 
II - com a entrega do produto da realização das garantias e com a utilização dos mecanismos e salvaguardas de que tratam os $\S \S 2^{\circ}$ e $3^{\circ}$ do art. $4^{\circ}$, quando inexistentes ou insuficientes os ativos negociados ou os recursos a transferir.

Parágrafo único. Se, após adotadas as providências de que tratam os incisos I e II, houver saldo positivo, será ele transferido ao participante, integrando a respectiva massa, se for o caso, e se houver saldo negativo, constituirá ele crédito da câmara ou do prestador de serviços de compensação e de liquidação contra o participante.

Art. 9ำ A infração às normas legais e regulamentares que regem o sistema de pagamentos sujeita as câmaras e os prestadores de serviços de compensação e de liquidação, seus administradores e membros de conselhos fiscais, consultivos e assemelhados às penalidades previstas:

I - no art. 44 da Lei no 4.595, de 31 de dezembro de 1964, aplicáveis pelo Banco Central do Brasil;

II - no art. 11 da Lei no 6.385, de 7 de dezembro de 1976, aplicáveis pela Comissão de Valores Mobiliários.

Parágrafo único. Das decisões proferidas pelo Banco Central do Brasil e pela Comissão de Valores Mobiliários, com fundamento neste artigo, caberá recurso, sem efeito suspensivo, para o Conselho de Recursos do Sistema Financeiro Nacional, no prazo de quinze dias.

Art. 10. O Conselho Monetário Nacional, o Banco Central do Brasil e a Comissão de Valores Mobiliários, nas suas respectivas esferas de competência, baixarão as normas e instruções necessárias ao cumprimento desta Lei.

Art. 11. Ficam convalidados os atos praticados com base na Medida Provisória n⿳ํㅜ 2.115-15, de 26 de janeiro de 2001.

Art. 12. Esta Lei entra em vigor na data de sua publicação.

Congresso Nacional, em 27 de março de 2001; $180^{\circ}$ da Independência e $113^{\circ}$ da República.

Senador JADER BARBALHO

Presidente do Congresso Nacional 


\title{
站 \\ BANCO CENTRAL DO BRASIL
}

\author{
RESOLUÇÃO Nº 2882
}

Dispõe sobre o sistema de pagamentos e as câmaras e os prestadores de serviços de compensação e de liquidação que o integram.

O BANCO CENTRAL DO BRASIL, na forma do art. $9^{\circ}$ da Lei $\mathrm{n}^{\circ} .4 .595$, de 31 de dezembro de 1964, torna público que o CONSELHO MONETÁRIO NACIONAL, em sessão realizada em 30 de agosto de 2001 , tendo em conta as disposições dos arts. $4^{\circ}$, inciso VIII, e 11 , inciso VII, da referida lei, dos arts. $3^{\circ}$, incisos I, III, IV e parágrafo único, e 15 , inciso VI e parágrafos $2^{\circ}$ e $3^{\circ}$, da Lei $\mathrm{n}^{\circ}$. 6.385 , de 7 de dezembro de 1976, e da Lei $\mathrm{n}^{\circ}$. 10.214, de 27 de março de 2001,

\section{R E S O L V E U:}

Art. $1^{\circ}$ Estabelecer que o sistema de pagamentos deve ser estruturado segundo princípios que assegurem sua eficiência, segurança, integridade e confiabilidade.

Art. $2^{\circ}$ Sujeitam-se ao disposto nesta Resolução as câmaras e os prestadores de serviços de compensação e de liquidação que operam qualquer um dos sistemas integrantes do sistema de pagamentos, cujo funcionamento:

I - resulte em movimentações interbancárias; e

II - envolva pelo menos três participantes diretos para fins de liquidação, dentre instituições financeiras ou demais instituições autorizadas a funcionar pelo Banco Central do Brasil.

Parágrafo único. Para os efeitos desta Resolução, considera se:

I - câmara de compensação e de liquidação: pessoa jurídica que exerce, em caráter principal, a atividade de que trata o caput;

II - prestador de serviços de compensação e de liquidação: pessoa jurídica que exerce, em caráter acessório, a atividade de que trata o caput;

III - participante direto para fins de liquidação: pessoa jurídica que assume a posição de parte contratante para fins de liquidação, no âmbito do sistema integrante do sistema de pagamentos, perante a câmara ou o prestador de serviços de compensação ou outro participante direto;

IV - participante indireto para fins de liquidação: pessoa jurídica, com acesso a sistema integrante do sistema de pagamentos, cujas operações são liquidadas por intermédio de um participante direto.

Art. $3^{\circ}$ No sistema de pagamentos devem ser observadas as regras gerais a seguir enumeradas, aplicáveis pelo Banco Central do Brasil, que considerará, para tanto, as especificidades de cada um dos sistemas que o integram:

Resolução n² 2882, de 30 de agosto de 2001 


\section{4 \\ BANCO CENTRAL DO BRASIL}

I - os participantes devem ter acesso a informações claras e objetivas, que lhes permitam identificar os riscos em que incorram nos sistemas que utilizem;

II - as regras e procedimentos devem possibilitar e incentivar o gerenciamento e a contenção dos riscos de crédito e de liquidez, bem como estabelecer claramente, para estes fins, as obrigações das câmaras e dos prestadores de serviços de compensação e de liquidação e dos participantes;

III - a liquidação de obrigação, em caráter irrevogável e incondicional, em conta mantida no Banco Central do Brasil, deve ocorrer, o mais cedo possível, no dia para o qual estipulada;

IV - a tradição do ativo negociado e a efetivação do correspondente pagamento devem ser mutuamente condicionadas;

V - as câmaras e os prestadores de serviços de compensação e de liquidação devem, no mínimo, assegurar, em caso de inadimplência de participante, a liquidação tempestiva de obrigações em montante equivalente à maior posição compensada devedora neles apurada, ressalvado o risco de emissor;

VI - a infra-estrutura operacional das câmaras e dos prestadores de serviços de compensação e de liquidação deve ter adequado nível de segurança e confiabilidade, dispondo de planos de contingência e de recuperação capazes de assegurar o processamento no próprio ciclo de liquidação;

VII - os meios e procedimentos para a liquidação de obrigações devem satisfazer as necessidades dos usuários e ser economicamente eficientes;

VIII - os critérios de acesso aos sistemas devem ser públicos, objetivos e claros, possibilitando ampla participação, admitidas restrições com enfoque, sobretudo, na contenção de riscos; e

IX - a estrutura organizacional e administrativa das câmaras e dos prestadores de serviços de compensação e de liquidação deve ser efetiva e transparente, de modo a possibilitar, inclusive, a avaliação do desempenho dos administradores e contemplar os interesses dos participantes.

Art. $4^{\circ} \mathrm{O}$ Banco Central do Brasil atuará no sentido de promover a solidez, o normal funcionamento e o contínuo aperfeiçoamento do sistema de pagamentos, de acordo com o estabelecido nesta Resolução.

Art. $5^{\circ} \mathrm{Com}$ vistas à adequação das câmaras e dos prestadores de serviços de compensação e de liquidação aos valores, princípios e regras aplicáveis ao sistema de pagamentos, o Banco Central do Brasil deverá:

I - regulamentar suas atividades;

II - autorizar o funcionamento de seus sistemas;

Resolução n 2882, de 30 de agosto de 2001 


\section{4 \\ BANCO CENTRAL DO BRASIL}

III - exercer a supervisão de suas atividades, observando, no que se refere à aplicação de penalidades, o disposto na Resolução $\mathrm{n}^{\circ}$. 1.065 , de 5 de dezembro de 1985 , com a redação dada pela Resolução $\mathrm{n}^{\circ}$. 2.228, de 20 de dezembro de 1995.

Parágrafo $1^{\circ} \mathrm{A}$ regulamentação de que trata o inciso I poderá contemplar regras diferenciadas para as câmaras e os prestadores de serviços de compensação e de liquidação considerados sistemicamente importantes pelo Banco Central do Brasil.

Parágrafo $2^{\circ}$ A supervisão a que se refere o inciso III compreende, quando for o caso, o acesso do Banco Central do Brasil aos documentos e informações que considere necessários à avaliação da conformidade, ao disposto na legislação e regulamentação em vigor, dos serviços, inerentes ao processo de liquidação, prestados por terceiros que tenham vínculo operacional com a câmara ou prestador de serviços de compensação e de liquidação.

Art. $6^{\circ}$ No que concerne às câmaras e aos prestadores de serviços de compensação e de liquidação, compete à Comissão de Valores Mobiliários, no que diz respeito a operações com valores mobiliários:

I - regulamentar suas atividades;

II - autorizar o funcionamento de seus sistemas; e

III - exercer a supervisão de suas atividades, observando, no que se refere à aplicação de penalidades, o disposto no artigo 11, da Lei $\mathrm{n}^{\circ}$. 6.385, de 7 de dezembro de 1976 .

Parágrafo $1^{\circ}$ Além da regulamentação, da autorização e da supervisão de que tratam os incisos I a III, sujeitam-se as câmaras e os prestadores de serviços de compensação e de liquidação de que trata o caput à autorização para funcionamento e à supervisão de seus sistemas pelo Banco Central do Brasil, ao qual compete, com exclusividade, a análise dos aspectos relacionados com o risco à solidez e ao normal funcionamento do Sistema Financeiro Nacional.

Parágrafo $2^{\circ} \mathrm{O}$ disposto no parágrafo anterior aplica-se às câmaras e aos prestadores de serviços de compensação e de liquidação já autorizados pela Comissão de Valores Mobiliários quando da data de entrada em vigor desta Resolução.

\section{Art. $7^{\circ}$ (Revogado pela Resolução 3.081, de 29/05/2003.)}

Art. $8^{\circ}$ Aplicam-se às câmaras e aos prestadores de serviços de compensação e de liquidação as exigências quanto à implementação de sistemas de controles internos de que trata a Resolução $\mathrm{n}^{\circ}$. 2.554 , de 24 de setembro de 1998.

Art. $9^{\circ}$. O Banco Central do Brasil operará, exclusivamente, sistemas com liquidação bruta em tempo real.

Art. 10. Fica o Banco Central do Brasil autorizado a:

I - regulamentar a troca eletrônica de mensagens no sistema de pagamentos;

Resolução n 2882, de 30 de agosto de 2001 


\section{4 \\ BANCO CENTRAL DO BRASIL}

II - estabelecer prazo para a adequação das câmaras e dos prestadores de serviços de compensação e de liquidação ao disposto nesta Resolução.

Art. 11. Ficam o Banco Central do Brasil e a Comissão de Valores Mobiliários, nas respectivas áreas de competência, autorizados a baixar as normas complementares e a adotar as medidas que julgarem necessárias ao cumprimento do disposto nesta Resolução, podendo, inclusive, estabelecer as condições para alterações nos regulamentos dos sistemas.

Art. 12. Esta Resolução entra em vigor na data de sua publicação, exceto o art. $9^{\circ}$, que entrará em vigor na data de início do novo sistema de pagamentos, a ser estabelecida pelo Banco Central do Brasil.

Brasília, 30 de agosto de 2001.

Ilan Goldfajn

Presidente, interino

Este texto não substitui o publicado no DOU e no Sisbacen. 


\section{4 \\ BANCO CENTRAL DO BRASIL}

CIRCULAR N 3.057

Aprova regulamento que disciplina o funcionamento dos sistemas operados pelas câmaras e pelos prestadores de serviços de compensação e de liquidação que integram o sistema de pagamentos.

A Diretoria Colegiada do Banco Central do Brasil, em sessão realizada em 31 de agosto de 2001, tendo em vista o disposto na Lei 10.214, de 27 de março de 2001, e no art. 11 da Resolução 2.882, de 30 de agosto de 2001,

\section{DE C I D I U :}

Art. $1^{\circ}$ Aprovar o Regulamento anexo, que dispõe sobre o funcionamento dos sistemas operados pelas câmaras e pelos prestadores de serviços de compensação e de liquidação integrantes do sistema de pagamentos.

Art. $2^{\circ}$ Estabelecer que o pedido de autorização de funcionamento, de que tratam o inciso II do art. $5^{\circ}$ e o parágrafo $1^{\circ}$ do art. $6^{\circ}$ da Resolução 2.882 , de 30 de agosto de 2001 , deve ser instruído com:

I - estatuto ou contrato social e suas alterações;

II - comprovação de atendimento ao limite mínimo de patrimônio líquido;

III - atos de constituição e de registro ou averbação do patrimônio especial, sempre que for o caso;

IV - documento "CAPEF - Composição de Capital", modelo CADOC n ${ }^{\circ} 38029-8$, da câmara ou do prestador de serviços de compensação e de liquidação e das pessoas jurídicas que participem de seu capital social;

V - documentos "CAPEF - Formulário Cadastral - Dados Pessoais", modelo CADOC n ${ }^{\circ} 38027-0$, e "CAPEF - Informações sobre Ato de Eleição ou Nomeação", modelo CADOC $\mathrm{n}^{\circ} 38006-7$, referentes aos integrantes de órgãos estatutários da câmara ou do prestador de serviços de compensação e de liquidação;

$$
\begin{aligned}
& \text { VI - regulamento do sistema; } \\
& \text { VII - descrição detalhada: }
\end{aligned}
$$

a) de todos os processos operacionais relacionados com o sistema que será operado pela câmara ou pelo prestador de serviços de compensação e de liquidação, inclusive quando realizados por terceiros, compreendendo, entre outros, conforme a natureza do sistema, o registro, a confirmação, a aceitação, a compensação e a liquidação de obrigações, relativos a

Circular $n^{\circ} 3.057$, de 31 de agosto de 2001 . 


\section{4 \\ BANCO CENTRAL DO BRASIL}

operações, e a custódia e a transferência de títulos, valores mobiliários e outros ativos financeiros;

b) dos equipamentos e dos meios de comunicação que darão suporte ao sistema;

c) dos procedimentos e mecanismos básicos relacionados com o acesso técnico dos participantes ao sistema;

VIII - fluxograma geral e fluxograma de cada processo de que trata a alínea "a" do inciso anterior; e

IX - documentação que evidencie a capacidade da câmara ou do prestador de serviços de compensação e de liquidação de cumprir o objeto social, considerados os aspectos técnico-operacionais, organizacionais, administrativos e financeiros, com descrição detalhada dos mecanismos de gerenciamento e contenção de riscos.

Parágrafo único. A documentação de que trata este artigo deve ser entregue ao Departamento de Operações Bancárias e de Sistema de Pagamentos (Deban).

Art. $3^{\circ}$ As câmaras e os prestadores de serviços de compensação e de liquidação em funcionamento na data da entrada em vigor desta Circular deverão entregar ao Deban, até $1^{\circ}$ de outubro de 2001, a documentação mencionada no artigo anterior, com vistas à análise de sua adequação aos valores, princípios e regras aplicáveis ao sistema de pagamentos.

Art. $4^{\circ}$ Esta Circular entra em vigor na data de sua publicação.

Brasília, 31 de agosto de 2001.

Luiz Fernando Figueiredo Sérgio

Diretor
Darcy da Silva Alves

Diretor

Este texto não substitui o publicado no DOU e no Sisbacen. 


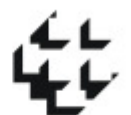 \\ BANCO CENTRAL DO BRASIL}

Regulamento Anexo à Circular n 3057, de 31 de agosto de 2001, que disciplina o funcionamento dos sistemas operados pelas câmaras e pelos prestadores de serviços de compensação e de liquidação integrantes do sistema de pagamentos.

\section{CAPÍTULO I \\ DO ÂMBITO DE APLICAÇÃO}

Art. $1^{\circ}$ Sujeitam-se ao disposto neste Regulamento as câmaras e os prestadores de serviços de compensação e de liquidação de que trata o art. $2^{\circ}$ da Resolução 2.882 , de 30 de agosto de 2001, cujos sistemas são autorizados a funcionar pelo Banco Central do Brasil.

\section{CAPITULO II DAS DEFINIÇÕES}

Art. $2^{\circ}$ Para os efeitos deste Regulamento, as expressões e termos relacionados são definidos como segue:

I - aceitação: processo de verificação do enquadramento de uma operação, para fins de liquidação, aos requisitos previamente estabelecidos no regulamento do sistema de liquidação, especialmente no tocante à administração e contenção de riscos;

II - certeza de liquidação: garantia de que a operação, uma vez aceita, será efetivamente liquidada, nos termos e extensão estabelecidos no regulamento do sistema operado pela câmara ou pelo prestador de serviços de compensação e de liquidação;

III - compensação: processo que envolve a apuração da posição líquida (créditos menos débitos) de cada participante;

IV - compensação bilateral: compensação envolvendo os participantes aos pares;

V - compensação multilateral: procedimento destinado à apuração da soma dos resultados bilaterais devedores e credores de cada participante em relação aos demais. $\mathrm{O}$ resultado da compensação multilateral também corresponde ao resultado de cada participante em relação à câmara ou prestador de serviços de compensação e de liquidação que assuma a posição de parte contratante para fins de liquidação das obrigações, realizada por seu intermédio;

VI - depósito de títulos, valores mobiliários ou outros ativos financeiros: processo que envolve a guarda e o registro de títulos, valores mobiliários ou outros ativos financeiros;

VII - evento definitivo: qualquer evento, como a liquidação e a transferência de fundos ou de títulos e valores mobiliários, que ocorre em caráter irrevogável e incondicional;

VIII - índice de disponibilidade: índice que expressa percentualmente o grau de disponibilidade do sistema para os participantes, calculado como segue:

$$
\begin{aligned}
& \mathrm{id}=(\mathrm{hf} / \mathrm{hp}) \times 100, \text { onde: } \\
& \mathrm{id}=\text { indice de disponibilidade; }
\end{aligned}
$$

Circular $\mathrm{n}^{\circ} 3.057$, de 31 de agosto de 2001. 


\section{4 \\ BANCO CENTRAL DO BRASIL}

hf $=$ número de horas de efetivo funcionamento de um determinado sistema, ao longo dos últimos doze meses, desconsideradas eventuais prorrogações do horário normal de funcionamento;

$\mathrm{hp}=$ número de horas em que o sistema deveria estar aberto para uso pelos participantes, ao longo dos últimos doze meses, segundo seu horário normal de funcionamento;

IX - liquidação: processo de extinção de obrigações;

tempo real;

$X$ - liquidação bruta em tempo real: liquidação de obrigações, uma a uma, em

XI - liquidação diferida: liquidação realizada em momento posterior ao de aceitação das operações que dão origem às correspondentes obrigações;

XII - operação: salvo se especificada no texto, é toda e qualquer transação comandada em um sistema que possa resultar em transferência de fundos, títulos, valores mobiliários ou outros ativos financeiros;

XIII - operação aceita: operação acolhida pela câmara ou pelo prestador de serviços de compensação e de liquidação para fins de liquidação;

XIV - ordem de crédito: ordem de transferência de fundos da conta do participante emitente para a conta do participante favorecido;

XV - posição financeira: saldo financeiro de um participante, a cada momento, em um sistema de liquidação;

XVI - processamento: conjunto de procedimentos que antecedem a liquidação e, quando for o caso, a compensação;

XVII - risco de emissor: risco de não ser honrado compromisso relacionado com a emissão ou o resgate do principal e acessórios do título ou valor mobiliário;

XVIII - risco de crédito: risco de uma parte contratante não liquidar uma obrigação no momento esperado e não fazê-lo no futuro;

XIX - risco de liquidez: risco de uma parte contratante liquidar uma obrigação em momento posterior ao inicialmente acordado;

$\mathrm{XX}$ - risco operacional: risco de erro humano ou de falha de equipamentos, programas de computador ou sistema de telecomunicações imprescindiveis para o funcionamento de determinado sistema;

XXI - sistema de liquidação: complexo de instalações, equipamentos e sistemas computacionais e de comunicação disponibilizado por uma câmara ou prestador de serviços de compensação e de liquidação, para liquidação de operações segundo regras e procedimentos formalmente estabelecidos;

Circular $n^{\circ} 3.057$, de 31 de agosto de 2001 . 


\section{4 \\ BANCO CENTRAL DO BRASIL}

XXII - sistema híbrido de liquidação: sistema que combina características dos sistemas de liquidação diferida e dos sistemas de liquidação bruta em tempo real;

XXIII - sistema sistemicamente importante: sistema de liquidação em que o volume ou a natureza dos negócios, a critério do Banco Central do Brasil, é capaz de oferecer risco à solidez e ao normal funcionamento do Sistema Financeiro Nacional.

\section{CAPÍTULO III \\ DOS SISTEMAS DE LIQUIDAÇÃO}

Seção I

Objeto de Liquidação

Art. $3^{\circ}$ Podem ser objeto de liquidação em um sistema de liquidação, isolada ou conjuntamente, as obrigações oriundas de:

I - cheques e outros documentos;

II - ordens eletrônicas de débito e de crédito;

III - transferências de fundos e outros ativos financeiros;

IV - operações com títulos e valores mobiliários;

V - operações realizadas em bolsas de mercadorias e de futuros;

VI - outras operações, inclusive envolvendo derivativos financeiros.

Parágrafo único. O Banco Central do Brasil, a seu exclusivo critério e em exame caso a caso, pode restringir o conjunto de operações cujas obrigações sejam passíveis de liquidação em um mesmo sistema.

$$
\text { Seção II }
$$

Sistemas de Liquidação Diferida

Art. $4^{\circ}$ Nos sistemas de liquidação diferida:

I - a liquidação financeira deve ser precedida de compensação; e

II - a liquidação financeira interbancária é definitiva no momento em que efetuadas as resultantes movimentações nas contas Reservas Bancárias ou nas Contas de Liquidação mantidas no Banco Central do Brasil. (Redação dada pela Circular 3.439, de $\underline{1 / 3 / 2009 .)}$

Seção III

Sistemas de Liquidação Bruta em Tempo Real

Circular $\mathrm{n}^{\circ} 3.057$, de 31 de agosto de 2001. 


\section{4 \\ BANCO CENTRAL DO BRASIL} interbancária:

Art. $5^{\circ}$ Nos sistemas de liquidação bruta em tempo real, a liquidação financeira

I - deve ser feita diretamente nas contas Reservas Bancárias ou nas Contas de Liquidação mantidas pelos participantes no Banco Central do Brasil; (Redação dada pela Circular 3.439, de 1/3/2009.)

II - é definitiva no momento em que efetuadas as movimentações nas contas Reservas Bancárias ou nas Contas de Liquidação mantidas pelos participantes no Banco Central do Brasil. (Redação dada pela Circular 3.439, de 1/3/2009.)

Art. $6^{\circ}$ Nos sistemas de liquidação bruta em tempo real de transferência de fundos, a informação neles originada atinente à transferência de fundos somente deve ser fornecida ao beneficiário no momento em que a transferência for definitiva.

Seção IV

Sistemas Híbridos de Liquidação

Art. $7^{\circ}$ Os sistemas híbridos de liquidação serão examinados pelo Banco Central do Brasil, caso a caso, observados, no que couber, os requisitos estabelecidos neste Regulamento para os sistemas de liquidação diferida e para os sistemas de liquidação bruta em tempo real.

Seção V

Sistemas Sistemicamente Importantes

Brasil:

Art. $8^{\circ}$ São considerados sistemicamente importantes pelo Banco Central do

I - os sistemas de liquidação de transações com ativos financeiros, títulos, valores mobiliários, derivativos financeiros e moedas estrangeiras, independentemente do valor individual de cada transação e do giro financeiro diário: (Redação dada pela Circular 3.539, de $\underline{02 / 06 / 2011 .)}$

II - os sistemas de liquidação de transferências de fundos e de outras obrigações interbancárias não relacionadas com as transações de que trata o inciso I, que se enquadrem em pelo menos uma das situações indicadas a seguir:

a) existência de giro financeiro diário médio superior a $4 \%$ (quatro por cento) do giro financeiro diário médio do Sistema de Transferência de Reservas - STR;

b) possibilidade de que os efeitos da inadimplência de um participante sobre outros participantes (efeito-contágio), em sistemas de liquidação diferida que utilizem compensação multilateral, a critério do Banco Central do Brasil, coloquem em risco a fluidez dos pagamentos no âmbito do Sistema de Pagamentos Brasileiro.

é calculado:

$\S 1^{\circ}$ Para fins do disposto na alínea "a" do inciso II, o giro financeiro diário médio

Circular $n^{\circ} 3.057$, de 31 de agosto de 2001 . 


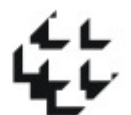 \\ BANCO CENTRAL DO BRASIL} de avaliação; e

I - tomando-se as trinta maiores posições observadas nos seis meses anteriores ao

II - desconsiderando-se, no caso do STR, as movimentações nas quais remetente e beneficiária são a mesma instituição financeira.

$\S 2^{\circ}$ Nas situações de que trata o inciso II do caput:

I - a avaliação será feita mensalmente; e

II - o Banco Central do Brasil concederá prazo de até seis meses, contados do mês seguinte ao da avaliação, para a câmara ou o prestador de serviços de compensação e de liquidação promover as necessárias adaptações decorrentes do enquadramento do sistema que opere como sistemicamente importante.

$\S 3^{\circ} \mathrm{Na}$ situação de que trata a alínea "a" do inciso II do caput, será considerado o movimento esperado para os primeiros dois semestres civis completos de funcionamento, no caso de sistemas em início de funcionamento. (Redação dada pela Circular 3.539, de $\underline{02 / 06 / 2011 .)}$

I - será considerado o movimento esperado para os primeiros dois semestres civis completos de funcionamento, no caso de sistemas em início de funcionamento; e

II - o Banco Central do Brasil poderá manter o enquadramento de um sistema como não-sistemicamente importante se, a seu exclusivo critério, o giro financeiro observado em determinado período, que justificaria o enquadramento como sistemicamente importante, for considerado anormal e com pouca possibilidade de se repetir em períodos seguintes.

\section{(Art. $8^{\circ}$ com redação dada pela Circular 3.437, de 13/2/2009.)}

Art. $9^{\circ}$ Independentemente do disposto no art. $8^{\circ}$, o Banco Central do Brasil poderá, a seu exclusivo critério, em exame de caso a caso e com foco no risco, enquadrar ou desenquadrar determinado sistema de liquidação de transferência de fundos como sistemicamente importante. (Redação dada pela Circular 3.539, de 02/06/2011.)

Parágrafo único. No caso de enquadramento de um sistema como sistemicamente importante, será concedido prazo de até seis meses para a câmara ou o prestador de serviços de compensação e de liquidação promover as necessárias adaptações. (Incluído pela Circular 3.539. de $02 / 06 / 2011$.

Art. 10. Nos sistemas sistemicamente importantes, o índice de disponibilidade deve ser igual ou superior a $99,8 \%$ (noventa e nove vírgula oito por cento).

Art. 11. Nos sistemas de liquidação diferida considerados sistemicamente importantes:

I - a liquidação financeira do resultado compensado das operações aceitas deve ocorrer diretamente no Banco Central do Brasil;

Circular $n^{\circ} 3.057$, de 31 de agosto de 2001 . 


\section{4 \\ BANCO CENTRAL DO BRASIL}

operação:

II - a liquidação pode ser diferida, em relação ao momento da aceitação da

a) até o final do dia, no caso de transferências de fundos;

b) por até um dia útil, no caso de operações à vista com títulos e valores mobiliários, exceto ações; bolsa de valores;

c) por até três dias úteis, no caso de operações à vista com ações realizadas em situações;

d) pelo prazo que vier a ser definido pelo Banco Central do Brasil, nas demais cada dia;

III - preferencialmente deve ocorrer mais de uma sessão de liquidação ao longo de

IV - a câmara ou o prestador de serviços de compensação e de liquidação deve:

a) assumir a posição de parte contratante para fins de liquidação das obrigações, realizada por seu intermédio, ressalvado o risco de emissor; e

b) assegurar a liquidação das obrigações relativas às operações aceitas, constituindo patrimônio especial e adotando mecanismos e salvaguardas adequados, tais como:

1. definição de limites operacionais;

participantes;

2. instituição de mecanismos de compartilhamento de perdas entre os

3. constituição de garantias pelos participantes;

4. constituição de fundo de garantia de liquidação;

5. contratação de seguro de garantia de liquidação; e

6. contratação de linhas de crédito bancário.

$\S 1^{\circ} \mathrm{O}$ Banco Central do Brasil pode fixar prazo de liquidação diverso daquele estipulado na alínea "c" do inciso II deste artigo, observados os princípios que assegurem a eficiência, segurança, integridade e confiabilidade do sistema de pagamentos, em caso de oferta simultânea de ações em bolsas de valores nacional e estrangeira. (Incluído pela Circular 3.469. de 29/9/2009.)

$\S 2^{\circ} \mathrm{O}$ ato de divulgação do prazo de que trata o $\S 1^{\circ}$ deverá explicitar a operação a que se aplica, bem como as datas de início e de término de sua vigência. (Incluído pela Circular 3.469, de 29/9/2009.)

Circular $n^{\circ} 3.057$, de 31 de agosto de 2001 . 


\section{4 \\ BANCO CENTRAL DO BRASIL}

Art. 12. A adequação dos mecanismos e salvaguardas de que trata a alínea "b" do inciso IV do artigo anterior será avaliada pelo Banco Central do Brasil, caso a caso, conforme a natureza e as especificidades do sistema de liquidação a que digam respeito, exigindo-se diversificação na escolha de terceiros que ofereçam linhas de crédito.

Art. 13. As câmaras e os prestadores de serviços de compensação e de liquidação que operem sistemas de liquidação diferida considerados sistemicamente importantes devem solicitar ao Banco Central do Brasil a abertura de conta destinada exclusivamente:

I - à liquidação definitiva dos resultados por eles apurados; e

II - à realização de movimentações financeiras diretamente relacionadas aos mecanismos e salvaguardas adotados nos sistemas de liquidação que operem, ou vinculadas a eventos de custódia atinentes à liquidação de obrigações de emissor.

Parágrafo $1^{\circ}$ São acolhidas na conta titulada pelas entidades referidas no caput, exclusivamente, movimentações:

Bancárias;

I - a crédito, em contrapartida a débito comandado por titular de conta Reservas

II - a débito, comandada pelo titular, em contrapartida a crédito em conta Reservas Bancárias.

Parágrafo $2^{\circ}$ A conta titulada pelas referidas entidades deve apresentar saldo igual a zero ao final de cada dia.

Art. 14. Os sistemas de liquidação de transferência de fundos sistemicamente importantes somente podem ser operados por câmaras de compensação e de liquidação que tenham como objeto social exclusivo as atividades diretamente relacionadas ao processamento, compensação e liquidação de pagamentos.

\section{Seção VI}

Regulamento do Sistema

Art. 15. Do regulamento de cada sistema de liquidação devem constar, clara e objetivamente, todos os aspectos relevantes relacionados com o seu funcionamento, tais como:

I - critérios de acesso, suspensão e exclusão de participante;

II - horários e regras de funcionamento, inclusive horários de liquidação, direta ou indireta, no Banco Central do Brasil;

III - obrigações da câmara ou do prestador de serviços de compensação e de liquidação e dos participantes, inclusive no que diz respeito à administração e à contenção dos riscos de crédito, de liquidez e operacional;

IV - requisitos para aceitação de uma operação;

Circular $\mathrm{n}^{\circ} 3.057$, de 31 de agosto de 2001. 


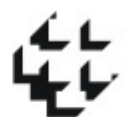 \\ BANCO CENTRAL DO BRASIL}

V - momento a partir do qual a câmara ou prestador de serviços de compensação e de liquidação aceita a operação;

VI - mecanismos e salvaguardas adotados pelo sistema para administração dos riscos de crédito, de liquidez e operacional;

VII - eventos que caracterizam a inadimplência de participante;

VIII - procedimentos a serem adotados no caso de inadimplência de participante;

IX - planos de contingência e recuperação, com detalhamento dos procedimentos a serem adotados no caso de falhas operacionais; $\mathrm{e}$

$\mathrm{X}$ - terceiros contratados para realizar etapas relacionadas com as atividades-fim da câmara ou do prestador de serviços de compensação e de liquidação, consideradas importantes pelo Banco Central do Brasil.

Art. 16. As câmaras e os prestadores de serviços de compensação e de liquidação devem divulgar tempestivamente a todos os participantes qualquer alteração relacionada com o funcionamento dos sistemas de liquidação por eles operados.

Art. 17. As câmaras e os prestadores de serviços de compensação e de liquidação devem exigir, como garantia de compromissos assumidos pelos participantes no âmbito do sistema de liquidação por eles operados, preferencialmente a entrega de ativos líquidos.

Parágrafo único. Os ativos devem ser tomados em garantia com adequado deságio em relação ao preço de mercado e em montante suficiente à cobertura das obrigações a que se relacionam.

\section{CAPÍTULO IV}

\section{DAS CÂMARAS E DOS PRESTADORES DE SERVIÇOS DE COMPENSAÇÃO E DE LIQUIDAÇÃO}

Seção I

Capital Social e Patrimônio

Art. 18. A câmara ou o prestador de serviços de compensação e de liquidação deve manter patrimônio líquido compatível com os riscos inerentes aos sistemas de liquidação que opere, observados os seguintes limites mínimos:

I - R\$5.000.000,00 (cinco milhões de reais), no caso de ser responsável por sistema de liquidação considerado não sistemicamente importante;

II - R \$30.000.000,00 (trinta milhões de reais), no caso de ser responsável por sistema de liquidação considerado sistemicamente importante.

Circular $\mathrm{n}^{\circ} 3.057$, de 31 de agosto de 2001 . 


\section{4 \\ BANCO CENTRAL DO BRASIL}

Parágrafo $1^{\circ}$ Se a câmara ou o prestador de serviços de compensação e de liquidação operar mais de um sistema de liquidação, os limites mínimos de patrimônio líquido referidos no caput devem corresponder à soma dos respectivos limites mínimos exigidos para operar cada sistema.

Parágrafo $2^{\circ}$ Se o sistema de liquidação for operado por prestador de serviços de compensação e de liquidação, o montante mínimo de patrimônio líquido deve ser acrescido de outros exigidos pelo exercício das demais atividades.

Parágrafo $3^{\circ}$ Os valores referidos neste artigo poderão ser modificados pelo Banco Central do Brasil, observada periodicidade não inferior a dois anos.

Art. 19. Para atender o disposto no art. $5^{\circ}$ da Lei 10.214, de 27 de março de 2001, as câmaras e os prestadores de serviços de compensação e de liquidação devem separar patrimônio especial mínimo de $\mathrm{R} \$ 10.000 .000,00$ (dez milhões de reais), constituído exclusivamente por títulos públicos federais, para cada um dos sistemas considerados sistemicamente importantes que operem.

Parágrafo $1^{\circ}$ Os títulos públicos federais separados como patrimônio especial na forma do caput devem ser transferidos, no Sistema Especial de Liquidação e de Custódia (Selic), para conta vinculada específica de cada sistema, ficando bloqueados à negociação. ao patrimônio especial.

Parágrafo $2^{\circ}$ Os rendimentos dos títulos públicos federais devem ser incorporados

Parágrafo $3^{\circ}$ A câmara ou o prestador de serviços de compensação e de liquidação deve providenciar o imediato reforço do patrimônio especial, sempre que, avaliado com base nos preços unitários utilizados pelo Banco Central do Brasil em suas operações compromissadas, apresentar valor inferior ao mínimo estipulado no caput.

Seção II

Organização e Administração

Art. 20. A câmara ou o prestador de serviços de compensação e de liquidação deve contar com pessoal técnica e administrativamente capacitado, que lhe possibilite o pleno atingimento de seu objeto social.

Art. 21. Os responsáveis pela administração da câmara ou do prestador de serviços de compensação e de liquidação devem ser profissionais de reconhecida competência técnica na matéria, com autonomia de gestão, nos termos de seu contrato ou estatuto social.

Seção III

Autorização para Alterações em Regulamentos

Art. 22. As alterações em regulamentos relacionadas com os aspectos a seguir indicados dependem da prévia autorização do Banco Central do Brasil:

Circular $\mathrm{n}^{\circ} 3.057$, de 31 de agosto de 2001 . 


\section{4 \\ BANCO CENTRAL DO BRASIL}

respeito:

I - o sistema de liquidação operado pela entidade, especialmente no que diz
a) a sua segurança e integridade;
b) aos planos de contingência e de recuperação;
c) a sua interligação, quando for o caso, com outros sistemas;
II - as sistemáticas operacionais de:
a) registro, confirmação e aceitação de operações;
b) transferência de fundos;
c) depósito de títulos, valores mobiliários ou outros ativos financeiros;
d) compensação;
e) liquidação;

III - os mecanismos e procedimentos de administração e contenção dos riscos de crédito e de liquidez, inclusive os destinados a assegurar a certeza de liquidação, quando for o caso, e os relacionados com a constituição, administração e execução de garantias.

Parágrafo único. As demais alterações promovidas no regulamento de cada sistema de liquidação operado pela câmara ou prestador de serviços de compensação e de liquidação devem ser comunicadas ao Banco Central do Brasil no prazo de trinta dias.

Art. 23. No exame do pedido de autorização de que tratam os arts. $5^{\circ}$, inciso II, e $6^{\circ}$, parágrafo $1^{\circ}$, da Resolução 2.882, de 30 de agosto de 2001, o Banco Central do Brasil analisará, no âmbito do sistema de pagamentos, todos os processos executados pela câmara ou prestador de serviços de compensação e de liquidação, bem como os que lhes antecedem.

Art. 24. A contratação de terceiros para a realização de processos executados pela câmara ou pelo prestador de serviços de compensação e de liquidação depende de prévia aprovação do Banco Central do Brasil, que examinará o atendimento às exigências regulamentares relativas à eficiência, segurança, integridade e confiabilidade dos sistemas de liquidação.

\section{Seção IV}

Supervisão

Art. 25. As câmaras e os prestadores de serviços de compensação e de liquidação são supervisionados pelo Banco Central do Brasil, com foco nos valores, princípios e regras aplicáveis ao sistema de pagamentos.

Circular $\mathrm{n}^{\circ} 3.057$, de 31 de agosto de 2001 . 


\section{4 \\ BANCO CENTRAL DO BRASIL}

Parágrafo único. A supervisão poderá ser estendida a terceiros se estes realizarem, a critério do Banco Central do Brasil, etapas importantes relacionadas com as atividades-fim das entidades de que trata o caput, hipótese em que a extensão deverá constar dos contratos entre elas e os terceiros.

\section{CAPÍTULO V \\ DOS PARTICIPANTES}

Art. 26. As câmaras e os prestadores de serviços de compensação e de liquidação devem aceitar como participantes nos respectivos sistemas de liquidação por eles operados, entre outros, as instituições financeiras e demais instituições autorizadas a funcionar pelo Banco Central do Brasil, cujas atividades sejam compatíveis com as operações liquidadas por intermédio desses sistemas.

Parágrafo $1^{\circ}$ Nos sistemas de liquidação diferida, admite-se que a câmara ou prestador de serviços de compensação e de liquidação estabeleça, no regulamento do sistema por ele operado, critérios objetivos, públicos e claros de acesso baseados, sobretudo, na capacitação dos participantes para administrar e conter os riscos de crédito e de liquidez.

Parágrafo $2^{\circ} \mathrm{O}$ disposto no parágrafo anterior não exime o participante da necessidade de estar técnica e operacionalmente capacitado para promover seu acesso aos sistemas de liquidação operados pela câmara ou prestador de serviços de compensação e de liquidação.

Art. 27. Os participantes são responsáveis pela exatidão dos dados informados nas suas operações, no âmbito de cada sistema de liquidação.

\section{CAPÍTULO VI \\ DAS DISPOSIÇÕES GERAIS E TRANSITÓRIAS}

Art. 28. As câmaras e os prestadores de serviços de compensação e de liquidação e os terceiros por eles contratados devem observar a legislação e a regulamentação atinentes ao sigilo de dados.

Art. 29. Os planos de contingência e de recuperação, necessários à continuidade dos serviços na hipótese de falhas de equipamentos ou programas de computador, ou de interrupção, por qualquer razão, do fornecimento de energia elétrica, dos serviços de telecomunicação ou de qualquer outro insumo, obrigatoriamente incluem:

I - a instalação e operação de centro de processamento secundário que permita a retomada do efetivo funcionamento do sistema de liquidação em prazo não superior a:

a) trinta minutos, quando se tratar de sistemas de liquidação bruta em tempo real; ou

b) duas horas, em se tratando de sistemas de liquidação diferida;

Circular n $\mathrm{n}^{\circ} 3.057$, de 31 de agosto de 2001. 


\section{位 \\ BANCO CENTRAL DO BRASIL}

II - a previsão de procedimentos de emergência, no caso de simultâneo impedimento dos centros de processamento principal e secundário.

Parágrafo único. As câmaras e os prestadores de serviços de compensação e de liquidação que operem sistemas de liquidação não considerados sistemicamente importantes poderão, a exclusivo critério do Banco Central do Brasil, adotar, com os objetivos mencionados no caput, mecanismos e procedimentos substitutivos aos de que trata o inciso I.

Art. 30. As câmaras e os prestadores de serviços de compensação e de liquidação devem comunicar imediatamente ao Banco Central do Brasil:

I - a inadimplência, caracterizada na forma de seu regulamento, de instituições financeiras e demais instituições autorizadas a funcionar pelo Banco Central do Brasil verificada nos sistemas de liquidação por eles operados;

II - a suspensão ou a exclusão de participante;

III - as ocorrências que possam impedir ou atrasar o normal funcionamento do sistema de liquidação.

Art. 31. Os sistemas de liquidação de transferência eletrônica de fundos devem operar com base em ordens de crédito.

Art. 32. As câmaras e os prestadores de serviços de compensação e de liquidação, que operem sistemas de liquidação de transferência eletrônica de fundos, devem implementar medidas que busquem evitar a concentração, tanto no que diz respeito a valor quanto a quantidade, do registro de ordens ao final do período para tanto previsto.

Art. 33. Nos sistemas de liquidação de operações com títulos, valores mobiliários ou outros ativos financeiros, inclusive moeda estrangeira, a transferência definitiva do ativo negociado deve ocorrer simultaneamente à liquidação financeira definitiva.

Art. 34. A análise quanto ao enquadramento do Serviço de Compensação de Cheques e Outros Papéis - SCCOP, como sistemicamente importante ou não, deverá ser realizada pela primeira vez em julho de 2002, com a aplicação do disposto no parágrafo $2^{\circ}$ do art. $8^{\circ}$ e, a partir de janeiro de 2003 , de acordo com as demais disposições do mesmo artigo. (Ver prazo prorrogado pela Circular 3.138, de 25/7/2002.)

Circular $n^{\circ} 3.057$, de 31 de agosto de 2001. 